This document was prepared in conjunction with work accomplished under Contract No. DE-AC09-96SR18500 with the U. S. Department of Energy.

\title{
DISCLAIMER
}

This report was prepared as an account of work sponsored by an agency of the United States Government. Neither the United States Government nor any agency thereof, nor any of their employees, nor any of their contractors, subcontractors or their employees, makes any warranty, express or implied, or assumes any legal liability or responsibility for the accuracy, completeness, or any third party's use or the results of such use of any information, apparatus, product, or process disclosed, or represents that its use would not infringe privately owned rights. Reference herein to any specific commercial product, process, or service by trade name, trademark, manufacturer, or otherwise, does not necessarily constitute or imply its endorsement, recommendation, or favoring by the United States Government or any agency thereof or its contractors or subcontractors. The views and opinions of authors expressed herein do not necessarily state or reflect those of the United States Government or any agency thereof. 


\section{NEPHELINE FORMATION STUDY FOR SLUDGE BATCH 4 (SB4): PHASE 1 EXPERIMENTAL RESULTS}

D.K. Peeler

T.B. Edwards

I.A. Reamer

R.J. Workman

August 2005

Immobilization Technology Section Savannah River National Laboratory Aiken, SC 29808 


\section{DISCLAIMER}

This report was prepared by Westinghouse Savannah River Company (WSRC) for the United States Department of Energy under Contract No. DE-AC09-96SR18500 and is an account of work performed under that contract. Neither the United States Department of Energy, nor WSRC, nor any of their employees makes any warranty, expressed or implied, or assumes any legal liability or responsibility for the accuracy, completeness, or usefulness, of any information, apparatus, or product or process disclosed herein or represents that its use will not infringe privately owned rights. Reference herein to any specific commercial product, process or service by trademark, name, and manufacturer or otherwise does not necessarily constitute or imply endorsement, recommendation, or favoring of same by WSRC or by the United States Government or any agency thereof. The views and opinions of the authors expressed herein do not necessarily state or reflect those of the United States Government or any agency thereof.

\section{Printed in the United States of America \\ Prepared For U.S. Department of Energy}


Key Words: durability, crystallization, residual glass matrix effects

Retention: Permanent

\section{NEPHELINE FORMATION STUDY FOR SLUDGE BATCH 4 (SB4): PHASE 1 EXPERIMENTAL RESULTS}

D.K. Peeler

T.B. Edwards

I.A. Reamer

R.J. Workman

August 2005

Immobilization Technology Section Savannah River National Laboratory Aiken, SC 29808 


\section{REVIEWS AND APPROVALS}

\section{AUTHORS:}

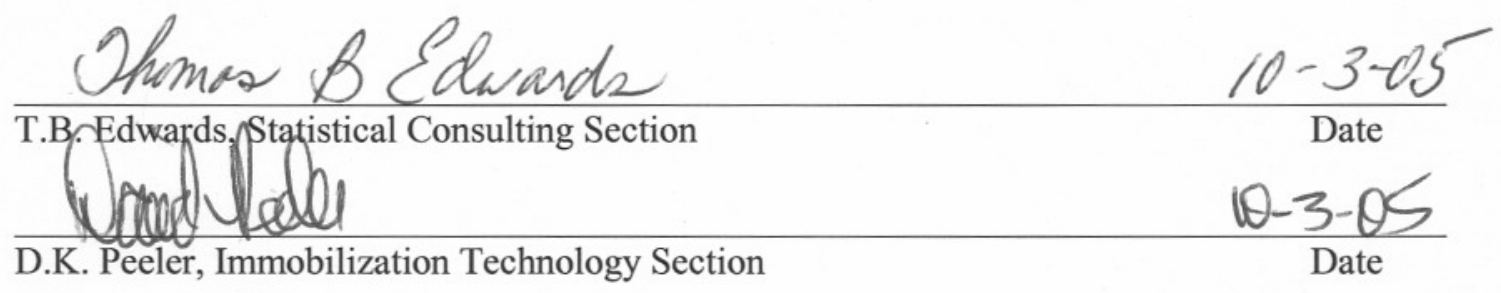

\section{TECHNICAL REVIEWER:}

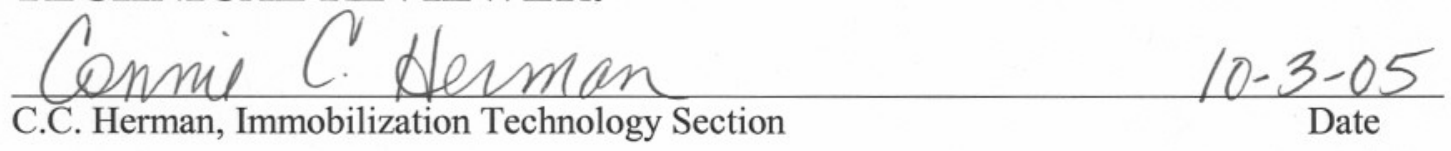

\section{APPROVERS:}

\section{Ifrlana ho}

E.W. Holtzscheiter, Manager, Immobilization Technology Section

$$
\text { Sfrana }
$$

S.L. Marra, Manager, Glass Formulation \& Process Development

J.E. Occhipinti, Manager, DWPF Process Engineering

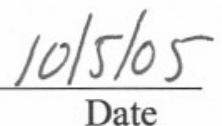

$10 / 5 / 05$

Date

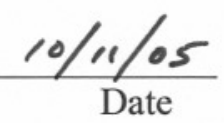




\section{EXECUTIVE SUMMARY}

Although it is well known that the addition of $\mathrm{Al}_{2} \mathrm{O}_{3}$ to borosilicate glasses enhances the durability of the waste form (through creation of network-forming tetrahedral $\mathrm{Na}^{+}-\left[\mathrm{AlO}_{4 / 2}\right]^{-}$ pairs), the combination of high $\mathrm{Al}_{2} \mathrm{O}_{3}$ and $\mathrm{Na}_{2} \mathrm{O}$ can lead to the formation of nepheline $\left(\mathrm{NaAlSiO}_{4}\right)$ - which can negatively impact durability. Given the projected high concentration of $\mathrm{Al}_{2} \mathrm{O}_{3}$ in SB4 (Lilliston 2005) and the potential use of a high $\mathrm{Na}_{2} \mathrm{O}$ based frit to improve melt rate and a high $\mathrm{Na}_{2} \mathrm{O}$ sludge due to settling problems, the potential formation of nepheline in various SB4 systems continues to be assessed. Twelve SB4-based glasses were fabricated and their durabilities (via the Product Consistency Test [PCT]) measured to assess the potential for nepheline formation and its potential negative impact on durability.

In terms of "acceptability," the results indicate that all of the study glasses produced are acceptable with respect to durability as defined by the PCT (normalized boron release values for all nepheline (NEPH) glasses were much lower than that of the Environmental Assessment (EA) glass $(16.695 \mathrm{~g} / \mathrm{L})$ ). The most durable glass is NEPH-04 (quenched) with a normalized boron release (NL [B]) of $0.61 \mathrm{~g} / \mathrm{L}$, while the least durable glass is NEPH-01 centerline canister cooled (ccc) with an NL [B] of $2.47 \mathrm{~g} / \mathrm{L}$ (based on the measured composition). In terms of predictability, most of the study glasses are predictable by the $\Delta \mathrm{G}_{\mathrm{p}}$ model. Those that are not predictable (i.e., they fall outside of the prediction limits) actually fall below the prediction interval (i.e., they are over predicted by the model) suggesting the model is conservative.

The Phase 1 PCT results suggest that for those glasses prone to nepheline formation (using the 0.62 value developed by Li et al. (2003) as a guide) ${ }^{1}$, a statistically significant difference in PCT response was observed for the two heat treatments but the impact on durability was of little or no practical concern. When one couples the PCT responses with the X-Ray Diffraction (XRD) results and/or visual observations, one could conclude that the formation of nepheline in these glasses does have a negative impact on durability. However, that impact may be of statistical significance, but the practical impact may not be sufficient to avoid a specific candidate frit for the SB4 glass system.

The results of this study not only suggest that the 0.62 value appears to be a reasonable guide to monitor sludge - frit systems with respect to potential nepheline formation, but also that the impact of nepheline, although statistically significant, has little or no practical impact in the SB4 system to durability as measured by the PCT. This latter statement must be qualified to some extent given only two glasses were selected which were actually "prone to nepheline formation" based on this general guide and the relatively volume \% of nepheline formed based on XRD results ( $\sim 0.5$ vol\%). If the presence of nepheline has no appreciable, adverse impact on durability for the recently revised SB4 systems, then as decisions regarding the viability of the SB4 options and the down select of candidate frits are pursued, little weight will be given to minimizing the likelihood of nepheline and the decisions will be dominated by waste throughput criteria. That is, the frit selection process will not have to consider the impact of nepheline on the ultimate durability of the product and can focus on recommending a frit that when coupled with the sludge can be processed over a waste loading (WL) interval of interest to the Defense Waste Processing Facility (DWPF) with melt rates meeting production expectations.

\footnotetext{
${ }^{1} \mathrm{Li}$ et al. (2003) indicated that sodium alumino-borosilicate glasses are prone to nepheline crystallization if their compositions projected on the $\mathrm{Na}_{2} \mathrm{O}-\mathrm{Al}_{2} \mathrm{O}_{3}-\mathrm{SiO}_{2}$ ternary fall within or close to the nepheline primary phase field. In particular, durable glasses with $\mathrm{SiO}_{2} /\left(\mathrm{SiO}_{2}+\mathrm{Na}_{2} \mathrm{O}+\mathrm{Al}_{2} \mathrm{O}_{3}\right)>0.62$, where the chemical formula stand for the mass fractions in the glass, do not tend to precipitate nepheline as their primary phase.
} 


\section{TABLE OF CONTENTS}

EXECUTIVE SUMMARY ..................................................................................................... V

LIST OF FIGURES ........................................................................................................ VII

LIST OF TABLES .................................................................................................................... VII

LIST OF ACRONYMS …........................................................................................VIII

1.0 INTRODUCTION.................................................................................................................. 1

2.0 EXPERIMENTAL ............................................................................................................ 3

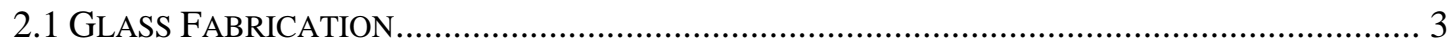

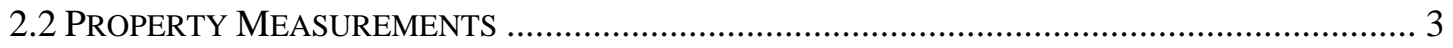

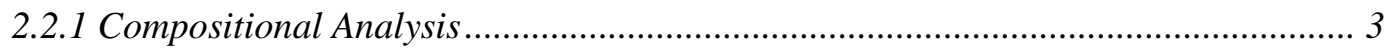

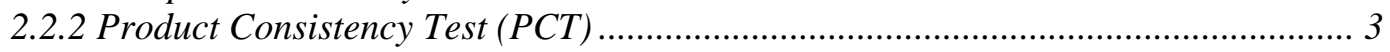

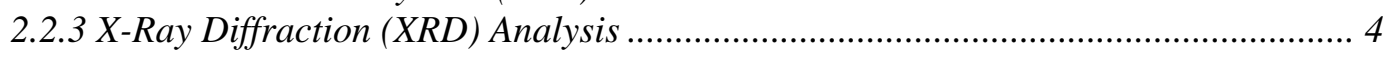

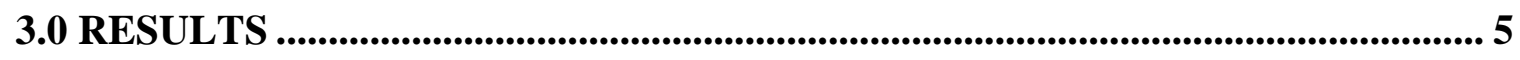

3.1 MEASUREMENTS IN ANALYTICAL SEQUENCE ............................................................... 5

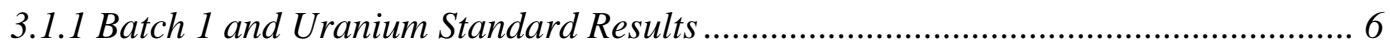

3.1.2 Composition Measurements by Glass Number ..................................................... 7

3.1.3 Measured versus Targeted Compositions ............................................................. 7

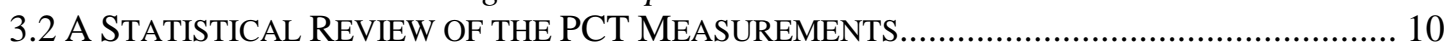

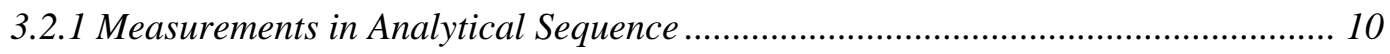

3.2.2 Results for the Samples of the Multi-Element Solution Standard............................ 11

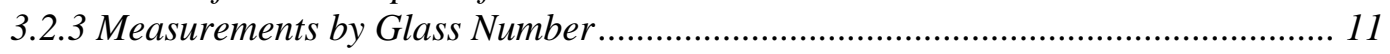

3.2.4 Normalized PCT Results ................................................................................... 11

3.2.5 Acceptability of the Nepheline Study Glasses and Predictability of the $\triangle G P$ Model

3.2.6 Heat Treatment Effects on PCTs

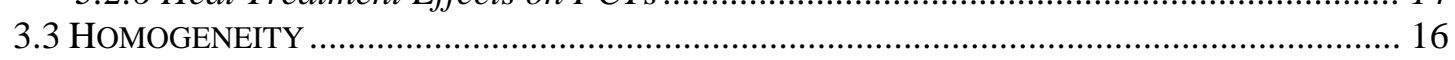

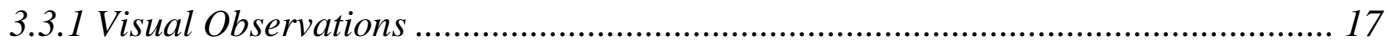

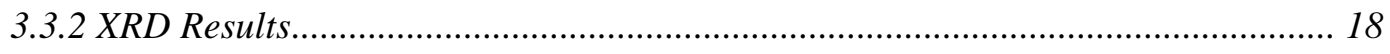

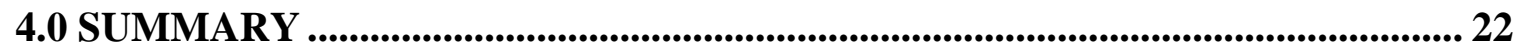

5.0 PATH FORWARD ....................................................................................................... 24

6.0 REFERENCES......................................................................................................... 25

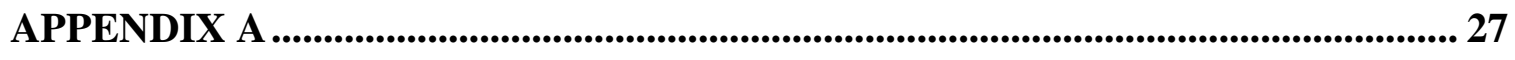

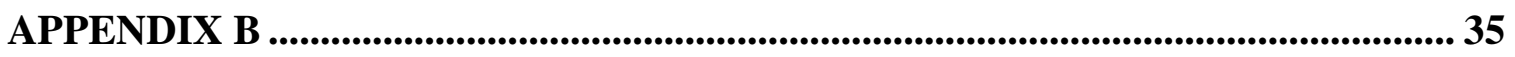




\section{LIST OF FIGURES}

Figure 3-1. Boron Durability Predictions for the Phase 1 Nepheline Study Glasses ................... 14 Figure 3-2. Normalized Release of Boron for NEPH Phase 1 Glasses -

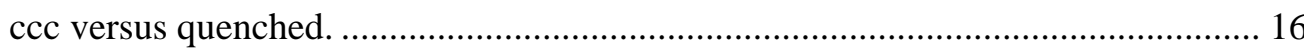

\section{LIST OF TABLES}

Table 3-1. Targeted and Measured Compositions (wt\%) of the NEPH Study Glasses.................. 8

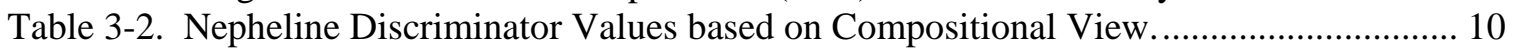

Table 3-3. Results from samples of the multi-element solution standard .................................... 11

Table 3-4. Normalized PCTs by Glass ID/Heat Treatment/Compositional View......................... 12

Table 3-5. Visual and XRD Results for the SB4 Nepheline Phase 1 Glasses.............................. 18 


\section{LIST OF ACRONYMS}

\begin{tabular}{ll} 
ADS & Analytical Development Section \\
ANOVA & analysis of variance \\
ARM & Approved Reference Material \\
ARP & Actinide Removal Process \\
ASTM & American Society for Testing and Materials \\
bc & bias-corrected \\
CBU & Closure Business Unit \\
cCC & centerline canister cooled \\
DWPF & Defense Waste Processing Facility \\
EA & Environmental Assessment \\
g/L & grams per liter \\
HLW & high-level waste \\
ICP-AES & Inductively-Coupled Plasma - Atomic Emission Spectroscopy \\
LM & lithium-metaborate \\
NEPH & nepheline \\
NL & normalized leachate (or normalized release) \\
PCT & Product Consistency Test \\
PF & peroxide fusion \\
pPm & parts per million \\
SB4 & Sludge Batch 4 \\
SRL & Savannah River Laboratory \\
SRNL & Savannah River National Laboratory \\
SRNL-ML & Savannah River National Laboratory - Mobile Laboratory \\
T $_{\text {L }}$ & liquidus temperature \\
$\mathrm{U}_{\text {std }}$ & uranium standard \\
WL & waste loading \\
XRD & X-ray diffraction \\
\hline
\end{tabular}




\subsection{INTRODUCTION}

Crystallization (or devitrification) in nuclear waste glasses is an important consideration in terms of processing and product performance (i.e., durability of the final waste form). With respect to the impact of crystallization on processability, DWPF uses a liquidus temperature $\left(\mathrm{T}_{\mathrm{L}}\right)$ model (Brown et al., 2001) and an imposed $\mathrm{T}_{\mathrm{L}}$ limit for feed acceptability to avoid bulk devitrification within the melter. In terms of product quality or the durability of the waste form, the impact of devitrification depends on the type and extent of crystallization.

As stated by Peeler et al. (2005), several studies have investigated the impacts of crystallization on DWPF-type glasses. The results of Bickford and Jantzen (1984) indicated that the formation of spinel had little or no effect on the durability of Savannah River Laboratory (SRL) 165- or SRL 131-based glasses, while the formation of acmite produced a small but noticeable increase in the rate of dissolution of the matrix glass. Cicero et al. (1993) assessed the durability of seven DWPF glass compositions and found that with respect to the impact of crystallization on durability, the type and extent of devitrification ultimately determined the durability of the glass. Kim et al. (1995) assessed the durability response of over 120 simulated high-level waste (HLW) glasses for Hanford as a function of thermal heat treatment (quenched versus ccc). The results of that study also indicated that crystallization, depending on the type and extent (or fraction), can have an adverse effect on chemical durability. Numerous other studies have assessed the devitrification potential of HLW glass and its potential impact on durability - Jantzen et al. (1984), Bickford and Jantzen (1986), Spilman et al. (1986), Marra and Jantzen (1993), Li et al. (1997), and Riley et al. (2001). In general, these studies agree that the impact of devitrification on durability is dependent upon the type and extent of crystallization.

The formation of nepheline and/or other aluminum/silicon-containing crystals is a potential in the SB4 system due to the projected compositional views recently evaluated coupled with the frit development strategy (Peeler and Edwards 2005). Compositional projections of SB4 by Lilliston (2005) indicated the sludge will be enriched in $\mathrm{Al}_{2} \mathrm{O}_{3}$ (relative to the $\mathrm{Al}_{2} \mathrm{O}_{3}$ concentrations of previous sludge batches processed through the DWPF). ${ }^{2}$ Peeler and Edwards (2005) have identified candidate frits (ranging in $\mathrm{Na}_{2} \mathrm{O}$ concentration from $8-13 \%$ by mass) for the SB4 compositional projections, which produce relatively large projected operating windows. The combination of high $\mathrm{Al}_{2} \mathrm{O}_{3}$ and $\mathrm{Na}_{2} \mathrm{O}$ concentrations, coupled with lower $\mathrm{SiO}_{2}$ concentrations as waste loadings increase, can lead to the formation of nepheline $\left(\mathrm{NaAlSiO}_{4}\right)$. Li et al. (2003) indicated that sodium alumino-borosilicate glasses are prone to nepheline crystallization if their compositions projected on the $\mathrm{Na}_{2} \mathrm{O}-\mathrm{Al}_{2} \mathrm{O}_{3}-\mathrm{SiO}_{2}$ ternary fall within or close to the nepheline primary phase field. In particular, durable glasses with $\mathrm{SiO}_{2} /\left(\mathrm{SiO}_{2}+\mathrm{Na}_{2} \mathrm{O}+\mathrm{Al}_{2} \mathrm{O}_{3}\right)>0.62$, where the chemical formula stands for the mass fractions in the glass, do not tend to precipitate nepheline as their primary phase.

Forty-eight SB4 glass compositions were screened using the nepheline discriminator to assess the potential formation of nepheline (Peeler et al., 2005). The 48 glasses were based on four specific blending scenarios as defined by Lilliston (2005), which based on theory increased the likelihood of nepheline formation. The four sludge options were: (1) 1100 Can Baseline, (2) 1100 Can Max

\footnotetext{
2 It is noted that prior to the issuance of this report, Elder (2005a and 2005b) issued revised SB4 compositions based on a decision not to include Tank 4 in SB4. In general, all of the projected SB4 options have relatively high $\mathrm{Al}_{2} \mathrm{O}_{3}$ and/or $\mathrm{Na}_{2} \mathrm{O}$ concentrations regardless of the Tank 4 decision. Although differences do exist between the two sets of compositional projections, use of these preliminary sludge compositions from Lilliston (2005) will provide insight into the potential effects of nepheline formation on durability for SB4-based glasses.
} 
Al, Na; Min Mn, Ni, (3) 1100 Can Max Mg, and (4) 1100 Can Max Ni; these were coupled with Frit 418 and Frit 320. Only two (NEPH-01 and NEPH-02) of the 48 glasses were classified as "prone to nepheline formation" using the guideline or discriminator value of 0.62 (from Li et al., 2003). These two glasses were based on Frit 320 and the 1100 Canister Max Al, Na case (with and without Actinide Removal Process (ARP)) and target 40\% WL, which agreed with theory regarding the potential for nepheline formation. ${ }^{3}$ Although Li et al. (2003) defined the "line of demarcation" between glasses that are prone to nepheline formation from those that are not based on a value of 0.62 , that line may be somewhat ill-defined (e.g., does the classification take into account potential kinetic effects such as slow cooling?). Therefore, to provide a higher probability of observing the formation of nepheline and the potential negative impact on durability, a value of 0.65 was used to establish the glasses to be tested in this study. Twelve glasses were identified or classified as "prone to nepheline formation" using this "less conservative" value. The objectives of this study were to fabricate these 12 glasses and assess the potential for nepheline formation and its impact on durability (as defined by the PCT).

The results of this study will provide valuable input to SB4 frit development efforts and subsequent feedback to the DWPF and Closure Business Unit (CBU) regarding the relative viability of the various SB4 options under consideration. Specifically, if the formation of nepheline for SB4 glasses is found through this study (or subsequent studies) to have an impact on durability that is overly detrimental, then candidate frits that lessen the likelihood of the formation of nepheline over an interval of waste loadings of interest to DWPF would move up the list of preferred frits. On the other hand, if the presence of nepheline has no appreciable, adverse impact on durability, then as decisions regarding the viability of the SB4 options and the down select of candidate frits are pursued, little weight will be given to minimizing the likelihood of nepheline and the decisions will be dominated by waste throughput criteria.

The experimental approach is summarized in Section 2.0. In Section 3.0, the results of the study are presented and discussed. More specifically, an assessment of the target versus measured compositions is provided to ensure the objectives of the task can be met. In addition, the PCT results for both quenched and centerline canister cooled glasses are presented for each study glass. The PCT results are discussed in terms of acceptability and model predictability. The result of both visual and XRD analyses are also presented and discussed in relation to the objectives of the task. Section 4.0 and Section 5.0 provide the summary and recommendations, respectively.

\footnotetext{
3 Both $\mathrm{Al}_{2} \mathrm{O}_{3}$ and $\mathrm{Na}_{2} \mathrm{O}$ concentrations in these glass systems increase as waste loadings are increased for the $1100 \mathrm{Can}$ Max Al, Na case. In addition, knowing that the primary source of $\mathrm{SiO}_{2}$ stems from the frit, as WLs increase the $\mathrm{SiO}_{2}$ content of the glass decreases - again increasing the probability of nepheline formation according to the discriminator developed by Li et al. (2003). Based on that theory, the probability of nepheline formation should increase as highalkali frits are used and should further increase with higher WLs for SB4.
} 


\subsection{EXPERIMENTAL}

\subsection{Glass Fabrication}

Each glass fabricated for this study, NEPH-01 through NEPH-12, was prepared from the proper proportions of reagent-grade metal oxides, carbonates, $\mathrm{H}_{3} \mathrm{BO}_{3}$, and salts in 150 -g batches. Once batched (SRNL 2002a), the glasses were melted using Savannah River National Laboratory (SRNL) technical procedure "Glass Melting” (SRNL 2002b). In general, the raw materials were thoroughly mixed and placed into a $95 \%$ Platinum $/ 5 \%$ Gold $250-\mathrm{mL}$ crucible. The batch was placed into a high-temperature furnace at the target melt temperature of $1150^{\circ} \mathrm{C}$. After an isothermal hold at $1150^{\circ} \mathrm{C}$ for $1.0 \mathrm{~h}$, the crucible was removed, and the glass was poured onto a clean stainless steel plate and allowed to air cool (quench). The glass pour patty was used as a sampling stock for the various property measurements (i.e., chemical composition and durability).

In order to bound the effects of thermal history on the product performance, approximately $25 \mathrm{~g}$ of each glass was heat-treated to simulate cooling along the centerline of a DWPF-type canister (Marra and Jantzen, 1993). This cooling regime is commonly referred to as the ccc curve.

\subsection{Property Measurements}

This section provides a general discussion of the chemical composition analyses, the PCTs, and the XRD analyses of the nepheline study glasses.

\subsubsection{Compositional Analysis}

To confirm that the "as-fabricated" glasses corresponded to the defined target compositions, a representative sample from each glass was submitted to the SRNL Mobile Laboratory (SRNLML) for chemical analysis under the auspices of an analytical plan. The plan (see Appendix A) identified the cations to be analyzed and the dissolution techniques (i.e., sodium peroxide fusion $[\mathrm{PF}]$ and lithium-metaborate [LM]) used. Samples prepared by LM dissolution were used to measure elemental concentrations of barium (Ba), calcium (Ca), cerium (Ce), chromium $(\mathrm{Cr})$, copper $(\mathrm{Cu})$, potassium $(\mathrm{K})$, lanthanum $(\mathrm{La})$, magnesium $(\mathrm{Mg})$, sodium $(\mathrm{Na})$, lead $(\mathrm{Pb})$, sulfur (S), thorium (Th), titanium (Ti), zinc (Zn), and zirconium (Zr), while samples from glasses prepared by $\mathrm{PF}$ dissolution were used to measure elemental concentrations of aluminum (Al), boron (B), iron (Fe), lithium (Li), manganese (Mn), nickel (Ni), silicon (Si), and uranium (U). Each glass was prepared in duplicate for each cation dissolution technique (PF and LM). All of the prepared samples were analyzed (twice for each element of interest) by Inductively Coupled Plasma - Atomic Emission Spectroscopy (ICP-AES) (with the instrumentation being recalibrated between the duplicate analyses). The analytical plan was developed in such a way as to provide the opportunity to evaluate potential sources of error. Glass standards were also intermittently run to assess the performance of the ICP - AES over the course of these analyses.

\subsubsection{Product Consistency Test (PCT)}

The PCT was performed in triplicate on each quenched and each ccc "NEPH" glass to assess chemical durability using technical procedure "Standard Test Methods for Determining Chemical Durability of Nuclear Waste Glasses: The Product Consistency Test (PCT)” (ASTM, 2002). Also 
included in this experimental test matrix was the EA glass (Jantzen et al., 1993), the Approved Reference Material (ARM) glass, and blanks from the sample cleaning batch. Samples were ground, washed, and prepared according to procedure (ASTM, 2002). Fifteen milliliters of Type I American Society for Testing and Materials (ASTM) water were added to $1.5 \mathrm{~g}$ of glass in stainless steel vessels. The vessels were closed, sealed, and placed in an oven at $90 \pm 2^{\circ} \mathrm{C}$ where the samples were maintained for 7 days. The resulting solutions (once cooled) were sampled (filtered and acidified), labeled (according to the analytical plan), and analyzed under the auspices of the analytical plan (see Appendix B). The overall philosophy of the plan was to provide an opportunity to assess the consistency (repeatability) of the PCT and analytical procedures in an effort to evaluate chemical durability of the "NEPH" glasses. Normalized release rates were calculated based on targeted, measured, and bias-corrected compositions using the average of the logs of the leachate concentrations.

\subsubsection{X-Ray Diffraction (XRD) Analysis}

Although visual observations for crystallization were performed and documented, representative samples for all "as-fabricated" (or quenched) and ccc SB4 glasses were submitted to the SRNL Analytical Development Section (ADS) for XRD analysis. ${ }^{4}$ Samples were run under conditions allowing an approximately 0.5 vol\% detection limit. That is, if crystals (or undissolved solids) are present at $0.5 \mathrm{vol} \%$ (or greater), the diffractometer will not only be capable of detecting these crystals but will also allow a qualitative measure (i.e., determine the type of crystal[s] present). Otherwise, a characteristically high background devoid of crystalline spectral lines indicates that the glass product is amorphous (suggesting either a completely amorphous product or that the degree of crystallization is below the detection limit).

\footnotetext{
4 Select glasses were initially submitted for XRD analysis based on a significant difference in the PCT response due to heat treatment, which may be indicative of nepheline or other crystalline formation and of the "negative" impact on the durability response in the ccc versions of these glasses. These included both quenched and ccc versions of NEPH-01, NEPH-02, NEPH-03, NEPH-04, and NEPH-09 (10 glasses total). That decision was made based solely on the PCT response and not visual observations of possible surface crystallization. To assess if the surface crystallization was nepheline or spinel (as presumed based on historical comparisons), all 24 glasses (both quenched and ccc of all 12 NEPH glasses) were submitted fro XRD analyses. Therefore, duplicate analyses are shown for select glasses.
} 


\subsection{RESULTS}

In this section, the results of the compositional assessment (target versus measured), the durability response, and the XRD results are presented. Initially the compositional results are presented to indicate that the measured compositions are in-line with the targeted compositions no significant batching errors were evident. The durability information for both quenched and ccc versions of each NEPH glass is then presented and discussed given it is the primary response variable of interest. The PCT results should provide a marker for those systems in which nepheline formation is likely. This section will flag or highlight significant differences observed between quenched and ccc versions of each glass. In addition, the acceptability of the NEPH glasses (measured releases compared to the EA glass benchmark) as well as the predictability of the glasses are also presented. Finally, visual and XRD results are presented which should support or provide a technical basis from which the impact (or lack thereof) of crystallization on durability can be assessed.

In this section, the measured versus targeted compositions of the twelve SB4 nepheline study glasses (NEPH-01 through NEPH-12) are presented and compared. The targeted compositions for these glasses are provided in Table C.1 of Appendix C. A sum of oxides column is provided in Table C.1 as well.

Table C.2 in Appendix C provides the elemental concentration measurements derived from the samples prepared using LM, and Table C.3 in Appendix C provides the measurements derived from the samples prepared using PF. Measurements for standards (Batch 1 and a uranium standard, $\mathrm{U}_{\text {std }}$ ) that were included in the SRNL-ML analytical plans along with the study glasses are also provided in these two tables. Also, note that the initial sodium values provided by the SRNL-ML appeared to be consistently higher than expected which led to the samples being remeasured for sodium by the SRNL-ML. The sodium values in Table C.2 are the remeasurements generated by the SRNL-ML.

The elemental concentrations were converted to oxide concentrations by multiplying the values for each element by the gravimetric factor for the corresponding oxide. During this process, an elemental concentration that was determined to be below the detection limit of the analytical procedures used by the SRNL-ML was reduced to half of that detection limit as the oxide concentration was determined.

In the sections that follow, the analytical sequences of the measurements are explored, the measurements of the standards are investigated and used for bias correction, the measurements for each glass are reviewed, the average chemical compositions (measured and bias-corrected) for each glass are determined, and comparisons are made between the measurements and the targeted compositions for the glasses.

\subsection{Measurements in Analytical Sequence}

Exhibit C.1 in Appendix C provides plots of the measurements generated by the SRNL-ML for samples prepared using the LM method. The plots are in analytical sequence with different symbols and colors being used to represent each of the study and standard glasses. Similar plots for the samples prepared using the PF method are provided in Exhibit C.2 in Appendix C. These plots include all of the measurement data from Tables C.2 and C.3. A review of these plots indicates no significant patterns or trends in the analytical process over the course of these 
measurements, and there appear to be no obvious outliers in these chemical composition measurements.

\subsubsection{Batch 1 and Uranium Standard Results}

In this section, the SRNL-ML measurements of the chemical compositions of the Batch 1 and $U_{\text {std }}$ glasses are reviewed. These measurements are investigated across the ICP-AES analytical blocks, and the results are used to bias correct the measurements for the study glasses.

Exhibit C.3 in Appendix C provides statistical analyses of the Batch 1 and $\mathrm{U}_{\text {std }}$ results generated by the LM prep method by block for each oxide of interest. The results include analysis of variance (ANOVA) investigations looking for statistically significant differences between the block means for each of the oxides for each of the standards. The results from the statistical tests for the Batch 1 standard may be summarized as follows: only $\mathrm{ZrO}_{2}$ has measurements that indicate a significant ICP-AES calibration effect on the block averages at the $5 \%$ significance level. For the $\mathrm{U}_{\text {std, }}$, only $\mathrm{ThO}_{2}$ has measurements that indicate a significant ICP-AES calibration effect on the block averages at the $5 \%$ significance level. This is probably an artifact of the detection limit for $\mathrm{ThO}_{2}$. The reference values for the oxide concentrations of the standards are given in the header for each set of measurements in the exhibit.

Exhibit C.4 in Appendix C provides a similar set of analyses for the measurements derived from samples prepared via the PF method. In this exhibit, none of the measurements for Batch 1 or for $\mathrm{U}_{\text {std }}$ indicate a significant ICP-AES calibration effect on these averages at the $5 \%$ significance level. The reference values for the oxide concentrations of the standards are given in the headers for each set of measurements in the exhibit.

The results provide little incentive for adjusting the measurements by the effect of the ICP-AES calibration; however, the average measurements do differ from the reference values for some of the oxides. See for example the analysis for $\mathrm{Na}_{2} \mathrm{O}$. In keeping with the analyses that have been conducted previously, the oxide measurements of the study glasses were bias-corrected (bc) for the effect of the ICP-AES calibration on each of the analytical blocks. The basis for this bias correction is presented as part of Exhibits C. 3 and C. 4 - the average measurement for Batch 1 for each ICP-AES set/block for $\mathrm{Al}_{2} \mathrm{O}_{3}, \mathrm{~B}_{2} \mathrm{O}_{3}, \mathrm{BaO}, \mathrm{CaO}, \mathrm{Cr}_{2} \mathrm{O}_{3}, \mathrm{CuO}, \mathrm{Fe}_{2} \mathrm{O}_{3}, \mathrm{Li}_{2} \mathrm{O}, \mathrm{MgO}, \mathrm{MnO}$, $\mathrm{Na}_{2} \mathrm{O}, \mathrm{NiO}, \mathrm{SiO}_{2}$, and $\mathrm{TiO}_{2}$ and the average measurement for $\mathrm{U}_{\text {std }}$ for each ICP-AES set/block for $\mathrm{U}_{3} \mathrm{O}_{8}$. The Batch 1 results served as the basis for bias correcting all of the oxides (that were bias corrected) except uranium. The $\mathrm{U}_{\text {std }}$ results were used to bias correct for uranium. For the other oxides, the Batch 1 results were used to conduct the bias correction as long as the reference value for the oxide concentration in the Batch 1 glass was greater than or equal to $0.1 \mathrm{wt} \%$. Thus, applying this approach and based upon the information in the exhibits, the Batch 1 results were used to bias correct the $\mathrm{Al}_{2} \mathrm{O}_{3}, \mathrm{~B}_{2} \mathrm{O}_{3}, \mathrm{BaO}, \mathrm{CaO}, \mathrm{Cr}_{2} \mathrm{O}_{3}, \mathrm{CuO}, \mathrm{Fe}_{2} \mathrm{O}_{3}, \mathrm{~K}_{2} \mathrm{O}, \mathrm{Li}_{2} \mathrm{O}, \mathrm{MgO}, \mathrm{MnO}$, $\mathrm{Na}_{2} \mathrm{O}, \mathrm{NiO}, \mathrm{SiO}_{2}$, and $\mathrm{TiO}_{2}$ measurements. No bias correction was conducted for $\mathrm{Ce}_{2} \mathrm{O}_{3}, \mathrm{La}_{2} \mathrm{O}_{3}$, $\mathrm{PbO}, \mathrm{SO}_{4}, \mathrm{ThO}_{2}, \mathrm{ZnO}$, or $\mathrm{ZrO}_{2}$.

The bias correction was conducted as follows. For each oxide, let $\overline{\mathrm{a}}_{\mathrm{ij}}$ be the average measurement for the $\mathrm{i}^{\text {th }}$ oxide at analytical block $\mathrm{j}$ for Batch 1 (or $\mathrm{U}_{\text {std }}$ for uranium), and let $\mathrm{t}_{\mathrm{i}}$ be the reference value for the $\mathrm{i}^{\text {th }}$ oxide for Batch 1 (or for $\mathrm{U}_{\text {std }}$ if uranium). (The averages and reference values are provided in Exhibits C.3 and C.4.) Let $\overline{\mathrm{c}}_{\mathrm{ijk}}$ be the average measurement for the $\mathrm{i}^{\text {th }}$ oxide at analytical block $\mathrm{j}$ for the $\mathrm{k}^{\text {th }}$ glass. The bias adjustment was conducted as follows: 


$$
\overline{\mathrm{c}}_{\mathrm{ijk}} \bullet\left(1-\frac{\overline{\mathrm{a}}_{\mathrm{ij}}-\mathrm{t}_{\mathrm{i}}}{\overline{\mathrm{a}}_{\mathrm{ij}}}\right)=\overline{\mathrm{c}}_{\mathrm{ijk}} \bullet \frac{\mathrm{t}_{\mathrm{i}}}{\overline{\mathrm{a}}_{\mathrm{ij}}}
$$

Bias-corrected measurements are indicated by a "bc" suffix, and such adjustments were performed for all of the oxides of this study except for $\mathrm{Ce}_{2} \mathrm{O}_{3}, \mathrm{La}_{2} \mathrm{O}_{3}, \mathrm{PbO}, \mathrm{SO}_{4}, \mathrm{ThO}_{2}, \mathrm{ZnO}$, and $\mathrm{ZrO}_{2}$. Both measured and measured "bc" values are included in the discussion that follows. In these discussions bias-corrected values for $\mathrm{Ce}_{2} \mathrm{O}_{3}, \mathrm{La}_{2} \mathrm{O}_{3}, \mathrm{PbO}, \mathrm{SO}_{4}, \mathrm{ThO}_{2}, \mathrm{ZnO}$, and $\mathrm{ZrO}_{2}$ are included for completeness (e.g., to allow a sum of oxides to be computed for the bias-corrected results). These bias-corrected values are the same as the original $\mathrm{Ce}_{2} \mathrm{O}_{3}, \mathrm{La}_{2} \mathrm{O}_{3}, \mathrm{PbO}, \mathrm{SO}_{4}, \mathrm{ThO}_{2}$, $\mathrm{ZnO}$, and $\mathrm{ZrO}_{2}$ values (i.e., once again, no bias correction was performed for this group of oxides).

\subsubsection{Composition Measurements by Glass Number}

Exhibits C.5 and C.6 in Appendix C provide plots of the oxide concentration measurements by Glass ID \# (including both Batch 1, labeled as glass numbered 100 and $U_{\text {std }}$, labeled as glass numbered 200) for the measured and bias-corrected values for the LM and PF preparation methods, respectively. Different symbols and colors are used to represent the different glasses. These plots show the individual measurements across the duplicates of each preparation method and the two ICP-AES calibrations. A review of the plots presented in these exhibits reveals the repeatability of the four individual, oxide values for each glass. There appears to be a good bit of scatter in the $\mathrm{Fe}_{2} \mathrm{O}_{3}, \mathrm{MnO}$, and $\mathrm{SiO}_{2}$ values. No other problems are evident in these plots.

More detailed discussions of the average, measured chemical compositions of the study glasses are provided in the sections that follow.

\subsubsection{Measured versus Targeted Compositions}

The four measurements for each oxide for each glass (over both preparation methods) were averaged to determine a representative chemical composition for each glass. These determinations were conducted both for the measured and for the bias-corrected data. Table 3-1 provides a summary of the target versus measured composition for the study glasses. Exhibit C.7 in Appendix C provides similar information (including the measured-bc compositional view) and highlights some of the oxides for which comparisons can be based.

Some general observations from Table 3-1 and the plots of Exhibit C.7 are offered. Considering the major oxides (i.e., $>0.5 \mathrm{wt} \%$ ) in glass, for nearly every nepheline study glass, the measured $\mathrm{Fe}_{2} \mathrm{O}_{3}, \mathrm{Li}_{2} \mathrm{O}, \mathrm{MnO}, \mathrm{NiO}$, and $\mathrm{SiO}_{2}$ values are less than their respective targeted concentrations (see shaded rows in Table 3-1). For $\mathrm{Na}_{2} \mathrm{O}$ the measured values for most of the study glasses fall above their respective targets for this oxide. The bias corrected values for most of these oxides fall nearer the targeted values.

Table C.4 in Appendix C provides a summary of the average compositions as well as the targeted compositions and some associated differences and relative differences. Notice that the targeted sums of oxides for the standard glasses do not sum to $100 \%$ due to an incomplete coverage of the oxides in the Batch 1 (glass \# 100) and $U_{\text {std }}$ (glass \# 200) glasses. All of the sums of oxides (both measured and bias-corrected) for the study glasses fall within the interval of 95 to $105 \mathrm{wt} \%$. 
Overall, these comparisons between the measured and targeted compositions suggest that there were some difficulties in hitting the targeted compositions for some of the oxides for some of the glasses. However, these differences were not seen as being of practical concern.

Table 3-1. Targeted and Measured Compositions (wt\%) of the NEPH Study Glasses.

\begin{tabular}{|c|c|c|c|c|c|c|c|c|c|c|c|c|}
\hline & \multicolumn{2}{|c|}{ NEPH-01 } & \multicolumn{2}{|c|}{ NEPH-02 } & \multicolumn{2}{|c|}{ NEPH-03 } & \multicolumn{2}{|c|}{ NEPH-04 } & \multicolumn{2}{|c|}{ NEPH-05 } & \multicolumn{2}{|c|}{ NEPH-06 } \\
\hline & Target & Meas. & Target & Meas. & Target & Meas. & Target & Meas. & Target & Meas. & Target & Meas. \\
\hline & (wt\%) & (wt\%) & (wt\%) & (wt\%) & (wt\%) & (wt\%) & (wt\%) & (wt\%) & (wt\%) & (wt\%) & (wt\%) & (wt\%) \\
\hline $\mathrm{Al}_{2} \mathrm{O}_{3}$ & 12.612 & 12.584 & 11.683 & 11.894 & 8.467 & 8.578 & 12.612 & 12.791 & 9.070 & 9.220 & 8.375 & 8.554 \\
\hline $\mathrm{B}_{2} \mathrm{O}_{3}$ & 4.800 & 4.676 & 4.800 & 4.572 & 4.800 & 4.749 & 4.800 & 4.749 & 4.800 & 4.741 & 4.800 & 4.636 \\
\hline $\mathrm{BaO}$ & 0.043 & 0.039 & 0.042 & 0.037 & 0.062 & 0.057 & 0.043 & 0.036 & 0.065 & 0.058 & 0.076 & 0.063 \\
\hline $\mathrm{CaO}$ & 0.884 & 0.890 & 0.839 & 0.810 & 0.848 & 0.853 & 0.884 & 0.867 & 0.893 & 0.899 & 0.723 & 0.735 \\
\hline $\mathrm{Ce}_{2} \mathrm{O}_{3}$ & 0.082 & 0.058 & 0.081 & 0.060 & 0.082 & 0.058 & 0.082 & 0.063 & 0.083 & 0.068 & 0.077 & 0.059 \\
\hline $\mathrm{Cr}_{2} \mathrm{O}_{3}$ & 0.092 & 0.102 & 0.087 & 0.089 & 0.096 & 0.103 & 0.092 & 0.091 & 0.101 & 0.099 & 0.105 & 0.103 \\
\hline $\mathrm{CuO}$ & 0.029 & 0.029 & 0.028 & 0.026 & 0.032 & 0.031 & 0.029 & 0.030 & 0.034 & 0.034 & 0.032 & 0.033 \\
\hline $\mathrm{Fe}_{2} \mathrm{O}_{3}$ & 9.087 & 8.442 & 8.701 & 7.909 & 9.897 & 9.243 & 9.087 & 8.367 & 10.404 & 9.671 & 9.240 & 8.392 \\
\hline $\mathrm{K}_{2} \mathrm{O}$ & 0.682 & 0.727 & 0.624 & 0.709 & 0.377 & 0.425 & 0.682 & 0.768 & 0.410 & 0.475 & 0.416 & 0.476 \\
\hline $\mathrm{La}_{2} \mathrm{O}_{3}$ & 0.034 & 0.027 & 0.034 & 0.026 & 0.036 & 0.026 & 0.034 & 0.025 & 0.037 & 0.029 & 0.034 & 0.024 \\
\hline $\mathrm{Li}_{2} \mathrm{O}$ & 4.800 & 4.596 & 4.800 & 4.655 & 4.800 & 4.687 & 4.800 & 4.693 & 4.800 & 4.698 & 4.800 & 4.698 \\
\hline $\mathrm{MgO}$ & 0.732 & 0.693 & 0.669 & 0.613 & 0.710 & 0.670 & 0.732 & 0.676 & 0.777 & 0.705 & 0.424 & 0.394 \\
\hline $\mathrm{MnO}$ & 1.913 & 1.791 & 1.905 & 1.723 & 2.289 & 2.172 & 1.913 & 1.785 & 2.335 & 2.220 & 2.352 & 2.188 \\
\hline $\mathrm{Na}_{2} \mathrm{O}$ & 16.348 & 17.085 & 16.987 & 17.456 & 16.682 & 17.085 & 13.948 & 14.423 & 16.011 & 16.546 & 16.504 & 17.018 \\
\hline $\mathrm{NiO}$ & 0.583 & 0.501 & 0.579 & 0.460 & 1.400 & 1.220 & 0.583 & 0.491 & 1.486 & 1.301 & 2.254 & 1.918 \\
\hline $\mathrm{PbO}$ & 0.081 & 0.071 & 0.078 & 0.063 & 0.065 & 0.056 & 0.081 & 0.068 & 0.066 & 0.059 & 0.063 & 0.055 \\
\hline $\mathrm{SO}_{4}$ & 0.442 & 0.393 & 0.508 & 0.423 & 0.506 & 0.462 & 0.442 & 0.391 & 0.439 & 0.394 & 0.504 & 0.446 \\
\hline $\mathrm{SiO}_{2}$ & 44.482 & 43.106 & 44.38 & 42.893 & 44.218 & 43.263 & 46.882 & 46.109 & 44.293 & 43.428 & 44.055 & 43.267 \\
\hline $\mathrm{ThO}_{2}$ & 0.020 & 0.092 & 0.018 & 0.087 & 0.013 & 0.132 & 0.020 & 0.091 & 0.014 & 0.136 & 0.011 & 0.146 \\
\hline $\mathrm{TiO}_{2}$ & 0.010 & 0.010 & 0.979 & 0.967 & 0.977 & 0.909 & 0.010 & 0.007 & 0.009 & 0.007 & 0.975 & 0.910 \\
\hline $\mathrm{U}_{3} \mathrm{O}_{8}$ & 2.111 & 2.001 & 2.036 & 1.998 & 3.489 & 3.351 & 2.111 & 2.001 & 3.711 & 3.455 & 4.013 & 3.723 \\
\hline $\mathrm{ZnO}$ & 0.040 & 0.042 & 0.039 & 0.038 & 0.049 & 0.067 & 0.040 & 0.039 & 0.051 & 0.053 & 0.050 & 0.055 \\
\hline $\mathrm{ZrO}_{2}$ & 0.095 & 0.090 & 0.094 & 0.083 & 0.109 & 0.100 & 0.095 & 0.084 & 0.112 & 0.101 & 0.120 & 0.109 \\
\hline
\end{tabular}


Table 3-1. Targeted and Measured Compositions (wt\%) of the Nepheline Study Glasses. (cont'd)

\begin{tabular}{|c|c|c|c|c|c|c|c|c|c|c|c|c|}
\hline & \multicolumn{2}{|c|}{ NEPH-07 } & \multicolumn{2}{|c|}{ NEPH-08 } & \multicolumn{2}{|c|}{ NEPH-09 } & \multicolumn{2}{|c|}{ NEPH-10 } & \multicolumn{2}{|c|}{ NEPH-11 } & \multicolumn{2}{|c|}{ NEPH-12 } \\
\hline & Target & Meas. & Target & Meas. & Target & Meas. & Target & Meas. & Target & Meas. & Target & Meas. \\
\hline & (wt\%) & (wt\%) & (wt\%) & (wt\%) & (wt\%) & (wt\%) & (wt\%) & (wt\%) & (wt\%) & (wt\%) & (wt\%) & (wt\%) \\
\hline $\mathrm{Al}_{2} \mathrm{O}_{3}$ & 8.969 & 9.343 & 11.683 & 12.012 & 11.035 & 11.228 & 8.097 & 8.257 & 8.664 & 8.885 & 10.222 & 10.430 \\
\hline $\mathrm{B}_{2} \mathrm{O}_{3}$ & 4.800 & 4.717 & 4.800 & 4.668 & 5.200 & 5.087 & 4.800 & 4.725 & 4.800 & 4.741 & 5.200 & 5.031 \\
\hline $\mathrm{BaO}$ & 0.080 & 0.077 & 0.042 & 0.036 & 0.038 & 0.031 & 0.062 & 0.056 & 0.065 & 0.061 & 0.037 & 0.033 \\
\hline $\mathrm{CaO}$ & 0.756 & 0.737 & 0.839 & 0.816 & 0.774 & 0.760 & 0.859 & 0.861 & 0.905 & 0.893 & 0.734 & 0.729 \\
\hline $\mathrm{Ce}_{2} \mathrm{O}_{3}$ & 0.078 & 0.060 & 0.081 & 0.056 & 0.072 & 0.048 & 0.081 & 0.066 & 0.083 & 0.061 & 0.071 & 0.055 \\
\hline $\mathrm{Cr}_{2} \mathrm{O}_{3}$ & 0.111 & 0.102 & 0.087 & 0.089 & 0.080 & 0.081 & 0.094 & 0.100 & 0.100 & 0.096 & 0.076 & 0.087 \\
\hline $\mathrm{CuO}$ & 0.034 & 0.036 & 0.028 & 0.028 & 0.025 & 0.024 & 0.032 & 0.031 & 0.033 & 0.035 & 0.024 & 0.023 \\
\hline $\mathrm{Fe}_{2} \mathrm{O}_{3}$ & 9.680 & 8.867 & 8.701 & 7.859 & 7.951 & 7.616 & 10.080 & 9.414 & 10.613 & 9.743 & 7.613 & 6.912 \\
\hline $\mathrm{K}_{2} \mathrm{O}$ & 0.454 & 0.494 & 0.624 & 0.724 & 0.597 & 0.673 & 0.334 & 0.380 & 0.363 & 0.384 & 0.546 & 0.604 \\
\hline $\mathrm{La}_{2} \mathrm{O}_{3}$ & 0.035 & 0.025 & 0.034 & 0.025 & 0.030 & 0.021 & 0.036 & 0.027 & 0.037 & 0.029 & 0.029 & 0.023 \\
\hline $\mathrm{Li}_{2} \mathrm{O}$ & 4.800 & 4.752 & 4.800 & 4.720 & 5.200 & 5.080 & 4.800 & 4.693 & 4.800 & 4.704 & 5.200 & 5.064 \\
\hline $\mathrm{MgO}$ & 0.462 & 0.444 & 0.669 & 0.622 & 0.641 & 0.580 & 0.784 & 0.720 & 0.859 & 0.818 & 0.585 & 0.556 \\
\hline $\mathrm{MnO}$ & 2.404 & 2.259 & 1.905 & 1.720 & 1.674 & 1.568 & 2.387 & 2.266 & 2.443 & 2.314 & 1.667 & 1.507 \\
\hline $\mathrm{Na}_{2} \mathrm{O}$ & 15.816 & 16.344 & 14.587 & 15.165 & 15.805 & 16.209 & 16.659 & 17.220 & 15.987 & 16.344 & 16.364 & 16.816 \\
\hline $\mathrm{NiO}$ & 2.426 & 2.053 & 0.579 & 0.481 & 0.510 & 0.436 & 1.425 & 1.251 & 1.514 & 1.313 & 0.507 & 0.414 \\
\hline $\mathrm{PbO}$ & 0.064 & 0.061 & 0.078 & 0.064 & 0.071 & 0.061 & 0.062 & 0.056 & 0.063 & 0.061 & 0.068 & 0.058 \\
\hline $\mathrm{SO}_{4}$ & 0.438 & 0.392 & 0.508 & 0.433 & 0.386 & 0.333 & 0.506 & 0.460 & 0.439 & 0.380 & 0.444 & 0.388 \\
\hline $\mathrm{SiO}_{2}$ & 44.114 & 43.641 & 46.789 & 45.888 & 47.921 & 47.111 & 44.225 & 43.267 & 44.301 & 43.588 & 47.840 & 46.315 \\
\hline $\mathrm{ThO}_{2}$ & 0.012 & 0.167 & 0.018 & 0.085 & 0.017 & 0.079 & 0.012 & 0.132 & 0.014 & 0.151 & 0.016 & 0.076 \\
\hline $\mathrm{TiO}_{2}$ & 0.006 & 0.014 & 0.979 & 0.917 & 0.009 & 0.007 & 0.978 & 0.932 & 0.009 & 0.017 & 0.856 & 0.808 \\
\hline $\mathrm{U}_{3} \mathrm{O}_{8}$ & 4.287 & 4.206 & 2.036 & 1.948 & 1.847 & 1.807 & 3.528 & 3.404 & 3.753 & 3.687 & 1.781 & 1.724 \\
\hline $\mathrm{ZnO}$ & 0.052 & 0.058 & 0.039 & 0.042 & 0.035 & 0.035 & 0.048 & 0.054 & 0.050 & 0.053 & 0.035 & 0.035 \\
\hline $\mathrm{ZrO}_{2}$ & 0.124 & 0.114 & 0.094 & 0.086 & 0.083 & 0.074 & 0.105 & 0.096 & 0.107 & 0.102 & 0.082 & 0.078 \\
\hline
\end{tabular}

Given slight differences between the measured and targeted compositions (in particular differences among the oxides contained in the nepheline discriminator function), one may question the impact of these differences on the classification of nepheline formation potential. The nepheline discriminator values were originally based on the targeted compositions, but the values were also assessed on the measured and measured-bias corrected compositions as well (see Table 3-2) to see if differences in classification would exist. That is, based on the measured or measure-bc values would any of the NEPH glasses be reclassified as being prone to nepheline formation or vice-versa? Based on the measured and measured-bias corrected compositions, only NEPH-01 and -02 are prone to the formation of nepheline, using the 0.62 discriminator value consistent with the targeted compositional views. 
Table 3-2. Nepheline Discriminator Values based on Compositional View. ${ }^{5}$

\begin{tabular}{|c|c|c|c|c|c|c|}
\hline Glass ID & $\begin{array}{l}\text { Comp. } \\
\text { view }\end{array}$ & $\begin{array}{c}\text { Nepheline } \\
\text { Value }\end{array}$ & $\begin{array}{c}\text { Comp. } \\
\text { view }\end{array}$ & $\begin{array}{c}\text { Nepheline } \\
\text { Value }\end{array}$ & $\begin{array}{c}\text { Comp. } \\
\text { view }\end{array}$ & $\begin{array}{c}\text { Nepheline } \\
\text { Value }\end{array}$ \\
\hline NEPH-01 & target & 0.606 & measured & 0.592 & measured-bc & 0.602 \\
\hline NEPH-02 & target & 0.608 & measured & 0.594 & measured-bc & 0.604 \\
\hline NEPH-03 & target & 0.637 & measured & 0.628 & measured-bc & 0.639 \\
\hline NEPH-04 & target & 0.638 & measured & 0.629 & measured-bc & 0.638 \\
\hline NEPH-05 & target & 0.638 & measured & 0.628 & measured-bc & 0.638 \\
\hline NEPH-06 & target & 0.639 & measured & 0.629 & measured-bc & 0.639 \\
\hline NEPH-07 & target & 0.64 & measured & 0.629 & measured-bc & 0.64 \\
\hline NEPH-08 & target & 0.64 & measured & 0.628 & measured-bc & 0.638 \\
\hline NEPH-09 & target & 0.641 & measured & 0.632 & measured-bc & 0.642 \\
\hline NEPH-10 & target & 0.641 & measured & 0.629 & measured-bc & 0.64 \\
\hline NEPH-11 & target & 0.642 & measured & 0.633 & measured-bc & 0.644 \\
\hline NEPH-12 & target & 0.643 & measured & 0.63 & measured-bc & 0.64 \\
\hline
\end{tabular}

Shaded cells indicate "prone to nepheline" formation based on the 0.62 value.

\subsection{A Statistical Review of the PCT Measurements}

Table D.1 in Appendix D provides the elemental leachate concentration measurements determined by the SRNL-ML for the solution samples generated by the PCTs. One of the quality control checkpoints for the PCT procedure is solution-weight loss over the course of the 7-day test. None of these PCT results indicated a solution-weight loss problem. However, one sample (x33) ${ }^{6}$ was inadvertently spilled and lost (as indicated in Table D.1). No measurements were possible for this sample. Any measurement in Table D.1 below the detection limit of the analytical procedure (indicated by a "<”) was replaced by $1 / 2$ of the detection limit in subsequent analyses. In addition to adjustments for detection limits, the values were adjusted for the acid dilution factors: the values for the study glasses, the blanks, and the ARM glass in Table D.1 were multiplied by 1.6667 to determine the values in parts per million (ppm) and the values for EA were multiplied by 16.6667 due to a greater dilution factor. Table D.2 in Appendix D provides the resulting measurements.

One of the important objectives of this study is the investigation of the effects of the heat treatment on the PCTs. In the sections that follow, the analytical sequence of the measurements is explored, the measurements of the standards are investigated and used to assess the overall accuracy of the ICP-AES measurement process, the measurements for each glass are reviewed, plots are provided that explore the effects of heat treatment on the PCTs for these glasses, the PCTs are normalized using the compositions (targeted, measured, and bias-corrected) presented in Table C.4, and the normalized PCTs are compared to durability predictions for these compositions generated from the current DWPF models (Jantzen et al., 1995).

\subsubsection{Measurements in Analytical Sequence}

Exhibits D.1 and D.2 in Appendix D provide plots of the leachate (ppm) concentrations in analytical sequence as generated by the SRNL-ML for all of the data and excluding EA, respectively. A different color and symbol is used for each study glass or standard. No problems are seen in these plots.

\footnotetext{
5 Nepheline discriminator values for the quenched and ccc heat treatments are the same.

6 “x33” was one of the triplicate PCT samples from NEPH-11ccc (see Appendix B).
} 


\subsubsection{Results for the Samples of the Multi-Element Solution Standard}

Exhibit D.3 in Appendix D provides analyses of the SRNL-ML measurements of the samples of the multi-element solution standard by ICP-AES analytical (or calibration) block. An ANOVA investigating for statistically significant differences among the block averages for these samples for each element of interest is included in these exhibits. These results indicate a statistically significant (at the $5 \%$ level) difference among the $\mathrm{Fe}, \mathrm{Li}$, and $\mathrm{Si}$ average measurements over these blocks. However, no bias correction of the PCT results for the study glasses was conducted. This approach was taken since the triplicate PCTs for a single study glass were placed in different ICPAES blocks. Averaging the ppm's for each set of triplicates helps to minimize the impact of the ICP-AES effects.

Table 3-3 summarizes the average measurements and the reference values for the 4 primary elements of interest. The results indicate consistent and accurate measurements from the SRNLML processes used to conduct these analyses.

Table 3-3. Results from samples of the multi-element solution standard

\begin{tabular}{|c|c|c|c|c||}
\hline $\begin{array}{c}\text { Analytical } \\
\text { Block }\end{array}$ & $\begin{array}{c}\text { Avg B } \\
\text { (ppm) }\end{array}$ & $\begin{array}{c}\text { Avg Li } \\
\text { (ppm) }\end{array}$ & $\begin{array}{c}\text { Avg Na } \\
\text { (ppm) }\end{array}$ & $\begin{array}{c}\text { Avg Si } \\
\text { (ppm) }\end{array}$ \\
\hline 1 & 20.10 & 9.66 & 80.97 & 51.30 \\
\hline 2 & 20.03 & 9.60 & 80.80 & 51.33 \\
\hline 3 & 19.90 & 9.60 & 82.03 & 52.13 \\
\hline 4 & 20.40 & 9.71 & 80.90 & 52.30 \\
\hline 5 & 20.67 & 9.81 & 81.57 & 52.77 \\
\hline 6 & 20.33 & 9.69 & 81.50 & 52.37 \\
\hline Grand Average & 20.24 & 9.68 & 81.29 & 52.03 \\
\hline Reference Value & 20.00 & 10.00 & 81.00 & 50.00 \\
\hline \% difference & $1.2 \%$ & $-3.2 \%$ & $0.4 \%$ & $4.1 \%$ \\
\hline
\end{tabular}

\subsubsection{Measurements by Glass Number}

Exhibits D.4 and D.5 in Appendix D provide plots of the leachate concentrations for each type of submitted sample: the study glasses and the standards (EA, ARM, the multi-element solution standard, and blanks) with and without EA, respectively. These plots allow for the assessment of the repeatability of the measurements, which suggests some scatter in the triplicate values for some analytes for some of the glasses. Also, note that the results from the two heat treatments are shown for each study glass and that some differences between the two sets of values are evident.

\subsubsection{Normalized PCT Results}

PCT leachate concentrations are typically normalized using the cation composition (expressed as a weight percent) in the glass to obtain a grams per liter $(\mathrm{g} / \mathrm{L})$ leachate concentration (see Table 3-4). The normalization of the PCTs is usually conducted using the measured compositions of the glasses. This is the preferred normalization process for the PCTs. For completeness, the targeted cation and the bias-corrected cation compositions were also used to conduct this normalization.

As is the usual convention, the common logarithm of the normalized PCT (normalized leachate, $\mathrm{NL}$ ) for each element of interest was determined and used for comparison. To accomplish this computation, one must: 
1. Determine the common logarithm of the elemental parts per million (ppm) leachate concentration for each of the triplicates and each of the elements of interest (these values are provided in Table D.2 of Appendix D),

2. Average the common logarithms over the triplicates for each element of interest, and then

3. Normalizing using measured composition (preferred method) - Subtract a quantity equal to 1 plus the common logarithm of the average cation measured concentration (expressed as a weight percent of the glass) from the average computed in step 2; $\boldsymbol{O R}$

3. Normalizing using target composition - Subtract a quantity equal to 1 plus the common logarithm of the target cation concentration (expressed as a weight percent of the glass) from the average computed in step 2; $\boldsymbol{O R}$

3. Normalizing using measured bias-corrected composition - Subtract a quantity equal to 1 plus the common logarithm of the measured bias-corrected cation concentration (expressed as a weight percent of the glass) from the average computed in step 2.

Exhibit D.7 in Appendix D provides scatter plots for these results and offers an opportunity to investigate the consistency in the leaching across the elements for the glasses of this study. All normalizations of the PCTs (i.e., those generated using the targeted, measured, and bias-corrected compositional views) and both heat treatments are represented in these plots.

Consistency in the leaching across the elements is typically demonstrated by a high degree of linear correlation among the values for pairs of these elements. A high degree of correlation is seen for most of these data for most of the pairs of the elements; the smallest correlation (76.62\%) is for the $\mathrm{Li}$ and $\mathrm{Na}$ ccc data for the measured and measured bc compositional views.

Table 3-4. Normalized PCTs by Glass ID/Heat Treatment/Compositional View.

\begin{tabular}{|c|c|c|c|c|c|c|c|c|c|c|}
\hline $\begin{array}{c}\text { Glass } \\
\text { ID }\end{array}$ & \begin{tabular}{c|c|} 
Heat \\
Treatment
\end{tabular} & Composition & $\begin{array}{l}\log N \mathrm{NL} \\
{[\mathrm{B}(\mathrm{g} / \mathrm{L})]} \\
\end{array}$ & \begin{tabular}{|c|}
$\log N L$ \\
{$[\mathrm{Li}(\mathrm{g} / \mathrm{L})]$}
\end{tabular} & $\begin{array}{c}\log \mathrm{NL} \\
{[\mathrm{Na}(\mathrm{g} / \mathrm{L})]}\end{array}$ & $\begin{array}{c}\log N \mathrm{NL} \\
{[\mathrm{Si}(\mathrm{g} / \mathrm{L})]}\end{array}$ & $\begin{array}{c}\mathbf{N L} \\
\mathbf{B}(\mathbf{g} / \mathbf{L}) \\
\end{array}$ & $\begin{array}{c}\text { NL } \\
\text { Li(g/L) }\end{array}$ & $\begin{array}{c}\mathrm{NL} \\
\mathrm{Na}(\mathrm{g} / \mathrm{L}) \\
\end{array}$ & $\begin{array}{c}\text { NL } \\
\text { Si(g/L) } \\
\end{array}$ \\
\hline ARM & \begin{tabular}{|c|}
- \\
\end{tabular} & reference & -0.223 & -0.189 & -0.247 & -0.489 & 0.60 & 0.65 & 0.57 & 0.32 \\
\hline EA & - & reference & 1.257 & 0.973 & 1.149 & 0.638 & 18.06 & 9.41 & 14.09 & 4.34 \\
\hline NEPH-01 & quenched & measured & -0.124 & -0.128 & -0.004 & -0.238 & 0.75 & 0.74 & 0.99 & 0.58 \\
\hline NEPH-01 & quenched & measured bc & -0.128 & -0.126 & 0.019 & -0.244 & 0.75 & 0.75 & 1.05 & 0.57 \\
\hline NEPH-01 & quenched & target & -0.135 & -0.147 & 0.015 & -0.252 & 0.73 & 0.71 & 1.04 & 0.56 \\
\hline NEPH-01ccC & CCC & measured & 0.392 & 0.436 & 0.168 & 0.019 & 2.47 & 2.73 & 1.47 & 1.04 \\
\hline NEPH-01cCC & CCC & measured bc & 0.388 & 0.438 & 0.191 & 0.014 & 2.44 & 2.74 & 1.55 & 1.03 \\
\hline NEPH-01ccC & CCC & target & 0.381 & 0.417 & 0.187 & 0.005 & 2.40 & 2.61 & 1.54 & 1.01 \\
\hline NEPH-02 & quenched & measured & -0.075 & -0.093 & 0.072 & -0.187 & 0.84 & 0.81 & 1.18 & 0.65 \\
\hline NEPH-02 & quenched & measured bc & -0.079 & -0.091 & 0.095 & -0.193 & 0.83 & 0.81 & 1.25 & 0.64 \\
\hline NEPH-02 & quenched & \begin{tabular}{|c|} 
target \\
\end{tabular} & -0.096 & -0.107 & 0.084 & -0.202 & 0.80 & 0.78 & 1.21 & 0.63 \\
\hline NEPH-02ccC & CCC & measured & 0.171 & 0.131 & 0.115 & -0.092 & 1.48 & 1.35 & 1.30 & 0.81 \\
\hline NEPH-02ccC & CCC & measured bc & 0.167 & 0.134 & 0.139 & -0.098 & 1.47 & 1.36 & 1.38 & 0.80 \\
\hline NEPH-02ccC & CCC & target & 0.150 & 0.118 & 0.127 & -0.107 & 1.41 & 1.31 & 1.34 & 0.78 \\
\hline NEPH-03 & quenched & measured & 0.076 & 0.033 & 0.155 & -0.084 & 1.19 & 1.08 & 1.43 & 0.82 \\
\hline NEPH-03 & quenched & measured bc & 0.072 & 0.035 & 0.178 & -0.089 & 1.18 & 1.08 & 1.51 & 0.81 \\
\hline NEPH-03 & quenched & target & 0.071 & 0.023 & 0.165 & -0.093 & 1.18 & 1.05 & 1.46 & 0.81 \\
\hline NEPH-03ccc & CCC & measured & 0.047 & 0.050 & 0.122 & -0.097 & 1.12 & 1.12 & 1.32 & 0.80 \\
\hline NEPH-03ccC & $\mathrm{CCC}$ & measured bc & 0.043 & 0.053 & 0.145 & -0.102 & 1.11 & 1.13 & 1.40 & 0.79 \\
\hline NEPH-03ccC & CCC & target & 0.043 & 0.040 & 0.132 & -0.106 & 1.10 & 1.10 & 1.36 & 0.78 \\
\hline NEPH-04 & quenched & measured & -0.213 & -0.173 & -0.144 & -0.317 & 0.61 & 0.67 & 0.72 & 0.48 \\
\hline
\end{tabular}




\begin{tabular}{|c|c|c|c|c|c|c|c|c|c|c|}
\hline $\begin{array}{c}\text { Glass } \\
\text { ID }\end{array}$ & \begin{tabular}{c|} 
Heat \\
Treatment
\end{tabular} & Composition & \begin{tabular}{|l}
$\log N \mathrm{~L}$ \\
{$[\mathrm{~B}(\mathrm{~g} / \mathrm{L})]$}
\end{tabular} & \begin{tabular}{|c|}
$\log N L$ \\
{$[\operatorname{Li}(g / L)]$}
\end{tabular} & \begin{tabular}{|c|}
$\log \mathrm{NL}$ \\
{$[\mathrm{Na}(\mathrm{g} / \mathrm{L})]$}
\end{tabular} & \begin{tabular}{|c|}
$\log N L$ \\
{$[\mathrm{Si}(\mathrm{g} / \mathrm{L})]$}
\end{tabular} & $\begin{array}{c}\mathbf{N L} \\
\mathrm{B}(\mathrm{g} / \mathrm{L})\end{array}$ & \begin{tabular}{|c|}
$\mathrm{NL}$ \\
$\mathrm{Li}(\mathrm{g} / \mathrm{L})$ \\
\end{tabular} & \begin{tabular}{|c|}
$\mathbf{N L}$ \\
$\mathrm{Na}(\mathbf{g} / \mathbf{L})$
\end{tabular} & $\begin{array}{c}\mathbf{N L} \\
\mathrm{Si}(\mathrm{g} / \mathrm{L})\end{array}$ \\
\hline NEPH-04 & quenched & measured bc & \begin{tabular}{|l|}
-0.217 \\
\end{tabular} & \begin{tabular}{|l|}
-0.171 \\
\end{tabular} & -0.120 & -0.322 & 0.61 & \begin{tabular}{|l|}
0.68 \\
\end{tabular} & \begin{tabular}{|l|}
0.76 \\
\end{tabular} & 0.48 \\
\hline NEPH-04 & quenched & target & -0.217 & -0.183 & -0.129 & -0.324 & 0.61 & 0.66 & 0.74 & 0.47 \\
\hline NEPH-04CCC & CCC & measured & -0.151 & -0.126 & -0.150 & -0.303 & 0.71 & 0.75 & 0.71 & 0.50 \\
\hline NEPH-04ccc & CCC & measured bc & -0.155 & -0.124 & -0.126 & -0.308 & 0.70 & 0.75 & 0.75 & 0.49 \\
\hline NEPH-04ccc & CCC & target & -0.155 & -0.136 & -0.135 & -0.310 & 0.70 & 0.73 & 0.73 & 0.49 \\
\hline NEPH-05 & quenched & measured & 0.036 & 0.008 & 0.116 & -0.138 & 1.09 & 1.02 & 1.31 & 0.73 \\
\hline NEPH-05 & quenched & measured bc & 0.032 & 0.010 & 0.139 & -0.143 & 1.08 & 1.02 & 1.38 & 0.72 \\
\hline NEPH-05 & quenched & target & 0.031 & -0.001 & 0.130 & -0.146 & 1.07 & 1.00 & 1.35 & 0.71 \\
\hline NEPH-05ccC & CCC & measured & 0.027 & 0.030 & 0.087 & -0.130 & 1.06 & 1.07 & 1.22 & 0.74 \\
\hline NEPH-05ccC & CCC & measured bc & 0.023 & 0.032 & 0.111 & -0.135 & 1.05 & 1.08 & 1.29 & 0.73 \\
\hline NEPH-05ccC & CCC & target & 0.021 & 0.021 & 0.101 & -0.139 & 1.05 & 1.05 & 1.26 & 0.73 \\
\hline NEPH-06 & quenched & measured & 0.077 & 0.044 & 0.168 & -0.090 & 1.19 & 1.11 & 1.47 & 0.81 \\
\hline NEPH-06 & quenched & measured bc & 0.073 & 0.047 & 0.192 & -0.095 & 1.18 & 1.11 & 1.56 & 0.80 \\
\hline NEPH-06 & quenched & target & 0.062 & 0.035 & 0.182 & -0.098 & 1.15 & 1.08 & 1.52 & 0.80 \\
\hline NEPH-06ccC & CCC & measured & 0.017 & 0.084 & 0.140 & -0.062 & 1.04 & 1.21 & 1.38 & 0.87 \\
\hline NEPH-06ccC & CCC & measured bc & 0.013 & 0.087 & 0.164 & -0.067 & 1.03 & 1.22 & 1.46 & 0.86 \\
\hline NEPH-06ccC & CCC & target & 0.002 & 0.075 & 0.154 & -0.069 & 1.00 & 1.19 & 1.42 & 0.85 \\
\hline NEPH-07 & quenched & measured & 0.038 & 0.005 & 0.116 & -0.141 & 1.09 & 1.01 & 1.31 & 0.72 \\
\hline NEPH-07 & quenched & measured bc & 0.034 & 0.007 & 0.140 & -0.146 & 1.08 & 1.02 & 1.38 & 0.71 \\
\hline NEPH-07 & quenched & target & 0.030 & 0.001 & 0.130 & -0.145 & 1.07 & 1.00 & 1.35 & 0.72 \\
\hline NEPH-07ccC & CCC & measured & -0.017 & 0.053 & 0.097 & -0.116 & 0.96 & 1.13 & 1.25 & 0.77 \\
\hline NEPH-07ccC & CCC & measured bc & -0.021 & 0.055 & 0.121 & -0.121 & 0.95 & 1.14 & 1.32 & 0.76 \\
\hline NEPH-07ccC & CCC & target & -0.025 & 0.049 & 0.112 & -0.121 & 0.94 & 1.12 & 1.29 & 0.76 \\
\hline NEPH-08 & quenched & measured & -0.161 & -0.135 & -0.077 & -0.264 & 0.69 & 0.73 & 0.84 & 0.54 \\
\hline NEPH-08 & quenched & measured bc & -0.165 & -0.133 & -0.053 & -0.269 & 0.68 & 0.74 & 0.88 & 0.54 \\
\hline NEPH-08 & quenched & target & -0.174 & -0.142 & -0.060 & -0.272 & 0.67 & 0.72 & 0.87 & 0.53 \\
\hline NEPH-08ccc & CCC & measured & -0.182 & -0.138 & -0.120 & -0.278 & 0.66 & 0.73 & 0.76 & 0.53 \\
\hline NEPH-08ccC & CCC & measured bc & -0.186 & -0.136 & -0.097 & -0.283 & 0.65 & 0.73 & 0.80 & 0.52 \\
\hline NEPH-08ccc & CCC & target & -0.194 & -0.145 & -0.103 & -0.286 & 0.64 & 0.72 & 0.79 & 0.52 \\
\hline NEPH-09 & quenched & measured & -0.135 & -0.062 & 0.032 & -0.201 & 0.73 & 0.87 & 1.08 & 0.63 \\
\hline NEPH-09 & quenched & measured bc & -0.139 & -0.060 & 0.056 & -0.207 & 0.73 & 0.87 & 1.14 & 0.62 \\
\hline NEPH-09 & quenched & target & -0.145 & -0.072 & 0.043 & -0.209 & 0.72 & 0.85 & 1.10 & 0.62 \\
\hline NEPH-09ccC & CCC & measured & -0.056 & 0.038 & 0.010 & -0.155 & 0.88 & 1.09 & 1.02 & 0.70 \\
\hline NEPH-09ccC & CCC & measured bc & -0.060 & 0.041 & 0.034 & -0.161 & 0.87 & 1.10 & 1.08 & 0.69 \\
\hline NEPH-09ccC & CCC & target & -0.065 & 0.028 & 0.021 & -0.163 & 0.86 & 1.07 & 1.05 & 0.69 \\
\hline SNEPH-10 & quenched & measured & 0.094 & 0.058 & 0.170 & -0.082 & 1.24 & 1.14 & 1.48 & 0.83 \\
\hline NEPH-10 & quenched & measured bc & 0.090 & 0.060 & 0.193 & -0.087 & 1.23 & 1.15 & 1.56 & 0.82 \\
\hline NEPH-10 & quenched & target & 0.087 & 0.048 & 0.184 & -0.092 & 1.22 & 1.12 & 1.53 & 0.81 \\
\hline NEPH-10ccc & CCC & measured & 0.060 & 0.068 & 0.128 & -0.087 & 1.15 & 1.17 & 1.34 & 0.82 \\
\hline NEPH-10ccC & CCC & measured bc & 0.056 & 0.070 & 0.152 & -0.092 & 1.14 & 1.18 & 1.42 & 0.81 \\
\hline NEPH-10ccC & CCC & target & 0.053 & 0.058 & 0.143 & -0.096 & 1.13 & 1.14 & 1.39 & 0.80 \\
\hline NEPH-11 & quenched & measured & & & & -0.127 & 1.14 & 1.07 & 1.36 & 0.75 \\
\hline NEPH-11 & quenched & measured bc & 0.054 & 0.032 & 0.156 & -0.132 & 1.13 & 1.08 & 1.43 & 0.74 \\
\hline NEPH-11 & quenched & target & 0.052 & 0.021 & 0.143 & -0.134 & 1.13 & 1.05 & 1.39 & 0.73 \\
\hline NEPH-11ccC & CCC & measured & 0.046 & 0.045 & 0.095 & -0.129 & 1.11 & 1.11 & 1.24 & 0.74 \\
\hline NEPH-11ccC & CCC & measured bc & 0.042 & 0.048 & 0.118 & -0.135 & 1.10 & 1.12 & 1.31 & 0.73 \\
\hline NEPH-11ccC & $\mathrm{CCC}$ & target & 0.041 & 0.037 & 0.105 & -0.136 & 1.10 & 1.09 & 1.27 & 0.73 \\
\hline NEPH-12 & quenched & measured & -0.088 & -0.041 & 0.077 & -0.141 & 0.82 & 0.91 & 1.19 & 0.72 \\
\hline NEPH-12 & quenched & measured bc & -0.092 & -0.039 & 0.100 & -0.146 & 0.81 & 0.91 & 1.26 & 0.71 \\
\hline NEPH-12 & quenched & target & -0.103 & -0.053 & 0.088 & -0.155 & 0.79 & 0.89 & 1.23 & 0.70 \\
\hline NEPH-12ccC & CCC & measured & -0.093 & -0.037 & 0.026 & -0.151 & 0.81 & 0.92 & 1.06 & 0.71 \\
\hline NEPH-12ccC & CCC & measured bc & -0.097 & -0.035 & 0.050 & -0.157 & 0.80 & 0.92 & 1.12 & 0.70 \\
\hline NEPH-12ccC & CCC & target & -0.107 & -0.048 & 0.038 & -0.165 & 0.78 & 0.89 & 1.09 & 0.68 \\
\hline
\end{tabular}

reference - see Jantzen et al. (1995) 


\subsubsection{Acceptability of the Nepheline Study Glasses and Predictability of the $\Delta$ GP Model}

As seen in Table 3-4, the durabilities for the nepheline study glasses are much better than those of EA (this is indicated for a glass by its normalized leachate being smaller than that of EA). The most durable glass is NEPH-04 (quenched) with a NL [B] of $0.61 \mathrm{~g} / \mathrm{L}$ (based on target, measured, and measured-bc compositions), while the least durable glass is NEPH-01 (ccc) with a NL [B] of $2.47 \mathrm{~g} / \mathrm{L}$ (based on the measured composition). Therefore, in terms of "acceptability", the results indicate that all NEPH glasses are acceptable with respect to durability as compared to the EA glass with a NL [B] of $16.695 \mathrm{~g} / \mathrm{L}$ (value from Jantzen et al., 1993), regardless of the presence of nepheline or any other crystalline phases (see Section 3.4 for more information).

Exhibit D.8 in Appendix D provides plots of the DWPF models that relate the logarithm of the normalized PCT (for each element of interest) to a linear function of a free energy of hydration term $\left(\Delta \mathrm{G}_{\mathrm{p}}, \mathrm{kcal} / 100 \mathrm{~g}\right.$ glass) derived from each of the glass compositional views (Jantzen et al., $1995)$ - the plot for the boron durability predictions is shown in Figure 3-1. Prediction limits, at a 95\% confidence, for an individual PCT result are plotted along with the linear fit. The EA and ARM results are also indicated on all plots (see Figure 3-1 and Exhibit D.8). As shown in Figure $3-1$, most of the study glasses are predictable by the $\Delta \mathrm{G}_{\mathrm{p}}$ model. Those that are not predictable (i.e., outside of the prediction limits) actually fall below the prediction interval (i.e., they are over predicted by the model) suggesting the model is conservative.
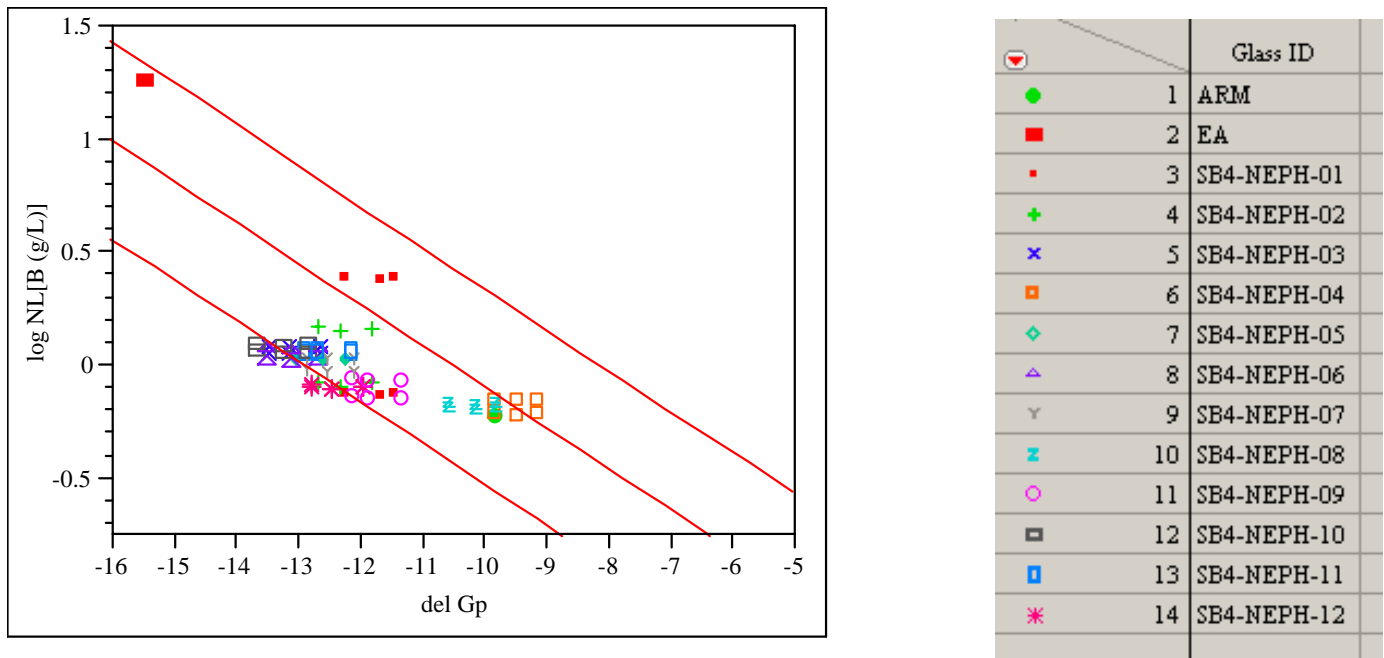

Figure 3-1. Boron Durability Predictions for the Phase 1 Nepheline Study Glasses (all compositional views and heat treatments)

\subsubsection{Heat Treatment Effects on PCTs}

Figure 3-2 provides an analysis of the effect of heat treatment on the PCTs for the nepheline study glasses. Figure 3-2 plots the common log of boron release versus heat treatment for each study glass. Glasses lying above the $45^{\circ}$ red line (NEPH-01, -02, -04, and -09) indicate that the release of $\mathrm{B}$ from the ccc glasses was greater than the quenched version. As previously discussed, NEPH-01 and NEPH-02 were the only two glasses that the 0.62 discriminator value suggested a high potential for nepheline formation. Glasses falling below the $45^{\circ}$ red line suggest 
that the NL [B] from the ccc glasses was lower (i.e., the ccc glasses are more durable) than their quenched counterparts. Although general statements regarding the differences between the quenched and ccc version of each glass could be made based on visual inspection of Figure 3-2, a more detailed assessment is warranted to provide a sound technical basis for the potential differences and to determine if the differences are of practical concern. Of particular interest are NEPH-01, -02, -04, and -09 given they appear to have a significant difference in PCT response between the two different heat treatments (especially given the ccc versions appear to be less durable than their quenched counterparts suggesting potential impacts due to nepheline).

Exhibit D.6 in Appendix D provides a closer look at the effect of heat treatment on the PCTs for each nepheline study glass by analyses of the common log of the measurements of the four primary analytes (B, Li, Na, and $\mathrm{Si}$ ) versus heat treatment. The analyses investigate for a statistically significant difference in the mean of the common logarithm of the PCT leachate concentrations due to heat treatment. At a 5\% significance level, the B, Li, Na, and Si values for NEPH-01 and for NEPH-02 indicate a statistically significant difference in the PCT response due to heat treatment with the cсc versions being statistically higher than the quenched versions. For NEPH-04 and NEPH-09, the release of B and Li for the ccc versions was significantly higher than the quenched versions (at a 5\% significance level).

Although the discussion regarding differences in PCT response from a statistical point of view is informative, one must also evaluate the practical impact of the measured differences and ultimately assess the usefulness of the nepheline screening tool to guide frit development efforts for SB4.

The measured NL [B] for NEPH-01 quenched and ccc are $0.73 \mathrm{~g} / \mathrm{L}$ and $2.40 \mathrm{~g} / \mathrm{L}$ (normalized to the target composition) - a three-fold decrease in durability as a result of heat treatment alone. To yield such a dramatic difference in PCT response just from heat treatment either the glass composition changed (unlikely) or crystallization occurred resulting in a significant measurable impact. The most likely candidate is the formation of nepheline given its classification by the discriminator value. It should be noted that although the PCT durability response for the ccc glasses was significantly decreased, the practical impact in terms of acceptance is minimal as the release is still much lower than the EA benchmark glass (i.e., $2.40 \mathrm{~g} / \mathrm{L}$ versus $16.695 \mathrm{~g} / \mathrm{L}$ ).

The PCT results for NEPH-02 quenched and ccc, $0.8 \mathrm{~g} / \mathrm{L}$ and $1.41 \mathrm{~g} / \mathrm{L}$ respectively, were also determined to be statistically significant. This glass was also classified as being prone to nepheline formation and the measured results suggest that nepheline formation was likely. However, the practical impact is of minimal concern regardless of the formation of nepheline or other possible crystalline phases that may deteriorate durability. 


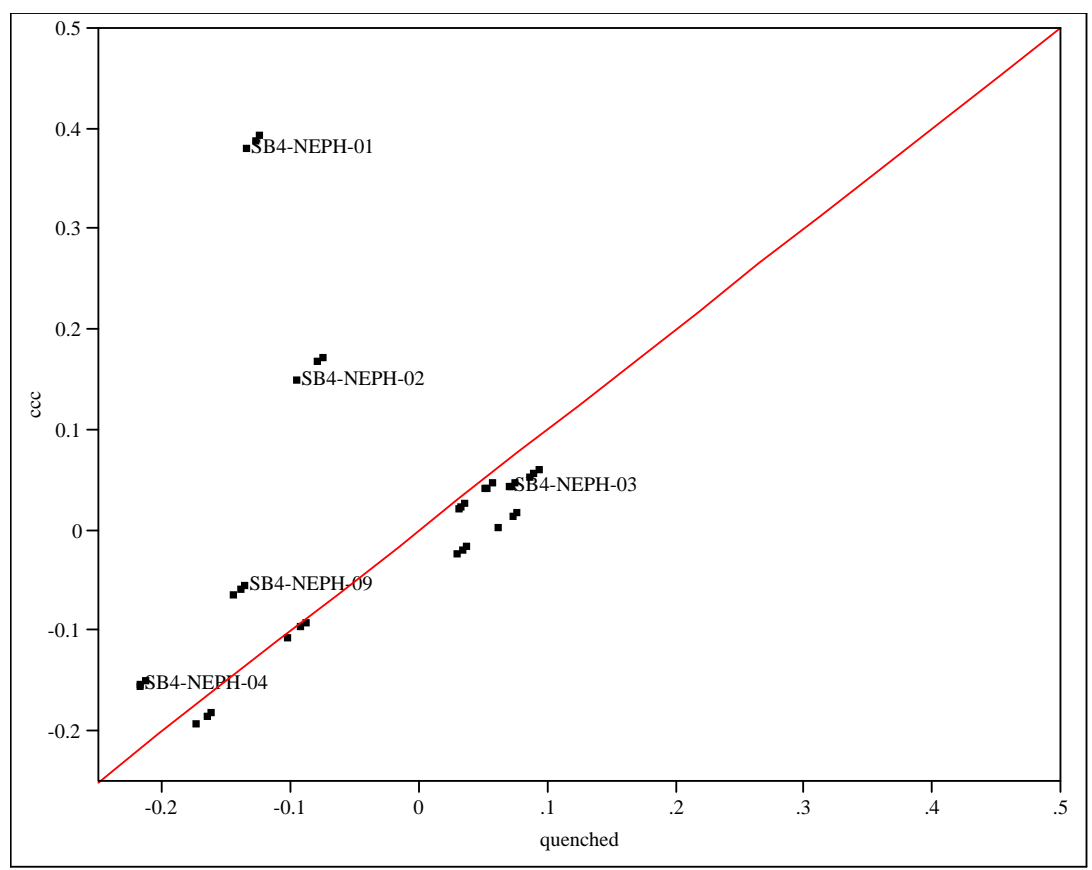

Figure 3-2. Normalized Release of Boron for NEPH Phase 1 Glasses - ccc versus quenched. (units are $\log \mathrm{NL}[\mathrm{B}]$ )

The measured durability of NEPH-03 is also of interest given it was the first glass which was not classified as being prone to nepheline formation based on the 0.62 value. The measured NL [B] values for the quenched and ccc versions of this glass were $1.18 \mathrm{~g} / \mathrm{L}$ and $1.12 \mathrm{~g} / \mathrm{L}$, respectively. The results suggest that the ccc version is more durable than the quenched suggesting nepheline formation is not likely or the vol\% is extremely low - regardless, there is no practical difference between the two heat treatments for this glass.

$\mathrm{NEPH}-04$ is also of interest given it was one of the four glasses lying above the $45^{\circ}$ line in Figure $3-2$. The NL $[\mathrm{B}]$ values for the quenched and ccc versions of this glass were $0.61 \mathrm{~g} / \mathrm{L}$ and 0.70 $\mathrm{g} / \mathrm{L}$. Although statistically significant, the difference is of no practical concern and may be within the random error of the PCT test itself.

NEPH-09 was the last glass whose measured durability response suggested that nepheline formation may have occurred as presented in Figure 3-2. The NL [B] values for the quenched and ccc versions of this glass were $0.85 \mathrm{~g} / \mathrm{L}$ and $1.07 \mathrm{~g} / \mathrm{L}$. The results suggest that, if nepheline is present, the impact on the durability of the product is minimal and of no practical concern.

The PCT response for all other NEPH glasses suggest that if devitrification occurred during the slower cooling, it had a positive impact on durability (i.e., the remaining glasses fall below the $45^{\circ}$ line in Figure 3-1). Therefore, the presence of nepheline (at least at concentrations extensive enough to affect the durability response) in these glasses is highly unlikely.

\subsection{Homogeneity}

Table 3-5 summarizes the visual and XRD results for the quenched and ccc "NEPH" study glasses. The use of "homogeneous" (for both visual and XRD results) indicates that the sample was classified as a single-phase system (i.e., no evidence of crystallization at the associated detection limit). The term "surface crystals" (used as a descriptor for visual observations) implies 
that the surface of the glass was characterized by the presence of crystallization while the crosssection of bulk glass appeared homogeneous (i.e., single-phased, black and shiny). ${ }^{7}$

\subsubsection{Visual Observations}

In general, visual observations indicate that devitrification (via surface crystallization only) is more prevalent in the ccc glasses than in the quenched glasses, as expected, given kinetics are more favorable during the slower cooling cycle. The surface crystallization is consistent with historical visual observations of DWPF-based glasses especially those targeting higher waste loadings. More specifically, use of descriptions such as a dull or matte texture and/or metalliclike surface is common for DWPF-type glasses targeting higher WLs and/or having undergone a slow cooling schedule. Previous XRD analyses have typically indicated that the textured or metallic-like surfaces are a result of spinels which precipitate during the cooling process. This is in-line with glass theory which suggests that as WL increases, the concentrations of $\mathrm{Fe}_{2} \mathrm{O}_{3}, \mathrm{NiO}$, $\mathrm{Cr}_{2} \mathrm{O}_{3}$ and/or $\mathrm{MnO}$ also increase, thus enhancing the likelihood of spinel devitrification. The results for NEPH-09 and NEPH-12 support this concept as they are the only two study glasses that targeted a lower WL (35\% instead of 40\%) and that were classified as homogeneous by both visual and XRD analyses. All other study glasses targeted 40\% WL and were classified as having surface crystallization via visual observations suggesting the possibility of spinel formation.

Although predominantly associated with the ccc glasses, surface devitrification was also observed in the quenched versions of NEPH-05, -06, -07, -10, and -11. Peeler et al. (2005) indicate that these glasses target high WLs (all 40\%) and are based on the 1100 can baseline (NEPH-05), the maximum NiO sludge option (NEPH-06 and NEPH-07), or the maximum MgO sludge option (NEPH-10 and NEPH-11). With the exception of NEPH-03, all other glasses are based on the maximum $\mathrm{Al}_{2} \mathrm{O}_{3}$ sludge option (with minimum concentrations of $\mathrm{MnO}$ and $\mathrm{NiO}$ ), which suggests that the presence of higher $\mathrm{MnO}$ and/or $\mathrm{NiO}$ concentrations in the sludge led to surface crystallization in both the quenched and ccc heat treated glasses. Again, from a glass science perspective, higher concentrations of $\mathrm{NiO}$ and/or $\mathrm{MnO}$ in the glass should lead to higher $\mathrm{T}_{\mathrm{L}}$ values as well as more rapid devitrification - all other things being equal.

\footnotetext{
7 Surface crystallization in the "NEPH" glasses was apparent through the presence of a "textured" surface that ranged in appearance from a "dull or matte" surface to a "highly metallic-like” surface. For select glasses, "islands or spots" of devitrification were also noted on the glass surface. For a more detailed description of the visual observations and XRD results of both the quenched and ccc glasses, see WSRC-NB-2005-00054.
} 
Table 3-5. Visual and XRD Results for the SB4 Nepheline Phase 1 Glasses.

\begin{tabular}{||c|c|c|c|c|c||}
\hline Glass & $\begin{array}{c}\text { Frit } \\
\text { ID }\end{array}$ & $\begin{array}{c}\text { Target } \\
\text { WL }\end{array}$ & $\begin{array}{c}\text { Heat } \\
\text { Treatment }\end{array}$ & Visual & XRD \\
\hline SB4-NEPH-01 & 320 & 40 & quenched & Homogeneous & Homogeneous/ Homogeneous \\
\hline SB4-NEPH-01 & 320 & 40 & ccc & Surface crystals & Nepheline/Homogeneous \\
\hline SB4-NEPH-02 & 320 & 40 & quenched & Homogeneous & Homogeneous/ Homogeneous \\
\hline SB4-NEPH-02 & 320 & 40 & ccc & Surface crystals & Homogeneous/ Homogeneous \\
\hline SB4-NEPH-03 & 320 & 40 & quenched & Homogeneous & Homogeneous/ Homogeneous \\
\hline SB4-NEPH-03 & 320 & 40 & ccc & Surface crystals & Trevorite/Homogeneous \\
\hline SB4-NEPH-04 & 418 & 40 & quenched & Homogeneous & Homogeneous/ Homogeneous \\
\hline SB4-NEPH-04 & 418 & 40 & ccc & Surface crystals & Carnegeite/Homogeneous \\
\hline SB4-NEPH-05 & 320 & 40 & quenched & Surface crystals & Homogeneous \\
\hline SB4-NEPH-05 & 320 & 40 & ccc & Surface crystals & Homogeneous \\
\hline SB4-NEPH-06 & 320 & 40 & quenched & Surface crystals & Homogeneous \\
\hline SB4-NEPH-06 & 320 & 40 & ccc & Surface crystals & Homogeneous \\
\hline SB4-NEPH-07 & 320 & 40 & quenched & Surface crystals & Homogeneous \\
\hline SB4-NEPH-07 & 320 & 40 & ccc & Surface crystals & Homogeneous \\
\hline SB4-NEPH-08 & 418 & 40 & quenched & Homogeneous & Homogeneous \\
\hline SB4-NEPH-08 & 418 & 40 & ccc & Surface crystals & Homogeneous \\
\hline SB4-NEPH-09 & 320 & 35 & quenched & Homogeneous & Homogeneous/Homogeneous \\
\hline SB4-NEPH-09 & 320 & 35 & ccc & Homogeneous & Homogeneous/Homogeneous \\
\hline SB4-NEPH-10 & 320 & 40 & quenched & Surface crystals & Homogeneous \\
\hline SB4-NEPH-10 & 320 & 40 & ccc & Surface crystals & Homogeneous \\
\hline SB4-NEPH-11 & 320 & 40 & quenched & Surface crystals & Homogeneous \\
\hline SB4-NEPH-11 & 320 & 40 & ccc & Surface crystals & Homogeneous \\
\hline SB4-NEPH-12 & 320 & 35 & quenched & Homogeneous & Homogeneous \\
\hline SB4-NEPH-12 & 320 & 35 & ccc & Homogeneous & Homogeneous \\
\hline \hline
\end{tabular}

\subsubsection{XRD Results}

Initially, NEPH-01, NEPH-02, NEPH-03, NEPH-04, and NEPH-09 (both quenched and ccc versions) were submitted for XRD analysis based on a potentially significant difference in PCT response between the quenched and ccc versions of each glass (see Figure 3-2). With the exception of NEPH-09, visual observations indicated the presence of surface devitrification on all ccc versions of these glasses while the quenched versions were homogeneous. The initial XRD analysis confirmed that the quenched versions of these glasses were void of crystallization (at the estimated 0.5 vol\% detection limit). In addition, the ccc versions of NEPH-02 and NEPH-09 (both based on the maximum $\mathrm{Al}_{2} \mathrm{O}_{3}$ sludge option) were also determined to be homogeneous based on XRD results. These latter results were confirmed through the second set of XRD results.

For the ccc versions of NEPH-01, NEPH-03, and NEPH-04, the initial XRD results indicated the presence of nepheline $\left(\mathrm{NaAlSiO}_{4}\right)$, trevorite $\left((\mathrm{Ni}, \mathrm{Fe}) \mathrm{Fe}_{2} \mathrm{O}_{4}\right)$, and carnegeite $\left(\mathrm{NaAlSiO}_{4}\right){ }^{8}$ respectively. Figure 3-3 and Figure 3-4 show the XRD patterns for NEPH-01 (quenched) and

\footnotetext{
${ }^{8}$ Nepheline and carnegeite have the same chemical formula, but differ in structure. Nepheline is the more stable of the two and is hexagonal in structure, while carnegeite is cubic. Also, carnegeite is the high-temperature version of $\mathrm{NaAlSiO}_{4}$, which means if it is present here then it formed metastabally.
} 
NEPH-01 (сcc), respectively. ${ }^{9}$ The presence of nepheline in NEPH-01ccc (Figure 3-4) is not surprising given it was one of two glasses (the other being NEPH-02) predicted to be prone to nepheline formation through the use of the 0.62 screening value. However, NEPH-02 quenched and NEPH-02 ccc were XRD amorphous (single phased) for both sets of analyses. Trevorite in NEPH-03ccc (see Figure 3-5) is also reasonable given visual observations of surface devitrification and the high targeted WL (although it was not based on a sludge targeting maximum $\mathrm{MnO}$ and/or $\mathrm{NiO}$ ).

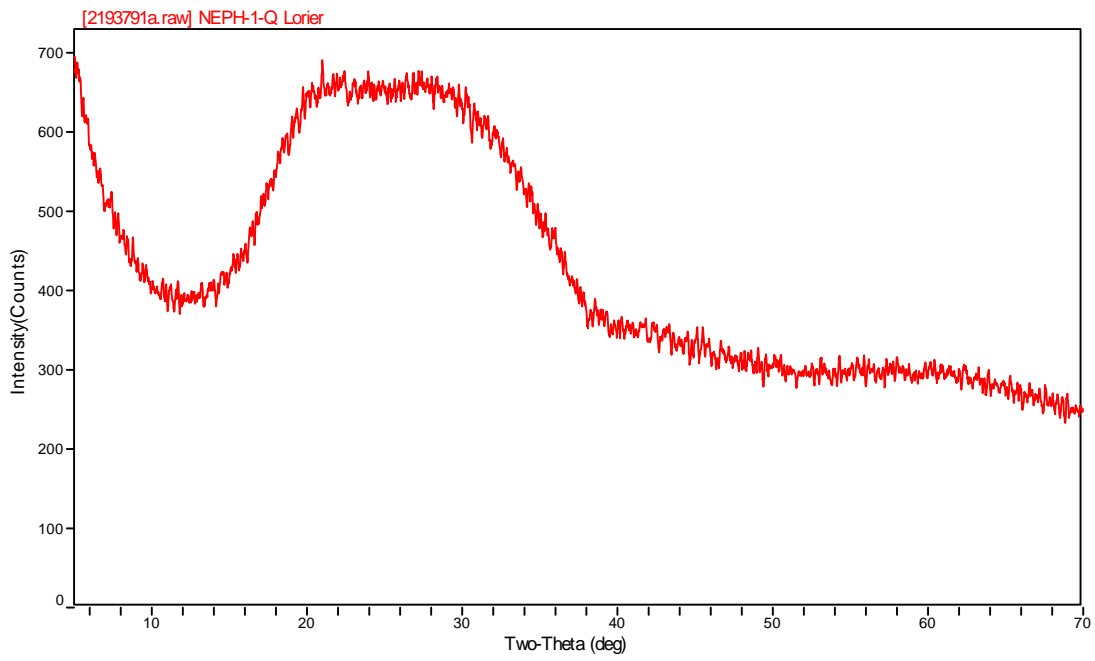

Figure 3-3. XRD Results of NEPH-01 quenched.

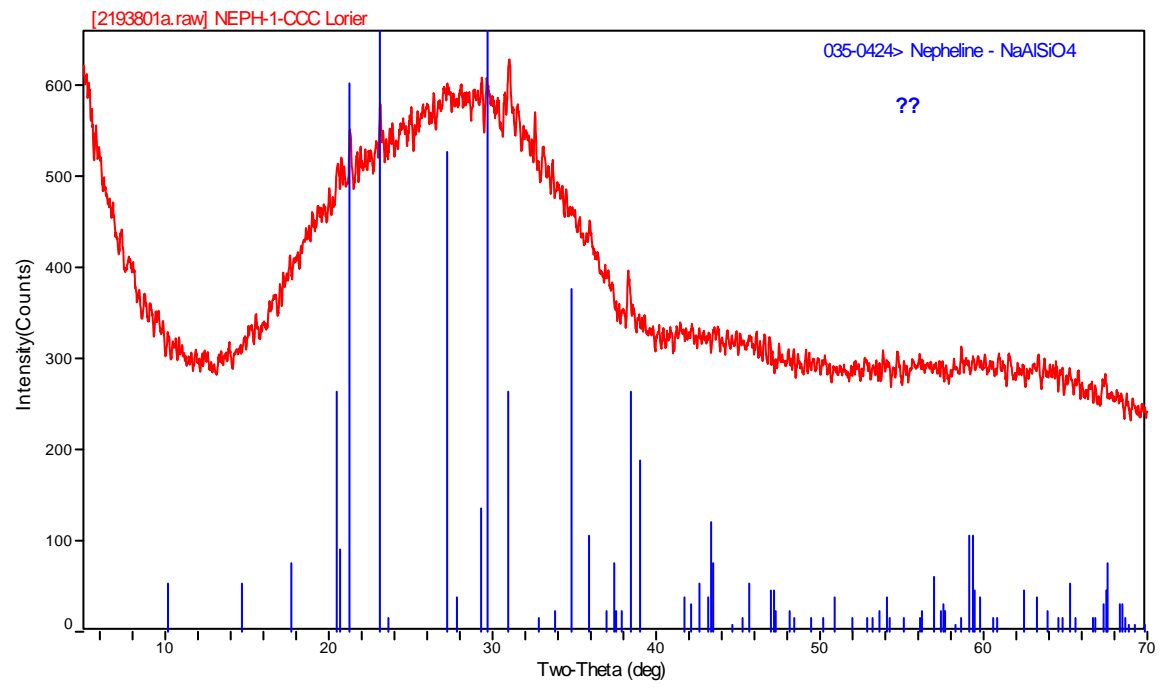

Figure 3-4. XRD Results of NEPH-01 ccc.

${ }^{9}$ All of the XRD results can be found in WSRC-NB-2005-00054. 


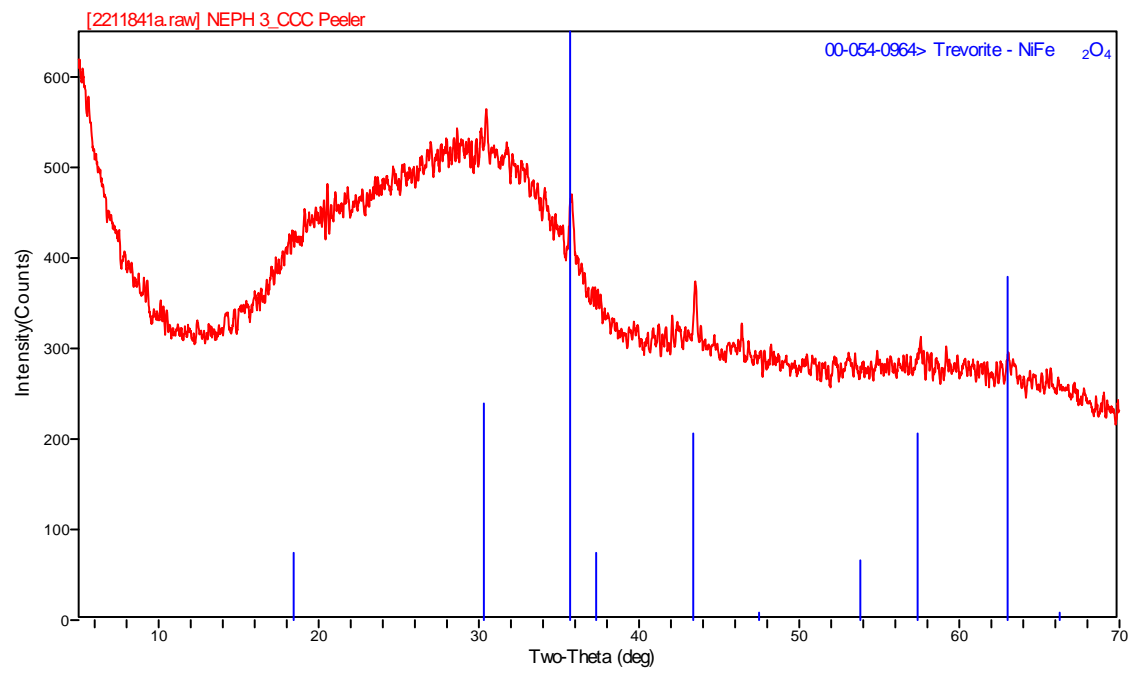

Figure 3-5. XRD Results of NEPH-03 ccc.

Although these results are consistent with expectations or historical data, other results are not as simple to explain. For example, why is NEPH-02ccc classified as homogeneous via XRD results when visual observations suggest surface devitrification? In addition, given NEPH-02 was classified as being prone to nepheline formation, why is nepheline not observed in the XRD results when a significant difference (statistically) in PCT response was measured? Why does $\mathrm{NEPH}-04$ ccc contain $\mathrm{NaAlSiO}_{4}$ (carnegeite) when it was not prone to nepheline formation via the 0.62 value as reported by Li et al. (2003) - even though the difference in PCT response was minimal for the quenched and ccc version at $0.66 \mathrm{~g} / \mathrm{L}$ and $0.73 \mathrm{~g} / \mathrm{L}$, respectively (no practical difference)? Why are there so many study glasses that were classified as homogeneous via XRD but visually have some degree of surface devitrification? Why are the XRD results "inconsistent" for NEPH-01ccc, NEPH-03ccc, and NEPH-04ccc for the duplicate analysis? Each of these questions or concerns is discussed below in more detail.

First consider the XRD results for NEPH-02ccc. Although predicted to be nepheline prone, XRD results did not detect nepheline in either the quenched or ccc glass. As noted in Section 3.3.6, the PCT results for NEPH-02 quenched and ccc were $0.8 \mathrm{~g} / \mathrm{L}$ and $1.41 \mathrm{~g} / \mathrm{L}$ respectively, which were determined to be statistically significant. The decrease in durability (by almost a factor of 2) does suggest a microstructure change in the glass upon slow cooling which negatively impacted durability. This result coupled with the fact that the 0.62 value indicated nepheline would form suggests that the presence of nepheline is likely but at a concentration below the detection limits of the diffractometer.

The "repeatability" (or lack thereof) associated with the duplicate XRD analyses for NEPH-01ccc NEPH-03ccc, and NEPH-04ccc suggests that the vol\% of each phase present is near the detection limit of the X-ray diffractometer. For example, initial XRD results suggested that carnegeite was present in NEPH-04ccc, while the second set of XRD results suggested this glass was homogeneous (which would agree with the 0.62 screening value). Conflicting XRD results for $\mathrm{NEPH-02ccc}$ also were obtained as the second result did not indicate the presence of nepheline while the initial result did. The XRD results for NEPH-03ccc were also conflicting. What does all this information mean? The crystallization vol\% appears to be near the detection limit of the 
instrument which is reflected in the "random nature" of the XRD results which could be influenced the sample taken for XRD analysis. The detection limit issue also appears to have played a significant role in identifying spinels related to surface crystallization for most ccc glasses.

Regardless of the questions or uncertainties associated with XRD results, the practical implication of the impact of devitrification on durability is measured directly by the PCT response. Based on the original nepheline discriminator value of 0.62 , it was postulated that NEPH-01 (0.606 nepheline value) and NEPH-02 (0.608 nepheline value) would form nepheline and could show a difference in PCT response between the ccc and quenched versions and/or show the presence of nepheline in the XRD analysis. Glass NEPH-01 showed both. Glass NEPH-02 only showed the PCT response difference, but no nepheline in the XRD analysis, indicating that if nepheline was present it was below the XRD detection limit. It should be noted that the presence of spinels would not have this dramatic of an impact in terms of the PCT response.

NEPH-03 (0.637 nepheline value) was the first study glass anticipated to be void of nepheline formation based on the 0.62 value. Although trevorite was observed in the ccc version, the PCT response showed no significant or practical difference between the two different heat treatments $(1.18 \mathrm{~g} / \mathrm{L}$ for the quenched versus a $1.12 \mathrm{~g} / \mathrm{L}$ for $\mathrm{CCC})$. The XRD results coupled with the PCT response (see Sections 3.3.4 and 3.36) suggest that nepheline is not present in this glass - as predicted by the 0.62 value.

NEPH-04 which has a nepheline discriminator value of 0.638 and showed the presence of carnegeite (a sodium aluminosilicate very similar to nepheline) in one of the two samples submitted for XRD analysis (the second sample was X-ray amorphous suggesting that the sample was homogeneous at the detection limit). NEPH-04 also showed a slight difference in PCT response between the quenched and ccc versions $-0.61 \mathrm{~g} / \mathrm{L}(\mathrm{q})$ and $0.71 \mathrm{~g} / \mathrm{L}$ (ccc) for NL [B] release. The responses may potentially be statistically different, but are not of practical concern (as the values may be within the random error of the test and/or analytical measurement uncertainties).

All other NEPH glasses (i.e., NEPH-05 through NEPH-12) were predicted to be "nepheline-free (based on the 0.62 value), classified as homogeneous by XRD analyses (for both quenched and ccc version), and showed no significant and/or practical difference in PCT response for the two heat treatments. Although circumstantial evidence (i.e., higher WLs and similar visual observations as compared to historical glasses) suggests that the surface crystallization is likely spinel formation, XRD results can not confirm its presence presumably due to detection limit issues. However, additional circumstantial evidence can be used to support this theory in the fact that the PCT response showed no significant or practical difference for these glasses which is consistent with the known impacts (or lack thereof) for spinel formation in high-level waste glasses.

These combined results suggest that the 0.62 value appears to be a reasonable guide to monitor SB4 - frit systems with respect to potential nepheline formation. In addition, the PCT results suggest that for those glasses prone to nepheline formation, a statistically significant difference in PCT response was observed for the two heat treatments but the impact on durability was of little or no practical concern. When one couples the PCT responses with the XRD results and/or visual observations, one could conclude that the formation of nepheline in these glasses does have a negative impact on durability. That impact may be of statistical significance but the practical impact may not be sufficient to avoid a specific frit candidate for SB4. 


\subsection{SUMMARY}

The formation of nepheline and/or other aluminum/silicon-containing crystals is potentially significant to the SB4 system due to the preliminary projected compositional views provided by Lilliston (2005) coupled with the frit development strategy. Li et al. (2003) indicated that sodium alumino-borosilicate glasses are prone to nepheline crystallization if their compositions projected on the $\mathrm{Na}_{2} \mathrm{O}-\mathrm{Al}_{2} \mathrm{O}_{3}-\mathrm{SiO}_{2}$ ternary fall within or close to the nepheline primary phase field. In particular, durable glasses with $\mathrm{SiO}_{2} /\left(\mathrm{SiO}_{2}+\mathrm{Na}_{2} \mathrm{O}+\mathrm{Al}_{2} \mathrm{O}_{3}\right)>0.62$, where the chemical formula stands for the mass fractions in the glass, do not precipitate nepheline as their primary phase. In order to provide insight into the applicability of the 0.62 value as a discriminator for observing the formation of nepheline and into its potential negative impact on durability, a value of 0.65 was used to establish the twelve "prone to nepheline formation" SB4 glasses tested in this study. The objectives of this study were to fabricate and test the durability (via the PCT) of the twelve SB4-based glasses to assess the potential for and/or the negative impact of nepheline formation.

In terms of "acceptability", the results indicate that all of the NEPH glasses produced are acceptable with respect to durability as defined by the PCT (NL [B] values of all "NEPH" glasses were much lower than that of the EA glass $(16.695 \mathrm{~g} / \mathrm{L}))$. The most durable glass is NEPH-04 (quenched) with a NL [B] of $0.61 \mathrm{~g} / \mathrm{L}$ (based on target, measured, and measured-bc compositions), while the least durable glass is NEPH-01 (ссc) with a NL [B] of $2.47 \mathrm{~g} / \mathrm{L}$ (based on the measured composition). In terms of predictability, most of the study glasses are predictable by the $\Delta \mathrm{G}_{\mathrm{p}}$ model. Those that are not predictable (i.e., they fall outside of the prediction limits) actually fall below the prediction interval (i.e., they are over predicted by the model) suggesting the model is conservative.

Although conflicting XRD data were obtained for some glasses leading to questions or uncertainties, the practical implication of the impact of devitrification on durability is measured directly by the PCT response. Based on the original nepheline discriminator value of 0.62 , it was postulated that NEPH-01 (with a 0.606 nepheline value) and NEPH-02 (with a 0.608 nepheline value) would form nepheline and could show a difference in PCT response between the ccc and quenched versions and/or show the presence of nepheline in the XRD analysis. Glass NEPH-01 showed both. Glass NEPH-02 only showed the PCT response difference, but no nepheline in the XRD analyses, indicating that if nepheline was present it was below the XRD detection limit. It should be noted that the presence of spinels would not have this dramatic of an impact in terms of the PCT response.

All other NEPH glasses (i.e., NEPH-05 through NEPH-12) were predicted to be "nepheline-free (based on the 0.62 value), classified as homogeneous by XRD analyses (for both quenched and ccc version), and showed no significant and/or practical difference in PCT response for the two heat treatments. Although circumstantial evidence (i.e., higher WLs and similar visual observations as compared to historical glasses) suggests that the surface crystallization is likely spinel formation, XRD results were not capable of confirming its presence presumably due to detection limit issues. However, additional circumstantial evidence can be used to support this theory in the fact that the PCT response showed no significant or practical difference for these glasses which is consistent with the known impact (or lack thereof) for spinel formation in highlevel waste glasses.

These combined results suggest that the 0.62 value appears to be a reasonable guide to monitor SB4 - frit systems with respect to potential nepheline formation. In addition, the PCT results suggest that for those glasses prone to nepheline formation, a statistically significant difference in 
PCT response was observed for the two heat treatments but the impact on durability was of little or no practical concern. When one couples the PCT responses with the XRD results and/or visual observations, one could conclude that the formation of nepheline in these glasses does have a negative impact on durability. That impact may be of statistical significance but the practical impact may not be sufficient to avoid a specific candidate frit for the SB4 glass system.

The results of this study not only suggest that the 0.62 value appears to be a reasonable guide to monitor sludge - frit systems with respect to potential nepheline formation, but also that the impact of nepheline, although statistically significant, has little or no practical impact in the SB4 system to durability as measured by the PCT. This latter statement must be qualified to some extent given only two glasses were selected which were actually "prone to nepheline formation" based on this general guide and the vol\% of nepheline present (if detected) was near the detection limit of the X-ray diffractometer (i.e., $~ 0.5 \mathrm{vol} \%$ ). If the presence of nepheline has no appreciable, adverse impact on durability for the recently revised SB4 systems, then as decisions regarding the viability of the SB4 options and the down select of candidate frits are pursued, little weight will be given to minimizing the likelihood of nepheline and the decisions will be dominated by waste throughput criteria. That is, the frit selection process will not have to consider the impact of nepheline on the ultimate durability of the product and can focus on recommending a frit that when coupled with the sludge can be processed over a WL interval of interest to DWPF with melt rates meeting production expectations. On the other hand, if the revised SB4 compositions lead to system where nepheline formation is a concern and it is demonstrated that the impact on durability is of practical significance or overly detrimental, then candidate frits, that lessen the likelihood of the formation of nepheline over an interval of waste loadings of interest to DWPF would move up the list of preferred frits. 


\subsection{PATH FORWARD}

Based on the results and observations of this study, the following recommendations are made:

- Utilize the nepheline discriminator value of 0.62 to assess the revised SB4 systems (based on Elder (2005a and 2005b)) for potential nepheline formation.

- Determine the incentive (e.g., waste loading being limited by nepheline predictions) for challenging the nepheline predictions. The current data suggest that even though nepheline does form (or is likely) the impact on durability is of little or no practical concern. If true for the revised SB4 systems, the data could form the technical basis for increasing WLs without compromising product quality.

- If frit - sludge systems are identified which are prone to nepheline formation, consideration should be given to conduct a second experimental study. If a study is performed, glasses should be selected to "challenge" the nepheline formation potential over WLs which are within the acceptable operating window for DWPF. 


\subsection{REFERENCES}

ASTM 2002. "Standard Test Methods for Determining Chemical Durability of Nuclear Waste Glasses: The Product Consistency Test (PCT),” ASTM C-1285-2002.

Bickford, D.F. and C.M. Jantzen. 1984. "Devitrification of SRL Defense Waste Glass”, Sci. Basis for Nuclear Waste Management, VII, G.L. McVay (ed). Elsevier Publ., New York, pgs. 557-565.

Bickford, D.F. and C.M. Jantzen. 1986. "Devitrification of Defense Nuclear Waste Glasses: Role of Melt Insolubles”, J. Non-Crystalline Solids, 84 [1-3], pgs. 299-307.

Brown, K.G., C.M. Jantzen, and G. Ritzhaupt. 2001. Relating Liquidus Temperature to Composition for Defense Waste Processing Facility (DWPF) Process Control, WSRC-TR-200100520, Westinghouse Savannah River Company, Aiken, South Carolina.

Cicero, C.A., S.L. Marra, and M.K. Andrews. 1993. Phase Stability Determinations of DWPF Waste Glasses (U), WSRC-TR-93-227, Revision 0, Westinghouse Savannah River Company, Aiken, South Carolina.

Elder, HH. 2005a. Estimate of Sludge Batch 4 Calcine Composition, CBU-PIT-2005-00134, Revision 0, Westinghouse Savannah River Company, Aiken, South Carolina.

Elder, HH. 2005b. Estimate of Sludge Batch 4 Calcine Composition Additional Cases, CBU-PIT-2005-00176, Revision 0, Westinghouse Savannah River Company, Aiken, South Carolina.

Jantzen, C.M., D.F. Bickford, D.G. Karraker, and G.G. Wicks. 1984. “Time-TemperatureTransformation Kinetics in SRL Waste Glass”, Advances in Ceramics, Volume 8, American Ceramic Society, Westerville, OH, pgs. 30-38.

Jantzen, C.M., N.E. Bibler, D.C. Beam, C.L. Crawford, and M.A. Pickett. 1993. Characterization of the Defense Waste Processing Facility (DWPF) Environmental Assessment (EA) Glass Standard Reference Material, WSRC-TR-92-346, Revision 1, Westinghouse Savannah River Company, Aiken, South Carolina.

Jantzen, C.M., J.B. Pickett, K.G. Brown, T.B. Edwards, and D.C. Beam. 1995. Process/Product Models for the Defense Waste Processing Facility (DWPF): Part I. Predicting Glass Durability from Composition Using a Thermodynamic Hydration Energy Reaction Model (THERMO) (U), WSRC-TR-93-672, Revision 1, Volume 1, Westinghouse Savannah River Company, Aiken, South Carolina.

Kim, D.S., D.K. Peeler, and P. Hrma. 1995. "Effect of Crystallization on the Chemical Durability of Simulated Nuclear Waste Glasses”, Environmental Issues and Waste Management Technologies in the Ceramic and Nuclear Industries, Ceramic Transaction, Volume 61, pgs. 177 $-185$.

Li, H., J.D. Vienna, P. Hrma, D.E. Smith, and M.J. Schwieger. 1997. “Nepheline Precipitation in High-Level Waste Glasses - Compositional Effects and Impact on the Waste Form Acceptability”, Mat. Res. Soc. Proc., 465, pgs. 261- 268. 
Li, H., P. Hrma, J.D. Vienna, M. Qian, Y. Su, and D.E. Smith. 2003. "Effects of $\mathrm{Al}_{2} \mathrm{O}_{3}, \mathrm{~B}_{2} \mathrm{O}_{3}$, $\mathrm{Na}_{2} \mathrm{O}$, and $\mathrm{SiO}_{2}$ on Nepheline Formation in Borosilicate Glasses: Chemical and Physical Correlations”, Journal of Non-Crystalline Solids, 331, pgs. 202 - 216.

Lilliston, GR. 2005. Development of Elemental Sludge Compositions for Variations of Sludge Batch 4 (SB4), CBU-PIT-2004-00011, Revision 1, Westinghouse Savannah River Company, Aiken, South Carolina.

Marra, S.L. and C.M. Jantzen. 1993. Characterization of Projected DWPF Glass Heat Treated to Simulate Canister Centerline Cooling, WSRC-TR-92-142, Revision 1, Westinghouse Savannah River Company, Aiken, South Carolina.

Peeler, D.K. and T.B. Edwards. 2005. Frit Development Efforts for Sludge Batch 4 (SB4):

Model-Based Assessments, WSRC-TR-2005-00103, Revision 0, Westinghouse Savannah River Company, Aiken, South Carolina.

Peeler, D.K., T.B. Edwards, and T.H. Lorier. 2005. Nepheline Formation Potential in Sludge Batch 4 (SB4) Glasses, WSRC-TR-2005-00153, Revision 0, Westinghouse Savannah River Company, Aiken, South Carolina.

Riley, B.J., J.A. Rosario, and P. Hrma. 2001. Impact of HLW Glass Crystallinity on the PCT Response, PNNL-13491, Pacific Northwest National Laboratory, Richland, Washington.

Savannah River National Laboratory (SRNL). 2002a. “Glass Batching,” SRTC Procedure Manual, L29, ITS-0001, Westinghouse Savannah River Company, Aiken, South Carolina.

Savannah River National Laboratory (SRNL). 2002b. “Glass Melting,” SRTC Procedure Manual, L29, ITS-0003, Westinghouse Savannah River Company, Aiken, South Carolina.

Spilman, D.B., L.L. Hench, and D.E. Clark. 1986. "Devitrification and Subsequent Effects on the Leach Behavior of a Simulated Borosilicate Nuclear Waste Glass", Nuclear and Chemical Waste Management, Vol.6, pgs. 107 - 119. 


\section{APPENDIX A}

Analytical Plan Supporting the Chemical Composition Measurements (SRNL-SCS-2005-00018) 
April 11, 2005

To:

D. K. Peeler, 999-W

cc:

$$
\begin{array}{ll}
\text { R. A. } & \text { Baker, 773-42A } \\
\text { D. R. } & \text { Best, 786-1A (wo) } \\
\text { S. L. } & \text { Marra, 999-W (es) } \\
\text { I. A. } & \text { Reamer, 999-1W }
\end{array}
$$

P. A. Toole, 786-1A (wo)

R. C. Tuckfield, 773-42A

R. J. Workman, 999-1W

From: $\quad$ T. B. Edwards, 773-42A (5-5148)

Statistical Consulting Section

wo - without glass identifiers

es - executive summary only

R. A. Baker, Technical Reviewer

Date

R. C. Tuckfield, Manager

Date

Statistical Consulting Section

\section{An Analytical Plan for Measuring the Chemical Compositions of the Nepheline Study Glasses (U)}




\subsection{EXECUTIVE SUMMARY}

A study is being conducted by the Savannah River National Laboratory (SRNL) for the Defense Waste Processing Facility (DWPF) that involves investigating the potential impact of nepheline formation on the durability of high level waste glasses. To address this issue, several glass

compositions were identified for their potential for the formation of nepheline as part of the frit development activities for Sludge Batch 4 (SB4).

The chemical compositions of 12 of these glasses are to be determined by the Savannah River National Laboratory - Mobile Laboratory (SRNL-ML). This memorandum provides an analytical plan to direct and support these measurements at the SRNL-ML. 


\subsection{INTRODUCTION}

A study is being conducted by the Savannah River National Laboratory (SRNL) for the Defense Waste Processing Facility (DWPF) that involves investigating the potential impact of nepheline formation on the durability of high level waste glasses [1]. To address this issue, several glass compositions were selected for their potential for the formation of nepheline as part of the frit development activities for Sludge Batch 4 (SB4).

The chemical compositions of 12 glasses are to be determined by the Savannah River National Laboratory - Mobile Laboratory (SRNL-ML). This memorandum provides an analytical plan to direct and support these measurements at the SRNL-ML.

\subsection{Analytical Plan}

The analytical procedures used by the SRNL-ML to determine cation concentrations for a glass sample include steps for sample preparation and for instrument calibration. Each glass is to be prepared in duplicate by each of two dissolution methods: lithium metaborate (LM) fusion and sodium peroxide fusion (PF).

The primary measurements of interest are to be acquired as follows. The samples prepared by $\mathrm{LM}$ are to be measured for barium $(\mathrm{Ba})$, calcium $(\mathrm{Ca})$, cerium $(\mathrm{Ce})$, chromium $(\mathrm{Cr})$, copper $(\mathrm{Cu})$, potassium $(\mathrm{K})$, lanthanum $(\mathrm{La})$, magnesium $(\mathrm{Mg})$, sodium $(\mathrm{Na})$, lead $(\mathrm{Pb})$, sulfur $(\mathrm{S})$, thorium (Th), titanium (Ti), zinc (Zn), and zirconium (Zr) concentrations. Samples prepared by PF are to be measured for aluminum ( $\mathrm{Al})$, boron $(\mathrm{B})$, iron $(\mathrm{Fe})$, lithium $(\mathrm{Li})$, manganese $(\mathrm{Mn})$, nickel $(\mathrm{Ni})$, silicon (Si), and uranium (U). Samples dissolved by both preparation methods are to be measured using Inductively Coupled Plasma - Atomic Emission Spectrometry (ICP-AES). It should be noted that some of these elements are minor components that may be near detection limits for most, if not all, of the study glasses.

Randomizing the preparation steps and blocking and randomizing the measurements for the ICPAES are of primary concern in the development of this analytical plan. The sources of uncertainty for the analytical procedure used by the SRNL-ML to determine the cation concentrations for the submitted glass samples are dominated by the dissolution step in the preparation of the sample and by the calibrations of the ICP-AES.

Samples of glass standards will be included in the analytical plan to provide an opportunity for checking the performance of the instrumentation over the course of the analyses and for potential bias correction. Specifically, several samples of Waste Compliance Plan (WCP) Batch 1 (BCH) [2] and a uranium standard glass $\left(\mathrm{U}_{\text {std }}\right)$ are included in this analytical plan. The reference compositions of these glasses are provided in Table 1. 
Table 1: Oxide Compositions of WCP Batch 1 (BCH) (wt\%)

\begin{tabular}{|ccc|}
\hline $\begin{array}{c}\text { Oxide/ } \\
\text { Anion }\end{array}$ & $\begin{array}{c}\text { BCH } \\
\text { (wt \%) }\end{array}$ & $\begin{array}{c}\text { Ustd } \\
\text { (wt \%) }\end{array}$ \\
$\mathrm{Al}_{2} \mathrm{O}_{3}$ & 4.877 & 4.1 \\
$\mathrm{~B}_{2} \mathrm{O}_{3}$ & 7.777 & 9.209 \\
$\mathrm{BaO}$ & 0.151 & 0 \\
$\mathrm{CaO}$ & 1.22 & 1.301 \\
$\mathrm{Cr} \mathrm{O}_{3}$ & 0.107 & 0 \\
$\mathrm{Cs} 2$ & 0.06 & 0 \\
$\mathrm{CuO}$ & 0.399 & 0 \\
$\mathrm{Fe}_{2} \mathrm{O}_{3}$ & 12.839 & 13.196 \\
$\mathrm{~K}_{2} \mathrm{O}$ & 3.327 & 2.999 \\
$\mathrm{Li} \mathrm{O}_{2} \mathrm{O}$ & 4.429 & 3.057 \\
$\mathrm{MgO}$ & 1.419 & 1.21 \\
$\mathrm{MnO}_{\mathrm{Na} O}$ & 1.726 & 2.892 \\
$\mathrm{Nd}_{2} \mathrm{O}_{3}$ & 9.003 & 11.795 \\
$\mathrm{NiO}^{2}$ & 0.147 & 0 \\
$\mathrm{RuO}_{2}$ & 0.751 & 1.12 \\
$\mathrm{SiO}_{2}$ & 0.0214 & 0 \\
$\mathrm{SO}_{3}$ & 50.22 & 45.353 \\
$\mathrm{TiO}_{2}$ & 0 & 0 \\
$\mathrm{U}_{3} \mathrm{O}_{8}$ & 0.677 & 1.049 \\
$\mathrm{ZrO}_{2}$ & 0 & 2.406 \\
\hline
\end{tabular}

Each glass sample submitted to the SRNL-ML will be prepared in duplicate by the LM and PF dissolution methods. Every prepared sample will be read twice by ICP-AES, with the instrument being calibrated before each of these two sets of readings. This will lead to four measurements for each cation of interest for each submitted glass.

Table 2 presents identifying codes, n01 through $\mathrm{n} 12$, for the 12 glasses fabricated for this nepheline study. The table provides a naming convention that is to be used in analyzing the glasses and reporting the measurements of their compositions. ${ }^{10}$

Table 2: Glass Identifiers to Establish Blind Samples for the SRNL-ML

\begin{tabular}{|cc|cc|}
\hline Glass & Sample ID & Glass & Sample ID \\
ID & & ID & \\
SB4-NEPH-01 & $\mathrm{n} 05$ & SB4-NEPH-07 & n09 \\
SB4-NEPH-02 & $\mathrm{n} 10$ & SB4-NEPH-08 & n08 \\
SB4-NEPH-03 & n03 & SB4-NEPH-09 & n12 \\
SB4-NEPH-04 & n02 & SB4-NEPH-10 & n04 \\
SB4-NEPH-05 & n01 & SB4-NEPH-11 & n07 \\
SB4-NEPH-06 & n11 & SB4-NEPH-12 & n06 \\
\hline
\end{tabular}

10 Renaming these samples helps to ensure that they will be processed as blind samples within the SRNL-ML. Table 2 is not shown in its entirety in the copy going to the SRNL-ML. 


\subsection{PREPARATION OF THE SAMPLES}

Each of the 12 glasses included in this analytical plan is to be prepared in duplicate by the LM and PF dissolution methods. Thus, the total number of prepared glass samples is determined by $12 \cdot 2 \cdot 2=48$, not including the samples of the $\mathrm{BCH}$ and Ustd glass standards that are to be prepared.

Tables 3a and 3b provide blocking and (random) sequencing schema for conducting the preparation steps of the analytical procedures. One block of preparation work is provided for each preparation method to facilitate the scheduling of activities by work shift. The identifier for each of the prepared samples indicates the sample identifier (ID), preparation method, and duplicate number.

\section{Tables 3a and 3b: Preparation Blocks by Method}

Table 3a: LM
Lithium Metaborate)
Preparation Block
\begin{tabular}{|c|} 
LM Block \\
n03LM1 \\
n04LM1 \\
n03LM2 \\
n05LM1 \\
n07LM1 \\
n05LM2 \\
n08LM1 \\
n01LM1 \\
n09LM1 \\
n10LM1 \\
n01LM2 \\
n02LM1 \\
n12LM1 \\
n09LM2 \\
n02LM2 \\
n07LM2 \\
n04LM2 \\
n11LM1 \\
n06LM1 \\
n12LM2 \\
n06LM2 \\
n08LM2 \\
n10LM2 \\
n11LM2 \\
\hline
\end{tabular}

Table 3b: PF
(PEROXIDE FUSION)
PREPARATION BLOCK
\begin{tabular}{|c|} 
n07PF1 \\
n06PF1 \\
n10PF1 \\
n11PF1 \\
n10PF2 \\
n09PF1 \\
n08PF1 \\
n03PF1 \\
n12PF1 \\
n02PF1 \\
n09PF2 \\
n01PF1 \\
n04PF1 \\
n05PF1 \\
n06PF2 \\
n07PF2 \\
n11PF2 \\
n03PF2 \\
n08PF2 \\
n04PF2 \\
n01PF2 \\
n12PF2 \\
n02PF2 \\
n05PF2 \\
\hline
\end{tabular}

\subsection{ICP-AES Calibration Blocks}

The glass samples prepared by the LM and PF dissolution methods are to be analyzed using ICPAES instrumentation calibrated for the particular preparation method. After the initial set of cation concentration measurements, the ICP-AES instrumentation is to be recalibrated and a second set of concentration measurements for the cations determined. 
Randomized plans for measuring cation concentrations in the LM-prepared and PF-prepared samples are provided in Tables $4 \mathrm{a}$ and $4 \mathrm{~b}$, respectively. The cations to be measured are specified in the header of each table. In the tables, the sample identifiers for the 12 study glasses have been modified by the addition of a suffix (a "1" or a "2") to indicate whether the measurement was made during the first or second (respectively) ICP-AES calibration group. The identifiers for the $\mathrm{BCH}$ and Ustd samples have been further modified to indicate that each of these prepared samples is to be read 3 times (mirrored in the corresponding suffix of 1, 2, or 3) per calibration block.

Tables 4a and 4b:

ICP-AES Blocks \& Calibration Groups

for the Glass Samples By Preparation Method

Table 4a: LM Preparation Method (Used to Measure Elemental Ba, Ca, Ce, Cr, Cu, K, La, Mg, Na, Pb, S, Th, Ti, Zn, \& Zr)

\begin{tabular}{|cc|}
\hline Calibration & Calibration \\
1 & 2 \\
BCHLM11 & BCHLM21 \\
UstdLM11 & UstdLM21 \\
n09LM21 & n12LM22 \\
n11LM21 & n03LM12 \\
n01LM21 & n10LM12 \\
n12LM21 & n01LM22 \\
n12LM11 & n07LM22 \\
n01LM11 & n01LM12 \\
n07LM11 & n03LM22 \\
n03LM21 & n07LM12 \\
n04LM11 & n11LM22 \\
n02LM11 & n05LM12 \\
n05LM11 & n06LM12 \\
n05LM21 & n11LM12 \\
BCHLM12 & BCHLM22 \\
UstdLM12 & UstdLM22 \\
n09LM11 & n08LM12 \\
n08LM11 & n09LM22 \\
n06LM21 & n02LM12 \\
n04LM21 & n09LM12 \\
n10LM11 & n04LM12 \\
n10LM21 & n12LM12 \\
n07LM21 & n02LM22 \\
n02LM21 & n04LM22 \\
n06LM11 & n10LM22 \\
n11LM11 & n05LM22 \\
n08LM21 & n06LM22 \\
n03LM11 & n08LM22 \\
UstdLM13 & UstdLM23 \\
BCHLM13 & BCHLM23 \\
\hline & \\
\hline
\end{tabular}

Table 4b: PF Preparation Method (Used to Measure Elemental Al, B, Fe, $\mathrm{Li}, \mathrm{Mn}, \mathrm{Ni}, \mathrm{Si}, \& \mathrm{U})$

\begin{tabular}{|cc|}
\hline & \\
\hline Calibration & Calibration \\
BCHPF11 & BCHPF21 \\
UstdPF11 & UstdPF21 \\
n03PF11 & n05PF12 \\
n04PF21 & n01PF12 \\
n05PF11 & n07PF22 \\
n12PF11 & n09PF22 \\
n02PF11 & n12PF22 \\
n08PF21 & n03PF12 \\
n09PF21 & n02PF22 \\
n12PF21 & n11PF22 \\
n11PF11 & n01PF22 \\
n02PF21 & n11PF12 \\
n10PF11 & n06PF12 \\
n01PF11 & n04PF12 \\
BCHPF12 & BCHPF22 \\
UstdPF12 & UstdPF22 \\
n07PF21 & n06PF22 \\
n11PF21 & n09PF12 \\
n07PF11 & n08PF12 \\
n03PF21 & n08PF22 \\
n09PF11 & n05PF22 \\
n01PF21 & n04PF22 \\
n06PF21 & n12PF12 \\
n05PF21 & n02PF12 \\
n06PF11 & n03PF22 \\
n04PF11 & n10PF22 \\
n10PF21 & n10PF12 \\
n08PF11 & n07PF12 \\
UstdPF13 & UstdPF23 \\
BCHPF13 & BCHPF23 \\
\hline & \\
&
\end{tabular}




\subsection{Concluding Comments}

In summary, this analytical plan identifies two preparation blocks in Tables 3a and 3b and four ICP-AES calibration blocks in Tables $4 \mathrm{a}$ and $4 \mathrm{~b}$ for use by the SRNL-ML. The sequencing of the activities associated with each of the steps in the analytical procedures has been randomized. The size of each of the blocks was selected so that it could be completed in a single work shift.

If a problem is discovered while measuring samples in a calibration block, the instrument should be calibrated and the block of samples re-measured in its entirety. If for some reason the measurements are not conducted in the sequences presented in this report, a record should be made of the actual order used along with any explanative comments.

The analytical plan indicated in the preceding tables should be modified by the personnel of SRNL-ML to include any calibration check standards and/or other standards that are part of their routine operating procedures. It is also recommended that the solutions resulting from each of the prepared samples be archived for some period, considering the "shelf-life" of the solutions, in case questions arise during data analysis. This would allow for the solutions to be rerun without additional preparations, thus minimizing cost.

\subsection{REFERENCES}

[1] Peeler, D.K. and T.B. Edwards, "Nepheline Formation Potential in SB4 Glasses," WSRC-TR-2005-00153, Revision 0, 2005.

[2] Jantzen, C.M., J.B. Pickett, K.G. Brown, T.B. Edwards, and D.C. Beam, "Process/ Product Models for the Defense Waste Processing Facility (DWPF): Part I. Predicting Glass Durability from Composition Using a Thermodynamic Hydration Energy Reaction Model (THERMO ${ }^{\mathrm{TM}}$ ) (U),” WSRC-TR-93-673, Rev. 1, Volume 2, Table B.1, pp. B.9, 1995. 


\title{
APPENDIX B
}

\author{
PCT Analytical Plan
}

(SRNL-SCS-2005-000122) 
April 25, 2005

To: T. H. Lorier, SRNL

D. K. Peeler, 999-W

cc: $\quad$ R. A. Baker, 773-42A

D. R. Best, 786-1A (wo)

P. A. Toole, 786-1A (wo)

S. L. Marra, 999-W (es)

R. C. Tuckfield, 773-42A

I. A. Reamer, 999-1W

R. J. Workman, 999-1W

From: $\quad$ T. B. Edwards, 773-42A (5-5148)

Statistical Consulting Section

wo - without glass identifiers

es - executive summary only

R. A. Baker, Technical Reviewer

Date

R. C. Tuckfield, Manager

Date

Statistical Consulting Section

\section{An Analytical Plan for Measuring PCT Solutions from the Nepheline Study Glasses (U)}




\subsection{EXECUTIVE SUMMARY}

A study is being conducted by the Savannah River National Laboratory (SRNL) for the Defense Waste Processing Facility (DWPF) that involves investigating the potential impact of nepheline formation on the durability of high level waste glasses. To address this issue, several glass compositions were identified for their potential for the formation of nepheline as part of the frit development activities for Sludge Batch 4 (SB4). Twelve of these glasses were selected to be batched and fabricated; the durability of glasses is to be measured using the Product Consistency Test (PCT) as defined in ASTM C-1285-2002. Two heat treatments were utilized during the fabrication of each of these glasses. All 12 glasses were quenched (i.e., rapidly cooled) and cooled in accordance with the centerline-canister-cooling (ссc) regime.

The Savannah River National Laboratory-Mobile Laboratory (SRNL-ML) is to be used to measure elemental concentrations of the resulting leachate solutions from the PCTs. This memorandum provides an analytical plan for the SRNL-ML to follow in measuring the compositions of the leachate solutions resulting from the PCT procedures for the nepheline study glasses. 


\subsection{INTRODUCTION}

A study is being conducted by the Savannah River National Laboratory (SRNL) for the Defense Waste Processing Facility (DWPF) that involves investigating the potential impact of nepheline formation on the durability of high level waste glasses [1]. To address this issue, 12 glass compositions were selected for their potential for the formation of nepheline as part of the frit development activities for Sludge Batch 4 (SB4). The durability of glasses is to be measured using the Product Consistency Test (PCT) as defined in ASTM C-1285-2002 [2]. The glasses were cooled using two heat treatments: all 12 glasses were quenched (i.e., rapidly cooled); and all 12 were then re-melted and cooled in accordance with the centerline-canister-cooling (сcc) regime. This yielded 24 study glasses to be tested by PCT.

The Savannah River National Laboratory-Mobile Laboratory (SRNL-ML) is to be used to measure elemental concentrations of the resulting leachate solutions from the PCTs. This memorandum provides an analytical plan for the SRNL-ML to follow in measuring the compositions of the leachate solutions resulting from the PCT procedures for the nepheline study glasses listed in Table 1.

Table 1: Identifiers for the Nepheline Study Glasses

\begin{tabular}{|c|c|c|}
\hline SB4-NEPH-01 & SB4-NEPH-09 & SB4-NEPH-05ccC \\
\hline SB4-NEPH-02 & SB4-NEPH-10 & SB4-NEPH-06ccC \\
\hline SB4-NEPH-03 & SB4-NEPH-11 & SB4-NEPH-07ccc \\
\hline SB4-NEPH-04 & SB4-NEPH-12 & SB4-NEPH-08ccC \\
\hline SB4-NEPH-05 & SB4-NEPH-01ccc & SB4-NEPH-09ccc \\
\hline SB4-NEPH-06 & SB4-NEPH-02ccC & SB4-NEPH-10ccc \\
\hline SB4-NEPH-07 & SB4-NEPH-03ccc & SB4-NEPH-11ccc \\
\hline SB4-NEPH-08 & SB4-NEPH-04ccC & SB4-NEPH-12ccC \\
\hline
\end{tabular}

\subsection{DiscuSSION}

Each of the study glasses of Table 1 is to be subjected to the PCT in triplicate. In addition to those for the 24 study glasses, triplicate PCTs are to be conducted on a sample of the Approved Reference Material (ARM-1) glass and a sample of the Environmental Assessment (EA) glass. Two reagent blank samples are also to be included in these tests. This results in 80 sample solutions being required to complete these PCTs.

The leachates from these tests will be diluted by adding $4 \mathrm{~mL}$ of $0.4 \mathrm{M} \mathrm{HNO}_{3}$ to $6 \mathrm{~mL}$ of the leachate (a 6:10 volume to volume, v:v, dilution) before being submitted to the SRNL-ML. The EA leachates will be further diluted $(1: 10 \mathrm{v}: \mathrm{v})$ with deionized water prior to submission to the SRNL-ML in order to prevent problems with the nebulizer.

Table 2 presents identifying codes, $\mathrm{x} 01$ through $\mathrm{x} 80$, for the individual solutions required for the PCTs of the study glasses and of the standards (EA, ARM-1, and blanks). This provides a naming convention that is to be used by the SRNL-ML in analyzing the solutions and reporting the relevant concentration measurements. ${ }^{11}$

11

Renaming these samples ensures that they will be processed as blind samples by the SRNL-ML. This table does not contain the solution identifiers for those on the distribution list with a "wo" following their names. 
Table 2: Identifiers for the PCT Solutions

\begin{tabular}{|c|c|c|c|c|c|}
\hline $\begin{array}{l}\text { Original } \\
\text { Sample }\end{array}$ & $\begin{array}{l}\text { Solution } \\
\text { Identifier }\end{array}$ & $\begin{array}{l}\text { Original } \\
\text { Sample }\end{array}$ & $\begin{array}{l}\text { Solution } \\
\text { Identifier }\end{array}$ & $\begin{array}{l}\text { Original } \\
\text { Sample }\end{array}$ & $\begin{array}{l}\text { Solution } \\
\text { Identifier }\end{array}$ \\
\hline SB4-NEPH-01 & $\mathrm{x} 07$ & SB4-NEPH-05сcс & $\mathrm{x} 27$ & SB4-NEPH-10 & $\mathrm{x} 48$ \\
\hline SB4-NEPH-01 & $\mathrm{x} 14$ & SB4-NEPH-05cCC & $\mathrm{x} 16$ & SB4-NEPH-10 & $\mathrm{x} 52$ \\
\hline SB4-NEPH-01 & x79 & SB4-NEPH-05cCC & $\mathrm{x} 12$ & SB4-NEPH-10 & $\mathrm{x} 72$ \\
\hline SB4-NEPH-01cCC & x05 & SB4-NEPH-06 & x29 & SB4-NEPH-10ccC & x54 \\
\hline SB4-NEPH-01ccC & $\mathrm{x} 45$ & SB4-NEPH-06 & x78 & SB4-NEPH-10ccc & x51 \\
\hline SB4-NEPH-01cCC & $\mathrm{x} 22$ & SB4-NEPH-06 & x25 & SB4-NEPH-10ccC & $\mathrm{x} 57$ \\
\hline SB4-NEPH-02 & x76 & SB4-NEPH-06cCC & x34 & SB4-NEPH-11 & x69 \\
\hline SB4-NEPH-02 & x75 & SB4-NEPH-06сcC & $\mathrm{x} 41$ & SB4-NEPH-11 & x35 \\
\hline SB4-NEPH-02 & x15 & SB4-NEPH-06cCC & x74 & SB4-NEPH-11 & x64 \\
\hline SB4-NEPH-02cCC & $\mathrm{x} 23$ & SB4-NEPH-07 & x61 & SB4-NEPH-11ccC & x33 \\
\hline SB4-NEPH-02cCC & $x 67$ & SB4-NEPH-07 & x71 & SB4-NEPH-11cCC & $x 60$ \\
\hline SB4-NEPH-02ccC & $\mathrm{x} 02$ & SB4-NEPH-07 & x68 & SB4-NEPH-11ccc & x62 \\
\hline SB4-NEPH-03 & x36 & SB4-NEPH-07ccC & $\mathrm{x} 10$ & SB4-NEPH-12 & x26 \\
\hline SB4-NEPH-03 & $\mathrm{x} 42$ & SB4-NEPH-07cCC & $\mathrm{x} 47$ & SB4-NEPH-12 & $\mathrm{x} 03$ \\
\hline SB4-NEPH-03 & $\mathrm{x} 58$ & SB4-NEPH-07ccC & x21 & SB4-NEPH-12 & x53 \\
\hline SB4-NEPH-03cCC & $\mathrm{x} 49$ & SB4-NEPH-08 & x32 & SB4-NEPH-12ccC & x19 \\
\hline SB4-NEPH-03сcC & $\mathrm{x} 59$ & SB4-NEPH-08 & $\mathrm{x} 13$ & SB4-NEPH-12ccC & $\mathrm{x} 28$ \\
\hline SB4-NEPH-03сcC & $\mathrm{x} 77$ & SB4-NEPH-08 & $\mathrm{x} 17$ & SB4-NEPH-12ccC & $\mathrm{x} 24$ \\
\hline SB4-NEPH-04 & $\mathrm{x} 80$ & SB4-NEPH-08ccC & $\mathrm{x} 04$ & EA & $\mathrm{x} 70$ \\
\hline SB4-NEPH-04 & $\mathrm{x} 73$ & SB4-NEPH-08ccC & $\mathrm{x} 20$ & EA & $\mathrm{x} 01$ \\
\hline SB4-NEPH-04 & x38 & SB4-NEPH-08ccC & x65 & EA & $\mathrm{x} 06$ \\
\hline SB4-NEPH-04ccC & $\mathrm{x} 08$ & SB4-NEPH-09 & x55 & ARM-1 & x63 \\
\hline SB4-NEPH-04cCC & $\mathrm{x} 50$ & SB4-NEPH-09 & $\mathrm{x} 44$ & ARM-1 & x37 \\
\hline SB4-NEPH-04ccC & $\mathrm{x} 46$ & SB4-NEPH-09 & $\mathrm{x} 11$ & ARM-1 & x39 \\
\hline SB4-NEPH-05 & x09 & SB4-NEPH-09ccC & x30 & Blank & x56 \\
\hline SB4-NEPH-05 & $\mathrm{x} 18$ & SB4-NEPH-09cCC & x66 & Blank & x31 \\
\hline SB4-NEPH-05 & $\mathrm{x} 43$ & SB4-NEPH-09ccC & $\mathrm{x} 40$ & & \\
\hline
\end{tabular}

\subsection{Analytical Plan}

The analytical plan for the SRNL-ML is provided in this section. Each of the solution samples submitted to the SRNL-ML is to be analyzed only once for each of the following: boron (B), barium (Ba), cadmium (Cd), chromium $(\mathrm{Cr})$, iron $(\mathrm{Fe})$, lithium $(\mathrm{Li})$, sodium $(\mathrm{Na})$, lead $(\mathrm{Pb})$, silicon ( $\mathrm{Si})$, thorium (Th), and uranium (U). B, Li, Na, and $\mathrm{Si}$ are the elements that are to be used in the assessment of glass durability; the other elements are being monitored to address solution disposal issues in SRNL upon termination of the PCTs. The measurements are to be made in parts per million (ppm). The analytical procedure used by the SRNL-ML to determine the concentrations utilizes an Inductively Coupled Plasma - Atomic Emission Spectrometer (ICPAES). The PCT solutions (as identified in Table 2) are grouped in six ICP-AES blocks for processing by the SRNL-ML in Table 3. Each block requires a different calibration of the ICPAES. 
Table 3: ICP-AES Calibration Blocks for Leachate Measurements

\begin{tabular}{|c|c|c|c|c|c|}
\hline Block 1 & Block 2 & Block 3 & Block 4 & Block 5 & Block 6 \\
\hline std-b1-1 & std-b2-1 & std-b3-1 & std-b4-1 & std-b5-1 & std-b6-1 \\
\hline x76 & x66 & x72 & x31 & x16 & x17 \\
\hline x26 & x28 & x38 & $\mathrm{x} 49$ & $\mathrm{x} 18$ & x77 \\
\hline x56 & x67 & x62 & x32 & $\mathrm{x} 45$ & $\mathrm{x} 58$ \\
\hline x69 & x73 & $\mathrm{x} 11$ & $\mathrm{x} 10$ & $\mathrm{x} 01$ & x12 \\
\hline x54 & x35 & x15 & x29 & $\mathrm{x} 47$ & x25 \\
\hline x23 & x03 & $\mathrm{x} 02$ & $\mathrm{x} 07$ & x78 & x68 \\
\hline x08 & x52 & x40 & x34 & x13 & x65 \\
\hline std-b1-2 & std-b2-2 & std-b3-2 & std-b4-2 & std-b5-2 & std-b6-2 \\
\hline x63 & x37 & x24 & x70 & x42 & x06 \\
\hline x33 & x60 & x64 & x61 & $\mathrm{x} 14$ & x79 \\
\hline x30 & $\mathrm{x} 50$ & $\mathrm{x} 46$ & x36 & x71 & x74 \\
\hline $\mathrm{x} 48$ & x51 & $\mathrm{x} 53$ & $\mathrm{x} 09$ & x59 & $x 43$ \\
\hline x19 & x75 & x39 & x05 & $\mathrm{x} 41$ & $\mathrm{x} 22$ \\
\hline x80 & x44 & x57 & x27 & x20 & x21 \\
\hline $\begin{array}{c}\text { x55 } \\
\text { std-b1-3 }\end{array}$ & std-b2-3 & std-b3-3 & $\begin{array}{c}\text { x04 } \\
\text { std-b4-3 }\end{array}$ & std-b5-3 & std-b6-3 \\
\hline
\end{tabular}

A multi-element solution standard (denoted by "std-bi-j" where $\mathrm{i}=1$ to 6 represents the block number and $\mathrm{j}=1,2$, and 3 represents the position in the block) was added at the beginning, middle, and end of each of the three blocks. This standard may be useful in checking and correcting for bias in the concentration measurements arising from the ICP calibrations.

\subsection{SUMMARY}

In summary, this analytical plan provides identifiers for the PCT solutions in Table 2 and six ICPAES calibration blocks in Table 3 for the SRNL-ML to use in conducting the boron (B), barium $(\mathrm{Ba})$, cadmium $(\mathrm{Cd})$, chromium $(\mathrm{Cr})$, iron $(\mathrm{Fe})$, lithium $(\mathrm{Li})$, sodium $(\mathrm{Na})$, lead $(\mathrm{Pb})$, silicon $(\mathrm{Si})$, thorium (Th), and uranium (U) concentration measurements for this PCT study. The sequencing of the activities associated with each of the steps in the analytical procedure has been randomized. The size of the blocks was selected so that the block could be completed in a single work shift. If for some reason the measurements are not conducted in the sequence presented in this memorandum, the actual order should be recorded along with any explanative comments.

The analytical plan indicated in the preceding tables should be modified by the personnel of the SRNL-ML to include any calibration check standards and/or other standards that are part of their standard operating procedures.

\subsection{REFERENCES}

[1] Peeler, D.K. and T.B. Edwards, "Nepheline Formation Potential in SB4 Glasses," WSRC-TR-2005-00153, Revision 0, 2005.

[2] ASTM C-1285-2002, "Standard Test Methods for Determining Chemical Durability of Nuclear Waste Glasses: The Product Consistency Test (PCT),” ASTM, 2002. 


\section{APPENDIX C}

Tables and Exhibits Supporting the Analysis of the Chemical Composition Measurements of the Nepheline Study Glasses 
Table C.1: Targeted Oxide Concentrations (as wt\%'s) for the Nepheline Study Glasses

\begin{tabular}{|c|c|c|c|c|c|c|c|c|c|c|c|c|c|c|c|c|c|c|c|c|c|c|c|c|}
\hline Glass \# & Al2O3 & B2O3 & BaO & $\mathrm{CaO}$ & Ce2O3 & \begin{tabular}{|l|} 
Cr2O3 \\
\end{tabular} & $\mathrm{CuO}$ & Fe2O3 & K2O & La2O3 & \begin{tabular}{|l|} 
Li20 \\
\end{tabular} & MgO & MnO & $\mathrm{Na2O}$ & $\mathrm{NiO}$ & PbO & SO4 & $\mathrm{SiO} 2$ & \begin{tabular}{|l|} 
ThO2 \\
\end{tabular} & TiO2 & U308 & ZnO & ZrO2 & Sum \\
\hline SB4-NEPH-01 & 12.612 & 4.8 & 0.043 & 0.884 & 0.082 & \begin{tabular}{|l|}
0.092 \\
\end{tabular} & 0.029 & 9.087 & 0.682 & 0.034 & 4.8 & 0.732 & 1.913 & 16.348 & 0.583 & 0.081 & 0.442 & 44.482 & 0.02 & 0.01 & 2.111 & 0.04 & 0.095 & 100.002 \\
\hline SB4-NEPH-02 & 11.683 & 4.8 & 0.042 & 0.839 & 0.081 & 0.087 & 0.028 & 8.701 & 0.624 & 0.034 & 4.8 & 0.669 & 1.905 & 16.987 & 0.579 & 0.078 & 0.508 & 44.389 & 0.018 & 0.979 & 2.036 & 0.039 & 0.094 & 100 \\
\hline SB4-NEPH-03 & 8.467 & 4.8 & 0.062 & 0.848 & 0.082 & 0.096 & 0.032 & 9.897 & 0.377 & 0.036 & 4.8 & 0.71 & 2.289 & 16.682 & 1.4 & 0.065 & 0.506 & 44.218 & 0.013 & 0.977 & 3.489 & 0.049 & 0.109 & 100.004 \\
\hline SB4-NEPH-04 & 12.612 & 4.8 & 0.043 & 0.884 & 0.082 & 0.092 & 0.029 & 9.087 & 0.682 & 0.034 & 4.8 & 0.732 & 1.913 & 13.948 & 0.583 & 0.081 & 0.442 & 46.882 & 0.02 & 0.01 & 2.111 & 0.04 & 0.095 & 100.002 \\
\hline SB4-NEPH-05 & 9.07 & 4.8 & 0.065 & 0.893 & 0.083 & 0.101 & 0.034 & 10.404 & 0.41 & 0.037 & 4.8 & 0.777 & 2.335 & 16.011 & 1.486 & 0.066 & 0.439 & 44.293 & 0.014 & 0.009 & 3.711 & 0.051 & 0.112 & 100.001 \\
\hline SB4-NEPH-06 & 8.375 & 4.8 & 0.076 & 0.723 & 0.077 & 0.105 & 0.032 & 9.24 & 0.416 & 0.034 & 4.8 & 0.424 & 2.352 & 16.504 & 2.254 & 0.063 & 0.504 & 44.055 & 0.011 & 0.975 & 4.013 & 0.05 & 0.12 & 00.003 \\
\hline SB4-NEPH-07 & 8.969 & 4.8 & 0.08 & 0.756 & 0.078 & 0.111 & 0.034 & 9.68 & 0.454 & 0.035 & 4.8 & 0.462 & 2.404 & 15.816 & 2.426 & 0.064 & 0.438 & 44.114 & 0.012 & 0.006 & 4.287 & 0.052 & 0.124 & 100.002 \\
\hline SB4-NEPH-08 & 11.683 & 4.8 & 0.042 & 0.839 & 0.081 & 0.087 & 0.028 & 8.701 & 0.624 & 0.034 & 4.8 & 0.669 & 1.905 & 14.587 & 0.579 & 0.078 & 0.508 & 46.789 & 0.018 & 0.979 & 2.036 & 0.039 & 0.094 & 100 \\
\hline SB4-NEPH-09 & 11.035 & 5.2 & 0.038 & 0.774 & 0.072 & 0.08 & 0.025 & 7.951 & 0.597 & 0.03 & 5.2 & 0.641 & 1.674 & 15.805 & 0.51 & 0.071 & 0.386 & 47.921 & 0.017 & 0.009 & 1.847 & 0.035 & 0.083 & 100.001 \\
\hline \begin{tabular}{|l|} 
SB4-NEPH-10 \\
\end{tabular} & 8.097 & 4.8 & 0.062 & 0.859 & 0.081 & 0.094 & 0.032 & 10.088 & 0.334 & 0.036 & 4.8 & 0.784 & 2.387 & 16.659 & 1.425 & 0.062 & 0.506 & 44.225 & 0.012 & 0.978 & 3.528 & 0.048 & 0.105 & 100.002 \\
\hline SB4-NEPH-11 & 8.664 & 4.8 & 0.065 & 0.905 & 0.083 & 0.1 & 0.033 & 10.613 & 0.363 & 0.037 & 4.8 & 0.859 & 2.443 & 15.987 & 1.514 & 0.063 & 0.439 & 44.301 & 0.014 & 0.009 & 3.753 & 0.05 & 0.107 & 100.002 \\
\hline SB4-NEPH-12 & 10.222 & 5.2 & 0.037 & 0.734 & 0.071 & 0.076 & 0.024 & 7.613 & 0.546 & 0.029 & 5.2 & 0.585 & 1.667 & 16.364 & 0.507 & 0.068 & 0.444 & 47.84 & 0.016 & 0.856 & 1.781 & 0.035 & 0.082 & 99.997 \\
\hline
\end{tabular}


Table C.2: Measured Elemental Concentrations (wt\%) for Samples Prepared Using Lithium Metaborate

\begin{tabular}{|c|c|c|c|c|c|c|c|c|c|c|c|c|c|c|c|c|c|c|}
\hline Glass & SRNL-ML & & Analytical & & & & & & & & & & & & & & & \\
\hline ID & ID & Block & Sequence & Ba & Ca & $\mathrm{Ce}$ & $\mathrm{Cr}$ & $\mathbf{C u}$ & $\mathbf{K}$ & La & Mg & $\mathrm{Na}$ & $\mathbf{P b}$ & $\mathrm{S}$ & Th & $\mathbf{T i}$ & Zn & $\mathrm{Zr}$ \\
\hline Batch 1 & 3CHLM11 & 1 & 1 & 0.120 & 0.861 & $<0.010$ & 0.076 & 0.307 & 2.86 & $<0.010$ & 0.756 & 6.96 & $<0.010$ & $<0.100$ & $<0.010$ & 0.367 & $<0.010$ & 0.061 \\
\hline Ustd & stdLM11 & 1 & 2 & $<0.010$ & 0.905 & $<0.010$ & 0.163 & 0.004 & 2.34 & $<0.010$ & 0.665 & 8.82 & $<0.010$ & $<0.100$ & 0.076 & 0.555 & $<0.010$ & $<0.010$ \\
\hline SB4-NEPH-07 & N09LM21 & 1 & 3 & 0.066 & 0.529 & 0.050 & 0.068 & 0.028 & 0.417 & 0.021 & 0.260 & 12.0 & 0.052 & 0.124 & 0.144 & 0.007 & 0.045 & 0.082 \\
\hline SB4-NEPH-06 & N11LM21 & 1 & 4 & 0.055 & 0.537 & 0.050 & 0.069 & 0.027 & 0.392 & 0.020 & 0.236 & 12.6 & 0.053 & 0.141 & 0.130 & 0.550 & 0.044 & 0.080 \\
\hline SB4-NEPH-05 & $\mathrm{N} 01$ & 1 & 5 & 0.050 & 0.645 & 0.057 & 0.064 & 0.027 & 0.402 & 0.023 & 0.415 & 12.3 & 0.053 & 0.126 & 0.117 & 0.003 & 0.042 & 0.073 \\
\hline SB4-NEPH-09 & N12 & 1 & 6 & 0.027 & 0.542 & 0.041 & 0.055 & 0.019 & 0.545 & 0.017 & 0.348 & 12.1 & 0.059 & 0.113 & 0.070 & 0.003 & 0.028 & 0.054 \\
\hline SB4-NEPH-09 & $12 \mathrm{LM}$ & 1 & 7 & 0.027 & 0.544 & 0.040 & 0.052 & 0.019 & 0.578 & 0.017 & 0.334 & 12.0 & 0.051 & 0.097 & 0.067 & 0.002 & 0.027 & 0.053 \\
\hline SB4-NEPH-05 & & 1 & 8 & 0.051 & 0.635 & 0.058 & 0.068 & 0.027 & 0.390 & 0.024 & 0.426 & 12.4 & 0.054 & 0.138 & 0.119 & 0.003 & 0.042 & 0.074 \\
\hline SB4-NEPH-11 & 411 & 1 & & 0.054 & 0.628 & 0.052 & 0.065 & 0.027 & 0.311 & 0.024 & 0.494 & 12.3 & .059 & 0.132 & 0.130 & 0.008 & 0.042 & 0.074 \\
\hline SB4-NEPH-03 & 121 & 1 & 10 & 0.050 & 0.585 & 0.048 & 0.068 & 0.024 & 0.350 & 0.021 & 0.397 & 12.5 & 0.051 & 0.155 & 0.112 & 0.529 & 0.065 & 0.071 \\
\hline SB4-NEPH-10 & 11 & 1 & & 0.051 & 0.609 & 0.056 & 0.069 & 0.025 & 0.322 & 0.022 & 0.433 & 12.8 & .051 & 0.153 & 0.114 & 0.554 & 0.043 & 0.069 \\
\hline SB4-NEPH-04 & N02LM11 & 1 & 1. & 0.031 & 0.606 & 0.052 & 0.058 & 0.023 & 0.641 & 0.020 & 0.398 & 10.8 & 0.064 & 0.121 & 0.078 & 0.003 & 0.031 & 0.062 \\
\hline SB4-NEPH-01 & M11 & 1 & & 0.034 & 0.645 & 0.048 & 0.070 & 0.023 & 0.602 & 0.022 & 0.418 & 12.6 & .063 & 0.127 & 0.080 & 0.004 & 0.033 & 0.065 \\
\hline SB4-NEPH-01 & & 1 & 1 & 0.034 & 0.620 & 0.048 & 0.069 & 0.023 & 0.599 & 0.023 & 0.417 & 12.7 & 0.068 & 0.141 & 0.079 & 0.004 & 0.033 & 0.066 \\
\hline Batch 1 & & 1 & & 121 & 0.828 & $<0.010$ & 0.077 & 0.299 & 2.81 & $<0.010$ & 0.761 & 7.15 & $<0.010$ & $<0.100$ & $<0.010$ & 0.367 & $<0.010$ & 0.060 \\
\hline Ustd & stdLM12 & 1 & 1 & $<0.010$ & 0.886 & $<0.010$ & 0.164 & 0.004 & 2.32 & $<0.010$ & 0.672 & 9.04 & $<0.010$ & $<0.100$ & 0.073 & 0.554 & $<0.010$ & $<0.010$ \\
\hline SB4-NEPH-07 & N09LM11 & 1 & 17 & 0.069 & 0.521 & 0.050 & 0.071 & 0.030 & 0.409 & 0.021 & 0.269 & 12.1 & 0.056 & 0.124 & 0.145 & 0.007 & 0.046 & 0.083 \\
\hline SB4-NEPH-08 & 08LM11 & 1 & 1 & .031 & 0.582 & 0.046 & .058 & .022 & 0.643 & .021 & 0.363 & 11.3 & 057 & 40 & .071 & 0.529 & 0.037 & 0.061 \\
\hline SB4-NEPH-12 & N06LM21 & 1 & & .029 & 0.510 & 0.047 & 0.059 & 0.018 & 0.497 & 0.019 & 0.338 & 12.4 & 0.057 & 0.126 & 0.065 & 0.487 & 0.027 & 0.057 \\
\hline SB4-NEPH-10 & N04LM21 & 1 & 2 & 0.050 & 0.591 & 0.055 & 0.068 & 0.025 & 0.306 & 0.022 & 0.435 & 12.6 & 52 & 0.154 & 0.114 & 0.555 & 0.043 & 0.070 \\
\hline SB4-NEPH-02 & N10LM11 & 1 & 21 & 0.033 & 0.567 & 0.050 & 0.063 & 0.022 & 0.566 & 0.022 & 0.378 & 13.0 & 0.059 & 0.146 & 0.078 & 0.588 & 0.031 & 0.061 \\
\hline SB4-NEPH-02 & N10LM21 & 1 & & 0.033 & 0.577 & 0.049 & 0.060 & 0.019 & 0.606 & 0.021 & 0.364 & 12.7 & 0.057 & 0.130 & 0.074 & 0.569 & 0.030 & 0.060 \\
\hline SB4-NEPH-11 & N07LM21 & 1 & 23 & 0.055 & 0.637 & 0.051 & 0.067 & 0.028 & 0.329 & 0.024 & 0.495 & 12.1 & 0.056 & 0.121 & 0.132 & 0.009 & 0.043 & 0.074 \\
\hline SB4-NEPH-04 & N02LM21 & 1 & 24 & 0.033 & 0.608 & 0.053 & 0.066 & 0.024 & 0.625 & 0.021 & 0.417 & 10.6 & 0.064 & 0.135 & 0.079 & 0.003 & 0.032 & 0.060 \\
\hline SB4-NEPH-12 & & 1 & 25 & 0.029 & 0.514 & 0.046 & 0.059 & 0.018 & 0.499 & 0.019 & 0.336 & 12.5 & 0.050 & 0.136 & 0.065 & 0.479 & 0.028 & 0.057 \\
\hline SB4-NEPH-06 & & 1 & 26 & 0.057 & 0.504 & 0.049 & 0.072 & 0.026 & 0.398 & 0.020 & 0.239 & 12.7 & 0.051 & 0.1 & 0.126 & 0.542 & 0.044 & 0.079 \\
\hline SB4-NEPH-08 & N08L & 1 & 27 & 0.033 & 0.557 & 0.047 & 0.063 & 0.023 & 0.551 & 0.021 & 0.387 & 11.2 & 0.062 & 0.151 & 0.076 & 0.560 & 0.030 & 0.064 \\
\hline SB4-NEPH-03 & & 1 & 28 & 0.052 & 0.599 & 0.049 & 0.070 & 0.024 & 0.348 & 0.022 & 0.409 & 12.7 & 0.055 & 0.154 & 0.115 & 0.549 & 0.042 & 0.074 \\
\hline Ustd & & 1 & 29 & $<0.010$ & 0.860 & $<0.010$ & 0.168 & 0.004 & 2.27 & $<0.010$ & 0.682 & 9.19 & $<0.010$ & $<0.100$ & 0.073 & 0.552 & $<0.010$ & $<0.010$ \\
\hline Batch 1 & & 1 & 30 & 0.123 & 0.819 & $<0.010$ & 0.078 & 0.298 & 2.78 & $<0.010$ & 0.770 & 7.07 & $<0.010$ & $<0.100$ & $<0.010$ & 0.365 & $<0.010$ & 0.060 \\
\hline Batch 1 & & 2 & 1 & & 0.857 & $<0.010$ & 0.079 & 0.308 & 2.81 & $<0.0$ & 0.770 & 6.97 & & $<0$. & $<0.010$ & 0.372 & & 0.062 \\
\hline Ustd & & 2 & 2 & $<0.010$ & 0.902 & $<0.010$ & 0.166 & 0.004 & 2.29 & $<0.010$ & 0.678 & 8.89 & $<0.010$ & $<0.100$ & 0.077 & 0.563 & $<0.010$ & $<0.010$ \\
\hline SB4-NEPH-09 & & 2 & 3 & 0.030 & 0.532 & 0.043 & 0.060 & 0.020 & 0.532 & 0.020 & 0.371 & 11.9 & & 0.1 & 0.073 & 0.007 & 0.030 & 0.057 \\
\hline SB4-NEPH-03 & & 2 & 4 & & 0.636 & 0.052 & 0.072 & 0.026 & 0.352 & 0.024 & 0.407 & 12.7 & & 0.1 & 0.120 & 0.558 & 0.0 & 0.077 \\
\hline SB4-NEPH-02 & & 2 & 5 & & 0.576 & 0.053 & 0.061 & 0.023 & 0.567 & 0.023 & 0.375 & 13.0 & & 0.1 & 0.080 & 0.591 & 0.031 & 0.064 \\
\hline SB4-NEPH-05 & & 2 & $\theta$ & & 0.658 & 0.058 & 0.068 & 0.027 & 0.397 & 0.026 & 0.427 & 12.0 & & 31 & 0.120 & 0.006 & 0.044 & 0.076 \\
\hline SB4-NEPH-11 & & 2 & 7 & & 0.638 & 0.054 & 0.066 & 0.029 & 0.327 & 0.026 & 0.483 & 11.9 & 0.057 & 0.1 & 0.131 & 0.012 & 0.044 & 0.076 \\
\hline SB4-NEPH-05 & & 2 & 8 & & 0.633 & 0.060 & 0.072 & 0.028 & 0.389 & 0.026 & 0.435 & 12.4 & 0.056 & 0.1 & 0.123 & 0.007 & 0.044 & 0.078 \\
\hline SB4-NEPH-03 & & 2 & $S$ & & 0.620 & 0.051 & 0.072 & 0.026 & 0.363 & 0.024 & 0.405 & 12.8 & 0.051 & 60 & 0.117 & 0.544 & 0.067 & 0.076 \\
\hline \begin{tabular}{|l|} 
SB4-NEPH-11 \\
\end{tabular} & & 2 & & & 0.651 & 0.054 & 0.067 & 0.029 & 0.308 & 0.027 & 0.503 & 12.2 & & 34 & 0.138 & 0.012 & 0.044 & 0.078 \\
\hline SB4-NEPH-06 & N11LM22 & 2 & 11 & 0.058 & 0.533 & 0.052 & 0.072 & 0.028 & 0.386 & 0.022 & 0.243 & 12.6 & 0.051 & 0.152 & 0.129 & 0.552 & 0.047 & 0.083 \\
\hline
\end{tabular}


Table C.2: Measured Elemental Concentrations (wt\%) for Samples Prepared Using Lithium Metaborate

\begin{tabular}{|c|c|c|c|c|c|c|c|c|c|c|c|c|c|c|c|c|c|c|}
\hline Glass & SRNL-ML & & Analytical & & & & & & & & & & & & & & & \\
\hline ID & ID & Block & Sequence & Ba & $\mathbf{C a}$ & Ce & $\mathrm{Cr}$ & $\mathbf{C u}$ & $\mathbf{K}$ & $\mathbf{L a}$ & Mg & $\mathrm{Na}$ & $\mathbf{P b}$ & $\mathrm{S}$ & Th & $\mathbf{T i}$ & Zn & $\mathrm{Zr}$ \\
\hline SB4-NEPH-01 & N05LM12 & 2 & 12 & 0.036 & 0.636 & 0.051 & 0.071 & 0.024 & 0.605 & 0.024 & 0.418 & 12.6 & 0.068 & 0.122 & 0.084 & 0.008 & 0.034 & 0.069 \\
\hline SB4-NEPH-12 & N06LM12 & 2 & 13 & 0.030 & 0.527 & 0.048 & 0.059 & 0.019 & 0.509 & 0.020 & 0.327 & 12.4 & 0.054 & 0.130 & 0.067 & 0.475 & 0.029 & 0.058 \\
\hline SB4-NEPH-06 & N11LM12 & 2 & 14 & 0.057 & 0.529 & 0.052 & 0.070 & 0.027 & 0.407 & 0.021 & 0.233 & 12.6 & 0.051 & 0.152 & 0.129 & 0.539 & 0.044 & 0.081 \\
\hline Batch 1 & BCHLM22 & 2 & 15 & 0.118 & 0.855 & $<0.010$ & 0.076 & 0.307 & 2.81 & $<0.010$ & 0.739 & 6.98 & $<0.010$ & $<0.100$ & $<0.010$ & 0.362 & $<0.010$ & 0.062 \\
\hline Ustd & UstdLM22 & 2 & 16 & $<0.010$ & 0.895 & $<0.010$ & 0.163 & 0.004 & 2.29 & $<0.010$ & 0.662 & 9.22 & $<0.010$ & $<0.100$ & 0.077 & 0.551 & $<0.010$ & $<0.010$ \\
\hline SB4-NEPH-08 & N08LM12 & 2 & 17 & 0.032 & 0.609 & 0.048 & 0.058 & 0.023 & 0.649 & 0.022 & 0.357 & 11.2 & 0.055 & 0.131 & 0.073 & 0.529 & 0.038 & 0.063 \\
\hline SB4-NEPH-07 & N09LM22 & 2 & 18 & 0.069 & 0.532 & 0.052 & 0.070 & 0.029 & 0.412 & 0.023 & 0.269 & 12.2 & 0.060 & 0.135 & 0.149 & 0.010 & 0.049 & 0.086 \\
\hline SB4-NEPH-04 & N02LN12 & 2 & 19 & 0.033 & 0.627 & 0.055 & 0.060 & 0.024 & 0.647 & 0.023 & 0.403 & 10.9 & 0.060 & 0.136 & 0.081 & 0.006 & 0.032 & 0.065 \\
\hline SB4-NEPH-07 & N09LM12 & 2 & 20 & 0.072 & 0.527 & 0.053 & 0.072 & 0.031 & 0.405 & 0.023 & 0.274 & 12.2 & 0.060 & 0.141 & 0.150 & 0.010 & 0.048 & 0.087 \\
\hline SB4-NEPH-10 & N04LM12 & 2 & 21 & 0.052 & 0.633 & 0.059 & 0.070 & 0.026 & 0.326 & 0.025 & 0.436 & 12.9 & 0.052 & 0.151 & 0.118 & 0.563 & 0.045 & 0.075 \\
\hline SB4-NEPH-09 & N12LM12 & 2 & 22 & 0.029 & 0.555 & 0.043 & 0.055 & 0.020 & 0.582 & 0.019 & 0.347 & 12.1 & 0.058 & 0.119 & 0.070 & 0.006 & 0.029 & 0.056 \\
\hline SB4-NEPH-04 & N02LM22 & 2 & 23 & 0.034 & 0.640 & 0.056 & 0.065 & 0.025 & 0.640 & 0.023 & 0.413 & 10.5 & 0.066 & 0.131 & 0.083 & 0.006 & 0.033 & 0.063 \\
\hline SB4-NEPH-10 & N04LM22 & 2 & 24 & 0.051 & 0.629 & 0.058 & 0.068 & 0.026 & 0.308 & 0.024 & 0.433 & 12.8 & 0.053 & 0.157 & 0.118 & 0.563 & 0.044 & 0.073 \\
\hline SB4-NEPH-02 & N10LM22 & 2 & 25 & 0.033 & 0.596 & 0.053 & 0.060 & 0.021 & 0.617 & 0.023 & 0.362 & 13.1 & 0.058 & 0.155 & 0.077 & 0.573 & 0.032 & 0.063 \\
\hline SB4-NEPH-01 & N05LM22 & 2 & 26 & 0.036 & 0.645 & 0.051 & 0.070 & 0.024 & 0.609 & 0.025 & 0.420 & 12.8 & 0.066 & 0.135 & 0.083 & 0.008 & 0.035 & 0.069 \\
\hline SB4-NEPH-12 & N06LM22 & 2 & 27 & 0.031 & 0.535 & 0.050 & 0.062 & 0.019 & 0.502 & 0.021 & 0.342 & 12.6 & 0.056 & 0.127 & 0.070 & 0.497 & 0.029 & 0.061 \\
\hline SB4-NEPH-08 & N08LM22 & 2 & 28 & 0.035 & 0.585 & 0.051 & 0.066 & 0.024 & 0.562 & 0.024 & 0.395 & 11.3 & 0.065 & 0.157 & 0.080 & 0.581 & 0.033 & 0.068 \\
\hline Ustd & UstdLM23 & 2 & 29 & $<0.010$ & 0.917 & $<0.010$ & 0.166 & 0.004 & 2.33 & $<0.010$ & 0.677 & 9.24 & $<0.010$ & $<0.100$ & 0.079 & 0.562 & $<0.010$ & $<0.010$ \\
\hline Batch 1 & BCHLM23 & 2 & 30 & 0.116 & 0.877 & $<0.010$ & 0.072 & 0.309 & 2.75 & $<0.010$ & 0.736 & 7.16 & $<0.010$ & $<0.100$ & $<0.010$ & 0.357 & $<0.010$ & 0.062 \\
\hline
\end{tabular}


WSRC-TR-2005-00371

Revision 0

Table C.3: Measured Elemental Concentrations (wt\%) for Samples Prepared Using Peroxide Fusion

\begin{tabular}{|c|c|c|c|c|c|c|c|c|c|c|c|}
\hline Glass & SRNL-ML & & Analytical & & & & & & & & \\
\hline ID & ID & Block & Sequence & Al & $\mathbf{B}$ & $\mathbf{F e}$ & $\mathbf{L i}$ & Mn & $\mathbf{N i}$ & $\mathrm{Si}$ & $\mathbf{U}$ \\
\hline Batch 1 & BCHPF11 & 1 & 1 & 2.56 & 2.50 & 8.63 & 2.07 & 1.25 & 0.527 & 23.4 & $<0.100$ \\
\hline Ustd & UstdPF11 & 1 & 2 & 2.13 & 2.85 & 8.89 & 1.42 & 2.07 & 0.764 & 20.5 & 1.98 \\
\hline SB4-NEPH-03 & N03PF11 & 1 & 3 & 4.57 & 1.52 & 6.51 & 2.18 & 1.68 & 0.968 & 20.4 & 2.87 \\
\hline SB4-NEPH-10 & N04PF21 & 1 & 4 & 4.43 & 1.52 & 6.73 & 2.20 & 1.78 & 1.00 & 20.6 & 2.91 \\
\hline SB4-NEPH-01 & N05PF11 & 1 & 5 & 6.60 & 1.46 & 6.01 & 2.12 & 1.40 & 0.402 & 20.3 & 1.71 \\
\hline SB4-NEPH-09 & N12PF11 & 1 & 6 & 6.00 & 1.59 & 5.09 & 2.36 & 1.19 & 0.329 & 22.1 & 1.53 \\
\hline SB4-NEPH-04 & N02PF11 & 1 & 7 & 6.86 & 1.47 & 5.73 & 2.19 & 1.35 & 0.365 & 21.7 & 1.67 \\
\hline SB4-NEPH-08 & N08PF21 & 1 & 8 & 6.39 & 1.47 & 5.62 & 2.20 & 1.32 & 0.385 & 21.9 & 1.63 \\
\hline SB4-NEPH-07 & N09PF21 & 1 & 9 & 4.97 & 1.46 & 6.25 & 2.22 & 1.75 & 1.63 & 20.7 & 3.56 \\
\hline SB4-NEPH-09 & N12PF21 & 1 & 10 & 5.93 & 1.59 & 5.56 & 2.35 & 1.22 & 0.338 & 22.2 & 1.54 \\
\hline SB4-NEPH-06 & N11PF11 & 1 & 11 & 4.54 & 1.44 & 5.92 & 2.19 & 1.70 & 1.51 & 20.4 & 3.17 \\
\hline SB4-NEPH-04 & N02PF21 & 1 & 12 & 6.71 & 1.49 & 5.96 & 2.16 & 1.39 & 0.396 & 21.6 & 1.73 \\
\hline SB4-NEPH-02 & N10PF11 & 1 & 13 & 6.36 & 1.47 & 5.76 & 2.18 & 1.37 & 0.371 & 20.6 & 1.74 \\
\hline SB4-NEPH-05 & N01PF11 & 1 & 14 & 4.92 & 1.47 & 6.73 & 2.19 & 1.70 & 1.01 & 20.5 & 2.95 \\
\hline Batch 1 & BCHPF12 & 1 & 15 & 2.59 & 2.35 & 8.41 & 2.06 & 1.22 & 0.505 & 23.2 & $<0.100$ \\
\hline Ustd & UstdPF12 & 1 & 16 & 2.11 & 2.73 & 8.55 & 1.41 & 2.01 & 0.741 & 20.2 & 1.96 \\
\hline SB4-NEPH-11 & N07PF21 & 1 & 17 & 4.65 & 1.51 & 6.82 & 2.16 & 1.78 & 1.04 & 20.3 & 3.17 \\
\hline SB4-NEPH-06 & N11PF21 & 1 & 18 & 4.54 & 1.45 & 5.73 & 2.17 & 1.65 & 1.48 & 20.1 & 3.19 \\
\hline SB4-NEPH-11 & N07PF11 & 1 & 19 & 4.75 & 1.44 & 6.59 & 2.19 & 1.73 & 0.988 & 20.3 & 3.10 \\
\hline SB4-NEPH-03 & N03PF21 & 1 & 20 & 4.55 & 1.46 & 6.35 & 2.17 & 1.65 & 0.944 & 20.2 & 2.87 \\
\hline SB4-NEPH-07 & N09PF11 & 1 & 21 & 4.93 & 1.44 & 6.09 & 2.18 & 1.71 & 1.59 & 20.2 & 3.57 \\
\hline SB4-NEPH-05 & N01PF21 & 1 & 22 & 4.86 & 1.45 & 6.58 & 2.16 & 1.66 & 0.992 & 20.1 & 2.94 \\
\hline SB4-NEPH-12 & N06PF21 & 1 & 23 & 5.56 & 1.53 & 4.76 & 2.35 & 1.12 & 0.302 & 21.6 & 1.46 \\
\hline SB4-NEPH-01 & N05PF21 & 1 & 24 & 6.76 & 1.42 & 5.64 & 2.13 & 1.32 & 0.375 & 19.9 & 1.71 \\
\hline SB4-NEPH-12 & N06PF11 & 1 & 25 & 5.51 & 1.54 & 4.71 & 2.34 & 1.14 & 0.322 & 21.6 & 1.45 \\
\hline SB4-NEPH-10 & N04PF11 & 1 & 26 & 4.34 & 1.42 & 6.34 & 2.15 & 1.68 & 0.944 & 19.9 & 2.89 \\
\hline SB4-NEPH-02 & N10PF21 & 1 & 27 & 6.31 & 1.38 & 5.24 & 2.14 & 1.26 & 0.337 & 19.7 & 1.67 \\
\hline SB4-NEPH-08 & N08PF11 & 1 & 28 & 6.40 & 1.42 & 5.35 & 2.18 & 1.32 & 0.358 & 21.3 & 1.68 \\
\hline Ustd & UstdPF13 & 1 & 29 & 2.15 & 2.65 & 8.33 & 1.40 & 1.97 & 0.735 & 19.9 & 1.95 \\
\hline Batch 1 & BCHPF13 & 1 & 30 & 2.56 & 2.29 & 8.10 & 2.04 & 1.17 & 0.509 & 22.7 & $<0.100$ \\
\hline Batch 1 & BCHPF21 & 2 & 1 & 2.58 & 2.49 & 8.68 & 2.08 & 1.29 & 0.527 & 23.5 & $<0.100$ \\
\hline Ustd & UstdPF21 & 2 & 2 & 2.11 & 2.81 & 8.81 & 1.43 & 2.09 & 0.762 & 20.4 & 1.98 \\
\hline SB4-NEPH-01 & N05PF12 & 2 & 3 & 6.60 & 1.50 & 6.09 & 2.14 & 1.44 & 0.410 & 20.3 & 1.69 \\
\hline SB4-NEPH-05 & N01PF12 & 2 & 4 & 4.88 & 1.50 & 6.90 & 2.19 & 1.77 & 1.05 & 20.4 & 2.92 \\
\hline SB4-NEPH-11 & N07PF22 & 2 & 5 & 4.68 & 1.50 & 7.12 & 2.18 & 1.88 & 1.07 & 20.4 & 3.17 \\
\hline SB4-NEPH-07 & N09PF22 & 2 & 6 & 4.95 & 1.49 & 6.28 & 2.23 & 1.79 & 1.63 & 20.5 & 3.55 \\
\hline Batch 1 & BCHPF11 & 1 & 1 & 2.56 & 2.50 & 8.63 & 2.07 & 1.25 & 0.527 & 23.4 & $<0.100$ \\
\hline Ustd & UstdPF11 & 1 & 2 & 2.13 & 2.85 & 8.89 & 1.42 & 2.07 & 0.764 & 20.5 & 1.98 \\
\hline SB4-NEPH-03 & N03PF11 & 1 & 3 & 4.57 & 1.52 & 6.51 & 2.18 & 1.68 & 0.968 & 20.4 & 2.87 \\
\hline SB4-NEPH-10 & N04PF21 & 1 & 4 & 4.43 & 1.52 & 6.73 & 2.20 & 1.78 & 1.00 & 20.6 & 2.91 \\
\hline SB4-NEPH-01 & N05PF11 & 1 & 5 & 6.60 & 1.46 & 6.01 & 2.12 & 1.40 & 0.402 & 20.3 & 1.71 \\
\hline SB4-NEPH-09 & N12PF11 & 1 & 6 & 6.00 & 1.59 & 5.09 & 2.36 & 1.19 & 0.329 & 22.1 & 1.53 \\
\hline SB4-NEPH-04 & N02PF11 & 1 & 7 & 6.86 & 1.47 & 5.73 & 2.19 & 1.35 & 0.365 & 21.7 & 1.67 \\
\hline SB4-NEPH-08 & N08PF21 & 1 & 8 & 6.39 & 1.47 & 5.62 & 2.20 & 1.32 & 0.385 & 21.9 & 1.63 \\
\hline SB4-NEPH-07 & N09PF21 & 1 & 9 & 4.97 & 1.46 & 6.25 & 2.22 & 1.75 & 1.63 & 20.7 & 3.56 \\
\hline SB4-NEPH-09 & N12PF21 & 1 & 10 & 5.93 & 1.59 & 5.56 & 2.35 & 1.22 & 0.338 & 22.2 & 1.54 \\
\hline SB4-NEPH-06 & N11PF11 & 1 & 11 & 4.54 & 1.44 & 5.92 & 2.19 & 1.70 & 1.51 & 20.4 & 3.17 \\
\hline SB4-NEPH-04 & N02PF21 & 1 & 12 & 6.71 & 1.49 & 5.96 & 2.16 & 1.39 & 0.396 & 21.6 & 1.73 \\
\hline SB4-NEPH-02 & N10PF11 & 1 & 13 & 6.36 & 1.47 & 5.76 & 2.18 & 1.37 & 0.371 & 20.6 & 1.74 \\
\hline SB4-NEPH-05 & N01PF11 & 1 & 14 & 4.92 & 1.47 & 6.73 & 2.19 & 1.70 & 1.01 & 20.5 & 2.95 \\
\hline Batch 1 & BCHPF12 & 1 & 15 & 2.59 & 2.35 & 8.41 & 2.06 & 1.22 & 0.505 & 23.2 & $<0.100$ \\
\hline Ustd & UstdPF12 & 1 & 16 & 2.11 & 2.73 & 8.55 & 1.41 & 2.01 & 0.741 & 20.2 & 1.96 \\
\hline SB4-NEPH-11 & N07PF21 & 1 & 17 & 4.65 & 1.51 & 6.82 & 2.16 & 1.78 & 1.04 & 20.3 & 3.17 \\
\hline SB4-NEPH-06 & N11PF21 & 1 & 18 & 4.54 & 1.45 & 5.73 & 2.17 & 1.65 & 1.48 & 20.1 & 3.19 \\
\hline SB4-NEPH-11 & N07PF11 & 1 & 19 & 4.75 & 1.44 & 6.59 & 2.19 & 1.73 & 0.988 & 20.3 & 3.10 \\
\hline SB4-NEPH-03 & N03PF21 & 1 & 20 & 4.55 & 1.46 & 6.35 & 2.17 & 1.65 & 0.944 & 20.2 & 2.87 \\
\hline SB4-NEPH-07 & N09PF11 & 1 & 21 & 4.93 & 1.44 & 6.09 & 2.18 & 1.71 & 1.59 & 20.2 & 3.57 \\
\hline SB4-NEPH-05 & N01PF21 & 1 & 22 & 4.86 & 1.45 & 6.58 & 2.16 & 1.66 & 0.992 & 20.1 & 2.94 \\
\hline SB4-NEPH-09 & N12PF22 & 2 & 7 & 5.91 & 1.60 & 5.63 & 2.37 & 1.25 & 0.359 & 22.0 & 1.54 \\
\hline SB4-NEPH-03 & N03PF12 & 2 & 8 & 4.56 & 1.48 & 6.52 & 2.20 & 1.70 & 0.968 & 20.2 & 2.83 \\
\hline
\end{tabular}


WSRC-TR-2005-00371

Revision 0

Table C.3: Measured Elemental Concentrations (wt\%) for Samples Prepared Using Peroxide Fusion

\begin{tabular}{||c|c|c|c|c|c|c|c|c|c|c|c||}
\hline Glass & SRNL-ML & & Analytical & & & & & & & & \\
\hline ID & ID & Block & Sequence & Al & B & Fe & Li & Mn & Ni & Si & U \\
\hline SB4-NEPH-04 & N02PF22 & 2 & 9 & 6.63 & 1.49 & 6.04 & 2.17 & 1.43 & 0.405 & 21.4 & 1.71 \\
\hline SB4-NEPH-06 & N11PF22 & 2 & 10 & 4.52 & 1.43 & 5.93 & 2.19 & 1.72 & 1.52 & 20.3 & 3.14 \\
\hline SB4-NEPH-05 & N01PF22 & 2 & 11 & 4.86 & 1.47 & 6.85 & 2.19 & 1.75 & 1.04 & 20.2 & 2.91 \\
\hline SB4-NEPH-06 & N11PF12 & 2 & 12 & 4.51 & 1.44 & 5.90 & 2.18 & 1.71 & 1.52 & 20.1 & 3.13 \\
\hline SB4-NEPH-12 & N06PF12 & 2 & 13 & 5.50 & 1.58 & 4.93 & 2.36 & 1.22 & 0.347 & 21.7 & 1.44 \\
\hline SB4-NEPH-10 & N04PF12 & 2 & 14 & 4.34 & 1.47 & 6.65 & 2.18 & 1.78 & 0.990 & 20.2 & 2.87 \\
\hline Batch 1 & BCHPF22 & 2 & 15 & 2.61 & 2.40 & 8.66 & 2.11 & 1.28 & 0.526 & 23.5 & $<0.100$ \\
\hline Ustd & UstdPF22 & 2 & 16 & 2.16 & 2.77 & 8.81 & 1.43 & 2.08 & 0.776 & 20.3 & 1.96 \\
\hline SB4-NEPH-12 & N06PF22 & 2 & 17 & 5.51 & 1.60 & 4.94 & 2.36 & 1.19 & 0.333 & 21.7 & 1.50 \\
\hline SB4-NEPH-07 & N09PF12 & 2 & 18 & 4.93 & 1.47 & 6.19 & 2.20 & 1.75 & 1.604 & 20.2 & 3.59 \\
\hline SB4-NEPH-08 & N08PF12 & 2 & 19 & 6.31 & 1.45 & 5.47 & 2.19 & 1.36 & 0.384 & 21.3 & 1.65 \\
\hline SB4-NEPH-08 & N08PF22 & 2 & 20 & 6.33 & 1.46 & 5.55 & 2.20 & 1.33 & 0.385 & 21.3 & 1.65 \\
\hline SB4-NEPH-01 & N05PF22 & 2 & 21 & 6.68 & 1.43 & 5.88 & 2.15 & 1.39 & 0.388 & 20.1 & 1.68 \\
\hline SB4-NEPH-10 & N04PF22 & 2 & 22 & 4.37 & 1.46 & 6.62 & 2.19 & 1.78 & 1.00 & 20.2 & 2.88 \\
\hline SB4-NEPH-09 & N12PF12 & 2 & 23 & 5.93 & 1.54 & 5.03 & 2.36 & 1.20 & 0.345 & 21.8 & 1.52 \\
\hline SB4-NEPH-04 & N02PF12 & 2 & 24 & 6.88 & 1.45 & 5.68 & 2.20 & 1.36 & 0.380 & 21.5 & 1.68 \\
\hline SB4-NEPH-03 & N03PF22 & 2 & 25 & 4.48 & 1.44 & 6.48 & 2.16 & 1.70 & 0.957 & 20.1 & 2.80 \\
\hline SB4-NEPH-02 & N10PF22 & 2 & 26 & 6.27 & 1.40 & 5.43 & 2.16 & 1.33 & 0.364 & 19.8 & 1.66 \\
\hline SB4-NEPH-02 & N10PF12 & 2 & 27 & 6.24 & 1.43 & 5.70 & 2.17 & 1.38 & 0.375 & 20.1 & 1.71 \\
\hline SB4-NEPH-11 & N07PF12 & 2 & 28 & 4.73 & 1.44 & 6.73 & 2.21 & 1.78 & 1.03 & 20.5 & 3.07 \\
\hline Ustd & UstdPF23 & 2 & 29 & 2.13 & 2.72 & 8.64 & 1.41 & 2.05 & 0.763 & 20.1 & 1.95 \\
\hline Batch 1 & BCHPF23 & 2 & 30 & 2.56 & 2.33 & 8.43 & 2.05 & 1.25 & 0.516 & 22.9 & $<0.100$ \\
\hline
\end{tabular}


Table C.4: Average Measured and Bias-Corrected Chemical Compositions Versus Targeted Compositions by Oxide by Nepheline Study Glass

(100-Batch 1; $200-U$ std)

\begin{tabular}{|c|c|c|c|c|c|c|c|c|c|}
\hline & & & & Measured & & & Diff of & & $\%$ Diff \\
\hline & Glass & & Measured & Bias-Corrected & Targeted & Diff of & Meas. & $\%$ Diff of & Meas. of \\
\hline Glass ID & $\#$ & Oxide & $(w t \%)$ & (wt\%) & $(w t \%)$ & Measured & bc & Measured & bc \\
\hline SB4-NEPH-01 & 1 & $\mathrm{Al} 2 \mathrm{O} 3$ (wt\%) & 12.5841 & 12.6059 & 12.6120 & -0.0279 & -0.0061 & $-0.2 \%$ & $0.0 \%$ \\
\hline SB4-NEPH-01 & 1 & B2O3 (wt\%) & 4.6769 & 4.7197 & 4.8000 & -0.1231 & -0.0803 & $-2.6 \%$ & $-1.7 \%$ \\
\hline SB4-NEPH-01 & 1 & $\mathrm{BaO}(\mathrm{wt} \%)$ & 0.0391 & 0.0439 & 0.0430 & -0.0039 & 0.0009 & $-9.1 \%$ & $2.2 \%$ \\
\hline SB4-NEPH-01 & 1 & $\mathrm{CaO}(\mathrm{wt} \%)$ & 0.8906 & 0.9142 & 0.8840 & 0.0066 & 0.0302 & $0.7 \%$ & $3.4 \%$ \\
\hline SB4-NEPH-01 & 1 & $\mathrm{Ce} 2 \mathrm{O} 3$ (wt\%) & 0.0580 & 0.0580 & 0.0820 & -0.0240 & -0.0240 & $-29.3 \%$ & $-29.3 \%$ \\
\hline SB4-NEPH-01 & 1 & Cr2O3 (wt\%) & 0.1023 & 0.0981 & 0.0920 & 0.0103 & 0.0061 & $11.2 \%$ & $6.7 \%$ \\
\hline SB4-NEPH-01 & 1 & $\mathrm{CuO}(\mathrm{wt} \%)$ & 0.0294 & 0.0308 & 0.0290 & 0.0004 & 0.0018 & $1.4 \%$ & $6.1 \%$ \\
\hline SB4-NEPH-01 & 1 & $\mathrm{Fe} 2 \mathrm{O} 3(\mathrm{wt} \%)$ & 8.4424 & 8.9350 & 9.0870 & -0.6446 & -0.1520 & $-7.1 \%$ & $-1.7 \%$ \\
\hline SB4-NEPH-01 & 1 & $\mathrm{~K} 2 \mathrm{O}(\mathrm{wt} \%)$ & 0.7273 & 0.7166 & 0.6820 & 0.0453 & 0.0346 & $6.6 \%$ & $5.1 \%$ \\
\hline SB4-NEPH-01 & 1 & La2O3 (wt\%) & 0.0276 & 0.0276 & 0.0340 & -0.0064 & -0.0064 & $-18.9 \%$ & $-18.9 \%$ \\
\hline SB4-NEPH-01 & 1 & $\mathrm{Li} 2 \mathrm{O}$ (wt\%) & 4.5964 & 4.5718 & 4.8000 & -0.2036 & -0.2282 & $-4.2 \%$ & $-4.8 \%$ \\
\hline SB4-NEPH-01 & 1 & $\mathrm{MgO}$ (wt\%) & 0.6935 & 0.7858 & 0.7320 & -0.0385 & 0.0538 & $-5.3 \%$ & $7.4 \%$ \\
\hline SB4-NEPH-01 & 1 & $\mathrm{MnO}(\mathrm{wt} \%)$ & 1.7915 & 1.9263 & 1.9130 & -0.1215 & 0.0133 & $-6.3 \%$ & $0.7 \%$ \\
\hline SB4-NEPH-01 & 1 & $\mathrm{Na} 2 \mathrm{O}$ (wt\%) & 17.0859 & 16.1902 & 16.3480 & 0.7379 & -0.1578 & $4.5 \%$ & $-1.0 \%$ \\
\hline SB4-NEPH-01 & 1 & $\mathrm{NiO}(\mathrm{wt} \%)$ & 0.5010 & 0.5705 & 0.5830 & -0.0820 & -0.0125 & $-14.1 \%$ & $-2.1 \%$ \\
\hline SB4-NEPH-01 & 1 & $\mathrm{PbO}(\mathrm{wt} \%)$ & 0.0714 & 0.0714 & 0.0810 & -0.0096 & -0.0096 & $-11.9 \%$ & $-11.9 \%$ \\
\hline SB4-NEPH-01 & 1 & SO4 (wt\%) & 0.3932 & 0.3932 & 0.4420 & -0.0488 & -0.0488 & $-11.0 \%$ & $-11.0 \%$ \\
\hline SB4-NEPH-01 & 1 & $\mathrm{SiO} 2$ (wt\%) & 43.1069 & 43.6181 & 44.4820 & -1.3751 & -0.8639 & $-3.1 \%$ & $-1.9 \%$ \\
\hline SB4-NEPH-01 & 1 & ThO2 (wt\%) & 0.0927 & 0.0927 & 0.0200 & 0.0727 & 0.0727 & $363.7 \%$ & $363.7 \%$ \\
\hline SB4-NEPH-01 & 1 & $\mathrm{TiO} 2$ (wt\%) & 0.0100 & 0.0111 & 0.0100 & 0.0000 & 0.0011 & $0.1 \%$ & $11.4 \%$ \\
\hline SB4-NEPH-01 & 1 & U3O8 (wt\%) & 2.0017 & 2.0802 & 2.1110 & -0.1093 & -0.0308 & $-5.2 \%$ & $-1.5 \%$ \\
\hline SB4-NEPH-01 & 1 & $\mathrm{ZnO}(\mathrm{wt} \%)$ & 0.0420 & 0.0420 & 0.0400 & 0.0020 & 0.0020 & $5.0 \%$ & $5.0 \%$ \\
\hline SB4-NEPH-01 & 1 & $\mathrm{ZrO} 2$ (wt\%) & 0.0908 & 0.0908 & 0.0950 & -0.0042 & -0.0042 & $-4.4 \%$ & $-4.4 \%$ \\
\hline SB4-NEPH-01 & 1 & Sum of Oxides & 98.0548 & 97.9011 & 100.0020 & -1.9472 & -2.1009 & $-1.9 \%$ & $-2.1 \%$ \\
\hline SB4-NEPH-02 & 2 & $\mathrm{Al} 2 \mathrm{O} 3$ (wt\%) & 11.8944 & 11.9152 & 11.6830 & 0.2114 & 0.2322 & $1.8 \%$ & $2.0 \%$ \\
\hline SB4-NEPH-02 & 2 & B2O3 (wt\%) & 4.5723 & 4.6144 & 4.8000 & -0.2277 & -0.1856 & $-4.7 \%$ & $-3.9 \%$ \\
\hline SB4-NEPH-02 & 2 & $\mathrm{BaO}(\mathrm{wt} \%)$ & 0.0371 & 0.0417 & 0.0420 & -0.0049 & -0.0003 & $-11.6 \%$ & $-0.6 \%$ \\
\hline SB4-NEPH-02 & 2 & $\mathrm{CaO}(\mathrm{wt} \%)$ & 0.8101 & 0.8316 & 0.8390 & -0.0289 & -0.0074 & $-3.4 \%$ & $-0.9 \%$ \\
\hline SB4-NEPH-02 & 2 & Ce2O3 (wt\%) & 0.0600 & 0.0600 & 0.0810 & -0.0210 & -0.0210 & $-25.9 \%$ & $-25.9 \%$ \\
\hline SB4-NEPH-02 & 2 & $\mathrm{Cr} 2 \mathrm{O} 3$ (wt $\%)$ & 0.0892 & 0.0855 & 0.0870 & 0.0022 & -0.0015 & $2.5 \%$ & $-1.7 \%$ \\
\hline SB4-NEPH-02 & 2 & $\mathrm{CuO}(\mathrm{wt} \%)$ & 0.0266 & 0.0278 & 0.0280 & -0.0014 & -0.0002 & $-5.0 \%$ & $-0.6 \%$ \\
\hline SB4-NEPH-02 & 2 & Fe2O3 (wt\%) & 7.9098 & 8.3721 & 8.7010 & -0.7912 & -0.3289 & $-9.1 \%$ & $-3.8 \%$ \\
\hline SB4-NEPH-02 & 2 & $\mathrm{~K} 2 \mathrm{O}(\mathrm{wt} \%)$ & 0.7095 & 0.6991 & 0.6240 & 0.0855 & 0.0751 & $13.7 \%$ & $12.0 \%$ \\
\hline SB4-NEPH-02 & 2 & La2O3 (wt\%) & 0.0261 & 0.0261 & 0.0340 & -0.0079 & -0.0079 & $-23.3 \%$ & $-23.3 \%$ \\
\hline SB4-NEPH-02 & 2 & Li2O (wt\%) & 4.6556 & 4.6308 & 4.8000 & -0.1444 & -0.1692 & $-3.0 \%$ & $-3.5 \%$ \\
\hline SB4-NEPH-02 & 2 & $\mathrm{MgO}$ (wt\%) & 0.6131 & 0.6947 & 0.6690 & -0.0559 & 0.0257 & $-8.4 \%$ & $3.8 \%$ \\
\hline SB4-NEPH-02 & 2 & $\mathrm{MnO}$ (wt\%) & 1.7238 & 1.8537 & 1.9050 & -0.1812 & -0.0513 & $-9.5 \%$ & $-2.7 \%$ \\
\hline SB4-NEPH-02 & 2 & $\mathrm{Na} 2 \mathrm{O}$ (wt\%) & 17.4566 & 16.5416 & 16.9870 & 0.4696 & -0.4454 & $2.8 \%$ & $-2.6 \%$ \\
\hline SB4-NEPH-02 & 2 & $\mathrm{NiO}(\mathrm{wt} \%)$ & 0.4603 & 0.5241 & 0.5790 & -0.1187 & -0.0549 & $-20.5 \%$ & $-9.5 \%$ \\
\hline SB4-NEPH-02 & 2 & $\mathrm{PbO}(\mathrm{wt} \%)$ & 0.0638 & 0.0638 & 0.0780 & -0.0142 & -0.0142 & $-18.2 \%$ & $-18.2 \%$ \\
\hline SB4-NEPH-02 & 2 & SO4 (wt\%) & 0.4239 & 0.4239 & 0.5080 & -0.0841 & -0.0841 & $-16.6 \%$ & $-16.6 \%$ \\
\hline
\end{tabular}


Table C.4: Average Measured and Bias-Corrected Chemical Compositions Versus Targeted Compositions by Oxide by Nepheline Study Glass

(100 -Batch 1; $200-U$ std)

\begin{tabular}{|c|c|c|c|c|c|c|c|c|c|}
\hline & & & & Measured & & & Diff of & & $\%$ Diff \\
\hline & Glass & & Measured & Bias-Corrected & Targeted & Diff of & Meas. & $\%$ Diff of & Meas. of \\
\hline Glass ID & \# & Oxide & (wt\%) & $(w t \%)$ & $(w t \%)$ & Measured & bc & Measured & bc \\
\hline SB4-NEPH-02 & 2 & $\mathrm{SiO} 2$ (wt\%) & 42.8930 & 43.4031 & 44.3890 & -1.4960 & -0.9859 & $-3.4 \%$ & $-2.2 \%$ \\
\hline SB4-NEPH-02 & 2 & ThO2 (wt\%) & 0.0879 & 0.0879 & 0.0180 & 0.0699 & 0.0699 & $388.3 \%$ & $388.3 \%$ \\
\hline SB4-NEPH-02 & 2 & TiO2 (wt\%) & 0.9679 & 1.0763 & 0.9790 & -0.0111 & 0.0973 & $-1.1 \%$ & $9.9 \%$ \\
\hline SB4-NEPH-02 & 2 & U3O8 (wt\%) & 1.9987 & 2.0772 & 2.0360 & -0.0373 & 0.0412 & $-1.8 \%$ & $2.0 \%$ \\
\hline SB4-NEPH-02 & 2 & $\mathrm{ZnO}(\mathrm{wt} \%)$ & 0.0386 & 0.0386 & 0.0390 & -0.0004 & -0.0004 & $-1.1 \%$ & $-1.1 \%$ \\
\hline SB4-NEPH-02 & 2 & $\mathrm{ZrO} 2$ (wt\%) & 0.0837 & 0.0837 & 0.0940 & -0.0103 & -0.0103 & $-10.9 \%$ & $-10.9 \%$ \\
\hline SB4-NEPH-02 & 2 & Sum of Oxides & 97.9728 & 97.8010 & 100.0000 & -2.0272 & -2.1990 & $-2.0 \%$ & $-2.2 \%$ \\
\hline SB4-NEPH-03 & 3 & Al2O3 (wt\%) & 8.5783 & 8.5933 & 8.4670 & 0.1113 & 0.1263 & $1.3 \%$ & $1.5 \%$ \\
\hline SB4-NEPH-03 & 3 & B2O3 (wt\%) & 4.7494 & 4.7933 & 4.8000 & -0.0506 & -0.0067 & $-1.1 \%$ & $-0.1 \%$ \\
\hline SB4-NEPH-03 & 3 & $\mathrm{BaO}(\mathrm{wt} \%)$ & 0.0578 & 0.0650 & 0.0620 & -0.0042 & 0.0030 & $-6.8 \%$ & $4.8 \%$ \\
\hline SB4-NEPH-03 & 3 & $\mathrm{CaO}(\mathrm{wt} \%)$ & 0.8535 & 0.8759 & 0.8480 & 0.0055 & 0.0279 & $0.7 \%$ & $3.3 \%$ \\
\hline SB4-NEPH-03 & 3 & Ce2O3 (wt\%) & 0.0586 & 0.0586 & 0.0820 & -0.0234 & -0.0234 & $-28.6 \%$ & $-28.6 \%$ \\
\hline SB4-NEPH-03 & 3 & Cr2O3 (wt\%) & 0.1030 & 0.0988 & 0.0960 & 0.0070 & 0.0028 & $7.3 \%$ & $3.0 \%$ \\
\hline SB4-NEPH-03 & 3 & $\mathrm{CuO}(\mathrm{wt} \%)$ & 0.0313 & 0.0327 & 0.0320 & -0.0007 & 0.0007 & $-2.2 \%$ & $2.3 \%$ \\
\hline SB4-NEPH-03 & 3 & Fe2O3 (wt\%) & 9.2430 & 9.7833 & 9.8970 & -0.6540 & -0.1137 & $-6.6 \%$ & $-1.1 \%$ \\
\hline SB4-NEPH-03 & 3 & $\mathrm{~K} 2 \mathrm{O}(\mathrm{wt} \%)$ & 0.4255 & 0.4193 & 0.3770 & 0.0485 & 0.0423 & $12.9 \%$ & $11.2 \%$ \\
\hline SB4-NEPH-03 & 3 & La2O3 (wt\%) & 0.0267 & 0.0267 & 0.0360 & -0.0093 & -0.0093 & $-25.9 \%$ & $-25.9 \%$ \\
\hline SB4-NEPH-03 & 3 & Li2O (wt\%) & 4.6879 & 4.6629 & 4.8000 & -0.1121 & -0.1371 & $-2.3 \%$ & $-2.9 \%$ \\
\hline SB4-NEPH-03 & 3 & $\mathrm{MgO}(\mathrm{wt} \%)$ & 0.6707 & 0.7600 & 0.7100 & -0.0393 & 0.0500 & $-5.5 \%$ & $7.0 \%$ \\
\hline SB4-NEPH-03 & 3 & $\mathrm{MnO}(\mathrm{wt} \%)$ & 2.1724 & 2.3364 & 2.2890 & -0.1166 & 0.0474 & $-5.1 \%$ & $2.1 \%$ \\
\hline SB4-NEPH-03 & 3 & $\mathrm{Na} 2 \mathrm{O}(\mathrm{wt} \%)$ & 17.0859 & 16.1903 & 16.6820 & 0.4039 & -0.4917 & $2.4 \%$ & $-2.9 \%$ \\
\hline SB4-NEPH-03 & 3 & $\mathrm{NiO}(\mathrm{wt} \%)$ & 1.2206 & 1.3899 & 1.4000 & -0.1794 & -0.0101 & $-12.8 \%$ & $-0.7 \%$ \\
\hline SB4-NEPH-03 & 3 & $\mathrm{PbO}(\mathrm{wt} \%)$ & 0.0568 & 0.0568 & 0.0650 & -0.0082 & -0.0082 & $-12.6 \%$ & $-12.6 \%$ \\
\hline SB4-NEPH-03 & 3 & $\mathrm{SO} 4(\mathrm{wt} \%)$ & 0.4629 & 0.4629 & 0.5060 & -0.0431 & -0.0431 & $-8.5 \%$ & $-8.5 \%$ \\
\hline SB4-NEPH-03 & 3 & $\mathrm{SiO} 2$ (wt\%) & 43.2673 & 43.7817 & 44.2180 & -0.9507 & -0.4363 & $-2.1 \%$ & $-1.0 \%$ \\
\hline SB4-NEPH-03 & 3 & ThO2 (wt\%) & 0.1320 & 0.1320 & 0.0130 & 0.1190 & 0.1190 & $915.4 \%$ & $915.4 \%$ \\
\hline SB4-NEPH-03 & 3 & TiO2 (wt\%) & 0.9091 & 1.0109 & 0.9770 & -0.0679 & 0.0339 & $-7.0 \%$ & $3.5 \%$ \\
\hline SB4-NEPH-03 & 3 & U3O8 (wt\%) & 3.3519 & 3.4834 & 3.4890 & -0.1371 & -0.0056 & $-3.9 \%$ & $-0.2 \%$ \\
\hline SB4-NEPH-03 & 3 & $\mathrm{ZnO}(\mathrm{wt} \%)$ & 0.0675 & 0.0675 & 0.0490 & 0.0185 & 0.0185 & $37.8 \%$ & $37.8 \%$ \\
\hline SB4-NEPH-03 & 3 & $\mathrm{ZrO} 2$ (wt\%) & 0.1006 & 0.1006 & 0.1090 & -0.0084 & -0.0084 & $-7.7 \%$ & $-7.7 \%$ \\
\hline SB4-NEPH-03 & 3 & Sum of Oxides & 98.4477 & 98.6113 & 100.0040 & -1.5563 & -1.3927 & $-1.6 \%$ & $-1.4 \%$ \\
\hline SB4-NEPH-04 & 4 & $\mathrm{Al} 2 \mathrm{O} 3$ (wt\%) & 12.7919 & 12.8141 & 12.6120 & 0.1799 & 0.2021 & $1.4 \%$ & $1.6 \%$ \\
\hline SB4-NEPH-04 & 4 & $\mathrm{~B} 2 \mathrm{O} 3$ (wt\%) & 4.7494 & 4.7932 & 4.8000 & -0.0506 & -0.0068 & $-1.1 \%$ & $-0.1 \%$ \\
\hline SB4-NEPH-04 & 4 & $\mathrm{BaO}(\mathrm{wt} \%)$ & 0.0366 & 0.0411 & 0.0430 & -0.0064 & -0.0019 & $-15.0 \%$ & $-4.4 \%$ \\
\hline SB4-NEPH-04 & 4 & $\mathrm{CaO}(\mathrm{wt} \%)$ & 0.8679 & 0.8907 & 0.8840 & -0.0161 & 0.0067 & $-1.8 \%$ & $0.8 \%$ \\
\hline SB4-NEPH-04 & 4 & $\mathrm{Ce} 2 \mathrm{O} 3$ (wt\%) & 0.0633 & 0.0633 & 0.0820 & -0.0187 & -0.0187 & $-22.9 \%$ & $-22.9 \%$ \\
\hline SB4-NEPH-04 & 4 & Cr2O3 (wt\%) & 0.0910 & 0.0873 & 0.0920 & -0.0010 & -0.0047 & $-1.1 \%$ & $-5.1 \%$ \\
\hline SB4-NEPH-04 & 4 & $\mathrm{CuO}(\mathrm{wt} \%)$ & 0.0300 & 0.0314 & 0.0290 & 0.0010 & 0.0024 & $3.6 \%$ & $8.4 \%$ \\
\hline SB4-NEPH-04 & 4 & $\mathrm{Fe} 2 \mathrm{O} 3(\mathrm{wt} \%)$ & 8.3673 & 8.8569 & 9.0870 & -0.7197 & -0.2301 & $-7.9 \%$ & $-2.5 \%$ \\
\hline SB4-NEPH-04 & 4 & $\mathrm{~K} 2 \mathrm{O}(\mathrm{wt} \%)$ & 0.7688 & 0.7575 & 0.6820 & 0.0868 & 0.0755 & $12.7 \%$ & $11.1 \%$ \\
\hline SB4-NEPH-04 & 4 & La2O3 (wt\%) & 0.0255 & 0.0255 & 0.0340 & -0.0085 & -0.0085 & $-25.0 \%$ & $-25.0 \%$ \\
\hline
\end{tabular}


Table C.4: Average Measured and Bias-Corrected Chemical Compositions Versus Targeted Compositions by Oxide by Nepheline Study Glass

(100 -Batch 1; $200-U$ std)

\begin{tabular}{|c|c|c|c|c|c|c|c|c|c|}
\hline & & & & Measured & & & Diff of & & \% Diff \\
\hline & Glass & & Measured & Bias-Corrected & Targeted & Diff of & Meas. & $\%$ Diff of & Meas. of \\
\hline Glass ID & $\#$ & Oxide & $(w t \%)$ & $(w t \%)$ & (wt\%) & Measured & bc & Measured & bc \\
\hline SB4-NEPH-04 & 4 & Li2O (wt\%) & 4.6933 & 4.6682 & 4.8000 & -0.1067 & -0.1318 & $-2.2 \%$ & $-2.7 \%$ \\
\hline SB4-NEPH-04 & 4 & MgO (wt\%) & 0.6761 & 0.7661 & 0.7320 & -0.0559 & 0.0341 & $-7.6 \%$ & $4.7 \%$ \\
\hline SB4-NEPH-04 & 4 & $\mathrm{MnO}(\mathrm{wt} \%)$ & 1.7851 & 1.9199 & 1.9130 & -0.1279 & 0.0069 & $-6.7 \%$ & $0.4 \%$ \\
\hline SB4-NEPH-04 & 4 & $\mathrm{Na} 2 \mathrm{O}(\mathrm{wt} \%)$ & 14.4236 & 13.6674 & 13.9480 & 0.4756 & -0.2806 & $3.4 \%$ & $-2.0 \%$ \\
\hline SB4-NEPH-04 & 4 & $\mathrm{NiO}$ (wt\%) & 0.4918 & 0.5600 & 0.5830 & -0.0912 & -0.0230 & $-15.6 \%$ & $-4.0 \%$ \\
\hline SB4-NEPH-04 & 4 & $\mathrm{PbO}(\mathrm{wt} \%)$ & 0.0684 & 0.0684 & 0.0810 & -0.0126 & -0.0126 & $-15.6 \%$ & $-15.6 \%$ \\
\hline SB4-NEPH-04 & 4 & $\mathrm{SO} 4(\mathrm{wt} \%)$ & 0.3917 & 0.3917 & 0.4420 & -0.0503 & -0.0503 & $-11.4 \%$ & $-11.4 \%$ \\
\hline SB4-NEPH-04 & 4 & $\mathrm{SiO} 2(\mathrm{wt} \%)$ & 46.1019 & 46.6501 & 46.8820 & -0.7801 & -0.2319 & $-1.7 \%$ & $-0.5 \%$ \\
\hline SB4-NEPH-04 & 4 & ThO2 (wt\%) & 0.0913 & 0.0913 & 0.0200 & 0.0713 & 0.0713 & $356.6 \%$ & $356.6 \%$ \\
\hline SB4-NEPH-04 & 4 & $\mathrm{TiO} 2$ (wt\%) & 0.0075 & 0.0084 & 0.0100 & -0.0025 & -0.0016 & $-24.9 \%$ & $-16.4 \%$ \\
\hline SB4-NEPH-04 & 4 & U3O8 (wt\%) & 2.0017 & 2.0802 & 2.1110 & -0.1093 & -0.0308 & $-5.2 \%$ & $-1.5 \%$ \\
\hline SB4-NEPH-04 & 4 & $\mathrm{ZnO}(\mathrm{wt} \%)$ & 0.0398 & 0.0398 & 0.0400 & -0.0002 & -0.0002 & $-0.4 \%$ & $-0.4 \%$ \\
\hline SB4-NEPH-04 & 4 & $\mathrm{ZrO} 2$ (wt\%) & 0.0844 & 0.0844 & 0.0950 & -0.0106 & -0.0106 & $-11.1 \%$ & $-11.1 \%$ \\
\hline SB4-NEPH-04 & 4 & Sum of Oxides & 99.0191 & 99.1080 & 100.0020 & -0.9830 & -0.8940 & $-1.0 \%$ & $-0.9 \%$ \\
\hline SB4-NEPH-05 & 5 & Al2O3 (wt\%) & 9.2208 & 9.2368 & 9.0700 & 0.1508 & 0.1668 & $1.7 \%$ & $1.8 \%$ \\
\hline SB4-NEPH-05 & 5 & $\mathrm{~B} 2 \mathrm{O} 3(\mathrm{wt} \%)$ & 4.7413 & 4.7847 & 4.8000 & -0.0587 & -0.0153 & $-1.2 \%$ & $-0.3 \%$ \\
\hline SB4-NEPH-05 & 5 & $\mathrm{BaO}(\mathrm{wt} \%)$ & 0.0581 & 0.0653 & 0.0650 & -0.0069 & 0.0003 & $-10.7 \%$ & $0.4 \%$ \\
\hline SB4-NEPH-05 & 5 & $\mathrm{CaO}(\mathrm{wt} \%)$ & 0.8993 & 0.9232 & 0.8930 & 0.0063 & 0.0302 & $0.7 \%$ & $3.4 \%$ \\
\hline SB4-NEPH-05 & 5 & Ce2O3 (wt\%) & 0.0682 & 0.0682 & 0.0830 & -0.0148 & -0.0148 & $-17.8 \%$ & $-17.8 \%$ \\
\hline SB4-NEPH-05 & 5 & Cr2O3 (wt\%) & 0.0994 & 0.0954 & 0.1010 & -0.0016 & -0.0056 & $-1.6 \%$ & $-5.6 \%$ \\
\hline SB4-NEPH-05 & 5 & $\mathrm{CuO}(\mathrm{wt} \%)$ & 0.0341 & 0.0357 & 0.0340 & 0.0001 & 0.0017 & $0.3 \%$ & $5.0 \%$ \\
\hline SB4-NEPH-05 & 5 & Fe2O3 (wt\%) & 9.6719 & 10.2359 & 10.4040 & -0.7321 & -0.1681 & $-7.0 \%$ & $-1.6 \%$ \\
\hline SB4-NEPH-05 & 5 & $\mathrm{~K} 2 \mathrm{O}(\mathrm{wt} \%)$ & 0.4752 & 0.4682 & 0.4100 & 0.0652 & 0.0582 & $15.9 \%$ & $14.2 \%$ \\
\hline SB4-NEPH-05 & 5 & La2O3 (wt\%) & 0.0290 & 0.0290 & 0.0370 & -0.0080 & -0.0080 & $-21.5 \%$ & $-21.5 \%$ \\
\hline SB4-NEPH-05 & 5 & Li2O (wt\%) & 4.6987 & 4.6735 & 4.8000 & -0.1013 & -0.1265 & $-2.1 \%$ & $-2.6 \%$ \\
\hline SB4-NEPH-05 & 5 & $\mathrm{MgO}(\mathrm{wt} \%)$ & 0.7059 & 0.8000 & 0.7770 & -0.0711 & 0.0230 & $-9.1 \%$ & $3.0 \%$ \\
\hline SB4-NEPH-05 & 5 & $\mathrm{MnO}(\mathrm{wt} \%)$ & 2.2209 & 2.3878 & 2.3350 & -0.1141 & 0.0528 & $-4.9 \%$ & $2.3 \%$ \\
\hline SB4-NEPH-05 & 5 & $\mathrm{Na} 2 \mathrm{O}(\mathrm{wt} \%)$ & 16.5467 & 15.6790 & 16.0110 & 0.5357 & -0.3320 & $3.3 \%$ & $-2.1 \%$ \\
\hline SB4-NEPH-05 & 5 & $\mathrm{NiO}(\mathrm{wt} \%)$ & 1.3018 & 1.4820 & 1.4860 & -0.1842 & -0.0040 & $-12.4 \%$ & $-0.3 \%$ \\
\hline SB4-NEPH-05 & 5 & $\mathrm{PbO}(\mathrm{wt} \%)$ & 0.0590 & 0.0590 & 0.0660 & -0.0070 & -0.0070 & $-10.6 \%$ & $-10.6 \%$ \\
\hline SB4-NEPH-05 & 5 & SO4 (wt\%) & 0.3940 & 0.3940 & 0.4390 & -0.0450 & -0.0450 & $-10.3 \%$ & $-10.3 \%$ \\
\hline SB4-NEPH-05 & 5 & $\mathrm{SiO} 2(\mathrm{wt} \%)$ & 43.4278 & 43.9433 & 44.2930 & -0.8652 & -0.3497 & $-2.0 \%$ & $-0.8 \%$ \\
\hline SB4-NEPH-05 & 5 & ThO2 (wt\%) & 0.1363 & 0.1363 & 0.0140 & 0.1223 & 0.1223 & $873.3 \%$ & $873.3 \%$ \\
\hline SB4-NEPH-05 & 5 & $\mathrm{TiO} 2$ (wt\%) & 0.0079 & 0.0088 & 0.0090 & -0.0011 & -0.0002 & $-12.0 \%$ & $-2.0 \%$ \\
\hline SB4-NEPH-05 & 5 & U3O8 (wt\%) & 3.4551 & 3.5906 & 3.7110 & -0.2559 & -0.1204 & $-6.9 \%$ & $-3.2 \%$ \\
\hline SB4-NEPH-05 & 5 & $\mathrm{ZnO}(\mathrm{wt} \%)$ & 0.0535 & 0.0535 & 0.0510 & 0.0025 & 0.0025 & $5.0 \%$ & $5.0 \%$ \\
\hline SB4-NEPH-05 & 5 & $\mathrm{ZrO} 2$ (wt\%) & 0.1016 & 0.1016 & 0.1120 & -0.0104 & -0.0104 & $-9.2 \%$ & $-9.2 \%$ \\
\hline SB4-NEPH-05 & 5 & Sum of Oxides & 98.6761 & 98.8253 & 100.0010 & -1.3249 & -1.1757 & $-1.3 \%$ & $-1.2 \%$ \\
\hline SB4-NEPH-06 & 6 & $\mathrm{Al} 2 \mathrm{O} 3$ (wt\%) & 8.5547 & 8.5696 & 8.3750 & 0.1797 & 0.1946 & $2.1 \%$ & $2.3 \%$ \\
\hline SB4-NEPH-06 & 6 & $\mathrm{~B} 2 \mathrm{O} 3(\mathrm{wt} \%)$ & 4.6367 & 4.6794 & 4.8000 & -0.1633 & -0.1206 & $-3.4 \%$ & $-2.5 \%$ \\
\hline SB4-NEPH-06 & 6 & $\mathrm{BaO}(\mathrm{wt} \%)$ & 0.0634 & 0.0712 & 0.0760 & -0.0126 & -0.0048 & $-16.6 \%$ & $-6.3 \%$ \\
\hline
\end{tabular}


Table C.4: Average Measured and Bias-Corrected Chemical Compositions Versus Targeted Compositions by Oxide by Nepheline Study Glass

(100 -Batch 1; 200 -U std)

\begin{tabular}{|c|c|c|c|c|c|c|c|c|c|}
\hline & & & & Measured & & & Diff of & & \% Diff \\
\hline & Glass & & Measured & Bias-Corrected & Targeted & Diff of & Meas. & $\%$ Diff of & Meas. of \\
\hline Glass ID & \# & Oxide & $(w t \%)$ & $(w t \%)$ & $(w t \%)$ & Measured & bc & Measured & bc \\
\hline SB4-NEPH-06 & 6 & $\mathrm{CaO}(\mathrm{wt} \%)$ & 0.7356 & 0.7551 & 0.7230 & 0.0126 & 0.0321 & $1.7 \%$ & $4.4 \%$ \\
\hline SB4-NEPH-06 & 6 & Ce2O3 (wt\%) & 0.0594 & 0.0594 & 0.0770 & -0.0176 & -0.0176 & $-22.8 \%$ & $-22.8 \%$ \\
\hline SB4-NEPH-06 & 6 & Cr2O3 (wt\%) & 0.1034 & 0.0992 & 0.1050 & -0.0016 & -0.0058 & $-1.5 \%$ & $-5.5 \%$ \\
\hline SB4-NEPH-06 & 6 & $\mathrm{CuO}(\mathrm{wt} \%)$ & 0.0338 & 0.0354 & 0.0320 & 0.0018 & 0.0034 & $5.6 \%$ & $10.5 \%$ \\
\hline SB4-NEPH-06 & 6 & Fe2O3 (wt\%) & 8.3923 & 8.8827 & 9.2400 & -0.8477 & -0.3573 & $-9.2 \%$ & $-3.9 \%$ \\
\hline SB4-NEPH-06 & 6 & K2O (wt\%) & 0.4767 & 0.4697 & 0.4160 & 0.0607 & 0.0537 & $14.6 \%$ & $12.9 \%$ \\
\hline SB4-NEPH-06 & 6 & La2O3 (wt\%) & 0.0243 & 0.0243 & 0.0340 & -0.0097 & -0.0097 & $-28.4 \%$ & $-28.4 \%$ \\
\hline SB4-NEPH-06 & 6 & Li2O (wt\%) & 4.6987 & 4.6736 & 4.8000 & -0.1013 & -0.1264 & $-2.1 \%$ & $-2.6 \%$ \\
\hline SB4-NEPH-06 & 6 & MgO (wt\%) & 0.3942 & 0.4467 & 0.4240 & -0.0298 & 0.0227 & $-7.0 \%$ & $5.4 \%$ \\
\hline SB4-NEPH-06 & 6 & $\mathrm{MnO}(\mathrm{wt} \%)$ & 2.1886 & 2.3537 & 2.3520 & -0.1634 & 0.0017 & $-6.9 \%$ & $0.1 \%$ \\
\hline SB4-NEPH-06 & 6 & $\mathrm{Na} 2 \mathrm{O}(\mathrm{wt} \%)$ & 17.0185 & 16.1262 & 16.5040 & 0.5145 & -0.3778 & $3.1 \%$ & $-2.3 \%$ \\
\hline SB4-NEPH-06 & 6 & $\mathrm{NiO}(\mathrm{wt} \%)$ & 1.9183 & 2.1842 & 2.2540 & -0.3357 & -0.0698 & $-14.9 \%$ & $-3.1 \%$ \\
\hline SB4-NEPH-06 & 6 & $\mathrm{PbO}(\mathrm{wt} \%)$ & 0.0555 & 0.0555 & 0.0630 & -0.0075 & -0.0075 & $-11.9 \%$ & $-11.9 \%$ \\
\hline SB4-NEPH-06 & 6 & SO4 (wt\%) & 0.4464 & 0.4464 & 0.5040 & -0.0576 & -0.0576 & $-11.4 \%$ & $-11.4 \%$ \\
\hline SB4-NEPH-06 & 6 & $\mathrm{SiO} 2(\mathrm{wt} \%)$ & 43.2673 & 43.7812 & 44.0550 & -0.7877 & -0.2738 & $-1.8 \%$ & $-0.6 \%$ \\
\hline SB4-NEPH-06 & 6 & ThO2 (wt\%) & 0.1462 & 0.1462 & 0.0110 & 0.1352 & 0.1352 & $1229.3 \%$ & $1229.3 \%$ \\
\hline SB4-NEPH-06 & 6 & $\mathrm{TiO} 2$ (wt\%) & 0.9103 & 1.0123 & 0.9750 & -0.0647 & 0.0373 & $-6.6 \%$ & $3.8 \%$ \\
\hline SB4-NEPH-06 & 6 & U3O8 (wt\%) & 3.7233 & 3.8694 & 4.0130 & -0.2897 & -0.1436 & $-7.2 \%$ & $-3.6 \%$ \\
\hline SB4-NEPH-06 & 6 & $\mathrm{ZnO}(\mathrm{wt} \%)$ & 0.0557 & 0.0557 & 0.0500 & 0.0057 & 0.0057 & $11.4 \%$ & $11.4 \%$ \\
\hline SB4-NEPH-06 & 6 & $\mathrm{ZrO} 2$ (wt\%) & 0.1091 & 0.1091 & 0.1200 & -0.0109 & -0.0109 & $-9.1 \%$ & $-9.1 \%$ \\
\hline SB4-NEPH-06 & 6 & Sum of Oxides & 98.1810 & 98.3685 & 100.0030 & -1.8220 & -1.6345 & $-1.8 \%$ & $-1.6 \%$ \\
\hline SB4-NEPH-07 & 7 & $\mathrm{Al} 2 \mathrm{O} 3$ (wt\%) & 9.3436 & 9.3598 & 8.9690 & 0.3746 & 0.3908 & $4.2 \%$ & $4.4 \%$ \\
\hline SB4-NEPH-07 & 7 & B2O3 (wt\%) & 4.7172 & 4.7603 & 4.8000 & -0.0828 & -0.0397 & $-1.7 \%$ & $-0.8 \%$ \\
\hline SB4-NEPH-07 & 7 & $\mathrm{BaO}(\mathrm{wt} \%)$ & 0.0770 & 0.0866 & 0.0800 & -0.0030 & 0.0066 & $-3.7 \%$ & $8.3 \%$ \\
\hline SB4-NEPH-07 & 7 & $\mathrm{CaO}(\mathrm{wt} \%)$ & 0.7377 & 0.7573 & 0.7560 & -0.0183 & 0.0013 & $-2.4 \%$ & $0.2 \%$ \\
\hline SB4-NEPH-07 & 7 & Ce2O3 (wt\%) & 0.0600 & 0.0600 & 0.0780 & -0.0180 & -0.0180 & $-23.0 \%$ & $-23.0 \%$ \\
\hline SB4-NEPH-07 & 7 & Cr2O3 (wt\%) & 0.1027 & 0.0985 & 0.1110 & -0.0083 & -0.0125 & $-7.5 \%$ & $-11.3 \%$ \\
\hline SB4-NEPH-07 & 7 & $\mathrm{CuO}(\mathrm{wt} \%)$ & 0.0369 & 0.0386 & 0.0340 & 0.0029 & 0.0046 & $8.6 \%$ & $13.6 \%$ \\
\hline SB4-NEPH-07 & 7 & Fe2O3 (wt\%) & 8.8677 & 9.3861 & 9.6800 & -0.8123 & -0.2939 & $-8.4 \%$ & $-3.0 \%$ \\
\hline SB4-NEPH-07 & 7 & $\mathrm{~K} 2 \mathrm{O}(\mathrm{wt} \%)$ & 0.4948 & 0.4875 & 0.4540 & 0.0408 & 0.0335 & $9.0 \%$ & $7.4 \%$ \\
\hline SB4-NEPH-07 & 7 & La2O3 (wt\%) & 0.0258 & 0.0258 & 0.0350 & -0.0092 & -0.0092 & $-26.3 \%$ & $-26.3 \%$ \\
\hline SB4-NEPH-07 & 7 & Li2O (wt\%) & 4.7525 & 4.7271 & 4.8000 & -0.0475 & -0.0729 & $-1.0 \%$ & $-1.5 \%$ \\
\hline SB4-NEPH-07 & 7 & $\mathrm{MgO}(\mathrm{wt} \%)$ & 0.4444 & 0.5036 & 0.4620 & -0.0176 & 0.0416 & $-3.8 \%$ & $9.0 \%$ \\
\hline SB4-NEPH-07 & 7 & $\mathrm{MnO}(\mathrm{wt} \%)$ & 2.2596 & 2.4301 & 2.4040 & -0.1444 & 0.0261 & $-6.0 \%$ & $1.1 \%$ \\
\hline SB4-NEPH-07 & 7 & $\mathrm{Na} 2 \mathrm{O}(\mathrm{wt} \%)$ & 16.3445 & 15.4877 & 15.8160 & 0.5285 & -0.3283 & $3.3 \%$ & $-2.1 \%$ \\
\hline SB4-NEPH-07 & 7 & $\mathrm{NiO}(\mathrm{wt} \%)$ & 2.0532 & 2.3379 & 2.4260 & -0.3728 & -0.0881 & $-15.4 \%$ & $-3.6 \%$ \\
\hline SB4-NEPH-07 & 7 & $\mathrm{PbO}(\mathrm{wt} \%)$ & 0.0614 & 0.0614 & 0.0640 & -0.0026 & -0.0026 & $-4.1 \%$ & $-4.1 \%$ \\
\hline SB4-NEPH-07 & 7 & $\mathrm{SO} 4(\mathrm{wt} \%)$ & 0.3925 & 0.3925 & 0.4380 & -0.0455 & -0.0455 & $-10.4 \%$ & $-10.4 \%$ \\
\hline SB4-NEPH-07 & 7 & $\mathrm{SiO} 2$ (wt\%) & 43.6417 & 44.1603 & 44.1140 & -0.4723 & 0.0463 & $-1.1 \%$ & $0.1 \%$ \\
\hline SB4-NEPH-07 & 7 & ThO2 (wt\%) & 0.1673 & 0.1673 & 0.0120 & 0.1553 & 0.1553 & $1293.9 \%$ & $1293.9 \%$ \\
\hline SB4-NEPH-07 & 7 & $\mathrm{TiO} 2$ (wt\%) & 0.0142 & 0.0158 & 0.0060 & 0.0082 & 0.0098 & $136.3 \%$ & $162.9 \%$ \\
\hline
\end{tabular}


Table C.4: Average Measured and Bias-Corrected Chemical Compositions Versus Targeted Compositions by Oxide by Nepheline Study Glass

(100 -Batch 1; $200-U$ std)

\begin{tabular}{|c|c|c|c|c|c|c|c|c|c|}
\hline & & & & Measured & & & Diff of & & $\%$ Diff \\
\hline & Glass & & Measured & Bias-Corrected & Targeted & Diff of & Meas. & $\%$ Diff of & Meas. of \\
\hline Glass ID & \# & Oxide & (wt\%) & (wt\%) & $(w t \%)$ & Measured & bc & Measured & bc \\
\hline SB4-NEPH-07 & 7 & U308 (wt\%) & 4.2068 & 4.3719 & 4.2870 & -0.0802 & 0.0849 & $-1.9 \%$ & $2.0 \%$ \\
\hline SB4-NEPH-07 & 7 & $\mathrm{ZnO}(\mathrm{wt} \%)$ & 0.0585 & 0.0585 & 0.0520 & 0.0065 & 0.0065 & $12.5 \%$ & $12.5 \%$ \\
\hline SB4-NEPH-07 & 7 & $\mathrm{ZrO} 2(\mathrm{wt} \%)$ & 0.1141 & 0.1141 & 0.1240 & -0.0099 & -0.0099 & $-7.9 \%$ & $-7.9 \%$ \\
\hline SB4-NEPH-07 & 7 & Sum of Oxides & 99.2774 & 99.5009 & 100.0020 & -0.7246 & -0.5011 & $-0.7 \%$ & $-0.5 \%$ \\
\hline SB4-NEPH-08 & 8 & $\mathrm{Al} 2 \mathrm{O} 3(\mathrm{wt} \%)$ & 12.0125 & 12.0335 & 11.6830 & 0.3295 & 0.3505 & $2.8 \%$ & $3.0 \%$ \\
\hline SB4-NEPH-08 & 8 & $\mathrm{~B} 2 \mathrm{O} 3(\mathrm{wt} \%)$ & 4.6689 & 4.7117 & 4.8000 & -0.1311 & -0.0883 & $-2.7 \%$ & $-1.8 \%$ \\
\hline SB4-NEPH-08 & 8 & $\mathrm{BaO}(\mathrm{wt} \%)$ & 0.0366 & 0.0411 & 0.0420 & -0.0054 & -0.0009 & $-12.9 \%$ & $-2.1 \%$ \\
\hline SB4-NEPH-08 & 8 & $\mathrm{CaO}(\mathrm{wt} \%)$ & 0.8161 & 0.8375 & 0.8390 & -0.0229 & -0.0015 & $-2.7 \%$ & $-0.2 \%$ \\
\hline SB4-NEPH-08 & 8 & Ce2O3 (wt\%) & 0.0562 & 0.0562 & 0.0810 & -0.0248 & -0.0248 & $-30.6 \%$ & $-30.6 \%$ \\
\hline SB4-NEPH-08 & 8 & Cr2O3 (wt\%) & 0.0895 & 0.0859 & 0.0870 & 0.0025 & -0.0011 & $2.9 \%$ & $-1.3 \%$ \\
\hline SB4-NEPH-08 & 8 & $\mathrm{CuO}(\mathrm{wt} \%)$ & 0.0288 & 0.0301 & 0.0280 & 0.0008 & 0.0021 & $2.8 \%$ & $7.6 \%$ \\
\hline SB4-NEPH-08 & 8 & Fe2O3 (wt\%) & 7.8598 & 8.3195 & 8.7010 & -0.8412 & -0.3815 & $-9.7 \%$ & $-4.4 \%$ \\
\hline SB4-NEPH-08 & 8 & $\mathrm{~K} 2 \mathrm{O}(\mathrm{wt} \%)$ & 0.7243 & 0.7136 & 0.6240 & 0.1003 & 0.0896 & $16.1 \%$ & $14.4 \%$ \\
\hline SB4-NEPH-08 & 8 & La2O3 (wt\%) & 0.0258 & 0.0258 & 0.0340 & -0.0082 & -0.0082 & $-24.1 \%$ & $-24.1 \%$ \\
\hline SB4-NEPH-08 & 8 & Li2O (wt\%) & 4.7202 & 4.6950 & 4.8000 & -0.0798 & -0.1050 & $-1.7 \%$ & $-2.2 \%$ \\
\hline SB4-NEPH-08 & 8 & $\mathrm{MgO}(\mathrm{wt} \%)$ & 0.6226 & 0.7055 & 0.6690 & -0.0464 & 0.0365 & $-6.9 \%$ & $5.5 \%$ \\
\hline SB4-NEPH-08 & 8 & $\mathrm{MnO}(\mathrm{wt} \%)$ & 1.7205 & 1.8504 & 1.9050 & -0.1845 & -0.0546 & $-9.7 \%$ & $-2.9 \%$ \\
\hline SB4-NEPH-08 & 8 & $\mathrm{Na} 2 \mathrm{O}$ (wt\%) & 15.1650 & 14.3699 & 14.5870 & 0.5780 & -0.2171 & $4.0 \%$ & $-1.5 \%$ \\
\hline SB4-NEPH-08 & 8 & $\mathrm{NiO}(\mathrm{wt} \%)$ & 0.4810 & 0.5476 & 0.5790 & -0.0980 & -0.0314 & $-16.9 \%$ & $-5.4 \%$ \\
\hline SB4-NEPH-08 & 8 & $\mathrm{PbO}(\mathrm{wt} \%)$ & 0.0644 & 0.0644 & 0.0780 & -0.0136 & -0.0136 & $-17.5 \%$ & $-17.5 \%$ \\
\hline SB4-NEPH-08 & 8 & $\mathrm{SO} 4(\mathrm{wt} \%)$ & 0.4337 & 0.4337 & 0.5080 & -0.0743 & -0.0743 & $-14.6 \%$ & $-14.6 \%$ \\
\hline SB4-NEPH-08 & 8 & $\mathrm{SiO} 2$ (wt\%) & 45.8880 & 46.4341 & 46.7890 & -0.9010 & -0.3549 & $-1.9 \%$ & $-0.8 \%$ \\
\hline SB4-NEPH-08 & 8 & ThO2 (wt\%) & 0.0853 & 0.0853 & 0.0180 & 0.0673 & 0.0673 & $374.1 \%$ & $374.1 \%$ \\
\hline SB4-NEPH-08 & 8 & $\mathrm{TiO} 2$ (wt\%) & 0.9170 & 1.0197 & 0.9790 & -0.0620 & 0.0407 & $-6.3 \%$ & $4.2 \%$ \\
\hline SB4-NEPH-08 & 8 & U3O8 (wt\%) & 1.9486 & 2.0251 & 2.0360 & -0.0874 & -0.0109 & $-4.3 \%$ & $-0.5 \%$ \\
\hline SB4-NEPH-08 & 8 & $\mathrm{ZnO}(\mathrm{wt} \%)$ & 0.0429 & 0.0429 & 0.0390 & 0.0039 & 0.0039 & $10.1 \%$ & $10.1 \%$ \\
\hline SB4-NEPH-08 & 8 & $\mathrm{ZrO} 2$ (wt\%) & 0.0865 & 0.0865 & 0.0940 & -0.0075 & -0.0075 & $-8.0 \%$ & $-8.0 \%$ \\
\hline SB4-NEPH-08 & 8 & Sum of Oxides & 98.8648 & 98.9361 & 100.0000 & -1.1352 & -1.0639 & $-1.1 \%$ & $-1.1 \%$ \\
\hline SB4-NEPH-09 & 9 & $\mathrm{Al} 2 \mathrm{O} 3(\mathrm{wt} \%)$ & 11.2284 & 11.2479 & 11.0350 & 0.1934 & 0.2129 & $1.8 \%$ & $1.9 \%$ \\
\hline SB4-NEPH-09 & 9 & $\mathrm{~B} 2 \mathrm{O} 3$ (wt\%) & 5.0874 & 5.1345 & 5.2000 & -0.1126 & -0.0655 & $-2.2 \%$ & $-1.3 \%$ \\
\hline SB4-NEPH-09 & 9 & $\mathrm{BaO}(\mathrm{wt} \%)$ & 0.0315 & 0.0355 & 0.0380 & -0.0065 & -0.0025 & $-17.0 \%$ & $-6.7 \%$ \\
\hline SB4-NEPH-09 & 9 & $\mathrm{CaO}(\mathrm{wt} \%)$ & 0.7601 & 0.7804 & 0.7740 & -0.0139 & 0.0064 & $-1.8 \%$ & $0.8 \%$ \\
\hline SB4-NEPH-09 & 9 & Ce2O3 (wt\%) & 0.0489 & 0.0489 & 0.0720 & -0.0231 & -0.0231 & $-32.1 \%$ & $-32.1 \%$ \\
\hline SB4-NEPH-09 & 9 & Cr2O3 (wt\%) & 0.0811 & 0.0778 & 0.0800 & 0.0011 & -0.0022 & $1.4 \%$ & $-2.7 \%$ \\
\hline SB4-NEPH-09 & 9 & $\mathrm{CuO}(\mathrm{wt} \%)$ & 0.0244 & 0.0255 & 0.0250 & -0.0006 & 0.0005 & $-2.4 \%$ & $2.1 \%$ \\
\hline SB4-NEPH-09 & 9 & $\mathrm{Fe} 2 \mathrm{O} 3(\mathrm{wt} \%)$ & 7.6167 & 8.0624 & 7.9510 & -0.3343 & 0.1114 & $-4.2 \%$ & $1.4 \%$ \\
\hline SB4-NEPH-09 & 9 & $\mathrm{~K} 2 \mathrm{O}(\mathrm{wt} \%)$ & 0.6737 & 0.6637 & 0.5970 & 0.0767 & 0.0667 & $12.8 \%$ & $11.2 \%$ \\
\hline SB4-NEPH-09 & 9 & La2O3 (wt\%) & 0.0214 & 0.0214 & 0.0300 & -0.0086 & -0.0086 & $-28.7 \%$ & $-28.7 \%$ \\
\hline SB4-NEPH-09 & 9 & Li2O (wt\%) & 5.0808 & 5.0537 & 5.2000 & -0.1192 & -0.1463 & $-2.3 \%$ & $-2.8 \%$ \\
\hline SB4-NEPH-09 & 9 & $\mathrm{MgO}(\mathrm{wt} \%)$ & 0.5803 & 0.6577 & 0.6410 & -0.0607 & 0.0167 & $-9.5 \%$ & $2.6 \%$ \\
\hline SB4-NEPH-09 & 9 & $\mathrm{MnO}(\mathrm{wt} \%)$ & 1.5688 & 1.6873 & 1.6740 & -0.1052 & 0.0133 & $-6.3 \%$ & $0.8 \%$ \\
\hline
\end{tabular}


Table C.4: Average Measured and Bias-Corrected Chemical Compositions Versus Targeted Compositions by Oxide by Nepheline Study Glass

(100 -Batch 1; $200-U$ std)

\begin{tabular}{|c|c|c|c|c|c|c|c|c|c|}
\hline & & & & Measured & & & Diff of & & \% Diff \\
\hline & Glass & & Measured & Bias-Corrected & Targeted & Diff of & Meas. & $\%$ Diff of & Meas. of \\
\hline Glass ID & \# & Oxide & (wt\%) & (wt\%) & $(w t \%)$ & Measured & bc & Measured & bc \\
\hline SB4-NEPH-09 & 9 & $\mathrm{Na} 2 \mathrm{O}$ (wt\%) & 16.2097 & 15.3598 & 15.8050 & 0.4047 & -0.4452 & $2.6 \%$ & $-2.8 \%$ \\
\hline SB4-NEPH-09 & 9 & $\mathrm{NiO}(\mathrm{wt} \%)$ & 0.4361 & 0.4965 & 0.5100 & -0.0739 & -0.0135 & $-14.5 \%$ & $-2.6 \%$ \\
\hline SB4-NEPH-09 & 9 & $\mathrm{PbO}(\mathrm{wt} \%)$ & 0.0617 & 0.0617 & 0.0710 & -0.0093 & -0.0093 & $-13.1 \%$ & $-13.1 \%$ \\
\hline SB4-NEPH-09 & 9 & $\mathrm{SO} 4(\mathrm{wt} \%)$ & 0.3333 & 0.3333 & 0.3860 & -0.0527 & -0.0527 & $-13.7 \%$ & $-13.7 \%$ \\
\hline SB4-NEPH-09 & 9 & $\mathrm{SiO} 2(\mathrm{wt} \%)$ & 47.1181 & 47.6786 & 47.9210 & -0.8029 & -0.2424 & $-1.7 \%$ & $-0.5 \%$ \\
\hline SB4-NEPH-09 & 9 & ThO2 (wt\%) & 0.0797 & 0.0797 & 0.0170 & 0.0627 & 0.0627 & $368.5 \%$ & $368.5 \%$ \\
\hline SB4-NEPH-09 & 9 & $\mathrm{TiO} 2(\mathrm{wt} \%)$ & 0.0075 & 0.0084 & 0.0090 & -0.0015 & -0.0006 & $-16.6 \%$ & $-7.1 \%$ \\
\hline SB4-NEPH-09 & 9 & U308 (wt\%) & 1.8071 & 1.8780 & 1.8470 & -0.0399 & 0.0310 & $-2.2 \%$ & $1.7 \%$ \\
\hline SB4-NEPH-09 & 9 & $\mathrm{ZnO}(\mathrm{wt} \%)$ & 0.0355 & 0.0355 & 0.0350 & 0.0005 & 0.0005 & $1.4 \%$ & $1.4 \%$ \\
\hline SB4-NEPH-09 & 9 & $\mathrm{ZrO} 2(\mathrm{wt} \%)$ & 0.0743 & 0.0743 & 0.0830 & -0.0087 & -0.0087 & $-10.5 \%$ & $-10.5 \%$ \\
\hline SB4-NEPH-09 & 9 & Sum of Oxides & 99.2699 & 99.1202 & 100.0010 & -0.7311 & -0.8808 & $-0.7 \%$ & $-0.9 \%$ \\
\hline SB4-NEPH-10 & 10 & $\mathrm{Al} 2 \mathrm{O} 3$ (wt\%) & 8.2571 & 8.2715 & 8.0970 & 0.1601 & 0.1745 & $2.0 \%$ & $2.2 \%$ \\
\hline SB4-NEPH-10 & 10 & $\mathrm{~B} 2 \mathrm{O} 3$ (wt\%) & 4.7252 & 4.7688 & 4.8000 & -0.0748 & -0.0312 & $-1.6 \%$ & $-0.7 \%$ \\
\hline SB4-NEPH-10 & 10 & $\mathrm{BaO}(\mathrm{wt} \%)$ & 0.0569 & 0.0640 & 0.0620 & -0.0051 & 0.0020 & $-8.2 \%$ & $3.2 \%$ \\
\hline SB4-NEPH-10 & 10 & $\mathrm{CaO}(\mathrm{wt} \%)$ & 0.8612 & 0.8838 & 0.8590 & 0.0022 & 0.0248 & $0.3 \%$ & $2.9 \%$ \\
\hline SB4-NEPH-10 & 10 & $\mathrm{Ce} 2 \mathrm{O} 3$ (wt\%) & 0.0668 & 0.0668 & 0.0810 & -0.0142 & -0.0142 & $-17.6 \%$ & $-17.6 \%$ \\
\hline SB4-NEPH-10 & 10 & Cr2O3 (wt\%) & 0.1005 & 0.0964 & 0.0940 & 0.0065 & 0.0024 & $6.9 \%$ & $2.5 \%$ \\
\hline SB4-NEPH-10 & 10 & $\mathrm{CuO}$ (wt\%) & 0.0319 & 0.0334 & 0.0320 & -0.0001 & 0.0014 & $-0.2 \%$ & $4.4 \%$ \\
\hline SB4-NEPH-10 & 10 & Fe2O3 (wt\%) & 9.4146 & 9.9646 & 10.0880 & -0.6734 & -0.1234 & $-6.7 \%$ & $-1.2 \%$ \\
\hline SB4-NEPH-10 & 10 & $\mathrm{~K} 2 \mathrm{O}(\mathrm{wt} \%)$ & 0.3801 & 0.3745 & 0.3340 & 0.0461 & 0.0405 & $13.8 \%$ & $12.1 \%$ \\
\hline SB4-NEPH-10 & 10 & La2O3 (wt\%) & 0.0273 & 0.0273 & 0.0360 & -0.0087 & -0.0087 & $-24.3 \%$ & $-24.3 \%$ \\
\hline SB4-NEPH-10 & 10 & Li2O (wt\%) & 4.6933 & 4.6682 & 4.8000 & -0.1067 & -0.1318 & $-2.2 \%$ & $-2.7 \%$ \\
\hline SB4-NEPH-10 & 10 & $\mathrm{MgO}(\mathrm{wt} \%)$ & 0.7200 & 0.8159 & 0.7840 & -0.0640 & 0.0319 & $-8.2 \%$ & $4.1 \%$ \\
\hline SB4-NEPH-10 & 10 & $\mathrm{MnO}(\mathrm{wt} \%)$ & 2.2661 & 2.4369 & 2.3870 & -0.1209 & 0.0499 & $-5.1 \%$ & $2.1 \%$ \\
\hline SB4-NEPH-10 & 10 & $\mathrm{Na} 2 \mathrm{O}(\mathrm{wt} \%)$ & 17.2207 & 16.3180 & 16.6590 & 0.5617 & -0.3410 & $3.4 \%$ & $-2.0 \%$ \\
\hline SB4-NEPH-10 & 10 & $\mathrm{NiO}(\mathrm{wt} \%)$ & 1.2515 & 1.4249 & 1.4250 & -0.1735 & -0.0001 & $-12.2 \%$ & $0.0 \%$ \\
\hline SB4-NEPH-10 & 10 & $\mathrm{PbO}(\mathrm{wt} \%)$ & 0.0560 & 0.0560 & 0.0620 & -0.0060 & -0.0060 & $-9.7 \%$ & $-9.7 \%$ \\
\hline SB4-NEPH-10 & 10 & SO4 (wt\%) & 0.4606 & 0.4606 & 0.5060 & -0.0454 & -0.0454 & $-9.0 \%$ & $-9.0 \%$ \\
\hline SB4-NEPH-10 & 10 & $\mathrm{SiO} 2(\mathrm{wt} \%)$ & 43.2673 & 43.7812 & 44.2250 & -0.9577 & -0.4438 & $-2.2 \%$ & $-1.0 \%$ \\
\hline SB4-NEPH-10 & 10 & ThO2 (wt\%) & 0.1320 & 0.1320 & 0.0120 & 0.1200 & 0.1200 & $1000.0 \%$ & $1000.0 \%$ \\
\hline SB4-NEPH-10 & 10 & $\mathrm{TiO} 2$ (wt\%) & 0.9320 & 1.0364 & 0.9780 & -0.0460 & 0.0584 & $-4.7 \%$ & $6.0 \%$ \\
\hline SB4-NEPH-10 & 10 & U3O8 (wt\%) & 3.4049 & 3.5385 & 3.5280 & -0.1231 & 0.0105 & $-3.5 \%$ & $0.3 \%$ \\
\hline SB4-NEPH-10 & 10 & $\mathrm{ZnO}(\mathrm{wt} \%)$ & 0.0545 & 0.0545 & 0.0480 & 0.0065 & 0.0065 & $13.5 \%$ & $13.5 \%$ \\
\hline SB4-NEPH-10 & 10 & $\mathrm{ZrO} 2$ (wt\%) & 0.0969 & 0.0969 & 0.1050 & -0.0081 & -0.0081 & $-7.7 \%$ & $-7.7 \%$ \\
\hline SB4-NEPH-10 & 10 & Sum of Oxides & 98.8144 & 98.9779 & 100.0020 & -1.1876 & -1.0241 & $-1.2 \%$ & $-1.0 \%$ \\
\hline SB4-NEPH-11 & 11 & $\mathrm{Al} 2 \mathrm{O} 3(\mathrm{wt} \%)$ & 8.8854 & 8.9007 & 8.6640 & 0.2214 & 0.2367 & $2.6 \%$ & $2.7 \%$ \\
\hline SB4-NEPH-11 & 11 & $\mathrm{~B} 2 \mathrm{O} 3$ (wt\%) & 4.7413 & 4.7850 & 4.8000 & -0.0587 & -0.0150 & $-1.2 \%$ & $-0.3 \%$ \\
\hline SB4-NEPH-11 & 11 & $\mathrm{BaO}(\mathrm{wt} \%)$ & 0.0611 & 0.0687 & 0.0650 & -0.0039 & 0.0037 & $-6.0 \%$ & $5.7 \%$ \\
\hline SB4-NEPH-11 & 11 & $\mathrm{CaO}(\mathrm{wt} \%)$ & 0.8934 & 0.9171 & 0.9050 & -0.0116 & 0.0121 & $-1.3 \%$ & $1.3 \%$ \\
\hline SB4-NEPH-11 & 11 & Ce2O3 (wt\%) & 0.0618 & 0.0618 & 0.0830 & -0.0212 & -0.0212 & $-25.6 \%$ & $-25.6 \%$ \\
\hline SB4-NEPH-11 & 11 & Cr2O3 (wt\%) & 0.0968 & 0.0929 & 0.1000 & -0.0032 & -0.0071 & $-3.2 \%$ & $-7.1 \%$ \\
\hline
\end{tabular}


Table C.4: Average Measured and Bias-Corrected Chemical Compositions Versus Targeted Compositions by Oxide by Nepheline Study Glass

(100 -Batch 1; $200-U$ std)

\begin{tabular}{|c|c|c|c|c|c|c|c|c|c|}
\hline & & & & Measured & & & Diff of & & $\%$ Diff \\
\hline & Glass & & Measured & Bias-Corrected & Targeted & Diff of & Meas. & $\%$ Diff of & Meas. of \\
\hline Glass ID & \# & Oxide & (wt\%) & (wt\%) & $(w t \%)$ & Measured & bc & Measured & bc \\
\hline SB4-NEPH-11 & 11 & $\mathrm{CuO}(\mathrm{wt} \%)$ & 0.0354 & 0.0370 & 0.0330 & 0.0024 & 0.0040 & $7.2 \%$ & $12.1 \%$ \\
\hline SB4-NEPH-11 & 11 & Fe2O3 (wt\%) & 9.7434 & 10.3116 & 10.6130 & -0.8696 & -0.3014 & $-8.2 \%$ & $-2.8 \%$ \\
\hline SB4-NEPH-11 & 11 & $\mathrm{~K} 2 \mathrm{O}(\mathrm{wt} \%)$ & 0.3840 & 0.3783 & 0.3630 & 0.0210 & 0.0153 & $5.8 \%$ & $4.2 \%$ \\
\hline SB4-NEPH-11 & 11 & La2O3 (wt\%) & 0.0296 & 0.0296 & 0.0370 & -0.0074 & -0.0074 & $-20.0 \%$ & $-20.0 \%$ \\
\hline SB4-NEPH-11 & 11 & Li2O (wt\%) & 4.7041 & 4.6789 & 4.8000 & -0.0959 & -0.1211 & $-2.0 \%$ & $-2.5 \%$ \\
\hline SB4-NEPH-11 & 11 & $\mathrm{MgO}(\mathrm{wt} \%)$ & 0.8187 & 0.9276 & 0.8590 & -0.0403 & 0.0686 & $-4.7 \%$ & $8.0 \%$ \\
\hline SB4-NEPH-11 & 11 & $\mathrm{MnO}(\mathrm{wt} \%)$ & 2.3145 & 2.4885 & 2.4430 & -0.1285 & 0.0455 & $-5.3 \%$ & $1.9 \%$ \\
\hline SB4-NEPH-11 & 11 & $\mathrm{Na} 2 \mathrm{O}(\mathrm{wt} \%)$ & 16.3445 & 15.4874 & 15.9870 & 0.3575 & -0.4996 & $2.2 \%$ & $-3.1 \%$ \\
\hline SB4-NEPH-11 & 11 & $\mathrm{NiO}(\mathrm{wt} \%)$ & 1.3132 & 1.4951 & 1.5140 & -0.2008 & -0.0189 & $-13.3 \%$ & $-1.2 \%$ \\
\hline SB4-NEPH-11 & 11 & $\mathrm{PbO}(\mathrm{wt} \%)$ & 0.0617 & 0.0617 & 0.0630 & -0.0013 & -0.0013 & $-2.1 \%$ & $-2.1 \%$ \\
\hline SB4-NEPH-11 & 11 & SO4 (wt\%) & 0.3805 & 0.3805 & 0.4390 & -0.0585 & -0.0585 & $-13.3 \%$ & $-13.3 \%$ \\
\hline SB4-NEPH-11 & 11 & $\mathrm{SiO} 2$ (wt\%) & 43.5882 & 44.1050 & 44.3010 & -0.7128 & -0.1960 & $-1.6 \%$ & $-0.4 \%$ \\
\hline SB4-NEPH-11 & 11 & ThO2 (wt\%) & 0.1511 & 0.1511 & 0.0140 & 0.1371 & 0.1371 & $979.0 \%$ & $979.0 \%$ \\
\hline SB4-NEPH-11 & 11 & $\mathrm{TiO} 2$ (wt\%) & 0.0171 & 0.0190 & 0.0090 & 0.0081 & 0.0100 & $90.0 \%$ & $111.4 \%$ \\
\hline SB4-NEPH-11 & 11 & U3O8 (wt\%) & 3.6879 & 3.8326 & 3.7530 & -0.0651 & 0.0796 & $-1.7 \%$ & $2.1 \%$ \\
\hline SB4-NEPH-11 & 11 & $\mathrm{ZnO}(\mathrm{wt} \%)$ & 0.0538 & 0.0538 & 0.0500 & 0.0038 & 0.0038 & $7.7 \%$ & $7.7 \%$ \\
\hline SB4-NEPH-11 & 11 & $\mathrm{ZrO} 2$ (wt\%) & 0.1020 & 0.1020 & 0.1070 & -0.0050 & -0.0050 & $-4.7 \%$ & $-4.7 \%$ \\
\hline SB4-NEPH-11 & 11 & Sum of Oxides & 98.5705 & 98.7949 & 100.0020 & -1.4315 & -1.2071 & $-1.4 \%$ & $-1.2 \%$ \\
\hline SB4-NEPH-12 & 12 & $\mathrm{Al} 2 \mathrm{O} 3(\mathrm{wt} \%)$ & 10.4300 & 10.4482 & 10.2220 & 0.2080 & 0.2262 & $2.0 \%$ & $2.2 \%$ \\
\hline SB4-NEPH-12 & 12 & $\mathrm{~B} 2 \mathrm{O} 3(\mathrm{wt} \%)$ & 5.0311 & 5.0769 & 5.2000 & -0.1689 & -0.1231 & $-3.2 \%$ & $-2.4 \%$ \\
\hline SB4-NEPH-12 & 12 & $\mathrm{BaO}(\mathrm{wt} \%)$ & 0.0332 & 0.0373 & 0.0370 & -0.0038 & 0.0003 & $-10.2 \%$ & $0.9 \%$ \\
\hline SB4-NEPH-12 & 12 & $\mathrm{CaO}(\mathrm{wt} \%)$ & 0.7297 & 0.7489 & 0.7340 & -0.0043 & 0.0149 & $-0.6 \%$ & $2.0 \%$ \\
\hline SB4-NEPH-12 & 12 & Ce2O3 (wt\%) & 0.0559 & 0.0559 & 0.0710 & -0.0151 & -0.0151 & $-21.2 \%$ & $-21.2 \%$ \\
\hline SB4-NEPH-12 & 12 & Cr2O3 (wt\%) & 0.0873 & 0.0838 & 0.0760 & 0.0113 & 0.0078 & $14.9 \%$ & $10.2 \%$ \\
\hline SB4-NEPH-12 & 12 & $\mathrm{CuO}(\mathrm{wt} \%)$ & 0.0232 & 0.0242 & 0.0240 & -0.0008 & 0.0002 & $-3.5 \%$ & $0.9 \%$ \\
\hline SB4-NEPH-12 & 12 & $\mathrm{Fe} 2 \mathrm{O} 3(\mathrm{wt} \%)$ & 6.9126 & 7.3153 & 7.6130 & -0.7004 & -0.2977 & $-9.2 \%$ & $-3.9 \%$ \\
\hline SB4-NEPH-12 & 12 & $\mathrm{~K} 2 \mathrm{O}(\mathrm{wt} \%)$ & 0.6044 & 0.5955 & 0.5460 & 0.0584 & 0.0495 & $10.7 \%$ & $9.1 \%$ \\
\hline SB4-NEPH-12 & 12 & La2O3 (wt\%) & 0.0232 & 0.0232 & 0.0290 & -0.0058 & -0.0058 & $-20.1 \%$ & $-20.1 \%$ \\
\hline SB4-NEPH-12 & 12 & Li2O (wt\%) & 5.0647 & 5.0376 & 5.2000 & -0.1353 & -0.1624 & $-2.6 \%$ & $-3.1 \%$ \\
\hline SB4-NEPH-12 & 12 & $\mathrm{MgO}(\mathrm{wt} \%)$ & 0.5567 & 0.6308 & 0.5850 & -0.0283 & 0.0458 & $-4.8 \%$ & $7.8 \%$ \\
\hline SB4-NEPH-12 & 12 & $\mathrm{MnO}(\mathrm{wt} \%)$ & 1.5075 & 1.6204 & 1.6670 & -0.1595 & -0.0466 & $-9.6 \%$ & $-2.8 \%$ \\
\hline SB4-NEPH-12 & 12 & $\mathrm{Na} 2 \mathrm{O}$ (wt\%) & 16.8163 & 15.9347 & 16.3640 & 0.4523 & -0.4293 & $2.8 \%$ & $-2.6 \%$ \\
\hline SB4-NEPH-12 & 12 & $\mathrm{NiO}$ (wt\%) & 0.4148 & 0.4722 & 0.5070 & -0.0922 & -0.0348 & $-18.2 \%$ & $-6.9 \%$ \\
\hline SB4-NEPH-12 & 12 & $\mathrm{PbO}(\mathrm{wt} \%)$ & 0.0584 & 0.0584 & 0.0680 & -0.0096 & -0.0096 & $-14.1 \%$ & $-14.1 \%$ \\
\hline SB4-NEPH-12 & 12 & $\mathrm{SO} 4(\mathrm{wt} \%)$ & 0.3887 & 0.3887 & 0.4440 & -0.0553 & -0.0553 & $-12.5 \%$ & $-12.5 \%$ \\
\hline SB4-NEPH-12 & 12 & $\mathrm{SiO} 2(\mathrm{wt} \%)$ & 46.3158 & 46.8652 & 47.8400 & -1.5242 & -0.9748 & $-3.2 \%$ & $-2.0 \%$ \\
\hline SB4-NEPH-12 & 12 & ThO2 (wt\%) & 0.0760 & 0.0760 & 0.0160 & 0.0600 & 0.0600 & $374.7 \%$ & $374.7 \%$ \\
\hline SB4-NEPH-12 & 12 & $\mathrm{TiO} 2(w t \%)$ & 0.8081 & 0.8987 & 0.8560 & -0.0479 & 0.0427 & $-5.6 \%$ & $5.0 \%$ \\
\hline SB4-NEPH-12 & 12 & U3O8 (wt\%) & 1.7246 & 1.7922 & 1.7810 & -0.0564 & 0.0112 & $-3.2 \%$ & $0.6 \%$ \\
\hline SB4-NEPH-12 & 12 & $\mathrm{ZnO}(\mathrm{wt} \%)$ & 0.0352 & 0.0352 & 0.0350 & 0.0002 & 0.0002 & $0.5 \%$ & $0.5 \%$ \\
\hline SB4-NEPH-12 & 12 & $\mathrm{ZrO} 2$ (wt\%) & 0.0787 & 0.0787 & 0.0820 & -0.0033 & -0.0033 & $-4.0 \%$ & $-4.0 \%$ \\
\hline
\end{tabular}


Table C.4: Average Measured and Bias-Corrected Chemical Compositions Versus Targeted Compositions by Oxide by Nepheline Study Glass

(100 -Batch 1; $200-U$ std)

\begin{tabular}{|c|c|c|c|c|c|c|c|c|c|}
\hline & & & & Measured & & & Diff of & & $\%$ Diff \\
\hline & Glass & & Measured & Bias-Corrected & Targeted & Diff of & Meas. & \% Diff of & Meas. of \\
\hline Glass ID & $\#$ & Oxide & (wt\%) & (wt\%) & (wt\%) & Measured & bc & Measured & bc \\
\hline SB4-NEPH-12 & 12 & Sum of Oxides & 98.0121 & 97.8301 & 99.9970 & -1.9849 & -2.1669 & $-2.0 \%$ & $-2.2 \%$ \\
\hline Batch 1 & 100 & $\mathrm{Al} 2 \mathrm{O} 3$ (wt\%) & 4.8686 & 4.8770 & 4.8770 & -0.0084 & 0.0000 & $-0.2 \%$ & $0.0 \%$ \\
\hline Batch 1 & 100 & B2O3 (wt\%) & 7.7063 & 7.7770 & 7.7770 & -0.0707 & 0.0000 & $-0.9 \%$ & $0.0 \%$ \\
\hline Batch 1 & 100 & $\mathrm{BaO}(\mathrm{wt} \%)$ & 0.1344 & 0.1510 & 0.1510 & -0.0166 & 0.0000 & $-11.0 \%$ & $0.0 \%$ \\
\hline Batch 1 & 100 & $\mathrm{CaO}(\mathrm{wt} \%)$ & 1.1886 & 1.2200 & 1.2200 & -0.0314 & 0.0000 & $-2.6 \%$ & $0.0 \%$ \\
\hline Batch 1 & 100 & Ce2O3 (wt\%) & 0.0059 & 0.0059 & 0.0000 & 0.0059 & 0.0059 & & \\
\hline Batch 1 & 100 & Cr2O3 (wt\%) & 0.1116 & 0.1070 & 0.1070 & 0.0046 & 0.0000 & $4.3 \%$ & $0.0 \%$ \\
\hline Batch 1 & 100 & $\mathrm{CuO}(\mathrm{wt} \%)$ & 0.3814 & 0.3990 & 0.3990 & -0.0176 & 0.0000 & $-4.4 \%$ & $0.0 \%$ \\
\hline Batch 1 & 100 & $\mathrm{Fe} 2 \mathrm{O} 3(\mathrm{wt} \%)$ & 12.1310 & 12.8390 & 12.8390 & -0.7080 & 0.0000 & $-5.5 \%$ & $0.0 \%$ \\
\hline Batch 1 & 100 & K2O (wt\%) & 3.3769 & 3.3270 & 3.3270 & 0.0499 & 0.0000 & $1.5 \%$ & $0.0 \%$ \\
\hline Batch 1 & 100 & La2O3 (wt\%) & 0.0059 & 0.0059 & 0.0000 & 0.0059 & 0.0059 & & \\
\hline Batch 1 & 100 & $\mathrm{Li} 2 \mathrm{O}(\mathrm{wt} \%)$ & 4.4529 & 4.4290 & 4.4290 & 0.0239 & 0.0000 & $0.5 \%$ & $0.0 \%$ \\
\hline Batch 1 & 100 & $\mathrm{MgO}(\mathrm{wt} \%)$ & 1.2524 & 1.4190 & 1.4190 & -0.1666 & 0.0000 & $-11.7 \%$ & $0.0 \%$ \\
\hline Batch 1 & 100 & $\mathrm{MnO}(\mathrm{wt} \%)$ & 1.6054 & 1.7260 & 1.7260 & -0.1206 & 0.0000 & $-7.0 \%$ & $0.0 \%$ \\
\hline Batch 1 & 100 & Na2O (wt\%) & 9.5012 & 9.0030 & 9.0030 & 0.4982 & 0.0000 & $5.5 \%$ & $0.0 \%$ \\
\hline Batch 1 & 100 & $\mathrm{NiO}$ (wt\%) & 0.6596 & 0.7510 & 0.7510 & -0.0914 & 0.0000 & $-12.2 \%$ & $0.0 \%$ \\
\hline Batch 1 & 100 & $\mathrm{PbO}(\mathrm{wt} \%)$ & 0.0054 & 0.0054 & 0.0000 & 0.0054 & 0.0054 & & \\
\hline Batch 1 & 100 & SO4 (wt\%) & 0.1498 & 0.1498 & 0.0000 & 0.1498 & 0.1498 & & \\
\hline Batch 1 & 100 & $\mathrm{SiO} 2(\mathrm{wt} \%)$ & 49.6318 & 50.2200 & 50.2200 & -0.5882 & 0.0000 & $-1.2 \%$ & $0.0 \%$ \\
\hline Batch 1 & 100 & ThO2 (wt\%) & 0.0057 & 0.0057 & 0.0000 & 0.0057 & 0.0057 & & \\
\hline Batch 1 & 100 & $\mathrm{TiO} 2$ (wt\%) & 0.6088 & 0.6770 & 0.6770 & -0.0682 & 0.0000 & $-10.1 \%$ & $0.0 \%$ \\
\hline Batch 1 & 100 & U3O8 (wt\%) & 0.0590 & 0.0613 & 0.0000 & 0.0590 & 0.0613 & & \\
\hline Batch 1 & 100 & $\mathrm{ZnO}(\mathrm{wt} \%)$ & 0.0062 & 0.0062 & 0.0000 & 0.0062 & 0.0062 & & \\
\hline Batch 1 & 100 & $\mathrm{ZrO} 2$ (wt\%) & 0.0826 & 0.0826 & 0.0980 & -0.0154 & -0.0154 & $-15.7 \%$ & $-15.7 \%$ \\
\hline Batch 1 & 100 & Sum of Oxides & 98.3558 & 99.2447 & 99.0200 & -0.6642 & 0.2247 & $-0.7 \%$ & $0.2 \%$ \\
\hline U std & 200 & $\mathrm{Al} 2 \mathrm{O} 3$ (wt\%) & 4.0278 & 4.0347 & 4.1000 & -0.0722 & -0.0653 & $-1.8 \%$ & $-1.6 \%$ \\
\hline U std & 200 & B2O3 (wt\%) & 8.8708 & 8.9523 & 9.2090 & -0.3382 & -0.2567 & $-3.7 \%$ & $-2.8 \%$ \\
\hline U std & 200 & $\mathrm{BaO}(\mathrm{wt} \%)$ & 0.0056 & 0.0063 & 0.0000 & 0.0056 & 0.0063 & & \\
\hline U std & 200 & $\mathrm{CaO}(\mathrm{wt} \%)$ & 1.2511 & 1.2842 & 1.3010 & -0.0499 & -0.0168 & $-3.8 \%$ & $-1.3 \%$ \\
\hline U std & 200 & $\mathrm{Ce} 2 \mathrm{O} 3(\mathrm{wt} \%)$ & 0.0059 & 0.0059 & 0.0000 & 0.0059 & 0.0059 & & \\
\hline U std & 200 & Cr2O3 (wt\%) & 0.2412 & 0.2313 & 0.0000 & 0.2412 & 0.2313 & & \\
\hline U std & 200 & $\mathrm{CuO}(\mathrm{wt} \%)$ & 0.0050 & 0.0052 & 0.0000 & 0.0050 & 0.0052 & & \\
\hline U std & 200 & Fe2O3 (wt\%) & 12.3979 & 13.1219 & 13.1960 & -0.7981 & -0.0741 & $-6.0 \%$ & $-0.6 \%$ \\
\hline U std & 200 & K2O (wt\%) & 2.7786 & 2.7376 & 2.9990 & -0.2204 & -0.2614 & $-7.3 \%$ & $-8.7 \%$ \\
\hline U std & 200 & La2O3 (wt\%) & 0.0059 & 0.0059 & 0.0000 & 0.0059 & 0.0059 & & \\
\hline U std & 200 & Li2O (wt\%) & 3.0499 & 3.0336 & 3.0570 & -0.0071 & -0.0234 & $-0.2 \%$ & $-0.8 \%$ \\
\hline U std & 200 & $\mathrm{MgO}(\mathrm{wt} \%)$ & 1.1153 & 1.2638 & 1.2100 & -0.0947 & 0.0538 & $-7.8 \%$ & $4.4 \%$ \\
\hline U std & 200 & $\mathrm{MnO}(\mathrm{wt} \%)$ & 2.6405 & 2.8396 & 2.8920 & -0.2515 & -0.0524 & $-8.7 \%$ & $-1.8 \%$ \\
\hline U std & 200 & $\mathrm{Na} 2 \mathrm{O}$ (wt\%) & 12.2219 & 11.5812 & 11.7950 & 0.4269 & -0.2138 & $3.6 \%$ & $-1.8 \%$ \\
\hline U std & 200 & $\mathrm{NiO}(\mathrm{wt} \%)$ & 0.9631 & 1.0965 & 1.1200 & -0.1569 & -0.0235 & $-14.0 \%$ & $-2.1 \%$ \\
\hline U std & 200 & $\mathrm{PbO}(\mathrm{wt} \%)$ & 0.0054 & 0.0054 & 0.0000 & 0.0054 & 0.0054 & & \\
\hline
\end{tabular}


Table C.4: Average Measured and Bias-Corrected Chemical Compositions Versus Targeted Compositions by Oxide by Nepheline Study Glass (100-Batch 1; $200-U$ std)

\begin{tabular}{|c|c|c|c|c|c|c|c|c|c|}
\hline & & & & Measured & & & Diff of & & \% Diff \\
\hline & Glass & & Measured & Bias-Corrected & Targeted & Diff of & Meas. & $\%$ Diff of & Meas. of \\
\hline Glass ID & $\#$ & Oxide & (wt\%) & (wt\%) & (wt\%) & Measured & bc & Measured & bc \\
\hline U std & 200 & SO4 (wt\%) & 0.1498 & 0.1498 & 0.0000 & 0.1498 & 0.1498 & & \\
\hline U std & 200 & SiO2 (wt\%) & 43.2852 & 43.7987 & 45.3530 & -2.0678 & -1.5543 & $-4.6 \%$ & $-3.4 \%$ \\
\hline U std & 200 & ThO2 (wt\%) & 0.0863 & 0.0863 & 0.0000 & 0.0863 & 0.0863 & & \\
\hline U std & 200 & $\mathrm{TiO} 2$ (wt\%) & 0.9277 & 1.0316 & 1.0490 & -0.1213 & -0.0174 & $-11.6 \%$ & $-1.7 \%$ \\
\hline U std & 200 & U3O8 (wt\%) & 2.3152 & 2.4060 & 2.4060 & -0.0908 & 0.0000 & $-3.8 \%$ & $0.0 \%$ \\
\hline U std & 200 & $\mathrm{ZnO}$ (wt\%) & 0.0062 & 0.0062 & 0.0000 & 0.0062 & 0.0062 & & \\
\hline U std & 200 & $\mathrm{ZrO} 2$ (wt\%) & 0.0068 & 0.0068 & 0.0000 & 0.0068 & 0.0068 & & \\
\hline U std & 200 & Sum of Oxides & 96.3651 & 97.1979 & 99.6870 & -3.3219 & -2.4891 & $-3.3 \%$ & $-2.5 \%$ \\
\hline
\end{tabular}


Exhibit C.1: Oxide Measurements in Analytical Sequence for Samples Prepared Using the LM Method

BaO (wt\%) By Analytical Sequence

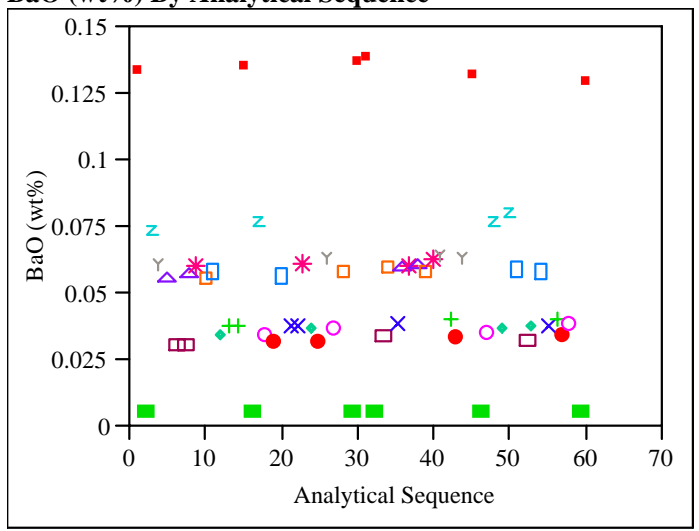

$\mathrm{CaO}$ (wt\%) By Analytical Sequence
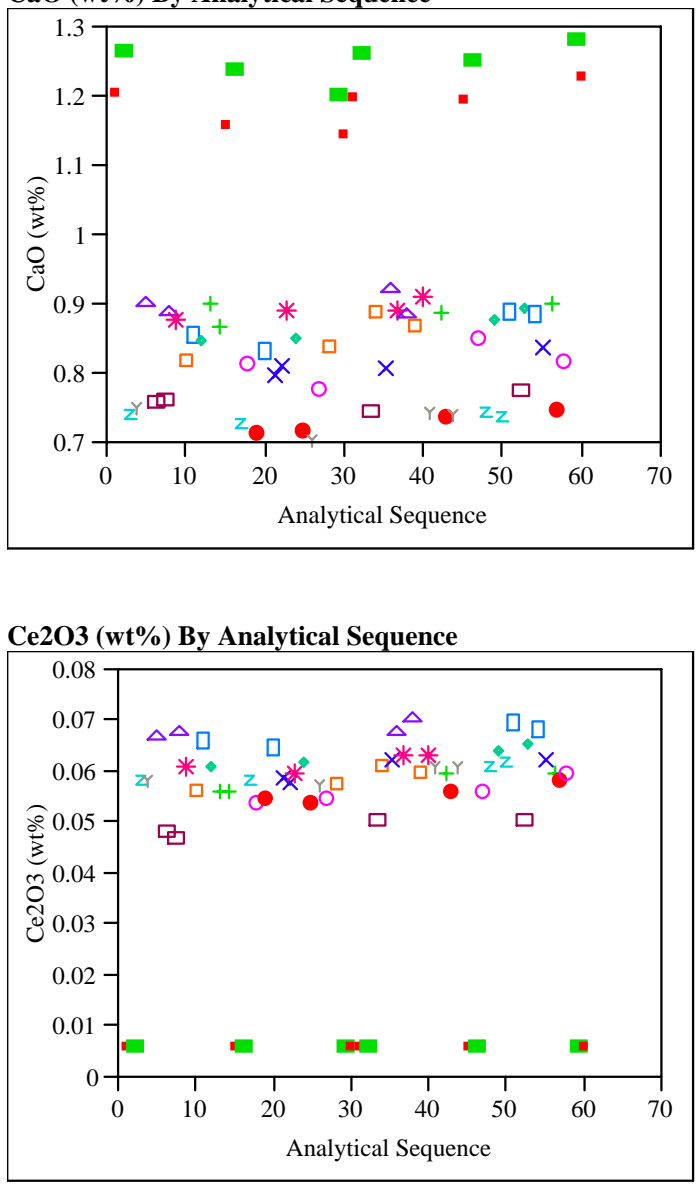

Cr2O3 (wt\%) By Analytical Sequence

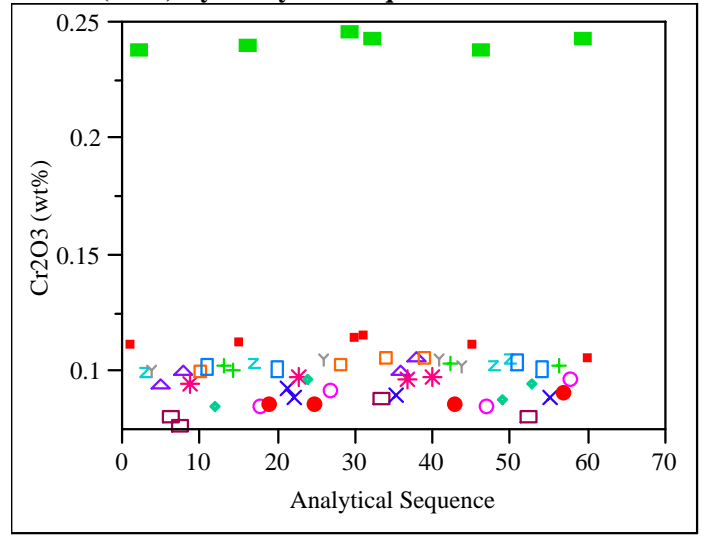

$\mathrm{CuO}(w \mathrm{t} \%)$ By Analytical Sequence

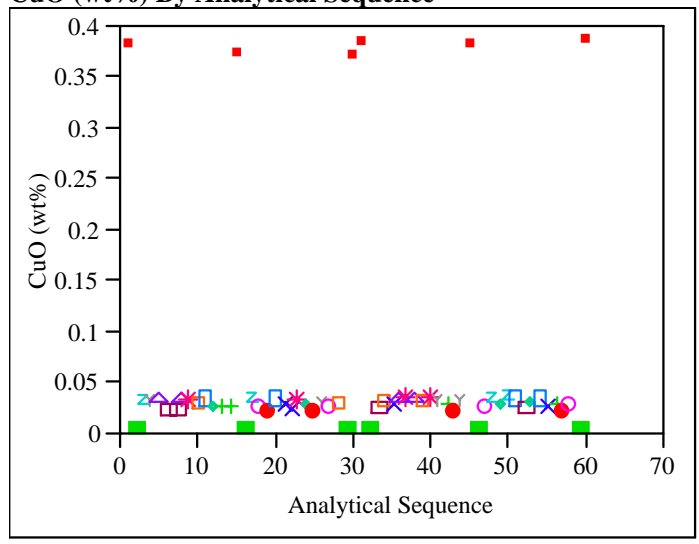

K2O (wt \%) By Analytical Sequence

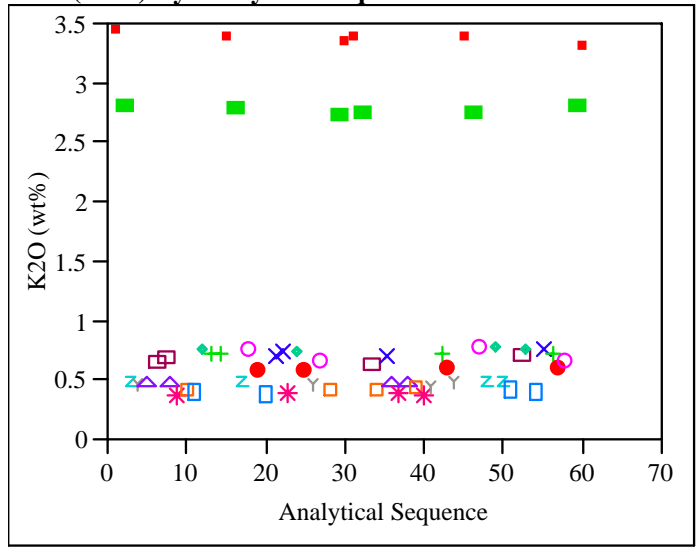




\section{Exhibit C.1: Oxide Measurements in Analytical Sequence for Samples Prepared Using the LM Method}
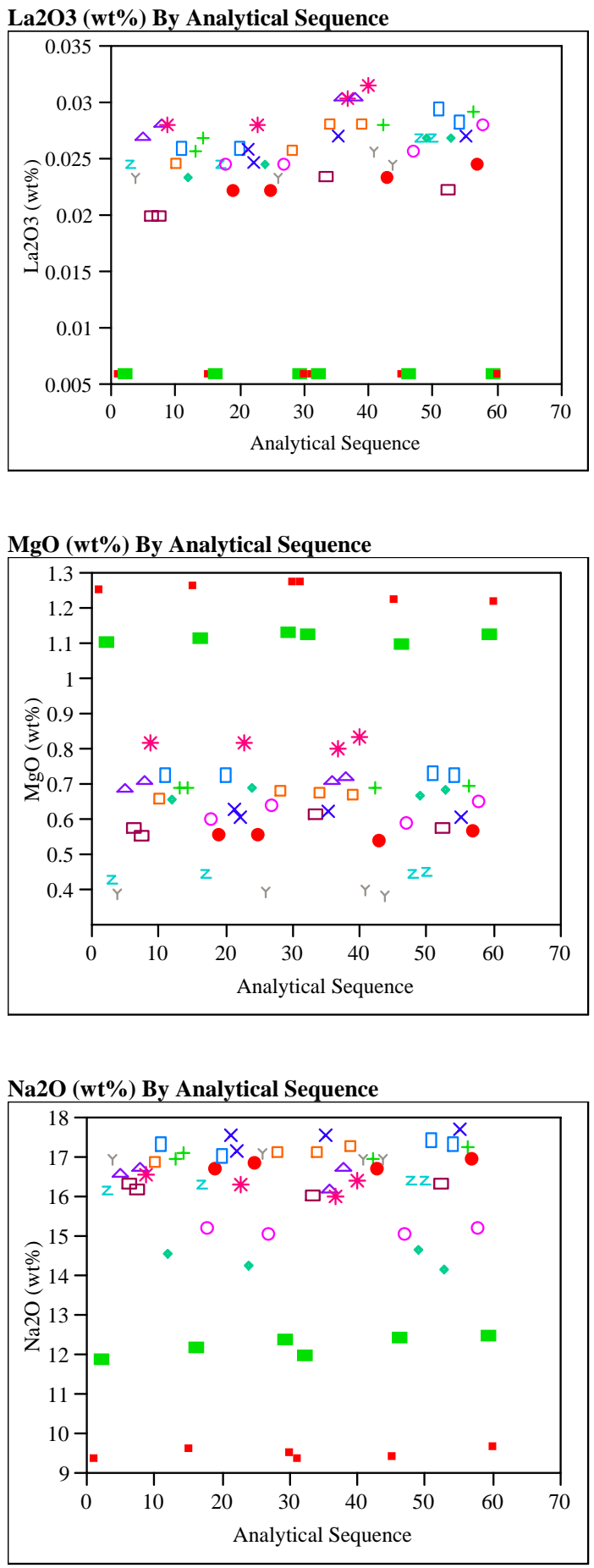

PbO (wt\%) By Analytical Sequence

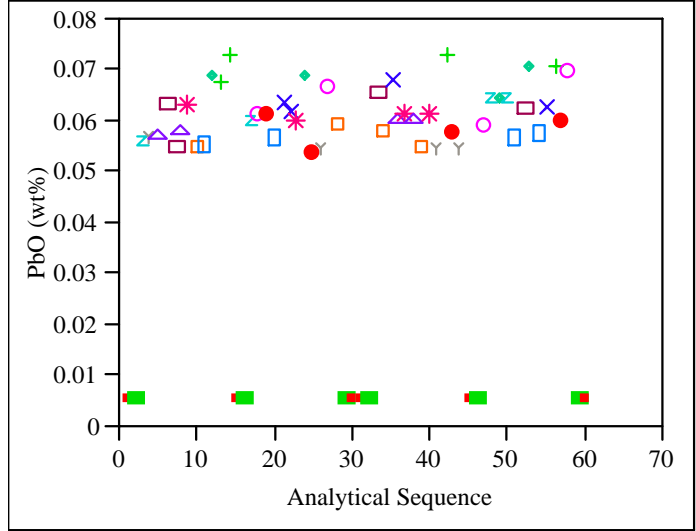

\section{SO4 (wt\%) By Analytical Sequence}

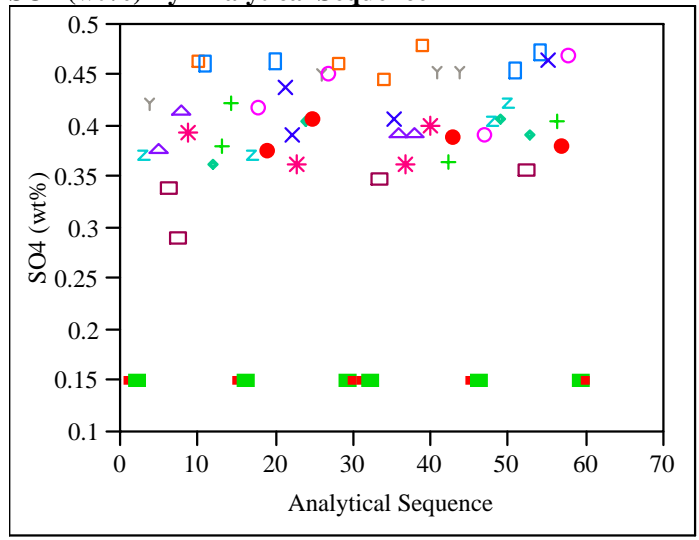

ThO2 (wt\%) By Analytical Sequence

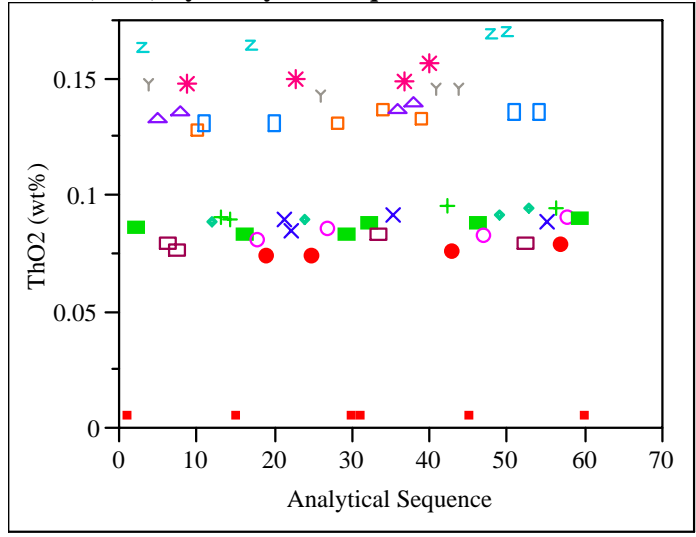


Exhibit C.1: Oxide Measurements in Analytical Sequence for Samples Prepared Using the LM Method

TiO2 (wt\%) By Analytical Sequence

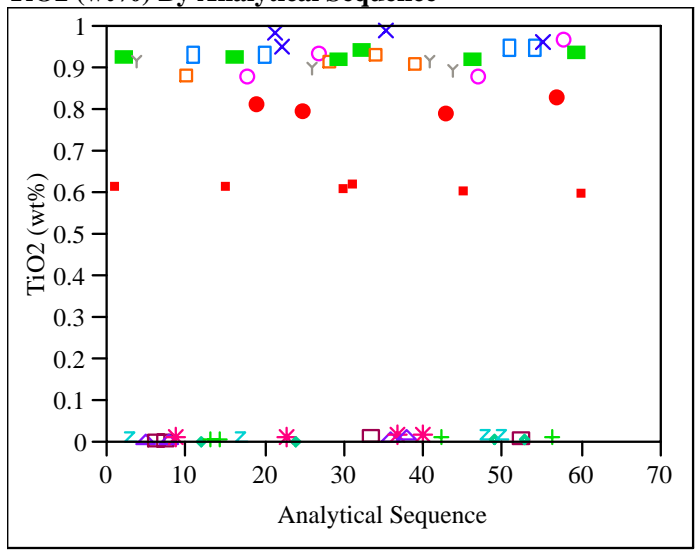

ZnO (wt\%) By Analytical Sequence

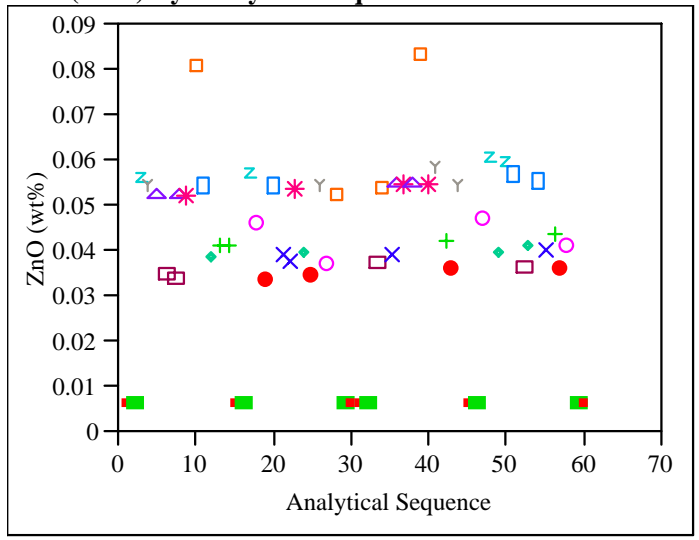

ZrO2 (wt\%) By Analytical Sequence

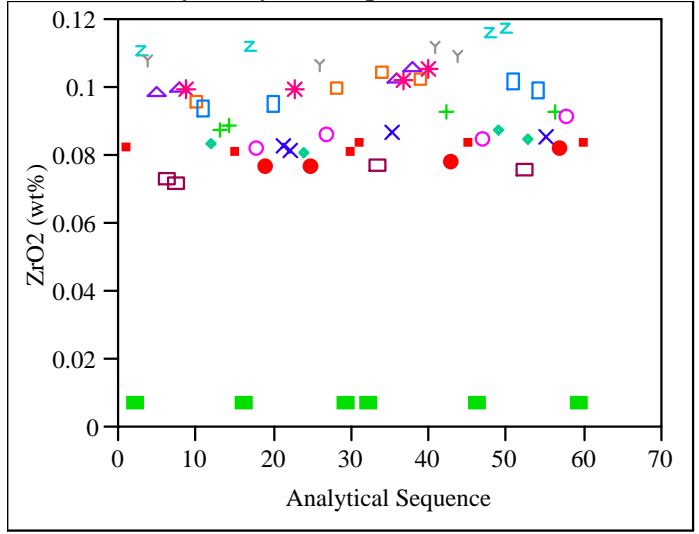


Exhibit C.2: Oxide Measurements in Analytical Sequence for Samples Prepared Using the PF Method

Al2O3 (wt\%) By Analytical Sequence

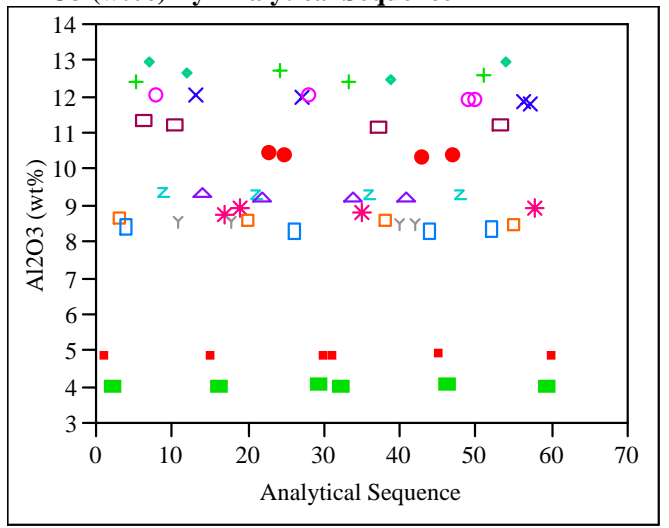

B2O3 (wt\%) By Analytical Sequence

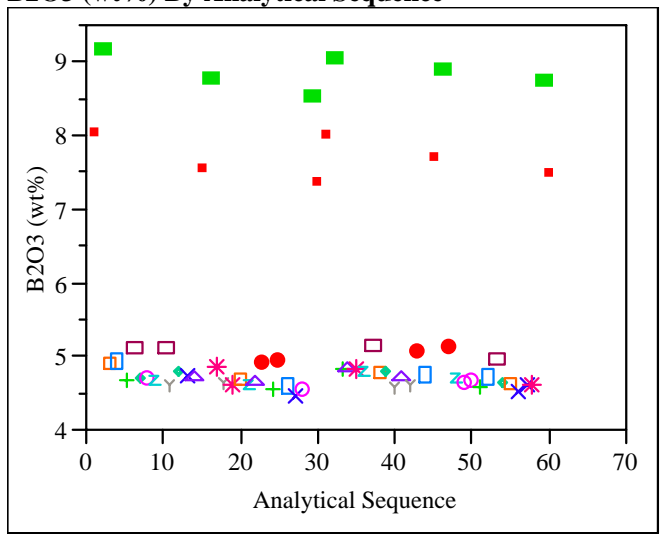

Fe2O3 (wt \%) By Analytical Sequence

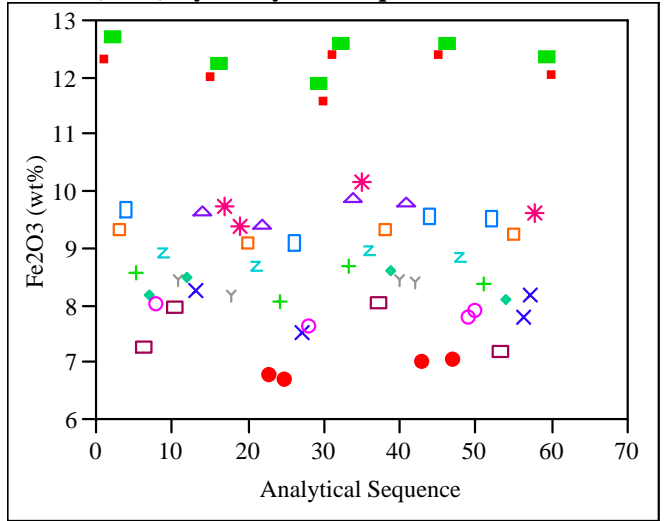

Li2O (wt\%) By Analytical Sequence

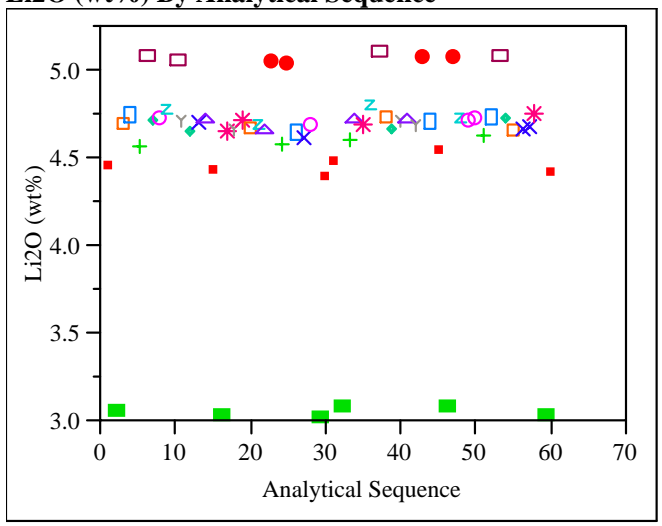

MnO (wt\%) By Analytical Sequence

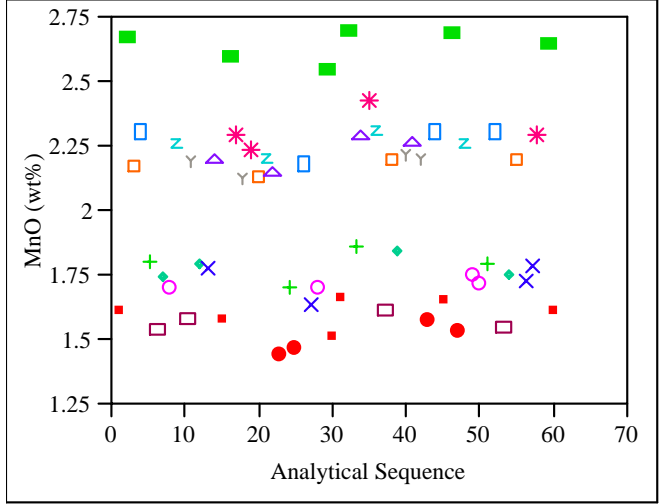

$\mathrm{NiO}$ (wt\%) By Analytical Sequence

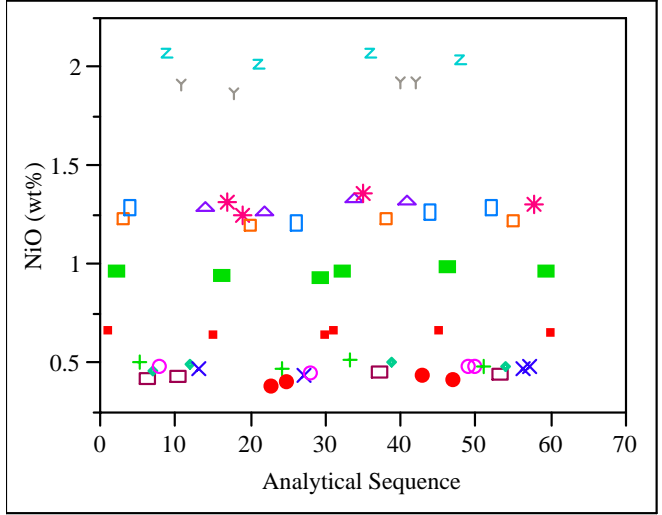


Exhibit C.2: Oxide Measurements in Analytical Sequence for Samples Prepared Using the PF Method

SiO2 (wt\%) By Analytical Sequence

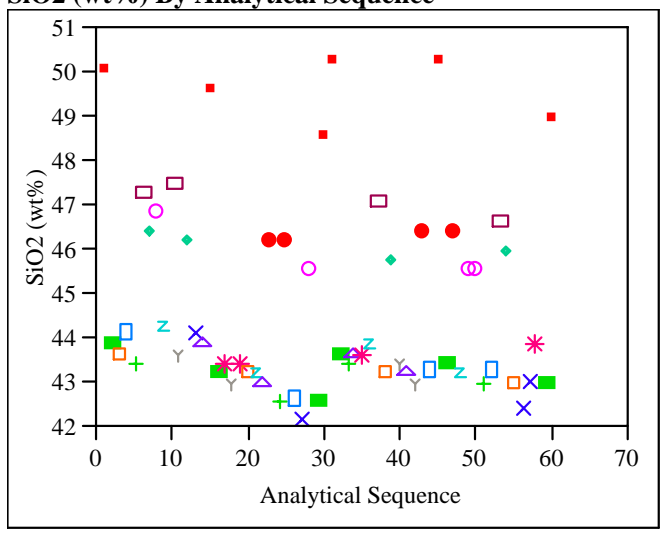

U3O8 (wt \%) By Analytical Sequence

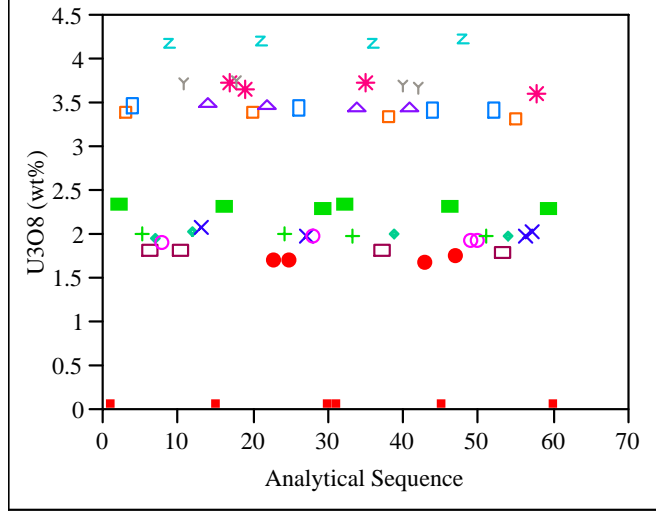




\section{Exhibit C.3: SRNL-ML Measurements by Analytical Block for Samples of the Standard Glasses Prepared Using the LM Method}

Glass ID=Batch 1

Oneway Analysis of BaO (wt \%) By Block

(Ref value: 0.151 wt\%)

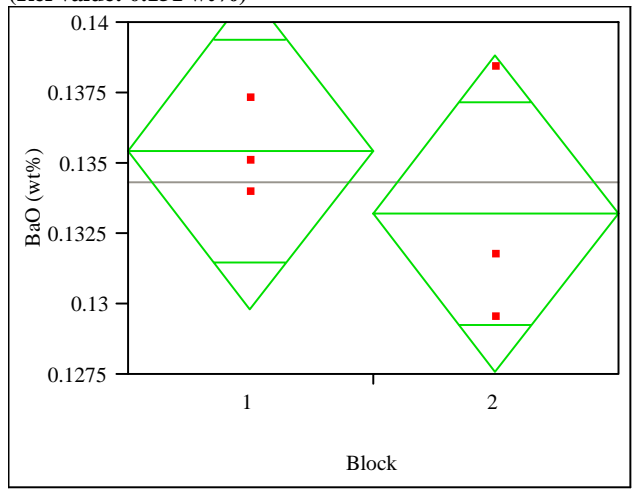

Oneway Anova

Summary of Fit

$\begin{array}{lr}\text { Rsquare } & 0.132353 \\ \text { Adj Rsquare } & -0.08456 \\ \text { Root Mean Square Error } & 0.003501 \\ \text { Mean of Response } & 0.134352 \\ \text { Observations (or Sum Wgts) } & 6 \\ \text { t Test } & \\ 1-2 & \\ \text { Assuming equal variances } & \end{array}$

Difference $\quad 0.00223$ t Ratio 0.781133

Std Err Dif 0.00286 DF 4

Upper CL Dif 0.01017 Prob $>|t| \quad 0.4784$

Lower CL Dif -0.00570 Prob $>t \quad 0.2392$

$\begin{array}{lll}\text { Confidence } & 0.95 \text { Prob }<\mathrm{t} & 0.7608\end{array}$

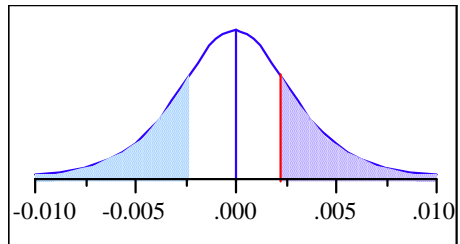

Analysis of Variance

Source DF Sum of Squares Mean Square F Ratio Prob > F

$\begin{array}{llllll}\text { Block } & 1 & 0.00000748 & 0.000007 & 0.6102 & 0.4784\end{array}$

$\begin{array}{llll}\text { Error } & 4 & 0.00004903 & 0.000012\end{array}$

C. Total $5 \quad 0.00005651$

Means for Oneway Anova

Level Number Mean Std Error Lower 95\% Upper 95\%

$\begin{array}{llllll}1 & 3 & 0.135469 & 0.00202 & 0.12986 & 0.14108\end{array}$

$\begin{array}{llllll}2 & 3 & 0.133236 & 0.00202 & 0.12762 & 0.13885\end{array}$

Std Error uses a pooled estimate of error variance

Oneway Analysis of $\mathrm{CaO}$ (wt\%) By Block

(Ref value: 1.22 wt \%)

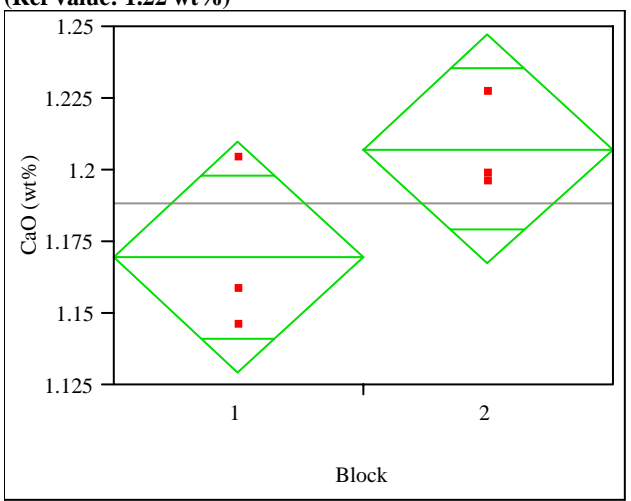

Oneway Anova

Summary of Fit

Rsquare

Adj Rsquare

0.46188

Root Mean Square Error $\quad 0.024971$

Mean of Response

1.18862

Observations (or Sum Wgts)

t Test

$1-2$

Assuming equal variances

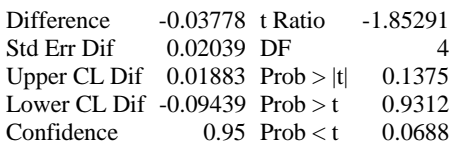

Confidence $\quad 0.95$ Prob $<\mathrm{t} \quad 0.0688$

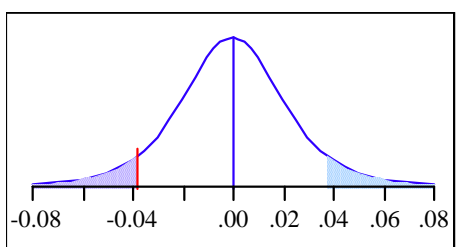

Analysis of Variance

Source DF Sum of Squares Mean Square F Ratio Prob $>$ F

$\begin{array}{lrrrrr}\text { Block } & 1 & 0.00214081 & 0.002141 & 3.4333 & 0.1375\end{array}$

$\begin{array}{llll}\text { Error } & 4 & 0.00249419 & 0.000624\end{array}$

C. Total $5 \quad 0.00463500$

Means for Oneway Anova

Level Number Mean Std Error Lower 95\% Upper 95\%

$\begin{array}{llllll}1 & 3 & 1.16973 & 0.01442 & 1.1297 & 1.2098\end{array}$

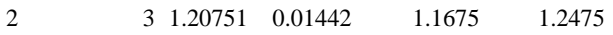

Std Error uses a pooled estimate of error variance 


\section{Exhibit C.3: SRNL-ML Measurements by Analytical Block for Samples of the Standard Glasses Prepared Using the LM Method}

Oneway Analysis of $\mathrm{Ce} 2 \mathrm{O} 3$ (wt \%) By Block

(Ref value: 0 wt\%)

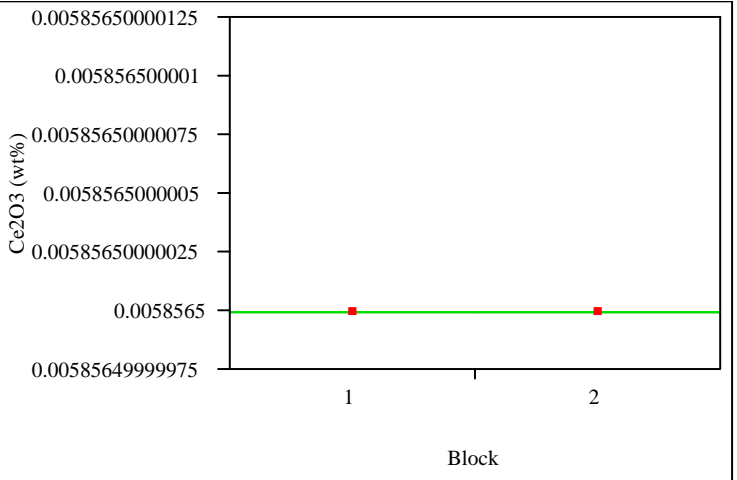

Oneway Anova

Summary of Fit

Rsquare

Adj Rsquare

Root Mean Square Error $\quad 0$

Mean of Response

Observations (or Sum Wgts) 6

t Test

Assuming equal variances
Oneway Analysis of Cr2O3 (wt\%) By Block (Ref value: 0.107 wt\%)

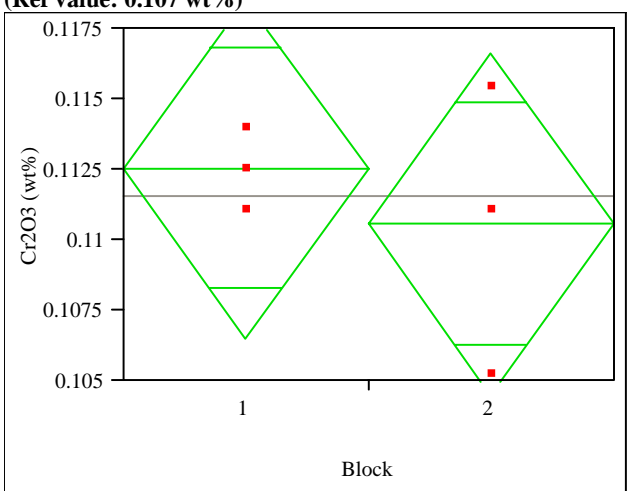

Oneway Anova

Summary of Fit

Rsquare

Adj Rsquare

0.090909

Root Mean Squar

Mean of Response

Observations (or Sum Wgts)

t Test

Assuming equal variances
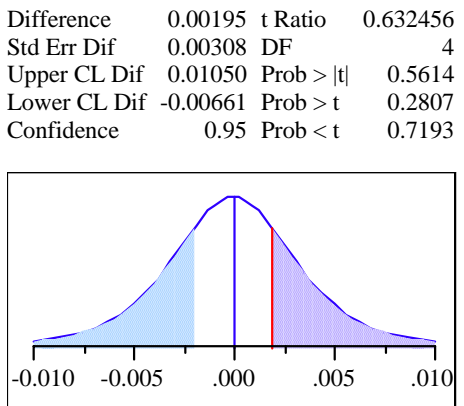

Analysis of Variance

Source DF Sum of Squares Mean Square F Ratio Prob > F $\begin{array}{llllll}\text { Block } & 1 & 0.00000570 & 0.000006 & 0.4000 & 0.5614\end{array}$

$\begin{array}{llll}\text { Error } & 4 & 0.00005697 & 0.000014\end{array}$

C. Total $5 \quad 0.00006266$

Means for Oneway Anova

Level Number Mean Std Error Lower 95\% Upper 95\%

$\begin{array}{llllll}1 & 3 & 0.112543 & 0.00218 & 0.10649 & 0.11859\end{array}$

$\begin{array}{llllll}2 & 3 & 0.110594 & 0.00218 & 0.10455 & 0.11664\end{array}$

Std Error uses a pooled estimate of error variance 


\section{Exhibit C.3: SRNL-ML Measurements by Analytical Block for Samples of the Standard Glasses Prepared Using the LM Method}

Oneway Analysis of $\mathrm{CuO}(\mathrm{wt} \%)$ By Block (Ref value: 0.399 wt \%)

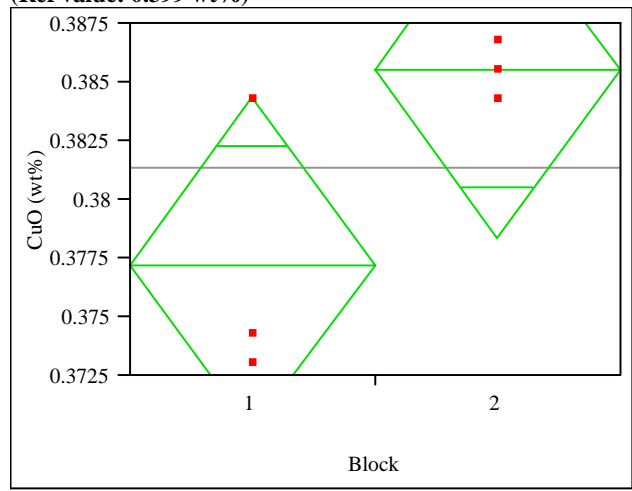

Oneway Anova

Summary of Fit

Rsquare

Adj Rsquare

Root Mean Square Error $\quad 0.004455$

Mean of Response $\quad 0.381382$

Observations (or Sum Wgts) 6

t Test

Assuming equal variances

Difference $\quad-0.00835$ t Ratio $\quad-2.29416$

Std Err Dif $\quad 0.00364$ DF

Upper CL Dif 0.00175 Prob $>|t| \quad 0.0835$

Lower CL Dif -0.01845 Prob $>\mathrm{t} \quad 0.9583$

Confidence $\quad 0.95$ Prob $<\mathrm{t} \quad 0.0417$

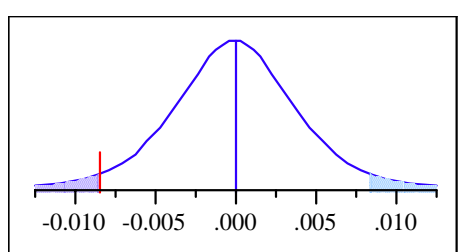

Analysis of Variance

Source DF Sum of Squares Mean Square F Ratio Prob $>$ F

$\begin{array}{llllll}\text { Block } & 1 & 0.00010447 & 0.000104 & 5.2632 & 0.0835\end{array}$

$\begin{array}{llll}\text { Error } & 4 & 0.00007939 & 0.000020\end{array}$

C. Total $5 \quad 0.00018386$

Means for Oneway Anova

Level Number Mean Std Error Lower 95\% Upper 95\%

$\begin{array}{llllll}1 & 3 & 0.377209 & 0.00257 & 0.37007 & 0.38435\end{array}$

$\begin{array}{llllll}2 & 3 & 0.385554 & 0.00257 & 0.37841 & 0.39270\end{array}$

Std Error uses a pooled estimate of error variance
Oneway Analysis of K2O (wt\%) By Block (Ref value: $3.327 \mathrm{wt} \%$ )

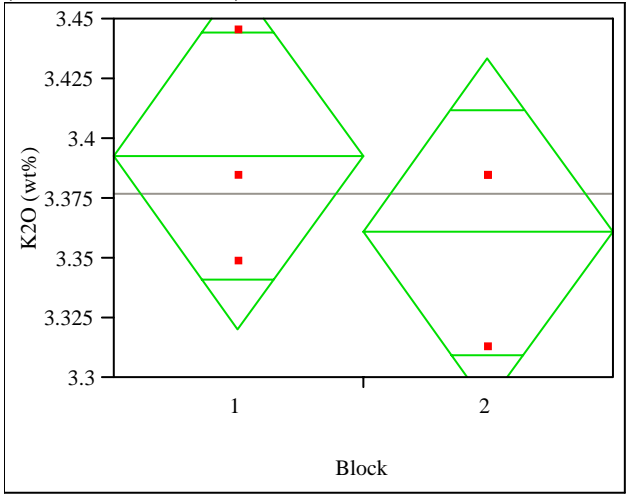

Oneway Anova

Summary of Fit

Rsquare

0.158416

Adj Rsquare

$-0.05198$

Root Mean Square Error $\quad 0.045339$

Mean of Response $\quad 3.376895$

Observations (or Sum Wgts)

t Test

1-2

Assuming equal variances
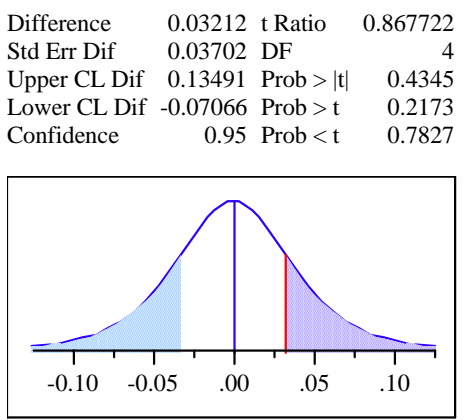

Analysis of Variance

Source DF Sum of Squares Mean Square F Ratio Prob $>$ F

$\begin{array}{llllll}\text { Block } & 1 & 0.00154780 & 0.001548 & 0.7529 & 0.4345\end{array}$

$\begin{array}{llll}\text { Error } & 4 & 0.00822268 & 0.002056\end{array}$

C. Total $5 \quad 0.00977048$

Means for Oneway Anova

Level Number Mean Std Error Lower 95\% Upper 95\%

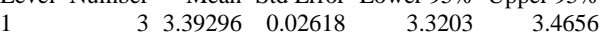

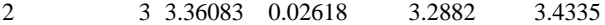

Std Error uses a pooled estimate of error variance 


\section{Exhibit C.3: SRNL-ML Measurements by Analytical Block for Samples of the Standard Glasses Prepared Using the LM Method}

Oneway Analysis of La2O3 (wt\%) By Block

(Ref value: 0 wt\%)

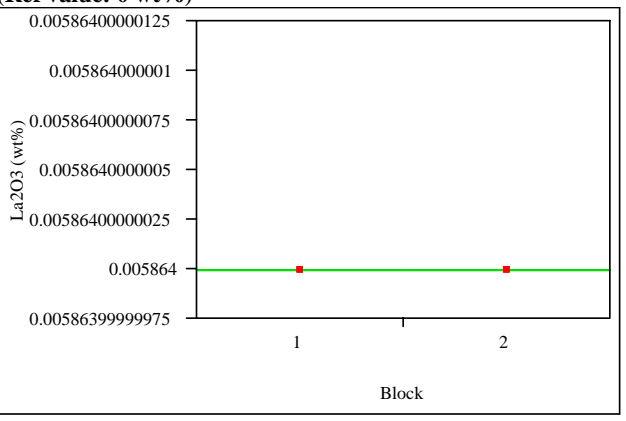

Oneway Anova

Summary of Fit

Rsquare

Adj Rsquare

Root Mean Square Error

Mean of Response

Observations (or Sum Wgts)

t Test

1-2

Assuming equal variances

Difference

Std Err Dif

0 t Ratio

Upper CL Dif

0 DF

Confidence 0.95 Prob $<\mathrm{t} \quad 0.5000$

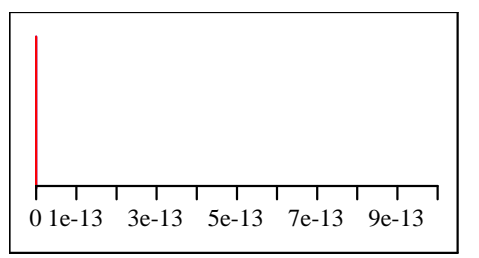

Analysis of Variance

$\begin{array}{lrrrr}\text { Source } & \text { DF } & \text { Sum of Squares } & \text { Mean Square } & \text { F Ratio Prob }>\text { F } \\ \text { Block } & 1 & 0 & 0 & . \\ \text { Error } & 4 & 0 & 0 & \\ \text { C. Total } & 5 & 0 & & \end{array}$

Block

C. Total 5

Means for Oneway Anova

Level Number Mean Std Error Lower 95\% Upper 95\%

$\begin{array}{llllll}1 & 3 & 0.005864 & 0 & 0.00586 & 0.00586\end{array}$

$\begin{array}{llllll}2 & 3 & 0.005864 & 0 & 0.00586 & 0.00586\end{array}$

Std Error uses a pooled estimate of error variance
Oneway Analysis of MgO (wt\%) By Block (Ref value: 1.419 wt \%)

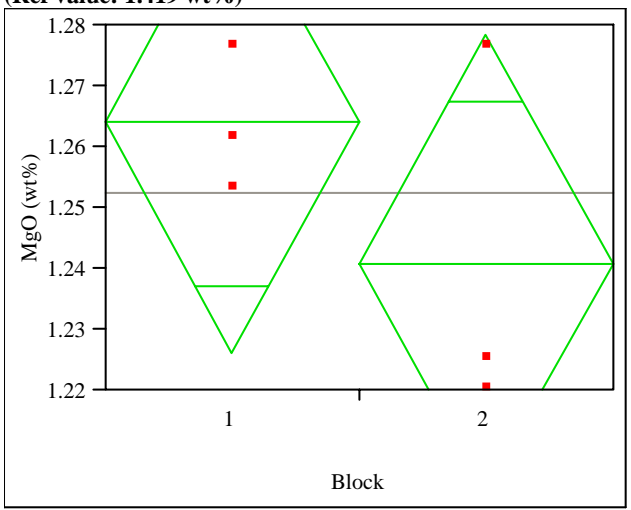

Oneway Anova

Summary of Fit

Rsquare

Adj Rsquare

0.266465

Root Mean Square Error $\quad 0.023585$

Mean of Response 1.252418

Observations (or Sum Wgts)

t Test

$1-2$

Assuming equal variances

$\begin{array}{lrlr}\text { Difference } & 0.02321 & \text { t Ratio } & 1.205424 \\ \text { Std Err Dif } & 0.01926 & \text { DF } & 4 \\ \text { Upper CL Dif } & 0.07668 \text { Prob }>|t| & 0.2945 \\ \text { Lower CL Dif } & -0.03025 \text { Prob }>t & 0.1472 \\ \text { Confidence } & 0.95 & \text { Prob }<\mathrm{t} & 0.8528\end{array}$

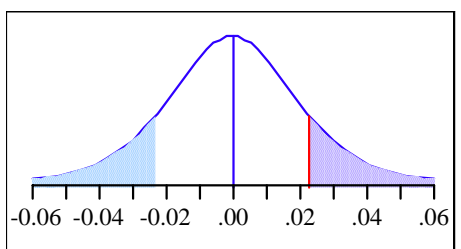

Analysis of Variance

Source DF Sum of Squares Mean Square F Ratio Prob > F

$\begin{array}{lrrrrr}\text { Block } & 1 & 0.00080829 & 0.000808 & 1.4530 & 0.2945\end{array}$

$\begin{array}{llll}\text { Error } & 4 & 0.00222510 & 0.000556\end{array}$

C. Total $5 \quad 0.00303339$

Means for Oneway Anova

Level Number Mean Std Error Lower 95\% Upper 95\%

$\begin{array}{llllll}1 & 3 & 1.26402 & 0.01362 & 1.2262 & 1.3018\end{array}$

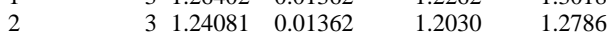

Std Error uses a pooled estimate of error variance 


\section{Exhibit C.3: SRNL-ML Measurements by Analytical Block for Samples of the Standard Glasses Prepared Using the LM Method}

Oneway Analysis of Na2O (wt\%) By Block (Ref value: $9.003 \mathrm{wt} \%$ )

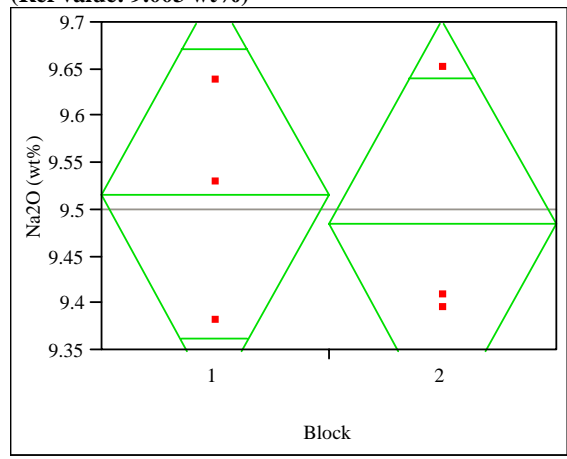

Oneway Anova

Summary of Fit

$\begin{array}{lr}\text { Rsquare } & 0.019499 \\ \text { Adj Rsquare } & -0.22563 \\ \text { Root Mean Square Error } & 0.136586 \\ \text { Mean of Response } & 9.501153 \\ \text { Observations (or Sum Wgts) } & 6 \\ \text { t Test } & \\ 1-2 & \\ \text { Assuming equal variances } & \end{array}$

Assuming equal variances

Difference $\quad 0.03145$ t Ratio 0.282038

Std Err Dif $\quad 0.11152$ DF

Upper CL Dif 0.34109 Prob $>|t| \quad 0.7919$

Lower CL Dif -0.27818 Prob $>t \quad 0.3960$

Confidence $\quad 0.95$ Prob $<\mathrm{t} \quad 0.6040$

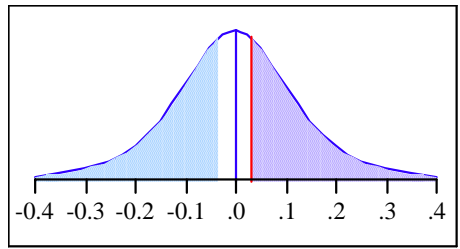

Analysis of Variance

Source DF Sum of Squares Mean Square F Ratio Prob $>$ F

$\begin{array}{llllll}\text { Block } & 1 & 0.00148397 & 0.001484 & 0.0795 & 0.7919\end{array}$

$\begin{array}{llll}\text { Error } & 4 & 0.07462240 & 0.018656\end{array}$

C. Total $5 \quad 0.07610637$

Means for Oneway Anova

Level Number Mean Std Error Lower 95\% Upper 95\%

$\begin{array}{lrrrrr}1 & 3 & 9.51688 & 0.07886 & 9.2979 & 9.7358\end{array}$

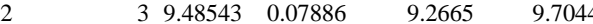

Std Error uses a pooled estimate of error variance
Oneway Analysis of PbO (wt\%) By Block

(Ref value: 0 wt \%)

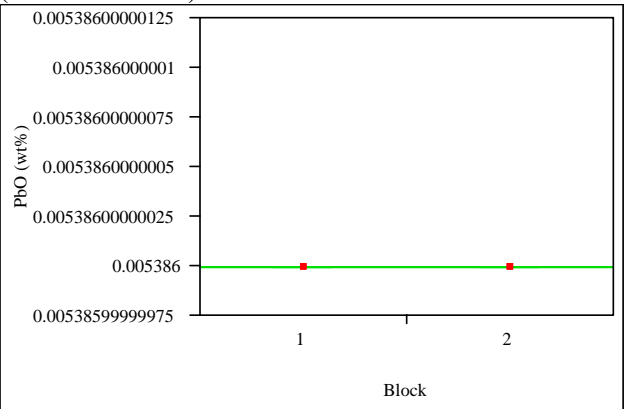

Oneway Anova

Summary of Fit

Rsquare

0
-0.25

Adj Rsquare

Root Mean Square Error $\quad 1.06 \mathrm{e}-18$

Mean of Response 0.005386

Observations (or Sum Wgts)

t Test

$1-2$

Assuming equal variances

$\begin{array}{lrlr}\text { Difference } & 0 & \text { t Ratio } & 0 \\ \text { Std Err Dif } & 8.674 \mathrm{e}-19 & \mathrm{DF} & 4 \\ \text { Upper CL Dif } & 2.408 \mathrm{e}-18 & \text { Prob }>|\mathrm{t}| & 1.0000\end{array}$

$\begin{array}{llll}\text { Upper CL Dif } & 2.408 \mathrm{e}-18 & \text { Prob }>|t| & 1.0000 \\ \text { Lower CL Dif } & -2.41 \mathrm{e}-18 & \text { Prob }>t & 0.5000\end{array}$

Confidence $\quad 0.95$ Prob $<\mathrm{t} \quad 0.5000$

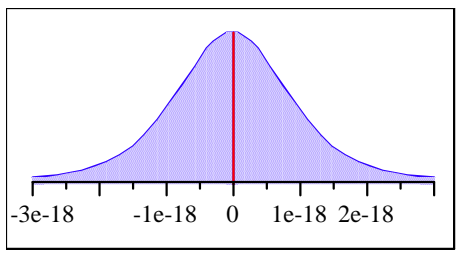

Analysis of Variance

Source DF Sum of Squares Mean Square F Ratio Prob $>$ F

$\begin{array}{lrrrrr}\text { Block } & 1 & 0 & 0 & 0.0000 & 1.0000\end{array}$

Error 4 4.5139e-36 1.128e-36

C. Total 5 4.5139e-36

Means for Oneway Anova

Level Number Mean Std Error Lower 95\% Upper 95\%

$\begin{array}{llllll}1 & 3 & 0.005386 & 6.133 \mathrm{e}-19 & 0.00539 & 0.00539\end{array}$

$\begin{array}{llllll}2 & 3 & 0.005386 & 6.133 \mathrm{e}-19 & 0.00539 & 0.00539\end{array}$

Std Error uses a pooled estimate of error variance 


\section{Exhibit C.3: SRNL-ML Measurements by Analytical Block for Samples of the Standard Glasses Prepared Using the LM Method}

Oneway Analysis of SO4 (wt\%) By Block

(Ref value: 0 wt \%)

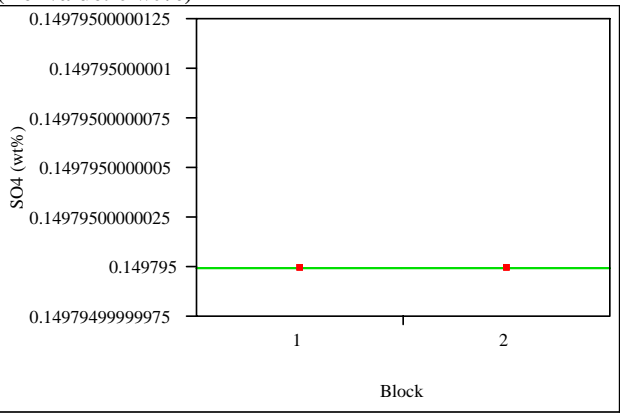

Oneway Anova

Summary of Fit

Rsquare

Adj Rsquare

Root Mean Square Erro

Mean of Response

Observations (or Sum Wgts)

t Test

1-2

Assuming equal variances

Difference

Std Err Dif

Upper CL Dif

$0 \mathrm{DF}$

0 Prob $>|\mathrm{t}| 1.000$

Lower CL Dif

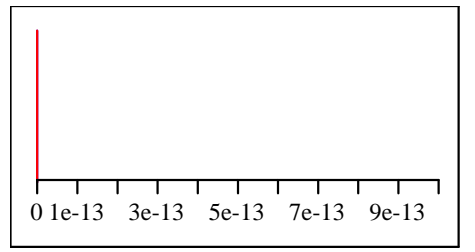

Analysis of Variance

Source DF Sum of Squares Mean Square F Ratio Prob $>$ F

$\begin{array}{ll}\text { Block } & 1 \\ \text { Error } & 4\end{array}$

C. Total 5

Means for Oneway Anova

Level Number Mean Std Error Lower 95\% Upper 95\%

$\begin{array}{llllll}1 & 3 & 0.149795 & 0 & 0.14979 & 0.14979\end{array}$

$\begin{array}{llllll}2 & 3 & 0.149795 & 0 & 0.14979 & 0.14979\end{array}$

Std Error uses a pooled estimate of error variance
Oneway Analysis of ThO2 (wt\%) By Block

(Ref value: 0 wt \%)

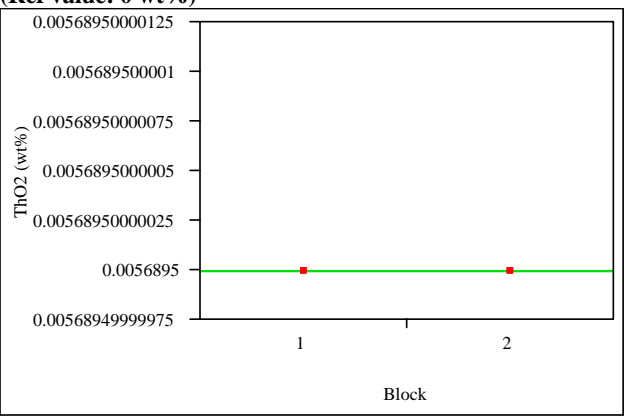

Oneway Anova

Summary of Fit

Rsquare

Adj Rsquare

Root Mean Square Error $\quad 0$

Mean of Response

Observations (or Sum Wgts) 6

t Test

1-2

Assuming equal variances

$\begin{array}{lrlr}\text { Difference } & 0 & \text { t Ratio } & \\ \text { Std Err Dif } & 0 & \text { DF } & 4 \\ \text { Upper CL Dif } & 0 & \text { Prob }>|t| & 1.0000 \\ \text { Lower CL Dif } & 0 & \text { Prob }>\text { t } & 0.5000 \\ \text { Confidence } & 0.95 & \text { Prob }<\mathrm{t} & 0.5000\end{array}$

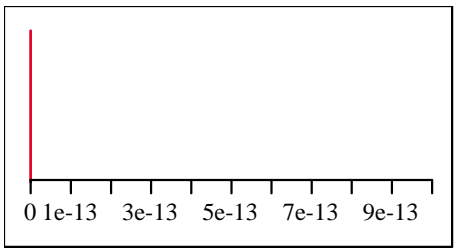

Analysis of Variance

Source DF Sum of Squares Mean Square F Ratio Prob $>$ F

$\begin{array}{ll}\text { Block } & 1 \\ \text { Error } & 4\end{array}$

C. Total 5

Means for Oneway Anova

Level Number Mean Std Error Lower 95\% Upper 95\%

$\begin{array}{llllll}1 & 3 & 0.005689 & 0 & 0.00569 & 0.00569\end{array}$

$\begin{array}{llllll}2 & 3 & 0.005689 & 0 & 0.00569 & 0.00569\end{array}$

Std Error uses a pooled estimate of error variance 


\section{Exhibit C.3: SRNL-ML Measurements by Analytical Block for Samples of the Standard Glasses Prepared Using the LM Method}

Oneway Analysis of TiO2 (wt\%) By Block (Ref value: $0.677 \mathrm{wt} \%$ )

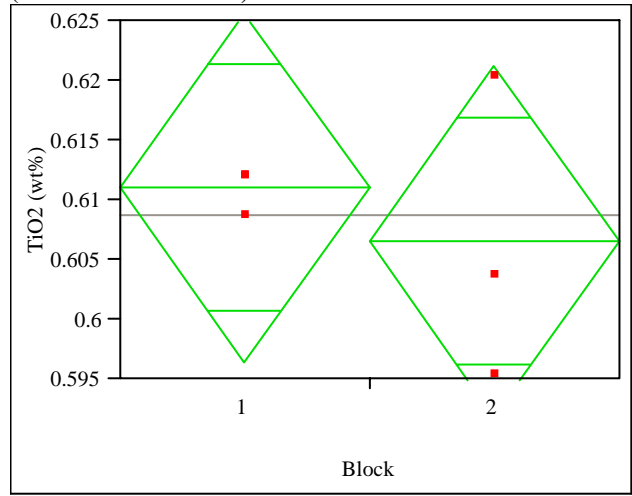

Oneway Anova

Summary of Fit

$\begin{array}{lr}\text { Rsquare } & 0.082051 \\ \text { Adj Rsquare } & -0.14744 \\ \text { Root Mean Square Error } & 0.009111 \\ \text { Mean of Response } & 0.60882 \\ \text { Observations (or Sum Wgts) } & 6 \\ \text { t Test } & \\ 1-2 & \\ \text { Assuming equal variances } & \end{array}$

$\begin{array}{lrlr}\text { Difference } & 0.00445 & \mathrm{t} \text { Ratio } & 0.597948 \\ \text { Std Err Dif } & 0.00744 & \text { DF } & 4 \\ \text { Upper CL Dif } & 0.02510 & \text { Prob }>|t| & 0.5821 \\ \text { Lower CL Dif } & -0.01621 & \text { Prob }>t & 0.2910 \\ \text { Confidence } & 0.95 & \text { Prob }<\mathrm{t} & 0.7090\end{array}$

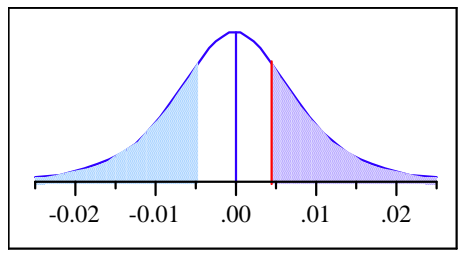

Analysis of Variance

Source DF Sum of Squares Mean Square F Ratio Prob > F

$\begin{array}{llllll}\text { Block } & 1 & 0.00002968 & 0.000030 & 0.3575 & 0.5821\end{array}$

$\begin{array}{llll}\text { Error } & 4 & 0.00033201 & 0.000083\end{array}$

C. Total $5 \quad 0.00036169$

Means for Oneway Anova

Level Number Mean Std Error Lower 95\% Upper 95\%

$\begin{array}{llllll}1 & 3 & 0.611044 & 0.00526 & 0.59644 & 0.62565\end{array}$

$2 \quad 3 \quad 0.606596 \quad 0.00526 \quad 0.59199 \quad 0.62120$

Std Error uses a pooled estimate of error variance
Oneway Analysis of $\mathrm{ZnO}(\mathrm{wt} \%)$ By Block

(Ref value: 0 wt \%)

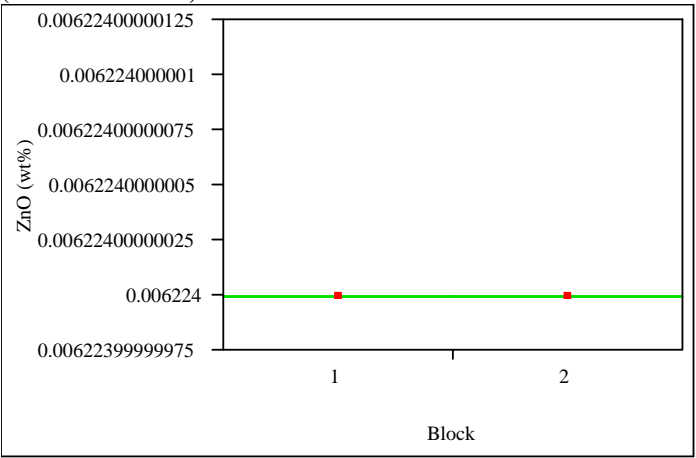

Oneway Anova

Summary of Fit

Rsquare

Adj Rsquare

Root Mean Square Error $\quad 0$

Mean of Response

Observations (or Sum Wgts) 6

t Test

1-2

Assuming equal variances

$\begin{array}{lrlr}\text { Difference } & 0 & \text { t Ratio } & \\ \text { Std Err Dif } & 0 & \text { DF } & 4 \\ \text { Upper CL Dif } & 0 & \text { Prob }>|t| & 1.0000 \\ \text { Lower CL Dif } & 0 & \text { Prob }>\text { t } & 0.5000 \\ \text { Confidence } & 0.95 & \text { Prob }<\mathrm{t} & 0.5000\end{array}$

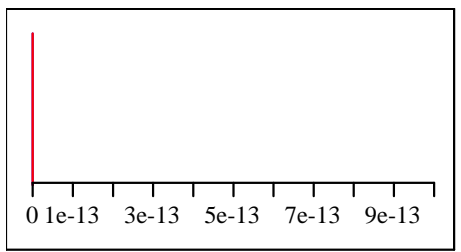

Analysis of Variance

Source DF Sum of Squares Mean Square F Ratio Prob $>$ F

$\begin{array}{lrrr}\text { Block } & 1 & 0 & 0 \\ \text { Error } & 4 & 0 & 0\end{array}$

C. Total 5

Means for Oneway Anova

Level Number Mean Std Error Lower 95\% Upper 95\%

$\begin{array}{llllll}1 & 3 & 0.006224 & 0 & 0.00622 & 0.00622\end{array}$

$\begin{array}{llllll}2 & 3 & 0.006224 & 0 & 0.00622 & 0.00622\end{array}$

Std Error uses a pooled estimate of error variance 


\section{Exhibit C.3: SRNL-ML Measurements by Analytical Block for Samples of the Standard Glasses Prepared Using the LM Method}

Oneway Analysis of ZrO2 (wt\%) By Block

(Ref value: 0.098 wt\%)

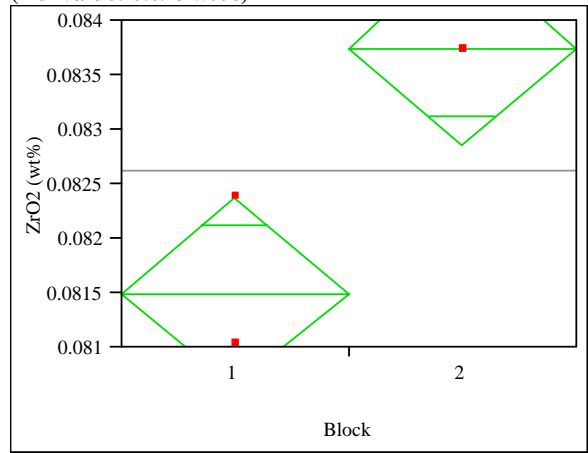

Oneway Anova

Summary of Fit

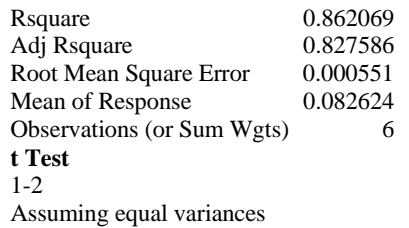

Assuming equal variances

Difference $\quad-0.00225$ t Ratio $\quad-5$

Std Err Dif $\quad 0.00045$ DF 4

Upper CL Dif -0.00100 Prob $>|t| 0.0075$

Lower CL Dif -0.00350 Prob $>$ t 0.9963

Confidence $\quad 0.95$ Prob $<\mathrm{t} \quad 0.0037$

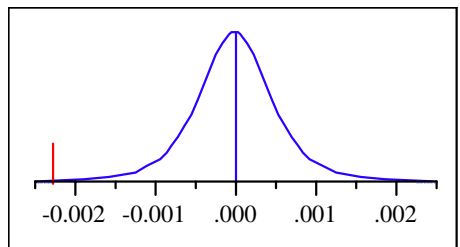

Analysis of Variance

Source DF Sum of Squares Mean Square F Ratio Prob $>$ F

$\begin{array}{lrrrrr}\text { Block } & 1 & 0.0000076 & 0.0000076 & 25.0000 & 0.0075\end{array}$

$\begin{array}{lll}\text { Error } \quad 4 \quad 0.00000122 & 3.0411 \mathrm{e}-7\end{array}$

C. Total $5 \quad 0.00000882$

Means for Oneway Anova

Level Number Mean Std Error Lower 95\% Upper 95\%

$\begin{array}{llllll}1 & 3 & 0.081498 & 0.00032 & 0.08061 & 0.08238\end{array}$

$\begin{array}{llllll}2 & 3 & 0.083750 & 0.00032 & 0.08287 & 0.08463\end{array}$

Std Error uses a pooled estimate of error variance

\section{Glass ID=Ustd}

Oneway Analysis of BaO (wt\%) By Block

(Ref value: 0 wt \%)

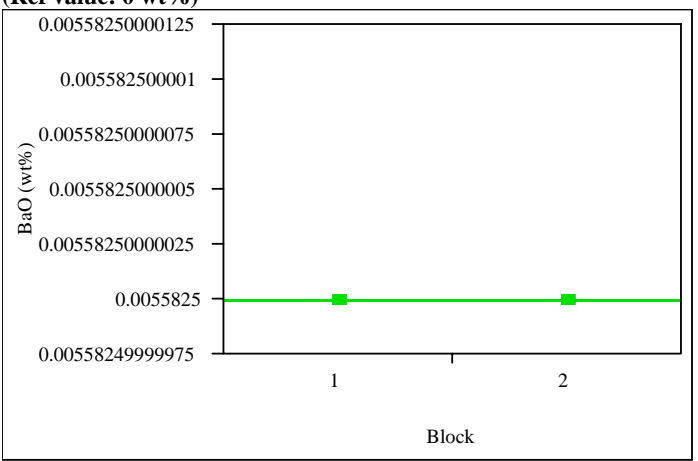

Oneway Anova

Summary of Fit

Rsquare

Adj Rsquare

Root Mean Square Error

Mean of Response

Observations (or Sum Wgts)

t Test

$1-2$

Assuming equal variances
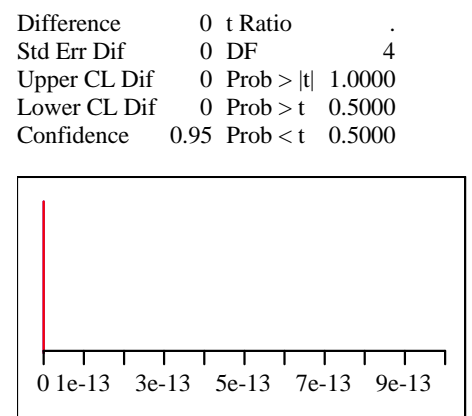

Analysis of Variance

Source DF Sum of Squares Mean Square F Ratio Prob > F

Block 1

Error 4

C. Total 5

Level Number Mean Std Error Lower 95\% Upper 95\%

$\begin{array}{llllll}1 & 3 & 0.005583 & 0 & 0.00558 & 0.00558\end{array}$

$\begin{array}{llllll}1 & 3 & 0.005583 & 0 & 0.00558 & 0.00558 \\ 2 & 3 & 0.005583 & 0 & 0.00558 & 0.00558\end{array}$

Std Error uses a pooled estimate of error variance 


\section{Exhibit C.3: SRNL-ML Measurements by Analytical Block for Samples of the Standard Glasses Prepared Using the LM Method}

Oneway Analysis of $\mathrm{CaO}(\mathrm{wt} \%)$ By Block (Ref value: $1.301 \mathrm{wt} \%$ )

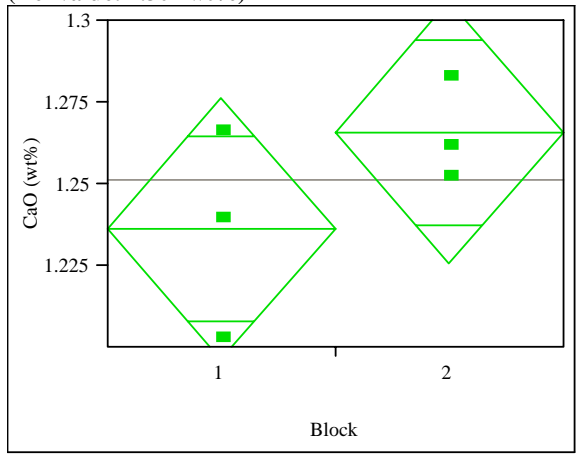

Oneway Anova

Summary of Fit

$\begin{array}{lr}\text { Rsquare } & 0.34189 \\ \text { Adj Rsquare } & 0.177362 \\ \text { Root Mean Square Error } & 0.024964 \\ \text { Mean of Response } & 1.251118 \\ \text { Observations (or Sum Wgts) } & 6 \\ \text { t Test } & \\ 1-2 & \\ \text { Assuming equal variances } & \end{array}$

Difference $\quad-0.02938$ t Ratio -1.44153

Std Err Dif $\quad 0.02038$ DF 4

Upper CL Dif 0.02721 Prob $>|t| 0.2229$

Lower CL Dif -0.08598 Prob $>\mathrm{t} \quad 0.8886$

Confidence

0.95 Prob $<\mathrm{t} \quad 0.1114$

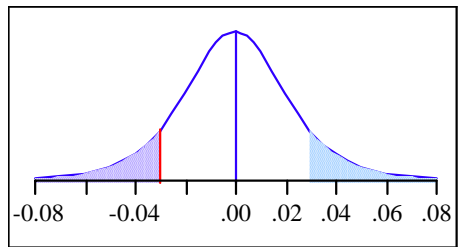

Analysis of Variance

Source DF Sum of Squares Mean Square F Ratio Prob $>$ F

$\begin{array}{llllll}\text { Block } & 1 & 0.00129506 & 0.001295 & 2.0780 & 0.2229\end{array}$

$\begin{array}{llll}\text { Error } & 4 & 0.00249288 & 0.000623\end{array}$

C. Total $5 \quad 0.00378794$

Means for Oneway Anova

Level Number Mean Std Error Lower 95\% Upper 95\%

$\begin{array}{lrrrrr}1 & 3 & 1.23643 & 0.01441 & 1.1964 & 1.2764\end{array}$

$\begin{array}{llllll}2 & 3 & 1.26581 & 0.01441 & 1.2258 & 1.3058\end{array}$

Std Error uses a pooled estimate of error variance
Oneway Analysis of Ce2O3 (wt\%) By Block

(Ref value: 0 wt\%)

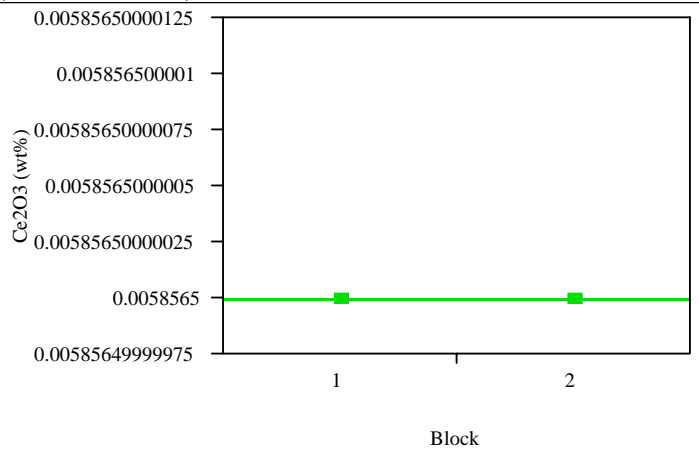

Oneway Anova

Summary of Fit

Rsquare

Adj Rsquare

Root Mean Square Error $\quad 0$

Mean of Response

Observations (or Sum Wgts) 6

t Test

Assuming equal variances
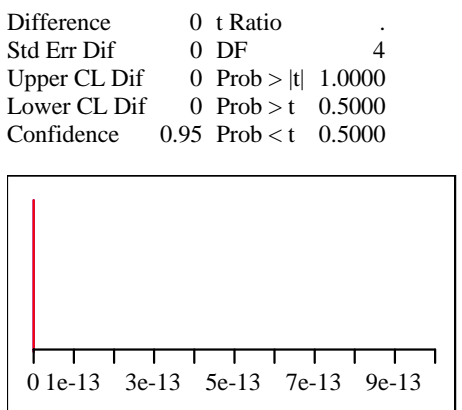

Analysis of Variance

Source DF Sum of Squares Mean Square F Ratio Prob $>$ F

Block 1

Error 4

C. Total 5

$\begin{array}{lll}0 & 0 \\ 0 & 0\end{array}$

(eans for Oneway Anova

Level Number Mean Std Error Lower 95\% Upper 95\%

$\begin{array}{llllll}1 & 3 & 0.005857 & 0 & 0.00586 & 0.00586\end{array}$

$\begin{array}{llllll}2 & 3 & 0.005857 & 0 & 0.00586 & 0.00586\end{array}$

Std Error uses a pooled estimate of error variance 


\section{Exhibit C.3: SRNL-ML Measurements by Analytical Block for Samples of the Standard Glasses Prepared Using the LM Method}

Oneway Analysis of Cr2O3 (wt\%) By Block

(Ref value: 0 wt \%)

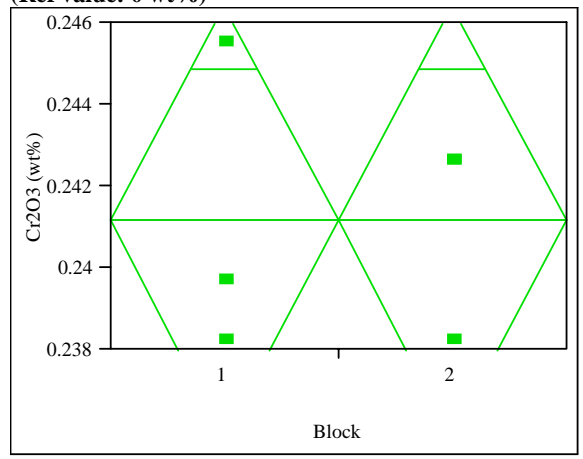

Oneway Anova

Summary of Fit

Rsquare

Adj Rsquare

$\begin{array}{ll}\text { Root Mean Square Error } & 0.003268 \\ \text { Mean of Response } & 0.241164\end{array}$

Observations (or Sum Wgts)

t Test

$1-2$

Assuming equal variances

$\begin{array}{lll}\text { Difference } & 0.00000 \text { t Ratio } & 0\end{array}$

Std Err Dif $\quad 0.00267$ DF

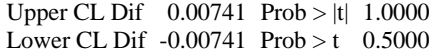

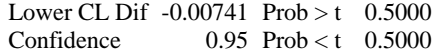

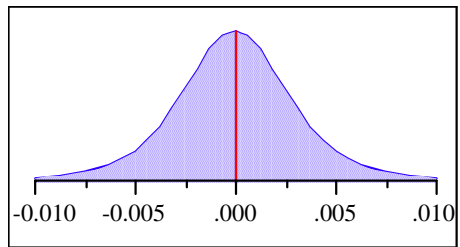

Analysis of Variance

Source DF Sum of Squares Mean Square F Ratio Prob > F

$\begin{array}{llllll}\text { Block } & 1 & 0.00000000 & 0.000000 & 0.0000 & 1.0000\end{array}$

$\begin{array}{llll}\text { Error } & 4 & 0.00004273 & 0.000011\end{array}$

C. Total $5 \quad 0.00004273$

Means for Oneway Anova

Level Number Mean Std Error Lower 95\% Upper 95\%

$\begin{array}{lllrrr}1 & 3 & 0.241164 & 0.00189 & 0.23593 & 0.24640\end{array}$

$\begin{array}{llll}3 & 0.241164 & 0.00189 & 0.23593\end{array}$

Std Error uses a pooled estimate of error variance
Oneway Analysis of $\mathrm{CuO}$ (wt\%) By Block

(Ref value: 0 wt \%)

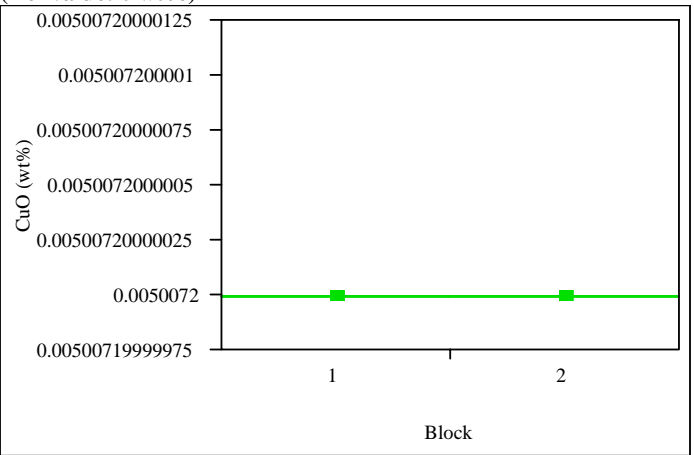

Oneway Anova

Summary of Fit

Rsquare

Adj Rsquare

Root Mean Square Error $\quad 0$

Mean of Respons

Observations (or Sum Wgts) 6

t Test

1-2

Assuming equal variances

$\begin{array}{lrlr}\text { Difference } & 0 & \text { t Ratio } & \\ \text { Std Err Dif } & 0 & \text { DF } & 4 \\ \text { Upper CL Dif } & 0 & \text { Prob }>|t| & 1.0000 \\ \text { Lower CL Dif } & 0 & \text { Prob }>\text { t } & 0.5000 \\ \text { Confidence } & 0.95 & \text { Prob }<\text { t } & 0.5000\end{array}$

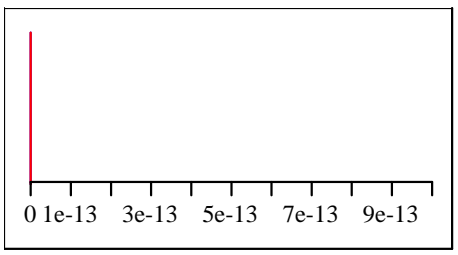

Analysis of Variance

Source DF Sum of Squares Mean Square F Ratio Prob $>$ F

Block 1

Error 4

C. Total 5

Means for Oneway Anova

Level Number Mean Std Error Lower 95\% Upper 95\%

$\begin{array}{llllll}1 & 3 & 0.005007 & 0 & 0.00501 & 0.00501\end{array}$

$\begin{array}{llllll}2 & 3 & 0.005007 & 0 & 0.00501 & 0.00501\end{array}$

Std Error uses a pooled estimate of error variance 


\section{Exhibit C.3: SRNL-ML Measurements by Analytical Block for Samples of the Standard Glasses Prepared Using the LM Method}

Oneway Analysis of K2O (wt\%) By Block (Ref value: $2.999 \mathrm{wt} \%$ )

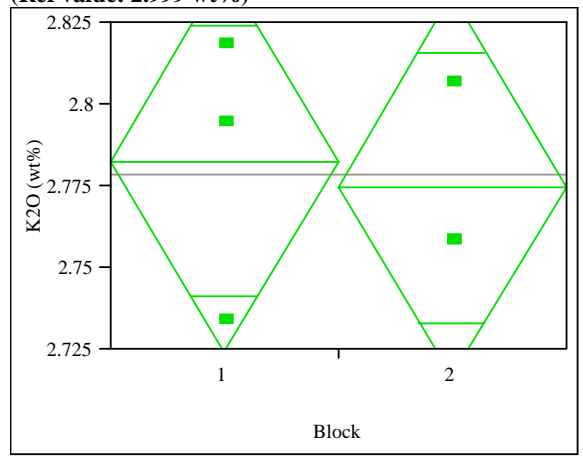

Oneway Anova

Summary of Fit

$\begin{array}{lr}\text { Rsquare } & 0.017857 \\ \text { Adj Rsquare } & -0.22768 \\ \text { Root Mean Square Error } & 0.036471 \\ \text { Mean of Response } & 2.778611 \\ \text { Observations (or Sum Wgts) } & 6 \\ \text { t Test } & \\ 1-2 & \\ \text { Assuming equal variances } & \end{array}$

Assuming equal variances

Difference $\quad 0.00803$ t Ratio 0.26968

Std Err Dif $\quad 0.02978$ DF 4

Upper CL Dif 0.09071 Prob $>|t| \quad 0.8007$

Lower CL Dif - 0.07465 Prob $>t \quad 0.4004$

$\begin{array}{lll}\text { Confidence } & 0.95 \text { Prob }<\mathrm{t} \quad 0.5996\end{array}$

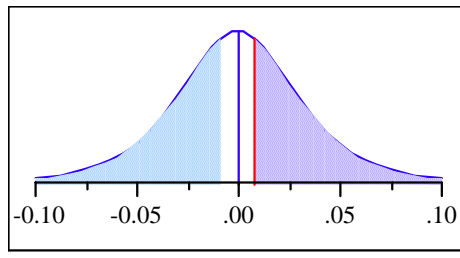

Analysis of Variance

Source DF Sum of Squares Mean Square F Ratio Prob $>$ F

$\begin{array}{llllll}\text { Block } & 1 & 0.00009674 & 0.000097 & 0.0727 & 0.8007\end{array}$

$\begin{array}{lll}\text { Error } & 4 & 0.00532056\end{array}$

C. Total $5 \quad 0.00541729$

Means for Oneway Anova

Level Number Mean Std Error Lower 95\% Upper 95\%

$\begin{array}{llllll}1 & 3 & 2.78263 & 0.02106 & 2.7242 & 2.8411\end{array}$

$\begin{array}{llllll}2 & 3 & 2.77460 & 0.02106 & 2.7161 & 2.8331\end{array}$

Std Error uses a pooled estimate of error variance
Oneway Analysis of La2O3 (wt\%) By Block

(Ref value: 0 wt\%)

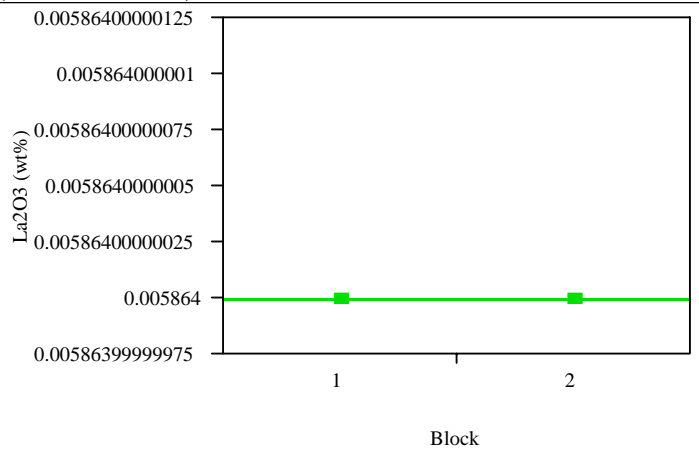

Oneway Anova

Summary of Fit

Rsquare

Adj Rsquare

Root Mean Square Error $\quad 0$

Mean of Response

Observations (or Sum Wgts) 6

t Test

$1-2$

Assuming equal variances
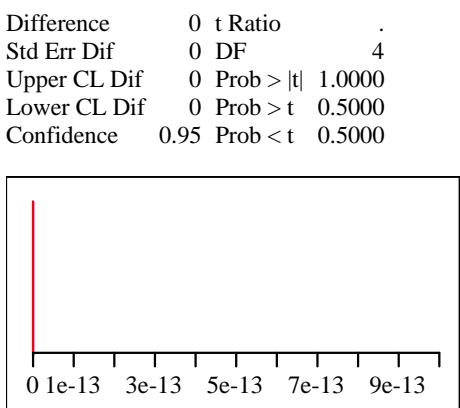

Analysis of Variance

Source DF Sum of Squares Mean Square F Ratio Prob $>$ F

Block 1

Error

4

C. Total 5

Means for Oneway Anova

Level Number Mean Std Error Lower 95\% Upper 95\%

$\begin{array}{lrrrrr}1 & 3 & 0.005864 & 0 & 0.00586 & 0.00586 \\ 2 & 3 & 0.005864 & 0 & 0.00586 & 0.00586\end{array}$

Std Error uses a pooled estimate of error variance 


\section{Exhibit C.3: SRNL-ML Measurements by Analytical Block for Samples of the Standard Glasses Prepared Using the LM Method}

Oneway Analysis of MgO (wt\%) By Block (Ref value: 1.21 wt\%)

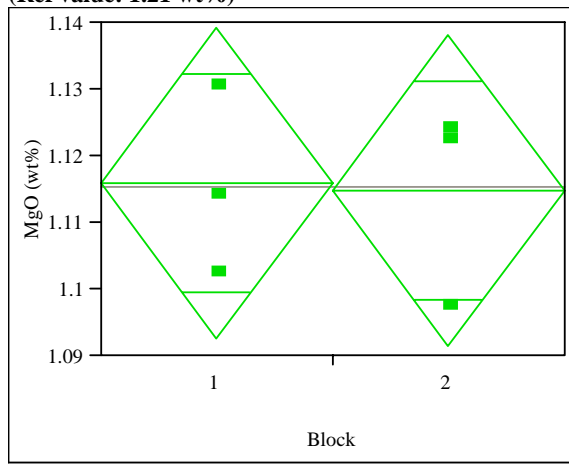

Oneway Anova

Summary of Fit

$$
\begin{array}{lr}
\text { Rsquare } & 0.002169 \\
\text { Adj Rsquare } & -0.24729 \\
\text { Root Mean Square Error } & 0.014518 \\
\text { Mean of Response } & 1.115349 \\
\text { Observations (or Sum Wgts) } & 6 \\
\text { t Test } & \\
1-2 & \\
\text { Assuming equal variances } &
\end{array}
$$

Difference $\quad 0.00111$ t Ratio 0.09325

Std Err Dif $\quad 0.01185$ DF 4

Upper CL Dif 0.03402 Prob $>|t| \quad 0.9302$

Lower CL Dif -0.03181 Prob $>$ t 0.4651

Confidence $\quad 0.95$ Prob $<\mathrm{t} \quad 0.5349$

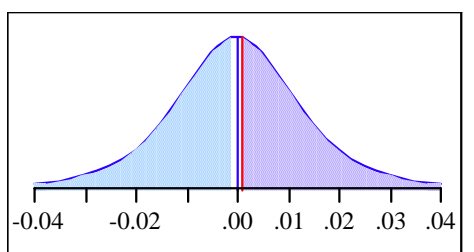

Analysis of Variance

Source DF Sum of Squares Mean Square F Ratio Prob > F

$\begin{array}{llllll}\text { Block } & 1 & 0.00000183 & 0.000002 & 0.0087 & 0.9302\end{array}$

$\begin{array}{llll}\text { Error } & 4 & 0.00084312 & 0.000211\end{array}$

C. Total $5 \quad 0.00084495$

Means for Oneway Anova

Level Number Mean Std Error Lower 95\% Upper 95\%

$\begin{array}{llrrrr}1 & 3 & 1.11590 & 0.00838 & 1.0926 & 1.1392\end{array}$

$\begin{array}{llllll}2 & 3 & 1.11480 & 0.00838 & 1.0915 & 1.1381\end{array}$

Std Error uses a pooled estimate of error variance
Oneway Analysis of Na2O (wt \%) By Block

(Ref value: $11.795 \mathrm{wt} \%$ )

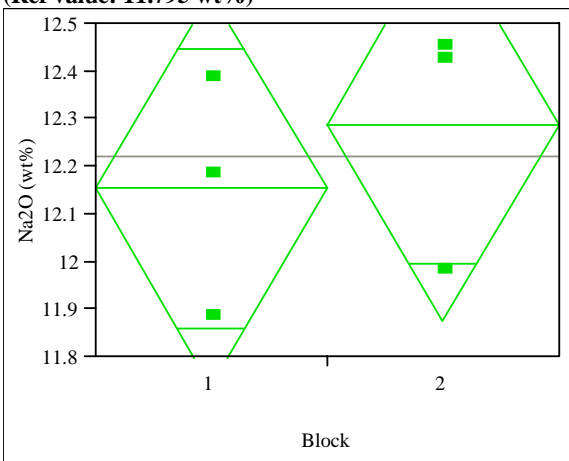

Oneway Anova

Summary of Fit

Rsquare

Adj Rsquare

0.09286

Root Mean Sq

$-0.13392$

Mean of Response

0.258005

Observations (or Sum Wgts) 6

t Test

$1-2$

Assuming equal variances

$\begin{array}{lrlr}\text { Difference } & -0.13480 & \text { t Ratio } & -0.63989 \\ \text { Std Err Dif } & 0.21066 \text { DF } & 4 \\ \text { Upper CL Dif } & 0.45009 \text { Prob }>|t| & 0.5571 \\ \text { Lower CL Dif } & -0.71969 \text { Prob }>t & 0.7215 \\ \text { Confidence } & 0.95 \text { Prob }<\mathrm{t} & 0.2785\end{array}$

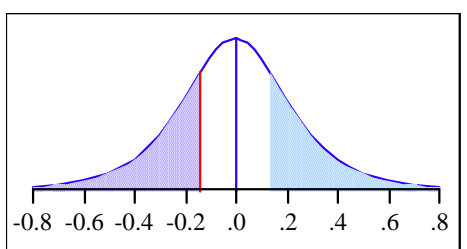

Analysis of Variance

Source DF Sum of Squares Mean Square F Ratio Prob $>$ F

$\begin{array}{llllll}\text { Block } & 1 & 0.02725656 & 0.027257 & 0.4095 & 0.5571\end{array}$

$\begin{array}{llll}\text { Error } & 4 & 0.26626631 & 0.066567\end{array}$

C. Total $5 \quad 0.29352287$

Means for Oneway Anova

Level Number Mean Std Error Lower 95\% Upper 95\%

$\begin{array}{lllllr}1 & 3 & 12.1545 & 0.14896 & 11.741 & 12.568\end{array}$

$\begin{array}{llllll}2 & 3 & 12.2893 & 0.14896 & 11.876 & 12.703\end{array}$

Std Error uses a pooled estimate of error variance 


\section{Exhibit C.3: SRNL-ML Measurements by Analytical Block for Samples of the Standard Glasses Prepared Using the LM Method}

Oneway Analysis of PbO (wt\%) By Block

(Ref value: 0 wt\%)

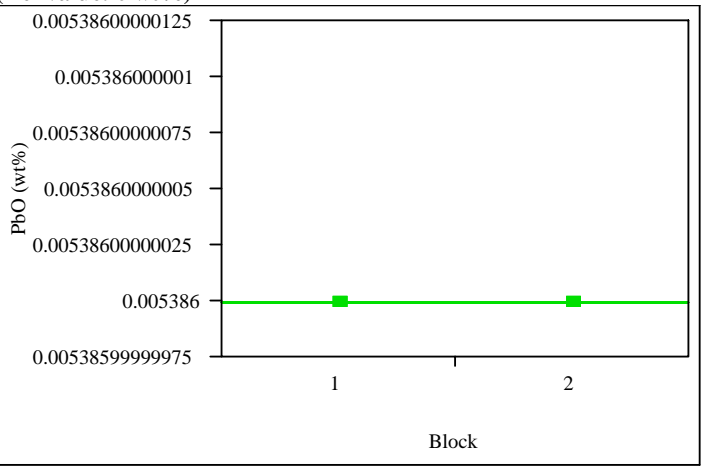

Oneway Anova

Summary of Fit

Rsquare

Adj Rsquare

Root Mean Square Error $\quad 1.06 \mathrm{e}-18$

Mean of Response $\quad 0.005386$

Observations (or Sum Wgts) 6

t Test

Assuming equal variances

Difference $\quad 0$ t Ratio 0

Std Err Dif $\quad 8.674$-19 DF 4

Upper CL Dif 2.408e-18 Prob $>|t| 1.0000$

Lower CL Dif $-2.41 \mathrm{e}-18$ Prob $>\mathrm{t} \quad 0.5000$

Confidence $\quad 0.95$ Prob $<\mathrm{t} \quad 0.5000$

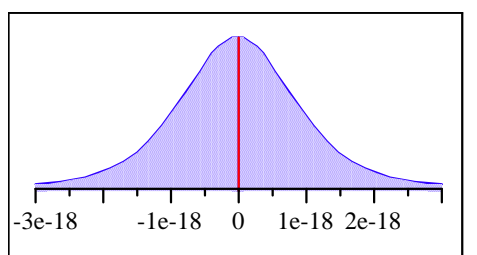

Analysis of Variance

Source DF Sum of Squares Mean Square F Ratio Prob $>$ F

$\begin{array}{llllll}\text { Block } & 1 & 0 & 0 & 0.0000 & 1.0000\end{array}$

Error $\quad 4 \quad 4.5139 \mathrm{e}-36 \quad 1.128 \mathrm{e}-36$

C. Total 5 4.5139e-36

Means for Oneway Anova

Level Number Mean Std Error Lower 95\% Upper 95\%

$\begin{array}{llllrr}1 & 3 & 0.005386 & 6.133 \mathrm{e}-19 & 0.00539 & 0.00539\end{array}$

$\begin{array}{llllll}2 & 3 & 0.005386 & 6.133 \mathrm{e}-19 & 0.00539 & 0.00539\end{array}$

Std Error uses a pooled estimate of error variance
Oneway Analysis of SO4 (wt \%) By Block

(Ref value: 0 wt \%)

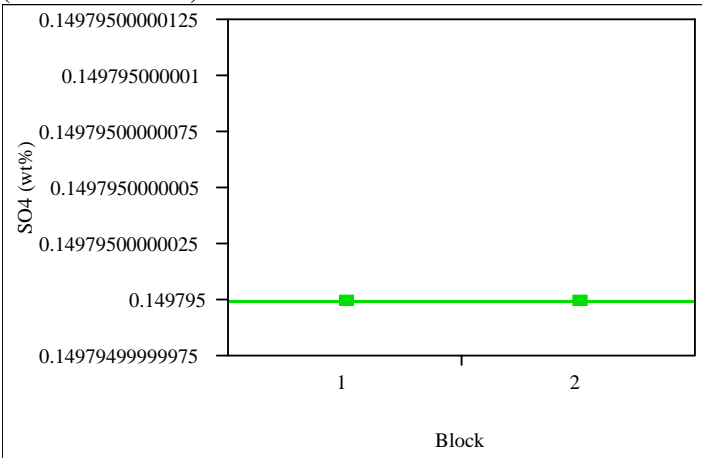

Oneway Anova

Summary of Fit

Rsquare

Adj Rsquare

Root Mean Square Error $\quad 0$

Mean of Response

Observations (or Sum Wgts) 6

t Test

$1-2$

Assuming equal variances

$\begin{array}{lrlr}\text { Difference } & 0 & \text { t Ratio } & . \\ \text { Std Err Dif } & 0 & \text { DF } & 4 \\ \text { Upper CL Dif } & 0 & \text { Prob }>|t| & 1.0000 \\ \text { Lower CL Dif } & 0 & \text { Prob }>\text { t } & 0.5000 \\ \text { Confidence } & 0.95 & \text { Prob }<\mathrm{t} & 0.5000\end{array}$

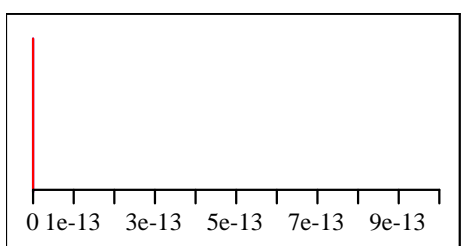

Analysis of Variance

Source DF Sum of Squares Mean Square F Ratio Prob $>$ F

Block 1

Error

4

C. Total 5

Means for Oneway Anova

Level Number Mean Std Error Lower 95\% Upper 95\%

$\begin{array}{lrrrrr}1 & 3 & 0.149795 & 0 & 0.14979 & 0.14979\end{array}$

$\begin{array}{llllll}1 & 3 & 0.149795 & 0 & 0.14979 & 0.14979\end{array}$

Std Error uses a pooled estimate of error variance 


\section{Exhibit C.3: SRNL-ML Measurements by Analytical Block for Samples of the Standard Glasses Prepared Using the LM Method}

Oneway Analysis of ThO2 (wt\%) By Block (Ref value: 0 wt\%)

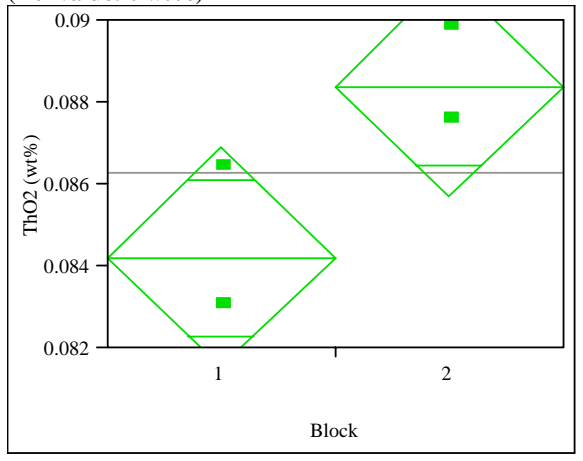

Oneway Anova

Summary of Fit

$\begin{array}{lr}\text { Rsquare } & 0.699422 \\ \text { Adj Rsquare } & 0.624277 \\ \text { Root Mean Square Error } & 0.001675 \\ \text { Mean of Response } & 0.086291 \\ \text { Observations (or Sum Wgts) } & 6 \\ \text { t Test } & \\ 1-2 & \\ \text { Assuming equal variances } & \end{array}$

$\begin{array}{lrlr}\text { Difference } & -0.00417 & \mathrm{t} \text { Ratio } & -3.05085 \\ \text { Std Err Dif } & 0.00137 & \text { DF } & 4 \\ \text { Upper CL Dif } & -0.00038 & \text { Prob }>|t| & 0.0380 \\ \text { Lower CL Dif } & -0.00797 & \text { Prob }>t & 0.9810 \\ \text { Confidence } & 0.95 & \text { Prob }<\mathrm{t} & 0.0190\end{array}$

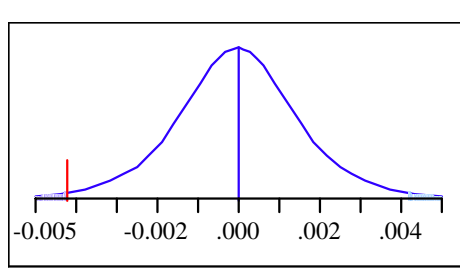

Analysis of Variance

Source DF Sum of Squares Mean Square F Ratio Prob > F

$\begin{array}{llllll}\text { Block } & 1 & 0.00002611 & 0.000026 & 9.3077 & 0.0380\end{array}$

$\begin{array}{llll}\text { Error } \quad 4 & 0.00001122 & 0.000003\end{array}$

C. Total $5 \quad 0.00003733$

Means for Oneway Anova

Level Number Mean Std Error Lower 95\% Upper 95\%

$\begin{array}{llllll}1 & 3 & 0.084205 & 0.00097 & 0.08152 & 0.08689\end{array}$

$\begin{array}{llllll}2 & 3 & 0.088377 & 0.00097 & 0.08569 & 0.09106\end{array}$

Std Error uses a pooled estimate of error variance
Oneway Analysis of TiO2 (wt\%) By Block (Ref value: 1.049 wt \%)

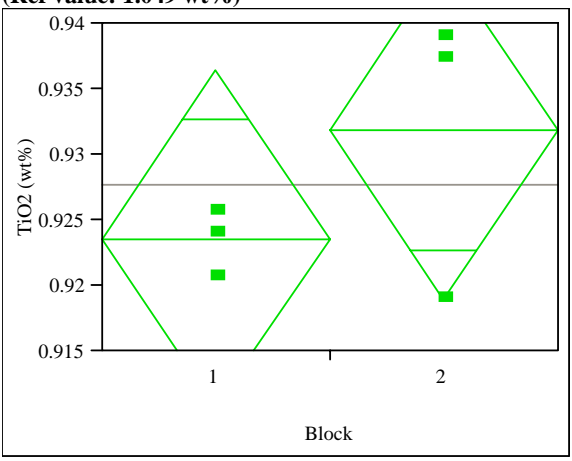

Oneway Anova

Summary of Fit

Rsquare

0.286624

Adj Rsquare

0.10828

Root Mean Square Error $\quad 0.008057$

Mean of Response 0.927686

Observations (or Sum Wgts)

t Test

1-2

Assuming equal variances

Difference $\quad-0.00834$ t Ratio $\quad-1.26773$

Std Err Dif $\quad 0.00658$ DF 4

Upper CL Dif 0.00993 Prob $>|\mathrm{t}| \quad 0.2737$

Lower CL Dif -0.02661 Prob $>\mathrm{t} \quad 0.8632$

$\begin{array}{lll}\text { Confidence } & 0.95 \text { Prob }<\mathrm{t} \quad 0.1368\end{array}$

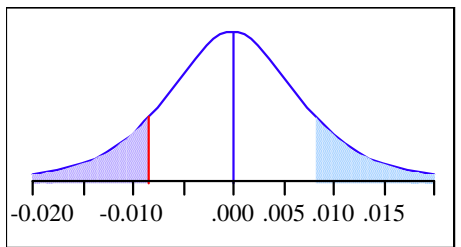

Analysis of Variance

Source DF Sum of Squares Mean Square F Ratio Prob $>$ F

$\begin{array}{llllll}\text { Block } & 1 & 0.00010433 & 0.000104 & 1.6071 & 0.2737\end{array}$

$\begin{array}{llll}\text { Error } & 4 & 0.00025967 & 0.000065\end{array}$

C. Total $5 \quad 0.00036401$

Means for Oneway Anova

Level Number Mean Std Error Lower 95\% Upper 95\%

$\begin{array}{llllll}1 & 3 & 0.923516 & 0.00465 & 0.91060 & 0.93643\end{array}$

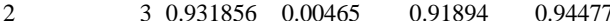

Std Error uses a pooled estimate of error variance 


\section{Exhibit C.3: SRNL-ML Measurements by Analytical Block for Samples of the Standard Glasses Prepared Using the LM Method}

Oneway Analysis of $\mathrm{ZnO}$ (wt\%) By Block

(Ref value: 0 wt \%)

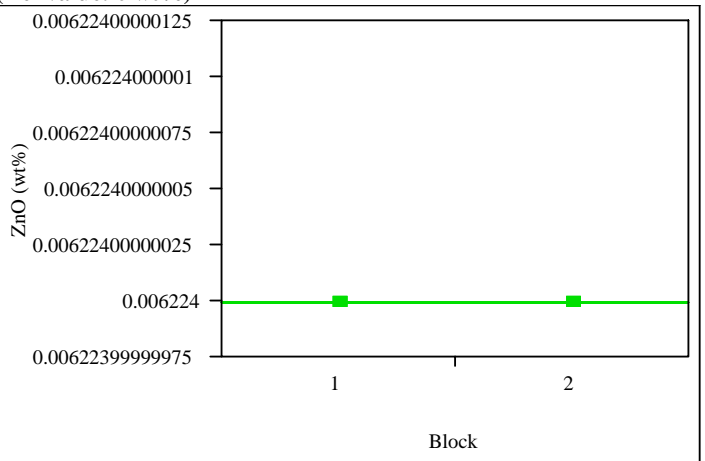

Oneway Anova

Summary of Fit

Rsquare

Adj Rsquare

Root Mean Square Error $\quad 0$

Mean of Response $\quad 0.006224$

Observations (or Sum Wgts) 6

t Test

Assuming equal variances

\section{Difference \\ Std Err Dif \\ Upper CL Dif \\ Lower CL D \\ t Ratio \\ $0 \mathrm{DF}$ \\ 0 Prob $>|t| 1.0000$ \\ 0 Prob $>\mathrm{t} \quad 0.5000$ \\ Confidence $\quad 0.95$ Prob $<\mathrm{t} \quad 0.5000$}

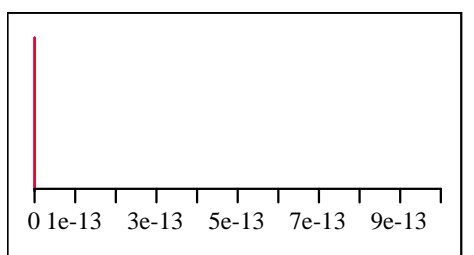

Analysis of Variance

Source DF Sum of Squares Mean Square F Ratio Prob > F

Block 1

Error

4

0

C. Total 5

Means for Oneway Anova

Level Number Mean Std Error Lower 95\% Upper 95\%

$\begin{array}{lrrrrr}1 & 3 & 0.006224 & 0 & 0.00622 & 0.00622\end{array}$

$\begin{array}{llllll}1 & 3 & 0.006224 & 0 & 0.00622 & 0.00622 \\ 2 & & 0 & 0.00622 & 0.00622\end{array}$

Std Error uses a pooled estimate of error variance
Oneway Analysis of ZrO2 (wt \%) By Block

(Ref value: 0 wt \%)

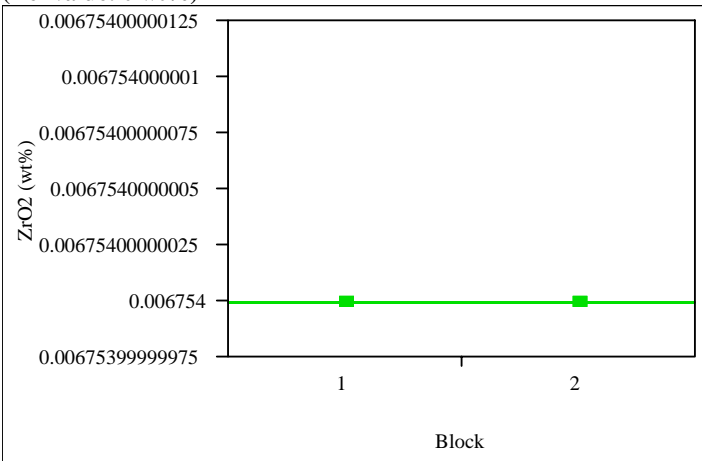

Oneway Anova

Summary of Fit

Rsquare

Adj Rsquare

Root Mean Square Error $\quad 0$

Mean of Response

Observations (or Sum Wgts) 6

t Test

Assuming equal variances

$\begin{array}{lrlr}\text { Difference } & 0 & \text { t Ratio } & . \\ \text { Std Err Dif } & 0 & \text { DF } & 4 \\ \text { Upper CL Dif } & 0 & \text { Prob }>|t| & 1.0000 \\ \text { Lower CL Dif } & 0 & \text { Prob }>\text { t } & 0.5000 \\ \text { Confidence } & 0.95 & \text { Prob }<\mathrm{t} & 0.5000\end{array}$

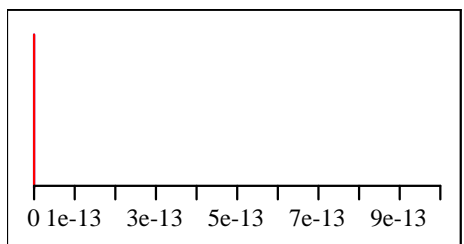

Analysis of Variance

Source DF Sum of Squares Mean Square F Ratio Prob $>$ F

Block 1

Error

4

C. Total 5

Means for Oneway Anova

Level Number Mean Std Error Lower 95\% Upper 95\%

$\begin{array}{lrrrrr}1 & 3 & 0.006754 & 0 & 0.00675 & 0.00675\end{array}$

$\begin{array}{llllll}1 & 3 & 0.006754 & 0 & 0.00675 & 0.00675\end{array}$

Std Error uses a pooled estimate of error variance 


\section{Exhibit C.4: SRNL-ML Measurements by Analytical Block for Samples of the Standard Glasses Prepared Using the PF Method}

Glass ID=Batch 1

Oneway Analysis of Al2O3 (wt\%) By Block

(Ref value: 4.877 wt\%)

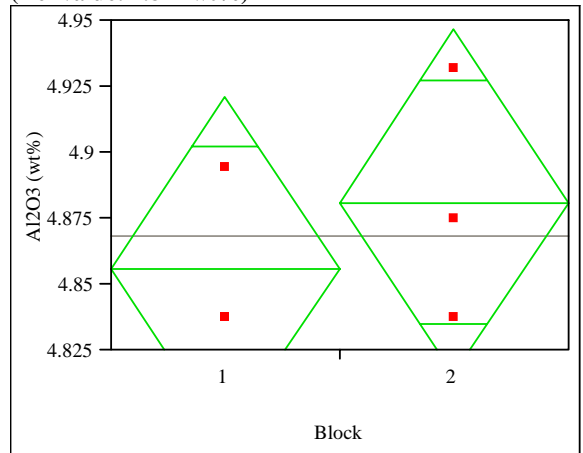

Oneway Anova

Summary of Fit

\section{Rsquare $\quad 0.125$ \\ Adj Rsquare $\quad-0.09375$ \\ Root Mean Square Error $\quad 0.040818$ \\ Mean of Response 4.868612 \\ Observations (or Sum Wgts) \\ t Test \\ $1-2$ \\ Assuming equal variances}
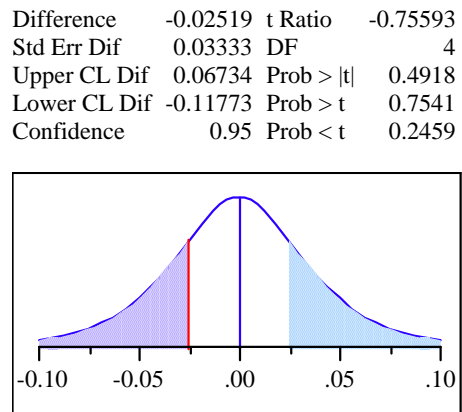

Analysis of Variance

Source DF Sum of Squares Mean Square F Ratio Prob $>$ F

$\begin{array}{llllll}\text { Block } & 1 & 0.00095206 & 0.000952 & 0.5714 & 0.4918\end{array}$

$\begin{array}{llll}\text { Error } & 4 & 0.00666439 & 0.001666\end{array}$

C. Total $5 \quad 0.00761645$

Means for Oneway Anova

Level Number Mean Std Error Lower 95\% Upper 95\%

$\begin{array}{lllllr}1 & 3 & 4.85601 & 0.02357 & 4.7906 & 4.9214\end{array}$

$\begin{array}{llllll}1 & 3 & 4.88121 & 0.02357 & 4.8158 & 4.9466\end{array}$

Std Error uses a pooled estimate of error variance
Oneway Analysis of B2O3 (wt\%) By Block

(Ref value: 7.777 wt \%)

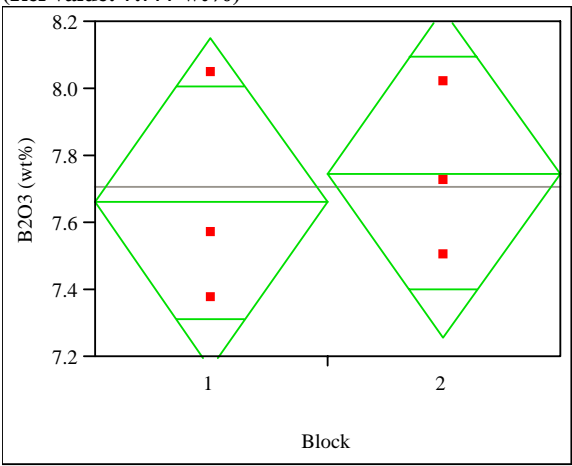

Oneway Anova

Summary of Fit

$\begin{array}{lr}\text { Rsquare } & 0.028571 \\ \text { Adj Rsquare } & -0.21429 \\ \text { Root Mean Square Error } & 0.306596 \\ \text { Mean of Response } & 7.706294 \\ \text { Observations (or Sum Wgts) } & 6 \\ \text { t Test } & \\ 1-2 & \\ \text { Assuming equal variances } & \end{array}$

Difference $\quad-0.08586$ t Ratio $\quad-0.343$

Std Err Dif 0.25033 DF 4

Upper CL Dif 0.60918 Prob $>|\mathrm{t}| 0.7489$

Lower CL Dif -0.78090 Prob $>t \quad 0.6256$

$\begin{array}{llll}\text { Confidence } & 0.95 \text { Prob }<\mathrm{t} & 0.3744\end{array}$

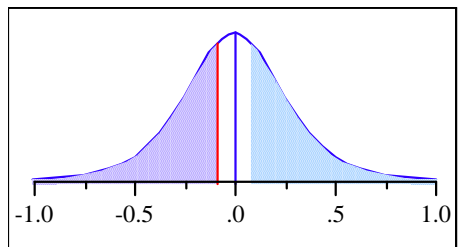

Analysis of Variance

Source DF Sum of Squares Mean Square F Ratio Prob $>$ F

$\begin{array}{llllll}\text { Block } & 1 & 0.01105894 & 0.011059 & 0.1176 & 0.7489\end{array}$

$\begin{array}{llll}\text { Error } & 4 & 0.37600395 & 0.094001\end{array}$

C. Total $5 \quad 0.38706289$

Means for Oneway Anova

Level Number Mean Std Error Lower 95\% Upper 95\%

$\begin{array}{lrrrrr}1 & 3 & 7.66336 & 0.17701 & 7.1719 & 8.1548 \\ 2 & 3 & 7.74923 & 0.17701 & 7.2578 & 8.2407\end{array}$

Std Error uses a pooled estimate of error variance 


\section{Exhibit C.4: SRNL-ML Measurements by Analytical Block for Samples of the Standard Glasses Prepared Using the PF Method}

Oneway Analysis of Fe2O3 (wt\%) By Block (Ref value: 12.839 wt \%)

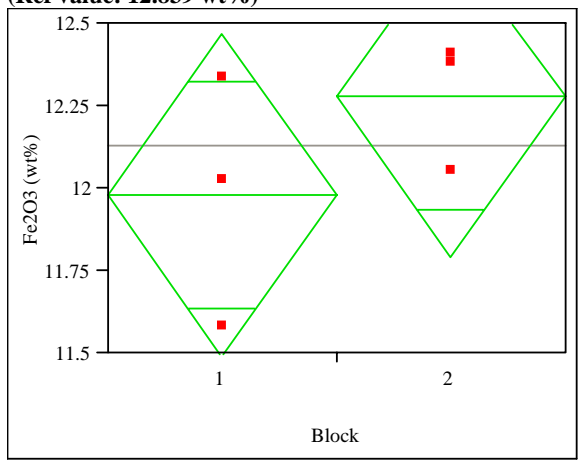

Oneway Anova

Summary of Fit

Rsquare 0.268303

Adj Rsquare

0.085378

Root Mean Square Error $\quad 0.303622$

Mean of Response

12.131

Observations (or Sum Wgts)

t Test

1-2

Assuming equal variances

Difference $\quad-0.30024$ t Ratio $\quad-1.21109$

Std Err Dif $\quad 0.24791$ DF

Upper CL Dif 0.38806 Prob $>|t| \quad 0.2925$

Lower CL Dif -0.98854 Prob $>\mathrm{t} \quad 0.8537$

Confidence

0.95 Prob $<\mathrm{t} \quad 0.1463$

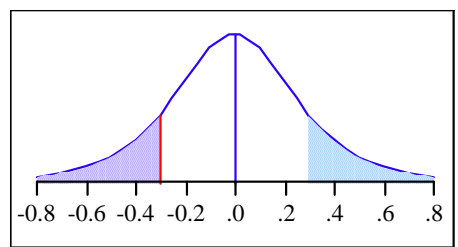

Analysis of Variance

Source DF Sum of Squares Mean Square F Ratio Prob $>$ F

$\begin{array}{llllll}\text { Block } & 1 & 0.13521338 & 0.135213 & 1.4667 & 0.2925\end{array}$

$\begin{array}{llll}\text { Error } & 4 & 0.36874519 & 0.092186\end{array}$

C. Total $5 \quad 0.50395858$

Means for Oneway Anova

Level Number Mean Std Error Lower 95\% Upper 95\%

$\begin{array}{lllrrr}1 & 3 & 11.9809 & 0.17530 & 11.494 & 12.468\end{array}$

$\begin{array}{llllll}2 & 3 & 12.2811 & 0.17530 & 11.794 & 12.768\end{array}$

Std Error uses a pooled estimate of error variance
Oneway Analysis of Li2O (wt\%) By Block (Ref value: $4.429 \mathrm{wt} \%$ )

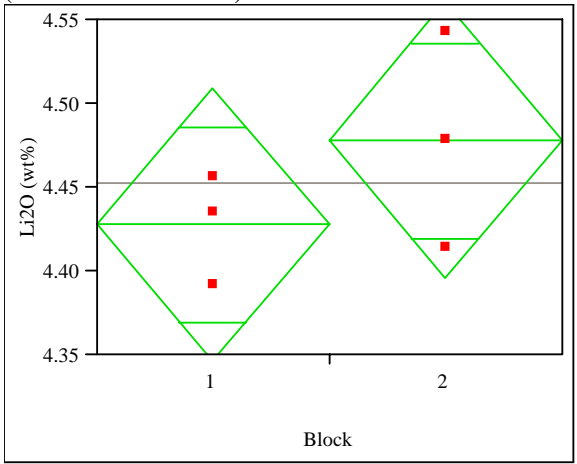

Oneway Anova

Summary of Fit

Rsquare

Adj Rsquare

0.264865

Root Mean Square

Mean of Response

$\quad 4.452915$

Observations (or Sum Wgts) 6

t Test

Assuming equal variances

$\begin{array}{lrlr}\text { Difference } & -0.05023 & \text { t Ratio } & -1.20049 \\ \text { Std Err Dif } & 0.04184 \text { DF } & 4 \\ \text { Upper CL Dif } & 0.06595 \text { Prob }>|t| & 0.2962 \\ \text { Lower CL Dif } & -0.16641 \text { Prob }>t & 0.8519 \\ \text { Confidence } & 0.95 \text { Prob }<\mathrm{t} & 0.1481\end{array}$

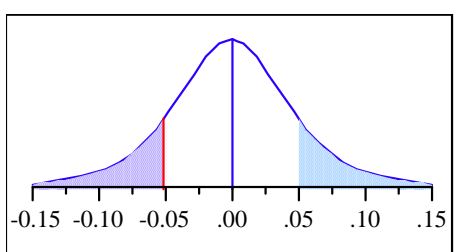

Analysis of Variance

Source DF Sum of Squares Mean Square F Ratio Prob > F

$\begin{array}{llllll}\text { Block } & 1 & 0.00378523 & 0.003785 & 1.4412 & 0.2962\end{array}$

$\begin{array}{llll}\text { Error } & 4 & 0.01050595 & 0.002626\end{array}$

C. Total $5 \quad 0.01429118$

Means for Oneway Anova

Level Number Mean Std Error Lower 95\% Upper 95\%

$\begin{array}{llllll}1 & 3 & 4.42780 & 0.02959 & 4.3456 & 4.5099\end{array}$

$\begin{array}{llllll}2 & 3 & 4.47803 & 0.02959 & 4.3959 & 4.5602\end{array}$

Std Error uses a pooled estimate of error variance 


\section{Exhibit C.4: SRNL-ML Measurements by Analytical Block for Samples of the Standard Glasses Prepared Using the PF Method}

Oneway Analysis of MnO (wt\%) By Block (Ref value: 1.726 wt \%)

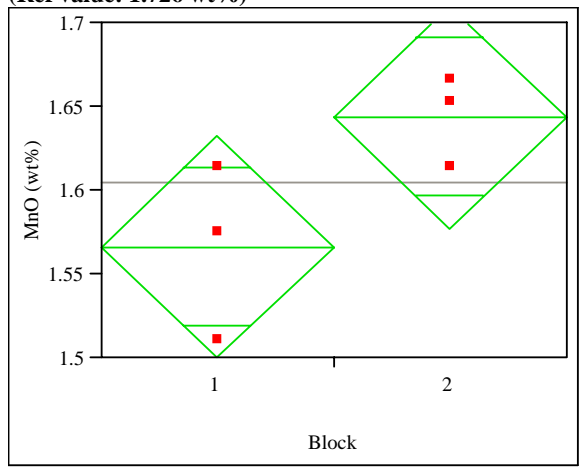

Oneway Anova

Summary of Fit

$\begin{array}{lr}\text { Rsquare } & 0.566434 \\ \text { Adj Rsquare } & 0.458042 \\ \text { Root Mean Square Error } & 0.041506 \\ \text { Mean of Response } & 1.605392 \\ \text { Observations (or Sum Wgts) } & 6 \\ \text { t Test } & \\ 1-2 & \\ \text { Assuming equal variances } & \end{array}$

Assuming equal variances

Difference $\quad-0.07747$ t Ratio $\quad-2.286$ Std Err Dif $\quad 0.03389$ D $0.03389 \mathrm{DF} \quad 4$ Upper CL Dif 0.01662 Prob $>|t| 0.0842$ Lower CL Dif -0.17156 Prob $>$ t 0.9579

Confidence $\quad 0.95$ Prob $<\mathrm{t} \quad 0.0421$

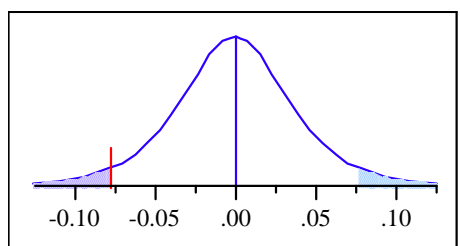

Analysis of Variance

Source DF Sum of Squares Mean Square F Ratio Prob > F

$\begin{array}{llllll}\text { Block } & 1 & 0.00900287 & 0.009003 & 5.2258 & 0.0842\end{array}$

$\begin{array}{llll}\text { Error } & 4 & 0.00689108 & 0.001723\end{array}$

C. Total $5 \quad 0.01589395$

Means for Oneway Anova

Level Number Mean Std Error Lower 95\% Upper 95\%

$\begin{array}{llllll}1 & 3 & 1.56666 & 0.02396 & 1.5001 & 1.6332\end{array}$

$\begin{array}{llllll}2 & 3 & 1.64413 & 0.02396 & 1.5776 & 1.7107\end{array}$

Std Error uses a pooled estimate of error variance
Oneway Analysis of $\mathrm{NiO}$ (wt \%) By Block

(Ref value: 0.751 wt \%)

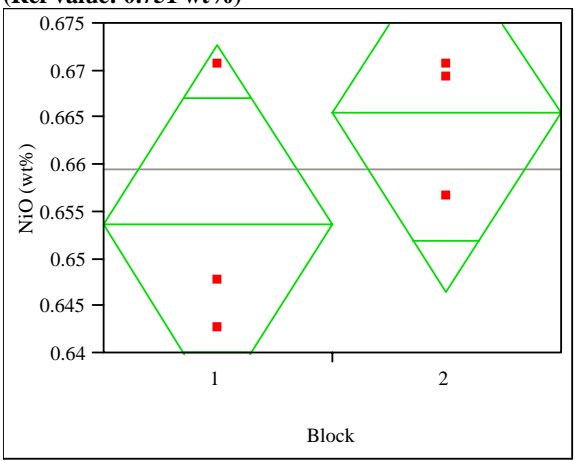

Oneway Anova

Summary of Fit

Rsquare

0.272601

Adj Rsquare

0.090751

Root Mean Square Error $\quad 0.01188$

Mean of Response

Observations (or Sum Wgts)

t Test

1-2

Assuming equal variances

Std Err Dif $\quad 0.00970$ DF $\quad-1.22435$

Upper CL Dif 0.01506 Prob $>|t| \quad 0.2880$

Lower CL Dif -0.03881 Prob $>t \quad 0.8560$

Confidence $\quad 0.95$ Prob $<\mathrm{t} \quad 0.1440$

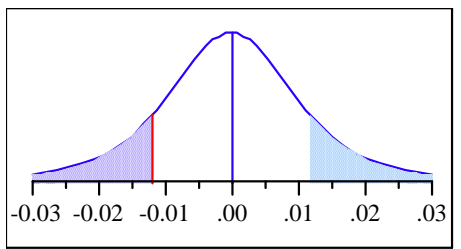

Analysis of Variance

Source DF Sum of Squares Mean Square F Ratio Prob $>$ F

$\begin{array}{llllll}\text { Block } & 1 & 0.00021158 & 0.000212 & 1.4990 & 0.2880\end{array}$

$\begin{array}{llll}\text { Error } & 4 & 0.00056458 & 0.000141\end{array}$

C. Total $5 \quad 0.00077616$

Means for Oneway Anova

Level Number Mean Std Error Lower 95\% Upper 95\%

$\begin{array}{llllll}1 & 3 & 0.653641 & 0.00686 & 0.63460 & 0.67268\end{array}$

$\begin{array}{llllll}2 & 3 & 0.665517 & 0.00686 & 0.64647 & 0.68456\end{array}$

Std Error uses a pooled estimate of error variance 


\section{Exhibit C.4: SRNL-ML Measurements by Analytical Block for Samples of the Standard Glasses Prepared Using the PF Method}

Oneway Analysis of SiO2 (wt\%) By Block (Ref value: $\mathbf{5 0 . 2 2}$ wt\%)

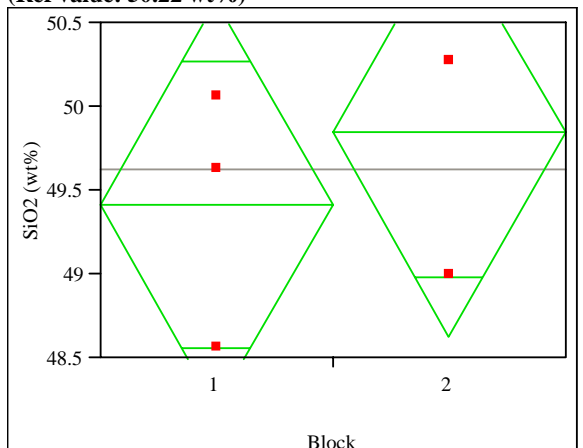

Oneway Anova

Summary of Fit

Rsquare $\quad 0.10714$

Adj Rsquare $\quad-0.11607$

Root Mean Square Error $\quad 0.756357$

Mean of Response 49.63176

Observations (or Sum Wgts) 6

t Test

$1-2$

Assuming equal variances

Difference $\quad-0.4279$ t Ratio $\quad-0.69282$

Std Err Dif $\quad 0.6176$ DF 4

Upper CL Dif 1.2868 Prob $>|t| \quad 0.5265$

Lower CL Dif -2.1425 Prob $>\mathrm{t} \quad 0.7367$

Confidence $\quad 0.95$ Prob $<\mathrm{t} \quad 0.2633$

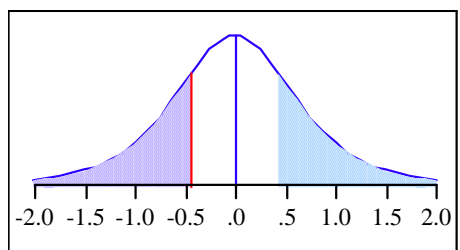

Analysis of Variance

Source DF Sum of Squares Mean Square F Ratio Prob $>$ F

$\begin{array}{llllll}\text { Block } & 1 & 0.2745963 & 0.274596 & 0.4800 & 0.5265\end{array}$

$\begin{array}{llll}\text { Error } & 4 & 2.2883022 & 0.572076\end{array}$

C. Total $5 \quad 2.5628985$

Means for Oneway Anova

Level Number Mean Std Error Lower 95\% Upper 95\%

$\begin{array}{llrrrr}1 & 3 & 49.4178 & 0.43668 & 48.205 & 50.630\end{array}$

$\begin{array}{llllll}2 & 3 & 49.8457 & 0.43668 & 48.633 & 51.058\end{array}$

Std Error uses a pooled estimate of error variance
Oneway Analysis of U3O8 (wt\%) By Block

(Ref value: 0 wt \%)

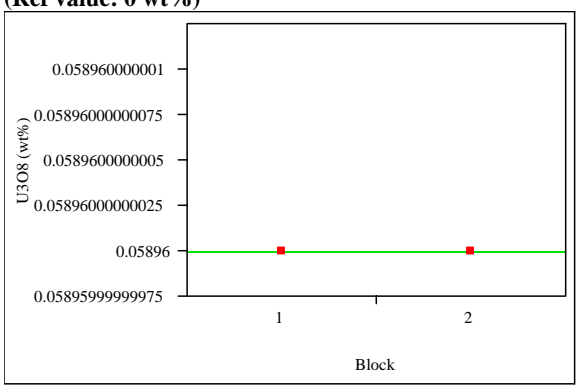

Oneway Anova

Summary of Fit

Rsquare

Adj Rsquare

Root Mean Square Error $\quad 0$

Mean of Response

Observations (or Sum Wgts) 6

t Test

$1-2$

Assuming equal variances
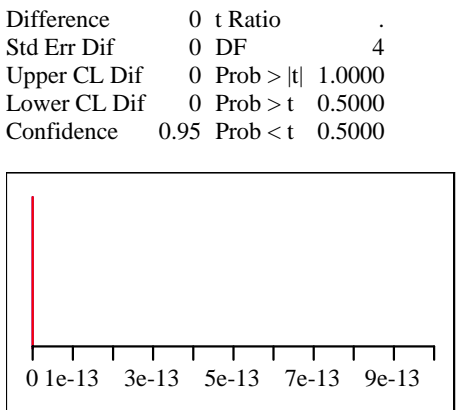

Analysis of Variance

Source DF Sum of Squares Mean Square F Ratio Prob $>$ F Block 1

Error 4

C. Total 5

Level Number Mean Std Error Lower 95\% Upper 95\%

$\begin{array}{rrrrrr}1 & 3 & 0.058960 & 0 & 0.05896 & 0.05896\end{array}$

$\begin{array}{llllll}1 & 3 & 0.058960 & 0 & 0.05896 & 0.05896\end{array}$

Std Error uses a pooled estimate of error variance 


\section{Exhibit C.4: SRNL-ML Measurements by Analytical Block for Samples of the Standard Glasses Prepared Using the PF Method}

Glass ID=Ustd

Oneway Analysis of Al2O3 (wt\%) By Block

(Ref value: $4.1 \mathrm{wt} \%$ )

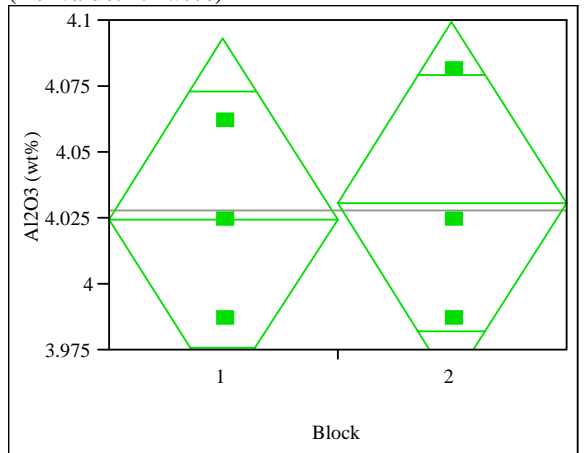

Oneway Anova

Summary of Fit

$\begin{array}{lr}\text { Rsquare } & 0.008 \\ \text { Adj Rsquare } & -0.24 \\ \text { Root Mean Square Error } & 0.042949 \\ \text { Mean of Response } & 4.027784 \\ \text { Observations (or Sum Wgts) } & 6 \\ \text { t Test } & \\ 1-2 & \\ \text { Assuming equal variances } & \end{array}$

Assuming equal variances
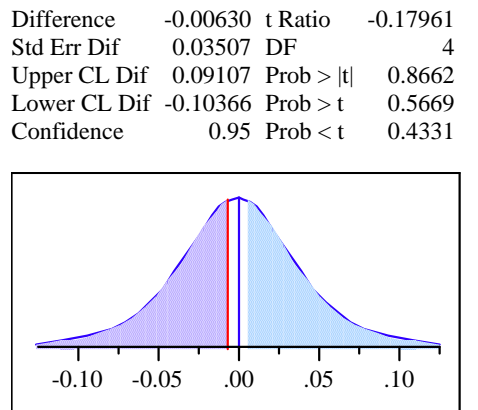

Analysis of Variance

Source DF Sum of Squares Mean Square F Ratio Prob $>$ F

$\begin{array}{llllll}\text { Block } & 1 & 0.00005950 & 0.000060 & 0.0323 & 0.8662\end{array}$

$\begin{array}{llll}\text { Error } & 4 & 0.00737843 & 0.001845\end{array}$

C. Total $5 \quad 0.00743794$

Means for Oneway Anova

Level Number Mean Std Error Lower 95\% Upper 95\%

$\begin{array}{lllllr}1 & 3 & 4.02464 & 0.02480 & 3.9558 & 4.0935\end{array}$

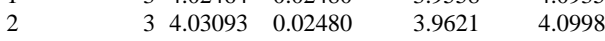

Std Error uses a pooled estimate of error variance
Oneway Analysis of B2O3 (wt\%) By Block

(Ref value: 9.209 wt\%)

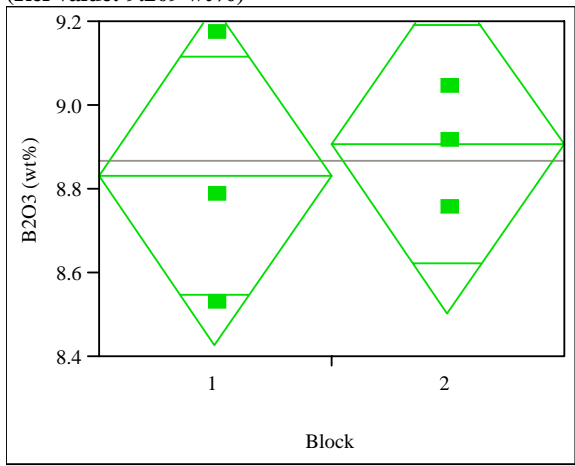

Oneway Anova

Summary of Fit

Rsquare

Adj Rsquare

0.032472

$-0.20941$

Mean of Response

Observations (or Sum Wgts) $\quad 6$

t Test

$1-2$

Assuming equal variances

Difference $\quad-0.07513$ t Ratio -0.3664 $\begin{array}{lll}\text { Std Err Dif } \quad 0.20505 \text { DF } & 4\end{array}$ Upper CL Dif 0.49419 Prob $>|t| 0.7326$

Lower CL Dif -0.64445 Prob $>$ t 0.6337

$\begin{array}{lll}\text { Confidence } & 0.95 \text { Prob }<\mathrm{t} \quad 0.3663\end{array}$

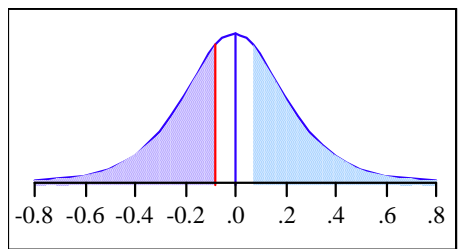

Analysis of Variance

Source DF Sum of Squares Mean Square F Ratio Prob $>$ F

$\begin{array}{llllll}\text { Block } & 1 & 0.00846700 & 0.008467 & 0.1342 & 0.7326\end{array}$

$\begin{array}{llll}\text { Error } & 4 & 0.25228206 & 0.063071\end{array}$

C. Total $5 \quad 0.26074906$

Means for Oneway Anova

Level Number Mean Std Error Lower 95\% Upper 95\%

$\begin{array}{rrrrrr}1 & 3 & 8.83326 & 0.14499 & 8.4307 & 9.2358\end{array}$

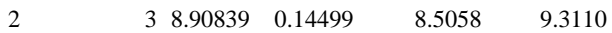

Std Error uses a pooled estimate of error variance 


\section{Exhibit C.4: SRNL-ML Measurements by Analytical Block for Samples of the Standard Glasses Prepared Using the PF Method}

Oneway Analysis of Fe2O3 (wt\%) By Block (Ref value: 13.196 wt \%)

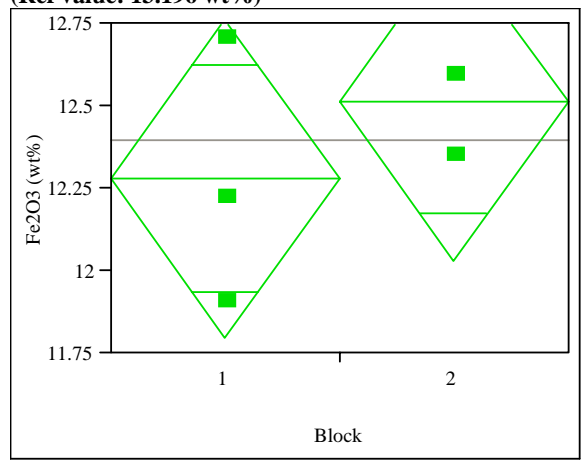

Oneway Anova

Summary of Fit
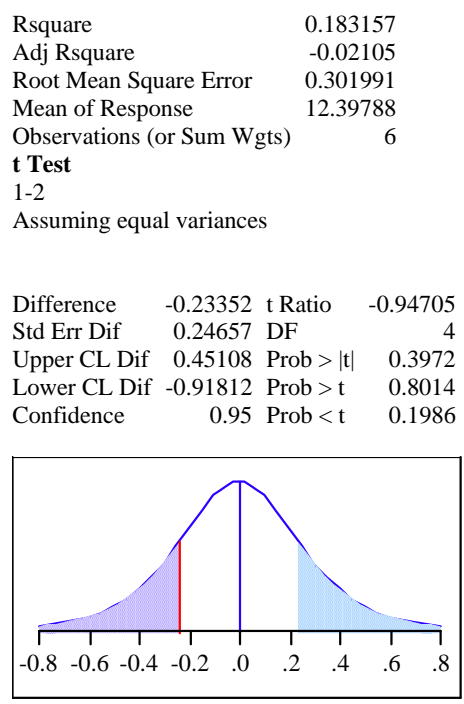

Analysis of Variance

Source DF Sum of Squares Mean Square F Ratio Prob $>$ F

$\begin{array}{llllll}\text { Block } & 1 & 0.08179575 & 0.081796 & 0.8969 & 0.3972\end{array}$

$\begin{array}{lll}\text { Error } & 4 & 0.36479338\end{array}$

C. Total $5 \quad 0.44658913$

Means for Oneway Anova

Level Number Mean Std Error Lower 95\% Upper 95\%

$\begin{array}{llllll}1 & 3 & 12.2811 & 0.17435 & 11.797 & 12.765\end{array}$

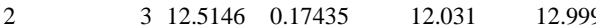

Std Error uses a pooled estimate of error variance
Oneway Analysis of Li2O (wt\%) By Block (Ref value: 3.057 wt \%)

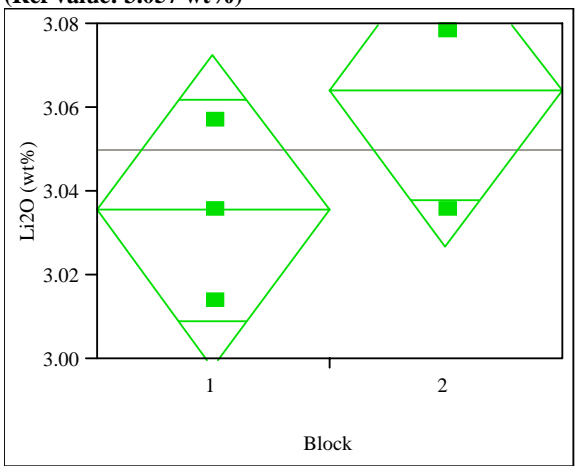

Oneway Anova

Summary of Fit

Rsquare

0.363636

Adj Rsquare

0.204545

Root Mean Square Error $\quad 0.023254$

Mean of Response 3.049942

Observations (or Sum Wgts) 6

t Test

$1-2$

Assuming equal variances

$\begin{array}{lrlr}\text { Difference } & -0.02871 & \text { t Ratio } & -1.51186 \\ \text { Std Err Dif } & 0.01899 \text { DF } & 4 \\ \text { Upper CL Dif } & 0.02401 \text { Prob }>|t| & 0.2051 \\ \text { Lower CL Dif } & -0.08142 & \text { Prob }>t & 0.8974 \\ \text { Confidence } & 0.95 & \text { Prob }<\mathrm{t} & 0.1026\end{array}$

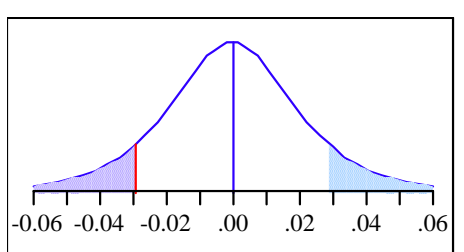

Analysis of Variance

Source DF Sum of Squares Mean Square F Ratio Prob > F

$\begin{array}{llllll}\text { Block } & 1 & 0.00123599 & 0.001236 & 2.2857 & 0.2051\end{array}$

$\begin{array}{llll}\text { Error } & 4 & 0.00216299 & 0.000541\end{array}$

C. Total $5 \quad 0.00339898$

Means for Oneway Anova

Level Number Mean Std Error Lower 95\% Upper 95\%

$\begin{array}{llllll}1 & 3 & 3.03559 & 0.01343 & 2.9983 & 3.0729\end{array}$

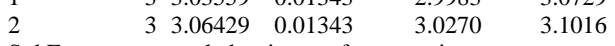

Std Error uses a pooled estimate of error variance 


\section{Exhibit C.4: SRNL-ML Measurements by Analytical Block for Samples of the Standard Glasses Prepared Using the PF Method}

Oneway Analysis of MnO (wt \%) By Block (Ref value: 2.892 wt \%)

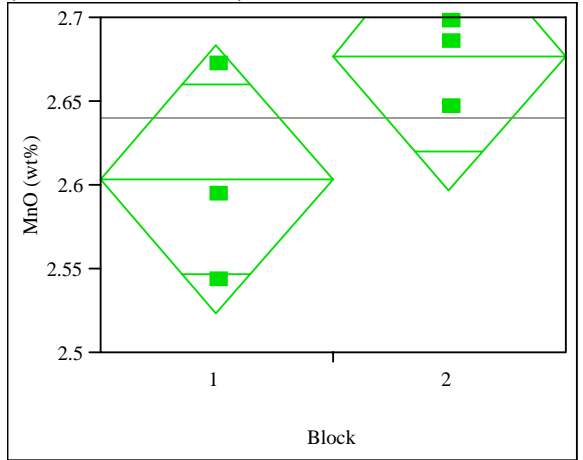

Oneway Anova

Summary of Fit

Rsquare $\quad 0.448062$

Adj Rsquare $\quad 0.310078$

Root Mean Square Error $\quad 0.049729$

Mean of Response 2.640504

Observations (or Sum Wgts) 6

t Test

$1-2$

Assuming equal variances

Difference $\quad-0.07317$ t Ratio $\quad-1.802$

Std Err Dif $\quad 0.04060$ DF 4

Upper CL Dif 0.03957 Prob $>|t| 0.1459$

Lower CL Dif -0.18590 Prob $>\mathrm{t} \quad 0.9271$

Confidence $\quad 0.95$ Prob $<\mathrm{t} \quad 0.0729$

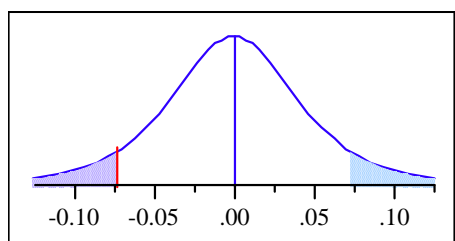

Analysis of Variance

Source DF Sum of Squares Mean Square F Ratio Prob $>$ F

$\begin{array}{llllll}\text { Block } & 1 & 0.00803033 & 0.008030 & 3.2472 & 0.1459\end{array}$

$\begin{array}{llll}\text { Error } & 4 & 0.00989204 & 0.002473\end{array}$

C. Total $5 \quad 0.01792237$

Means for Oneway Anova

Level Number Mean Std Error Lower 95\% Upper 95\%

$\begin{array}{llllll}1 & 3 & 2.60392 & 0.02871 & 2.5242 & 2.6836\end{array}$

$\begin{array}{llllll}1 & 3 & 2.67709 & 0.02871 & 2.5974 & 2.7568\end{array}$

Std Error uses a pooled estimate of error variance
Oneway Analysis of $\mathrm{NiO}$ (wt \%) By Block

(Ref value: $1.12 \mathrm{wt} \%$ )

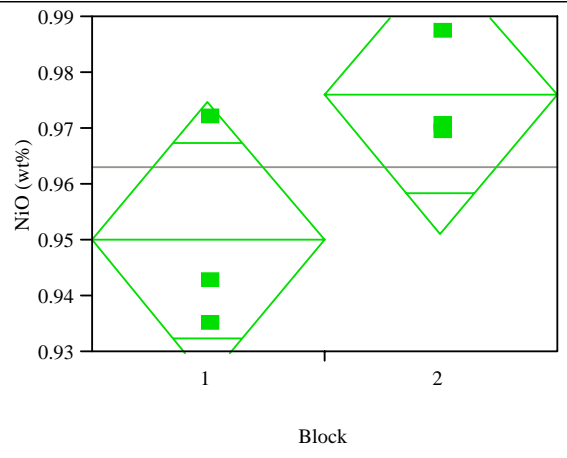

Oneway Anova

Summary of Fit

Rsquare

Adj Rsquare

0.512182

Root Mean S

Mean of Response

$\quad 0.96307$

Observations (or Sum Wgts)

t Test

Assuming equal variances

$\begin{array}{lrlr}\text { Difference } & -0.02587 & \text { t Ratio } & -2.04934 \\ \text { Std Err Dif } & 0.01263 \text { DF } & 4 \\ \text { Upper CL Dif } & 0.00918 \text { Prob }>|t| & 0.1098 \\ \text { Lower CL Dif } & -0.06093 \text { Prob }>t & 0.9451 \\ \text { Confidence } & 0.95 & \text { Prob }<\mathrm{t} & 0.0549\end{array}$

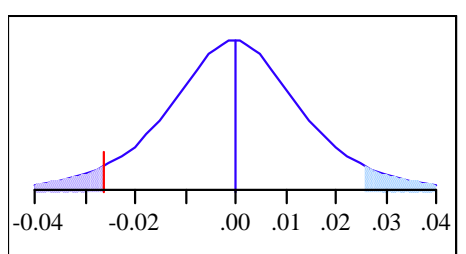

Analysis of Variance

Source DF Sum of Squares Mean Square F Ratio Prob > F

$\begin{array}{llllll}\text { Block } & 1 & 0.00100421 & 0.001004 & 4.1998 & 0.1098\end{array}$

$\begin{array}{llll}\text { Error } & 4 & 0.00095644 & 0.000239\end{array}$

C. Total $5 \quad 0.00196065$

Means for Oneway Anova

Level Number Mean Std Error Lower 95\% Upper 95\%

$\begin{array}{llllrr}1 & 3 & 0.950133 & 0.00893 & 0.92535 & 0.9749\end{array}$

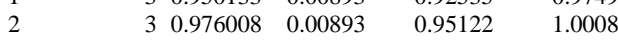

Std Error uses a pooled estimate of error variance 


\section{Exhibit C.4: SRNL-ML Measurements by Analytical Block for Samples of the Standard Glasses Prepared Using the PF Method}

Oneway Analysis of SiO2 (wt\%) By Block (Ref value: $45.353 \mathrm{wt} \%$ )

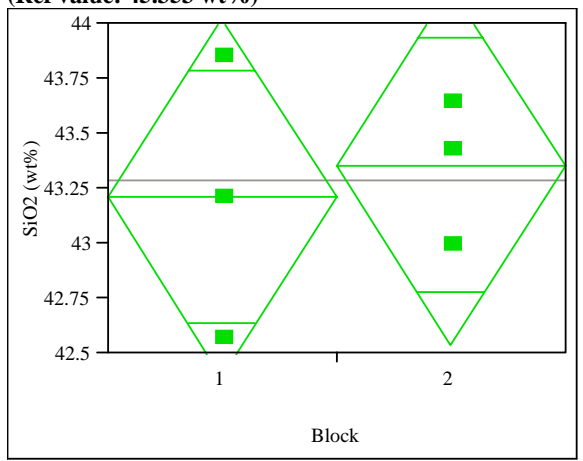

Oneway Anova

Summary of Fit

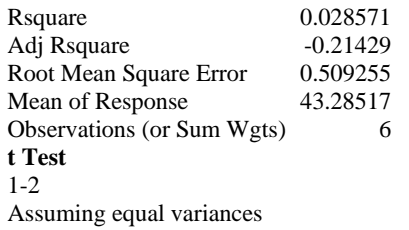

Difference $\quad-0.1426$ t Ratio $\quad-0.343$

Std Err Dif $\quad 0.4158$ DF 4

Upper CL Dif 1.0118 Prob $>|\mathrm{t}| 0.7489$

Lower CL Dif -1.2971 Prob $>$ t 0.6256

Confidence $\quad 0.95$ Prob $<\mathrm{t} \quad 0.3744$

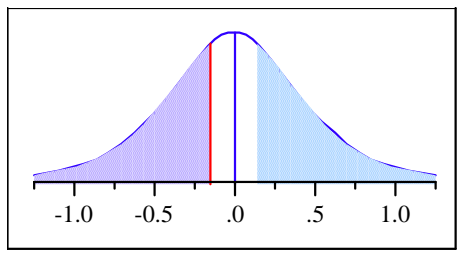

Analysis of Variance

Source DF Sum of Squares Mean Square F Ratio Prob > F

$\begin{array}{llllll}\text { Block } & 1 & 0.0305107 & 0.030511 & 0.1176 & 0.7489\end{array}$

$\begin{array}{llll}\text { Error } & 4 & 1.0373637 & 0.259341\end{array}$

C. Total $5 \quad 1.0678744$

Means for Oneway Anova

Level Number Mean Std Error Lower 95\% Upper 95\%

$\begin{array}{llllll}1 & 3 & 43.2139 & 0.29402 & 42.398 & 44.030\end{array}$

$\begin{array}{lllll}2 & 3 & 43.3565 & 0.29402 & 42.540\end{array} 44.173$

Std Error uses a pooled estimate of error variance
Oneway Analysis of U3O8 (wt\%) By Block

(Ref value: $2.406 \mathrm{wt} \%$ )

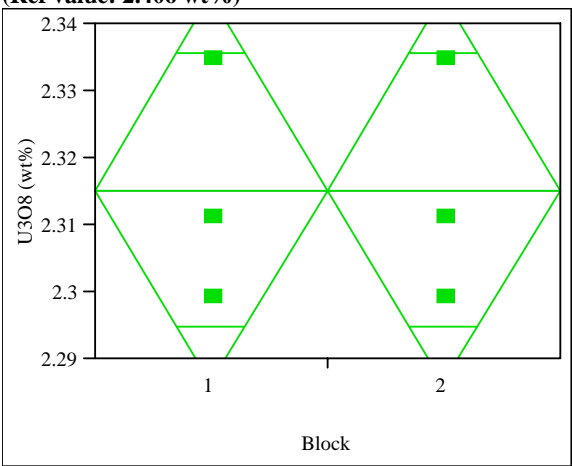

Oneway Anova

Summary of Fit

Rsquare

Adj Rsquare

0

Root Mean Square Error $\quad 0.018013$

Mean of Response 2.315163

Observations (or Sum Wgts) 6

t Test

$1-2$

Assuming equal variances

$\begin{array}{lrlr}\text { Difference } & 0.00000 & \text { t Ratio } & 0 \\ \text { Std Err Dif } & 0.01471 & \text { DF } & 4 \\ \text { Upper CL Dif } & 0.04083 \text { Prob }>|t| & 1.0000 \\ \text { Lower CL Dif } & -0.04083 \text { Prob }>\text { t } & 0.5000 \\ \text { Confidence } & 0.95 \text { Prob }<\text { t } & 0.5000\end{array}$

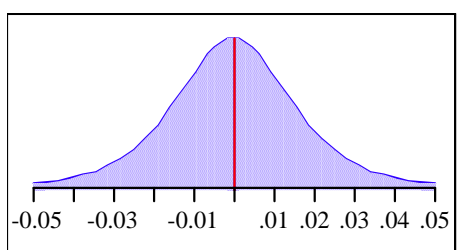

Analysis of Variance

Source DF Sum of Squares Mean Square F Ratio Prob > F

$\begin{array}{llllll}\text { Block } & 1 & 0.00000000 & 0.000000 & 0.0000 & 1.0000\end{array}$

$\begin{array}{llll}\text { Error } & 4 & 0.00129781 & 0.000324\end{array}$

C. Total $5 \quad 0.00129781$

Means for Oneway Anova

Level Number Mean Std Error Lower 95\% Upper 95\%

$\begin{array}{llllll}1 & 3 & 2.31516 & 0.01040 & 2.2863 & 2.3440\end{array}$

$\begin{array}{llllll}2 & 3 & 2.31516 & 0.01040 & 2.2863 & 2.3440\end{array}$

Std Error uses a pooled estimate of error variance 
Exhibit C.5: Measured and Measured Bias-Corrected Oxide Weight Percents by Glass \# for the Glasses Prepared Using the LM Method

(100 - Batch 1; 200 - Ustd)

BaO (wt\%) By Study Glass \#

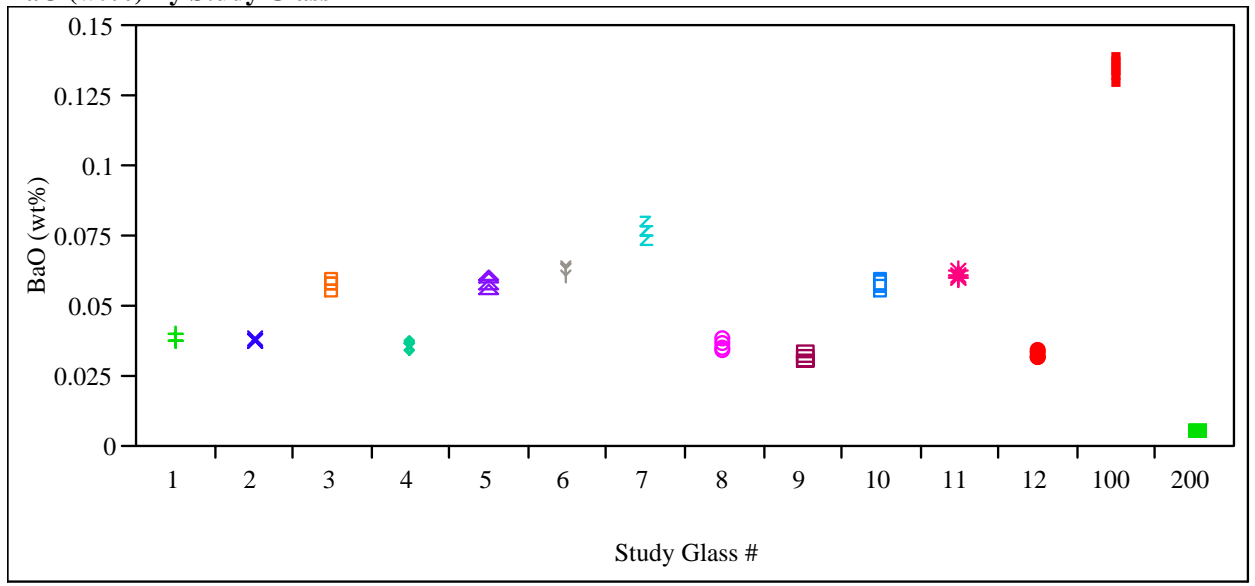

$\mathrm{CaO}(\mathrm{wt} \%)$ By Study Glass \#

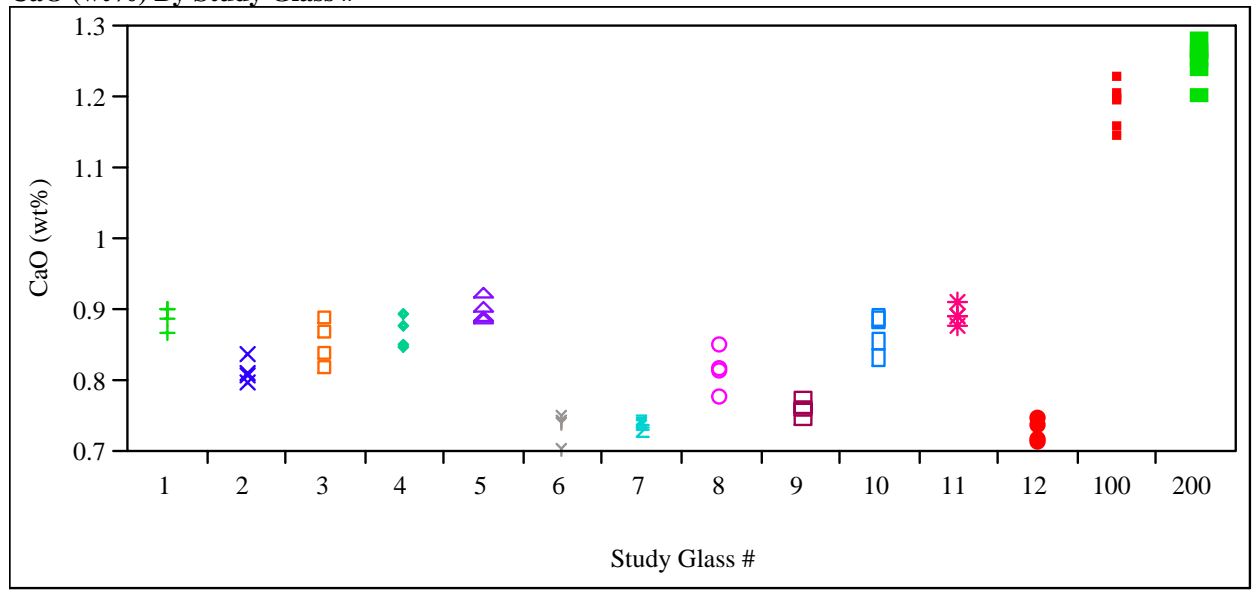

Ce2O3 (wt \%) By Study Glass \#

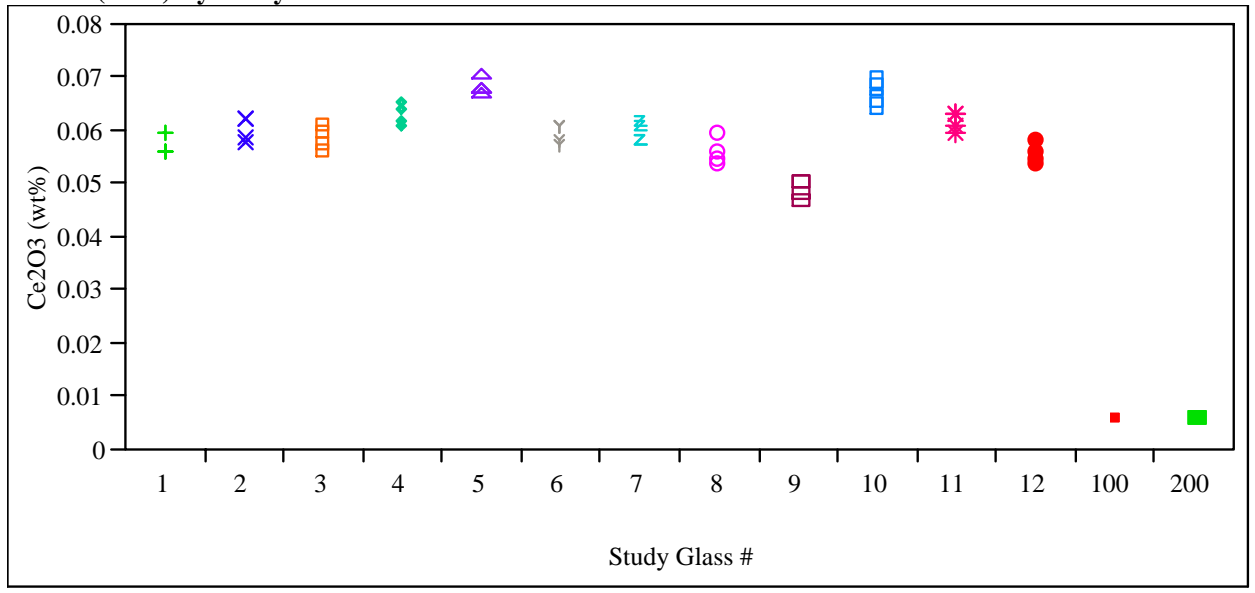


Exhibit C.5: Measured and Measured Bias-Corrected Oxide Weight Percents by Glass \# for the Glasses Prepared Using the LM Method

(100 - Batch 1; 200 - Ustd)

Cr2O3 (wt\%) By Study Glass \#

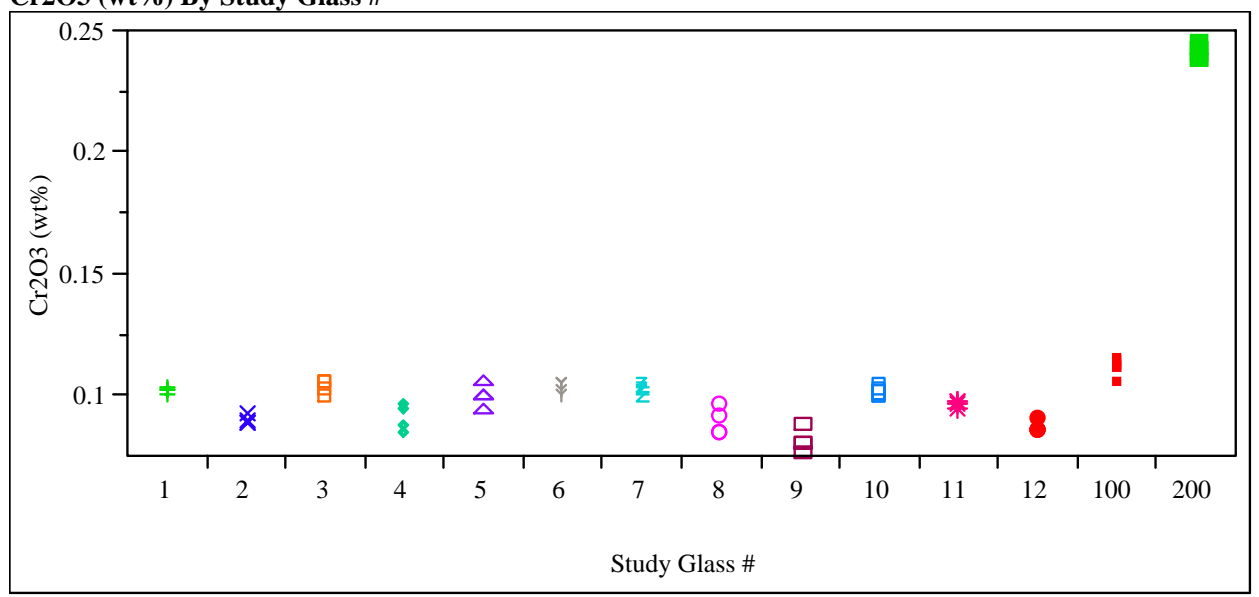

CuO (wt\%) By Study Glass \#

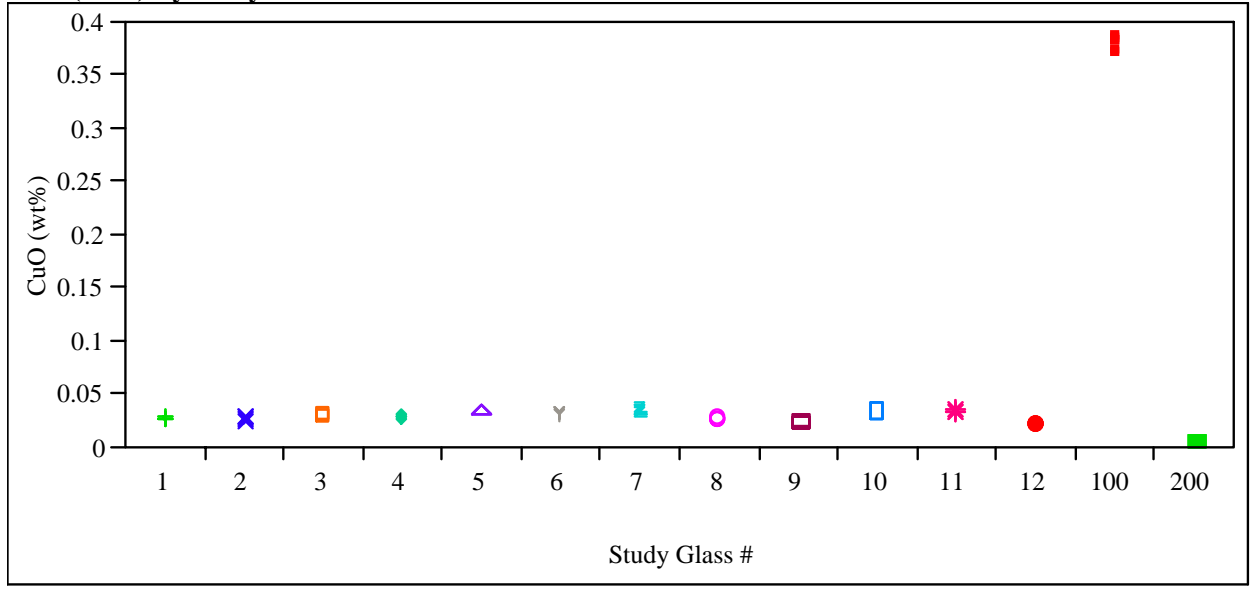

K2O (wt\%) By Study Glass \#

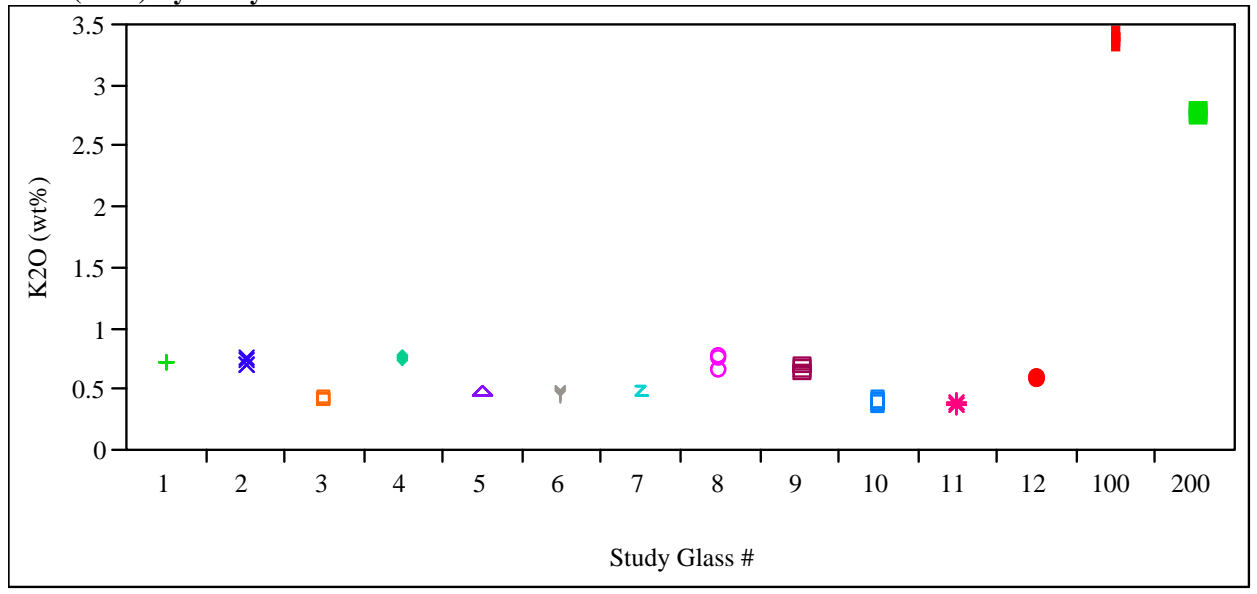


Exhibit C.5: Measured and Measured Bias-Corrected Oxide Weight Percents by Glass \# for the Glasses Prepared Using the LM Method

(100 - Batch 1; 200 - Ustd)

La2O3 (wt\%) By Study Glass \#

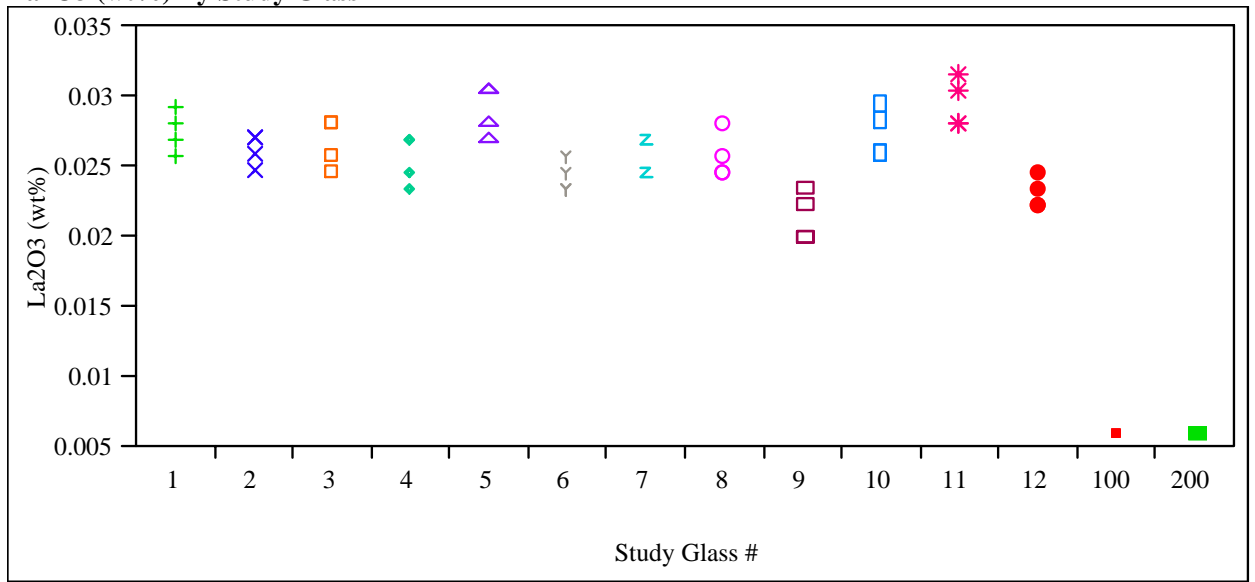

MgO (wt\%) By Study Glass \#

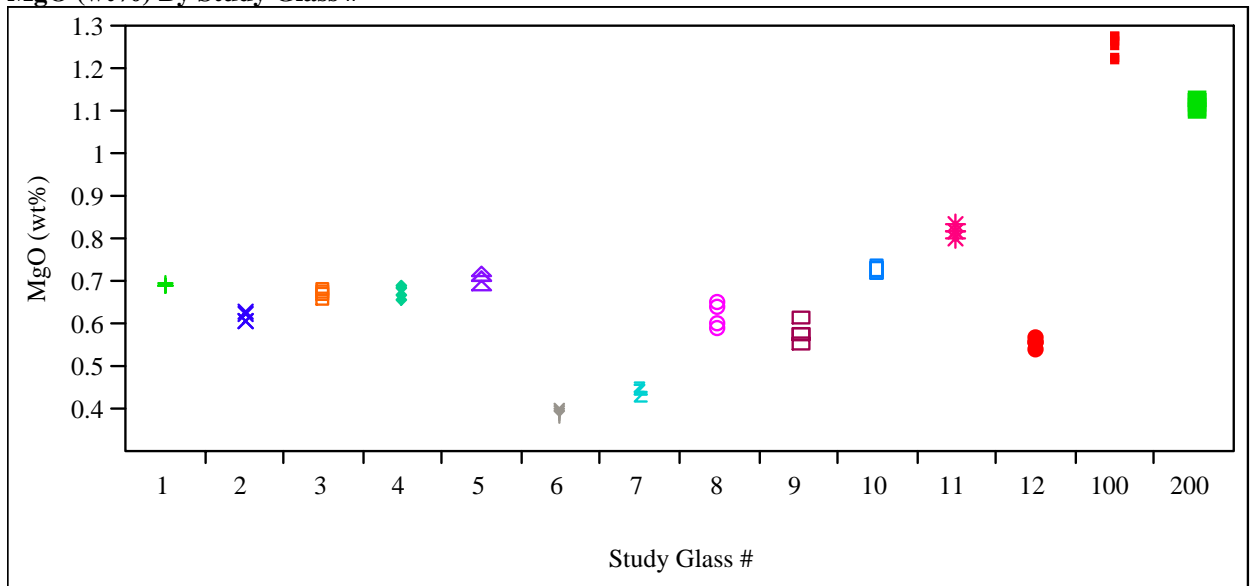

Na2O (wt \%) By Study Glass \#

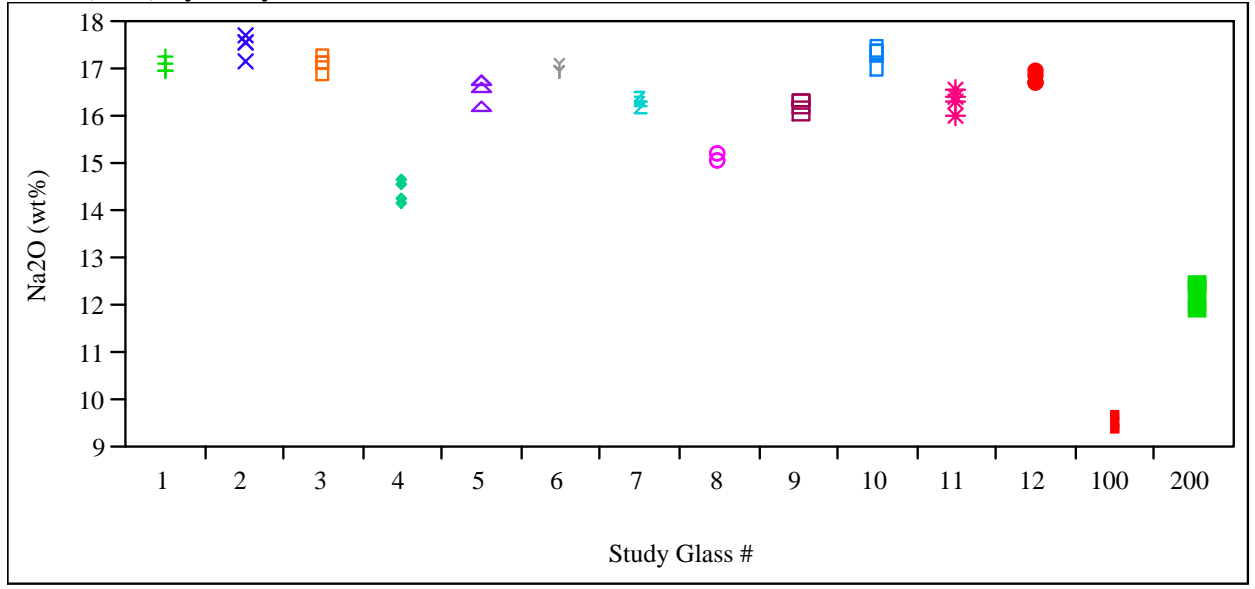


Exhibit C.5: Measured and Measured Bias-Corrected Oxide Weight Percents by Glass \# for the Glasses Prepared Using the LM Method

(100 - Batch 1; 200 - Ustd)

PbO (wt\%) By Study Glass \#

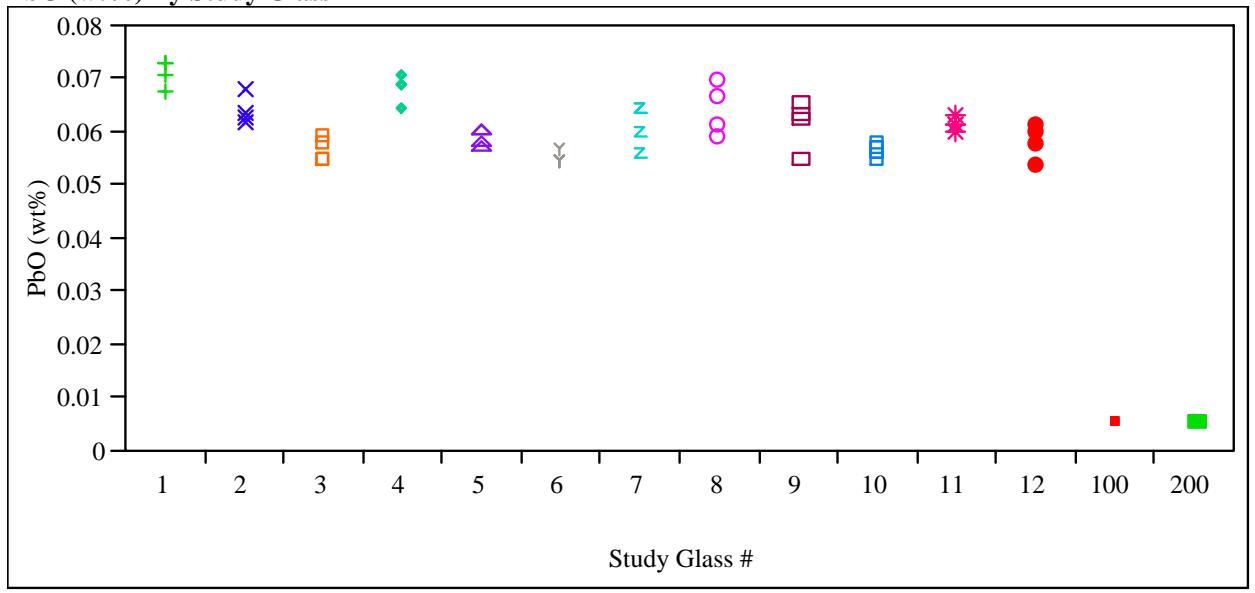

SO4 (wt\%) By Study Glass \#

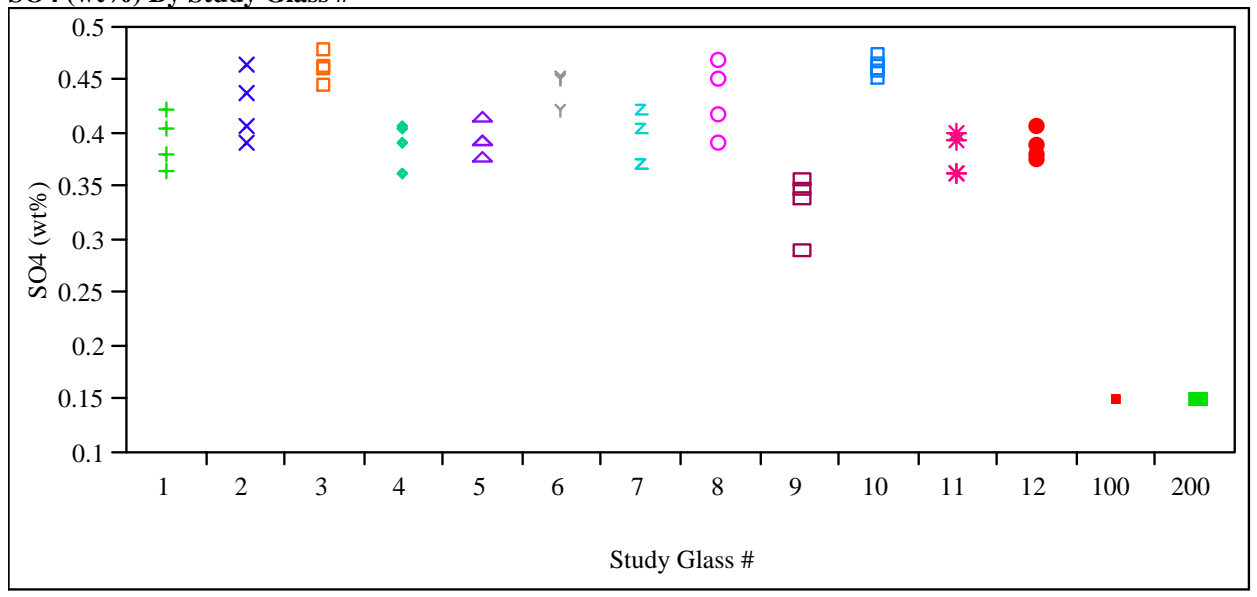

ThO2 (wt\%) By Study Glass \#

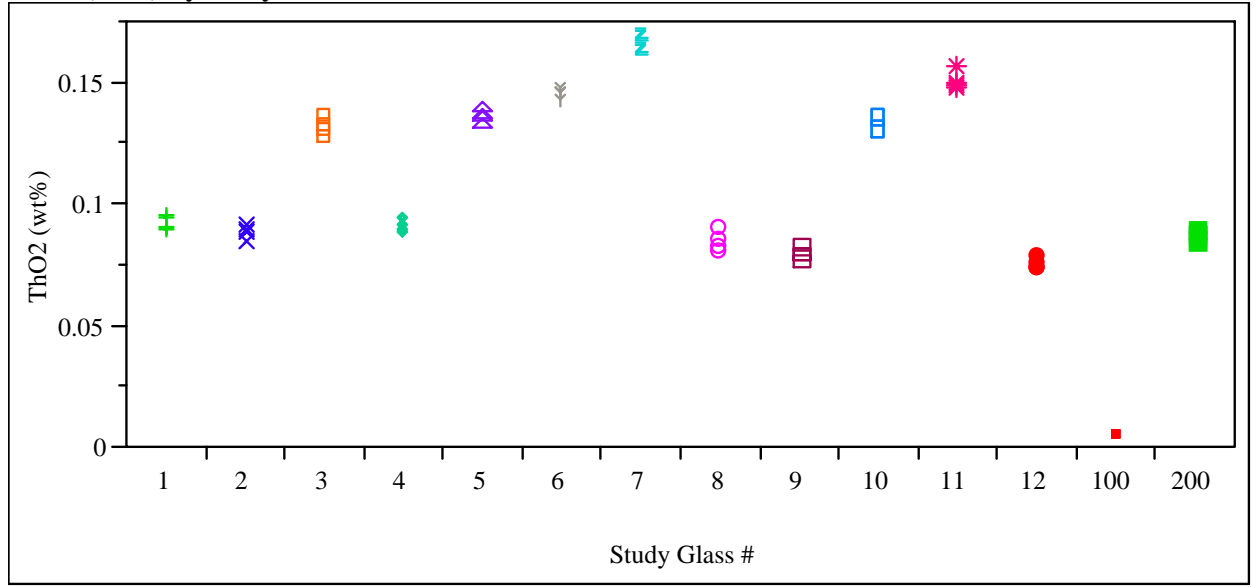


Exhibit C.5: Measured and Measured Bias-Corrected Oxide Weight Percents by Glass \# for the Glasses Prepared Using the LM Method

(100 - Batch 1; 200 - Ustd)

TiO2 (wt\%) By Study Glass \#

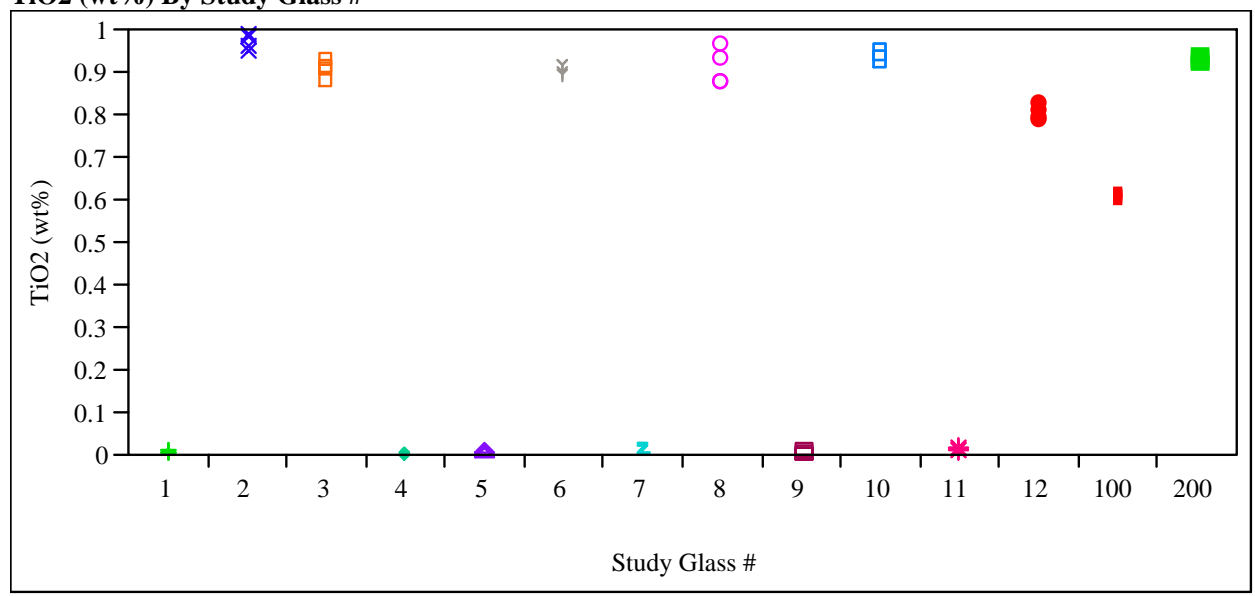

ZnO (wt\%) By Study Glass \#

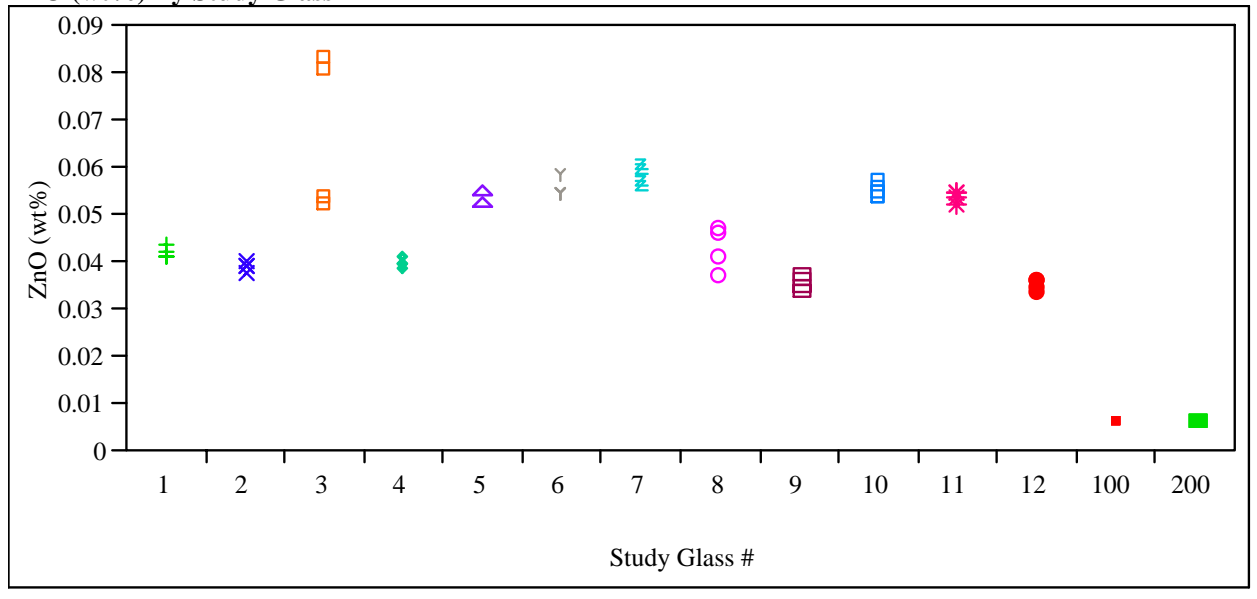

ZrO2 (wt\%) By Study Glass \#

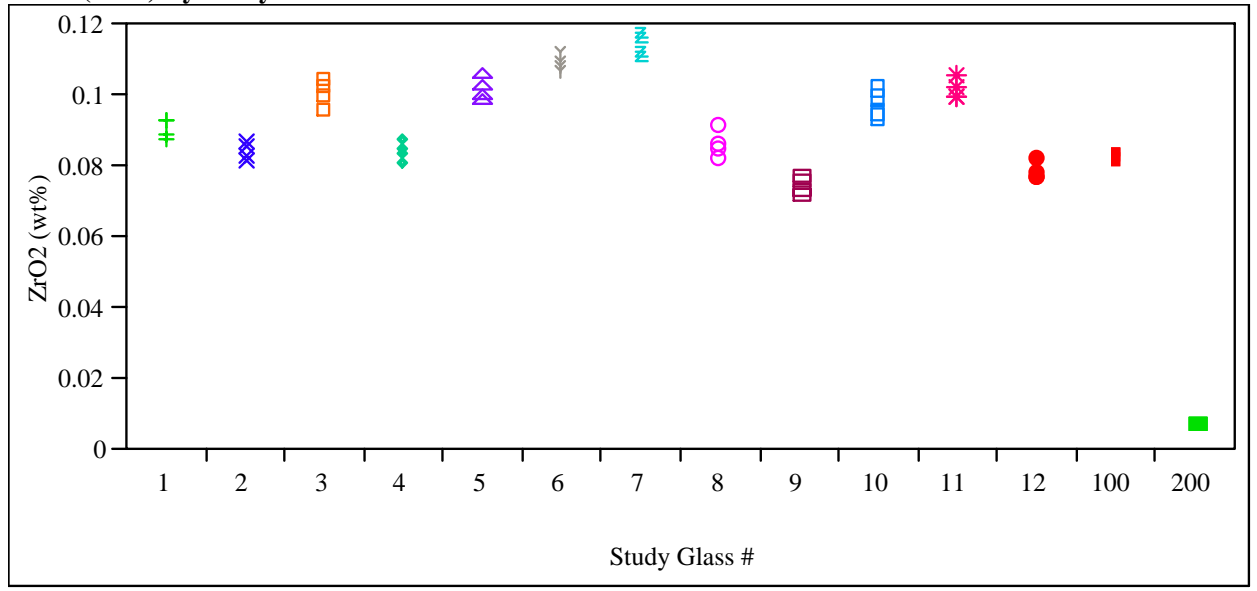


Exhibit C.5: Measured and Measured Bias-Corrected Oxide Weight Percents by Glass \# for the Glasses Prepared Using the LM Method

(100 - Batch 1; 200 - Ustd)

BaO bc (wt\%) By Study Glass \#

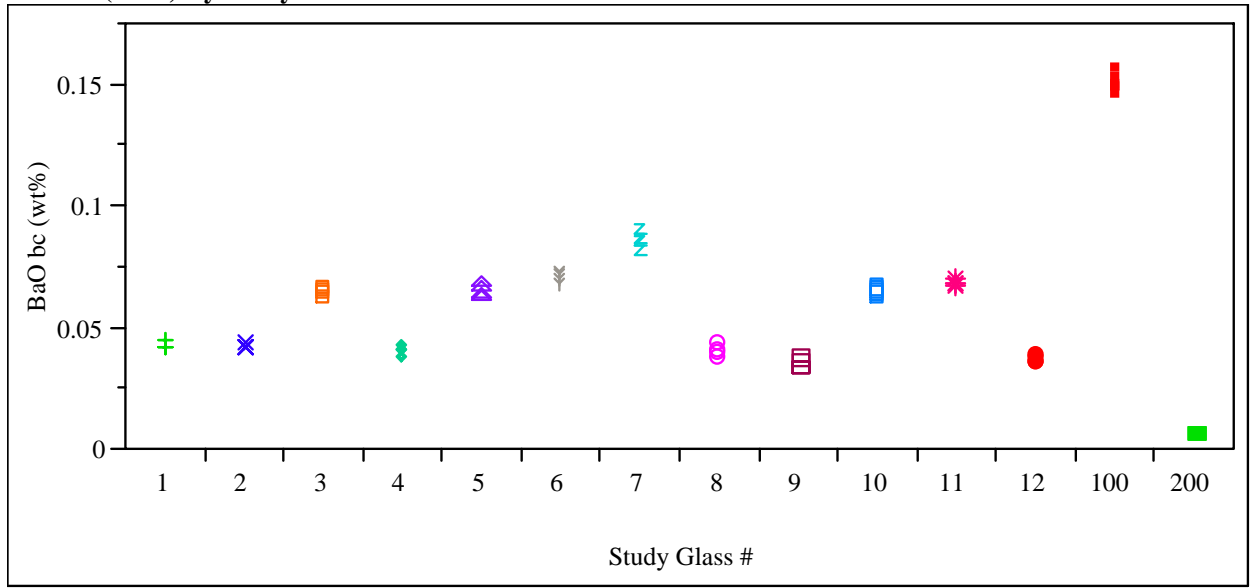

CaO bc (wt\%) By Study Glass \#

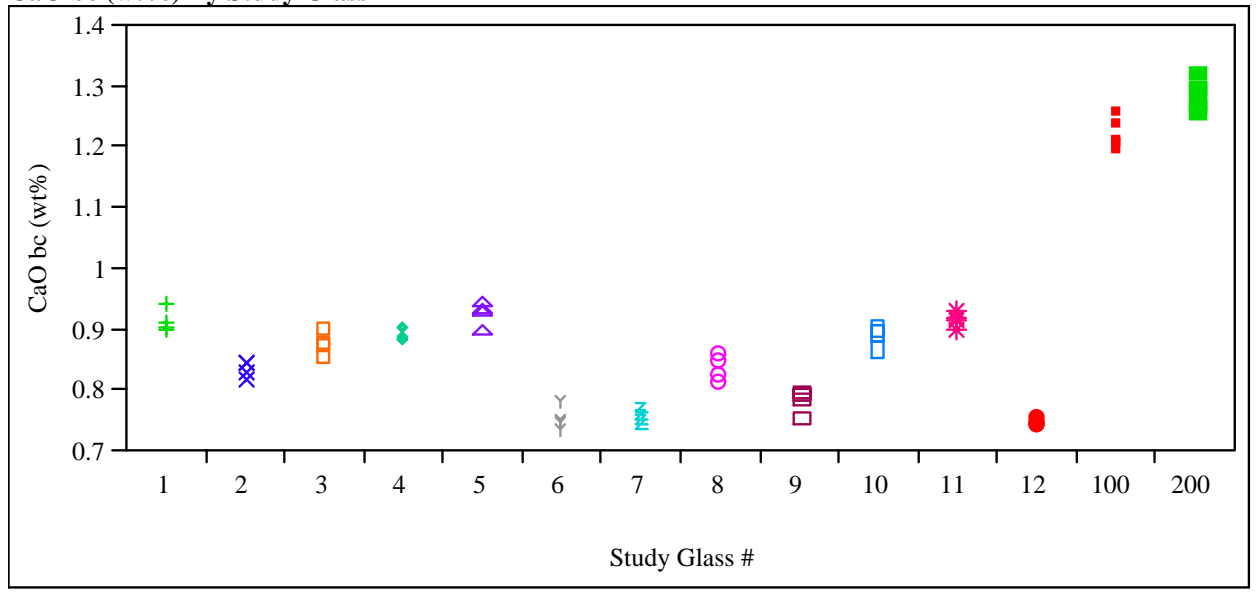

Ce2O3 bc (wt\%) By Study Glass \#

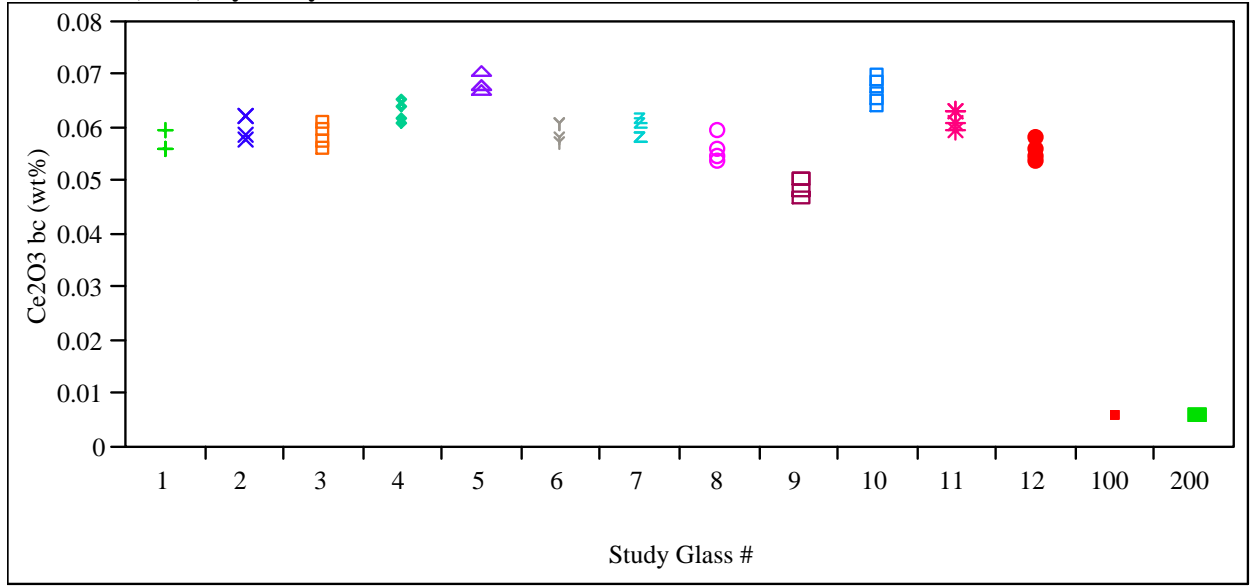


Exhibit C.5: Measured and Measured Bias-Corrected Oxide Weight Percents by Glass \# for the Glasses Prepared Using the LM Method

(100 - Batch 1; 200 - Ustd)

Cr2O3 bc (wt \%) By Study Glass \#

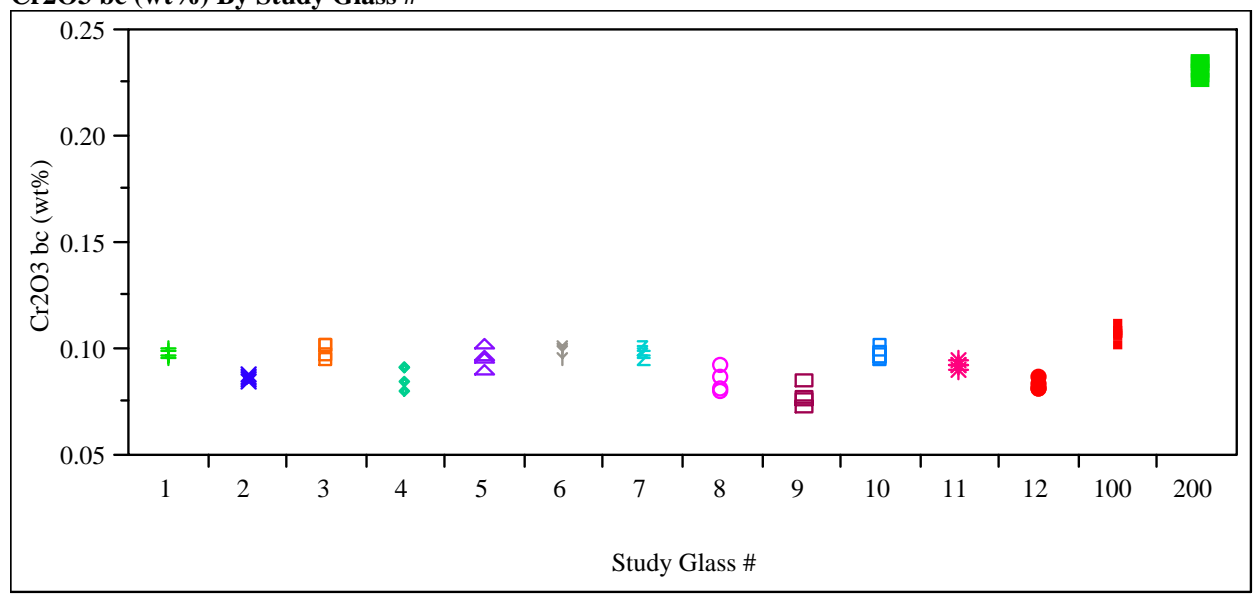

CuO bc (wt\%) By Study Glass \#

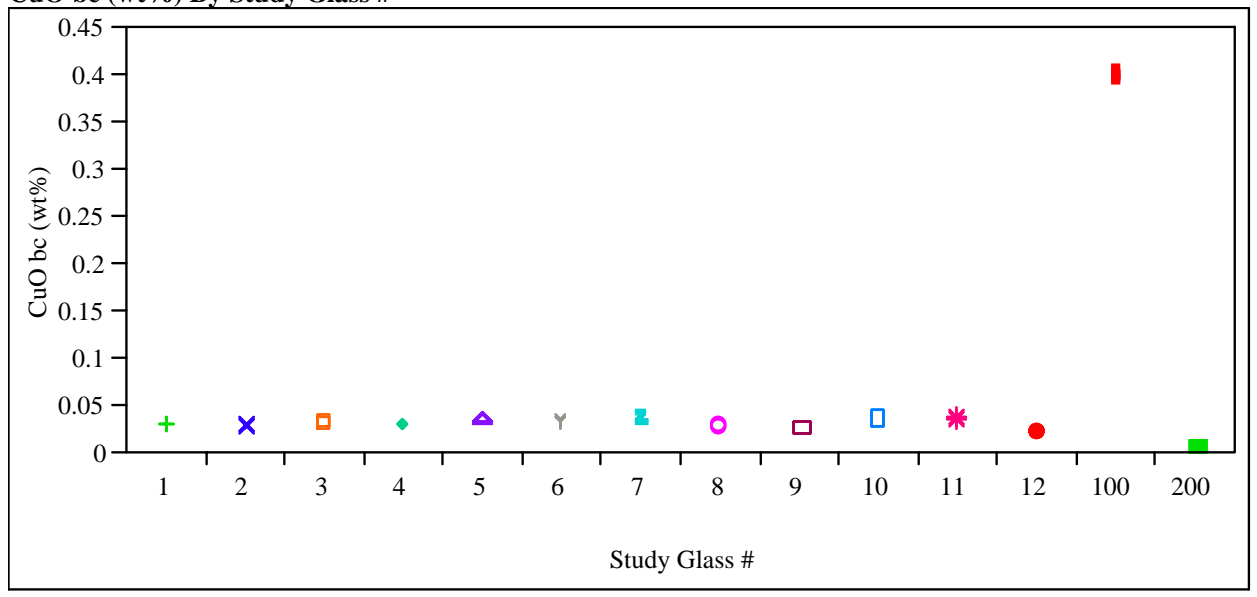

K2O bc (wt\%) By Study Glass \#

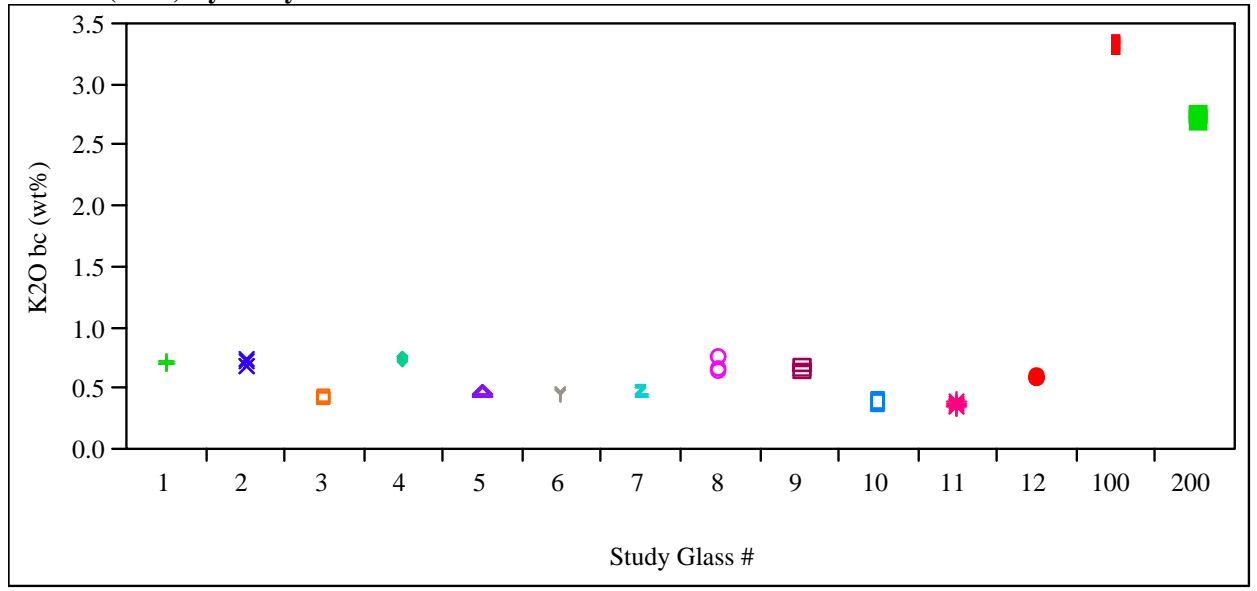


Exhibit C.5: Measured and Measured Bias-Corrected Oxide Weight Percents by Glass \# for the Glasses Prepared Using the LM Method

(100 - Batch 1; 200 - Ustd)

La203 bc (wt\%) By Study Glass \#

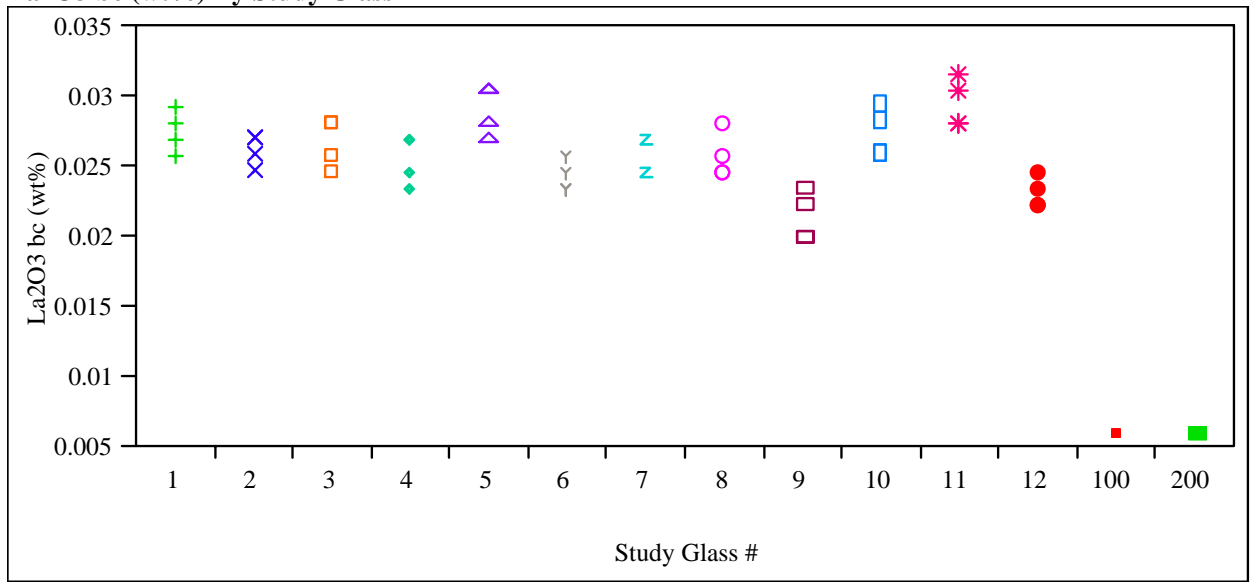

MgO bc (wt \%) By Study Glass \#

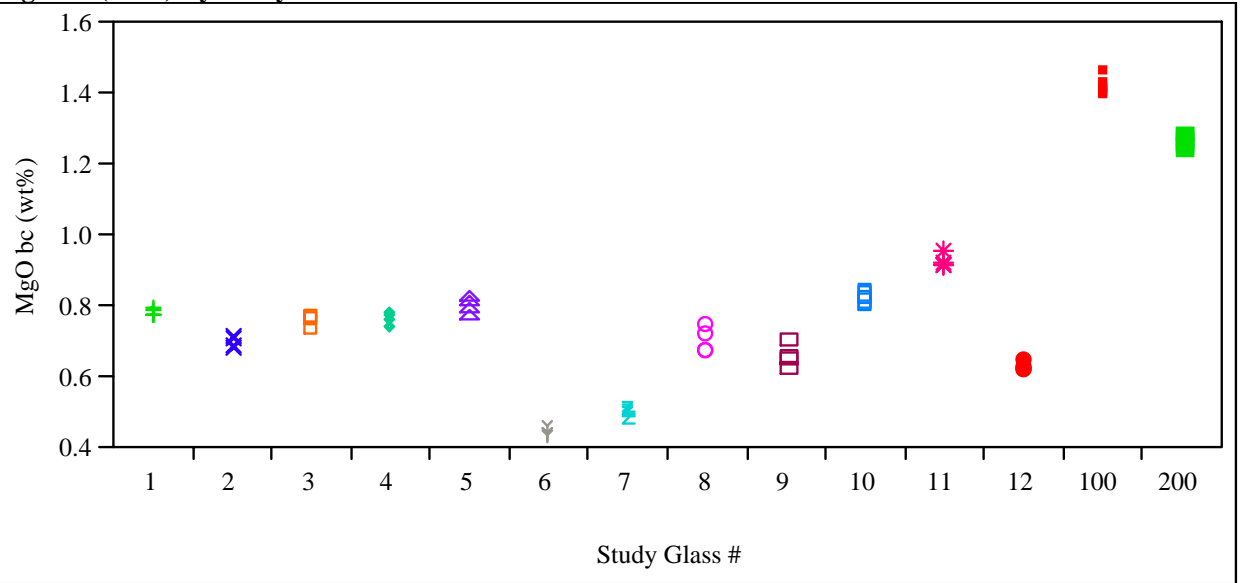

Na2O bc (wt \%) By Study Glass \#

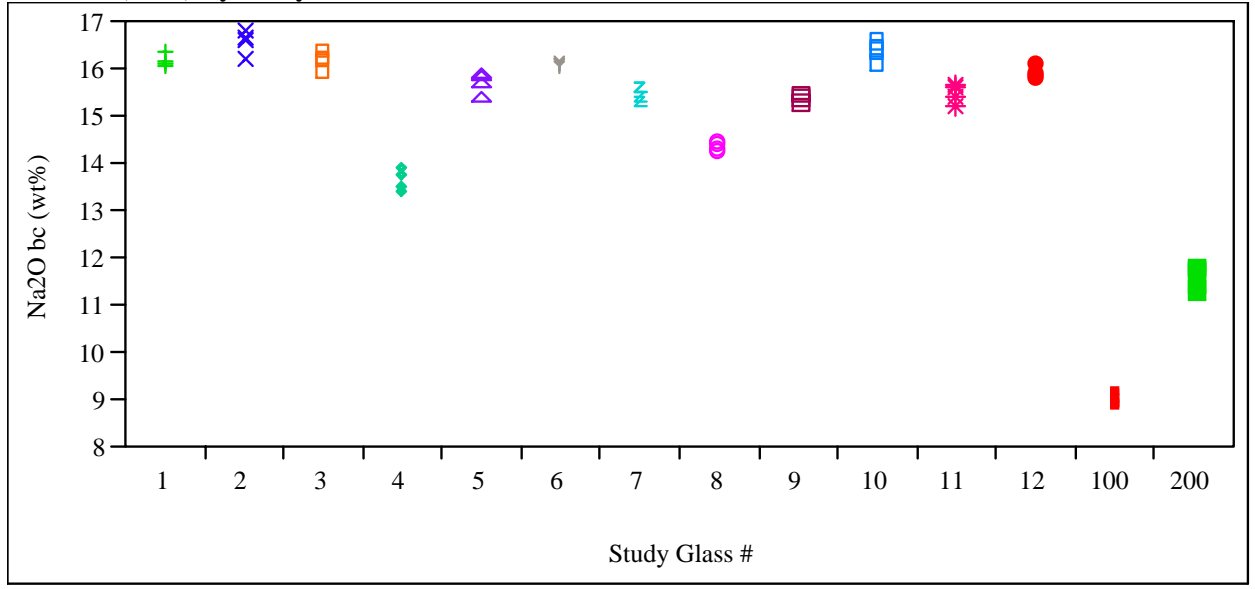


Exhibit C.5: Measured and Measured Bias-Corrected Oxide Weight Percents by Glass \# for the Glasses Prepared Using the LM Method

(100 - Batch 1; 200 - Ustd)

PbO bc (wt\%) By Study Glass \#

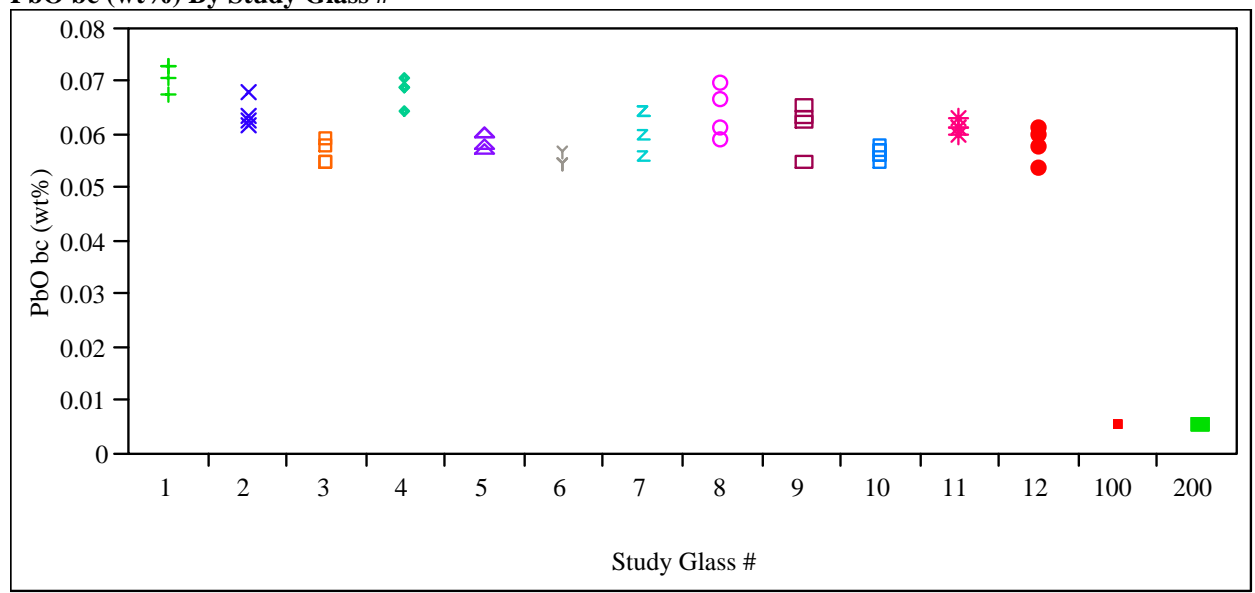

SO4 bc (wt\%) By Study Glass \#

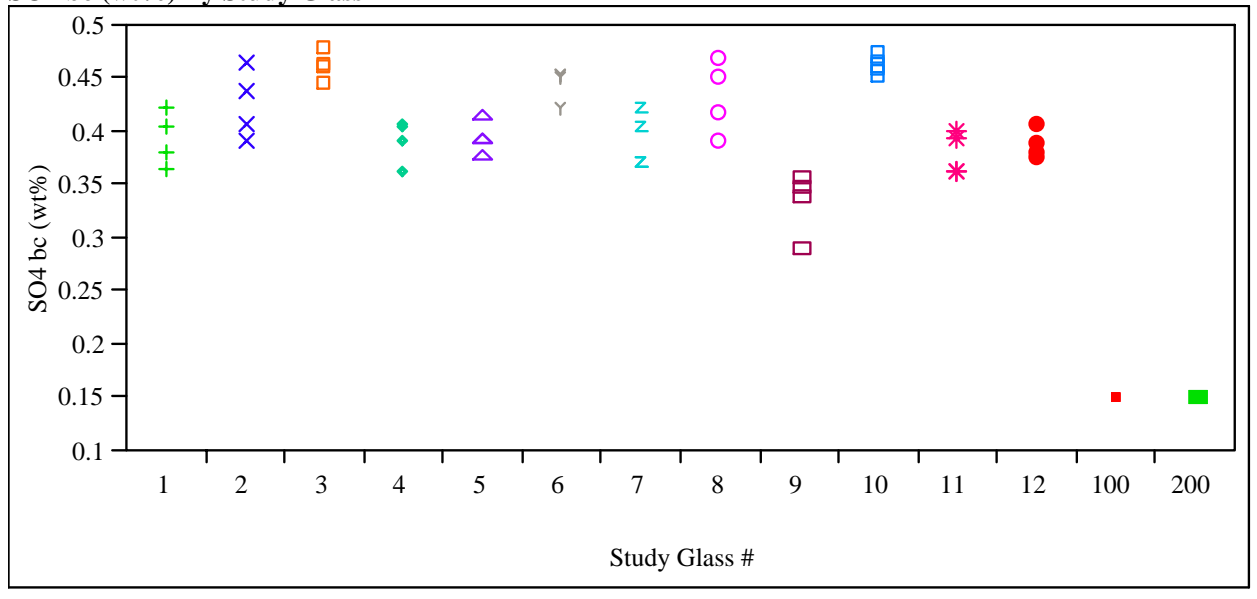

ThO2 bc (wt\%) By Study Glass \#

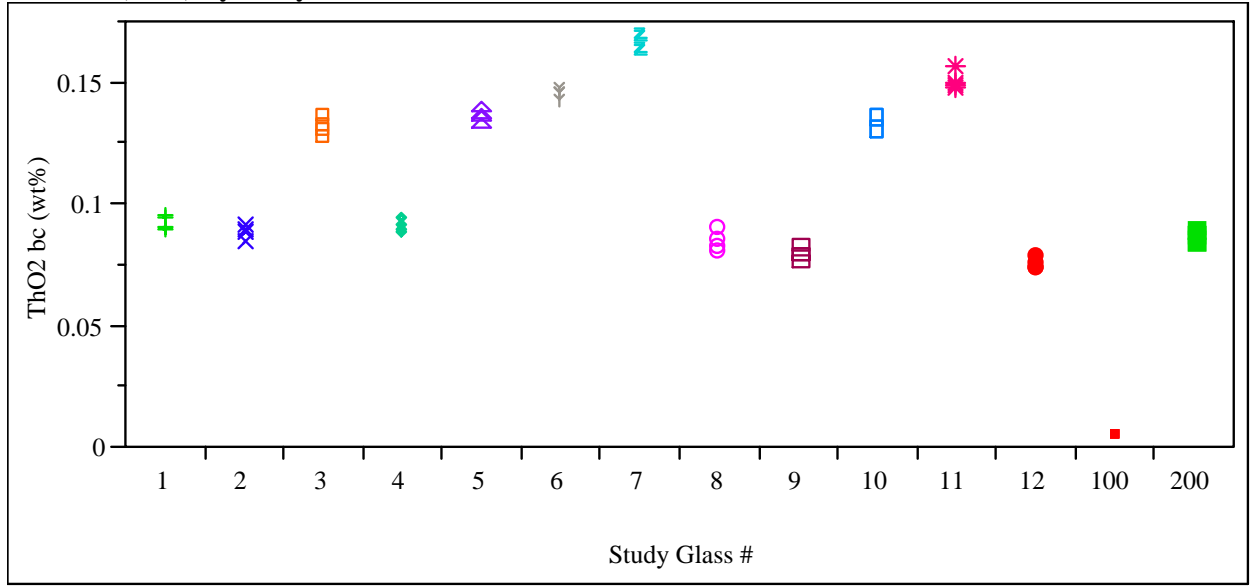


Exhibit C.5: Measured and Measured Bias-Corrected Oxide Weight Percents by Glass \# for the Glasses Prepared Using the LM Method

(100 - Batch 1; 200 - Ustd)

TiO2 bc (wt \%) By Study Glass \#

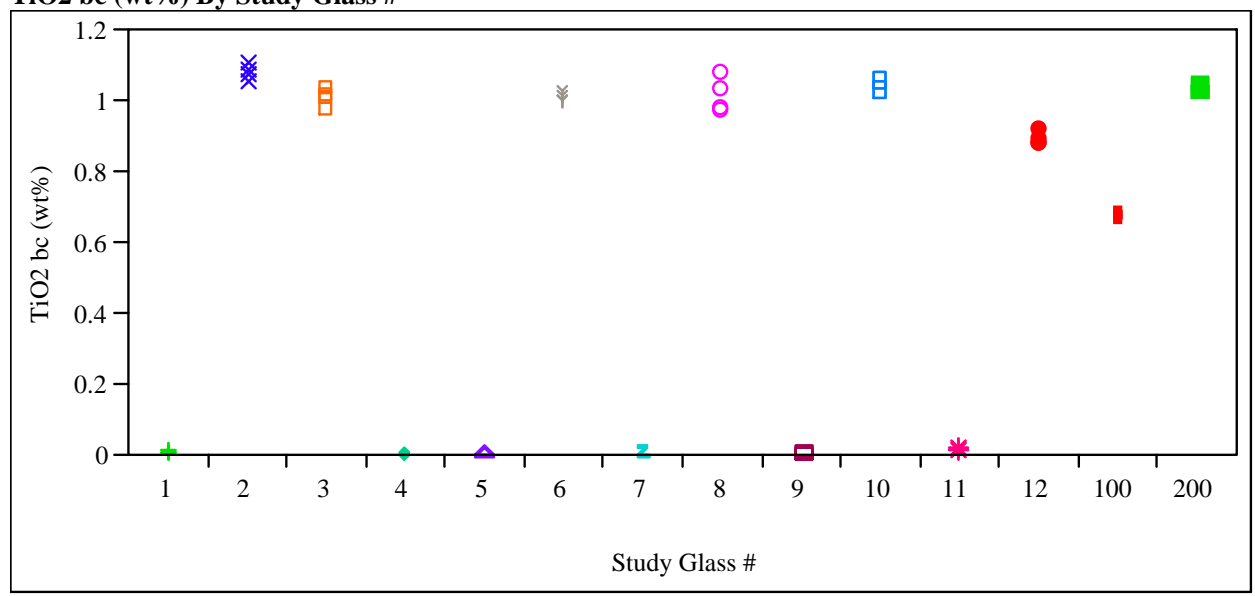

ZnO bc (wt \%) By Study Glass \#

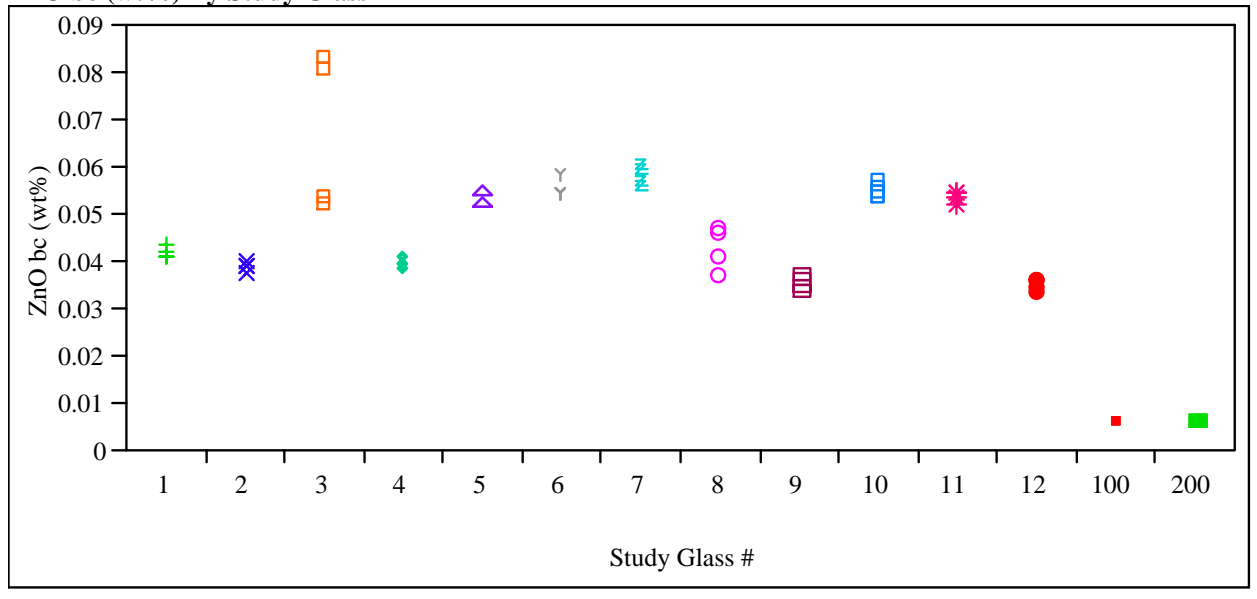

ZrO2 bc (wt\%) By Study Glass \#

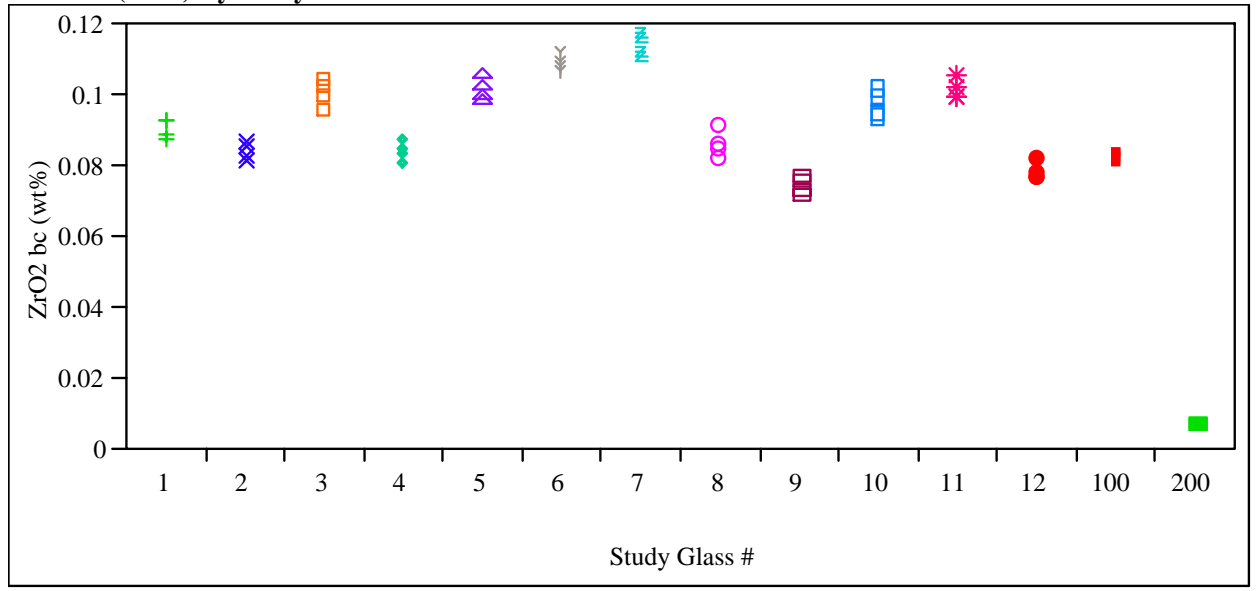


Exhibit C.6: Measured and Measured Bias-Corrected Oxide Weight Percents by Glass \# for the Glasses Prepared Using the PF Method

(100 - Batch 1; $200-U s t d)$

Oneway Analysis of Al2O3 (wt\%) By Glass \#

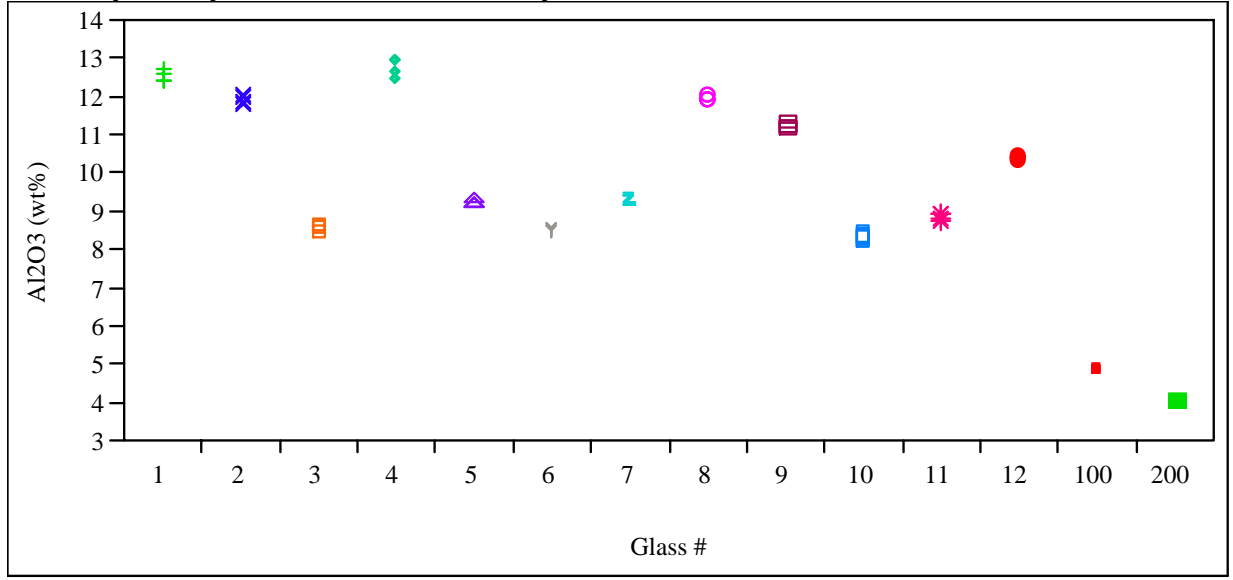

Oneway Analysis of B2O3 (wt \%) By Glass \#

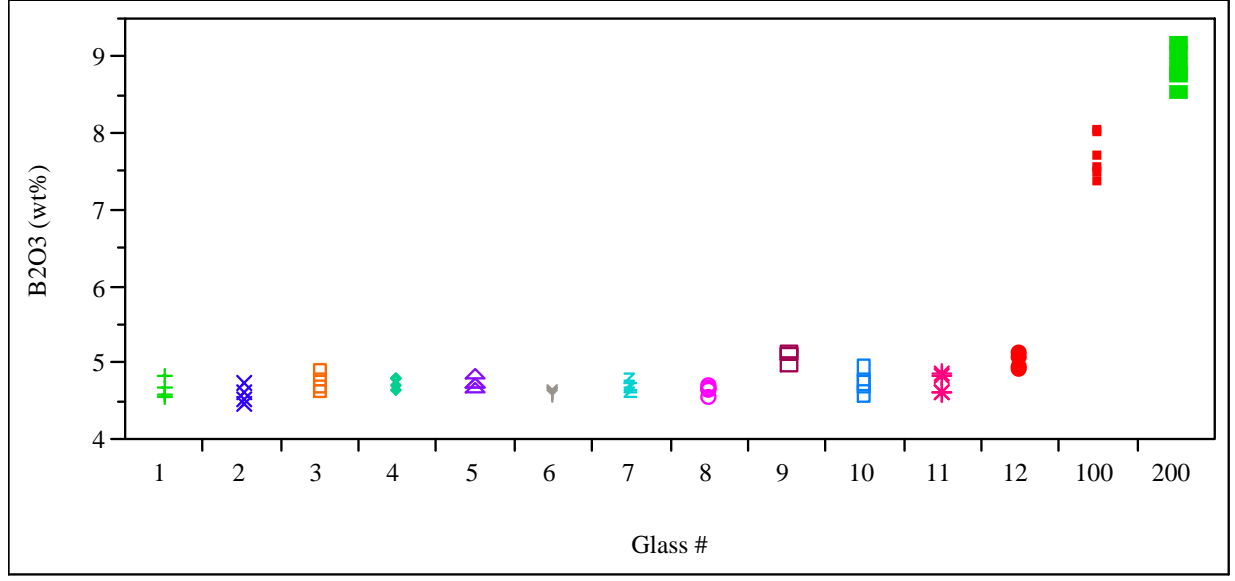

Oneway Analysis of Fe2O3 (wt \%) By Glass \#

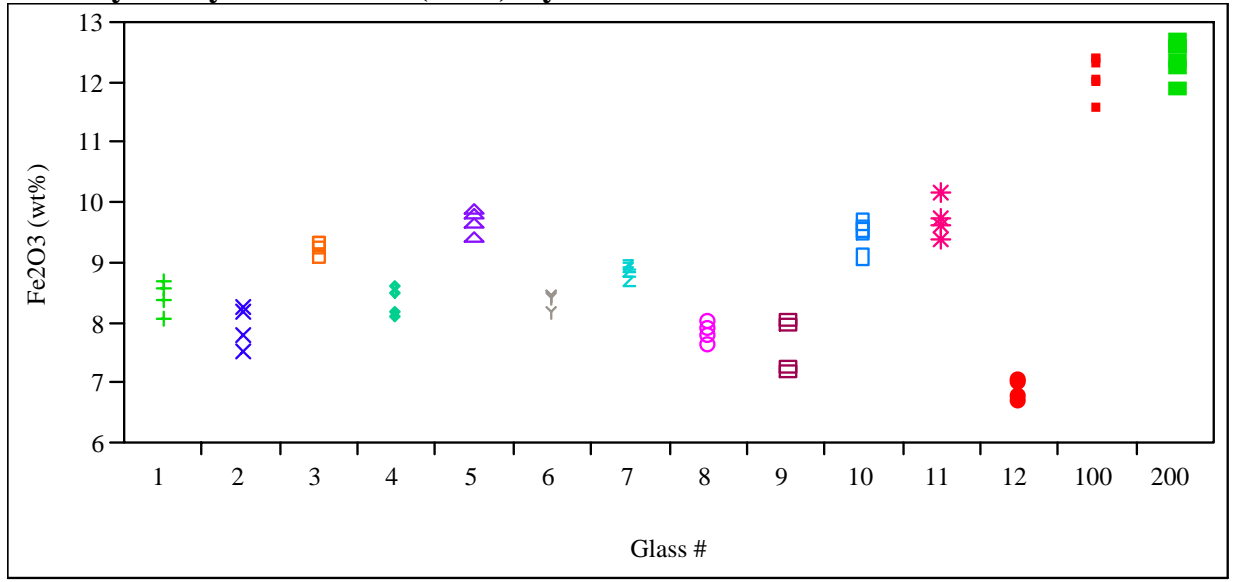


Exhibit C.6: Measured and Measured Bias-Corrected Oxide Weight Percents by Glass \# for the Glasses Prepared Using the PF Method

(100 - Batch 1; 200 - Ustd)

Oneway Analysis of Li2O (wt\%) By Glass \#

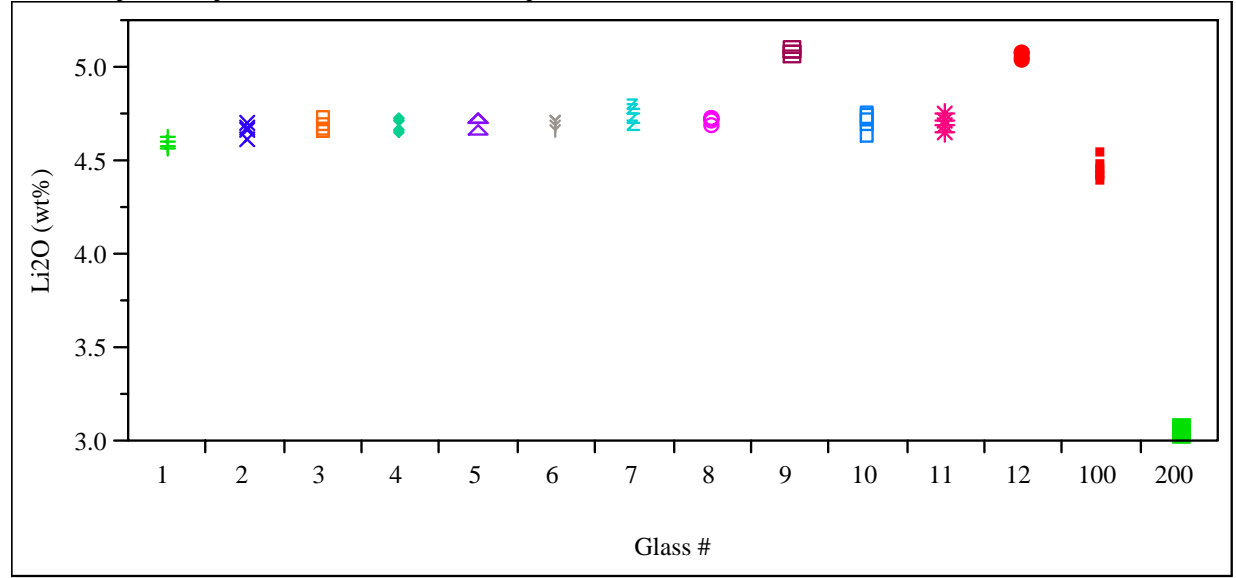

Oneway Analysis of MnO (wt \%) By Glass \#

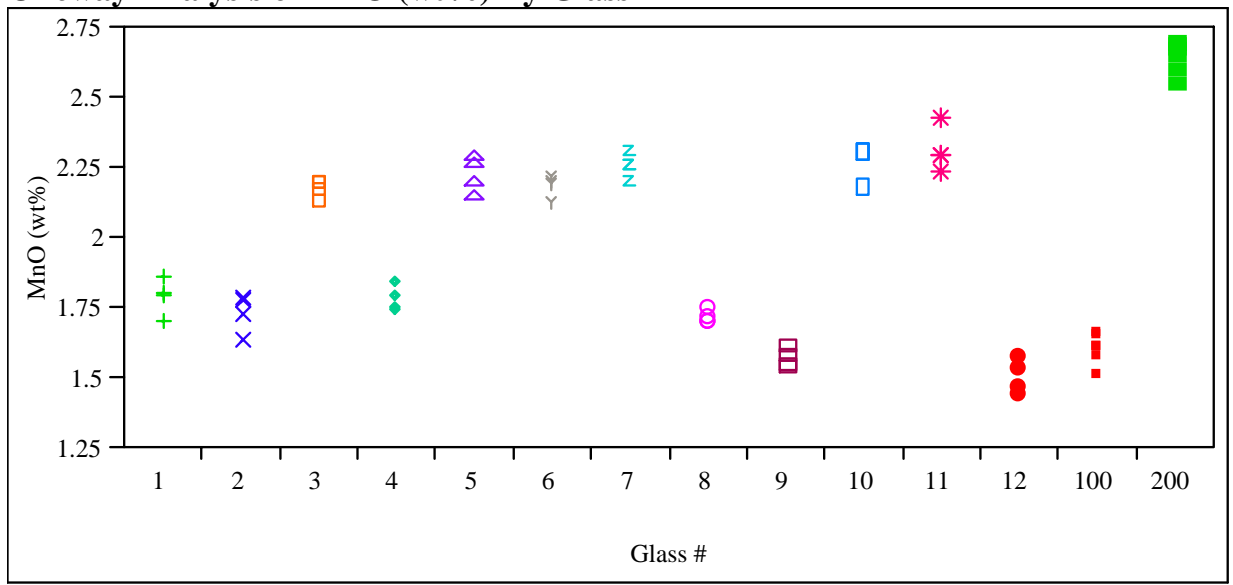

Oneway Analysis of NiO (wt \%) By Glass \#

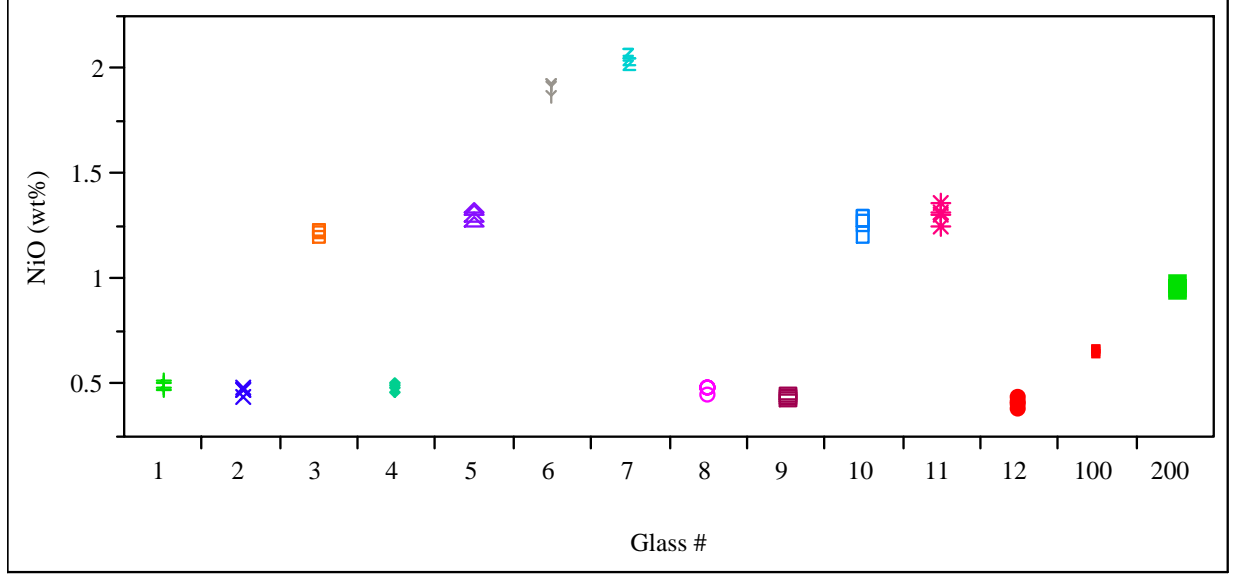


Exhibit C.6: Measured and Measured Bias-Corrected Oxide Weight Percents by Glass \# for the Glasses Prepared Using the PF Method

(100 - Batch 1; $200-$ Ustd)

Oneway Analysis of SiO2 (wt\%) By Glass \#

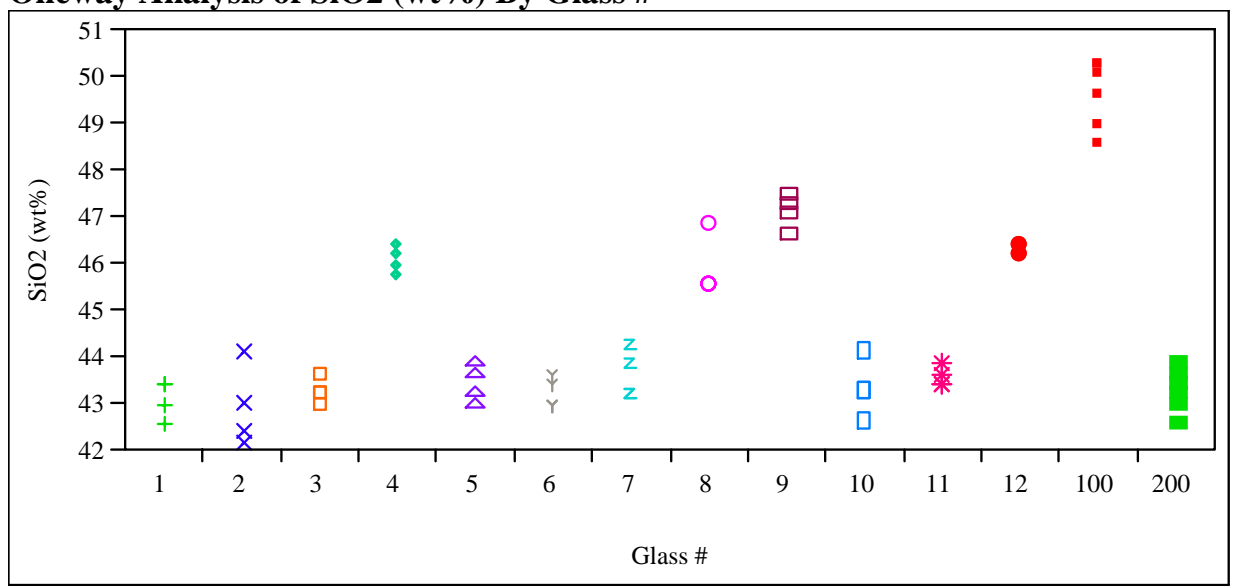

Oneway Analysis of U308 (wt \%) By Glass \#

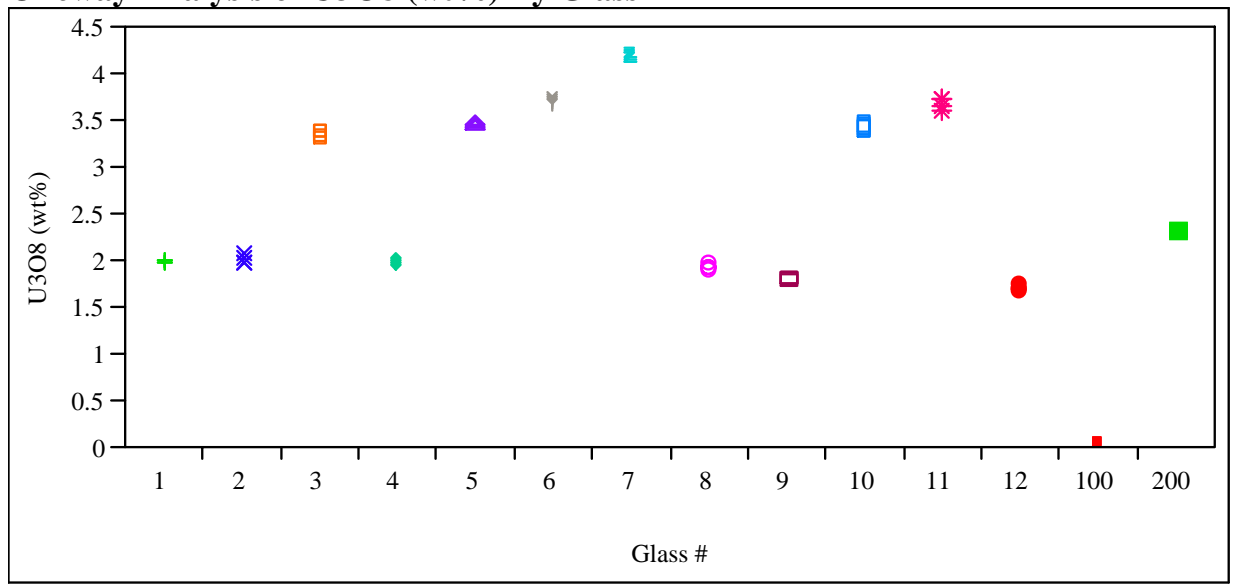

Oneway Analysis of Al2O3 bc (wt\%) By Glass \#

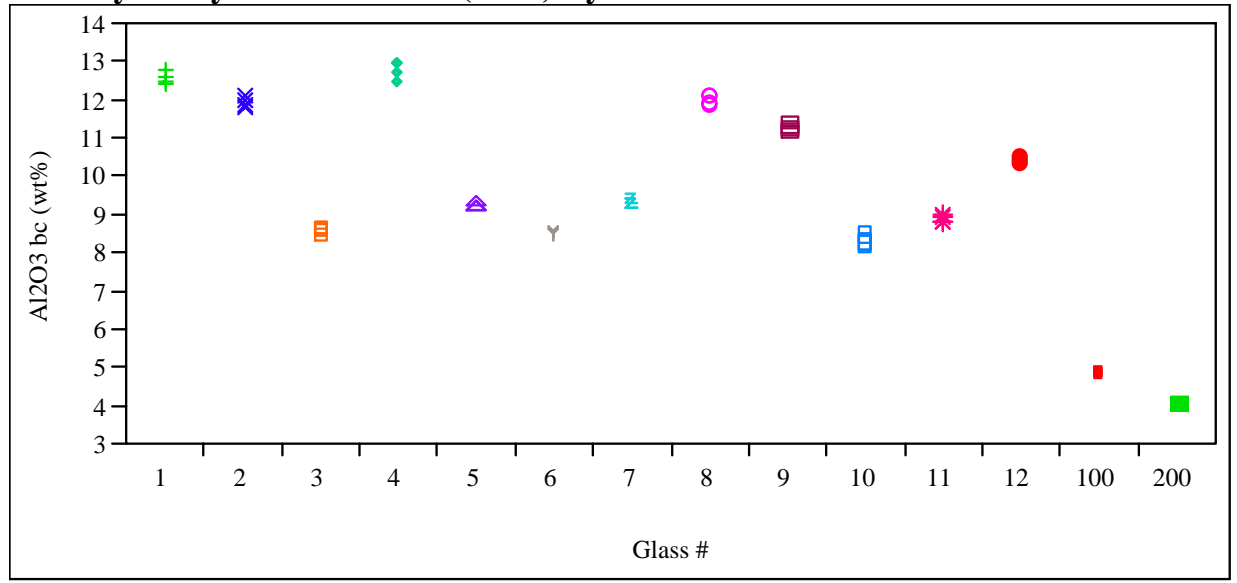


Exhibit C.6: Measured and Measured Bias-Corrected Oxide Weight Percents by Glass \# for the Glasses Prepared Using the PF Method

(100 - Batch 1; 200 - Ustd)

Oneway Analysis of B2O3 bc (wt \%) By Glass \#

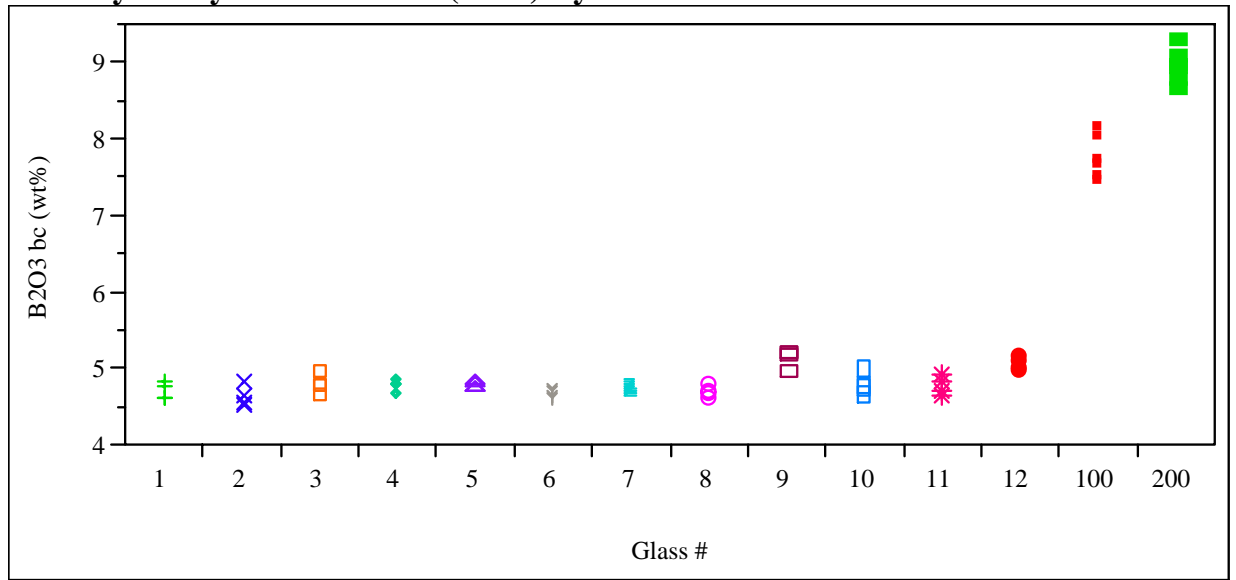

Oneway Analysis of Fe2O3 bc (wt\%) By Glass \#

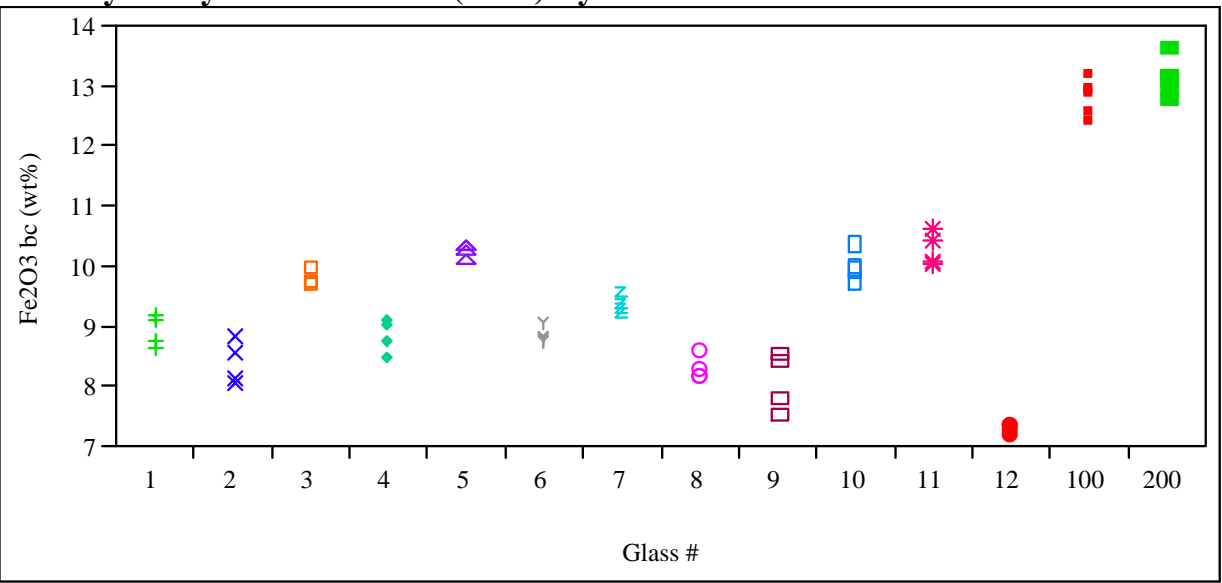

Oneway Analysis of Li2O bc (wt\%) By Glass \#

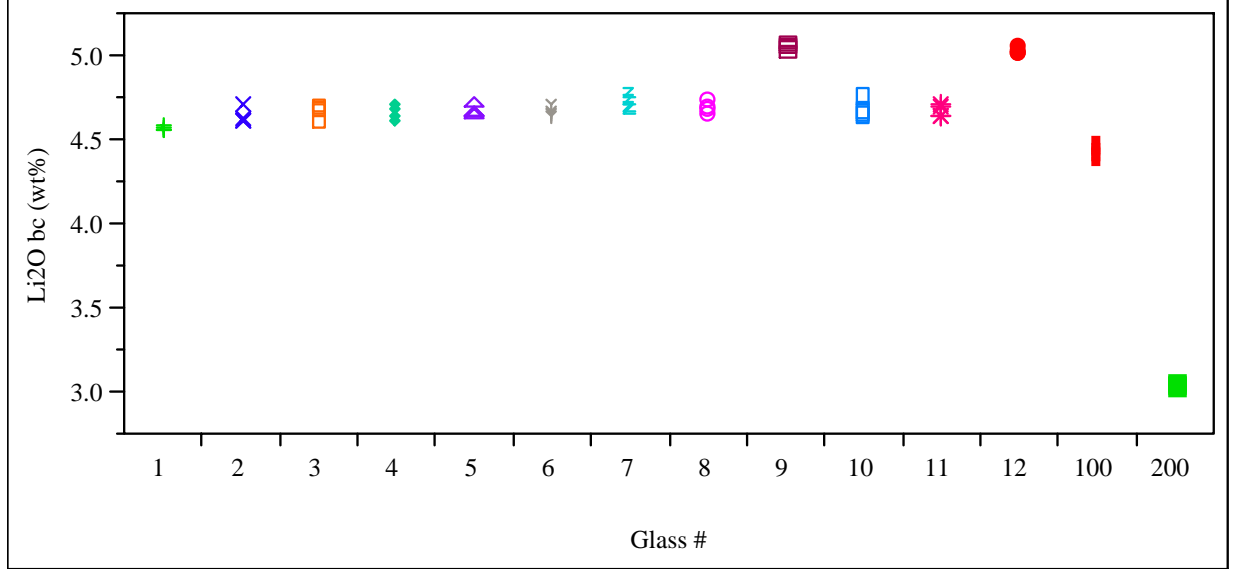


Exhibit C.6: Measured and Measured Bias-Corrected Oxide Weight Percents by Glass \# for the Glasses Prepared Using the PF Method

(100 - Batch 1; 200 - Ustd)

Oneway Analysis of $\mathrm{MnO}$ bc (wt \%) By Glass \#

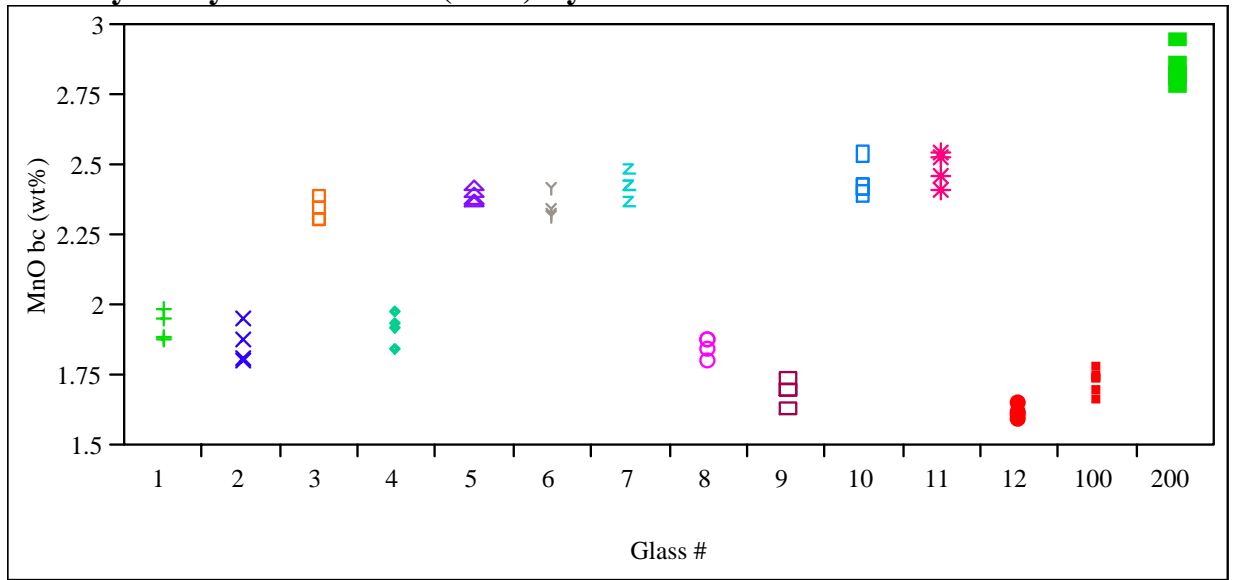

Oneway Analysis of NiO bc (wt \%) By Glass \#

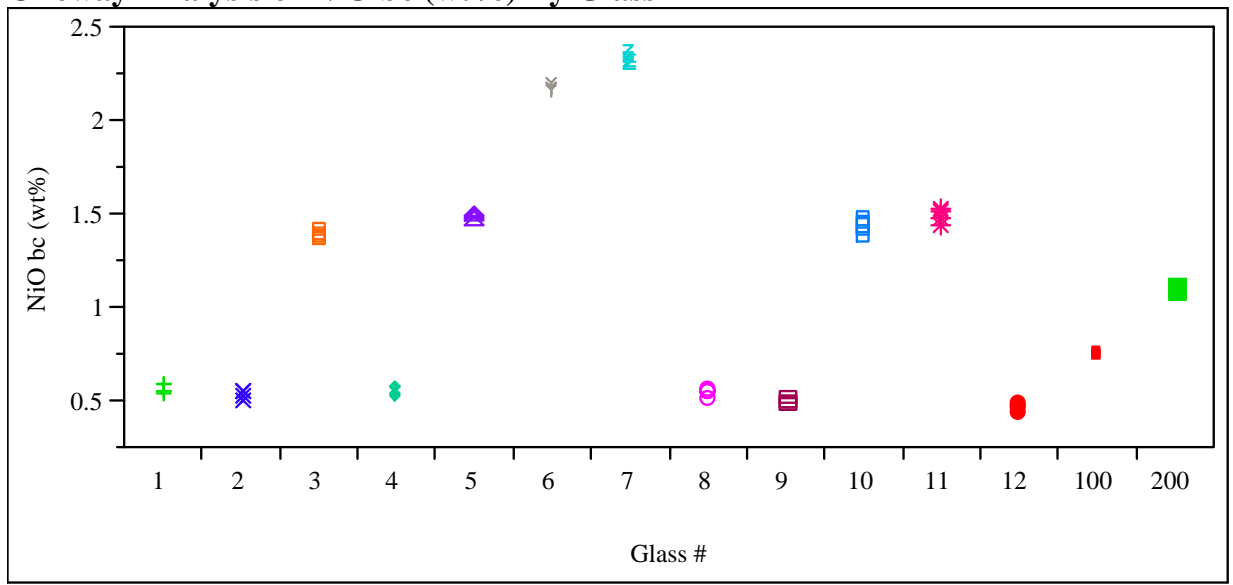

Oneway Analysis of SiO2 bc (wt \%) By Glass \#

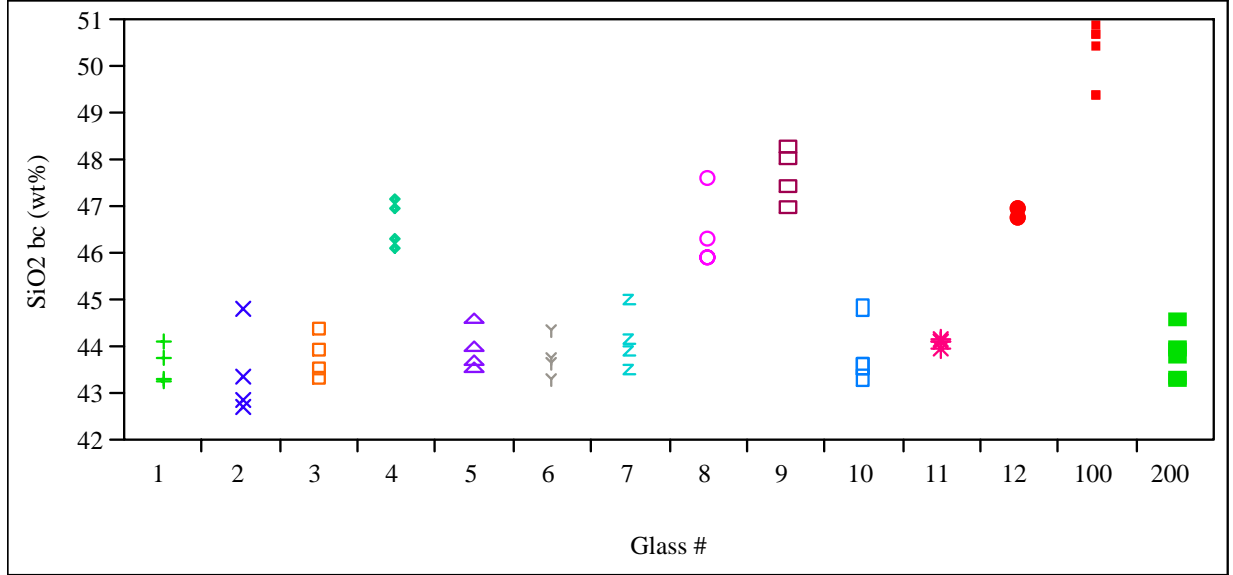


Exhibit C.6: Measured and Measured Bias-Corrected Oxide Weight Percents by Glass \# for the Glasses Prepared Using the PF Method

(100 - Batch 1; $200-$ Ustd)

Oneway Analysis of U3O8 bc (wt\%) By Glass \#

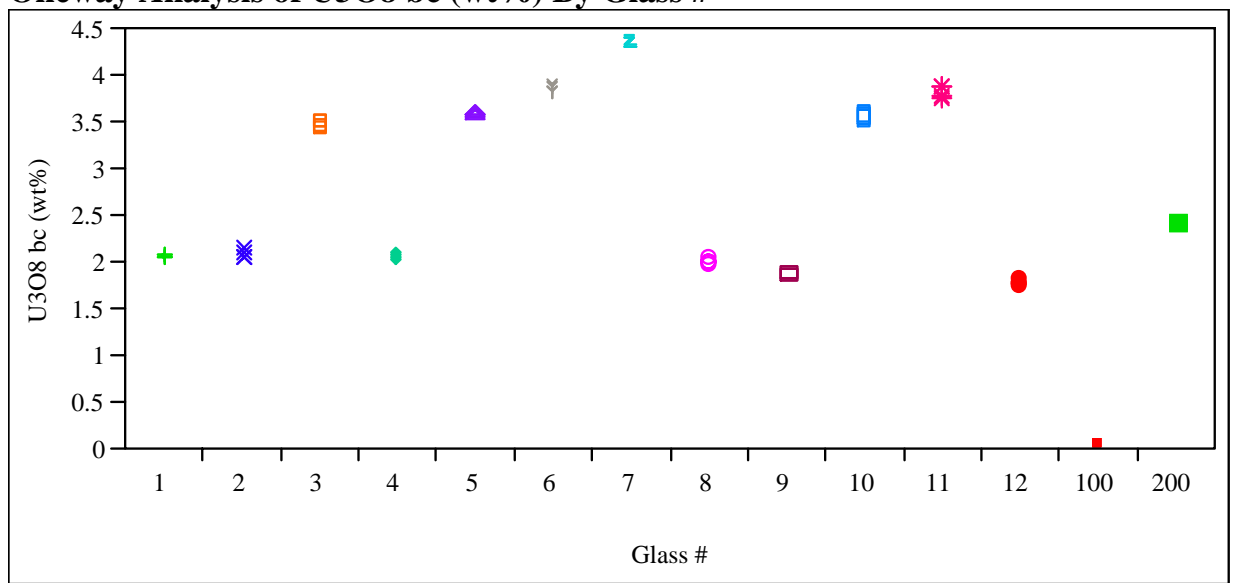


Exhibit C.7: Average Measured and Bias-Corrected (bc) Versus Targeted Compositions by Glass \# by Oxide

(100 - Batch 1; $200-U s t d)$

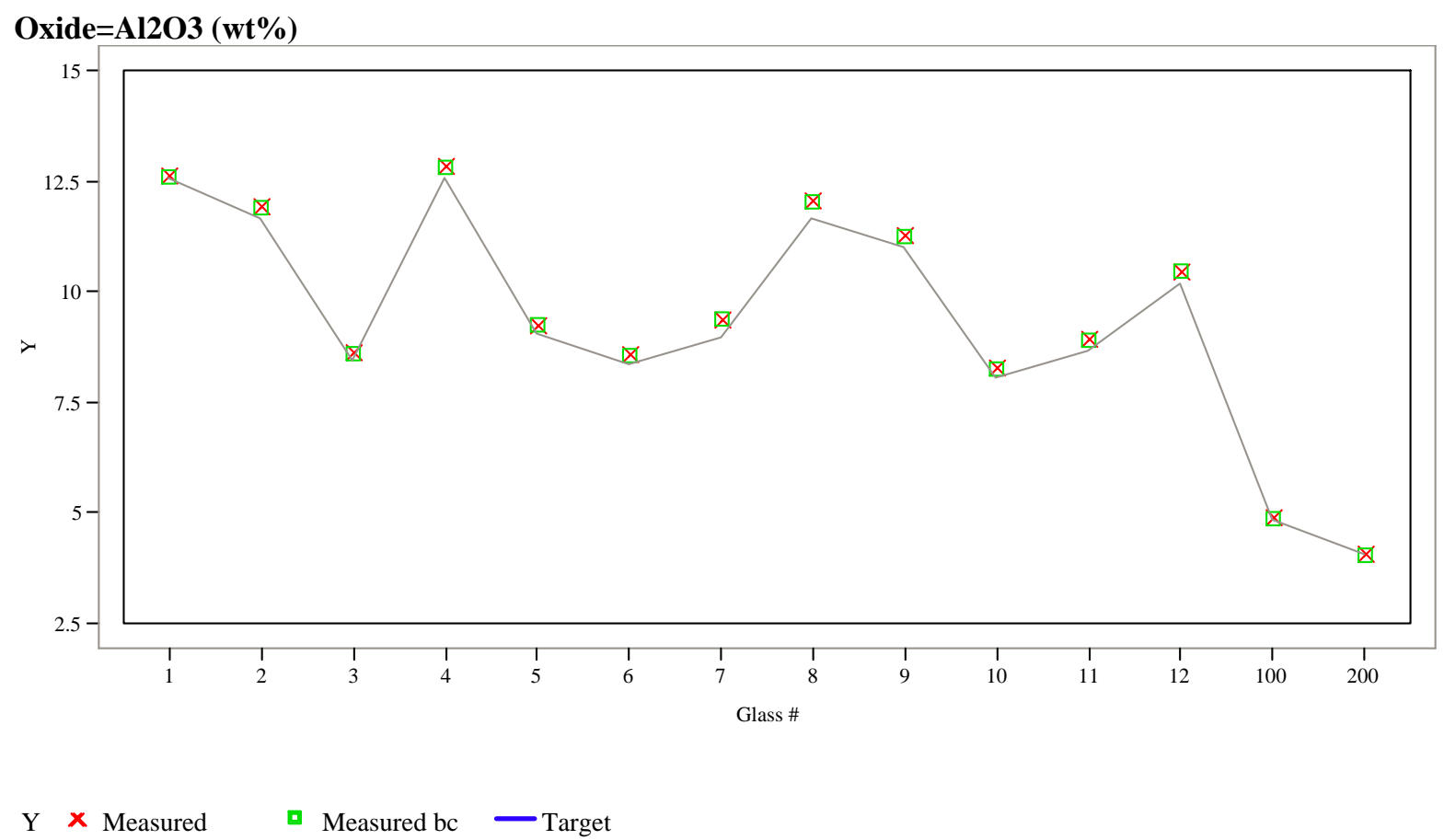

\section{Oxide $=$ B2O3 (wt \%)}

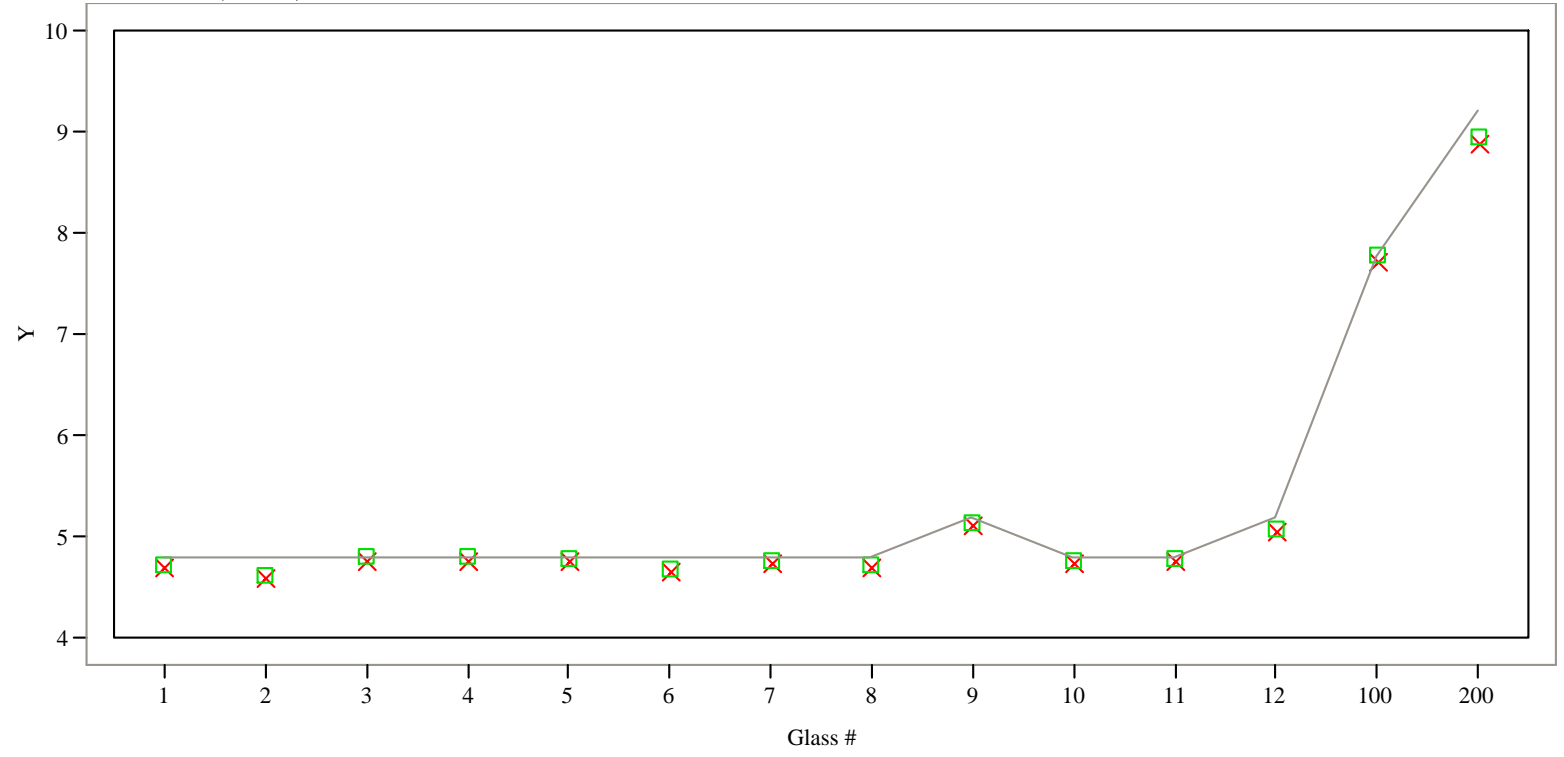

Y $\times$ Measured

- Measured bc - Target 
Exhibit C.7: Average Measured and Bias-Corrected (bc) Versus Targeted Compositions by Glass \# by Oxide

(100 - Batch 1; $200-U s t d)$
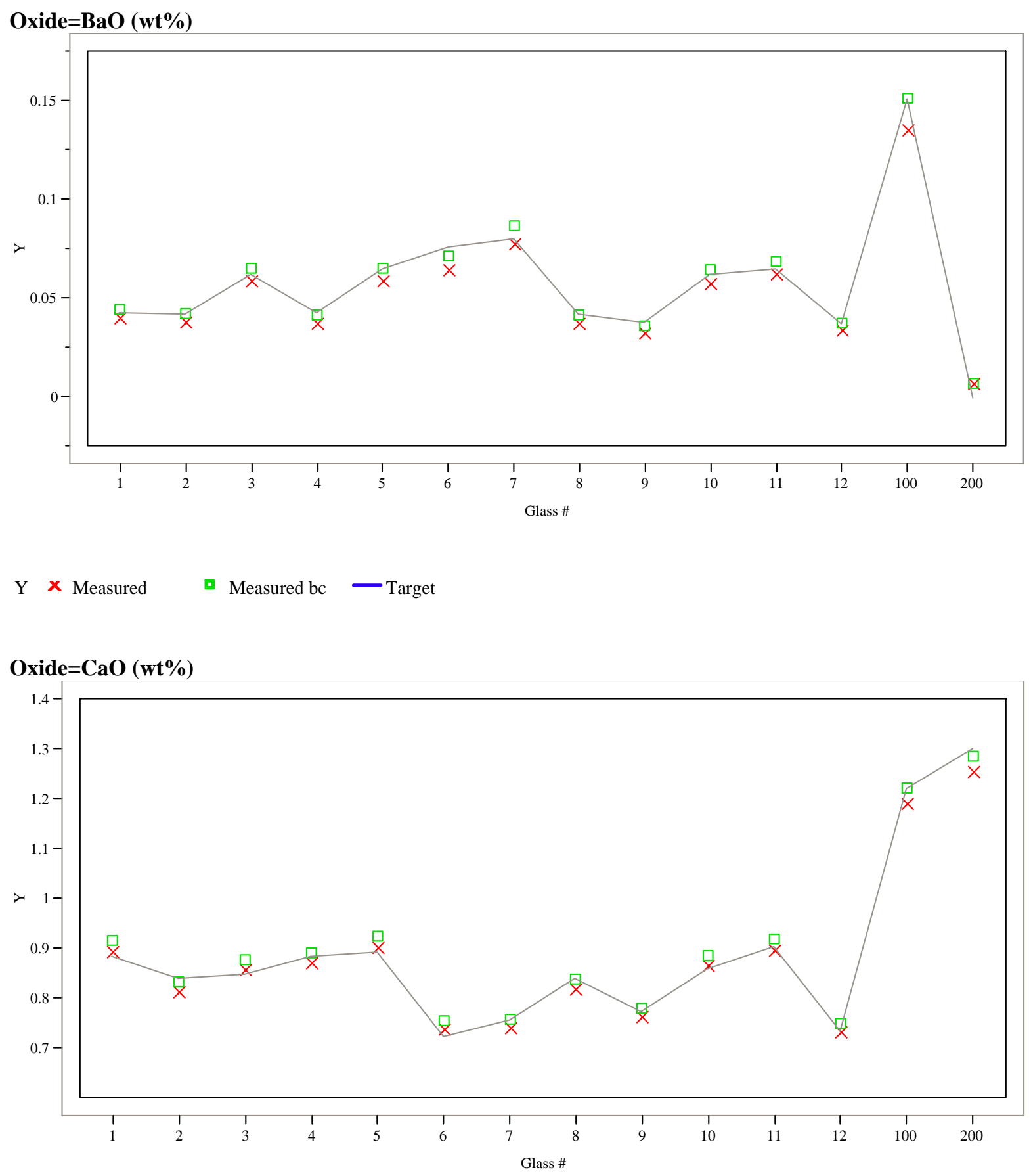

Y $\times$ Measured

- Measured bc Target 
Exhibit C.7: Average Measured and Bias-Corrected (bc) Versus Targeted Compositions by Glass \# by Oxide

(100 - Batch 1; $200-$ Ustd)

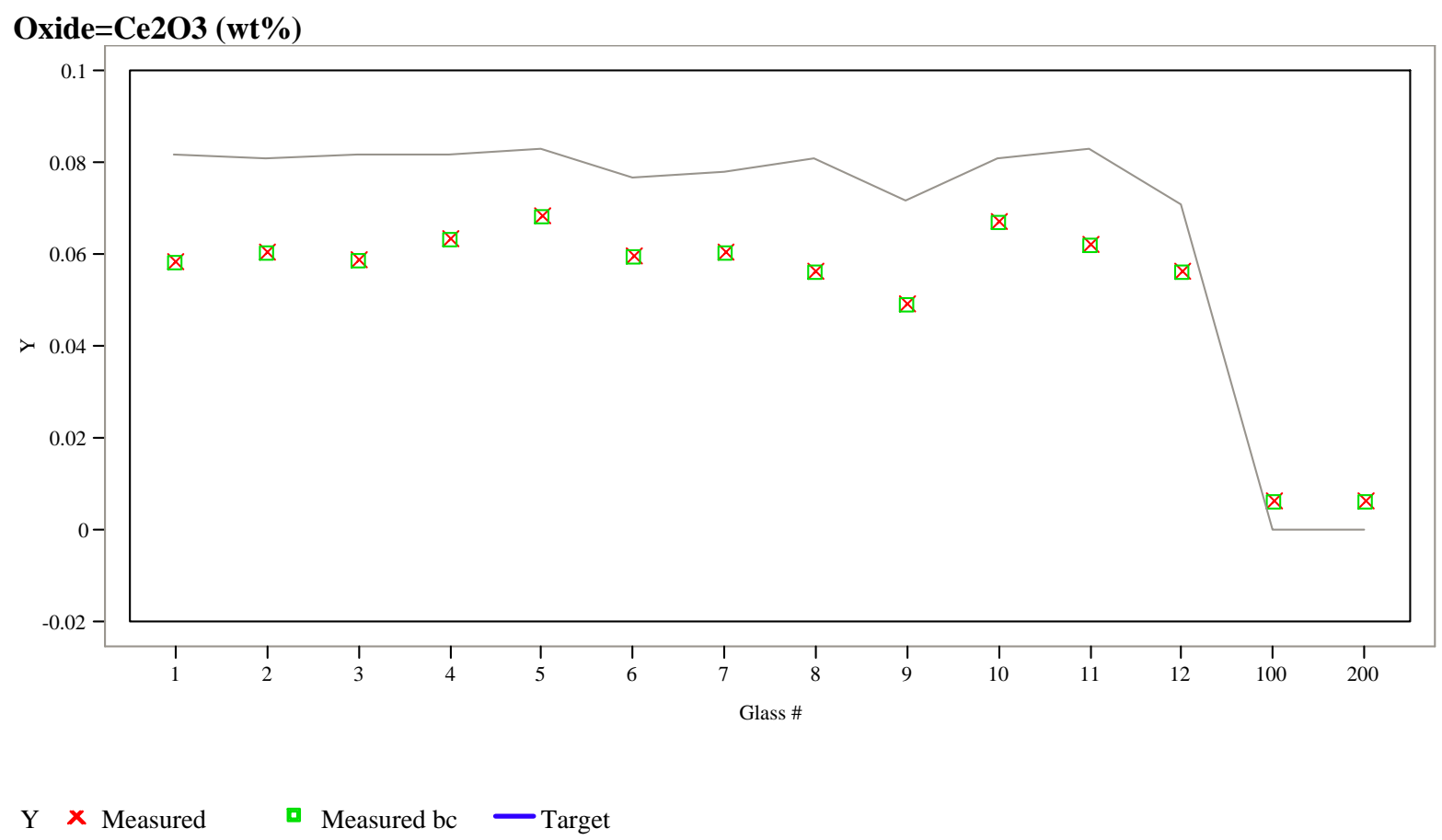

\section{Oxide $=\mathrm{Cr} 2 \mathrm{O} 3(\mathrm{wt} \%)$}

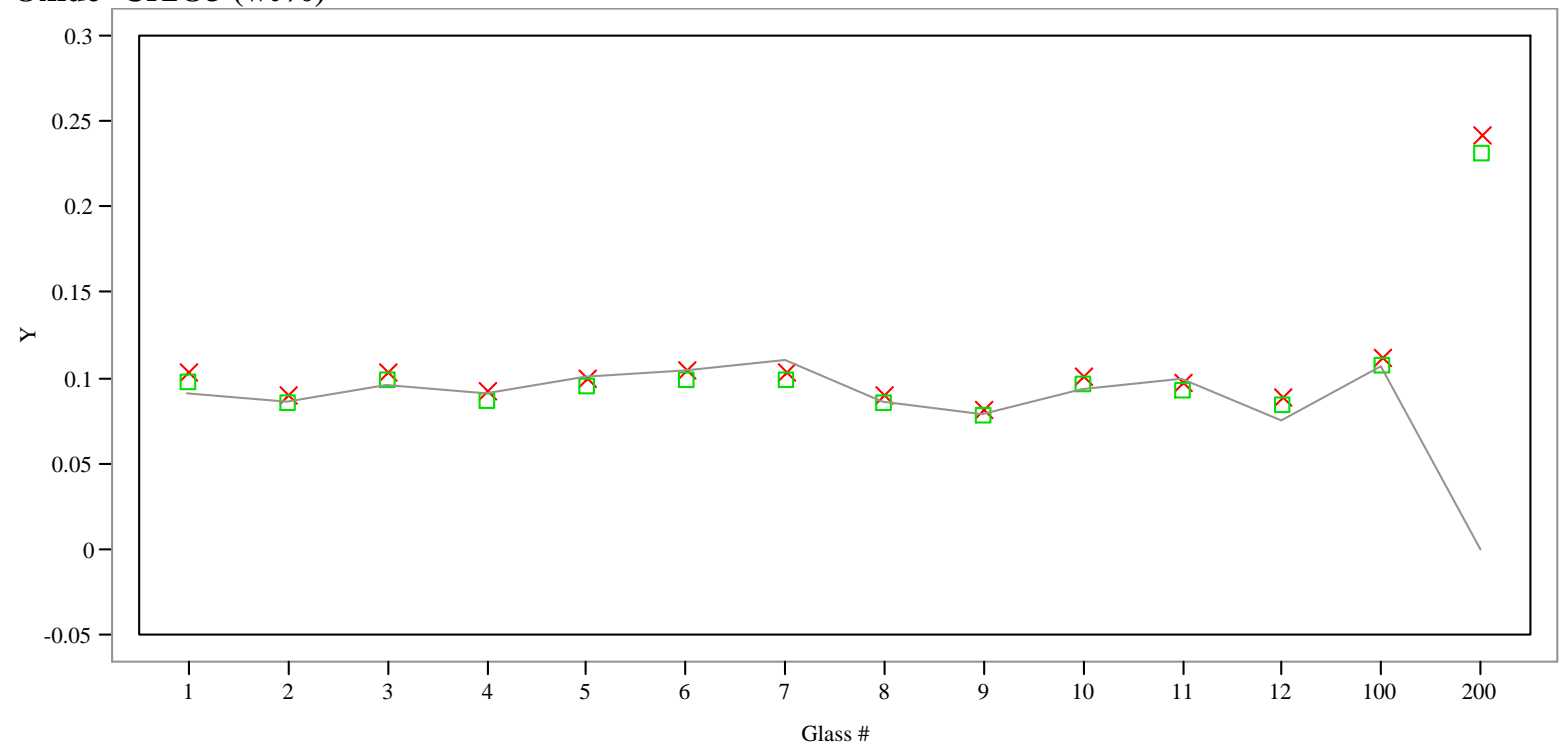

Y $\times$ Measured

- Measured bc — Target 
Exhibit C.7: Average Measured and Bias-Corrected (bc) Versus Targeted Compositions by Glass \# by Oxide

(100 - Batch 1; $200-$ Ustd)

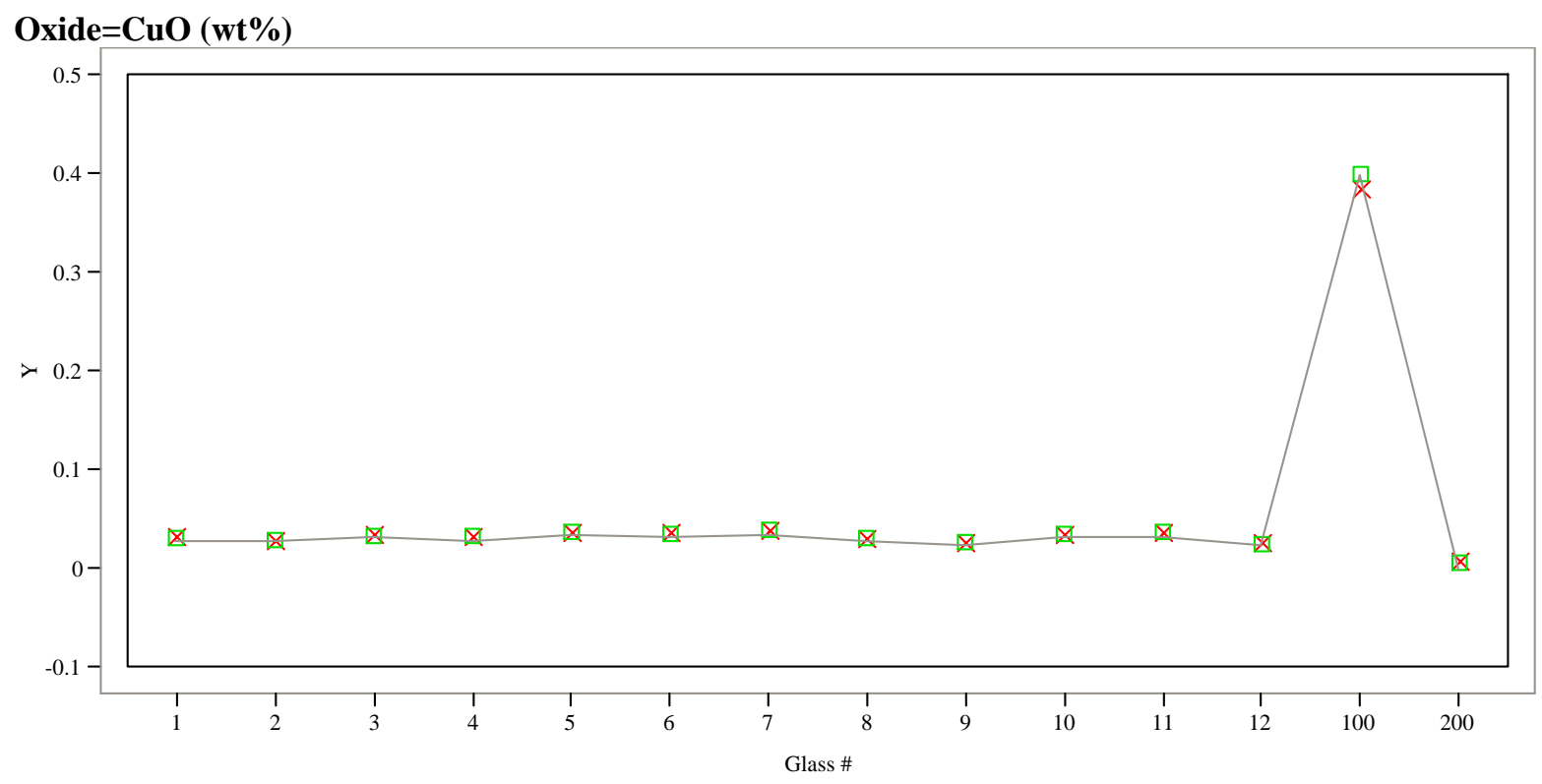

$\mathrm{Y} \times$ Measured $\quad$ Measured bc Target

\section{Oxide=Fe2O3 (wt \%)}

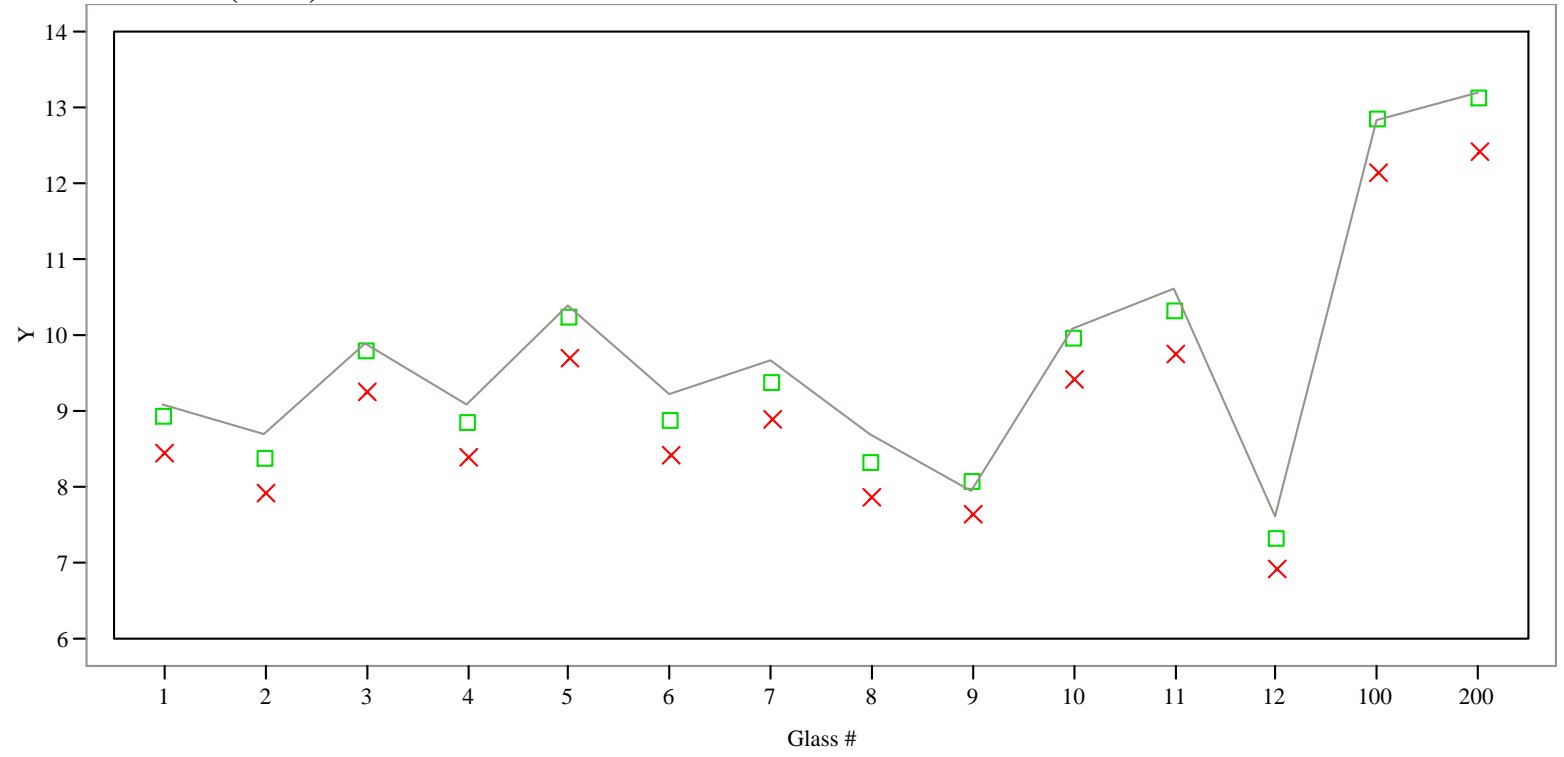

Y X Measured

- Measured bc - Target 
Exhibit C.7: Average Measured and Bias-Corrected (bc) Versus Targeted Compositions by Glass \# by Oxide

(100 - Batch 1; $200-$ Ustd)

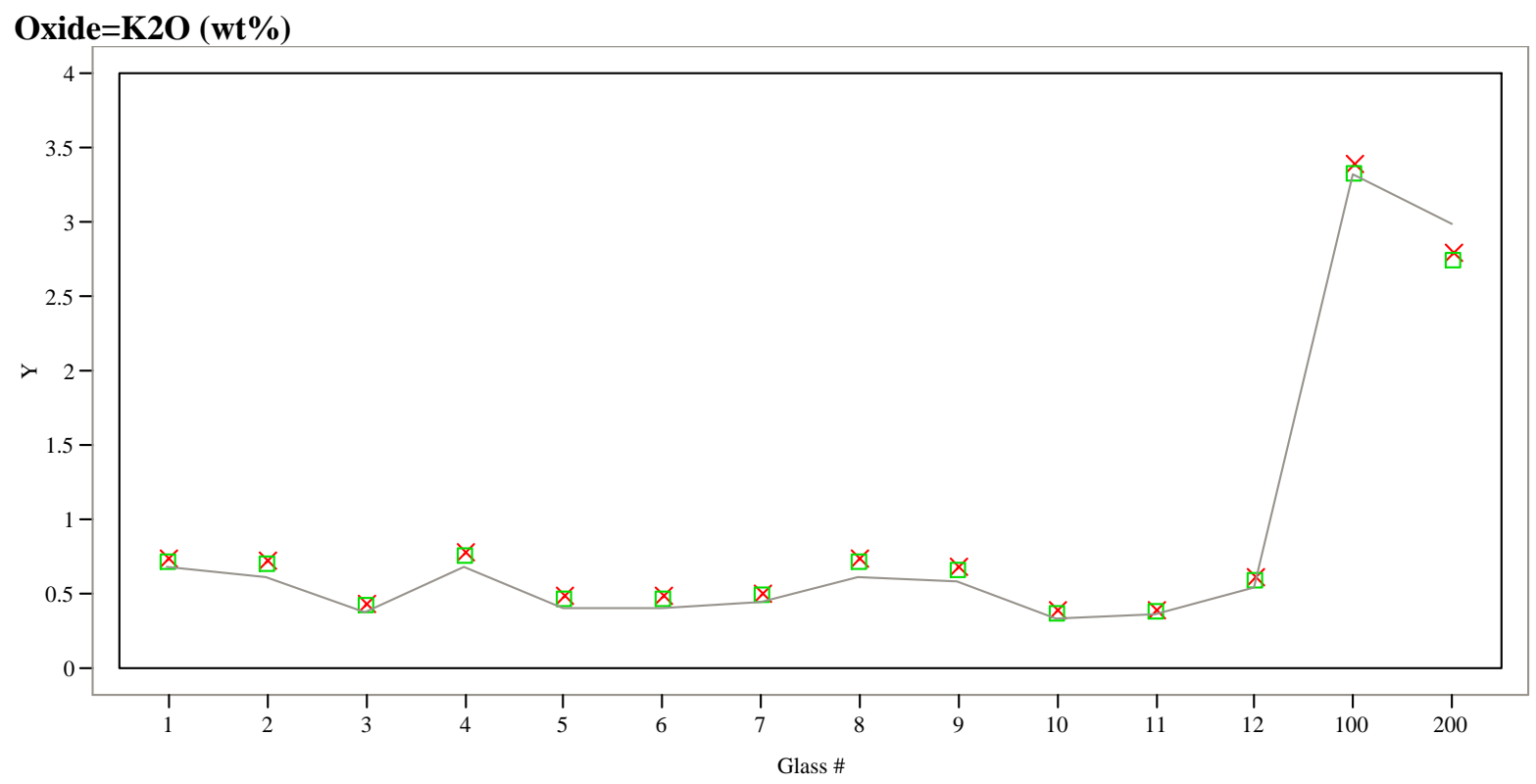

$\mathrm{Y} \times$ Measured $\square$ Measured bc - Target

Oxide $=$ La2O3 (wt\%)

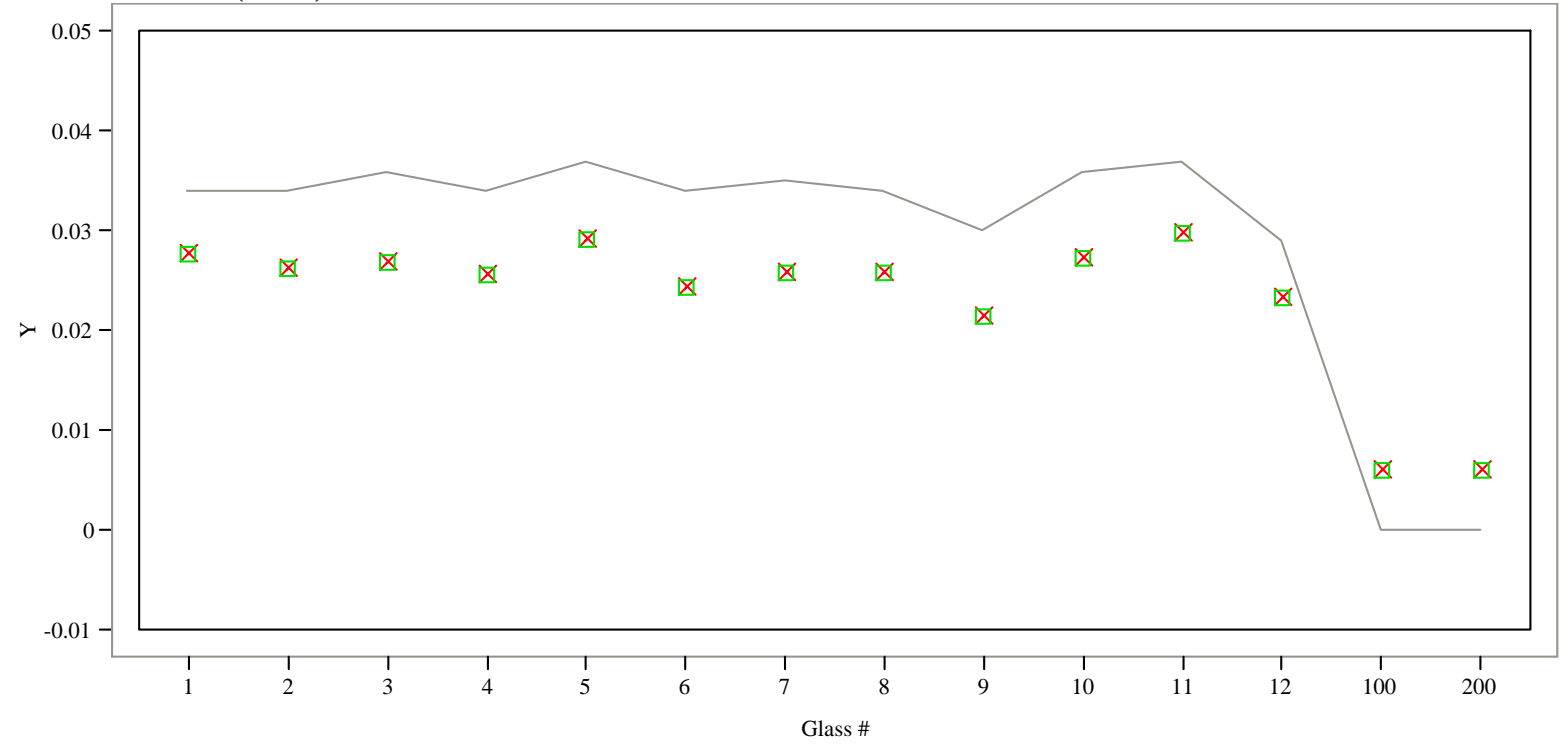

Y $\times$ Measured $\square$ Measured bc - Target 
Exhibit C.7: Average Measured and Bias-Corrected (bc) Versus Targeted Compositions by Glass \# by Oxide

(100 - Batch 1; $200-$ Ustd)

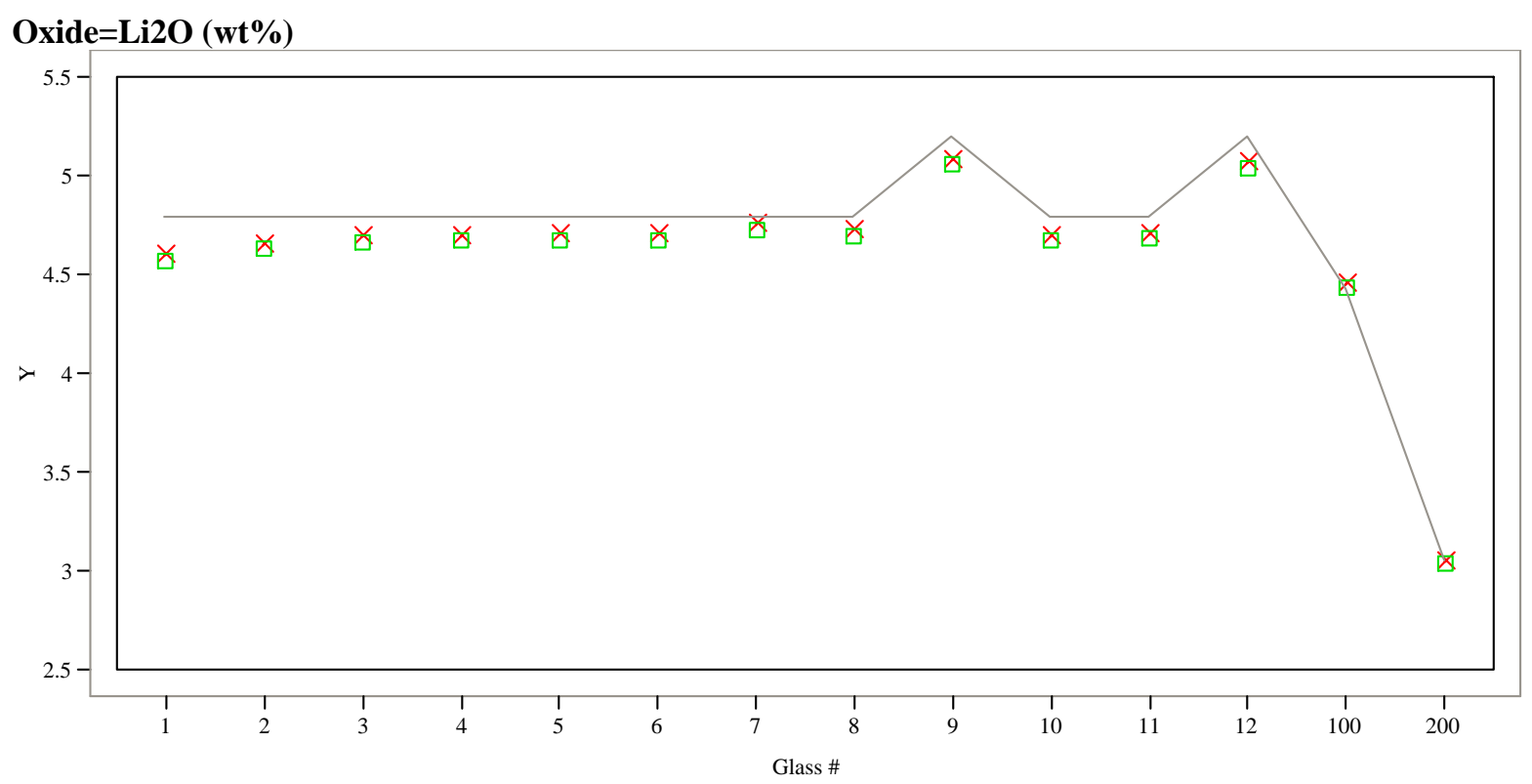

$\mathrm{Y} \times$ Measured $\square$ Measured bc - Target

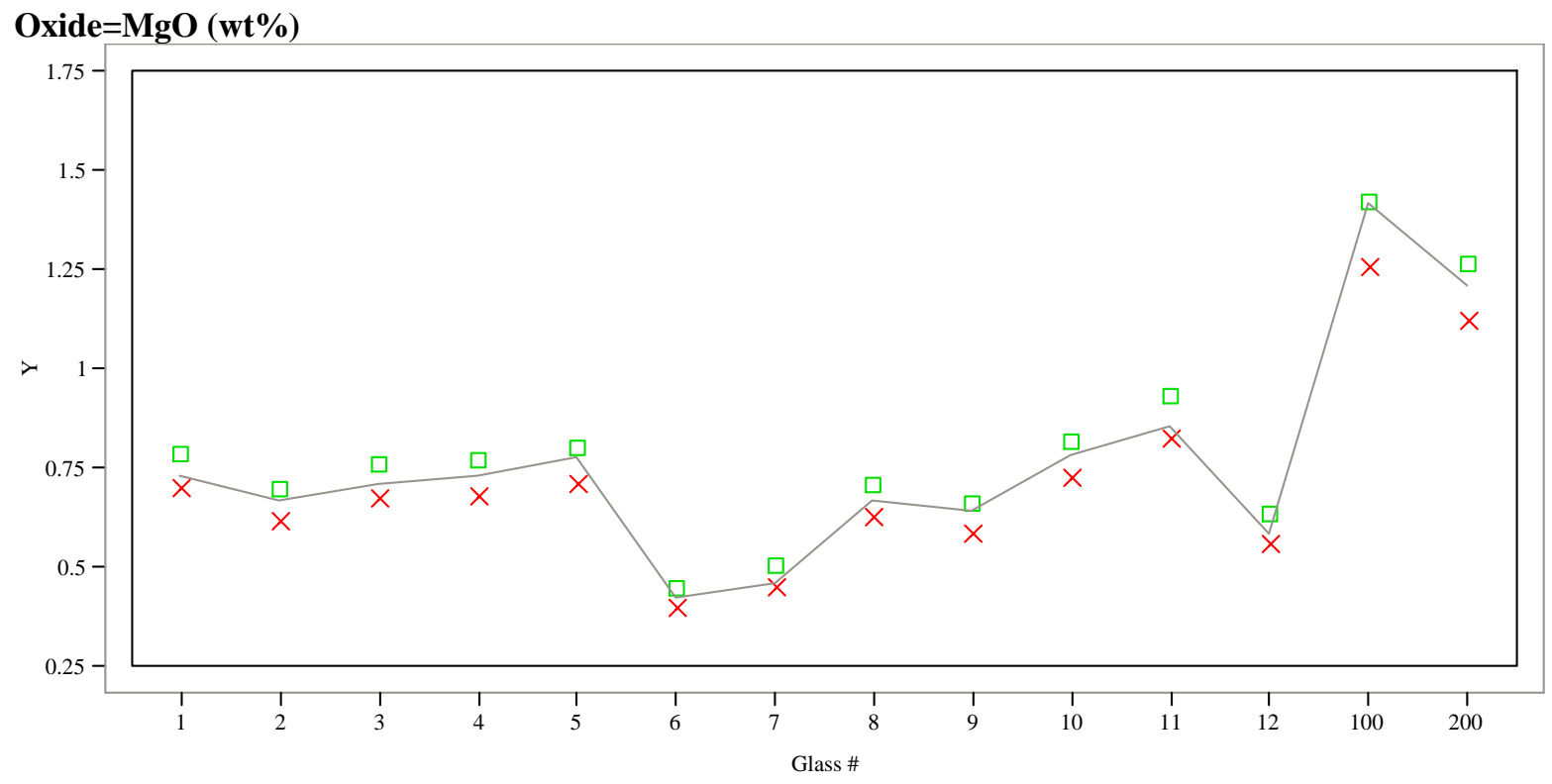

Y $\times$ Measured

- Measured bc Target 
Exhibit C.7: Average Measured and Bias-Corrected (bc) Versus Targeted Compositions by Glass \# by Oxide

(100 - Batch 1; $200-$ Ustd)

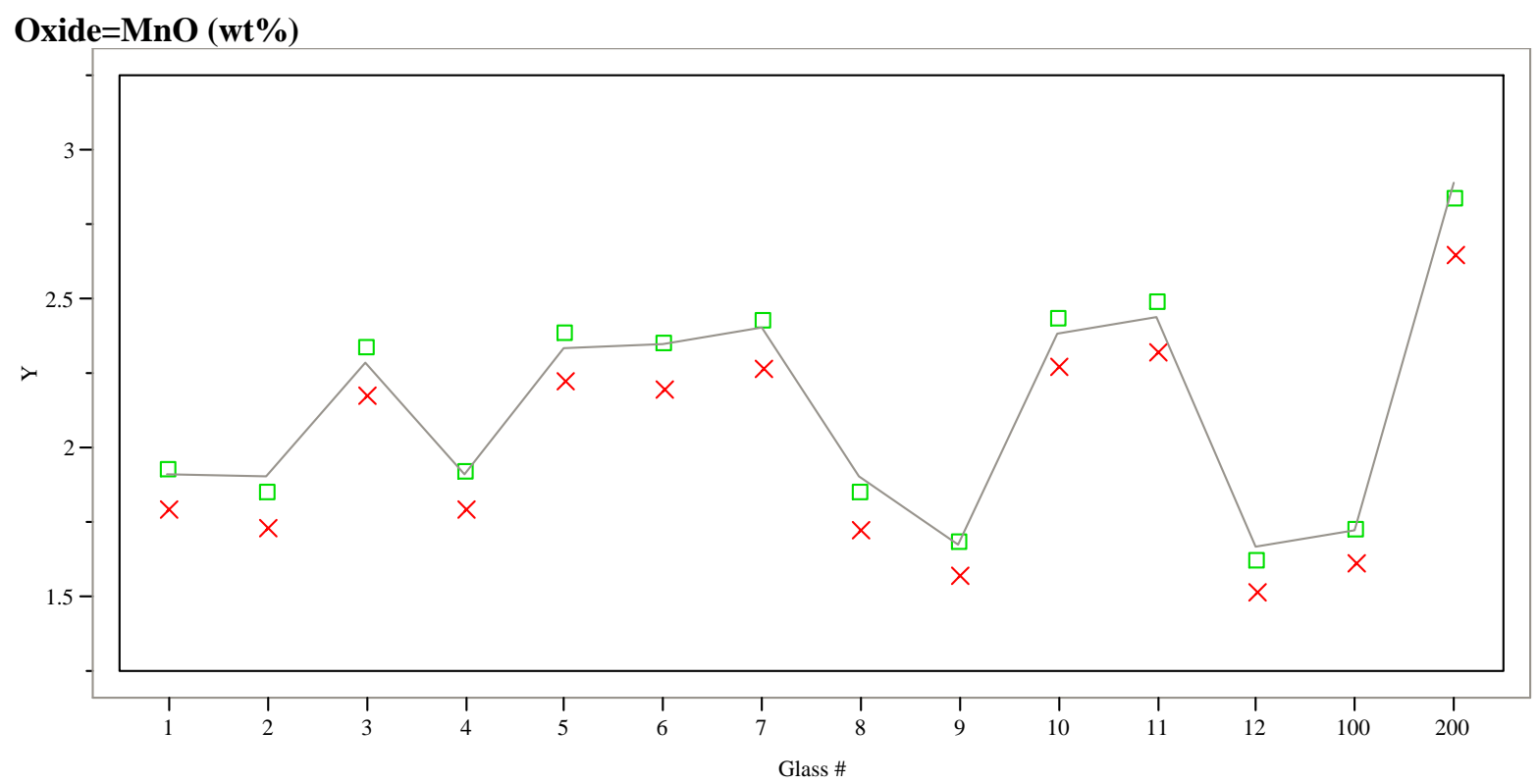

$\mathrm{Y} \times$ Measured $\square$ Measured bc - Target

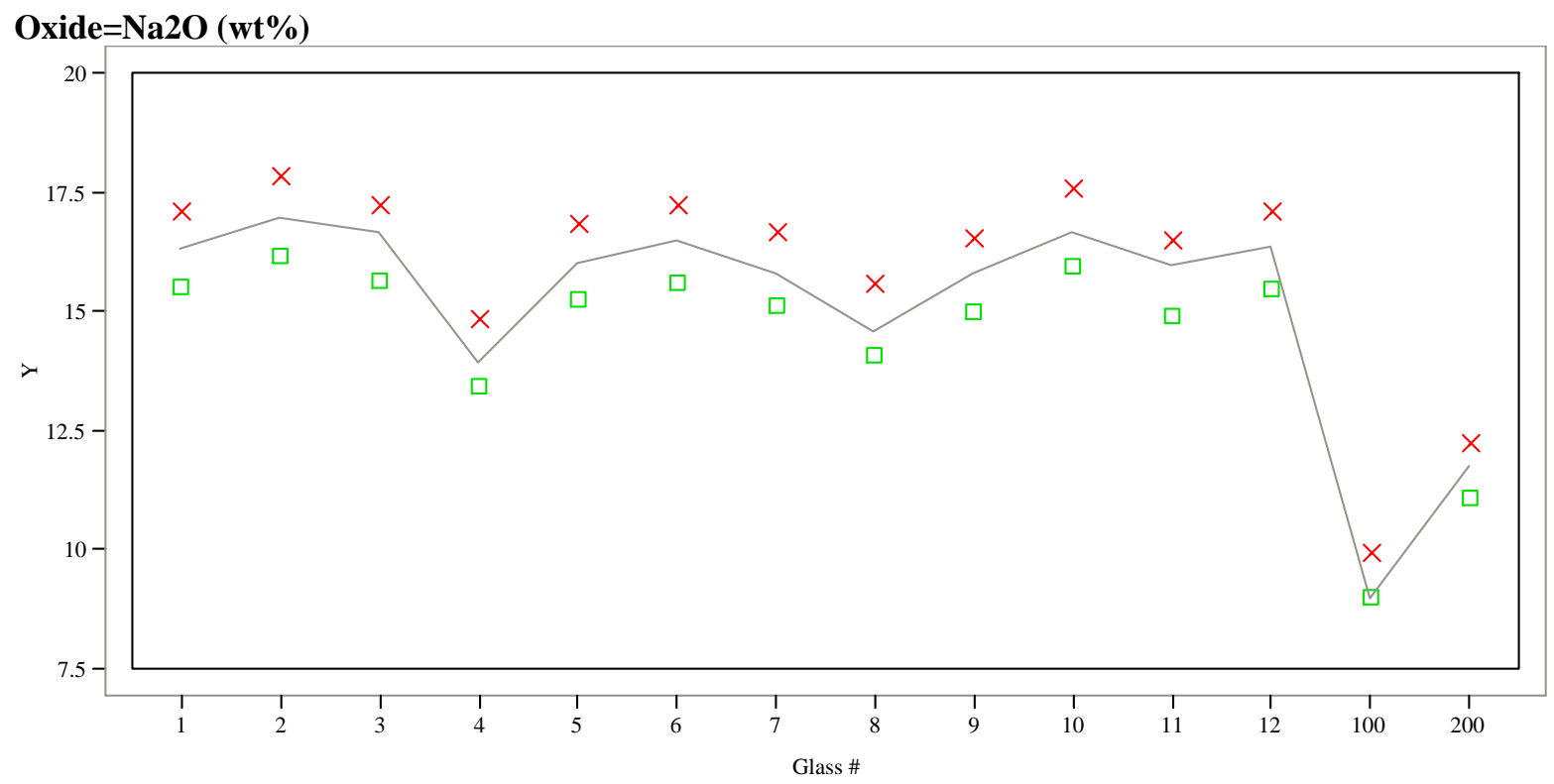

Y $\times$ Measured

- Measured bc - Target 
Exhibit C.7: Average Measured and Bias-Corrected (bc) Versus Targeted Compositions by Glass \# by Oxide

(100 - Batch 1; $200-$ Ustd)

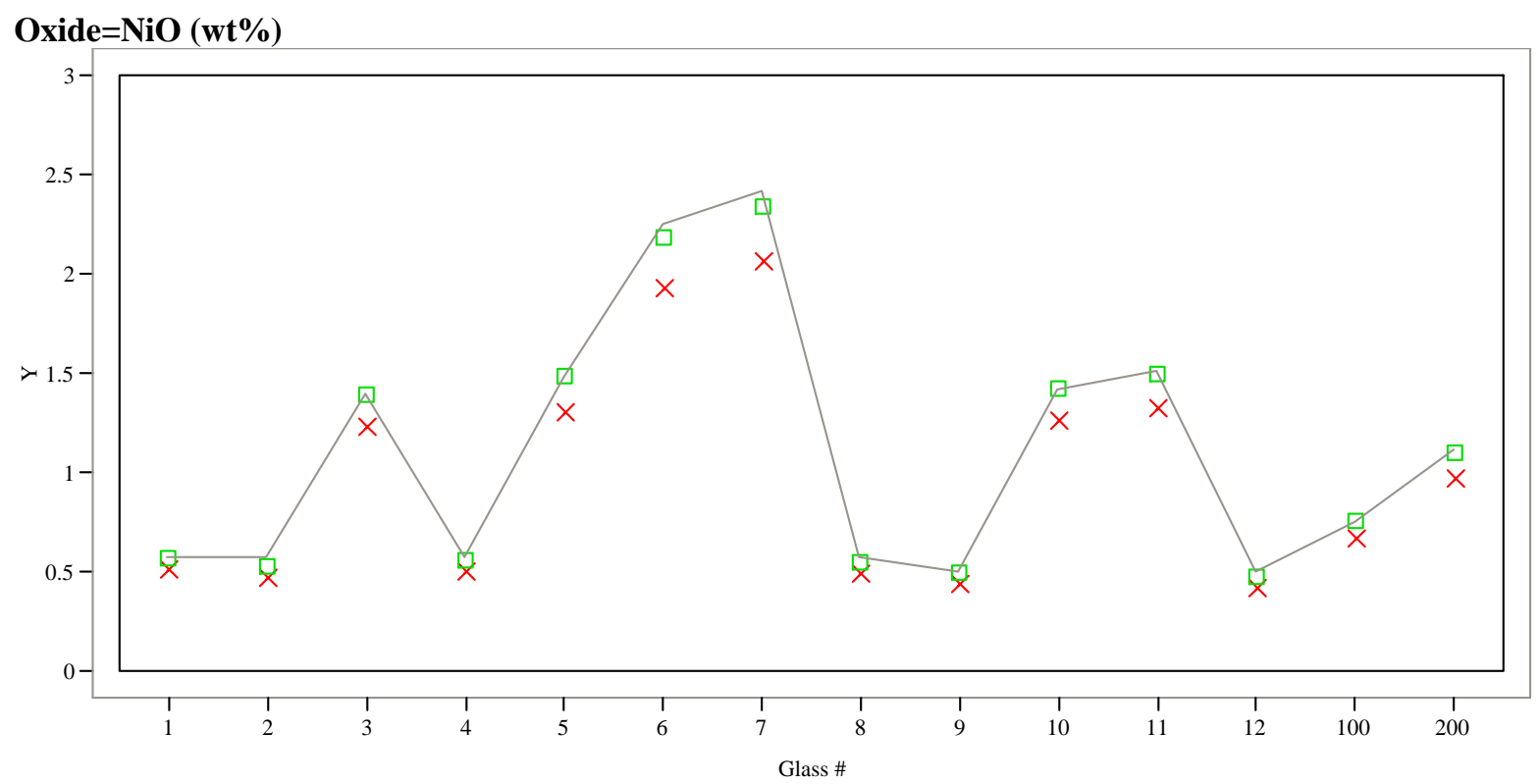

$\mathrm{Y} \times$ Measured $\square$ Measured bc - Target

\section{Oxide=PbO (wt \%)}

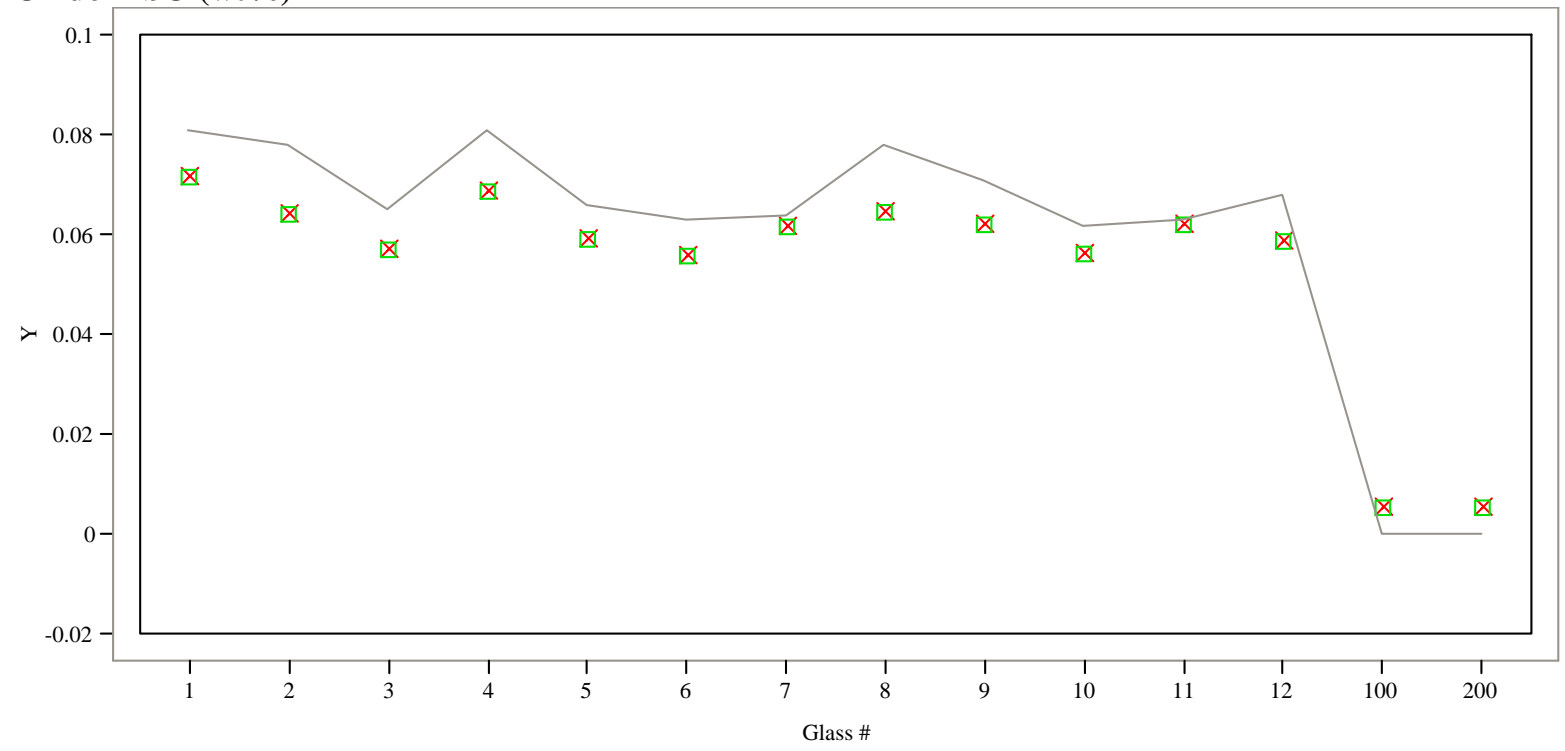

Y X Measured

- Measured bc - Target 
Exhibit C.7: Average Measured and Bias-Corrected (bc) Versus Targeted Compositions by Glass \# by Oxide

(100 - Batch 1; $200-$ Ustd)

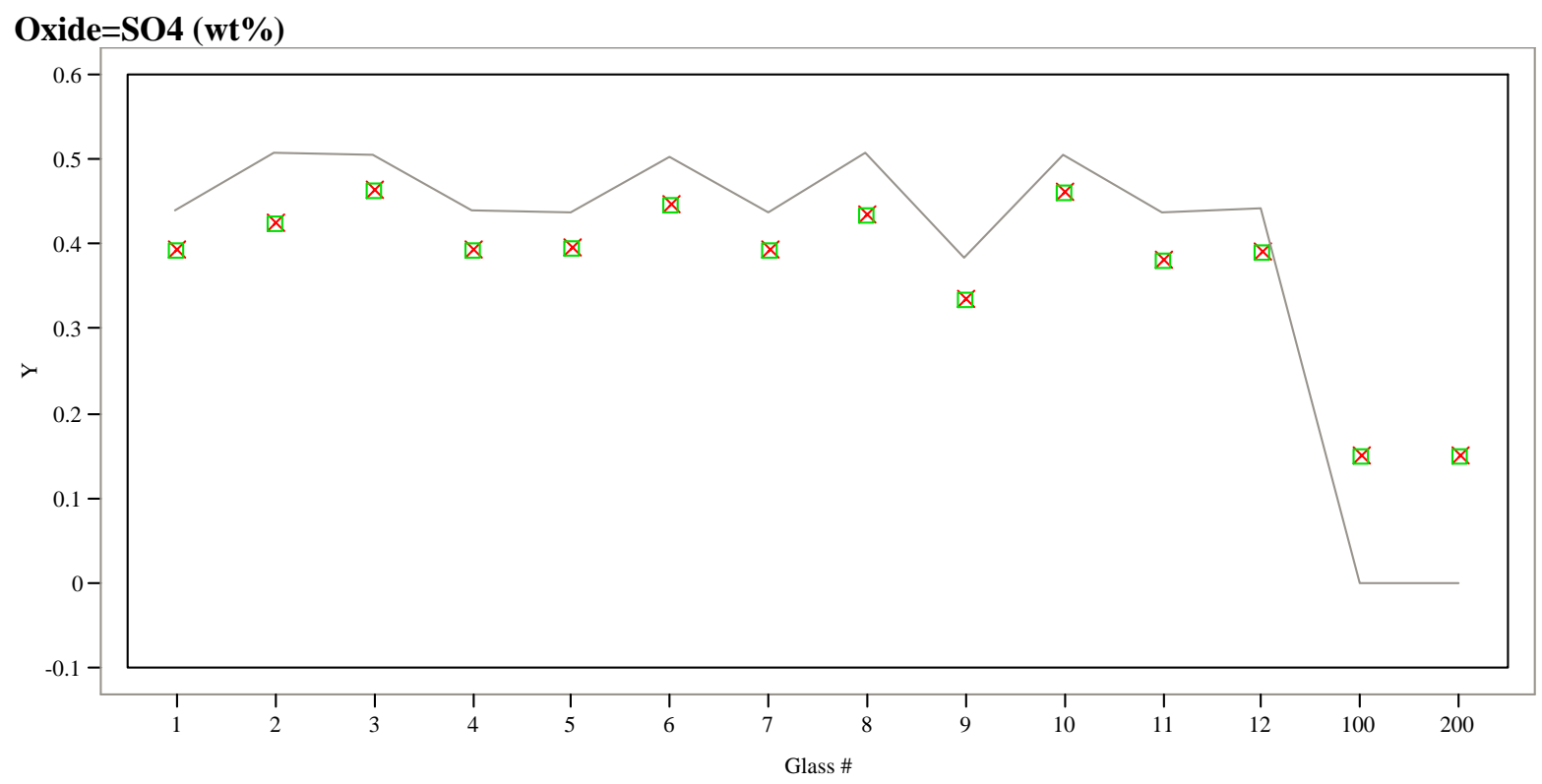

$\mathrm{Y} \times$ Measured $\square$ Measured bc - Target

Oxide $=\mathrm{SiO} 2($ wt $\%)$

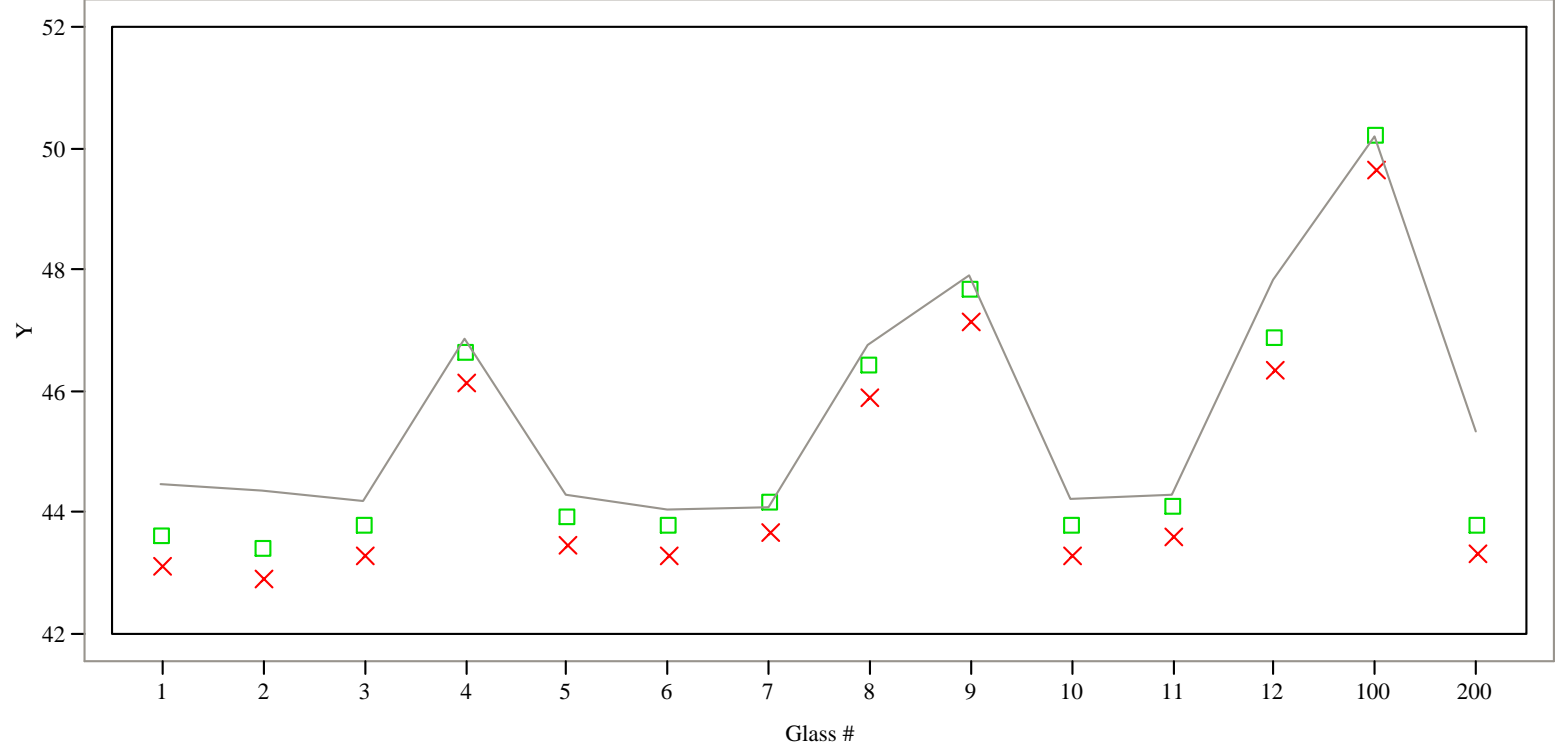

Y $\times$ Measured

- Measured bc - Target 
Exhibit C.7: Average Measured and Bias-Corrected (bc) Versus Targeted Compositions by Glass \# by Oxide

(100 - Batch 1; $200-U s t d)$
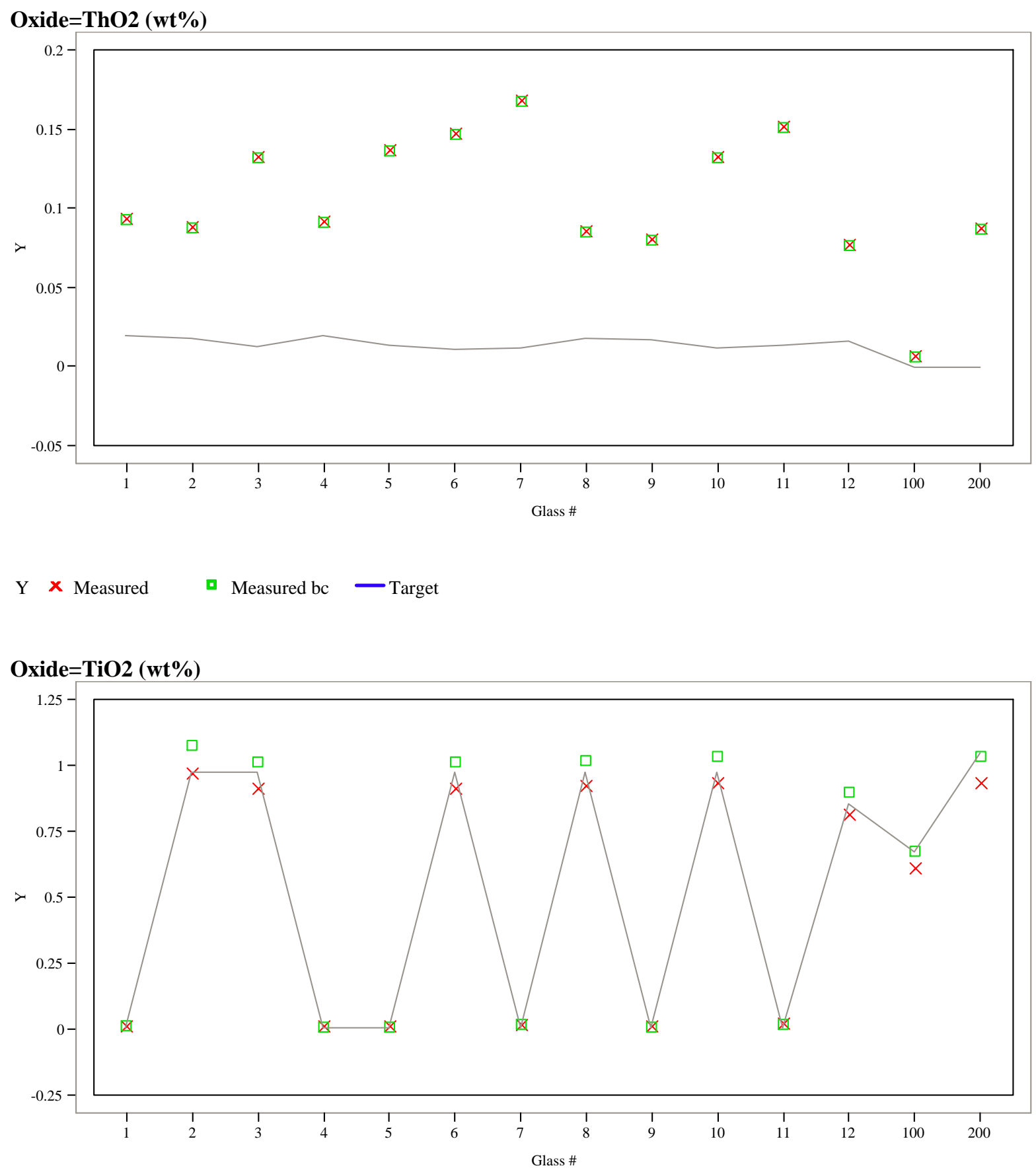

Y X Measured

- Measured bc — Target 
Exhibit C.7: Average Measured and Bias-Corrected (bc) Versus Targeted Compositions by Glass \# by Oxide

(100 - Batch 1; $200-$ Ustd)

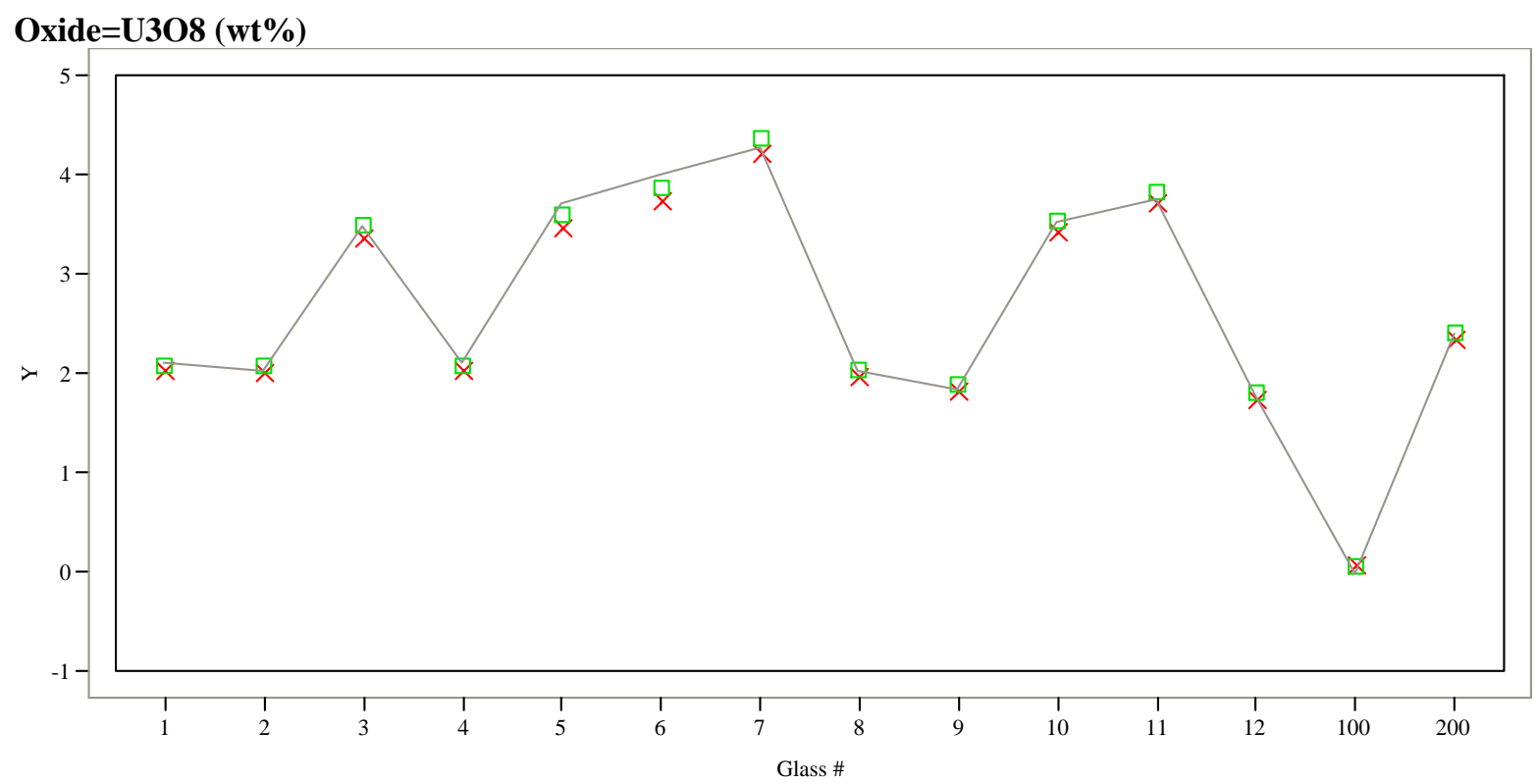

$\mathrm{Y} \times$ Measured $\square$ Measured bc - Target

\section{Oxide $=\mathrm{ZnO}(\mathrm{wt} \%)$}

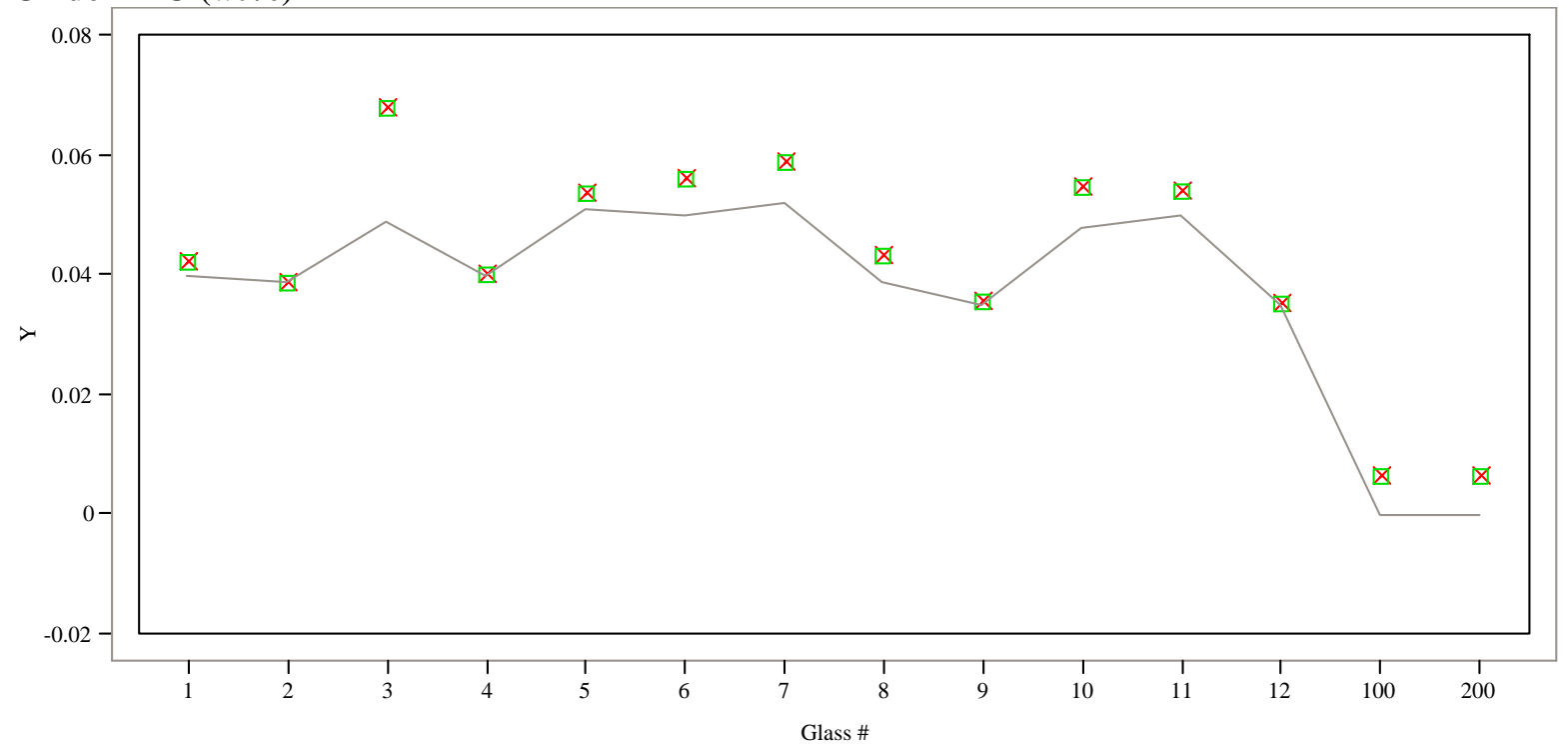

Y X Measured

- Measured bc - Target 
Exhibit C.7: Average Measured and Bias-Corrected (bc) Versus Targeted Compositions by Glass \# by Oxide

(100 - Batch 1; $200-$ Ustd)
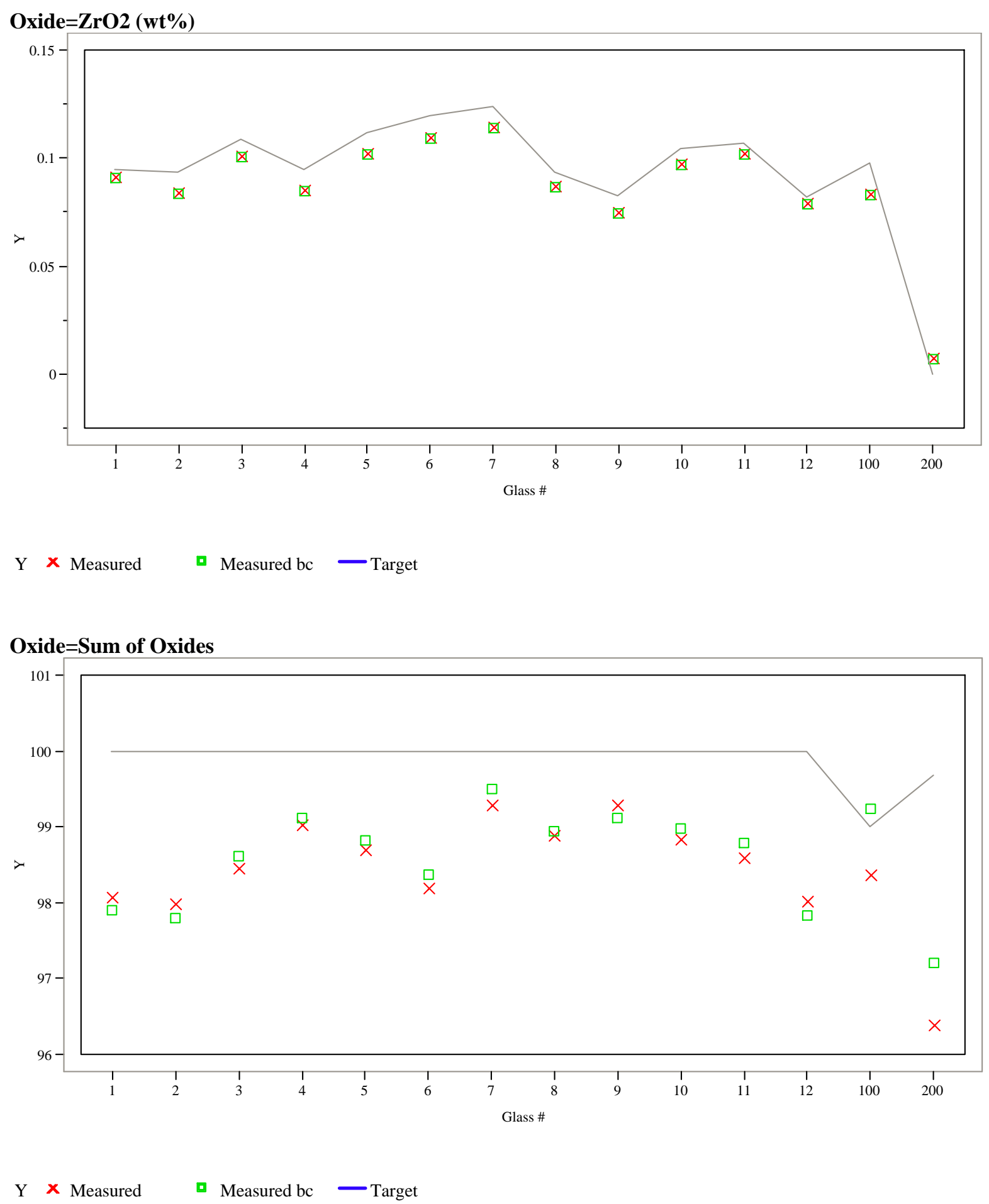


\section{APPENDIX D}

Tables and Exhibits Supporting the Analysis of the PCT Results for the Nepheline Study Glasses 
Table D.1: SRNL-ML Measurements of the PCT Solutions for the Nepheline Study Glasses

\begin{tabular}{|c|c|c|c|c|c|c|c|c|c|c|c|c|c|c|c|}
\hline \multirow[b]{2}{*}{ Glass ID } & \multirow[b]{2}{*}{$\begin{array}{c}\text { Heat } \\
\text { Treatment }\end{array}$} & \multirow[b]{2}{*}{ Block } & \multirow[b]{2}{*}{ Seq } & \multirow[b]{2}{*}{$\begin{array}{c}\text { SRNL-ML } \\
\text { ID } \\
\end{array}$} & \multicolumn{11}{|c|}{ Elemental Concentrations as received (ar) from the SRNL-ML (in ppm) } \\
\hline & & & & & B (ar) & Ba ar & Cd ar & Cr ar & Fe ar & Li ar & Na ar & Pb ar & Si ar & Th ar & U ar \\
\hline Soln Std & & 1 & 1 & STD-B1-1 & 20.5 & $<0.010$ & $<0.080$ & $<0.050$ & 4.02 & 9.68 & 79.9 & $<0.200$ & 51.8 & $<0.100$ & $<0.100$ \\
\hline SB4-NEPH-02 & quenched & 1 & 2 & X76 & 7.05 & $<0.010$ & $<0.080$ & $<0.050$ & 8.61 & 10.4 & 90 & $<0.200$ & 77.3 & $<0.100$ & 1.2 \\
\hline SB4-NEPH-12 & quenched & 1 & 3 & $\mathrm{X} 26$ & 7.48 & $<0.010$ & $<0.080$ & $<0.050$ & 14 & 12.7 & 88.2 & $<0.200$ & 92 & $<0.100$ & 2.53 \\
\hline Blank & & 1 & 4 & $\mathrm{X} 56$ & $<0.040$ & $<0.010$ & $<0.080$ & $<0.050$ & $<0.040$ & $<0.500$ & $<0.100$ & $<0.200$ & $<0.200$ & $<0.100$ & $<0.100$ \\
\hline SB4-NEPH-11 & quenched & 1 & 5 & X69 & 9.96 & $<0.010$ & $<0.080$ & $<0.050$ & 5.51 & 14.1 & 99.2 & $<0.200$ & 90.4 & $<0.100$ & 1.95 \\
\hline SB4-NEPH-10ccC & ccc & 1 & 6 & $\mathrm{X} 54$ & 10.2 & $<0.010$ & $<0.080$ & $<0.050$ & 6.71 & 15.3 & 103 & $<0.200$ & 98.6 & $<0.100$ & 1.59 \\
\hline SB4-NEPH-02ccC & сcC & 1 & 7 & $\mathrm{X} 23$ & 12.4 & $<0.010$ & $<0.080$ & $<0.050$ & 8.65 & 17 & 101 & $<0.200$ & 93.6 & $<0.100$ & 1.24 \\
\hline SB4-NEPH-04cCC & $\mathrm{cCC}$ & 1 & 8 & X08 & 6.04 & $<0.010$ & $<0.080$ & $<0.050$ & 4.15 & 9.79 & 44.7 & $<0.200$ & 63.2 & $<0.100$ & 3.47 \\
\hline Soln Std & & 1 & 9 & STD-B1-2 & 19.8 & $<0.010$ & $<0.080$ & $<0.050$ & 4.03 & 9.63 & 80.8 & $<0.200$ & 50.9 & $<0.100$ & $<0.100$ \\
\hline ARM-1 & & 1 & 10 & X63 & 12.7 & $<0.010$ & $<0.080$ & $<0.050$ & 0.252 & 9.22 & 24.4 & $<0.200$ & 42.1 & $<0.100$ & $<0.100$ \\
\hline SB4-NEPH-11CCC & $\mathrm{cCC}$ & 1 & 11 & X33 & \multicolumn{11}{|c|}{ This sample was inadvertently spilled and lost. } \\
\hline SB4-NEPH-09ccC & CCC & 1 & 12 & $\mathrm{X} 30$ & 8.13 & $<0.010$ & $<0.080$ & $<0.050$ & 12.3 & 15.2 & 73.1 & $<0.200$ & 90 & $<0.100$ & 4.79 \\
\hline SB4-NEPH-10 & quenched & 1 & 13 & $\mathrm{X} 48$ & 10.9 & $<0.010$ & $<0.080$ & $<0.050$ & 5.79 & 14.9 & 114 & $<0.200$ & 98.2 & $<0.100$ & 1.24 \\
\hline SB4-NEPH-12cCC & ссC & 1 & 14 & $\mathrm{X} 19$ & 7.41 & $<0.010$ & $<0.080$ & $<0.050$ & 13.6 & 12.9 & 79.7 & $<0.200$ & 90.3 & $<0.100$ & 2.62 \\
\hline SB4-NEPH-04 & quenched & 1 & 15 & $\mathrm{X} 80$ & 5.27 & $<0.010$ & $<0.080$ & $<0.050$ & 4.86 & 8.47 & 45.3 & $<0.200$ & 59.5 & $<0.100$ & 2.35 \\
\hline SB4-NEPH-09 & quenched & 1 & 16 & X55 & 6.9 & $<0.010$ & $<0.080$ & $<0.050$ & 11.5 & 11.7 & 77.7 & $<0.200$ & 82.2 & $<0.100$ & 4.31 \\
\hline Soln Std & & 1 & 17 & STD-B1-3 & 20 & $<0.010$ & $<0.080$ & $<0.050$ & 4.06 & 9.67 & 82.2 & $<0.200$ & 51.2 & $<0.100$ & $<0.100$ \\
\hline Soln Std & & 2 & 1 & STD-B2-1 & 20.5 & $<0.010$ & $<0.080$ & $<0.050$ & 4.17 & 9.62 & 80 & $<0.200$ & 51.6 & $<0.100$ & $<0.100$ \\
\hline SB4-NEPH-09ccC & $\mathrm{ccC}$ & 2 & 2 & X66 & 8.62 & $<0.010$ & $<0.080$ & $<0.050$ & 12.6 & 15.5 & 73.2 & $<0.200$ & 92.2 & $<0.100$ & 4.8 \\
\hline SB4-NEPH-12ccC & $\mathrm{ccC}$ & 2 & 3 & $\mathrm{X} 28$ & 7.63 & $<0.010$ & $<0.080$ & $<0.050$ & 13.7 & 13 & 78.6 & $<0.200$ & 91.5 & $<0.100$ & 2.5 \\
\hline SB4-NEPH-02cCC & $\mathrm{CCC}$ & 2 & 4 & X67 & 12.9 & $<0.010$ & $<0.080$ & $<0.050$ & 8.69 & 17.8 & 100 & $<0.200$ & 99.2 & $<0.100$ & 1.35 \\
\hline SB4-NEPH-04 & quenched & 2 & 5 & $\mathrm{X} 73$ & 5.51 & $<0.010$ & $<0.080$ & $<0.050$ & 5.2 & 8.87 & 46.3 & $<0.200$ & 63 & $<0.100$ & 3.3 \\
\hline SB4-NEPH-11 & quenched & 2 & 6 & X35 & 10.2 & $<0.010$ & $<0.080$ & $<0.050$ & 5.77 & 14 & 98.3 & $<0.200$ & 90.8 & $<0.100$ & 1.96 \\
\hline SB4-NEPH-12 & quenched & 2 & 7 & $\mathrm{X} 03$ & 7.76 & $<0.010$ & $<0.080$ & $<0.050$ & 14.1 & 12.8 & 89 & $<0.200$ & 93.8 & $<0.100$ & 2.78 \\
\hline SB4-NEPH-10 & quenched & 2 & 8 & X52 & 10.8 & $<0.010$ & $<0.080$ & $<0.050$ & 6.09 & 14.8 & 112 & $<0.200$ & 99.3 & $<0.100$ & 1.28 \\
\hline Soln Std & & 2 & 9 & STD-B2-2 & 19.8 & $<0.010$ & $<0.080$ & $<0.050$ & 4.08 & 9.57 & 80.6 & $<0.200$ & 51.2 & $<0.100$ & $<0.100$ \\
\hline ARM-1 & & 2 & 10 & X37 & 12.6 & $<0.010$ & $<0.080$ & $<0.050$ & 0.197 & 9.08 & 24.8 & $<0.200$ & 41.9 & $<0.100$ & $<0.100$ \\
\hline SB4-NEPH-11ccc & $\mathrm{cCC}$ & 2 & 11 & $\mathrm{X} 60$ & 9.87 & $<0.010$ & $<0.080$ & $<0.050$ & 5.93 & 14.5 & 90.7 & $<0.200$ & 90 & $<0.100$ & 1.75 \\
\hline SB4-NEPH-04cCC & $\mathrm{CCC}$ & 2 & 12 & $\mathrm{X} 50$ & 6.49 & $<0.010$ & $<0.080$ & $<0.050$ & 4.53 & 10 & 47 & $<0.200$ & 65.8 & $<0.100$ & 2.98 \\
\hline SB4-NEPH-10cCC & cсC & 2 & 13 & $\mathrm{X} 51$ & 10.2 & $<0.010$ & $<0.080$ & $<0.050$ & 7.06 & 15.3 & 103 & $<0.200$ & 99.4 & $<0.100$ & 1.84 \\
\hline SB4-NEPH-02 & quenched & 2 & 14 & $\mathrm{X} 75$ & 7.3 & $<0.010$ & $<0.080$ & $<0.050$ & 8.85 & 10.5 & 94.9 & $<0.200$ & 78.1 & $<0.100$ & 1.21 \\
\hline SB4-NEPH-09 & quenched & 2 & 15 & $\mathrm{X} 44$ & 7.02 & $<0.010$ & $<0.080$ & $<0.050$ & 11.2 & 13.6 & 78.8 & $<0.200$ & 83.3 & $<0.100$ & 4.33 \\
\hline
\end{tabular}


Table D.1: SRNL-ML Measurements of the PCT Solutions for the Nepheline Study Glasses

\begin{tabular}{|c|c|c|c|c|c|c|c|c|c|c|c|c|c|c|c|}
\hline \multirow[b]{2}{*}{ Glass ID } & \multirow[b]{2}{*}{$\begin{array}{c}\text { Heat } \\
\text { Treatment }\end{array}$} & \multirow[b]{2}{*}{ Block } & \multirow[b]{2}{*}{ Seq } & \multirow[b]{2}{*}{$\begin{array}{c}\text { SRNL-ML } \\
\text { ID } \\
\end{array}$} & \multicolumn{11}{|c|}{ Elemental Concentrations as received (ar) from the SRNL-ML (in ppm) } \\
\hline & & & & & B (ar) & Ba ar & Cd ar & Crar & Fe ar & Li ar & Na ar & Pb ar & Si ar & Th ar & U ar \\
\hline Soln Std & & 2 & 16 & STD-B2-3 & 19.8 & $<0.010$ & $<0.080$ & $<0.050$ & 3.98 & 9.6 & 81.8 & $<0.200$ & 51.2 & $<0.100$ & $<0.100$ \\
\hline Soln Std & & 3 & 1 & STD-B3-1 & 20.3 & $<0.010$ & $<0.080$ & $<0.050$ & 3.94 & 9.56 & 81.8 & $<0.200$ & 52.1 & $<0.100$ & $<0.100$ \\
\hline SB4-NEPH-10 & quenched & 3 & 2 & X72 & 11.1 & $<0.010$ & $<0.080$ & $<0.050$ & 6.84 & 15.1 & 114 & $<0.200$ & 104 & $<0.100$ & 1.58 \\
\hline SB4-NEPH-04 & quenched & 3 & 3 & $\mathrm{X} 38$ & 5.49 & $<0.010$ & $<0.080$ & $<0.050$ & 4.86 & 9.02 & 46.8 & $<0.200$ & 64.6 & $<0.100$ & 3.26 \\
\hline SB4-NEPH-11ccC & $\mathrm{CCC}$ & 3 & 4 & X62 & 9.78 & $<0.010$ & $<0.080$ & $<0.050$ & 5.91 & 14.6 & 90.4 & $<0.200$ & 91.5 & $<0.100$ & 1.51 \\
\hline SB4-NEPH-09 & quenched & 3 & 5 & $\mathrm{X} 11$ & 6.9 & $<0.010$ & $<0.080$ & $<0.050$ & 11.6 & 11.6 & 76.7 & $<0.200$ & 83.8 & $<0.100$ & 4.32 \\
\hline SB4-NEPH-02 & quenched & 3 & 6 & $\mathrm{X} 15$ & 7.18 & $<0.010$ & $<0.080$ & $<0.050$ & 8.72 & 10.5 & 90.2 & $<0.200$ & 79 & $<0.100$ & 1.06 \\
\hline SB4-NEPH-02ccC & CCC & 3 & 7 & $\mathrm{X} 02$ & 12.6 & $<0.010$ & $<0.080$ & $<0.050$ & 9.53 & 17.9 & 103 & $<0.200$ & 99 & $<0.100$ & 1.13 \\
\hline SB4-NEPH-09ccc & CCC & 3 & 8 & $\mathrm{X} 40$ & 8.28 & $<0.010$ & $<0.080$ & $<0.050$ & 13.1 & 15.7 & 75.3 & $<0.200$ & 95 & $<0.100$ & 4.74 \\
\hline Soln Std & & 3 & 9 & STD-B3-2 & 19.8 & $<0.010$ & $<0.080$ & $<0.050$ & 4 & 9.64 & 80.9 & $<0.200$ & 52.3 & $<0.100$ & $<0.100$ \\
\hline SB4-NEPH-12ccC & CCC & 3 & 10 & X24 & 7.66 & $<0.010$ & $<0.080$ & $<0.050$ & 13.4 & 13 & 80.2 & $<0.200$ & 93.2 & $<0.100$ & 2.79 \\
\hline SB4-NEPH-11 & quenched & 3 & 11 & X64 & 10.1 & $<0.010$ & $<0.080$ & $<0.050$ & 5.48 & 14 & 98.9 & $<0.200$ & 92.4 & $<0.100$ & 1.9 \\
\hline SB4-NEPH-04cCC & CCC & 3 & 12 & $\mathrm{X} 46$ & 6.24 & $<0.010$ & $<0.080$ & $<0.050$ & 4.51 & 9.57 & 44.8 & $<0.200$ & 64.3 & $<0.100$ & 2.38 \\
\hline SB4-NEPH-12 & quenched & 3 & 13 & $\mathrm{X} 53$ & 7.72 & $<0.010$ & $<0.080$ & $<0.050$ & 14.1 & 13 & 90.7 & $<0.200$ & 95.7 & $<0.100$ & 2.66 \\
\hline ARM-1 & & 3 & 14 & X39 & 12.5 & $<0.010$ & $<0.080$ & $<0.050$ & $<0.040$ & 9.21 & 23.9 & $<0.200$ & 43 & $<0.100$ & $<0.100$ \\
\hline SB4-NEPH-10ccc & CCC & 3 & 15 & $\mathrm{X} 57$ & 9.94 & $<0.010$ & $<0.080$ & $<0.050$ & 8.09 & 15.3 & 103 & $<0.200$ & 100 & $<0.100$ & 2.11 \\
\hline Soln Std & & 3 & 16 & STD-B3-3 & 19.6 & $<0.010$ & $<0.080$ & $<0.050$ & 4.07 & 9.6 & 83.4 & $<0.200$ & 52 & $<0.100$ & $<0.100$ \\
\hline Soln Std & & 4 & 1 & STD-B4-1 & 20.6 & $<0.010$ & $<0.080$ & $<0.050$ & 4.07 & 9.73 & 80.6 & $<0.200$ & 52.3 & $<0.100$ & $<0.100$ \\
\hline Blank & & 4 & 2 & X31 & $<0.040$ & $<0.010$ & $<0.080$ & $<0.050$ & $<0.040$ & $<0.500$ & $<0.100$ & $<0.200$ & $<0.200$ & $<0.100$ & $<0.100$ \\
\hline SB4-NEPH-03cCC & CCC & 4 & 3 & $\mathrm{X} 49$ & 9.66 & $<0.010$ & $<0.080$ & $<0.050$ & 6.47 & 14.8 & 97.7 & $<0.200$ & 95.2 & $<0.100$ & 1.23 \\
\hline SB4-NEPH-08 & quenched & 4 & 4 & X32 & 5.81 & $<0.010$ & $<0.080$ & $<0.050$ & 6.25 & 9.68 & 57.6 & $<0.200$ & 70.2 & $<0.100$ & 0.286 \\
\hline SB4-NEPH-07cCC & CCC & 4 & 5 & $\mathrm{X} 10$ & 8.21 & $<0.010$ & $<0.080$ & $<0.050$ & 9.32 & 14.9 & 90.2 & $<0.200$ & 93.4 & $<0.100$ & 1.96 \\
\hline SB4-NEPH-06 & quenched & 4 & 6 & $\mathrm{X} 29$ & 9.95 & $<0.010$ & $<0.080$ & $<0.050$ & 5.8 & 14.3 & 109 & $<0.200$ & 96.4 & $<0.100$ & 1.36 \\
\hline SB4-NEPH-01 & quenched & 4 & 7 & $\mathrm{X} 07$ & 6.15 & $<0.010$ & $<0.080$ & $<0.050$ & 7.36 & 9.4 & 73.6 & $<0.200$ & 68 & $<0.100$ & 2.31 \\
\hline SB4-NEPH-06ccC & cCC & 4 & 8 & X34 & 8.72 & $<0.010$ & $<0.080$ & $<0.050$ & 13.8 & 15.8 & 103 & $<0.200$ & 104 & $<0.100$ & 5.05 \\
\hline Soln Std & & 4 & 9 & STD-B4-2 & 20.1 & $<0.010$ & $<0.080$ & $<0.050$ & 3.99 & 9.68 & 80.8 & $<0.200$ & 52.2 & $<0.100$ & $<0.100$ \\
\hline EA & & 4 & 10 & X70 & 38.3 & $<0.010$ & $<0.080$ & $<0.050$ & $<0.040$ & 11.3 & 106 & $<0.200$ & 59.7 & $<0.100$ & $<0.100$ \\
\hline SB4-NEPH-07 & quenched & 4 & 11 & X61 & 9.73 & $<0.010$ & $<0.080$ & $<0.050$ & 5.81 & 13.6 & 95.8 & $<0.200$ & 89.4 & $<0.100$ & 1.54 \\
\hline SB4-NEPH-03 & quenched & 4 & 12 & $\mathrm{X} 36$ & 10.3 & $<0.010$ & $<0.080$ & $<0.050$ & 9.11 & 13.9 & 108 & $<0.200$ & 98.2 & $<0.100$ & 1.39 \\
\hline SB4-NEPH-05 & quenched & 4 & 13 & X09 & 9.48 & $<0.010$ & $<0.080$ & $<0.050$ & 8 & 13.1 & 96.3 & $<0.200$ & 87.8 & $<0.100$ & 1.94 \\
\hline SB4-NEPH-01cCC & CCC & 4 & 14 & $\mathrm{X} 05$ & 21.7 & $<0.010$ & $<0.080$ & $<0.050$ & 13.2 & 35.7 & 113 & $<0.200$ & 128 & $<0.100$ & 5.7 \\
\hline SB4-NEPH-05сcC & сCC & 4 & 15 & $\mathrm{X} 27$ & 9.16 & $<0.010$ & $<0.080$ & $<0.050$ & 6.2 & 14 & 89.1 & $<0.200$ & 88.1 & $<0.100$ & 1.3 \\
\hline
\end{tabular}


Table D.1: SRNL-ML Measurements of the PCT Solutions for the Nepheline Study Glasses

\begin{tabular}{|c|c|c|c|c|c|c|c|c|c|c|c|c|c|c|c|}
\hline \multirow[b]{2}{*}{ Glass ID } & \multirow[b]{2}{*}{$\begin{array}{c}\text { Heat } \\
\text { Treatment }\end{array}$} & \multirow[b]{2}{*}{ Block } & \multirow[b]{2}{*}{ Seq } & \multirow[b]{2}{*}{$\begin{array}{c}\text { SRNL-ML } \\
\text { ID } \\
\end{array}$} & \multicolumn{11}{|c|}{ Elemental Concentrations as received (ar) from the SRNL-ML (in ppm) } \\
\hline & & & & & B (ar) & Ba ar & Cd ar & Crar & $\mathrm{Fe}$ ar & $\mathrm{Li}$ ar & Na ar & Pb ar & Si ar & Th ar & U ar \\
\hline SB4-NEPH-08ccC & сcC & 4 & 16 & X04 & 5.55 & $<0.010$ & $<0.080$ & $<0.050$ & 5.27 & 9.53 & 50.4 & $<0.200$ & 67.7 & $<0.100$ & 0.178 \\
\hline Soln Std & & 4 & 17 & STD-B4-3 & 20.5 & $<0.010$ & $<0.080$ & $<0.050$ & 3.98 & 9.73 & 81.3 & $<0.200$ & 52.4 & $<0.100$ & $<0.100$ \\
\hline Soln Std & & 5 & 1 & STD-B5-1 & 20.8 & $<0.010$ & $<0.080$ & $<0.050$ & 3.87 & 9.79 & 81.8 & $<0.200$ & 52.6 & $<0.100$ & $<0.100$ \\
\hline SB4-NEPH-05ccC & $\mathrm{cCC}$ & 5 & 2 & $\mathrm{X} 16$ & 9.92 & $<0.010$ & $<0.080$ & $<0.050$ & 9.08 & 14.6 & 92.8 & $<0.200$ & 95 & $<0.100$ & 2.01 \\
\hline SB4-NEPH-05 & quenched & 5 & 3 & $\mathrm{X} 18$ & 9.85 & $<0.010$ & $<0.080$ & $<0.050$ & 7.38 & 13.6 & 95.6 & $<0.200$ & 91.5 & $<0.100$ & 1.75 \\
\hline SB4-NEPH-01cCC & CCC & 5 & 4 & $\mathrm{X} 45$ & 21.5 & $<0.010$ & $<0.080$ & $<0.050$ & 12 & 34.7 & 110 & $<0.200$ & 127 & $<0.100$ & 5.39 \\
\hline EA & & 5 & 5 & $\mathrm{X} 01$ & 37.9 & $<0.010$ & $<0.080$ & $<0.050$ & $<0.040$ & 11.2 & 105 & $<0.200$ & 59.5 & $<0.100$ & $<0.100$ \\
\hline SB4-NEPH-07ccC & CCC & 5 & 6 & $\mathrm{X} 47$ & 8.85 & $<0.010$ & $<0.080$ & $<0.050$ & 9.82 & 15.3 & 90.7 & $<0.200$ & 95.3 & $<0.100$ & 2.18 \\
\hline SB4-NEPH-06 & quenched & 5 & 7 & $\mathrm{X78}$ & 10.6 & $<0.010$ & $<0.080$ & $<0.050$ & 6.26 & 14.6 & 112 & $<0.200$ & 99.3 & $<0.100$ & 1.69 \\
\hline SB4-NEPH-08 & quenched & 5 & 8 & $\mathrm{X} 13$ & 6.11 & $<0.010$ & $<0.080$ & $<0.050$ & 5.8 & 9.56 & 55.6 & $<0.200$ & 69.7 & $<0.100$ & 0.445 \\
\hline Soln Std & & 5 & 9 & STD-B5-2 & 20.5 & $<0.010$ & $<0.080$ & $<0.050$ & 3.89 & 9.77 & 81.2 & $<0.200$ & 52.9 & $<0.100$ & $<0.100$ \\
\hline SB4-NEPH-03 & quenched & 5 & 10 & X42 & 10.8 & $<0.010$ & $<0.080$ & $<0.050$ & 9.05 & 14.3 & 110 & $<0.200$ & 101 & $<0.100$ & 1.79 \\
\hline SB4-NEPH-01 & quenched & 5 & 11 & $\mathrm{X} 14$ & 6.82 & $<0.010$ & $<0.080$ & $<0.050$ & 6.79 & 9.63 & 75.9 & $<0.200$ & 71 & $<0.100$ & 2.6 \\
\hline SB4-NEPH-07 & quenched & 5 & 12 & X71 & 9.74 & $<0.010$ & $<0.080$ & $<0.050$ & 5.13 & 13.5 & 95.8 & $<0.200$ & 89 & $<0.100$ & 1.62 \\
\hline SB4-NEPH-03ccC & CCC & 5 & 13 & X59 & 9.86 & $<0.010$ & $<0.080$ & $<0.050$ & 6.62 & 14.6 & 99.3 & $<0.200$ & 96.5 & $<0.100$ & 1.52 \\
\hline SB4-NEPH-06ccC & CCC & 5 & 14 & $\mathrm{X} 41$ & 9.13 & $<0.010$ & $<0.080$ & $<0.050$ & 13.4 & 15.7 & 105 & $<0.200$ & 105 & $<0.100$ & 5.39 \\
\hline SB4-NEPH-08ccC & CCC & 5 & 15 & X20 & 5.94 & $<0.010$ & $<0.080$ & $<0.050$ & 4.77 & 9.63 & 51.6 & $<0.200$ & 68.1 & $<0.100$ & 0.274 \\
\hline Soln Std & & 5 & 16 & STD-B5-3 & 20.7 & $<0.010$ & $<0.080$ & $<0.050$ & 3.77 & 9.87 & 81.7 & $<0.200$ & 52.8 & $<0.100$ & $<0.100$ \\
\hline Soln Std & & 6 & 1 & STD-B6-1 & 20.8 & $<0.010$ & $<0.080$ & $<0.050$ & 3.98 & 9.74 & 80.7 & $<0.200$ & 52.6 & $<0.100$ & $<0.100$ \\
\hline SB4-NEPH-08 & quenched & 6 & 2 & $\mathrm{X} 17$ & 6.08 & $<0.010$ & $<0.080$ & $<0.050$ & 6.15 & 9.67 & 56.5 & $<0.200$ & 70.5 & $<0.100$ & 0.487 \\
\hline SB4-NEPH-03ccC & $\mathrm{CCC}$ & 6 & 3 & X77 & 10.1 & $<0.010$ & $<0.080$ & $<0.050$ & 9.59 & 14.6 & 105 & $<0.200$ & 99.6 & $<0.100$ & 2.25 \\
\hline SB4-NEPH-03 & quenched & 6 & 4 & $\mathrm{X} 58$ & 10.5 & $<0.010$ & $<0.080$ & $<0.050$ & 9.91 & 14.1 & 108 & $<0.200$ & 101 & $<0.100$ & 1.52 \\
\hline SB4-NEPH-05ccC & CCC & 6 & 5 & $\mathrm{X} 12$ & 9.13 & $<0.010$ & $<0.080$ & $<0.050$ & 9.04 & 13.5 & 88.2 & $<0.200$ & 87.9 & $<0.100$ & 1.94 \\
\hline SB4-NEPH-06 & quenched & 6 & 6 & $\mathrm{X} 25$ & 10.4 & $<0.010$ & $<0.080$ & $<0.050$ & 6.04 & 14.6 & 114 & $<0.200$ & 100 & $<0.100$ & 1.57 \\
\hline SB4-NEPH-07 & quenched & 6 & 7 & X68 & 9.3 & $<0.010$ & $<0.080$ & $<0.050$ & 5.61 & 13.1 & 93.6 & $<0.200$ & 87.2 & $<0.100$ & 1.47 \\
\hline SB4-NEPH-08ccC & CCC & 6 & 8 & X65 & 5.7 & $<0.010$ & $<0.080$ & $<0.050$ & 5.71 & 9.57 & 51.6 & $<0.200$ & 67.8 & $<0.100$ & 0.291 \\
\hline Soln Std & & 6 & 9 & STD-B6-2 & 20 & $<0.010$ & $<0.080$ & $<0.050$ & 4.04 & 9.65 & 80.7 & $<0.200$ & 52.1 & $<0.100$ & $<0.100$ \\
\hline EA & & 6 & 10 & X06 & 37.9 & $<0.010$ & $<0.080$ & $<0.050$ & 0.312 & 11 & 105 & $<0.200$ & 58.9 & $<0.100$ & $<0.100$ \\
\hline SB4-NEPH-01 & quenched & 6 & 11 & $\mathrm{X79}$ & 6.71 & $<0.010$ & $<0.080$ & $<0.050$ & 6.76 & 9.56 & 76.6 & $<0.200$ & 70.5 & $<0.100$ & 2.36 \\
\hline SB4-NEPH-06ccC & $\mathrm{cCC}$ & 6 & 12 & $\mathrm{X} 74$ & 9.1 & $<0.010$ & $<0.080$ & $<0.050$ & 12.5 & 16.2 & 106 & $<0.200$ & 107 & $<0.100$ & 5.12 \\
\hline SB4-NEPH-05 & quenched & 6 & 13 & $\mathrm{X} 43$ & 9.47 & $<0.010$ & $<0.080$ & $<0.050$ & 6.86 & 13.3 & 96.7 & $<0.200$ & 86.9 & $<0.100$ & 2 \\
\hline SB4-NEPH-01ccC & сCC & 6 & 14 & $\mathrm{X} 22$ & 21.3 & $<0.010$ & $<0.080$ & $<0.050$ & 11.6 & 34.4 & 113 & $<0.200$ & 124 & $<0.100$ & 6.01 \\
\hline
\end{tabular}


Table D.1: SRNL-ML Measurements of the PCT Solutions for the Nepheline Study Glasses

\begin{tabular}{|c|c|c|c|c|c|c|c|c|c|c|c|c|c|c|c|}
\hline & & & & & \multicolumn{11}{|c|}{ Elemental Concentrations as received (ar) from the SRNL-ML (in ppm) } \\
\hline Glass ID & $\begin{array}{c}\text { Heat } \\
\text { Treatment }\end{array}$ & Block & Seq & $\begin{array}{c}\text { SRNL-ML } \\
\text { ID }\end{array}$ & B (ar) & Ba ar & Cd ar & Cr ar & Fe ar & Li ar & Na ar & Pb ar & Si ar & Th ar & $\mathbf{U}$ ar \\
\hline SB4-NEPH-07cCC & ccC & 6 & 15 & X21 & 8.31 & $<0.010$ & $<0.080$ & $<0.050$ & 8.94 & 14.7 & 92.2 & $<0.200$ & 92.4 & $<0.100$ & 2.07 \\
\hline Soln Std & & 6 & 16 & STD-B6-3 & 20.2 & $<0.010$ & $<0.080$ & $<0.050$ & 3.95 & 9.67 & 83.1 & $<0.200$ & 52.4 & $<0.100$ & $<0.100$ \\
\hline
\end{tabular}


Table D.2: SRNL-ML Measurements of the PCT Solutions for the Study Glasses After Appropriate Adjustments

\begin{tabular}{|c|c|c|c|c|c|c|c|c|c|c|c|c|c|c|c|}
\hline & & & & & \multicolumn{11}{|c|}{ Elemental Concentrations Adjusted for Dilution Effects (in ppm) } \\
\hline Glass ID & $\begin{array}{c}\text { Heat } \\
\text { Treatment }\end{array}$ & Block & Seq & $\begin{array}{l}\text { SRNL- } \\
\text { ML ID }\end{array}$ & B & $\mathbf{B a}$ & Cd & $\mathrm{Cr}$ & $\mathbf{F e}$ & $\mathbf{L i}$ & $\mathrm{Na}$ & $\mathbf{P b}$ & $\mathrm{Si}$ & Th & $\mathbf{U}$ \\
\hline Soln Std & & 1 & 1 & STD-B1-1 & 20.5000 & 0.0050 & 0.0400 & 0.0250 & 4.0200 & 9.6800 & 79.9000 & 0.1000 & 51.8000 & 0.0500 & 0.0500 \\
\hline SB4-NEPH-02 & quenched & 1 & 2 & $\mathrm{X} 76$ & 11.7502 & 0.0083 & 0.0667 & 0.0417 & 14.3503 & 17.3337 & 150.0030 & 0.1667 & 128.8359 & 0.0833 & 2.0000 \\
\hline SB4-NEPH-12 & quenched & 1 & 3 & $\mathrm{X} 26$ & 12.4669 & 0.0083 & 0.0667 & 0.0417 & 23.3338 & 21.1671 & 147.0029 & 0.1667 & 153.3364 & 0.0833 & 4.2168 \\
\hline Blank & & 1 & 4 & $\mathrm{X} 56$ & 0.0333 & 0.0083 & 0.0667 & 0.0417 & 0.0333 & 0.4167 & 0.0833 & 0.1667 & 0.1667 & 0.0833 & 0.0833 \\
\hline SB4-NEPH-11 & quenched & 1 & 5 & $\mathrm{X} 69$ & 16.6003 & 0.0083 & 0.0667 & 0.0417 & 9.1835 & 23.5005 & 165.3366 & 0.1667 & 150.6697 & 0.0833 & 3.2501 \\
\hline SB4-NEPH-10ccC & CCC & 1 & 6 & $\mathrm{X} 54$ & 17.0003 & 0.0083 & 0.0667 & 0.0417 & 11.1836 & 25.5005 & 171.6701 & 0.1667 & 164.3366 & 0.0833 & 2.6501 \\
\hline SB4-NEPH-02ccC & $\mathrm{ccC}$ & 1 & 7 & $\mathrm{X} 23$ & 20.6671 & 0.0083 & 0.0667 & 0.0417 & 14.4170 & 28.3339 & 168.3367 & 0.1667 & 156.0031 & 0.0833 & 2.0667 \\
\hline SB4-NEPH-04cCC & $\mathrm{CCC}$ & 1 & 8 & $\mathrm{X} 08$ & 10.0669 & 0.0083 & 0.0667 & 0.0417 & 6.9168 & 16.3170 & 74.5015 & 0.1667 & 105.3354 & 0.0833 & 5.7834 \\
\hline Soln Std & & 1 & 9 & STD-B1-2 & 19.8000 & 0.0050 & 0.0400 & 0.0250 & 4.0300 & 9.6300 & 80.8000 & 0.1000 & 50.9000 & 0.0500 & 0.0500 \\
\hline ARM-1 & & 1 & 10 & X63 & 21.1671 & 0.0083 & 0.0667 & 0.0417 & 0.4200 & 15.3670 & 40.6675 & 0.1667 & 70.1681 & 0.0833 & 0.0833 \\
\hline SB4-NEPH-11ccC & $\mathrm{CCC}$ & 1 & 11 & $\mathrm{X} 33$ & \multicolumn{11}{|c|}{ This sample was inadvertently spilled and lost. } \\
\hline SB4-NEPH-09ccC & $\mathrm{ccC}$ & 1 & 12 & X30 & 13.5503 & 0.0083 & 0.0667 & 0.0417 & 20.5004 & 25.3338 & 121.8358 & 0.1667 & 150.0030 & 0.0833 & 7.9835 \\
\hline SB4-NEPH-10 & quenched & 1 & 13 & $\mathrm{X} 48$ & 18.1670 & 0.0083 & 0.0667 & 0.0417 & 9.6502 & 24.8338 & 190.0038 & 0.1667 & 163.6699 & 0.0833 & 2.0667 \\
\hline SB4-NEPH-12ccC & $\mathrm{ccc}$ & 1 & 14 & $\mathrm{X} 19$ & 12.3502 & 0.0083 & 0.0667 & 0.0417 & 22.6671 & 21.5004 & 132.8360 & 0.1667 & 150.5030 & 0.0833 & 4.3668 \\
\hline SB4-NEPH-04 & quenched & 1 & 15 & $\mathrm{X} 80$ & 8.7835 & 0.0083 & 0.0667 & 0.0417 & 8.1002 & 14.1169 & 75.5015 & 0.1667 & 99.1687 & 0.0833 & 3.9167 \\
\hline SB4-NEPH-09 & quenched & 1 & 16 & X55 & 11.5002 & 0.0083 & 0.0667 & 0.0417 & 19.1671 & 19.5004 & 129.5026 & 0.1667 & 137.0027 & 0.0833 & 7.1835 \\
\hline Soln Std & & 1 & 17 & STD-B1-3 & 20.0000 & 0.0050 & 0.0400 & 0.0250 & 4.0600 & 9.6700 & 82.2000 & 0.1000 & 51.2000 & 0.0500 & 0.0500 \\
\hline Soln Std & & 2 & 1 & STD-B2-1 & 20.5000 & 0.0050 & 0.0400 & 0.0250 & 4.1700 & 9.6200 & 80.0000 & 0.1000 & 51.6000 & 0.0500 & 0.0500 \\
\hline SB4-NEPH-09ccC & ссC & 2 & 2 & X66 & 14.3670 & 0.0083 & 0.0667 & 0.0417 & 21.0004 & 25.8339 & 122.0024 & 0.1667 & 153.6697 & 0.0833 & 8.0002 \\
\hline SB4-NEPH-12cCC & $\mathrm{CCC}$ & 2 & 3 & $\mathrm{X} 28$ & 12.7169 & 0.0083 & 0.0667 & 0.0417 & 22.8338 & 21.6671 & 131.0026 & 0.1667 & 152.5031 & 0.0833 & 4.1668 \\
\hline SB4-NEPH-02cCC & CCC & 2 & 4 & $\mathrm{X} 67$ & 21.5004 & 0.0083 & 0.0667 & 0.0417 & 14.4836 & 29.6673 & 166.6700 & 0.1667 & 165.3366 & 0.0833 & 2.2500 \\
\hline SB4-NEPH-04 & quenched & 2 & 5 & $\mathrm{X73}$ & 9.1835 & 0.0083 & 0.0667 & 0.0417 & 8.6668 & 14.7836 & 77.1682 & 0.1667 & 105.0021 & 0.0833 & 5.5001 \\
\hline SB4-NEPH-11 & quenched & 2 & 6 & $\mathrm{X} 35$ & 17.0003 & 0.0083 & 0.0667 & 0.0417 & 9.6169 & 23.3338 & 163.8366 & 0.1667 & 151.3364 & 0.0833 & 3.2667 \\
\hline SB4-NEPH-12 & quenched & 2 & 7 & $\mathrm{X} 03$ & 12.9336 & 0.0083 & 0.0667 & 0.0417 & 23.5005 & 21.3338 & 148.3363 & 0.1667 & 156.3365 & 0.0833 & 4.6334 \\
\hline SB4-NEPH-10 & quenched & 2 & 8 & X52 & 18.0004 & 0.0083 & 0.0667 & 0.0417 & 10.1502 & 24.6672 & 186.6704 & 0.1667 & 165.5033 & 0.0833 & 2.1334 \\
\hline Soln Std & & 2 & 9 & STD-B2-2 & 19.8000 & 0.0050 & 0.0400 & 0.0250 & 4.0800 & 9.5700 & 80.6000 & 0.1000 & 51.2000 & 0.0500 & 0.0500 \\
\hline ARM-1 & & 2 & 10 & X37 & 21.0004 & 0.0083 & 0.0667 & 0.0417 & 0.3283 & 15.1336 & 41.3342 & 0.1667 & 69.8347 & 0.0833 & 0.0833 \\
\hline SB4-NEPH-11ccC & $\mathrm{cCC}$ & 2 & 11 & $\mathrm{X} 60$ & 16.4503 & 0.0083 & 0.0667 & 0.0417 & 9.8835 & 24.1672 & 151.1697 & 0.1667 & 150.0030 & 0.0833 & 2.9167 \\
\hline SB4-NEPH-04ccC & CCC & 2 & 12 & $\mathrm{X} 50$ & 10.8169 & 0.0083 & 0.0667 & 0.0417 & 7.5502 & 16.6670 & 78.3349 & 0.1667 & 109.6689 & 0.0833 & 4.9668 \\
\hline SB4-NEPH-10ccC & cCC & 2 & 13 & $\mathrm{X} 51$ & 17.0003 & 0.0083 & 0.0667 & 0.0417 & 11.7669 & 25.5005 & 171.6701 & 0.1667 & 165.6700 & 0.0833 & 3.0667 \\
\hline SB4-NEPH-02 & quenched & 2 & 14 & $\mathrm{X} 75$ & 12.1669 & 0.0083 & 0.0667 & 0.0417 & 14.7503 & 17.5004 & 158.1698 & 0.1667 & 130.1693 & 0.0833 & 2.0167 \\
\hline SB4-NEPH-09 & quenched & 2 & 15 & $\mathrm{X} 44$ & 11.7002 & 0.0083 & 0.0667 & 0.0417 & 18.6670 & 22.6671 & 131.3360 & 0.1667 & 138.8361 & 0.0833 & 7.2168 \\
\hline
\end{tabular}


Table D.2: SRNL-ML Measurements of the PCT Solutions for the Study Glasses After Appropriate Adjustments

\begin{tabular}{|c|c|c|c|c|c|c|c|c|c|c|c|c|c|c|c|}
\hline \multirow[b]{2}{*}{ Glass ID } & \multirow[b]{2}{*}{$\begin{array}{c}\text { Heat } \\
\text { Treatment }\end{array}$} & \multirow[b]{2}{*}{ Block } & \multirow[b]{2}{*}{ Seq } & \multirow[b]{2}{*}{$\begin{array}{l}\text { SRNL- } \\
\text { ML ID } \\
\end{array}$} & \multicolumn{11}{|c|}{ Elemental Concentrations Adjusted for Dilution Effects (in ppm) } \\
\hline & & & & & B & Ba & Cd & $\mathrm{Cr}$ & $\mathbf{F e}$ & $\mathbf{L i}$ & $\mathrm{Na}$ & $\mathbf{P b}$ & Si & Th & $\mathbf{U}$ \\
\hline Soln Std & & 2 & 16 & STD-B2-3 & 19.8000 & 0.0050 & 0.0400 & 0.0250 & 3.9800 & 9.6000 & 81.8000 & 0.1000 & 51.2000 & 0.0500 & 0.0500 \\
\hline Soln Std & & 3 & 1 & STD-B3-1 & 20.3000 & 0.0050 & 0.0400 & 0.0250 & 3.9400 & 9.5600 & 81.8000 & 0.1000 & 52.1000 & 0.0500 & 0.0500 \\
\hline SB4-NEPH-10 & quenched & 3 & 2 & $\mathrm{X} 72$ & 18.5004 & 0.0083 & 0.0667 & 0.0417 & 11.4002 & 25.1672 & 190.0038 & 0.1667 & 173.3368 & 0.0833 & 2.6334 \\
\hline SB4-NEPH-04 & quenched & 3 & 3 & X38 & 9.1502 & 0.0083 & 0.0667 & 0.0417 & 8.1002 & 15.0336 & 78.0016 & 0.1667 & 107.6688 & 0.0833 & 5.4334 \\
\hline SB4-NEPH-11сcC & $\mathrm{cCC}$ & 3 & 4 & X62 & 16.3003 & 0.0083 & 0.0667 & 0.0417 & 9.8502 & 24.3338 & 150.6697 & 0.1667 & 152.5031 & 0.0833 & 2.5167 \\
\hline SB4-NEPH-09 & quenched & 3 & 5 & $\mathrm{X} 11$ & 11.5002 & 0.0083 & 0.0667 & 0.0417 & 19.3337 & 19.3337 & 127.8359 & 0.1667 & 139.6695 & 0.0833 & 7.2001 \\
\hline SB4-NEPH-02 & quenched & 3 & 6 & $\mathrm{X} 15$ & 11.9669 & 0.0083 & 0.0667 & 0.0417 & 14.5336 & 17.5004 & 150.3363 & 0.1667 & 131.6693 & 0.0833 & 1.7667 \\
\hline SB4-NEPH-02ccC & cCC & 3 & 7 & $\mathrm{X} 02$ & 21.0004 & 0.0083 & 0.0667 & 0.0417 & 15.8837 & 29.8339 & 171.6701 & 0.1667 & 165.0033 & 0.0833 & 1.8834 \\
\hline SB4-NEPH-09ccC & сcC & 3 & 8 & $\mathrm{X} 40$ & 13.8003 & 0.0083 & 0.0667 & 0.0417 & 21.8338 & 26.1672 & 125.5025 & 0.1667 & 158.3365 & 0.0833 & 7.9002 \\
\hline Soln Std & & 3 & 9 & STD-B3-2 & 19.8000 & 0.0050 & 0.0400 & 0.0250 & 4.0000 & 9.6400 & 80.9000 & 0.1000 & 52.3000 & 0.0500 & 0.0500 \\
\hline SB4-NEPH-12ccC & $\mathrm{CCC}$ & 3 & 10 & $\mathrm{X} 24$ & 12.7669 & 0.0083 & 0.0667 & 0.0417 & 22.3338 & 21.6671 & 133.6693 & 0.1667 & 155.3364 & 0.0833 & 4.6501 \\
\hline SB4-NEPH-11 & quenched & 3 & 11 & $\mathrm{X} 64$ & 16.8337 & 0.0083 & 0.0667 & 0.0417 & 9.1335 & 23.3338 & 164.8366 & 0.1667 & 154.0031 & 0.0833 & 3.1667 \\
\hline SB4-NEPH-04ccC & $\mathrm{cCC}$ & 3 & 12 & $\mathrm{X} 46$ & 10.4002 & 0.0083 & 0.0667 & 0.0417 & 7.5168 & 15.9503 & 74.6682 & 0.1667 & 107.1688 & 0.0833 & 3.9667 \\
\hline SB4-NEPH-12 & quenched & 3 & 13 & $\mathrm{X} 53$ & 12.8669 & 0.0083 & 0.0667 & 0.0417 & 23.5005 & 21.6671 & 151.1697 & 0.1667 & 159.5032 & 0.0833 & 4.4334 \\
\hline ARM-1 & & 3 & 14 & X39 & 20.8338 & 0.0083 & 0.0667 & 0.0417 & 0.0333 & 15.3503 & 39.8341 & 0.1667 & 71.6681 & 0.0833 & 0.0833 \\
\hline SB4-NEPH-10ccC & $\mathrm{CCC}$ & 3 & 15 & X57 & 16.5670 & 0.0083 & 0.0667 & 0.0417 & 13.4836 & 25.5005 & 171.6701 & 0.1667 & 166.6700 & 0.0833 & 3.5167 \\
\hline Soln Std & & 3 & 16 & STD-B3-3 & 19.6000 & 0.0050 & 0.0400 & 0.0250 & 4.0700 & 9.6000 & 83.4000 & 0.1000 & 52.0000 & 0.0500 & 0.0500 \\
\hline Soln Std & & 4 & 1 & STD-B4-1 & 20.6000 & 0.0050 & 0.0400 & 0.0250 & 4.0700 & 9.7300 & 80.6000 & 0.1000 & 52.3000 & 0.0500 & 0.0500 \\
\hline Blank & & 4 & 2 & X31 & 0.0333 & 0.0083 & 0.0667 & 0.0417 & 0.0333 & 0.4167 & 0.0833 & 0.1667 & 0.1667 & 0.0833 & 0.0833 \\
\hline SB4-NEPH-03ccC & $\mathrm{CCC}$ & 4 & 3 & $\mathrm{X} 49$ & 16.1003 & 0.0083 & 0.0667 & 0.0417 & 10.7835 & 24.6672 & 162.8366 & 0.1667 & 158.6698 & 0.0833 & 2.0500 \\
\hline SB4-NEPH-08 & quenched & 4 & 4 & X32 & 9.6835 & 0.0083 & 0.0667 & 0.0417 & 10.4169 & 16.1337 & 96.0019 & 0.1667 & 117.0023 & 0.0833 & 0.4767 \\
\hline SB4-NEPH-07ccC & $\mathrm{CCC}$ & 4 & 5 & $\mathrm{X} 10$ & 13.6836 & 0.0083 & 0.0667 & 0.0417 & 15.5336 & 24.8338 & 150.3363 & 0.1667 & 155.6698 & 0.0833 & 3.2667 \\
\hline SB4-NEPH-06 & quenched & 4 & 6 & X29 & 16.5837 & 0.0083 & 0.0667 & 0.0417 & 9.6669 & 23.8338 & 181.6703 & 0.1667 & 160.6699 & 0.0833 & 2.2667 \\
\hline SB4-NEPH-01 & quenched & 4 & 7 & $\mathrm{X} 07$ & 10.2502 & 0.0083 & 0.0667 & 0.0417 & 12.2669 & 15.6670 & 122.6691 & 0.1667 & 113.3356 & 0.0833 & 3.8501 \\
\hline SB4-NEPH-06ccc & $\mathrm{CCC}$ & 4 & 8 & X34 & 14.5336 & 0.0083 & 0.0667 & 0.0417 & 23.0005 & 26.3339 & 171.6701 & 0.1667 & 173.3368 & 0.0833 & 8.4168 \\
\hline Soln Std & & 4 & 9 & STD-B4-2 & 20.1000 & 0.0050 & 0.0400 & 0.0250 & 3.9900 & 9.6800 & 80.8000 & 0.1000 & 52.2000 & 0.0500 & 0.0500 \\
\hline EA & & 4 & 10 & $\mathrm{X} 70$ & 638.3346 & 0.0833 & 0.6667 & 0.4167 & 0.3333 & 188.3337 & 1766.6702 & 1.6667 & 995.0020 & 0.8333 & 0.8333 \\
\hline SB4-NEPH-07 & quenched & 4 & 11 & X61 & 16.2170 & 0.0083 & 0.0667 & 0.0417 & 9.6835 & 22.6671 & 159.6699 & 0.1667 & 149.0030 & 0.0833 & 2.5667 \\
\hline SB4-NEPH-03 & quenched & 4 & 12 & $\mathrm{X} 36$ & 17.1670 & 0.0083 & 0.0667 & 0.0417 & 15.1836 & 23.1671 & 180.0036 & 0.1667 & 163.6699 & 0.0833 & 2.3167 \\
\hline SB4-NEPH-05 & quenched & 4 & 13 & X09 & 15.8003 & 0.0083 & 0.0667 & 0.0417 & 13.3336 & 21.8338 & 160.5032 & 0.1667 & 146.3363 & 0.0833 & 3.2334 \\
\hline SB4-NEPH-01ccC & $\mathrm{ccc}$ & 4 & 14 & $\mathrm{X} 05$ & 36.1674 & 0.0083 & 0.0667 & 0.0417 & 22.0004 & 59.5012 & 188.3371 & 0.1667 & 213.3376 & 0.0833 & 9.5002 \\
\hline SB4-NEPH-05сcC & ссс & 4 & 15 & $\mathrm{X} 27$ & 15.2670 & 0.0083 & 0.0667 & 0.0417 & 10.3335 & 23.3338 & 148.5030 & 0.1667 & 146.8363 & 0.0833 & 2.1667 \\
\hline
\end{tabular}


Table D.2: SRNL-ML Measurements of the PCT Solutions for the Study Glasses After Appropriate Adjustments

\begin{tabular}{|c|c|c|c|c|c|c|c|c|c|c|c|c|c|c|c|}
\hline \multirow[b]{2}{*}{ Glass ID } & \multirow[b]{2}{*}{$\begin{array}{c}\text { Heat } \\
\text { Treatment } \\
\end{array}$} & \multirow[b]{2}{*}{ Block } & \multirow[b]{2}{*}{ Seq } & \multirow[b]{2}{*}{$\begin{array}{l}\text { SRNL- } \\
\text { ML ID }\end{array}$} & \multicolumn{11}{|c|}{ Elemental Concentrations Adjusted for Dilution Effects (in ppm) } \\
\hline & & & & & B & Ba & Cd & $\mathbf{C r}$ & $\mathbf{F e}$ & $\mathbf{L i}$ & $\mathrm{Na}$ & $\mathbf{P b}$ & Si & Th & $\mathbf{U}$ \\
\hline SB4-NEPH-08ccC & cсC & 4 & 16 & $\mathrm{X} 04$ & 9.2502 & 0.0083 & 0.0667 & 0.0417 & 8.7835 & 15.8837 & 84.0017 & 0.1667 & 112.8356 & 0.0833 & 0.2967 \\
\hline Soln Std & & 4 & 17 & STD-B4-3 & 20.5000 & 0.0050 & 0.0400 & 0.0250 & 3.9800 & 9.7300 & 81.3000 & 0.1000 & 52.4000 & 0.0500 & 0.0500 \\
\hline Soln Std & & 5 & 1 & STD-B5-1 & 20.8000 & 0.0050 & 0.0400 & 0.0250 & 3.8700 & 9.7900 & 81.8000 & 0.1000 & 52.6000 & 0.0500 & 0.0500 \\
\hline SB4-NEPH-05ccC & cCC & 5 & 2 & $\mathrm{X} 16$ & 16.5337 & 0.0083 & 0.0667 & 0.0417 & 15.1336 & 24.3338 & 154.6698 & 0.1667 & 158.3365 & 0.0833 & 3.3501 \\
\hline SB4-NEPH-05 & quenched & 5 & 3 & $\mathrm{X} 18$ & 16.4170 & 0.0083 & 0.0667 & 0.0417 & 12.3002 & 22.6671 & 159.3365 & 0.1667 & 152.5031 & 0.0833 & 2.9167 \\
\hline SB4-NEPH-01ccC & $\mathrm{cCC}$ & 5 & 4 & $\mathrm{X} 45$ & 35.8341 & 0.0083 & 0.0667 & 0.0417 & 20.0004 & 57.8345 & 183.3370 & 0.1667 & 211.6709 & 0.0833 & 8.9835 \\
\hline EA & & 5 & 5 & $\mathrm{X} 01$ & 631.6679 & 0.0833 & 0.6667 & 0.4167 & 0.3333 & 186.6670 & 1750.0035 & 1.6667 & 991.6687 & 0.8333 & 0.8333 \\
\hline SB4-NEPH-07ccC & CCC & 5 & 6 & $\mathrm{X} 47$ & 14.7503 & 0.0083 & 0.0667 & 0.0417 & 16.3670 & 25.5005 & 151.1697 & 0.1667 & 158.8365 & 0.0833 & 3.6334 \\
\hline SB4-NEPH-06 & quenched & 5 & 7 & X78 & 17.6670 & 0.0083 & 0.0667 & 0.0417 & 10.4335 & 24.3338 & 186.6704 & 0.1667 & 165.5033 & 0.0833 & 2.8167 \\
\hline SB4-NEPH-08 & quenched & 5 & 8 & $\mathrm{X} 13$ & 10.1835 & 0.0083 & 0.0667 & 0.0417 & 9.6669 & 15.9337 & 92.6685 & 0.1667 & 116.1690 & 0.0833 & 0.7417 \\
\hline Soln Std & & 5 & 9 & STD-B5-2 & 20.5000 & 0.0050 & 0.0400 & 0.0250 & 3.8900 & 9.7700 & 81.2000 & 0.1000 & 52.9000 & 0.0500 & 0.0500 \\
\hline SB4-NEPH-03 & quenched & 5 & 10 & X42 & 18.0004 & 0.0083 & 0.0667 & 0.0417 & 15.0836 & 23.8338 & 183.3370 & 0.1667 & 168.3367 & 0.0833 & 2.9834 \\
\hline SB4-NEPH-01 & quenched & 5 & 11 & $\mathrm{X} 14$ & 11.3669 & 0.0083 & 0.0667 & 0.0417 & 11.3169 & 16.0503 & 126.5025 & 0.1667 & 118.3357 & 0.0833 & 4.3334 \\
\hline SB4-NEPH-07 & quenched & 5 & 12 & X71 & 16.2337 & 0.0083 & 0.0667 & 0.0417 & 8.5502 & 22.5005 & 159.6699 & 0.1667 & 148.3363 & 0.0833 & 2.7001 \\
\hline SB4-NEPH-03ccC & CCC & 5 & 13 & X59 & 16.4337 & 0.0083 & 0.0667 & 0.0417 & 11.0336 & 24.3338 & 165.5033 & 0.1667 & 160.8366 & 0.0833 & 2.5334 \\
\hline SB4-NEPH-06ccC & $\mathrm{CCC}$ & 5 & 14 & $\mathrm{X} 41$ & 15.2170 & 0.0083 & 0.0667 & 0.0417 & 22.3338 & 26.1672 & 175.0035 & 0.1667 & 175.0035 & 0.0833 & 8.9835 \\
\hline SB4-NEPH-08ccC & $\mathrm{CCC}$ & 5 & 15 & $\mathrm{X} 20$ & 9.9002 & 0.0083 & 0.0667 & 0.0417 & 7.9502 & 16.0503 & 86.0017 & 0.1667 & 113.5023 & 0.0833 & 0.4567 \\
\hline Soln Std & & 5 & 16 & STD-B5-3 & 20.7000 & 0.0050 & 0.0400 & 0.0250 & 3.7700 & 9.8700 & 81.7000 & 0.1000 & 52.8000 & 0.0500 & 0.0500 \\
\hline Soln Std & & 6 & 1 & STD-B6-1 & 20.8000 & 0.0050 & 0.0400 & 0.0250 & 3.9800 & 9.7400 & 80.7000 & 0.1000 & 52.6000 & 0.0500 & 0.0500 \\
\hline SB4-NEPH-08 & quenched & 6 & 2 & $\mathrm{X} 17$ & 10.1335 & 0.0083 & 0.0667 & 0.0417 & 10.2502 & 16.1170 & 94.1686 & 0.1667 & 117.5024 & 0.0833 & 0.8117 \\
\hline SB4-NEPH-03ccC & $\mathrm{CCC}$ & 6 & 3 & X77 & 16.8337 & 0.0083 & 0.0667 & 0.0417 & 15.9837 & 24.3338 & 175.0035 & 0.1667 & 166.0033 & 0.0833 & 3.7501 \\
\hline SB4-NEPH-03 & quenched & 6 & 4 & $\mathrm{X} 58$ & 17.5004 & 0.0083 & 0.0667 & 0.0417 & 16.5170 & 23.5005 & 180.0036 & 0.1667 & 168.3367 & 0.0833 & 2.5334 \\
\hline SB4-NEPH-05сcC & сCC & 6 & 5 & $\mathrm{X} 12$ & 15.2170 & 0.0083 & 0.0667 & 0.0417 & 15.0670 & 22.5005 & 147.0029 & 0.1667 & 146.5029 & 0.0833 & 3.2334 \\
\hline SB4-NEPH-06 & quenched & 6 & 6 & $\mathrm{X} 25$ & 17.3337 & 0.0083 & 0.0667 & 0.0417 & 10.0669 & 24.3338 & 190.0038 & 0.1667 & 166.6700 & 0.0833 & 2.6167 \\
\hline SB4-NEPH-07 & quenched & 6 & 7 & X68 & 15.5003 & 0.0083 & 0.0667 & 0.0417 & 9.3502 & 21.8338 & 156.0031 & 0.1667 & 145.3362 & 0.0833 & 2.4500 \\
\hline SB4-NEPH-08ccC & cCC & 6 & 8 & X65 & 9.5002 & 0.0083 & 0.0667 & 0.0417 & 9.5169 & 15.9503 & 86.0017 & 0.1667 & 113.0023 & 0.0833 & 0.4850 \\
\hline Soln Std & & 6 & 9 & STD-B6-2 & 20.0000 & 0.0050 & 0.0400 & 0.0250 & 4.0400 & 9.6500 & 80.7000 & 0.1000 & 52.1000 & 0.0500 & 0.0500 \\
\hline EA & & 6 & 10 & X06 & 631.6679 & 0.0833 & 0.6667 & 0.4167 & 5.2000 & 183.3337 & 1750.0035 & 1.6667 & 981.6686 & 0.8333 & 0.8333 \\
\hline SB4-NEPH-01 & quenched & 6 & 11 & X79 & 11.1836 & 0.0083 & 0.0667 & 0.0417 & 11.2669 & 15.9337 & 127.6692 & 0.1667 & 117.5024 & 0.0833 & 3.9334 \\
\hline SB4-NEPH-06ccC & $\mathrm{cCC}$ & 6 & 12 & $\mathrm{X} 74$ & 15.1670 & 0.0083 & 0.0667 & 0.0417 & 20.8338 & 27.0005 & 176.6702 & 0.1667 & 178.3369 & 0.0833 & 8.5335 \\
\hline SB4-NEPH-05 & quenched & 6 & 13 & $\mathrm{X} 43$ & 15.7836 & 0.0083 & 0.0667 & 0.0417 & 11.4336 & 22.1671 & 161.1699 & 0.1667 & 144.8362 & 0.0833 & 3.3334 \\
\hline SB4-NEPH-01сcC & сCC & 6 & 14 & X22 & 35.5007 & 0.0083 & 0.0667 & 0.0417 & 19.3337 & 57.3345 & 188.3371 & 0.1667 & 206.6708 & 0.0833 & 10.0169 \\
\hline
\end{tabular}


Table D.2: SRNL-ML Measurements of the PCT Solutions for the Study Glasses After Appropriate Adjustments

\begin{tabular}{|c|c|c|c|c|c|c|c|c|c|c|c|c|c|c|c|}
\hline & & & & & \multicolumn{11}{|c|}{ Elemental Concentrations Adjusted for Dilution Effects (in ppm) } \\
\hline Glass ID & $\begin{array}{c}\text { Heat } \\
\text { Treatment }\end{array}$ & Block & Seq & $\begin{array}{l}\text { SRNL- } \\
\text { ML ID }\end{array}$ & B & $\mathbf{B a}$ & Cd & $\mathrm{Cr}$ & $\mathbf{F e}$ & $\mathbf{L i}$ & $\mathrm{Na}$ & $\mathbf{P b}$ & $\mathrm{Si}$ & Th & $\mathbf{U}$ \\
\hline SB4-NEPH-07ccc & ссC & 6 & 15 & X21 & 13.8503 & 0.0083 & 0.0667 & 0.0417 & 14.9003 & 24.5005 & 153.6697 & 0.1667 & 154.0031 & 0.0833 & 3.4501 \\
\hline Soln Std & & 6 & 16 & STD-B6-3 & 20.2000 & 0.0050 & 0.0400 & 0.0250 & 3.9500 & 9.6700 & 83.1000 & 0.1000 & 52.4000 & 0.0500 & 0.0500 \\
\hline
\end{tabular}




\section{Exhibit D.1: SRNL-ML PCT Measurements in Analytical Sequence for Study Glasses, EA, ARM, Blanks,} and Solution Standards
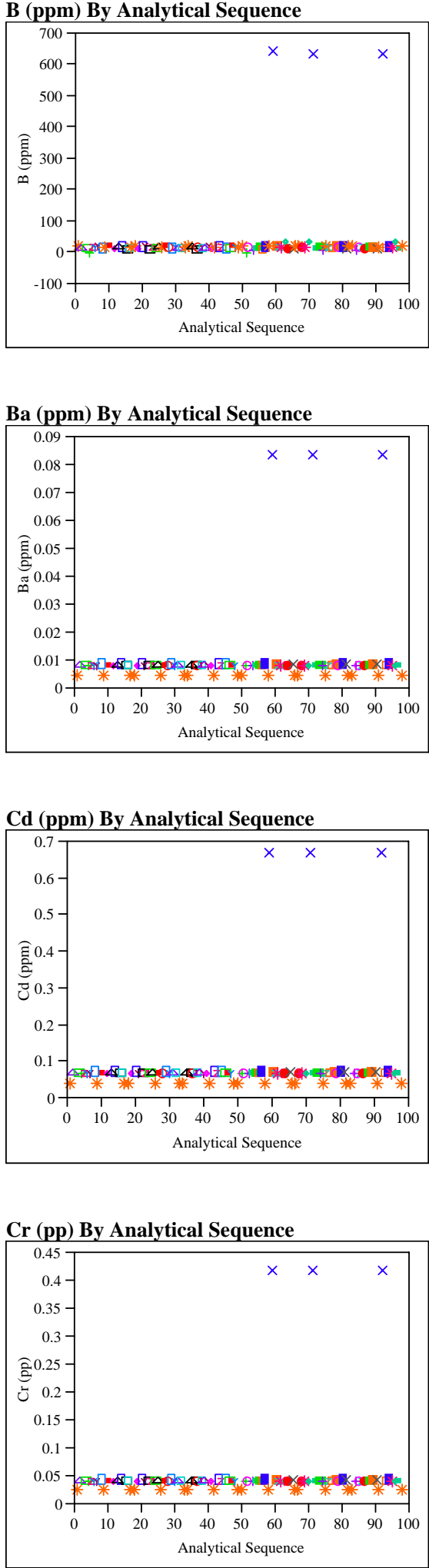
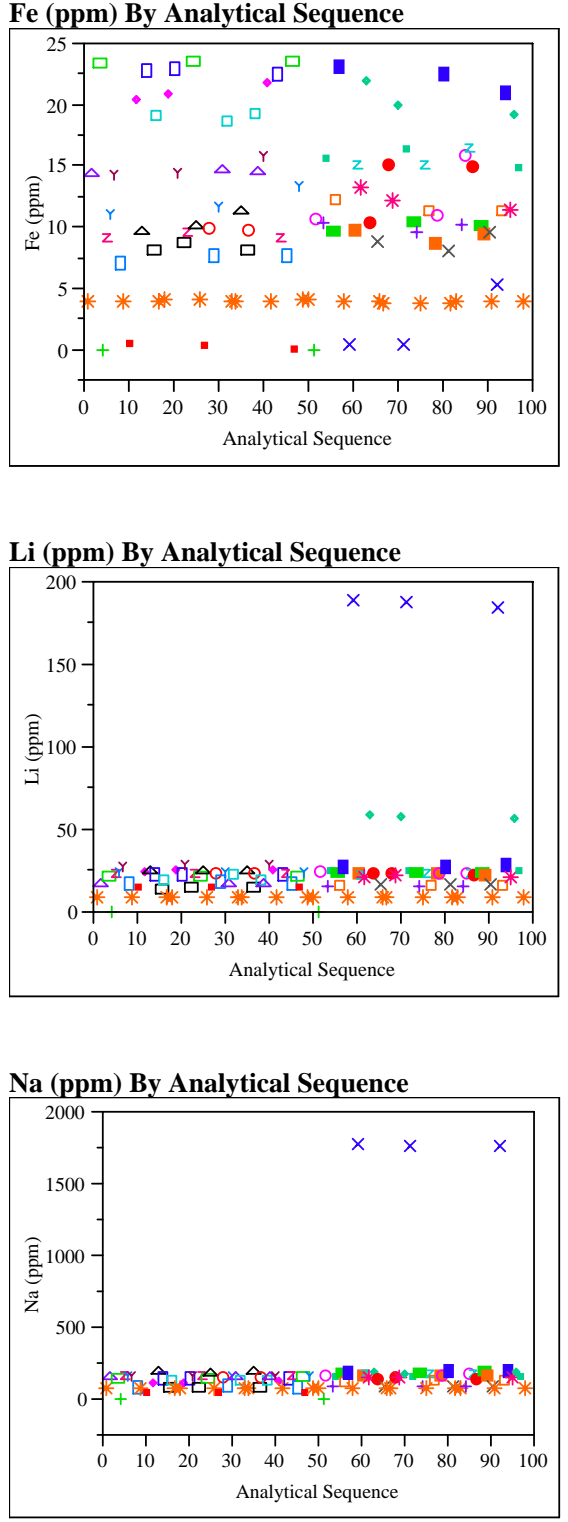
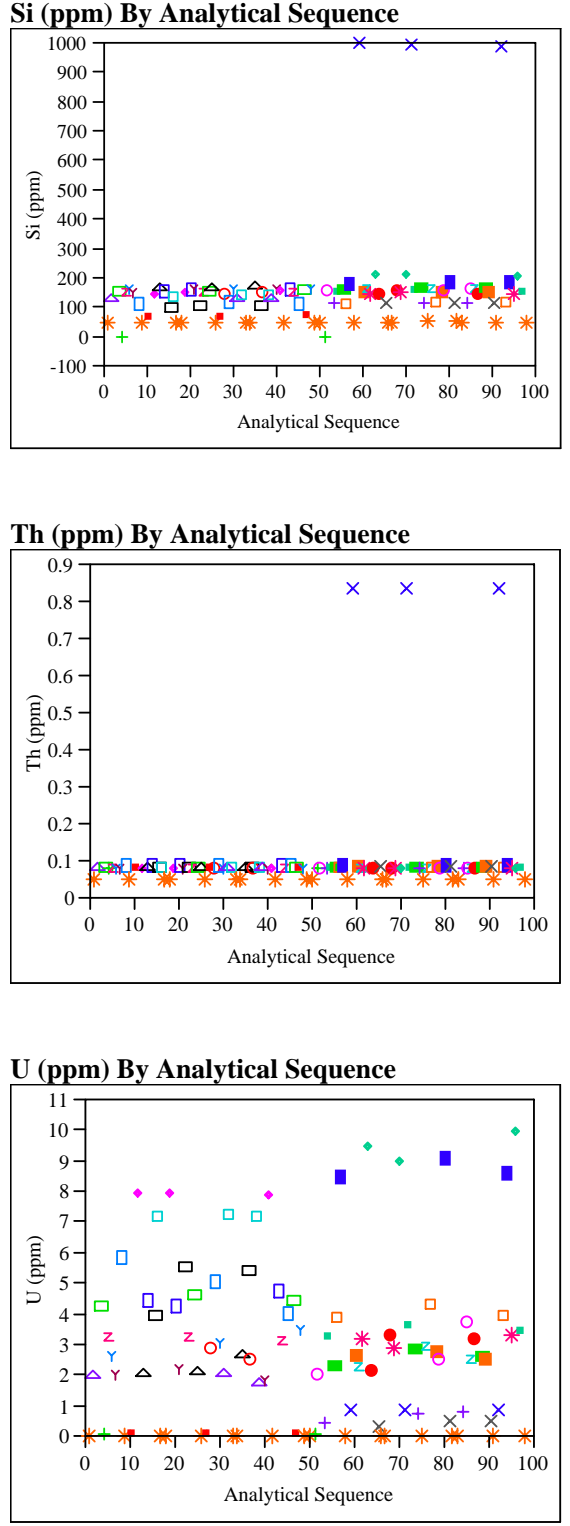

Th (ppm) By Analytical Sequence

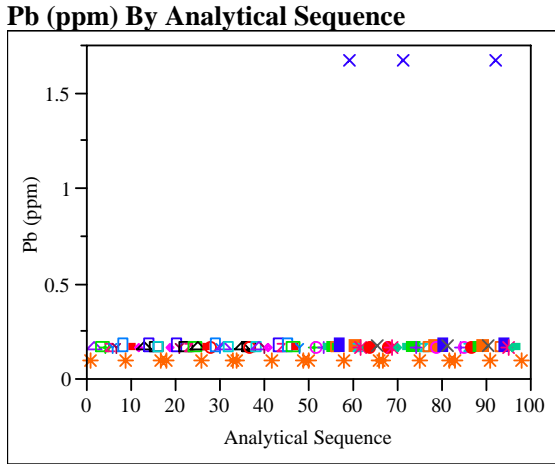




\section{Exhibit D.2: SRNL-ML PCT Measurements in Analytical Sequence for Study Glasses, ARM, Blanks, and} Standards Solutions
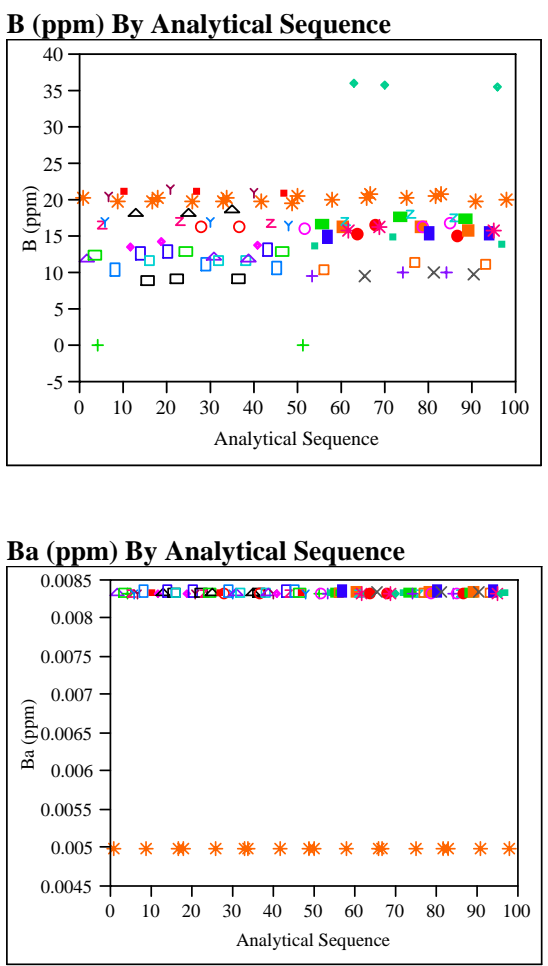

\section{Cd (ppm) By Analytical Sequence}

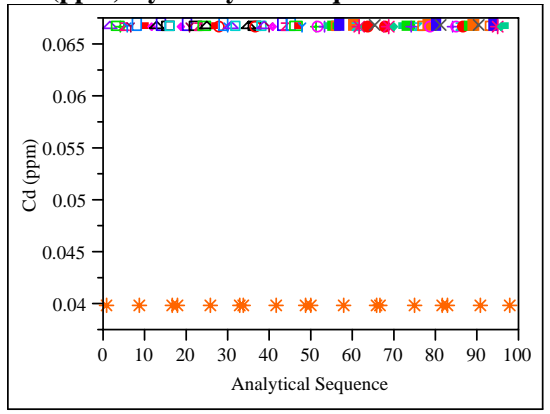

Cr (pp) By Analytical Sequence

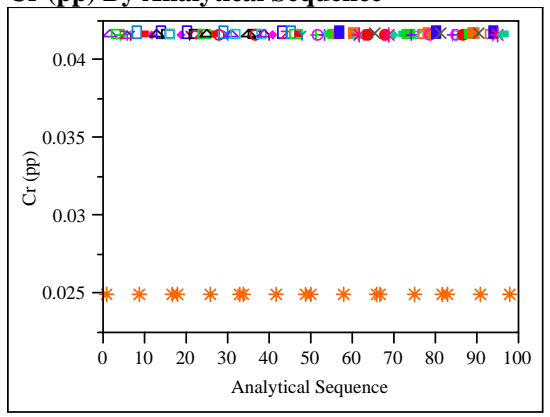

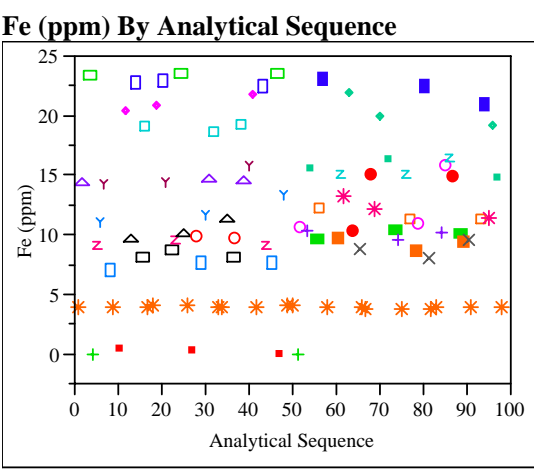

\section{Li (ppm) By Analytical Sequence}

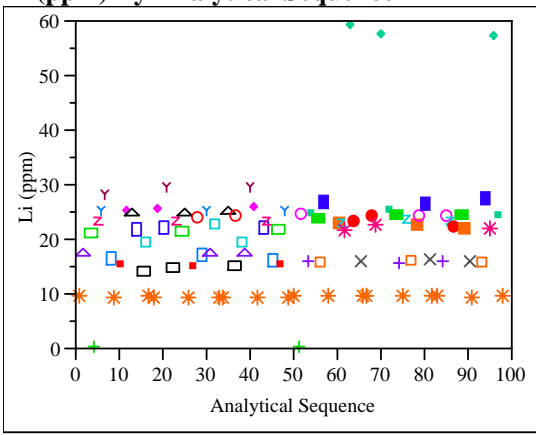

Na (ppm) By Analytical Sequence

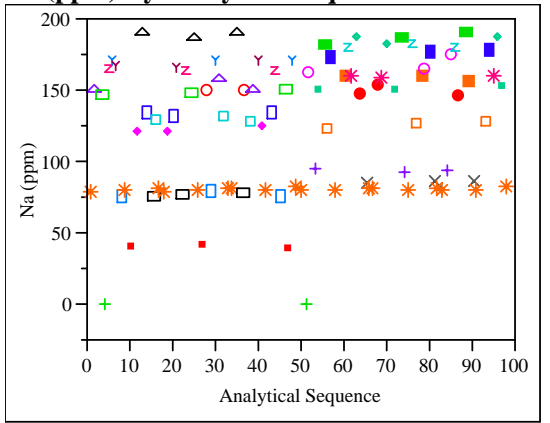

Pb (ppm) By Analytical Sequence

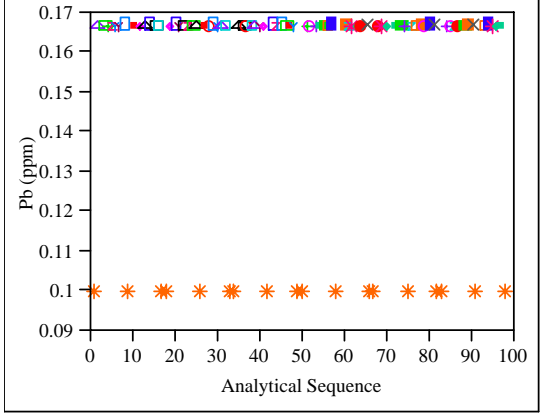

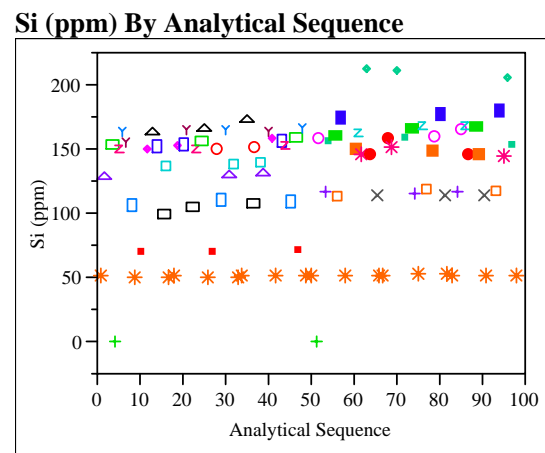

Th (ppm) By Analytical Sequence

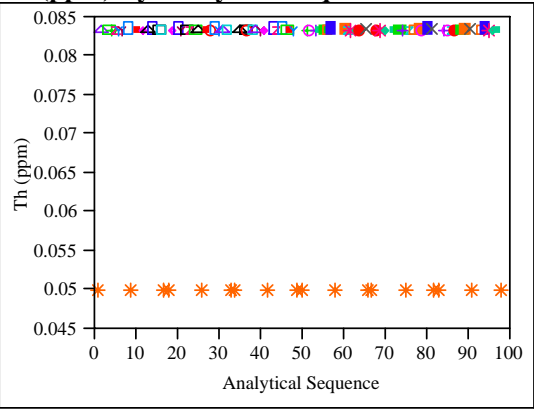

U (ppm) By Analytical Sequence

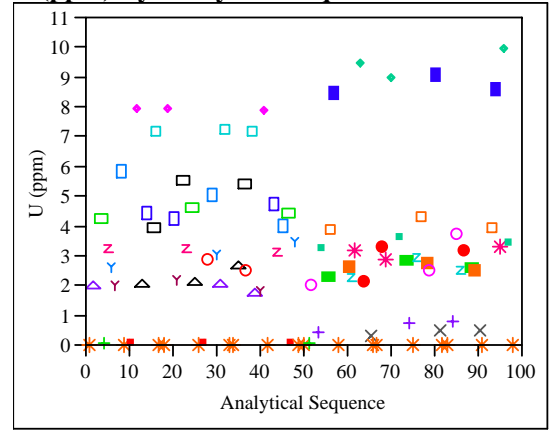




\section{Exhibit D.3: Measurements of the Multi-Element Solution Standard by Set and ICP Block}

Oneway Analysis of B (ppm) By Block

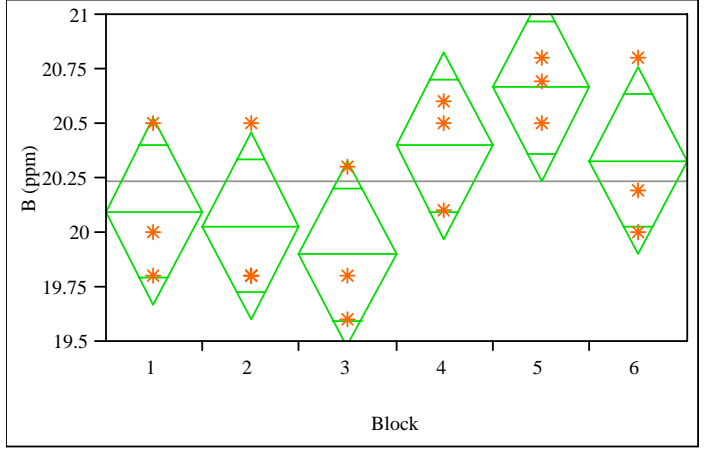

Oneway Anova

$\begin{array}{lr}\text { Rsquare } & 0.461522 \\ \text { Adj Rsquare } & 0.237156 \\ \text { Root Mean Square Error } & 0.339116 \\ \text { Mean of Response } & 20.23889 \\ \text { Observations (or Sum Wgts) } & 18\end{array}$

Analysis of Variance

Source DF Sum of Squares Mean Square F Ratio Prob $>$ F

$\begin{array}{llllll}\text { Block } & 5 & 1.1827778 & 0.236556 & 2.0570 & 0.1420\end{array}$

$\begin{array}{lrrr}\text { Error } & 12 & 1.3800000 & 0.115000\end{array}$

2.5627778

Level Number Mean Std Error Lower 95\% Upper 95\%

$\begin{array}{llllll}1 & 3 & 20.1000 & 0.19579 & 19.673 & 20.527\end{array}$

$\begin{array}{llllll}1 & 3 & 20.1000 & 0.19579 & 19.673 & 20.527 \\ 2 & 3 & 20.0333 & 0.19579 & 19.607 & 20.460\end{array}$

$\begin{array}{llllll}1 & 3 & 20.0333 & 0.19579 & 19.607 & 20.460 \\ 3 & 3 & 19.9000 & 0.19579 & 19.473 & 20.327 \\ 4 & 3 & 20.4000 & 0.19579 & 19.973 & 20.827\end{array}$

$\begin{array}{llllll}4 & 3 & 20.4000 & 0.19579 & 19.973 & 20.827 \\ 5 & 3 & 20.6667 & 0.19579 & 20.240 & 21.093\end{array}$

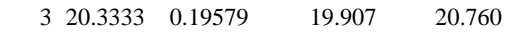

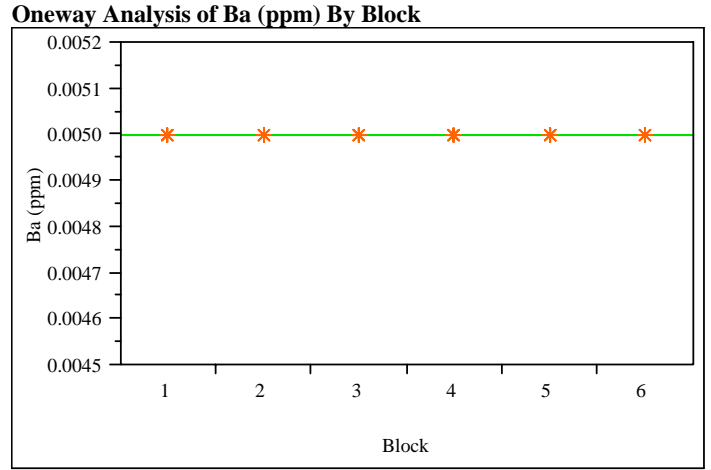

\section{Oneway Anova}

Summary of Fi

\section{Rsquare}

Adj Rsquare

$\begin{array}{lr}\text { Root Mean Square Error } & 0 \\ \text { Mean of Response } & 0.005\end{array}$

Observations (or Sum Wgts) 18

Analysis of Variance

Source DF Sum of Squares Mean Square F Ratio Prob > F

$\begin{array}{lrll}\text { Block } & 5 & 0 & 0 \\ \text { Error } & 12 & 0 & 0\end{array}$

C. Total $17 \quad 0$

Means for Oneway Anova

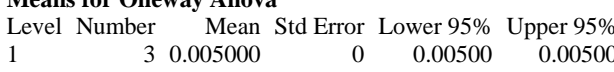

$\begin{array}{llllll}2 & 3 & 0.005000 & 0 & 0.00500 & 0.00500 \\ 3 & 3 & 0.005000 & 0 & 0.00500 & 0.00500\end{array}$

$\begin{array}{llllll}3 & 3 & 0.005000 & 0 & 0.00500 & 0.00500\end{array}$

$\begin{array}{llllll}5 & 3 & 0.005000 & 0 & 0.00500 & 0.00500 \\ 6 & 3 & 0.005000 & 0 & 0.00500 & 0.00500\end{array}$

Std Error uses a pooled estimate of error variance
Oneway Analysis of Cd (ppm) By Block

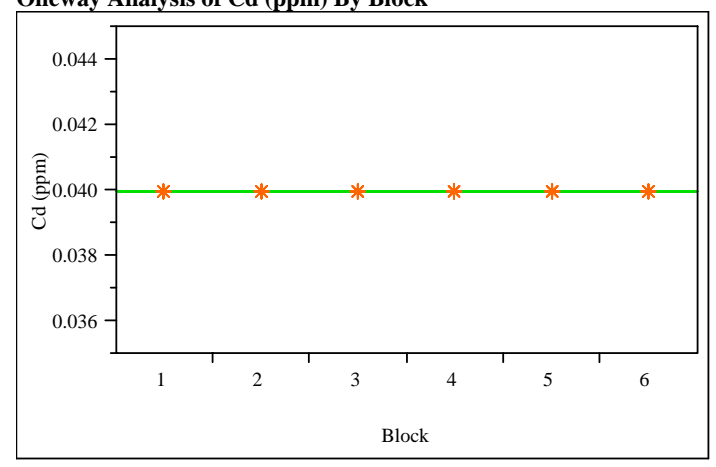

Oneway Anova

Summary of Fit

Rsquare

Adj Rsquare

Root Mean Square Error $\quad 0$

Mean of Response

Observations (or Sum Wgts)

Analysis of Variance

Source DF Sum of Squares Mean Square F Ratio Prob > F

$\begin{array}{lrrr}\text { Block } & 5 & 0 & 0 \\ \text { Error } & 12 & 0 & 0\end{array}$

$\begin{array}{lll}\text { Error } & 12 & 0 \\ \text { C. Total } & 17 & 0\end{array}$

Means for Oneway Anova

Level Number Mean Std Error Lower 95\% Upper 95\%

$\begin{array}{llllll}1 & 3 & 0.040000 & 0 & 0.04000 & 0.04000\end{array}$

$\begin{array}{llllll}1 & 3 & 0.040000 & 0 & 0.04000 & 0.04000\end{array}$

$\begin{array}{llllll}1 & 3 & 0.040000 & 0 & 0.04000 & 0.04000 \\ 3 & 3 & 0.040000 & 0 & 0.04000 & 0.04000 \\ 4 & 3 & 0.040000 & 0 & 0.04000 & 0.04000\end{array}$

$\begin{array}{llllll}4 & 3 & 0.040000 & 0 & 0.04000 & 0.04000 \\ 5 & 3 & 0.040000 & 0 & 0.04000 & 0.04000\end{array}$

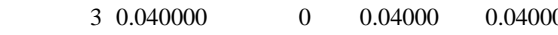




\section{Exhibit D.3: Measurements of the Multi-Element Solution Standard by Set and ICP Block}

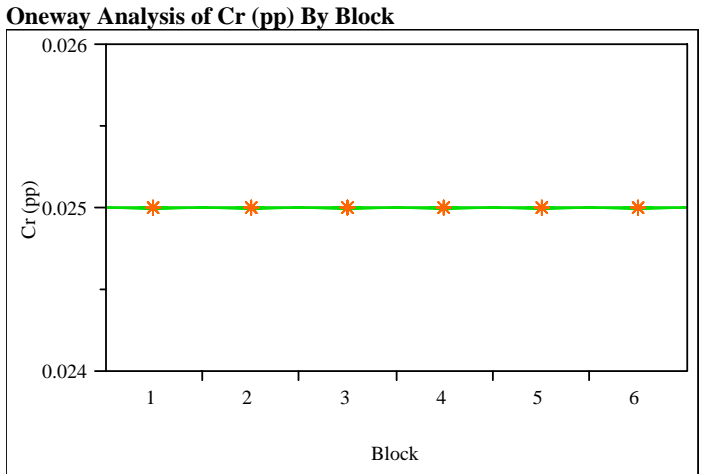

Oneway Anova

Rsquare

$\begin{array}{lr}0 \\ \text { Adj Rsquare } & -0.41667\end{array}$

Root Mean Square Error $\quad 4.25 \mathrm{e}-18$

0.025
Mean of Response

Analysis of Variance

Source DF Sum of Squares Mean Square F Ratio Prob $>$ F Block 5 $\begin{array}{lrrr}\text { Error } & 12 & 2.1667 \mathrm{e}-34 & 1.806 \mathrm{e}-35\end{array}$

C. Total $17 \quad 2.1667 \mathrm{e}-34$

Means for Oneway Anova

Level Number Mean Std Error Lower 95\% Upper 95\%

$\begin{array}{llllll}1 & 3 & 0.025000 & 2.453 \mathrm{e}-18 & 0.02500 & 0.02500\end{array}$

$\begin{array}{llllll}1 & 3 & 0.025000 & 2.453 \mathrm{e}-18 & 0.02500 & 0.02500\end{array}$

$\begin{array}{llllll}1 & 3 & 0.025000 & 2.453 \mathrm{e}-18 & 0.02500 & 0.02500 \\ 4 & 3 & 0.025000 & 2.453 \mathrm{e} & 0.02500 & 0.02500\end{array}$

$\begin{array}{lllll}3 & 0.025000 & 2.453 \mathrm{e}-18 & 0.02500 & 0.02500\end{array}$

$\begin{array}{llllll}5 & 3 & 0.025000 & 2.453 \mathrm{e}-18 & 0.02500 & 0.02500 \\ 6 & 3 & 0.025000 & 2.453 \mathrm{e}-18 & 0.02500 & 0.02500\end{array}$

Std Error uses a pooled estimate of error variance

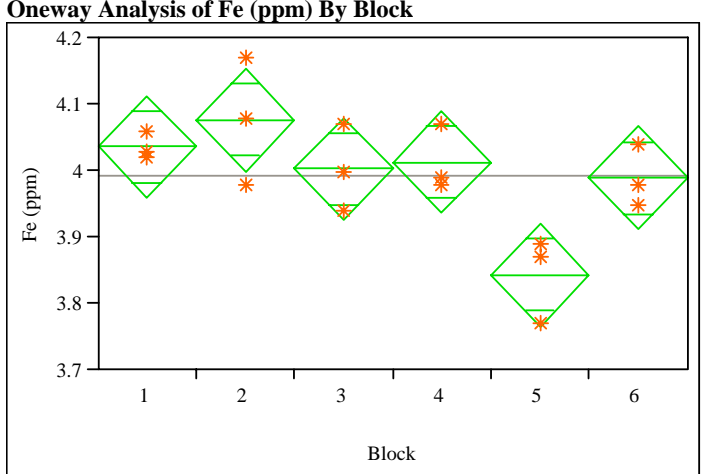

Oneway Anova

Summary of Fit

Rsquare

Adj Rsquare

0.680995

\begin{tabular}{ll}
0.580977 \\
\hline
\end{tabular}

Mean of Response 3.09388

Observations (or Sum Wgts)

Analysis of Variance

Source DF Sum of Squares Mean Square F Ratio Prob > F

$\begin{array}{lllllll}\text { Block } & 5 & 0.09549444 & 0.019099 & 5.1234 & 0.0096\end{array}$

$\begin{array}{lrrr}\text { Block } & 5 & 0.09549444 & 0.019099 \\ \text { Error } & 12 & 0.04473333 & 0.003728\end{array}$

$\begin{array}{lll}\text { C. Total } & 17 & 0.14022778\end{array}$

Means for Oneway Anova

Level Number Mean Std Error Lower 95\% Upper 95\%

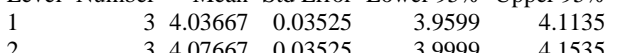

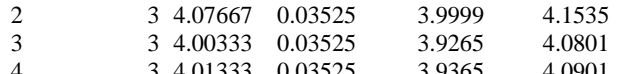

$\begin{array}{llllll}4 & 3 & 4.01333 & 0.03525 & 3.9365 & 4.0901 \\ 5 & 3 & 3.84333 & 0.03525 & 3.7665 & 3.9201\end{array}$

$\begin{array}{llllll}5 & 3 & 3.84333 & 0.03525 & 3.7665 & 3.9201 \\ 6 & 3 & 3.99000 & 0.03525 & 3.9132 & 4.0668\end{array}$

Std Error uses a pooled estimate of error variance
Oneway Analysis of Li (ppm) By Block

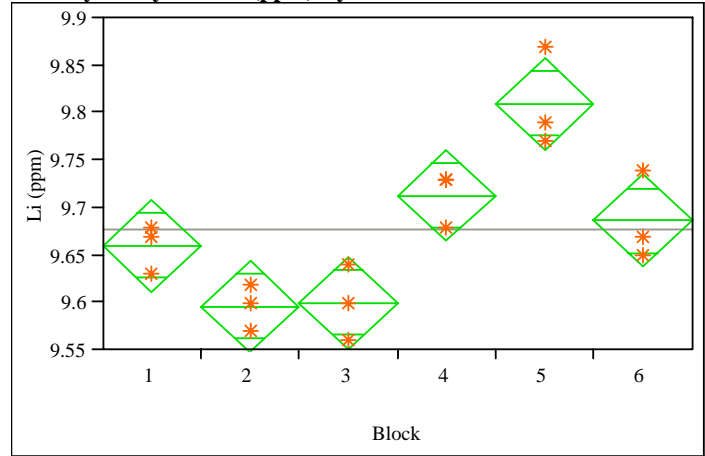

Oneway Anova

Summary of Fit

Rsquare

$\begin{array}{ll}\text { Adj Rsquare } & 0.844125 \\ & 0.779177\end{array}$

Root Mean Square Error $\quad 0.038297$

Mean of Response $\quad 0.038297$

Observations (or Sum Wgts) 9.677778

Observations (or Sum $W$

Analysis of Variance

DF Sum of Squares Mean Square F Ratio Prob > F

$\begin{array}{lllll}5 & 0.09531111 & 0.019062 & 12.9970 & 0.0002\end{array}$

$\begin{array}{llll}\text { Error } & 12 & 0.01760000 & 0.001467\end{array}$

0.11291111

Level Number Mean Std Error Lower 95\% Upper 95\%

$\begin{array}{llllll}1 & 3 & 9.66000 & 0.02211 & 9.6118 & 9.7082 \\ 2 & 3 & 9.59667 & 0.02211 & 9.5485 & 9.6448\end{array}$

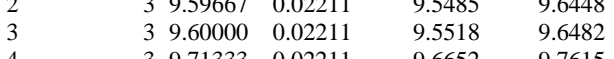

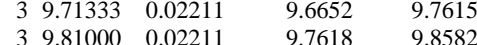

$\begin{array}{llllll}5 & 3 & 9.810067 & 0.02211 & 9.7618 & 9.8582 \\ 6 & 3 & 0.02211 & 9.6385 & 9.7348\end{array}$

Std Error uses a pooled estimate of error variance 


\section{Exhibit D.3: Measurements of the Multi-Element Solution Standard by Set and ICP Block}

Oneway Analysis of Na (ppm) By Block

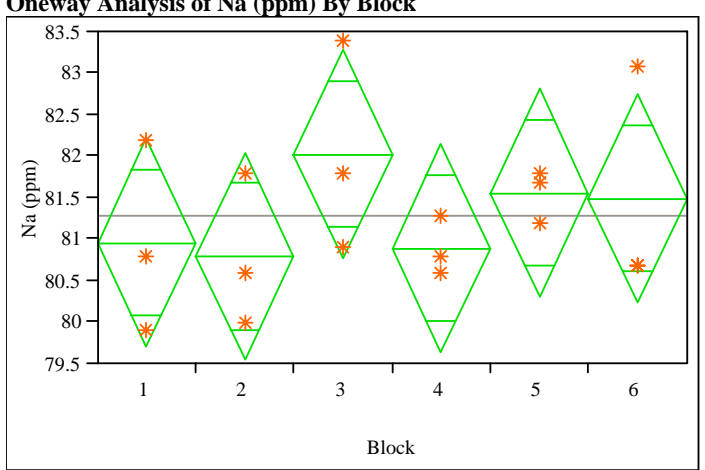

Oneway Anova

ummary of Fit

\section{Adj Rsquare \\ 0.228042 \\ $-0.09361$ \\ Root Mean Square Erro \\ 0.994987 \\ Observations (or Sum Wgts) \\ 1.29444}

Analysis of Variance

Source DF Sum of Squares Mean Square F Ratio Prob > F

$\begin{array}{lllllll}\text { Block } & 5 & 3.509444 & 0.701889 & 0.7090 & 0.6281\end{array}$

$\begin{array}{lrrr}\text { Error } & 12 & 11.880000 & 0.990000\end{array}$

C. Total $17 \quad 15.389444$

Level Number Mean Std Error Lower 95\% Upper 95\%

Mean Std Error Lower 95\% Upper 95\%

$\begin{array}{llllll}1 & 3 & 80.9667 & 0.57446 & 79.715 & 82.218 \\ 2 & 3 & 80.8000 & 0.57446 & 79.548 & 82.052\end{array}$

\begin{tabular}{llllll}
1 & 3 & 80.8000 & 0.57446 & 79.548 & 82.052 \\
3 & 3 & 82.0333 & 0.57446 & 80.782 & 83.285 \\
\hline & 3 & 30000 & 0.57446 & 79.648 & 82.152
\end{tabular}

$\begin{array}{llllll}4 & 3 & 80.9000 & 0.57446 & 79.648 & 82.152 \\ 5 & 3 & 81.5667 & 0.57446 & 80.315 & 82.818\end{array}$

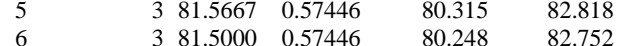

Std Error uses a pooled estimate of error variance

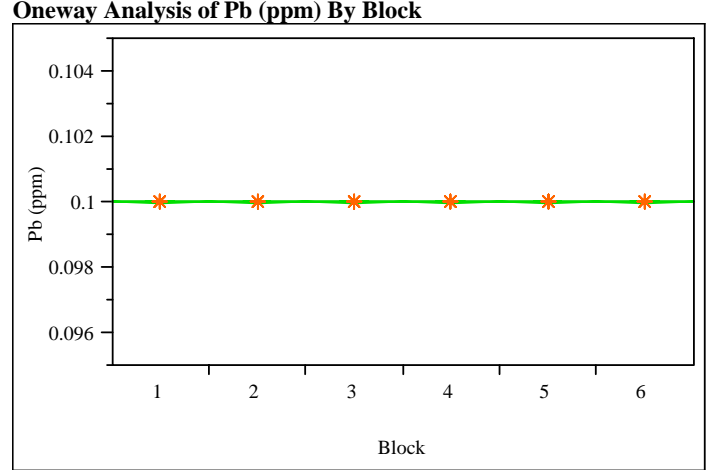

\section{Oneway Anova}

\section{Rsquare}

Adj Rsquare

Root Mean Square Error $\quad-0.41667$

$\begin{array}{lr}\text { Mean of Response } & 0.1 \\ \text { Observations (or Sum Wgts) } & 18\end{array}$

Analysis of Variance

Source DF Sum of Squares Mean Square F Ratio Prob > F $\begin{array}{lrrrrr}\text { Block } & 5 & 0 & 0 & 0.0000 & 1.0000\end{array}$ $\begin{array}{lrrr}\text { Error } & 12 & 3.4667 \mathrm{e}-33 & 2.889 \mathrm{e}-34\end{array}$

$\begin{array}{ll}\text { C. Total } 17 & 3.4667 \mathrm{e}-33 \\ \text { Means for Oneway Anova }\end{array}$

Level Number Mean Std Error Lower 95\% Upper 95\%

$\begin{array}{llllll}1 & 3 & 0.100000 & 9.813 \mathrm{e}-18 & 0.10000 & 0.10000\end{array}$

$\begin{array}{llllll}1 & 3 & 0.100000 & 9.813 \mathrm{e}-18 & 0.10000 & 0.10000 \\ 3 & 3 & 0.100000 & 9.813 \mathrm{e}-18 & 0.10000 & 0.10000\end{array}$

$\begin{array}{llllll}3 & 3 & 0.100000 & 9.813 \mathrm{e}-18 & 0.10000 & 0.10000 \\ 4 & 3 & 0.10000 & 9.813-18 & 0.10000 & 0.10000\end{array}$

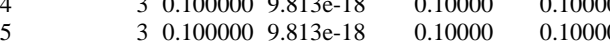

$\begin{array}{llllll}5 & 3 & 0.1000000 & 9.813 \mathrm{e}-18 & 0.10000 & 0.10000 \\ 6 & 3 & 0.10000 & 9.813 \mathrm{e}-18 & 0.10000 & 0.10000\end{array}$

Std Error uses a pooled estimate of error variance
Oneway Analysis of Si (ppm) By Block

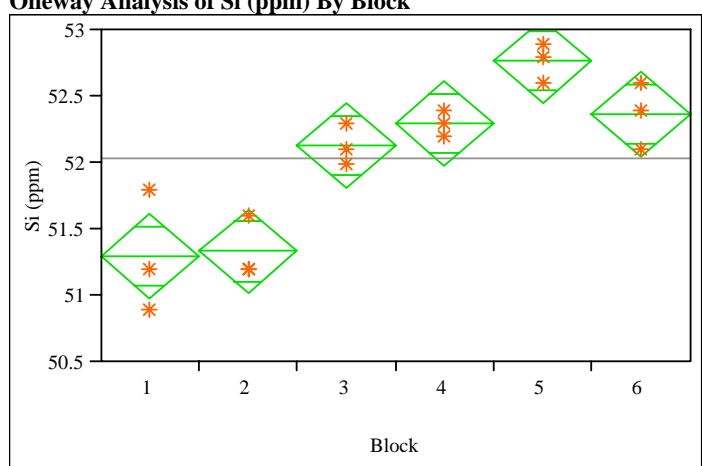

Oneway Anova

Summary of Fit

Rsquare

Adj Rsquare

Root Mean Square Error $\quad 0.82018$

Mean of Response $\quad 52.03333$

Observations (or Sum Wgts)

Analysis of Variance

Analysis of Variance

DF Sum of Squares Mean Square F Ratio Prob > F

$\begin{array}{llllll} & & & \\ \end{array}$

$\begin{array}{lll}\text { Error } & 12 & 0.7666667\end{array}$

C. Total $17-6.0400000$

Level Number Mean Std Error Lower 95\% Upper 95\%

1 - $31.3000-0.14593 \quad 50.982$ Upper $95 \%$

$\begin{array}{llllll}1 & 3 & 51.3000 & 0.14593 & 50.982 & 51.618 \\ 2 & 3 & 51.3333 & 0.14993 & 51.015 & 51.651 \\ 3 & 3 & 5.1333 & 0.14593 & 51.815 & 52.451\end{array}$

$\begin{array}{llllll}3 & 3 & 52.1333 & 0.14593 & 51.815 & 52.451 \\ 4 & 3 & 52.3000 & 0.14593 & 51.982 & 52.618\end{array}$

$\begin{array}{lllll}3 & 52.3000 & 0.14593 & 51.982 & 52.618 \\ 3 & 52.7667 & 0.14593 & 52.449 & 53.085\end{array}$

$\begin{array}{llllll}5 & 3 & 52.3667 & 0.14593 & 52.449 & 53.085 \\ 6 & 3 & 52.049 & 52.685\end{array}$

Std Error uses a pooled estimate of error variance 


\section{Exhibit D.3: Measurements of the Multi-Element Solution Standard by Set and ICP Block}

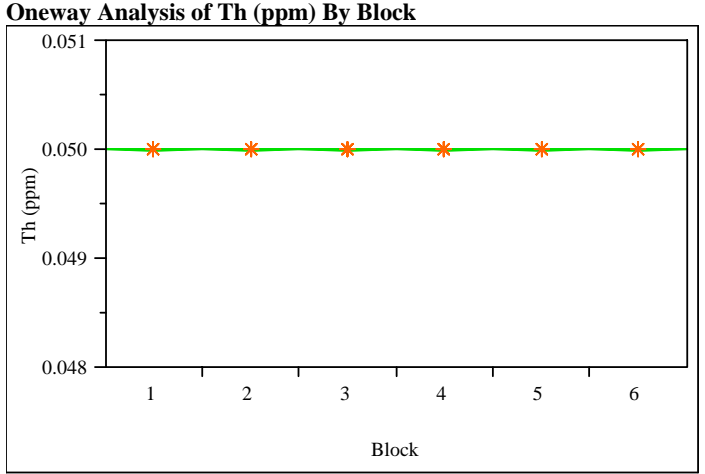

\section{Oneway Anova}

Summary of Fit

Rsquare

$\begin{array}{lr}0 \\ \text { Adj Rsquare } & -0.41667\end{array}$

Root Mean Square Error $\quad$ 8.5e-18

Mean of Response

Anatysions (or Sum Wgts)

Source DF Sum of Squares Mean Square F Ratio Prob $>$ F

$\begin{array}{lrrr}\text { Error } & 12 & 8.6667 \mathrm{e}-34 & 7.222 \mathrm{e}-35\end{array}$

C. Total $17 \quad 8.6667 \mathrm{e}-34$

$\begin{array}{lll}\text { Means for Oneway Anova } & \\ \text { Level Number Mean Std Error Lower 95\% Upper 95\% }\end{array}$

$\begin{array}{rrrrr}3 & 0.050000 & 4.907 \mathrm{e}-18 & 0.05000 & 0.05000\end{array}$

$\begin{array}{llllll}1 & 3 & 0.050000 & 4.907 \mathrm{e}-18 & 0.05000 & 0.05000 \\ 2 & 3 & 0.050000 & 4.907 \mathrm{e}-18 & 0.05000 & 0.05000\end{array}$

$\begin{array}{llllll}3 & 3 & 0.050000 & 4.907 \mathrm{e}-18 & 0.05000 & 0.05000\end{array}$

$\begin{array}{lllll}3 & 0.050000 & 4.907 \mathrm{e}-18 & 0.05000 & 0.05000\end{array}$

$\begin{array}{llllll}5 & 3 & 0.050000 & 4.907 \mathrm{e}-18 & 0.05000 & 0.05000 \\ 6 & 3 & 0.050000 & 4.907 \mathrm{e}-18 & 0.05000 & 0.05000\end{array}$

Std Error uses a pooled estimate of error variance

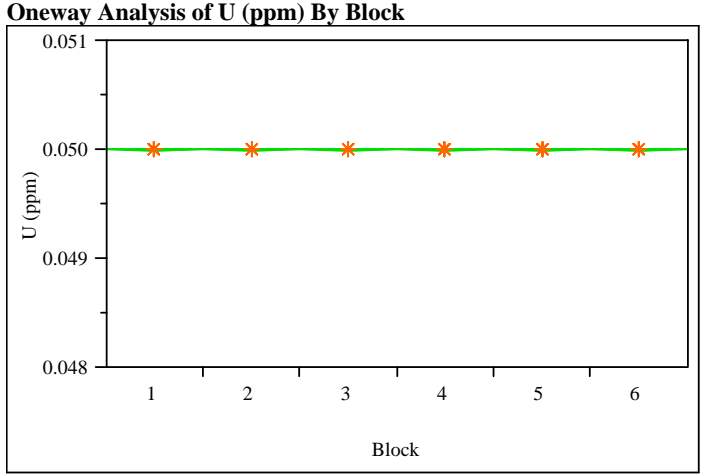

\section{Oneway Anova}

Summary of Fit

Rsquare

$\begin{array}{lr}-0.41667 \\ \text { Adj Rsquare } & 0.05\end{array}$

Square Error $\quad 8.5 \mathrm{e}-18$

$\begin{array}{lr}\text { Mean of Response } & 0.05 \\ \text { Observations (or Sum Wgts) } & 18\end{array}$

Analysis of Variance

Source DF Sum of Squares Mean Square F Ratio Prob > F

$\begin{array}{lrrrrr}\text { Block } & 5 & 0 & 0 & 0.0000 & 1.0000\end{array}$

$\begin{array}{lrrr}\text { Error } & 12 & 8.6667 \mathrm{e}-34 & 7.222 \mathrm{e}-35\end{array}$

C. Total $17 \quad 8.6667 \mathrm{e}-34$

Level Number Mean Std Error Lower 95\% Upper 95\%

$\begin{array}{lllllll}1 & 3 & 0.050000 & 4.907 \mathrm{e}-18 & 0.05000 & 0.05000\end{array}$

$\begin{array}{llllll}1 & 3 & 0.050000 & 4.907 \mathrm{e}-18 & 0.05000 & 0.05000\end{array}$

$\begin{array}{llllll}3 & 3 & 0.050000 & 4.907 \mathrm{e}-18 & 0.05000 & 0.05000\end{array}$

$\begin{array}{llllll}4 & 3 & 0.050000 & 4.907 \mathrm{e}-18 & 0.05000 & 0.05000\end{array}$

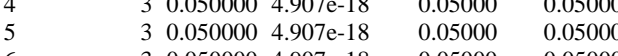

$\begin{array}{llllll}5 & 3 & 0.050000 & 4.907 \mathrm{e}-18 & 0.05000 & 0.05000 \\ 6 & 3 & 0.05000 & 0.05000\end{array}$ 


\section{Exhibit D.4: SRNL-ML PCT Measurements by Glass Number for Study Glasses and} Standards

(100 - Solution Standard; 101 - EA; 102 - ARM; 103 - Blanks)

B (ppm) By Glass \#

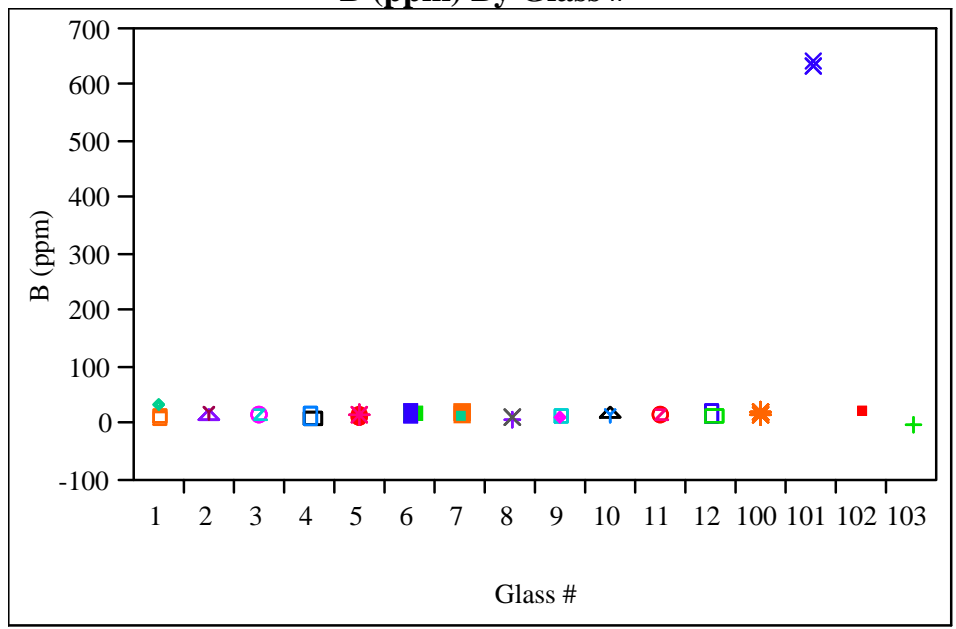

Ba (ppm) By Glass \#

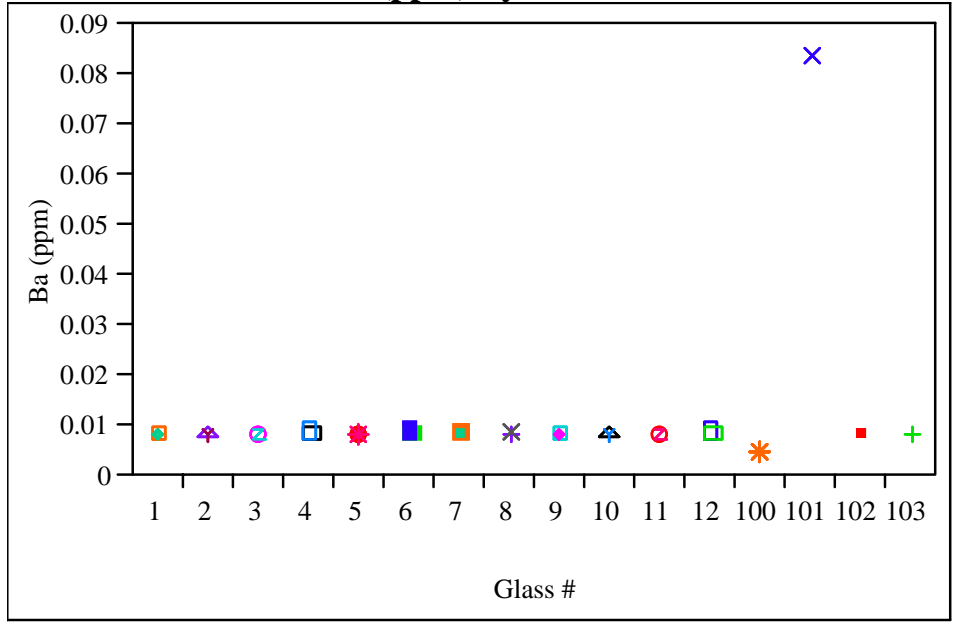

Cd (ppm) By Glass \#

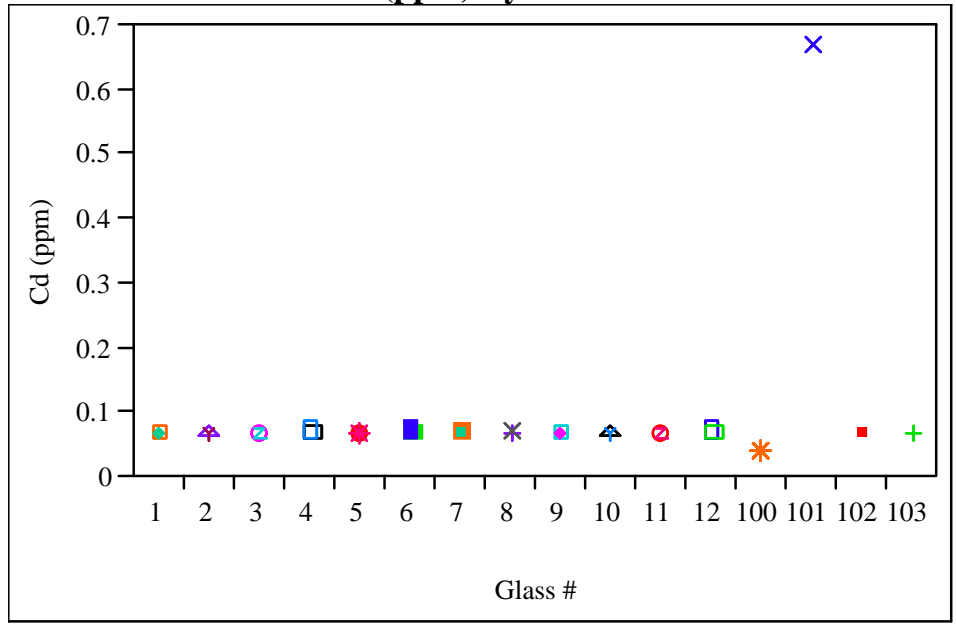


Exhibit D.4: SRNL-ML PCT Measurements by Glass Number for Study Glasses and Standards

(100 - Solution Standard; 101 - EA; 102 - ARM; 103 - Blanks)

\section{Cr (ppm) By Glass \#}

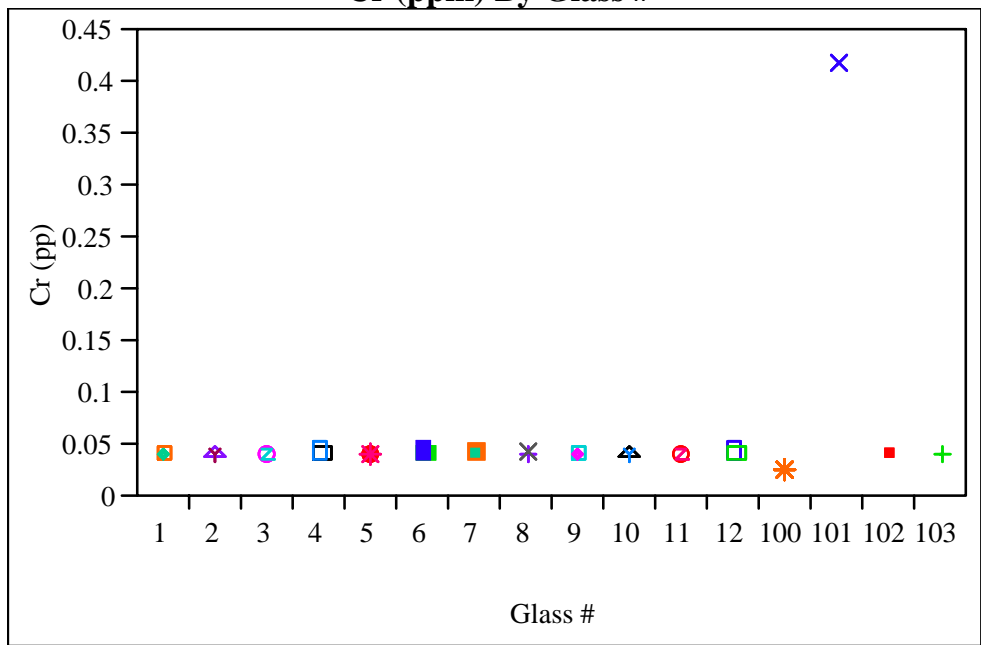

Fe (ppm) By Glass \#

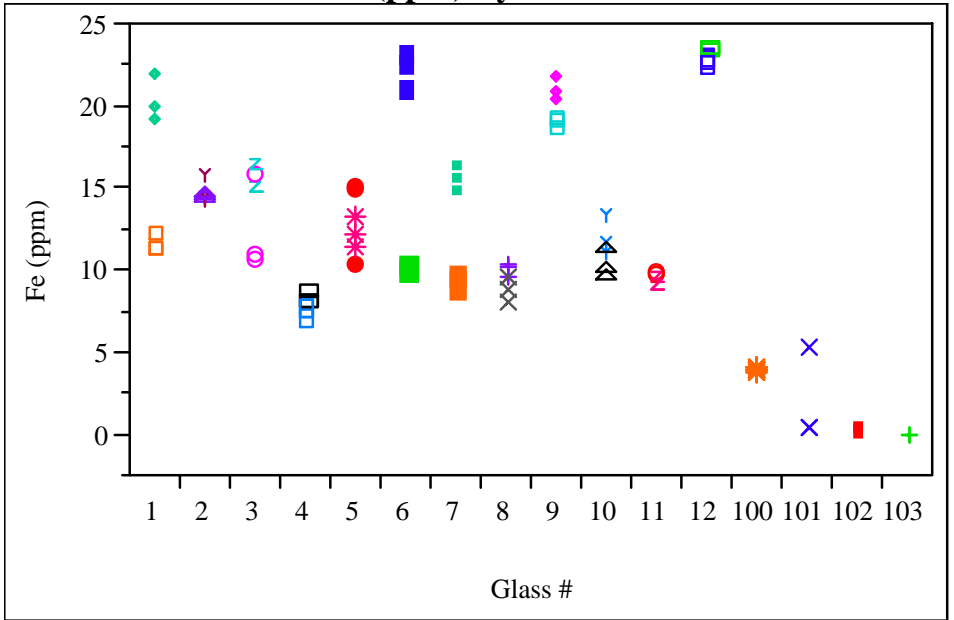

Li (ppm) By Glass \#

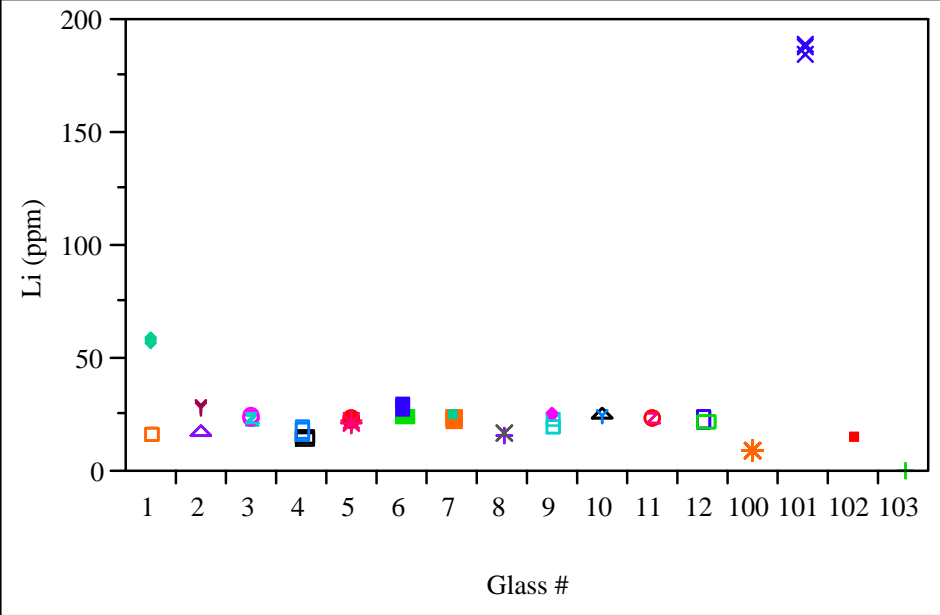




\section{Exhibit D.4: SRNL-ML PCT Measurements by Glass Number for Study Glasses and} Standards

(100 - Solution Standard; 101 - EA; 102 - ARM; 103 - Blanks)

Na (ppm) By Glass \#

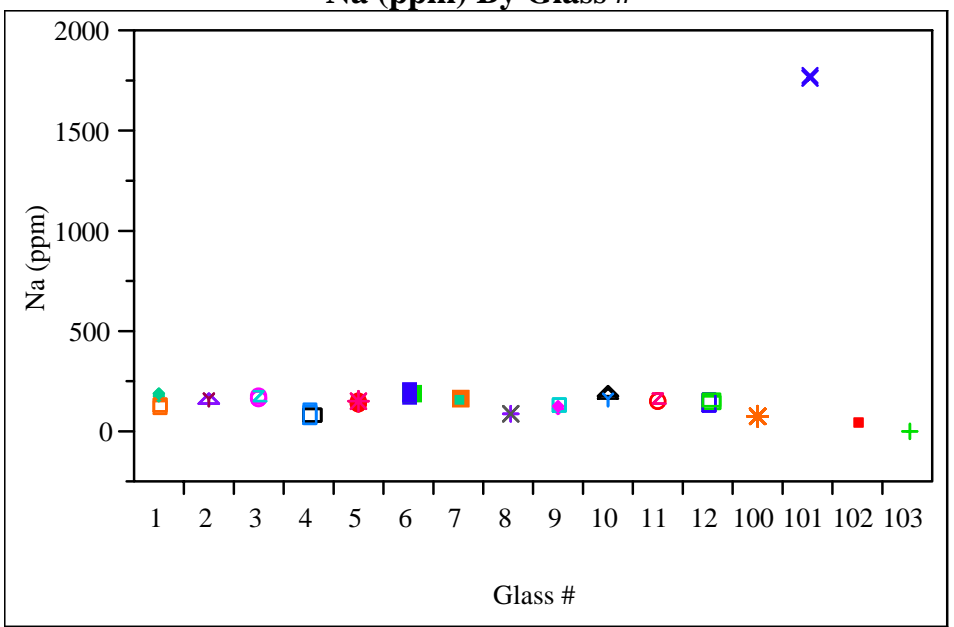

Pb (ppm) By Glass \#

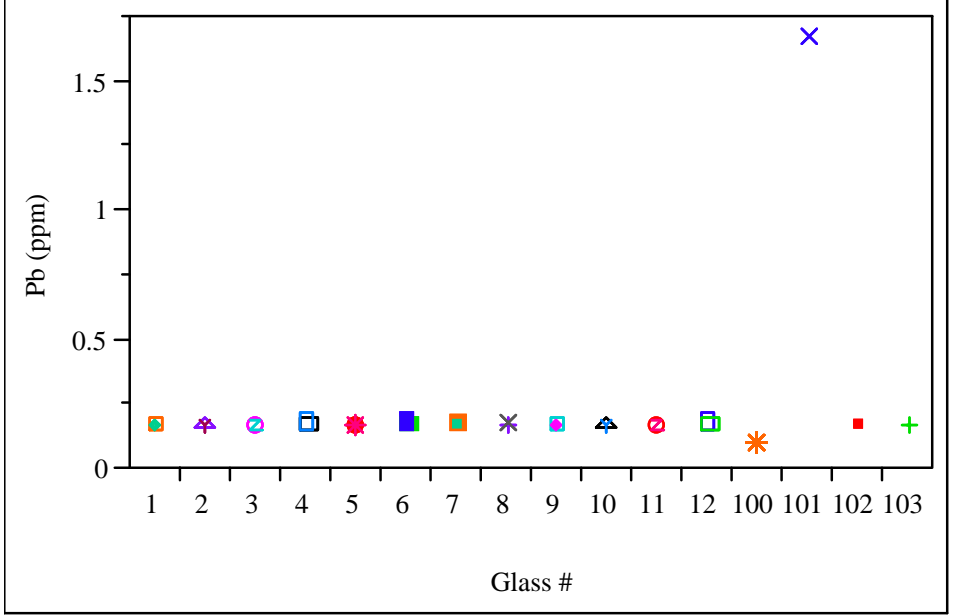

Si (ppm) By Glass \#

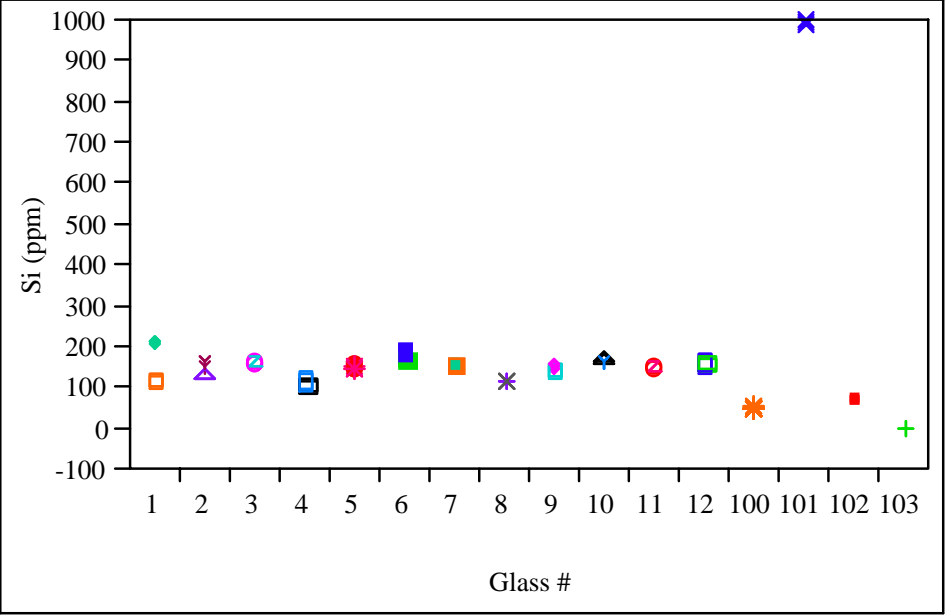


Exhibit D.4: SRNL-ML PCT Measurements by Glass Number for Study Glasses and Standards

(100 - Solution Standard; 101 - EA; 102 - ARM; 103 - Blanks)

Th (ppm) By Glass \#

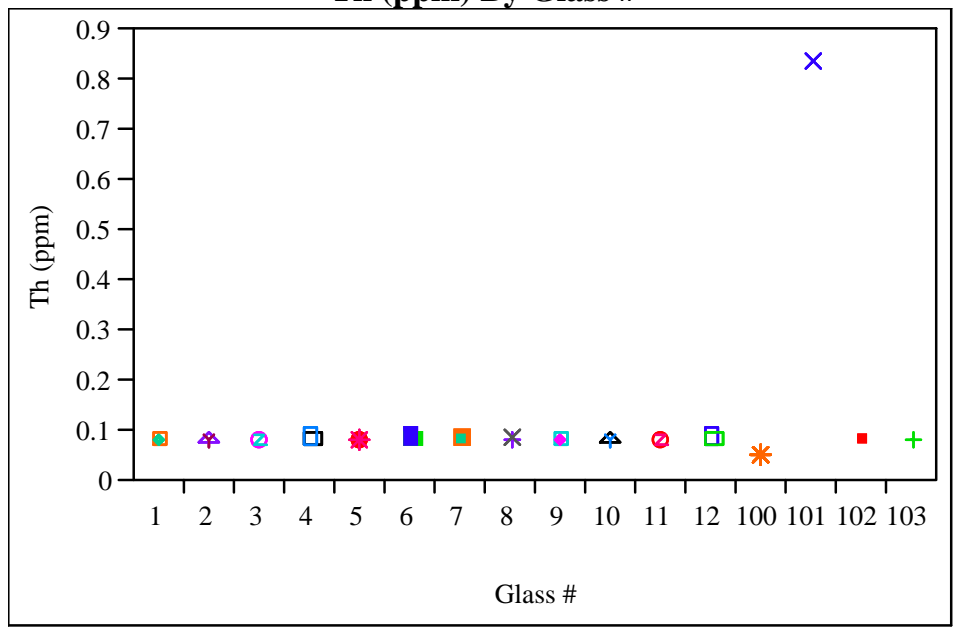

U (ppm) By Glass \#

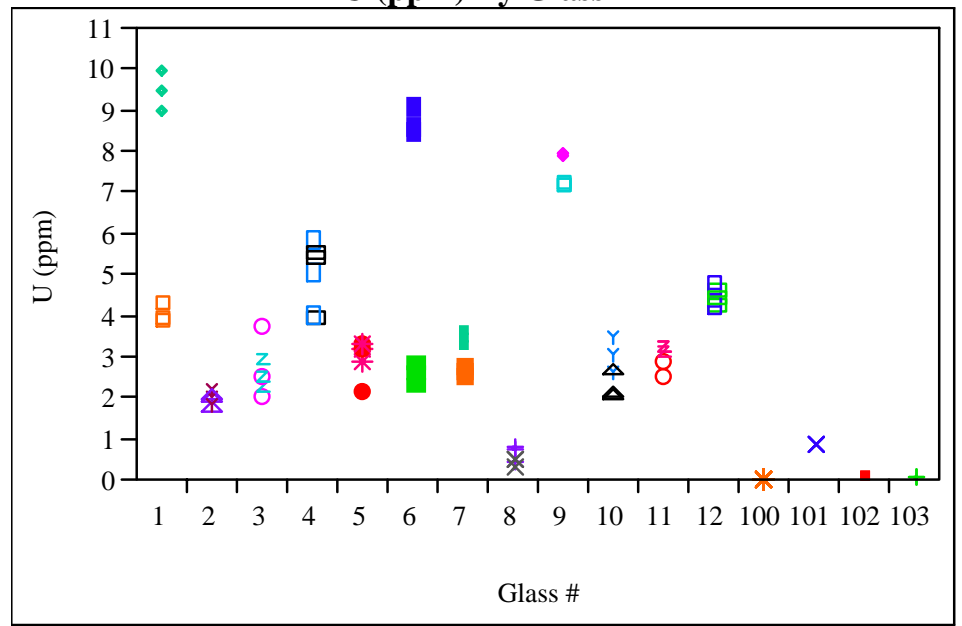


Exhibit D.5: SRNL-ML PCT Measurements by Glass Number for Study Glasses and Standards Except EA

(100 - Solution Standard; 102 - ARM; 103 - Blanks)

B (ppm) By Glass \#

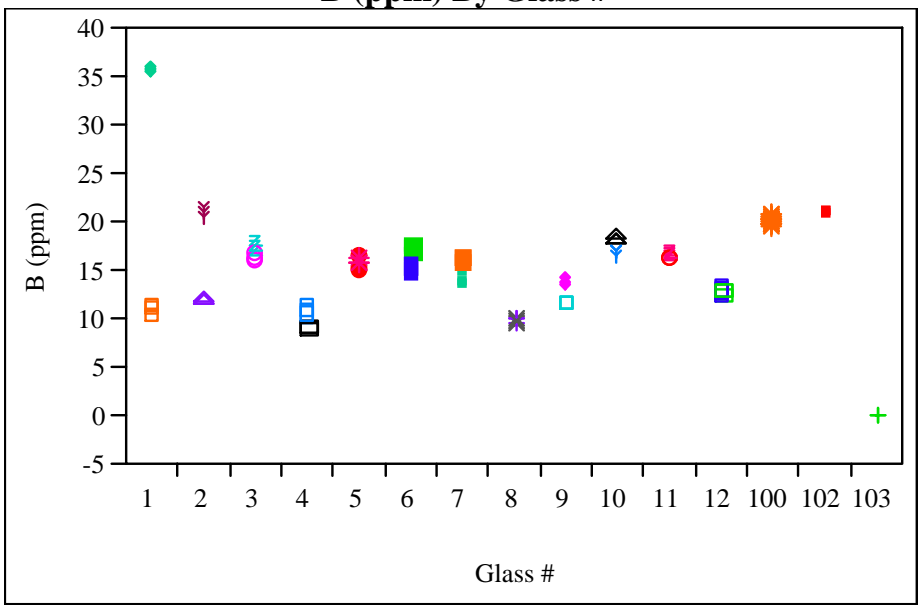

Ba (ppm) By Glass \#

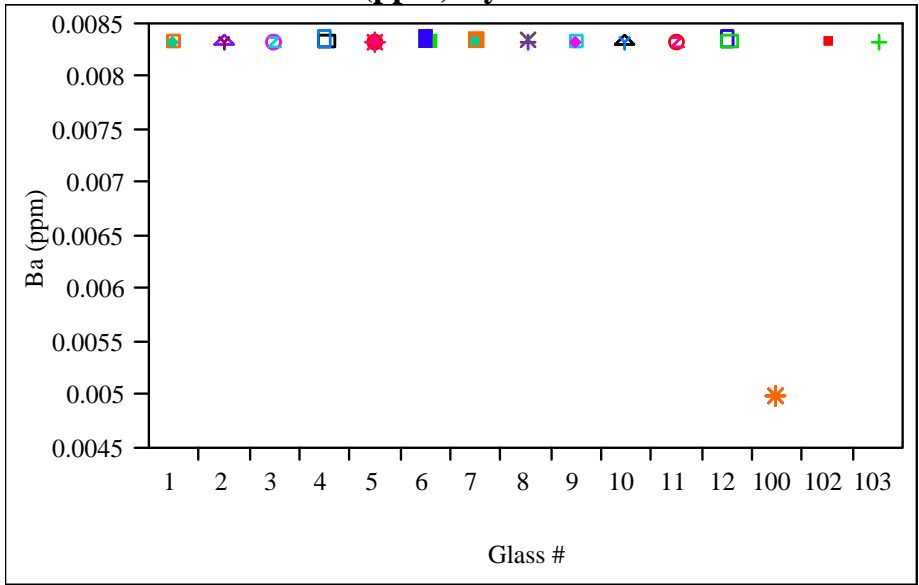

Cd (ppm) By Glass \#

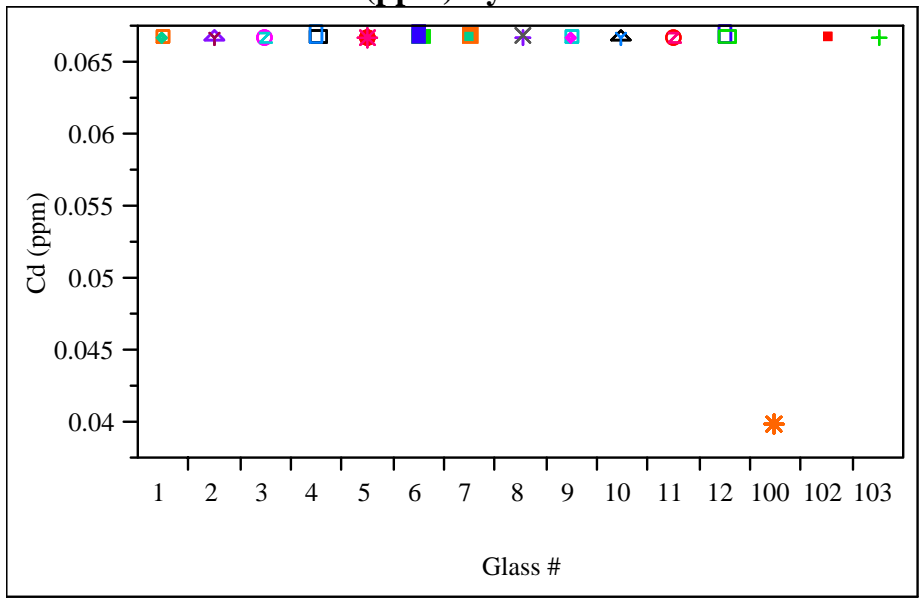


Exhibit D.5: SRNL-ML PCT Measurements by Glass Number for Study Glasses and Standards Except EA

(100 - Solution Standard; 102 - ARM; 103 - Blanks)

Cr (ppm) By Glass \#

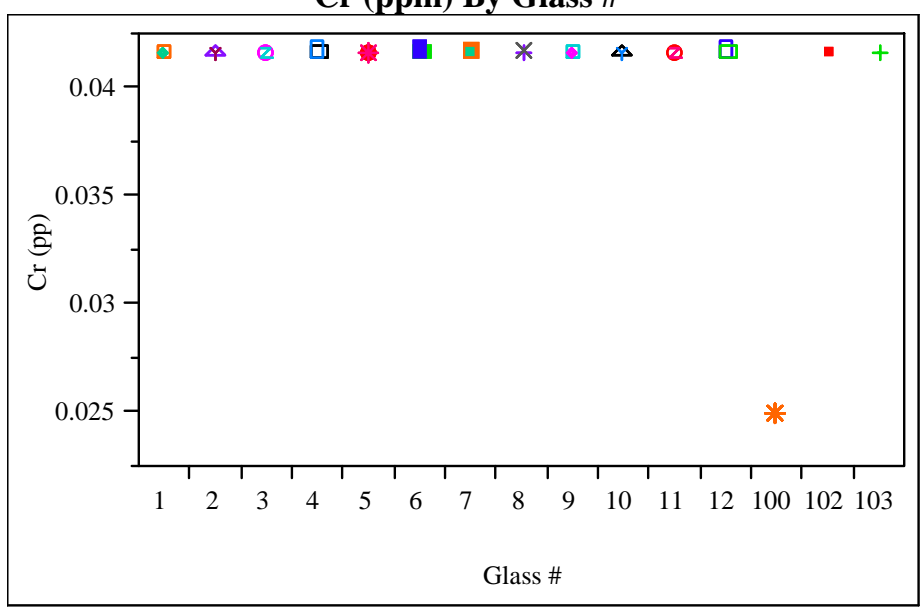

Fe (ppm) By Glass \#

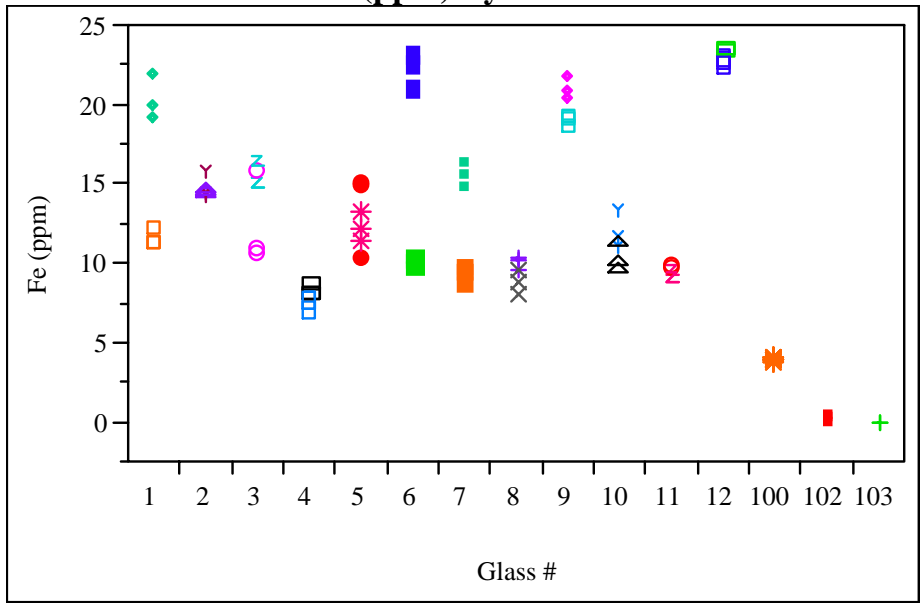

Li (ppm) By Glass \#

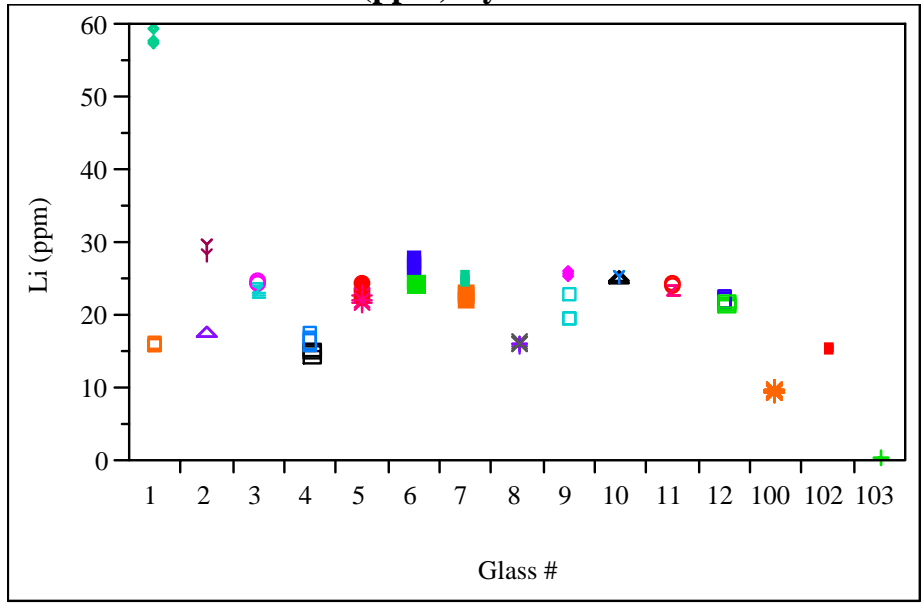


Exhibit D.5: SRNL-ML PCT Measurements by Glass Number for Study Glasses and Standards Except EA

(100 - Solution Standard; 102 - ARM; 103 - Blanks)

Na (ppm) By Glass \#

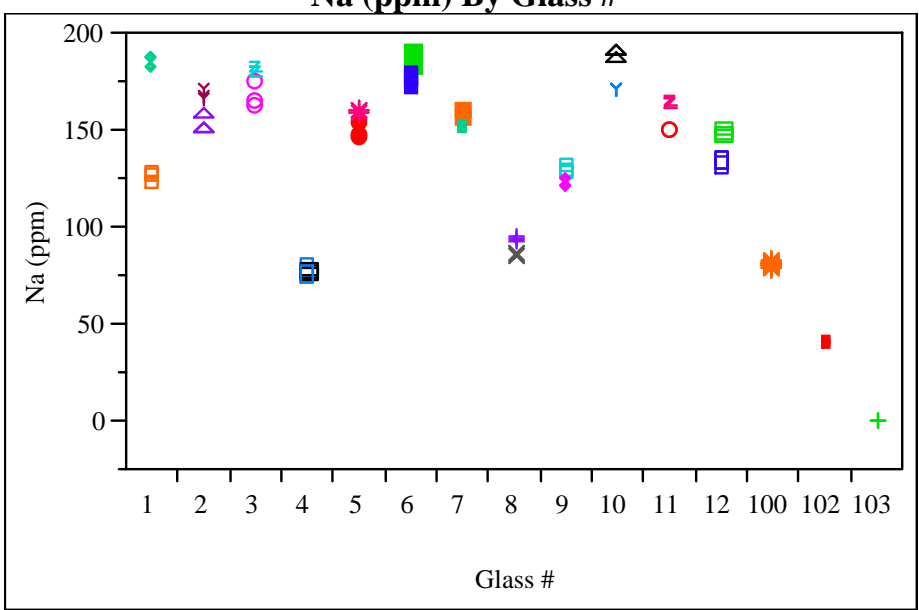

Pb (ppm) By Glass \#

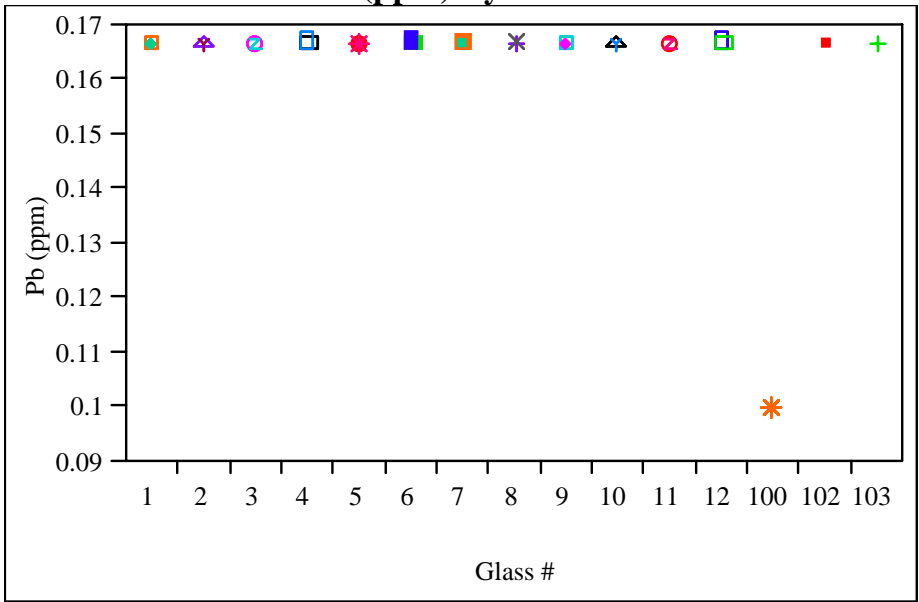

Si (ppm) By Glass \#

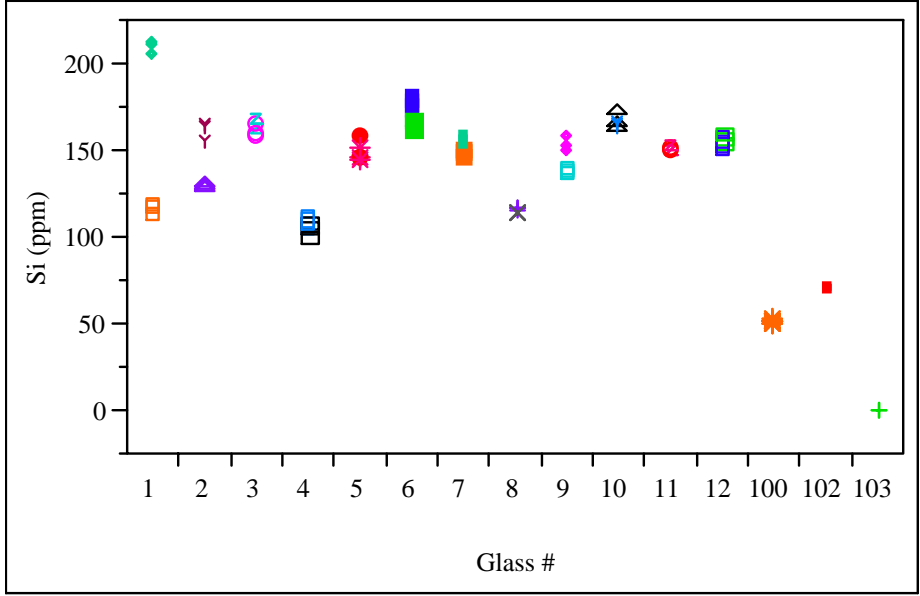


Exhibit D.5: SRNL-ML PCT Measurements by Glass Number for Study Glasses and Standards Except EA

(100 - Solution Standard; 102 - ARM; 103 - Blanks)

Th (ppm) By Glass \#

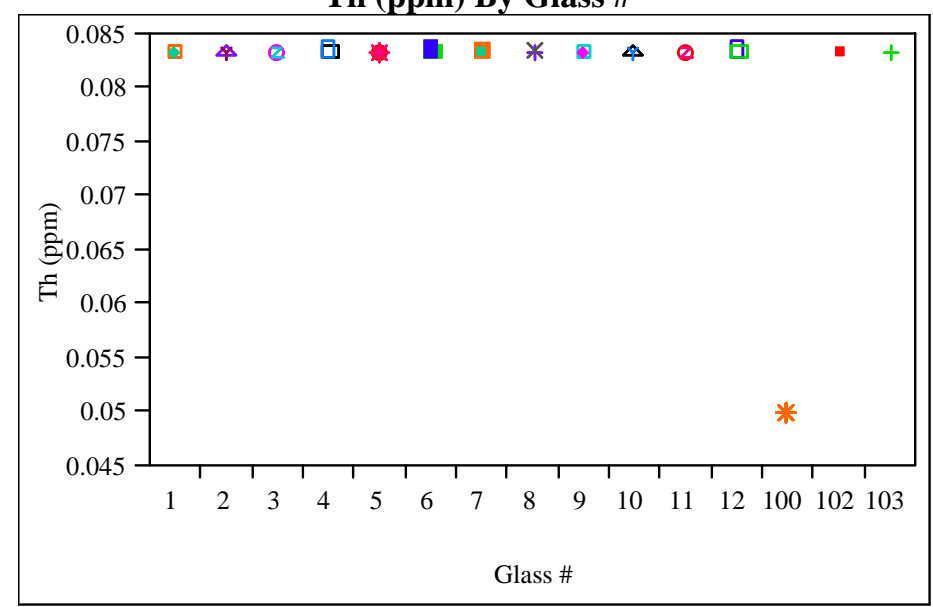

U (ppm) By Glass \#

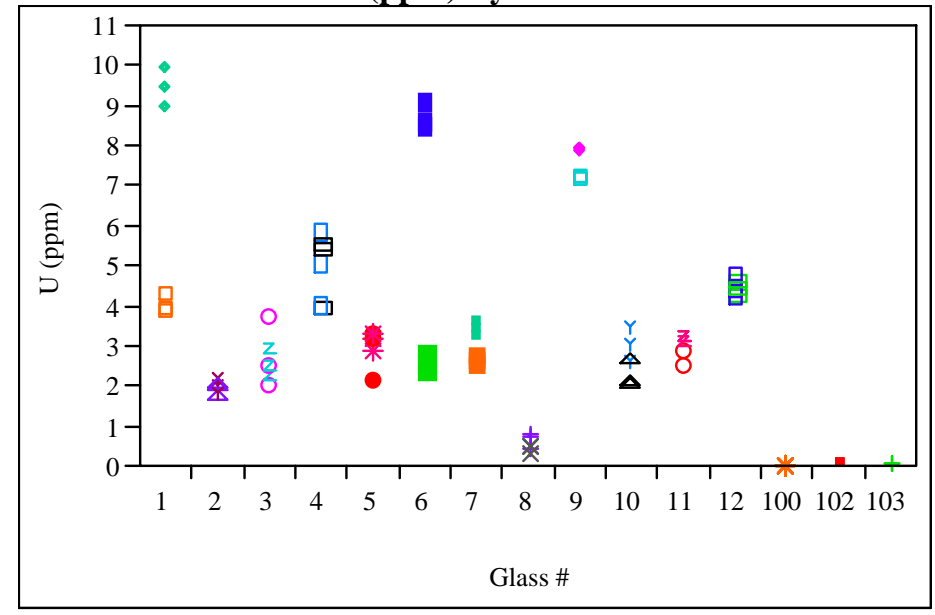




\section{Exhibit D.6: Effects of Heat Treatment on PCT Response by Study Glass}

Glass \#=1

Oneway Analysis of $\log [\mathrm{B}$ ppm] By Heat

Treatment

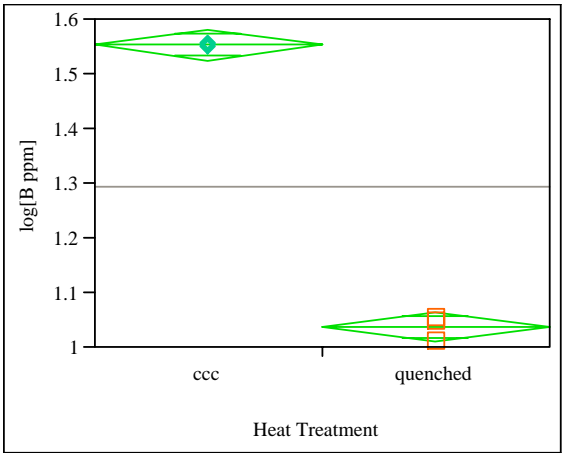

\section{Oneway Anova}

\section{Rsquare}

Adj Rsquare
Root Mean Sq

Root Mean Square E

Observations (or Sum Wgts)

t Test

ccc-quenched

Assuming equal variances
Oneway Analysis of $\log [\mathrm{Li}$ ppm] By Heat

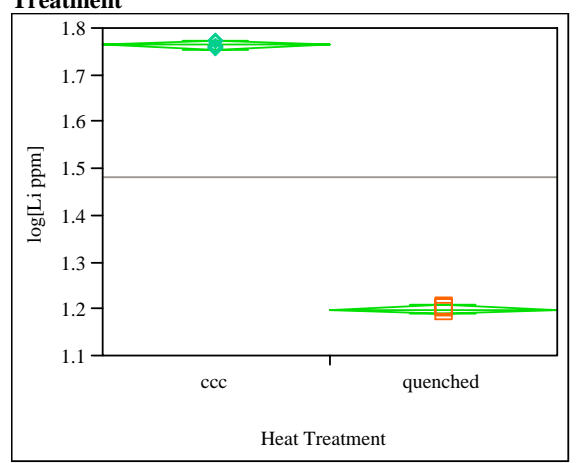

\section{Oneway Anova}

Rsquare

Adj Rsquare

Root Mean Square Error

Mean of Response

Observations (or Sum Wgts)

t Test

Assuming equal variances

$\begin{array}{lrr}\text { Difference } & 0.564115 \text { t Ratio } & 97.70954 \\ \text { Std Err Dif } & 0.005773 \text { DF } & 4 \\ \text { Upper CL Dif } & 0.580144 \text { Prob }>|t| & <.0001 \\ \text { Lower CL } & 0.548085 \text { Prob }>\text { t } & <.0001 \\ \begin{array}{l}\text { Dif } \\ \text { Confidence }\end{array} & 0.95 \text { Prob }<\mathrm{t} & 1.0000\end{array}$

$\begin{array}{lll}\text { Confidence } & 0.95 \text { Prob }<\mathrm{t} & 1.0000\end{array}$

Means for Oneway Anova

Level Number Mean $\begin{array}{rrr}\text { Std Lower } & \text { Upper } \\ \text { Error } & 95 \% & 95 \%\end{array}$ $\begin{array}{llllll}\text { ccC } & 3 & 1.76504 & 0.00408 & 1.7537 & 1.7764\end{array}$ $\begin{array}{lllllll}\text { quenched } & 3 & 1.20093 & 0.00408 & 1.1896 & 1.2123\end{array}$ Std Error uses a pooled estimate of error variance
Level Number Mean Std Lower Uppe

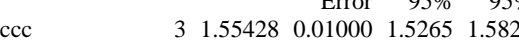
$\begin{array}{lllllll}\text { quenched } & 3 & 1.03832 & 0.01000 & 1.0106 & 1.0661\end{array}$ Std Error uses a pooled estimate of error variance
Oneway Analysis of $\log [\mathrm{Na}$ ppm] By Heat

Treatment

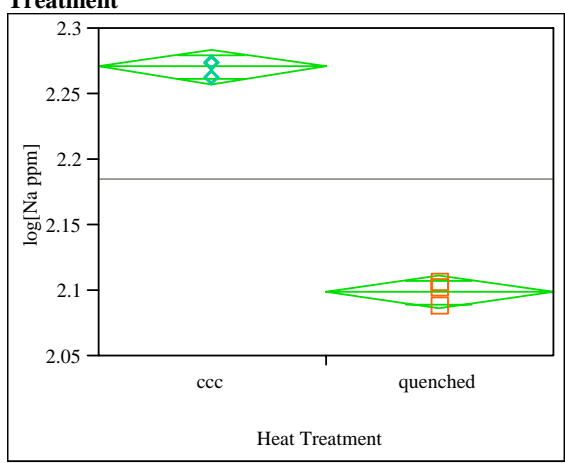

\section{Oneway Anova}

Summary of Fit

Rsquare

Root Mean Square Error

Mean of Response

Observations (or Sum Wgts)

t Test

Assuming equal variances

$\begin{array}{lrrr}\text { Difference } & 0.172067 \text { t Ratio } & 26.33095 \\ \text { Std Err Dif } & 0.006535 \text { DF } & 4 \\ \text { Upper CL Dif } & 0.190211 \text { Prob }>|t| & <.0001 \\ \text { Lower CL } & 0.153924 \text { Prob }>t & <.0001 \\ \begin{array}{l}\text { Dif } \\ \text { Confidence }\end{array} & 0.95 \text { Prob }<\mathrm{t} & 1.0000\end{array}$

Oneway Analysis of $\log [\mathrm{Si}$ ppm] By Heat

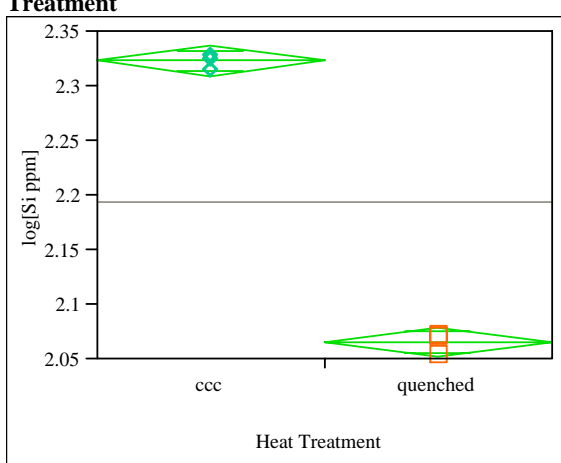

\section{Oneway Anova}

Rsquare

Adj Rsquare

Root Mean Square Erro

0.996938

Mean of Response

ns (or Sum Wgts)

t Test

Assuming equal variances

Difference $\quad 0.257493$ t Ratio $\quad 36.08895$

$\begin{array}{llr}\text { Std Err Dif } & 0.007135 \text { DF } & 4 \\ \text { Upper CL Dif } & 0.277303 \text { Prob }>|t| & <.0001 \\ \text { Lower CL } & 0.237683 \text { Prob }>\text { t } & <.001\end{array}$

0.237683 Prob $>t$

$<.0001$

Confidence $\quad 0.95$ Prob $<t \quad 1.0000$

Means for Oneway Anova

Level Number Mean Std Lower Upper Level Number Mean $\begin{array}{r}\text { Std Lower Upper } \\ \text { Error }\end{array}$ $\begin{array}{llllll}\text { ccc } & 3 & 2.27104 & 0.00462 & 2.2582 & 2.2839\end{array}$ Std Error uses a pooled estimate of error variance $\begin{array}{llllll}\text { ccc } & 3 & 2.32334 & 0.00505 & 2.3093 & 2.3373\end{array}$ Std Error uses a pooled estimate of error variance 
Exhibit D.6: Effects of Heat Treatment on PCT Response by Study Glass (continued)

Glass \#=2

Oneway Analysis of $\log [\mathrm{B}$ ppm] By Heat

Treatment

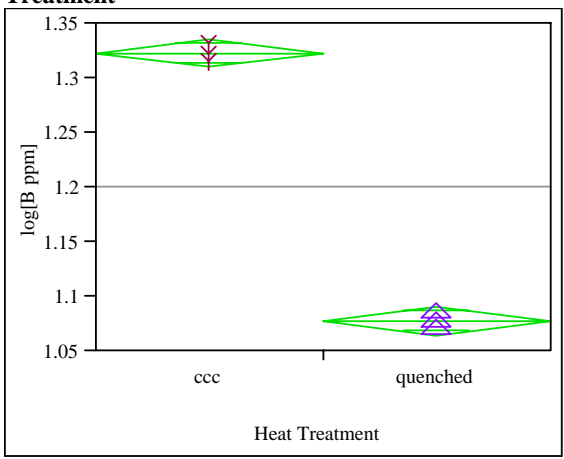

Oneway Anova

Summary of Fit

Rsquare

Adj Rsquare

Root Mean Square Error

(obse Response

(or Sum Wgts)

uenched

Assuming equal variances

$\begin{array}{lrlr}\text { Difference } & 0.245582 \text { t Ratio } & 37.03979 \\ \text { Std Err Dif } & 0.006630 \text { DF } & 4 \\ \text { Upper CL Dif } & 0.263990 \text { Prob }>|t| & <.0001 \\ \text { Lower CL } & 0.227173 \text { Prob }>\text { t } & <.0001 \\ \begin{array}{l}\text { Dif } \\ \text { Confidence }\end{array} & 0.95 \text { Prob }<\mathrm{t} & 1.0000\end{array}$

Means for Oneway Anova

Level Number Mean Std Lower Upper $\begin{array}{llllll}\text { ccc } & 3 & 1.32332 & 0.00469 & 1.3103 & 1.3363\end{array}$

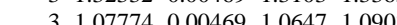
Std Error uses a pooled estimate of error variance
Oneway Analysis of $\log [\mathrm{Li}$ ppm] By Heat

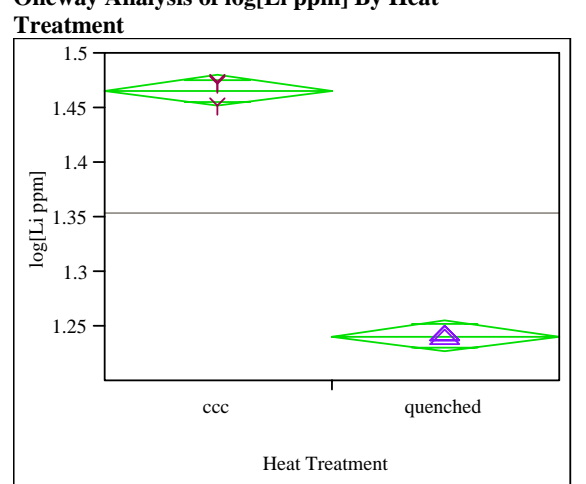

Oneway Anova

\section{Rsquare}

Root Mean Square Error

Mean of Response

Observations (or Sum Wgts)

t Test

ccc-quenched

Assuring equal variances

$\begin{array}{lrrr}\text { Difference } & 0.224770 \text { t Ratio } & 31.08291 \\ \text { Std Err Dif } & 0.007231 \text { DF } & 4 \\ \text { Upper CL Dif } & 0.244847 \text { Prob }>|t| & <.0001 \\ \text { Lower CL } & 0.204693 \text { Prob }>t & <.0001 \\ \text { Dif } & & \\ \text { Confidence } & 0.95 \text { Prob }<t & 1.0000\end{array}$

Means for Oneway Anova

Level Number Mean Std Lower Upper $\begin{array}{llrrrr}\text { cCC } & 3 & 1.46643 & 0.00511 & 1.4522 & 1.4806\end{array}$ $\begin{array}{lllllll}\text { quenched } & 3 & 1.24166 & 0.00511 & 1.2275 & 1.2559\end{array}$ Std Error uses a pooled estimate of error variance

0.994846

0.008857
1.354046
Oneway Analysis of $\log [\mathrm{Na}$ ppm] By Heat

Treatment

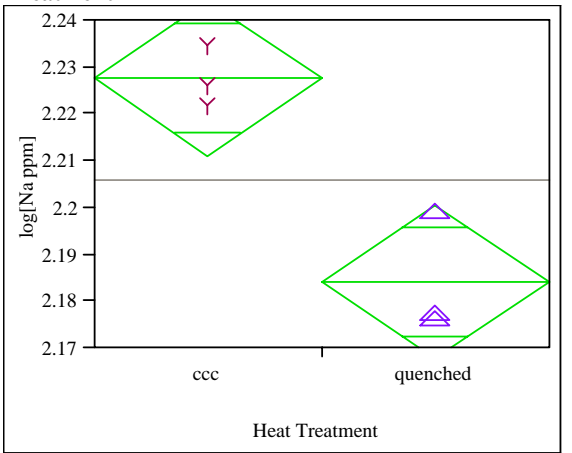

Oneway Anova

Summary of Fit

Rsquare

Adj Rsquare

Root Mean Square Erro

Mean of Respon

Observations (or Sum Wgts)

Test

ccc-quenched
Assuming equal variances

Difference $\quad 0.043481$ t Ratio $\quad 5.169088$

Std Err Dif 0.008412 DF $\quad 0.020126$ Prob $>1$

Upper CL Dif 0.066836 Prob $>|t| \quad 0.0067$

$\begin{array}{lll} & 0.020126 \text { Prob }>t & 0.0033\end{array}$

Dif

0.95 Prob $<\mathrm{t} \quad 0.9967$

Means for Oneway Anova

Level Number Mean Std Lower Upper

32.227580 .005952 .211122 .2441

32.227580 .005952 .21112 .244

quenched $\quad \begin{array}{lll}3 & 2.18410 & 0.00595 \\ \text { Std Error uses a pooled estimate of error variance }\end{array}$
Oneway Analysis of $\log [\mathrm{Si}$ ppm] By Heat

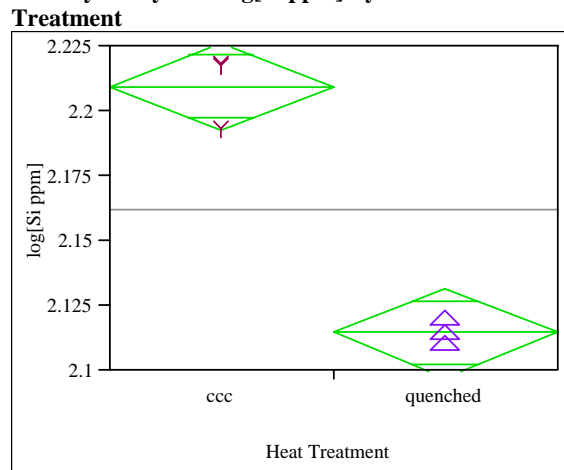

\section{Oneway Anova}

Rsquare

0.967475

Adj Rsquare

Root Mean Square

0.959343

Mean of Response $\quad 2.16217$

Observations (or Sum Wgts)

Assuming equal variances

$\begin{array}{lrr}\text { Difference } & 0.094988 \text { t Ratio } & 10.90786 \\ \text { Std Err Dif } & 0.008708 \text { DF } & 4 \\ \text { Upper CL Dif } & 0.119166 \text { Prob }>|t| & 0.0004 \\ \text { Lower CL } & 0.070810 \text { Prob }>\text { t } & 0.0002 \\ \begin{array}{l}\text { Dif } \\ \text { Confidence }\end{array} & & \\ & & \\ & & \end{array}$

Means for Oneway Anova

Level Number Mean Std Lower Upper $\begin{array}{llllll}\text { ccc } & 3 & 2.20967 & 0.00616 & 2.1926 & 2.2268\end{array}$

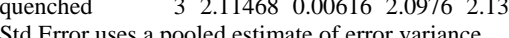


Exhibit D.6: Effects of Heat Treatment on PCT Response by Study Glass (continued)

Glass \#=3

Oneway Analysis of $\log [\mathrm{B}$ ppm] By Heat

Treatment

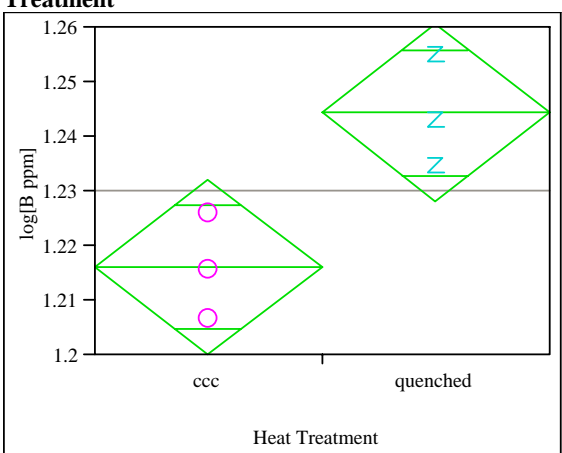

Oneway Anova

Summary of Fit

Rsquare

Adj Rsquare

Root Mean Square Error

Orean of Response

(or Sum Wgts)

Assuming equal variances

$\begin{array}{lrlr}\text { Difference } & -0.02809 \text { t Ratio } & -3.43231 \\ \text { Std Err Dif } & 0.00818 \text { DF } & 4 \\ \text { Upper CL Dif } & -0.00537 \text { Prob }>|t| & 0.0265 \\ \begin{array}{l}\text { Lower CL } \\ \text { Dif } \\ \text { Confidence }\end{array} & -0.05082 \text { Prob }>\mathrm{t} & 0.9868 \\ & & \\ & & & \\ & & & \end{array}$

Means for Oneway Anova

Level Number Mean Std Lower Upper $\begin{array}{llllll}\text { ccc } & 3 & 1.21625 & 0.00579 & 1.2002 & 1.2323\end{array}$ $\begin{array}{lllllll}3 & 1.21625 & 0.00579 & 1.2002 & 1.2323\end{array}$ Std Error uses a pooled estimate of error variance
Oneway Analysis of $\log [\mathrm{Li}$ ppm] By Heat

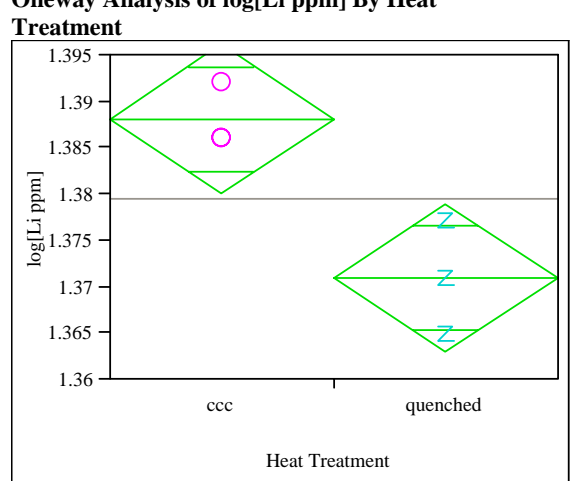

\section{Oneway Anova}

Rsquare

Adj Rsquare

Root Mean Square Erro

Mean of Response

Observations (or Sum Wgts)

t Test

ccc-quenched

Assuming equal variances

$\begin{array}{lllr}\text { Difference } & 0.017132 \text { t Ratio } & 4.213811 \\ \text { Std Err Dif } & 0.004066 \text { DF } & 4 \\ \text { Upper CL Dif } & 0.028421 \text { Prob }>|t| & 0.0135 \\ \text { Lower CL } & 0.005844 \text { Prob }>t & 0.0068 \\ \text { Dif } & & \end{array}$

$\begin{array}{lll}\text { Confidence } & 0.95 \text { Prob }<\mathrm{t} & 0.9932\end{array}$

Means for Oneway Anova

Level Number Mean Std Lower Upper $\begin{array}{llrrrr} & & & \text { Error } & 95 \% & 95 \% \\ \text { ccc } & 3 & 1.38818 & 0.00287 & 1.3802 & 1.3962\end{array}$

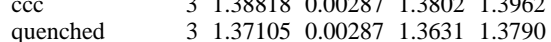
Std Error uses a pooled estimate of error variance
Oneway Analysis of log[Na ppm] By Heat

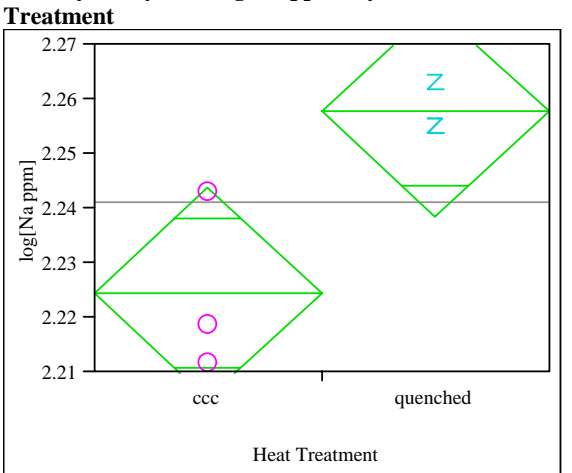

\section{Oneway Anova}

Summary of $F$

Rsquare

Adj Rsquare

Root Mean Square Erro

Mean of Respon

Obsivations (or Sum Wgts)

Test

cc-quenched

Assuming equal variances

$\begin{array}{lrlr}\text { Difference } & -0.03340 \text { t Ratio } & -3.39372 \\ \text { Std Err Dif } & 0.00984 \text { DF } & 4 \\ \text { Upper CL Dif } & -0.00608 \text { Prob }>|t| & 0.0274 \\ \begin{array}{l}\text { Lower CL } \\ \text { Dif } \\ \text { Confidence }\end{array} & -0.06073 \text { Prob }>\mathrm{t} & 0.9863 \\ & 0.95 \text { Prob }<\mathrm{t} & 0.0137\end{array}$

Confidence $\quad 0.95$ Prob $<t \quad 0.0137$

\section{Means for Oneway Anova}

Level Number Mean Std Lower Upper 3 CCC $32.224540 .006962 .2052 \quad 2.2439$ 32.224540 .006962 .20522 .2439 Std Error uses a pooled estimate of error variance
Oneway Analysis of $\log [\mathrm{Si}$ ppm] By Heat

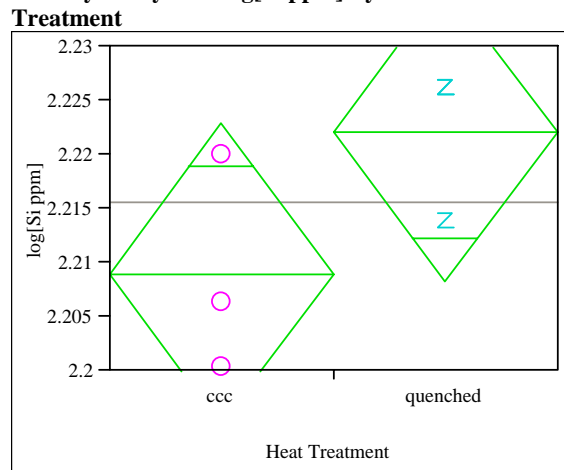

\section{Oneway Anova}

Rsquare

Adj Rsquare

Root Mean Square

0.325512

Mean of Response 2.215554

Observations (or Sum Wgts)

t Test

ccc-quenched

Assuming equal variances

Difference $\quad-0.01311$ t Ratio $\quad-1.84744$ $\begin{array}{lrr}\text { Std Err Dif } & 0.00710 \text { DF } & 4 \\ \text { Upper CL Dif } & 0.00659 \text { Prob }>|t| & 0.1384 \\ \text { Lower CL } & -0.03281 \text { Prob }>t & 0.9308\end{array}$

$\begin{array}{lll}\text { Dif } & -0.03281 & \text { Prob }>t \\ \text { Confidence } & 0.95 \text { Prob }<\mathrm{t} & 0.0692\end{array}$

Means for Oneway Anova

Level Number Mean Std Lower Upper $\begin{array}{lrrrrr} & & & \text { Error } & 95 \% & 95 \% \\ \text { ccc } & 3 & 2.20900 & 0.00502 & 2.1951 & 2.2229 \\ \text { quenched } & 3 & 2.22211 & 0.00502 & 2.2082 & 2.2360\end{array}$ Std Error uses a pooled estimate of error variance 


\section{Exhibit D.6: Effects of Heat Treatment on PCT Response by Study Glass (continued)}

Glass \#=4

Oneway Analysis of $\log [\mathrm{B}$ ppm] By Heat

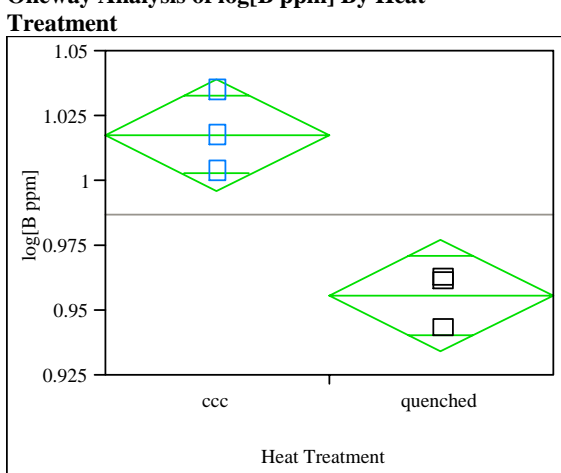

Oneway Anova

Summary of Fit

Rsquare

Adj Rsquare

Root Mean Square Erro

Observations (or Sum Wgts)

t Test

ccc-quenched

Assuming equal variances

$\begin{array}{lrlr}\text { Difference } & 0.061977 \text { t Ratio } & 5.661425 \\ \text { Std Err Dif } & 0.010947 \text { DF } & 4 \\ \text { Upper CL Dif } & 0.092372 \text { Prob }>|t| & 0.0048 \\ \text { Lower CL } & 0.031583 \text { Prob }>\text { t } & 0.0024 \\ \text { Dif } & & \\ \text { Confidence } & 0.95 \text { Prob }<\mathrm{t} & 0.9976\end{array}$

Confidence $\quad 0.95$ Prob $<\mathrm{t} \quad 0.9976$

\section{Analysis of Variance}

Level Number Mean Std Lower Upper $\begin{array}{llllll}\text { ccC } & 3 & 1.01801 & 0.00774 & 0.99652 & 1.0395\end{array}$ $\begin{array}{llllllll}\text { quenched } & 3 & 0.95604 & 0.00774 & 0.93454 & 0.9775\end{array}$ Std Error uses a pooled estimate of error variance

\section{Oneway Analysis of $\log [\mathrm{Li} \mathrm{ppm}] \mathrm{By} \mathrm{Heat}$}

\section{Treatment}

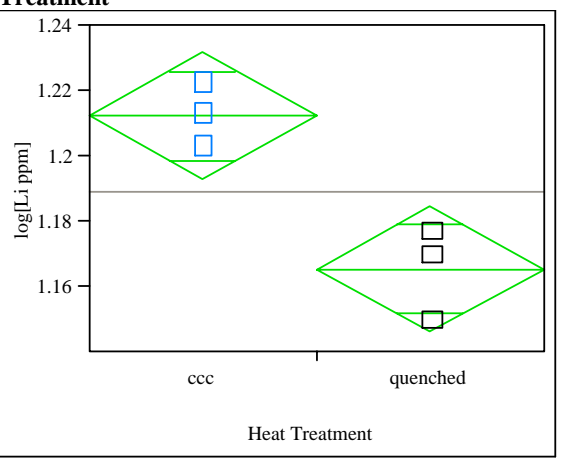

Oneway Anova

\section{Rsquare}

Root Meare

Mean of Response

Observations (or Sum Wgts)

Test

ccc-quenched

Assuming equal variances

$\begin{array}{lrr}\text { Difference } & 0.046894 \text { t Ratio } & 4.758678 \\ \text { Std Err Dif } & 0.009854 \text { DF } & 4 \\ \text { Upper CL Dif } & 0.074254 \text { Prob }>|t| & 0.0089 \\ \text { Lower CL } & 0.019534 \text { Prob }>\text { t } & 0.0045 \\ \text { Dif } & & \\ \text { Confidence } & 0.95 \text { Prob }<\mathrm{t} & 0.9955\end{array}$

\section{Analysis of Variance}

Means for Oneway Anova

Level Number Mean Std Lower Upper

$\begin{array}{llllll}\text { CCC } & 3 & 1.21242 & 0.00697 & 1.1931 & 1.2318\end{array}$

$\begin{array}{llllllll}3 & 1.16553 & 0.00697 & 1.1462 & 1.1849\end{array}$

Std Error uses a pooled estimate of error variance

0.812348

0.012069
Oneway Analysis of $\log [\mathrm{Na}$ ppm] By Heat

Treatment

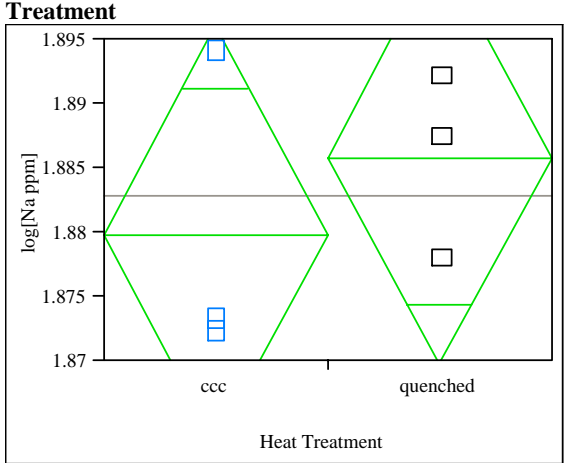

\section{Oneway Anova}

Summary of $F$

\section{Rsquare}

Root Mean Square Erro

Mean of Respon

Observations (or Sum Wgts)

t Test

Assuming equal variances

Difference $\quad-0.00608$ t Ratio $\quad-0.73826$ $\begin{array}{llr}\text { Std Err Dif } & 0.00824 \mathrm{DF} & 4 \\ & 0.01679 \mathrm{PF} & \end{array}$ Upper CL Dif $\quad 0.01679$ Prob $>|t| \quad 0.5013$ $\begin{array}{lll}\text { Lower CL } & -0.02895 \text { Prob }>t \quad 0.7493\end{array}$

$$
\begin{array}{ll}
\text { Dif } & \\
\text { Confidence } & 0.95 \text { Prob }<\mathrm{t} \quad 0.2507
\end{array}
$$

\section{Analysis of Variance}

Level Number Mean Std Lower Upper $\begin{array}{rrrr}\text { Error } & 95 \% & 95 \% \\ & & 95 \% & \end{array}$

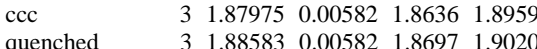
Std Error uses a pooled estimate of error variance
Oneway Analysis of $\log [\mathrm{Si}$ ppm] By Heat

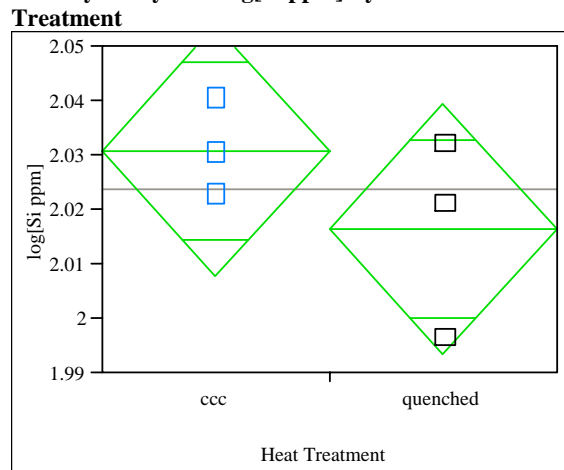

Oneway Anova

Summary of Fit

Rsquare

Adj Rsquare

Root Mean Square Error

Observations (or Sum Wgts)

ccc-quenched
Assuming equal variances

$\begin{array}{lrrr}\text { Difference } & 0.01435 \mathrm{t} \text { Ratio } & 1.224548 \\ \text { Std Err Dif } & 0.01172 \text { DF } & 4 \\ \text { Upper CL Dif } & 0.04690 \text { Prob }>|t| & 0.2879 \\ \text { Lower CL } & -0.01819 \text { Prob }>t & 0.1440 \\ \text { Dif } & & \end{array}$

Confidence $\quad 0.95$ Prob $<t \quad 0.8560$

\section{Analysis of Variance}

Means for Oneway Anova
Level Number Mean Std Lower Upper

$\begin{array}{rrrrr}\text { Error } & 95 \% & 95 \% \\ & & \text { Number Mean } & \text { S }\end{array}$

quenched $\quad 3$ 2.01655 0.008291 .99352 .0396

Std Error uses a pooled estimate of eror variance 
Exhibit D.6: Effects of Heat Treatment on PCT Response by Study Glass (continued)

Glass \#=5

Oneway Analysis of $\log [\mathrm{B}$ ppm] By Heat

Treatment

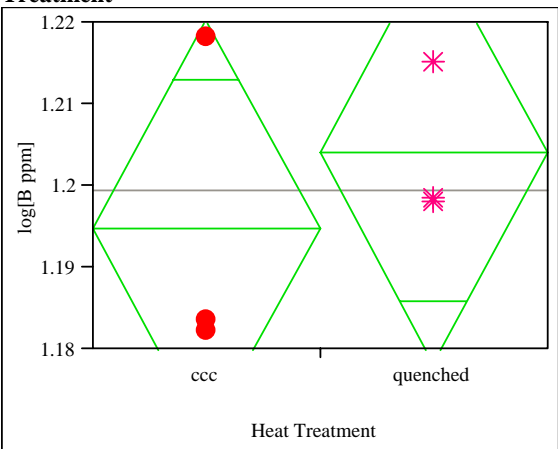

Oneway Anova

Summary of Fit

Rsquare

Adj Rsquare

Root Mean Square Error

Mean of Response

Observations (or Sum Wgts)

t Tes

ccc-quenched

Assuming equal variances

$\begin{array}{lrr}\text { Difference } & -0.00924 \text { t Ratio } & -0.70768 \\ \text { Std Err Dif } & 0.01306 \text { DF } & 4 \\ \text { Upper CL Dif } & 0.02701 \text { Prob }>|t| & 0.5182 \\ \text { Lower CL } & -0.04549 \text { Prob }>\mathrm{t} & 0.7409 \\ \begin{array}{l}\text { Dif } \\ \text { Confidence }\end{array} & 0.95 \text { Prob }<\mathrm{t} & 0.2591\end{array}$

Means for Oneway Anova

Level Number Mean Std Lower Upper $\begin{array}{llllll}\text { CCC } & 3 & 1.19482 & 0.00923 & 1.1692 & 1.2204\end{array}$ $\begin{array}{llllll}\text { cec } & 3 & 1.19482 & 0.00923 & 1.1692 & 1.2204\end{array}$ Std Error uses a pooled estimate of error variance
Oneway Analysis of $\log [\mathrm{Li}$ ppm] By Heat

\section{Treatment}

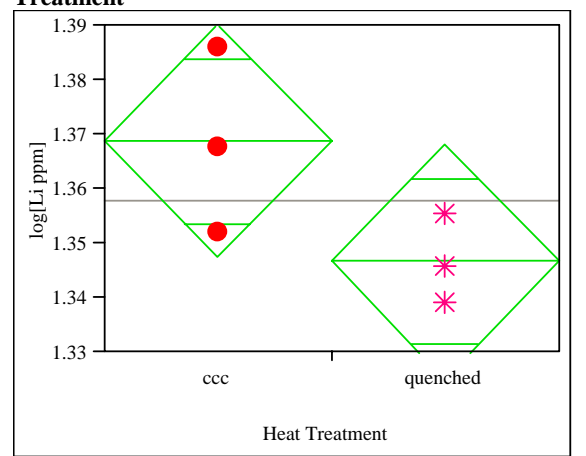

Oneway Anova

Rsquare

Adj Rsquare

Root Mean Square Erro

Observations (or Sum Wgts)

t Test

Asc-quenched

Assuming equal variances

$\begin{array}{lrrr}\text { Difference } & 0.02205 \text { t Ratio } & 2.022029 \\ \text { Std Err Dif } & 0.01091 \text { DF } & 4 \\ \text { Upper CL Dif } & 0.05233 \text { Prob }>|t| & 0.1132 \\ \text { Lower CL } & -0.00823 \text { Prob }>t & 0.0566 \\ \text { Dif } & & \\ \text { Confiden } & & \end{array}$

Confidence $\quad 0.95$ Prob $<t \quad 0.9434$

Means for Oneway Anova

Level Number Mean Std Lower Upper $\begin{array}{llllll}\text { ccC } & 3 & 1.36880 & 0.00771 & 1.3474 & 1.3902\end{array}$

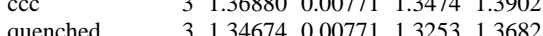
Std Error uses a pooled estimate of error variance
Oneway Analysis of log[Na ppm] By Heat

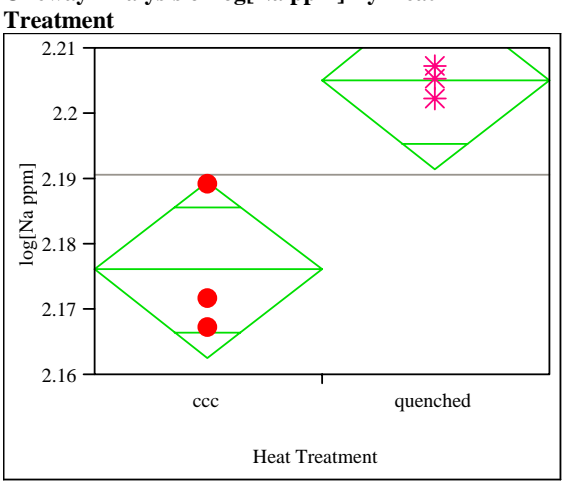

Oneway Anova

Summary of Fit

Rsquare

Adj Rsquare

Root Mean Square Erro

Mean of Response

Observations (or Sum Wgts)

t Test

cc-quenched

Assuming equal variances

$\begin{array}{lrr}\text { Difference } & -0.02887 \text { t Ratio } & -4.18396 \\ \text { Std Err Dif } & 0.00690 \text { DF } & 4 \\ \text { Upper CL Dif } & -0.00971 \text { Prob }>|t| & 0.0139 \\ \begin{array}{l}\text { Lower CL } \\ \text { Dif } \\ \text { Confidence }\end{array} & -0.04803 \text { Prob }>\mathrm{t} & 0.9931 \\ & 0.95 \text { Prob }<\mathrm{t} & 0.0069\end{array}$

Confidence $\quad 0.95$ Prob $<\mathrm{t} \quad 0.0069$

\section{Means for Oneway Anova}

Level Number Mean Std Lower Upper $\begin{array}{llllll}3 & 2.17616 & 0.00488 & 2.1626 & 2.1897\end{array}$

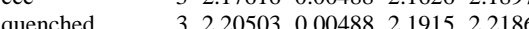
Std Error uses a pooled estimate of error variance
Oneway Analysis of $\log [\mathrm{Si}$ ppm] By Heat

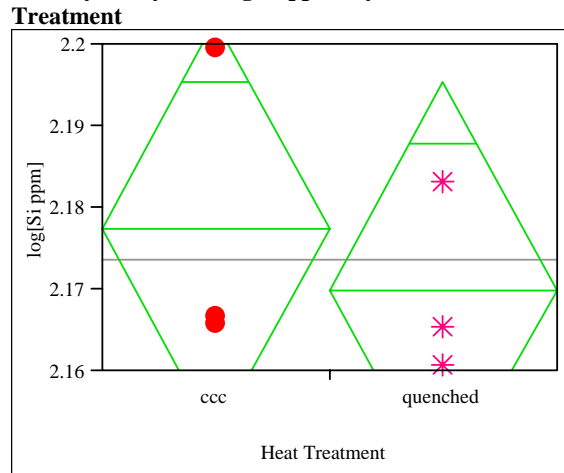

Oneway Anova

Summary of Fit

Rsquare

Adj Rsquare

Root Mean Square Error

Observations (or Sum Wgts)

ccc-quenched

Assuming equal variances

$\begin{array}{lrr}\text { Difference } & 0.00758 \text { t Ratio } & 0.582204 \\ \text { Std Err Dif } & 0.01303 \text { DF } & 4 \\ \text { Upper CL Dif } & 0.04375 \text { Prob }>|t| & 0.5917 \\ \text { Lower CL } & -0.02858 \text { Prob }>\text { t } & 0.2958 \\ \text { Dif } & & \\ \text { Confidence } & 0.95 \text { Prob }<\mathrm{t} & 0.7042\end{array}$

Means for Oneway Anova

Level Number Mean Std Lower Upper $\begin{array}{llllll}\text { ccc } & 3 & 2.17742 & 0.00921 & 2.1518 & 2.2030\end{array}$ $\begin{array}{lllllll}\text { ccc } & & 3 & 2.17742 & 0.00921 & 2.1518 & 2.2030 \\ \text { quenched } & & 3 & 2.16984 & 0.00921 & 2.1443 & 2.1954\end{array}$ quenched 
Exhibit D.6: Effects of Heat Treatment on PCT Response by Study Glass (continued)

Glass \#=6

Oneway Analysis of $\log [\mathrm{B}$ ppm] By Heat

Treatmen

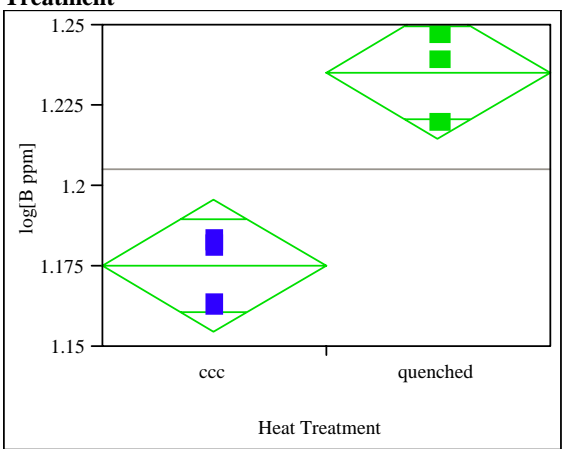

Oneway Anova

Oneway Anova
Summary of Fi

Rsquare

Adj Rsquare

0.893385

$\begin{array}{ll}0.866731 \\ \text { Adj Rsquare } & 0.012702\end{array}$

Mean of Response

Observations (or Sum Wgts)

t Test

t Test

Assuming equal variances

Difference $\quad-0.06004$ t Ratio $\quad-5.78947$

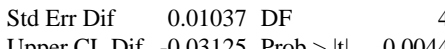

Upper CL Dif -0.03125 Prob $>|t| \quad 0.0044$

Lower CL Dif -0.08884 Prob $>t \quad 0.9978$
Confidence

Means for Oneway Anova

Level Number Mean Std Lower Upper $\begin{array}{llllll}\text { ccc } & 3 & 1.17520 & 0.00733 & 1.1548 & 1.1956\end{array}$ $\begin{array}{llllllll}\text { quenched } & 3 & 1.23524 & 0.00733 & 1.2149 & 1.2556\end{array}$ Std Error uses a pooled estimate of error variance

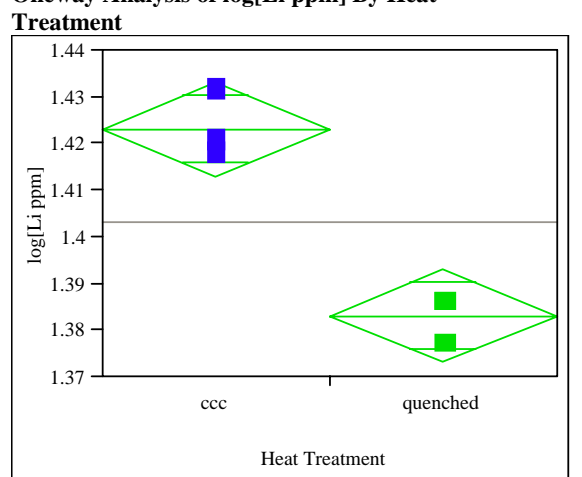

Oneway Anova

Rsquare

Adj Rsquare

Root Mean Square

Oneway Anova

0.938325

0.006281

1.40321

Observations (or Sum Wgts)

Assuming equal variances

Difference $\quad 0.040010$ t Ratio $\quad 7.801049$

7.801049
4
0.0015

Upper CL Dif 0.054250 Prob $>|t| 0.0015$

Lower CL Dif 0.025770 Prob $>$ t 0.0007

Confidence 0.95 Prob $<$

\section{Means for Oneway Anova}

Level Number Mean Std Lower Upper $\begin{array}{llllll}\text { ccC } & 3 & 1.42321 & 0.00363 & 1.4131 & 1.4333\end{array}$ $\begin{array}{llllll}\text { cec } & 3 & 1.42321 & 0.00363 & 1.4131 & 1.4333\end{array}$ Std Error uses a pooled estimate of error variance

Summary of Fit

Rsquare

Adj Rsquare

Oneway Analysis of $\log [\mathrm{Na}$ ppm] By Heat

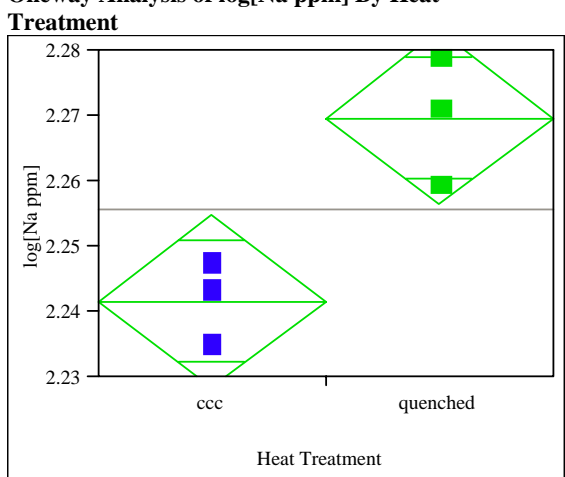

Root Mean Square

Mean of Response
Observations (or Sum Wgts)

0.812251

0.008265
2.255671

6

Tes

ccc-quenched
Assuming equal variances

Difference $\quad-0.02807$ t Ratio $\quad-4.15993$

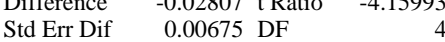

Upper CL Dif -0.00934 Prob $>|t| \quad 0.0141$

Lower CL Dif -0.04681 Prob $>t \quad 0.9929$

Confidence $\quad 0.95 \mathrm{Prob}<\mathrm{t} \quad 0.0071$

\section{Means for Oneway Anova}

Level Number Mean Std Lower Upper

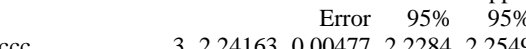

$\begin{array}{llllll} & 3 & 2.24163 & 0.00477 & 2.2284 & 2.2549\end{array}$

Std Error uses a pooled estimate of error variance
Oneway Analysis of $\log [\mathrm{Si}$ ppm] By Heat

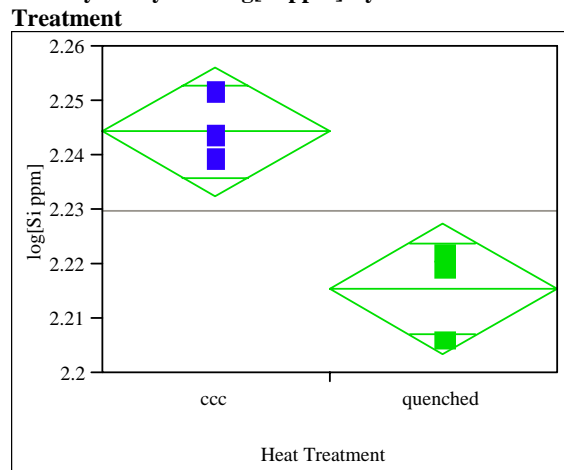

Oneway Anova

Summary of Fit

Rsquare

Root Mean Square Error $\quad 0.811519$

Root Mean Square Eror $\quad 0.007447$

Observations (or Sum Wgts) 2.229963

t Test

ccc-quenched

Assuming equal variances

Difference $\quad 0.028860$ t Ratio $\quad 4.746356$

$\begin{array}{lll}\text { Std Err Dif } & 0.006080 \text { DF } & 4\end{array}$

Upper CL Dif 0.045742 Prob $>|t| \quad 0.0090$

Lower CL Dif 0.011978 Prob $>t \quad 0.0045$

\section{Means for Oneway Anova}

Level Number Mean Std Lower Upper

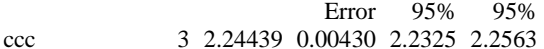
$\begin{array}{lllllll} & 3 & 2.24439 & 0.00430 & 2.2325 & 2.2563\end{array}$ Std Error uses a pooled estimate of ent variance 


\section{Exhibit D.6: Effects of Heat Treatment on PCT Response by Study Glass (continued)}

Glass \#=7

Oneway Analysis of $\log [\mathrm{B}$ ppm] By Heat

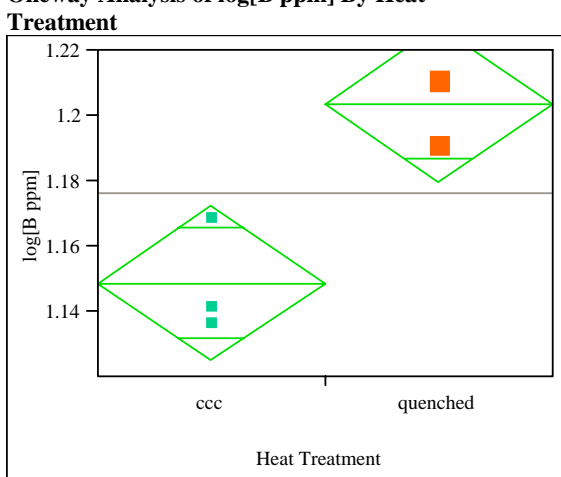

Oneway Anova

Summary of Fit

\section{Rsquare}

dj Rsquare

0.837045

1.176198

(or Sum Wgts)

Assuming equal variances

$\begin{array}{lrlr}\text { Difference } & -0.05476 \text { t Ratio } & -4.53284 \\ \text { Std Err Dif } & 0.01208 \text { DF } & 4 \\ \text { Upper CL Dif } & -0.02122 \text { Prob }>|t| & 0.0106 \\ \text { Lower CL Dif } & -0.08829 & \text { Prob }>t & 0.9947 \\ \text { Confidence } & 0.95 \text { Prob }<\mathrm{t} & 0.0053\end{array}$

Lower CL Dif -0.08829 Prob $>t \quad 0.994$

\section{Means for Oneway Anova}

Level Number Mean Std Lower Upper $\begin{array}{llllll}\text { ccc } & 3 & 1.14882 & 0.00854 & 1.1251 & 1.1725\end{array}$ $\begin{array}{llllll}\text { ccc } & 3 & 1.14882 & 0.00854 & 1.1251 & 1.1725\end{array}$ Std Error uses a pooled estimate of error variance

\section{Oneway Analysis of $\log [\mathrm{Li}$ ppm] By Heat}

\section{Treatment}

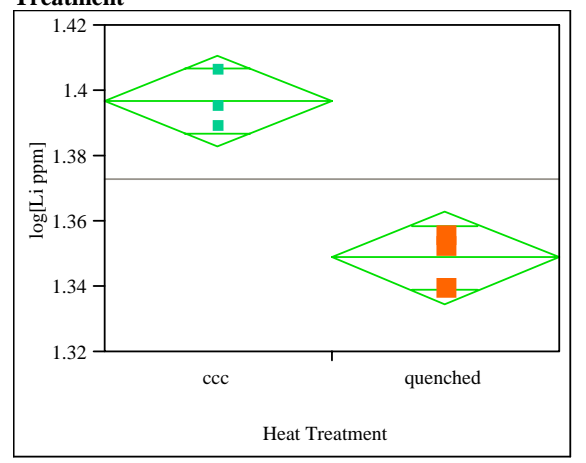

Oneway Anova

Rsquare

Adj Rsquare

Root Mean Square

0.919022

0.898777
0.008728

0.008728

Observations (or Sum Wgts)

1.372914
6

t Test

ccc-quenched Assuming equal variances

Difference $\quad 0.048017$ t Ratio 6.737655

Upper CL Dif 0.067804 Prob $>1 t \quad 0.0025$

Lower CL Dif 0.028230 Prob $>1 \quad 0.0025$

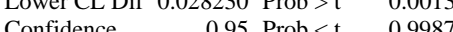

Means for Oneway Anova

Level Number Mean Std Lower Upper

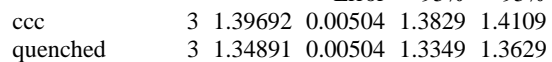
Std Error uses a pooled estimate of error variance
Oneway Analysis of log[Na ppm] By Heat

Treatment

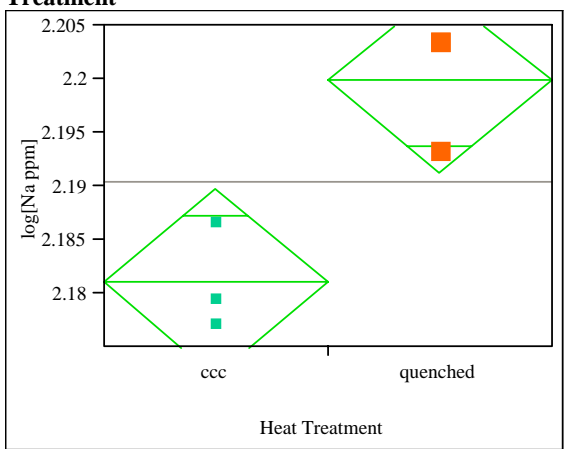

\section{Oneway Anova}

Summary of

Rsquare

$\begin{array}{ll} & 0.819609 \\ \text { Adj Rsquare } & 0.774512\end{array}$

Root Mean Square Error $\quad 0.005407$

Mean of Response 2.190449

Observations (or Sum Wgts)

6

t Test

Assuming equal variances

$\begin{array}{lll}\text { Difference } & -0.01882 \text { t Ratio } & -4.26311\end{array}$

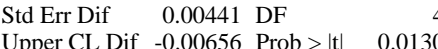

Upper CL Dif -0.00656 Prob $>|t| \quad 0.0130$

$\begin{array}{lll}\text { Confidence } & 0.95 \text { Prob }<\mathrm{t} \quad 0.0065\end{array}$

Means for Oneway Anova

Level Number Mean Std Lower Upper $\begin{array}{llllll}\text { cCC } & 3 & 2.18104 & 0.00312 & 2.1724 & 2.1897\end{array}$ $\begin{array}{llllll}\text { quenched } & 3 & 2.19986 & 0.00312 & 2.1912 & 2.2085\end{array}$ Std Error uses a pooled estimate of error variance
Oneway Analysis of $\log [\mathrm{Si}$ ppm] By Heat

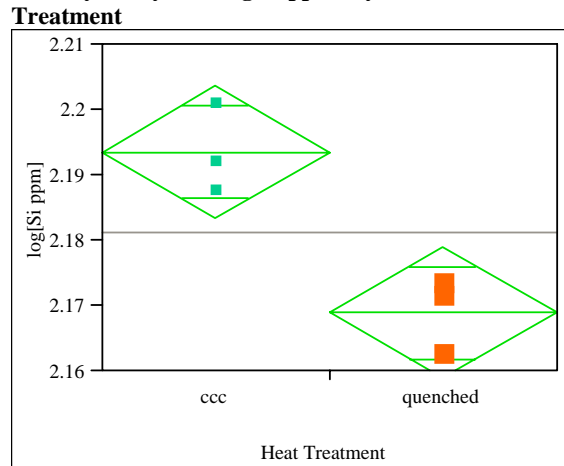

Oneway Anova

Summary of Fit

Rsquare

Adj Rsquare $\quad 0.85088$

Adj Rsquare $\quad 0.813612$

Mean of Response 2.18125

Observions (or

um Wgts)

enched

Assuming equal variances

Difference $\quad 0.024623$ t Ratio $\quad 4.777627$

$\begin{array}{llr}\text { Std Err Dif } & 0.005154 \text { DF } & 4\end{array}$

Upper CL Dif 0.03832 Prob $>\mid n-0.0088$

$\begin{array}{lll} & \text { Lower CL Dif } 0.010314 \text { Prob }>t \quad 0.0044 \\ 0.95 \text { Prob }<\mathrm{t} & 0.9956\end{array}$

Means for Oneway Anova

Level Number Mean Std Lower Upper $\begin{array}{llllll}\text { ccc } & 3 & 2.19356 & 0.00364 & 2.1834 & 2.2037\end{array}$ $\begin{array}{lllllll}\text { quenched } & 3 & 2.19356 & 0.00364 & 2.1834 & 2.2037 \\ & & 2.16894 & 0.00364 & 2.1588 & 2.1791\end{array}$ Std Frror uses a pooled estimate of error variance 
Exhibit D.6: Effects of Heat Treatment on PCT Response by Study Glass (continued)

Glass \#=8

Oneway Analysis of $\log [\mathrm{B}$ ppm] By Heat

Treatment

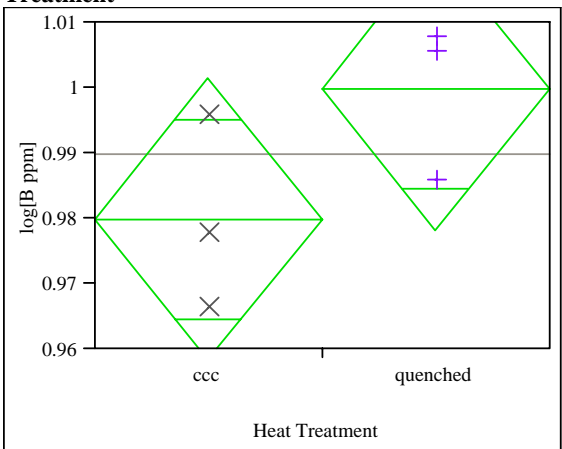

Oneway Anova

Summary of Fit

$\begin{array}{lr}\text { Rsquare } & 0.45175 \\ \text { Adj Rsquare } & 0.314688\end{array}$

0.45175
0.01353

Mean of Response

Observations (or Sum

0.98987

Orvervations (or Sum Wgts)

Test

Assuming equal variances

Difference $\quad-0.02006$ t Ratio $\quad-1.81547$

$\begin{array}{lll}\text { Std Err Dif } \quad 0.01105 \text { DF } & 4\end{array}$

$\begin{array}{lll}\text { Upper CL Dif } & 0.01062 \text { Prob }>|t| & 0.1436\end{array}$

Lower CL Dif -0.05073 Prob $>t \quad 0.9282$

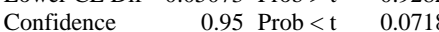

\section{Means for Oneway Anova}

Level Number Mean Std Lower Upper $\begin{array}{llllll} & & & \text { Error } & 95 \% & 95 \% \\ \text { ccc } & 3 & 0.979842 & 0.00781 & 0.95815 & 1.0015\end{array}$ quenched $\quad 30.9998980 .007810 .9782110216$ Std Error uses a pooled estimate of error variance
Oneway Analysis of $\log [\mathrm{Li}$ ppm] By Heat

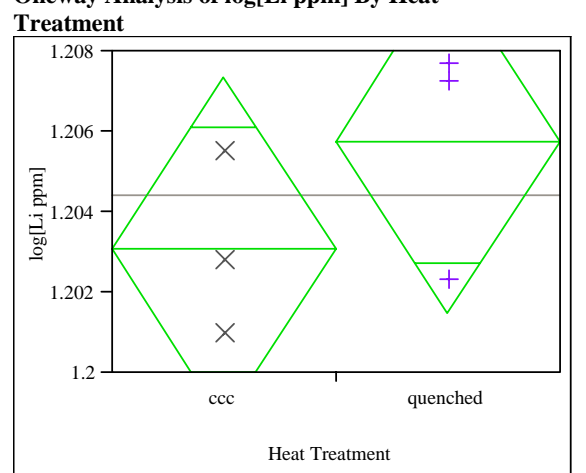

\section{Oneway Anova}

Rsquare

Adj Rsquare

\begin{tabular}{ll}
0.278788 \\
0.098485 \\
\hline
\end{tabular}

quare Error $\quad 0.002669$

Mean of Response 1.204423

Observations (or Sum Wgts)

6

t Test

Assuming equal variances

Difference $\quad-0.00271$ t Ratio $\quad-1.24347$

$\begin{array}{lrr}\text { Std Err Dif } & 0.00218 \text { DF } & 4 \\ \text { Upper CL } & 0.00334 \text { Prob }>|t| & 0.2816\end{array}$

$\begin{array}{lrl}\text { Upper CL Dif } & 0.00334 \text { Prob }>|t| & 0.2816 \\ \text { Lower } & & \end{array}$

Confidence $\quad 0.95$ Prob $<\mathrm{t} \quad 0.1408$

Means for Oneway Anova

Level Number Mean rtd Lower $\begin{array}{rr}\text { Upper } \\ \text { Error }\end{array}$ $\begin{array}{llllll}\text { ccc } & 3 & 1.20307 & 0.00154 & 1.1988 & 1.2073\end{array}$ $\begin{array}{lllllll}\text { quenched } \quad 3 & 1.20578 & 0.00154 & 1.2015 & 1.2101\end{array}$ Std Error uses a pooled estimate of error variance
Oneway Analysis of $\log [\mathrm{Na}$ ppm] By Heat

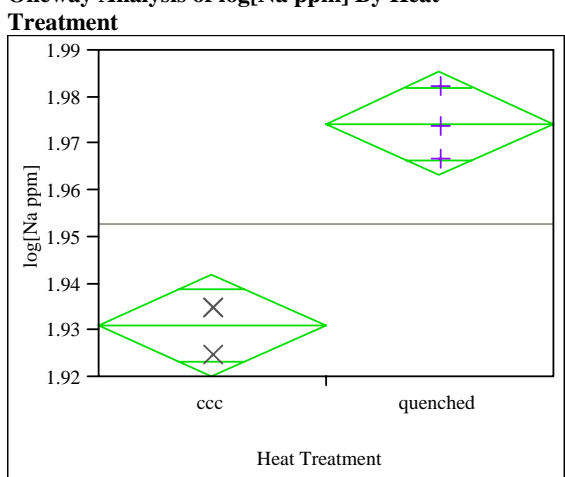

Oneway Anova

Summary of Fit

\section{Rsquare}

Adj Rsquare

0.937351
0.921688

Root Mean Square Error $\quad 0.006851$

Mean of Response

0.006851
1.952737

Observations (or Sum Wgts)

t Test

ccc-quenched

Assuming equal variances

Difference $\quad-0.04327$ t Ratio $\quad-7.73611$

Std Err Dif $\quad 0.00559$ DF

-7.73611
4

Upper CL Dif -0.02774 Prob $>|t| \quad 0.0015$

Lower CL Dif -0.05880 Prob $>t \quad 0.9992$

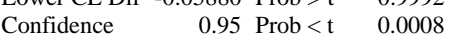

\section{Means for Oneway Anova}

Level Number Mean Std Lower Upper

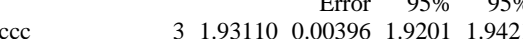
$\begin{array}{llllll} & 3 & 1.93110 & 0.00396 & 1.9201 & 1.9421\end{array}$ Std Error uses a pooled estimate of error variance
Oneway Analysis of $\log [\mathrm{Si}$ ppm] By Heat

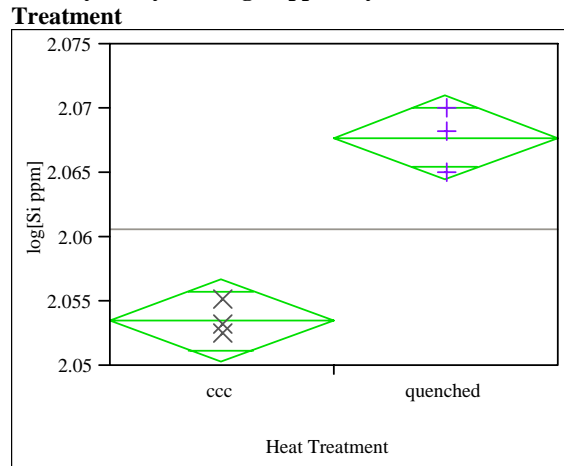

Oneway Anova

Summary of Fit

Rsquare

Adj Rsquare $\quad 0.9374$

Root Mean Square Error $\quad 0.002006$

Mean of Response 2.060645

t Test

t Test

Assuming equal variances

Difference $\quad-0.01426$ t Ratio $\quad-8.71117$

$\begin{array}{lrr}\text { Std Err Dif } & 0.00164 \text { DF } & 4 \\ \text { Upper } & & -8.71117\end{array}$

$\begin{array}{rrr}\text { Upper CL Dif }-0.00972 \text { Prob }>|t| & 0.0010 \\ \text { Lower CL Dif }-0.01881 & \text { Prob }>t & 0.9995\end{array}$

Confidence $\quad 0.95$ Prob $<\mathrm{t} \quad 0.0005$

Means for Oneway Anova

Level Number Mean $\begin{array}{r}\text { Std Lower } \\ \text { Error }\end{array}$ $\begin{array}{llllll}\text { ccc } & 3 & 2.05351 & 0.00116 & 2.0503 & 2.0567\end{array}$ Std Error uses a pooled estime $0.00116 \quad 2.0646 \quad 2.0710$ 
Exhibit D.6: Effects of Heat Treatment on PCT Response by Study Glass (continued)

Glass \#=9
Oneway Analysis of $\log [\mathrm{B}$ ppm $]$ By Heat

Treatment

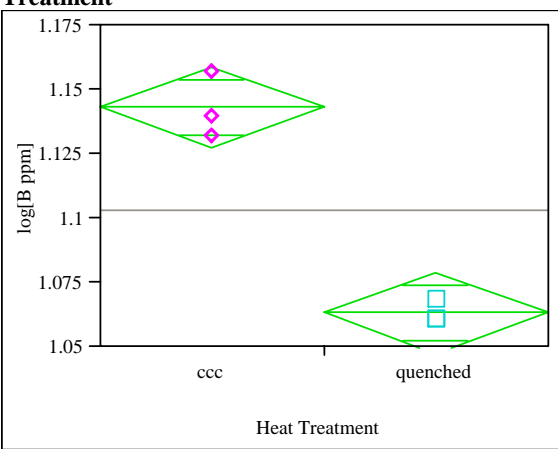

Oneway Anova

Oneway Anova

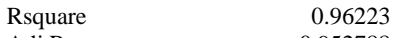

0.96223

Adj Rsquare $\quad 0.952788$

Root $M$ Rense 1.103135

Observations (or Sum Wgts)

t Test
ccc-quenched

Assuming equal variances

Difference $\quad 0.079864$ t Ratio 10.09479

$\begin{array}{llr}\text { Std Err Dif } & 0.007911 \text { DF } & 4 \\ \text { Uper CL Dif } & 0.101830 \text { Prob }>|t| & 0.0005\end{array}$

Upper CL Dif 0.101830 Prob $>|t| \quad 0.0005$

$\begin{array}{lll}\text { Confidence } & 0.95 \text { Prob }<t & 0.9997\end{array}$

Means for Oneway Anova

Level Number Mean Std Lower Upper $\begin{array}{llllll}\text { ccC } & 3 & 1.14307 & 0.00559 & 1.1275 & 1.158\end{array}$ $\begin{array}{lllllll}\text { quenched } & 3 & 1.06320 & 0.00559 & 1.0477 & 1.0787\end{array}$ Std Error uses a pooled estimate of error variance

\section{Oneway Analysis of $\log [\mathrm{Li}$ ppm] By Heat}

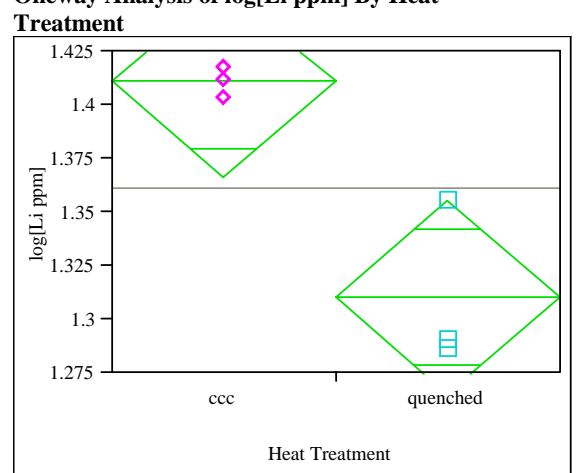

\section{Oneway Anova}

Rsquare

Adj Rsquare

Root Mean Squ

Mean of Response

t Test

Assuming equal variances

Difference $\quad 0.100631$ t Ratio 4.413488

Std Err Dif 0.022801 DF 4

Upper CL Dif 0.163936 Prob $>|t| \quad 0.0116$

Lower CL Dif 0.037326 Prob $>t \quad 0.0058$

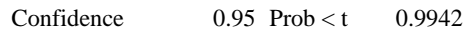

Means for Oneway Anova

Level Number Mean rtd Lower $\begin{array}{rrr}\text { Upper } \\ \text { Error }\end{array}$ $\begin{array}{llllll}\text { ccc } & 3 & 1.41122 & 0.01612 & 1.3665 & 1.4560\end{array}$ Std Error uses a pooled estimate of error variance
Oneway Analysis of $\log [\mathrm{Na}$ ppm] By Heat

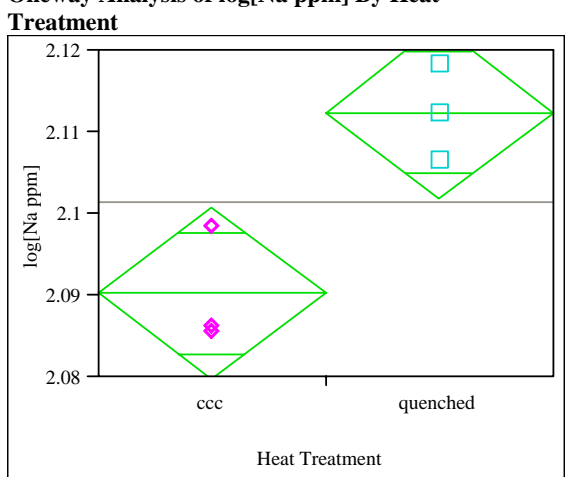

Oneway Anova

Summary of Fit

\section{Rsquare}

dj Rsquare

(20)

\section{Root Mean Squa}

0.808622
0.760777

Mean of Respons

Observations (or Sum Wgts)

0.760777

\section{t Test}

ccc-quenched
Assuming equal variances

Difference $\quad-0.02217$ t Ratio $\quad-4.11108$

$\begin{array}{lll}\text { Std Err Dif } & 0.00539 \mathrm{DF} & 4\end{array}$

$\begin{array}{lll}\text { Upper CL Dif }-0.00720 \text { Prob }>|t| & 0.0147\end{array}$

Lower CL Dif -0.03715 Prob $>t \quad 0.9926$

$\begin{array}{lrl}\text { Confidence } & 0.95 \text { Prob }<\mathrm{t} \quad 0.0074\end{array}$

\section{Means for Oneway Anova}

Level Number Mean Std Lower Upper $\begin{array}{lrrrrr} & & & \text { Error } & 95 \% & 95 \% \\ \text { ссс } & 32.09027 & 0.00381 & 2.0797 & 2.1009\end{array}$

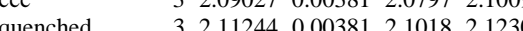
Std Error uses a pooled estimate of error variance
Oneway Analysis of $\log [\mathrm{Si}$ ppm] By Heat

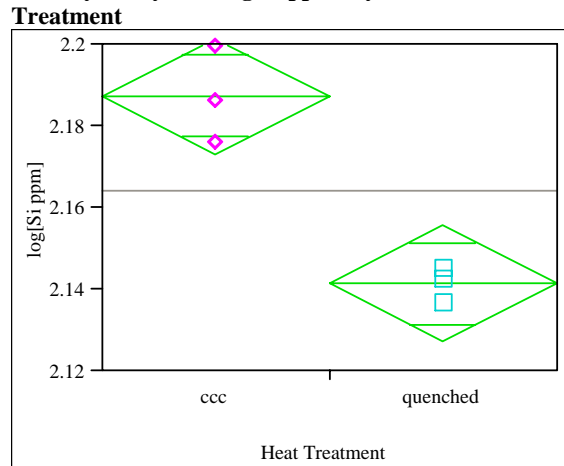

Oneway Anova

Summary of Fit

Rsquare

Adj Rsquare

Root Mean Square

Observations (or Sum Wgts)

t Test

ccc-quenched

Assuming equal variances

Difference $\quad 0.045979$ t Ratio $\quad 6.361315$

$\begin{array}{lll}\text { Std Err Dif } 0.007228 \text { DF } & 4\end{array}$

Upper CL Dif 0.066047 Prob $>|t| \quad 0.0031$

Lower CL Dif 0.025911 Prob $>t \quad 0.0016$

\section{Means for Oneway Anova}

Level Number Mean Std Lower Upper $\begin{array}{lrrrrr} & & & \text { Error } & 95 \% & 95 \% \\ \text { ccc } & 3 & 2.18742 & 0.00511 & 2.1732 & 2.2016\end{array}$ $\begin{array}{llllllll} & 3 & 2.18742 & 0.00511 & 2.1732 & 2.2016\end{array}$ Std Error uses a pooled estimate of error variance 
Exhibit D.6: Effects of Heat Treatment on PCT Response by Study Glass (continued)

Glass \#=10

Oneway Analysis of $\log [\mathrm{B}$ ppm] By Heat

Treatment

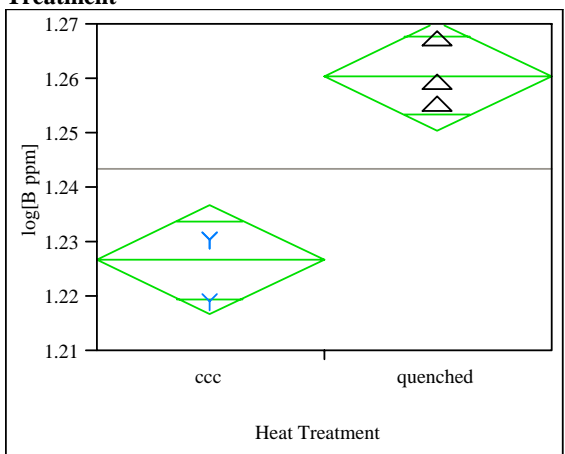

Oneway Anova

Summary of Fit

Rsquare

Adj Rsquare

0.916279

Square Error 0.006268

Mean of Response 1.243651

Observations (or Sum Wgts)

t Test

ccc-quenched

Assuming equal variances

$\begin{array}{lrr}\text { Difference } & -0.03386 \text { t Ratio } & -6.61646 \\ \text { Std Err Dif } & 0.00512 \text { DF } & 4 \\ \text { Upper CL Dif } & -0.01965 \text { Prob }>|t| & 0.0027 \\ \text { Lower CL Dif } & -0.04807 \text { Prob }>\text { t } & 0.9986 \\ \text { Cofing }\end{array}$

Upper CL Dif -0.01965 Prob $>|t| \quad 0.0027$

Confidence $\quad 0.95$ Prob $<\mathrm{t} \quad 0.0014$

\section{Means for Oneway Anova}

Level Number Mean Std Lower Upper $\begin{array}{llllll}\text { ccc } & 3 & 1.22672 & 0.00362 & 1.2167 & 1.2368\end{array}$ $\begin{array}{llllll} & 3 & 1.22672 & 0.00362 & 1.2167 & 1.2368\end{array}$ Std Error uses a pooled estimate of error variance
Oneway Analysis of $\log [\mathrm{Li}$ ppm] By Heat

\section{Treatment}

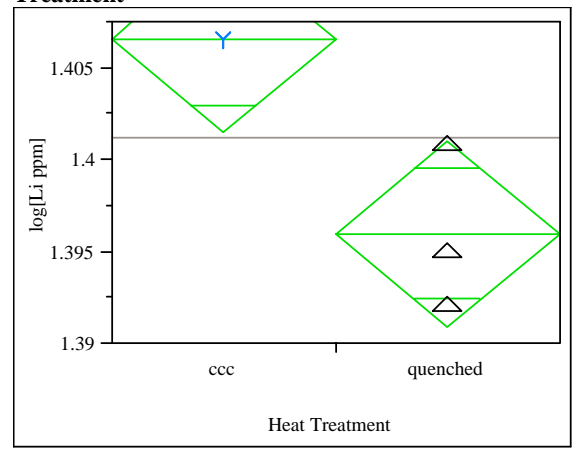

\section{Oneway Anova
Summary of Fit}

Rsquare

Adj Rsquare

Mean of Response $\quad 0.003136$

Observations (or Sum Wgts)

t Test

ccc-quenched

Assuming equal variances

Difference $\quad 0.010550$ t Ratio 4.119694

$\begin{array}{llr}\text { Std Err Dif } & 0.002561 \mathrm{DF} & 4 \\ \text { Upper } & \end{array}$

$\begin{array}{lll}\text { Upper CL Dif } 0.017660 \text { Prob }>|t| & 0.0146 \\ \text { Lor } & \end{array}$

$\begin{array}{lrl} & \text { Lower CL Dif } & 0.003440 \\ \text { Confidence } & 0.95 \text { Prob }<\mathrm{t} & 0.9927\end{array}$

Means for Oneway Anova

Level Number Mean Std Lower Upper

$\begin{array}{llllll}\text { ccC } & 3 & 1.40655 & 0.00181 & 1.4015 & 1.4116\end{array}$ $\begin{array}{lllllll}\text { quenched } & 3 & 1.39600 & 0.00181 & 1.3910 & 1.4010\end{array}$ Std Error uses a pooled estimate of error variance
Oneway Analysis of log[Na ppm] By Heat

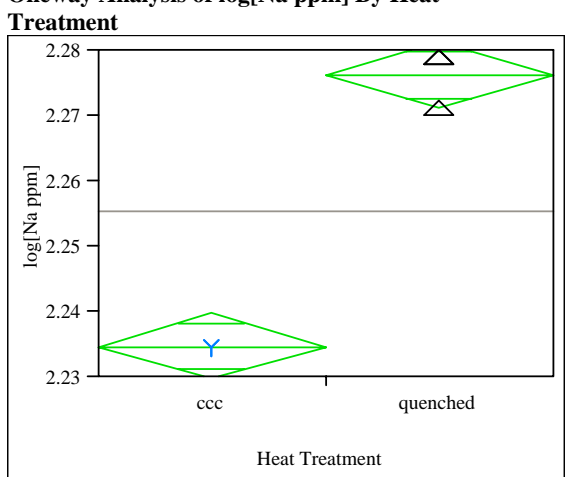

Oneway Anova

Summary of Fit

\section{Rsquare}

\section{Adj Rsquare}

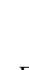

\subsection{5}

Tquare Error $\quad 0.003138$

Mean of Response

0.003138
2.255447

Observations (or Sum Wgts)

t Test

Assuming equal variances

Difference $\quad-0.04151$ t Ratio $\quad-16.1986$

$0.00256 \mathrm{DF} \quad 4$

Upper CL Dif -0.03439 Prob $>|t|<.0001$

0.95 Prob $<\mathrm{t} \quad<.0001$

\section{Means for Oneway Anova}

Level Number Mean Std Lower Upper $\begin{array}{lrrrrr} & & & \text { Error } & 95 \% & 95 \% \\ \text { ccC } & 3 & 2.23469 & 0.00181 & 2.2297 & 2.2397\end{array}$

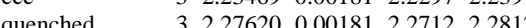
Std Error uses a pooled estimate of error variance
Oneway Analysis of log[Si ppm] By Heat

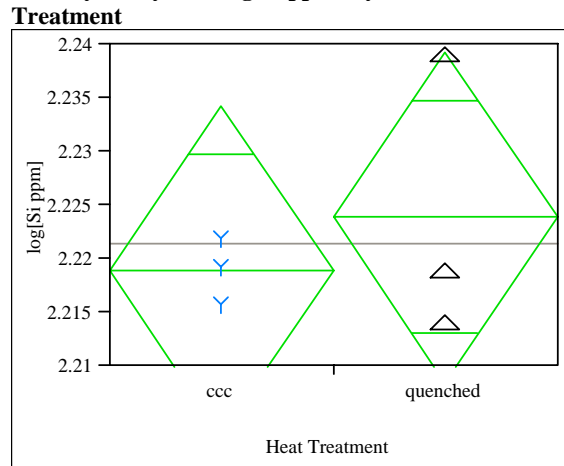

Oneway Anova

Summary of Fit

Rsquare

Root Mean Square Error $\quad 0.009594$

Mean of Response 2.221417

Observations (or Sum Wgts)

t Test

ccc-quenched

Assuming equal variances

Difference $\quad-0.00494$ t Ratio $\quad-0.63109$ Std Err Dif $\quad 0.00783$ DF

Upper CL Dif 0.01681 Prob $>|t| 0.5622$

Lower CL Dif -0.02669 Prob $>t \quad 0.7189$

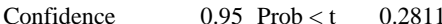

Means for Oneway Anova

Level Number Mean Std Lower Upper

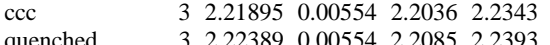
Std Error uses a pooled estimate of error variance 
Exhibit D.6: Effects of Heat Treatment on PCT Response by Study Glass (continued)

Glass \#=11

Oneway Analysis of $\log [\mathrm{B}$ ppm] By Heat

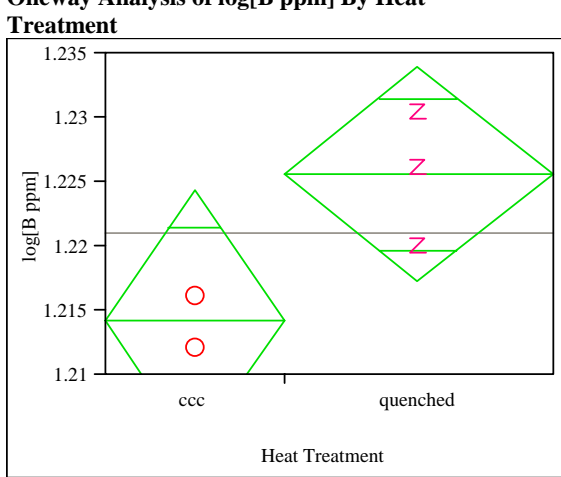

Oneway Anova

$\begin{array}{ll}\text { Rsquare } & 0.715793 \\ \text { Adj Rsquare } & 0.621057 \\ \text { Roun } & 0.004543\end{array}$

Root Mean Square Error $\quad 0.004543$

$\begin{array}{lr}\text { Mean of Response } & 1.221025 \\ \text { Observations (or Sum Wgts) } & 5\end{array}$

t Test

Assuming equal variances

Difference $\quad-0.01140$ t Ratio $\quad-2.74876$

$\begin{array}{llr}\text { Std Err Dif } & 0.00415 \text { DF } & 3 \\ \text { Un } & & \end{array}$

Upper CL Dif 0.00180 Prob $>|t| \quad 0.0708$

$\begin{array}{lrr}\text { Lower CL Dif } & -0.02460 \text { Prob }>t & 0.9646 \\ \text { Confidence } & 0.95 \text { Prob }<t & 0.0354\end{array}$

Means for Oneway Anova

Level Number Mean Std Lower Upper $\begin{array}{llllll}\text { ccc } & 2 & 1.21419 & 0.00321 & 1.2040 & 1.2244\end{array}$ $\begin{array}{llllll}\text { quenched } & 3 & 1.22558 & 0.00262 & 1.2172 & 1.2339\end{array}$ Std Error uses a pooled estimate of error variance
Oneway Analysis of $\log [\mathrm{Li}$ ppm] By Heat

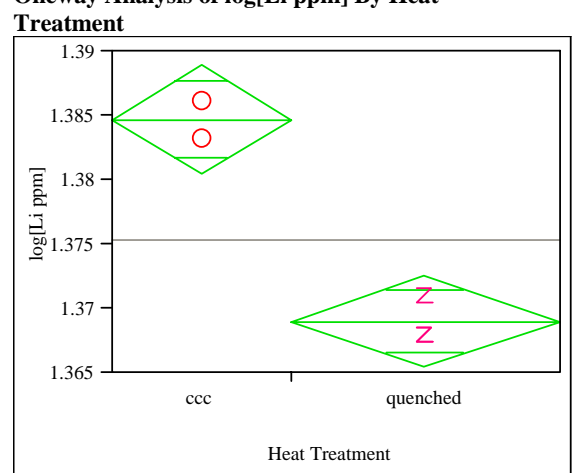

\section{Oneway Anova}

Rsquar

Adj Rsquare

0.95294
0.0019

Mean of Response 1.375297

Observat

ccc-quenched

Assuming equal variances

Difference $\quad 0.015702$ t Ratio $\quad 9.055303$

Std Err Dif 0.001734 DF

3
0.0028

Upper CL Dif 0.021220 Prob $>|t| \quad 0.0028$

$\begin{array}{lrl} & \text { Lower CL Dif } & 0.010184 \\ \text { Confidence } & 0.95 \text { Prob }>t & 0.0014 \\ & & \end{array}$

Means for Oneway Anova

Level Number Mean Std Lower Upper $\begin{array}{llllll}\text { ccc } & 2 & 1.38472 & 0.00134 & 1.3804 & 1.3890\end{array}$ Std Error uses a pooled estimate of error variance
Oneway Analysis of $\log [\mathrm{Na}$ ppm] By Heat

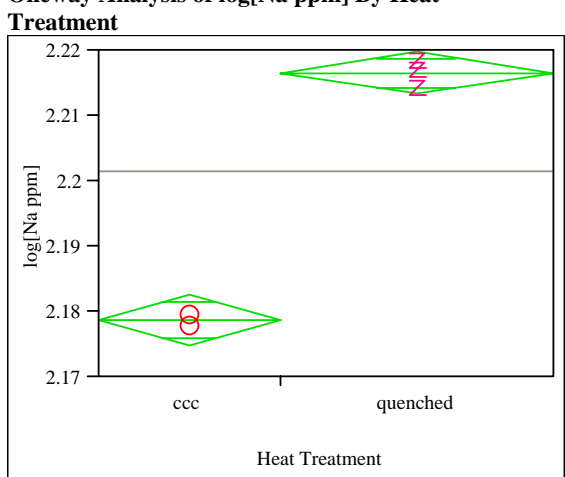

Oneway Anova

Summary of Fit

\section{Rsquare}

Adj Rsquare

(n)

\section{Root Mean Sq}

0.994703

Mean of Response

0.992938

Observations (or Sum Wgts) 2.201465

t Test

ccc-quenched

Assuming equal variances

Difference $\quad-0.03787$ t Ratio $\quad-23.7355$

$\begin{array}{llr}\text { Std Err Dif } \quad 0.00160 \text { DF } & 3\end{array}$

Upper CL Dif -0.03279 Prob $>|t| \quad 0.0002$

Lower CL Dif -0.04294 Prob $>t \quad 0.9999$

$\begin{array}{lrl}\text { Confidence } & 0.95 \mathrm{Prob}<\mathrm{t} \quad<.0001\end{array}$

\section{Means for Oneway Anova}

Level Number Mean Std Lower Upper

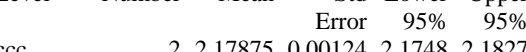

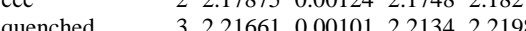
Std Error uses a pooled estimate of error variance
Oneway Analysis of $\log [\mathrm{Si}$ ppm] By Heat

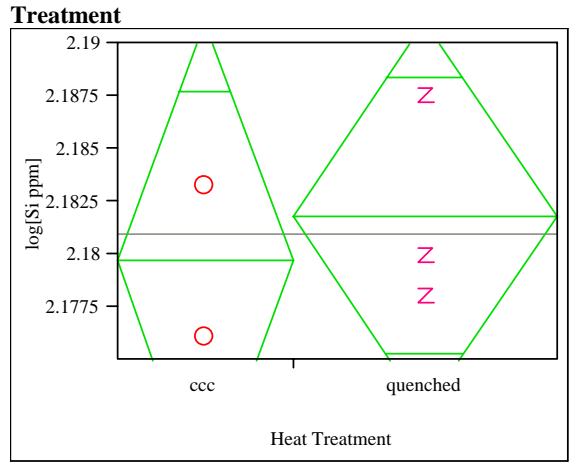

\section{Oneway Anova
Summary of Fit}

Rsquare

Adj Rsquare $\quad \begin{array}{ll}0.067414 \\ -0.24345\end{array}$

Root Mean Square Error $\quad 0.005042$

Mean of Response 2.180975

Observations (or Sum Wgts)

t Test

ccc-quenched

Assuming equal variances

Difference $\quad-0.00214$ t Ratio $\quad-0.46568$

Std Err Dif $\quad 0.00460$ DF $\quad 0.4658$

Upper CL Dif 0.01251 Prob $>|t| 0.6732$

Lower CL Dif -0.01679 Prob $>t \quad 0.6634$

Confidence $\quad 0.95$ Prob $<\mathrm{t} \quad 0.3366$

Means for Oneway Anova

Level Number Mean Std Lower Upper

$\begin{array}{lrrrrr} & & & \text { Error } & 95 \% & 95 \% \\ \text { ccC } & 2 & 2.17969 & 0.00357 & 2.1683 & 2.1910\end{array}$

$\begin{array}{llllll}\text { quenched } & 3 & 2.18183 & 0.00291 & 2.1726 & 2.1911\end{array}$

Std Error uses a pooled estimate of error variance 
Exhibit D.6: Effects of Heat Treatment on PCT Response by Study Glass (continued)

Glass \#=12

Oneway Analysis of $\log [\mathrm{B}$ ppm] By Heat

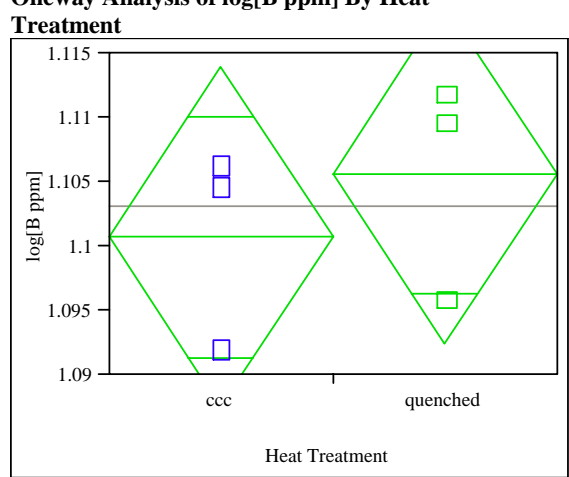

Oneway Anova

Summary of Fit

$\begin{array}{ll}\text { Rsquare } & 0.117964 \\ \text { Adj Rsquare } & -0.10254 \\ \text { Rogt Mean Squre Eror } & 0.008266\end{array}$

Root Mean Square Error $\quad 0.008266$

Mean of Response 1.103183

Observations (or Sum Wgts)

t Test

Assuming equal variances

Difference $\quad-0.00494$ t Ratio $\quad-0.73141$

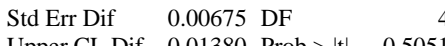

Upper CL Dif $\quad 0.01380$ Prob $>|t| \quad 0.5051$

$\begin{array}{lrr}\text { Lower CL Dif } & -0.02367 \text { Prob }>t & 0.7475 \\ \text { Confidence } & 0.95 \text { Prob }<t \quad 0.2525\end{array}$

Means for Oneway Anova

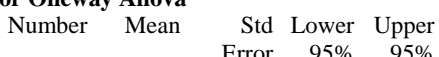

$\begin{array}{llllll} & & & & & \\ \text { ccc } & 3 & 1.10071 & 0.00477 & 1.0875 & 1.1140\end{array}$ $\begin{array}{lllllll}\text { quenched } & 3 & 1.10565 & 0.00477 & 1.0924 & 1.1189\end{array}$ Std Error uses a pooled estimate of error variance

\section{Oneway Analysis of $\log [\mathrm{Li} \mathrm{ppm}] \mathrm{By}$ Heat}

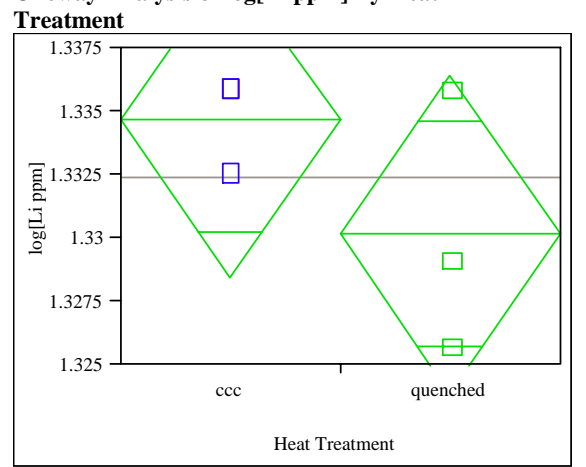

Oneway Anova

Summary of Fit

Rsqua

Adj Rsquare

Root Mean Square

Mean of Response

Observations (or Sum Wgts)

Test

ccc-quenched

Assuming equal variances

Difference $\quad 0.00451$ t Ratio 1.416255

Std Err Dif 0.00318 DF

4
0.2296

$\begin{array}{lrr}\text { Upper CL Dif } & 0.01334 \text { Prob }>|t| & 0.2296 \\ \text { Lower CL } & -0.00433 \text { Prob }>t & 0.1148\end{array}$

$\begin{array}{lrl}\text { Lower CL Dif } & -0.00433 \text { Prob }>t & 0.1148 \\ \text { Confidence } & 0.95 \text { Prob }<\mathrm{t} & 0.8852\end{array}$

Means for Oneway Anova

$$
\begin{array}{rrrr}
\text { Number Mean } & \begin{array}{r}
\text { Std } \\
\text { Error }
\end{array} \quad 95 \% & 95 \% \\
& & 95 \%
\end{array}
$$

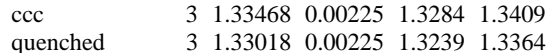
Std Error uses a pooled estimate of error variance
Oneway Analysis of $\log [\mathrm{Na}$ ppm] By Heat

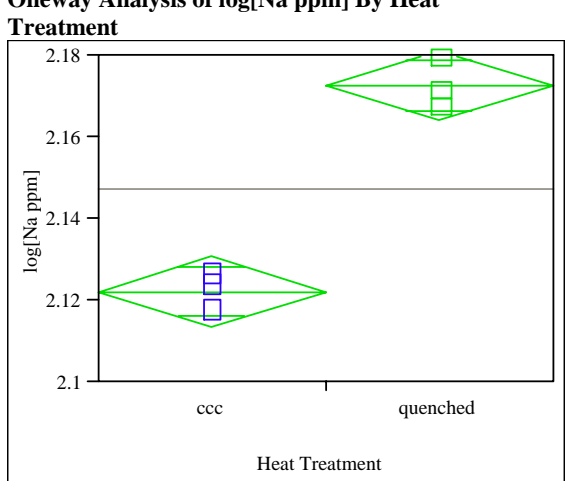

Oneway Anova

Summary of Fit

Rsqua

Adj Rsquare

0.970317
0.962896

Root Mean Square Error $\quad 0.005406$

ns (or Sum Wgts)

t Test

-quenched

Assuming equal variances

Difference $\quad-0.05047$ t Ratio $\quad-11.4349$

$\begin{array}{lll}\text { Dtd Err Dif } & 0.00441 \mathrm{DF} & 4\end{array}$

Upper CL Dif -0.03822 Prob $>|t| 0.0003$

Lower CL Dif -0.06272 Prob $>t \quad 0.9998$

$\begin{array}{lrl}\text { Confidence } & 0.95 \text { Prob }<\mathrm{t} \quad 0.0002\end{array}$

\section{Means for Oneway Anova}

Number Mean Std Lower Upper

$\begin{array}{llrrrr} & & & \text { Error } & 95 \% & 95 \% \\ \text { ccC } & 3 & 2.12221 & 0.00312 & 2.1135 & 2.1309\end{array}$

$\begin{array}{llllll}\text { ccc } & 3 & 2.12221 & 0.00312 & 2.1135 & 2.1309\end{array}$

Std Error uses a pooled estimate of error variance
Oneway Analysis of $\log [\mathrm{Si}$ ppm] By Heat

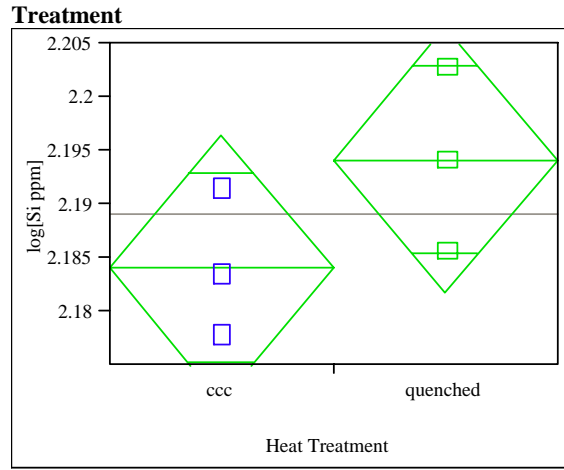

Oneway Anova

$\begin{array}{ll}\text { Rsquare } & 0.388863\end{array}$

Adj Rsquare $\quad 0.236079$

Root Mean Square Error $\quad 0.007774$

Observations (or Sum Wgts)

t Test

ccc-quenched

Assuming equal variances

Difference $\quad-0.01013$ t Ratio -1.59536

$\begin{array}{lrr}\text { Std Err Dif } & 0.00635 \text { DF } & 4 \\ \text { Upper C Dif } & 0.00750 \text { Prob }>|t| & 0.1859\end{array}$

$\begin{array}{lll}\text { Upper CL Dif } & 0.00750 \text { Prob }>|t| & 0.1859 \\ \text { Lower CL Dif }-0.02775 \text { Prob }>t & 0.9071\end{array}$

Confidence $\quad 0.95$ Prob $<\mathrm{t} \quad 0.0929$

Means for Oneway Anova

$$
\text { Number Mean Std Lower Upper }
$$

$\begin{array}{llllll}\text { ccC } & 3 & 2.18403 & 0.00449 & 2.1716 & 2.1965\end{array}$ $\begin{array}{lllllll}\text { quenched } & 3 & 2.19416 & 0.00449 & 2.1817 & 2.2066\end{array}$ Std Error uses a pooled estimate of error variance 
Exhibit D.7: Correlations and Scatter Plots of Normalized PCTs by Compositional View and Heat Treatment

\section{Comp View/Heat Treatment=measured bc-ccc}

\section{Correlations}

$\log \mathrm{NL}[\mathrm{B}(\mathrm{g} / \mathrm{L})]$
$\log \mathrm{NL}[\mathrm{Li}(\mathrm{g} / \mathrm{L})]$
$\log \mathrm{NL}[\mathrm{Na}(\mathrm{g} / \mathrm{L})]$

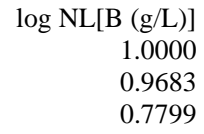

$\log \mathrm{NL}[\mathrm{B}(\mathrm{g} / \mathrm{L})]$

1.0000

0.9683

0.7799

$\log \mathrm{NL}[\mathrm{Si}(\mathrm{g} / \mathrm{L})]$

$$
\begin{array}{rr}
\log \mathrm{NL}[\mathrm{Na}(\mathrm{g} / \mathrm{L})] & \log \mathrm{NL}[\mathrm{Si}(\mathrm{g} / \mathrm{L})] \\
0.7799 & 0.8666 \\
0.7662 & 0.8896 \\
1.0000 & 0.9638 \\
0.9638 & 1.0000
\end{array}
$$

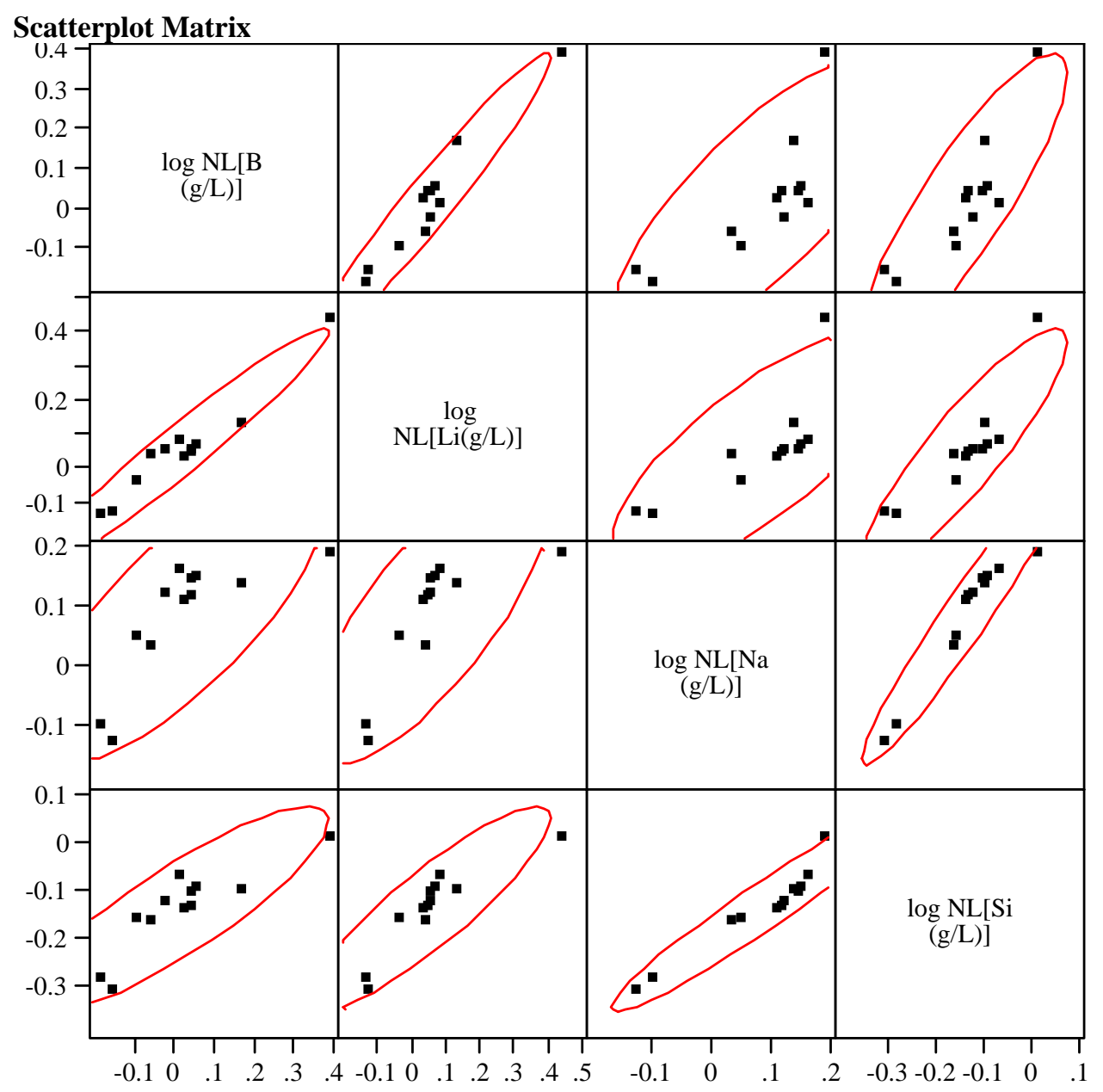


Exhibit D.7: Correlations and Scatter Plots of Normalized PCTs by Compositional View and Heat Treatment

\section{Comp View/Heat Treatment=measured bc-quenched}

\section{Correlations}

$\log \mathrm{NL}[\mathrm{B}(\mathrm{g} / \mathrm{L})]$

$\log \mathrm{NL}[\mathrm{Li}(\mathrm{g} / \mathrm{L})]$

$\log \mathrm{NL}[\mathrm{Na}(\mathrm{g} / \mathrm{L})]$

$\log \mathrm{NL}[\mathrm{Si}(\mathrm{g} / \mathrm{L})]$

$$
\begin{array}{r}
\log \text { NL[B }(\mathrm{g} / \mathrm{L})] \\
1.0000 \\
0.9617 \\
0.9411 \\
0.9382
\end{array}
$$
$\log \mathrm{NL}[\mathrm{Li}(\mathrm{g} / \mathrm{L})]$
0.9617
1.0000
0.9521
$\log \mathrm{NL}[\mathrm{Na}(\mathrm{g} / \mathrm{L})]$
0.9411
0.9521
1.0000
0.9829
$\log \mathrm{NL}[\mathrm{Si}(\mathrm{g} / \mathrm{L})]$
0.9382
0.9680
0.9829
1.0000

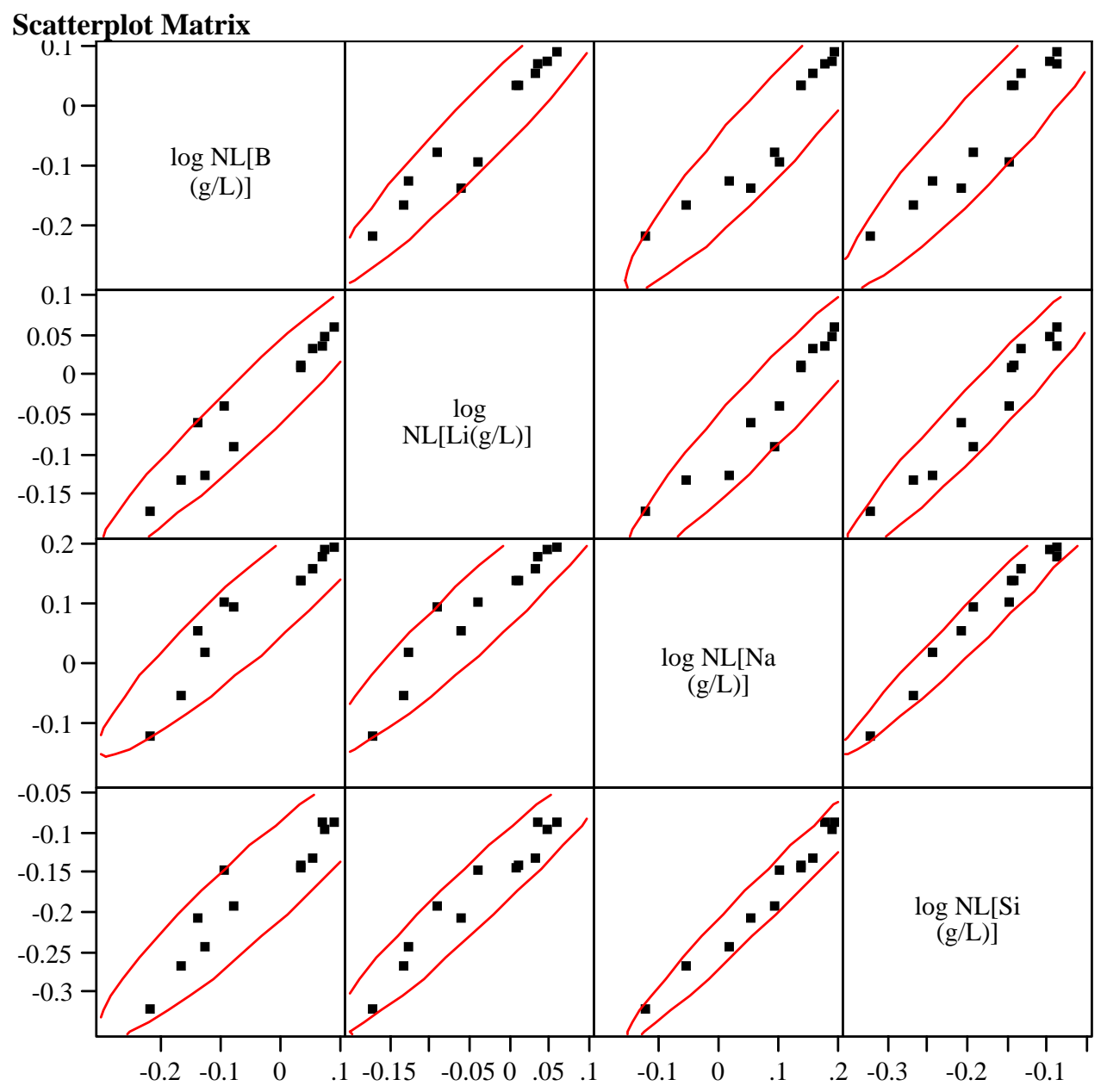


Exhibit D.7: Correlations and Scatter Plots of Normalized PCTs by Compositional View and Heat Treatment

\section{Comp View/Heat Treatment=measured-ccc}

\section{Correlations}

$\log \mathrm{NL}[\mathrm{B}(\mathrm{g} / \mathrm{L})]$

$\log \mathrm{NL}[\mathrm{Li}(\mathrm{g} / \mathrm{L})]$

$\log \mathrm{NL}[\mathrm{Na}(\mathrm{g} / \mathrm{L})]$

$\log \mathrm{NL}[\mathrm{Si}(\mathrm{g} / \mathrm{L})]$

$$
\begin{array}{r}
\log \mathrm{NL}[\mathrm{B}(\mathrm{g} / \mathrm{L})] \\
1.0000 \\
0.9683 \\
0.7799
\end{array}
$$
$\log \mathrm{NL}[\mathrm{Li}(\mathrm{g} / \mathrm{L})]$
0.9683
0.7662

$\log \mathrm{NL}[\mathrm{Na}(\mathrm{g} / \mathrm{L})]$

0.7799

0.7662

1.0000

0.9638

$\log \mathrm{NL}[\mathrm{Si}(\mathrm{g} / \mathrm{L})]$
0.8666
0.8896
0.9638
1.0000

\section{Scatterplot Matrix}

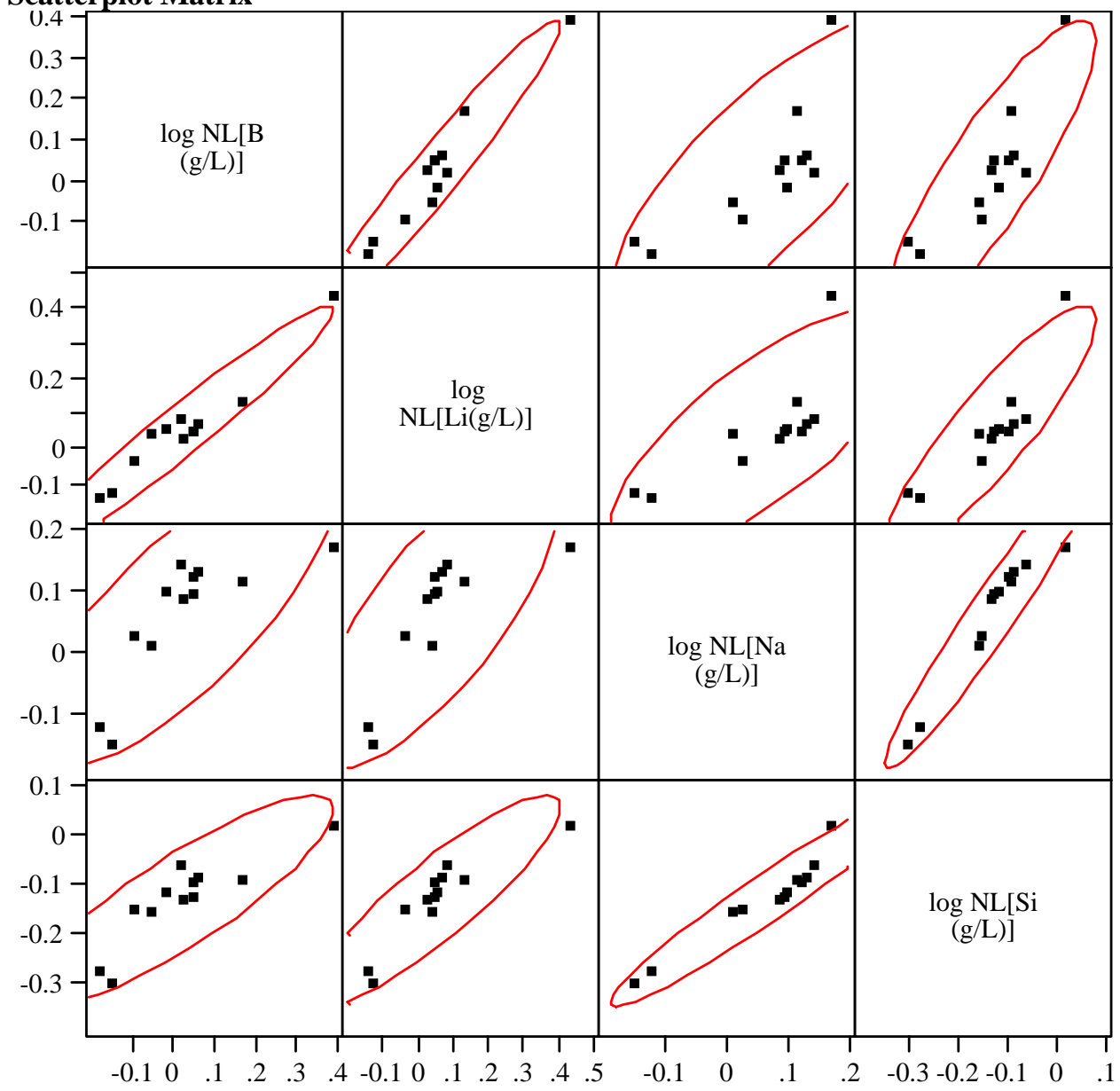


Exhibit D.7: Correlations and Scatter Plots of Normalized PCTs by Compositional View and Heat Treatment

\section{Comp View/Heat Treatment $=$ measured-quenched}

\section{Correlations}

$\log \mathrm{NL}[\mathrm{B}(\mathrm{g} / \mathrm{L})]$

$\log \mathrm{NL}[\mathrm{Li}(\mathrm{g} / \mathrm{L})]$

$\log \mathrm{NL}[\mathrm{Na}(\mathrm{g} / \mathrm{L})$

$\log \mathrm{NL}[\mathrm{Si}(\mathrm{g} / \mathrm{L})]$

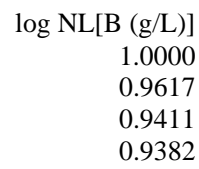

0.9829

1.0000

\section{Scatterplot Matrix}

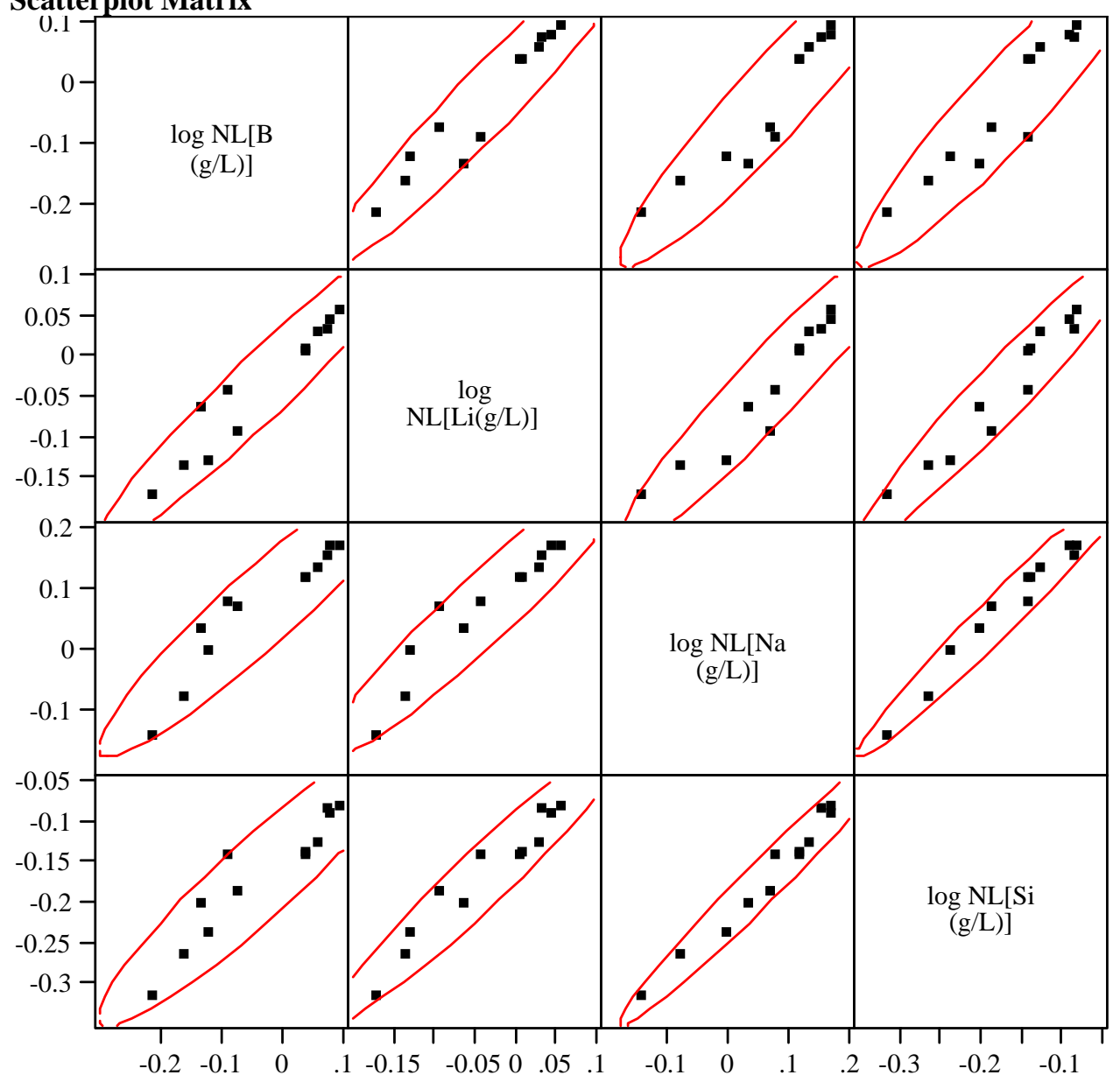


Exhibit D.7: Correlations and Scatter Plots of Normalized PCTs by Compositional View and Heat Treatment

\section{Comp View/Heat Treatment=target-ccc}

\section{Correlations}

$\log \mathrm{NL}[\mathrm{B}(\mathrm{g} / \mathrm{L})]$

$\log \mathrm{NL}[\mathrm{Li}(\mathrm{g} / \mathrm{L})]$

$\log \mathrm{NL}[\mathrm{Na}(\mathrm{g} / \mathrm{L})]$

$\log \mathrm{NL}[\mathrm{Si}(\mathrm{g} / \mathrm{L})]$

$$
\begin{array}{r}
\log \mathrm{NL}[\mathrm{B}(\mathrm{g} / \mathrm{L})] \\
1.0000 \\
0.9663 \\
0.7894
\end{array}
$$
$\log \mathrm{NL}[\mathrm{Li}(\mathrm{g} / \mathrm{L})]$
0.9663
1.0000
0.7826
0.8888
$\log \mathrm{NL}[\mathrm{Na}(\mathrm{g} / \mathrm{L})]$
0.7894
0.7826
1.0000
0.9707

$\log \mathrm{NL}[\mathrm{Si}(\mathrm{g} / \mathrm{L})]$
0.8578
0.8888
0.9707
1.0000

\section{Scatterplot Matrix}

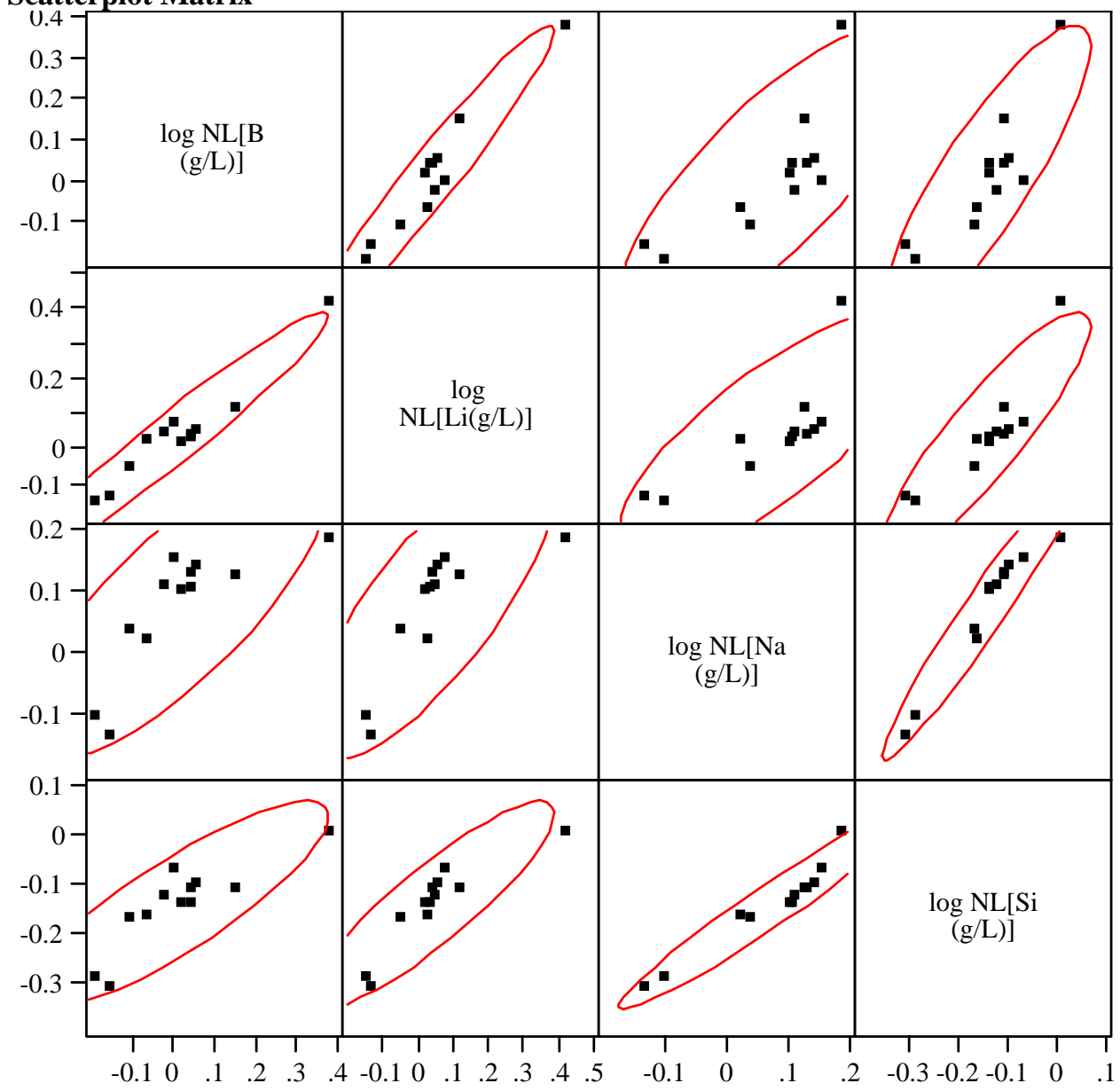


Exhibit D.7: Correlations and Scatter Plots of Normalized PCTs by Compositional View and Heat Treatment

\section{Comp View/Heat Treatment=target-quenched}

\section{Correlations}

$\log N L[B(g / L)]$

$\log \mathrm{NL}[\mathrm{Li}(\mathrm{g} / \mathrm{L})]$

$\log \mathrm{NL}[\mathrm{Na}(\mathrm{g} / \mathrm{L})]$

$\log \mathrm{NL}[\mathrm{Si}(\mathrm{g} / \mathrm{L})]$

$$
\begin{array}{r}
\log N L[B(g / L)] \\
1.0000 \\
0.9597 \\
0.9325
\end{array}
$$
$\log \mathrm{NL}[\mathrm{Li}(\mathrm{g} / \mathrm{L})]$
0.9597
1.0000
0.9417
0.9713
$\log \mathrm{NL}[\mathrm{Na}(\mathrm{g} / \mathrm{L})]$
0.9325
0.9417
1.0000
0.9801

$\log N L[S i(g / L)]$
0.9384
0.9713
0.9801
1.0000

\section{Scatterplot Matrix}

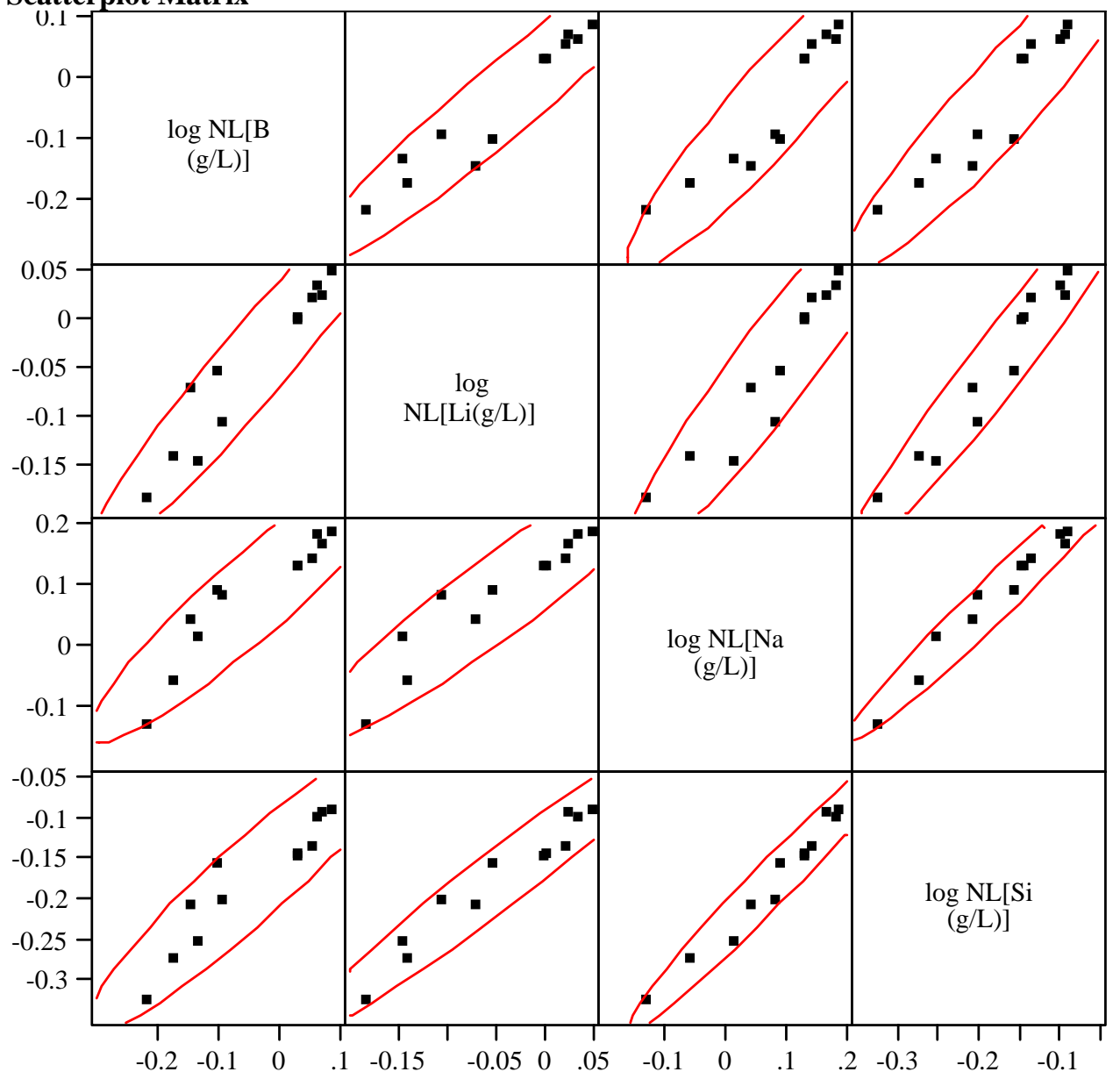


WSRC-TR-2005-00371

Revision 0

Exhibit D.8: del Gp $\left(\Delta G_{p}\right)$ Predictions versus Common Logarithm Normalized Leachate (log NL[.]) for B, Li, Na, and Si Over All Compositional Views and Heat Treatments

Fit of $\log$ NL[B (g/L)] By del Gp

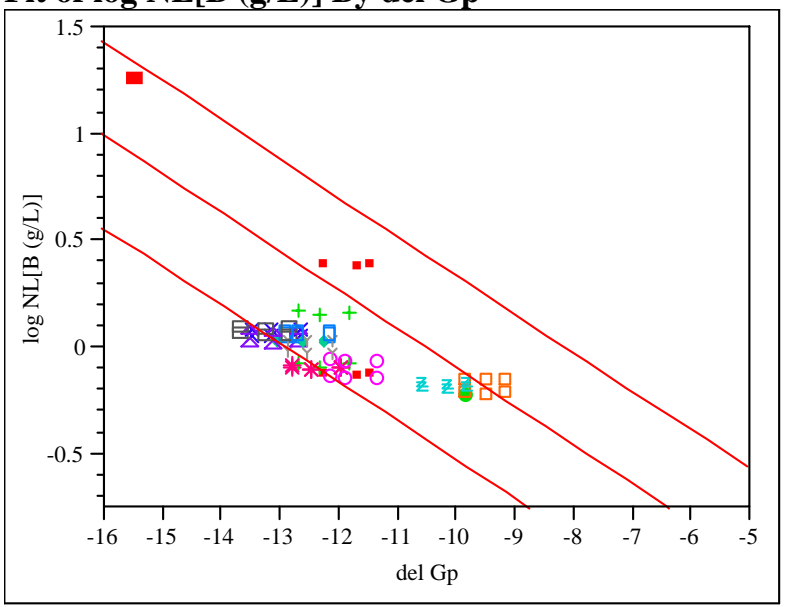

Fit of log NL[Li (g/L)] By del Gp

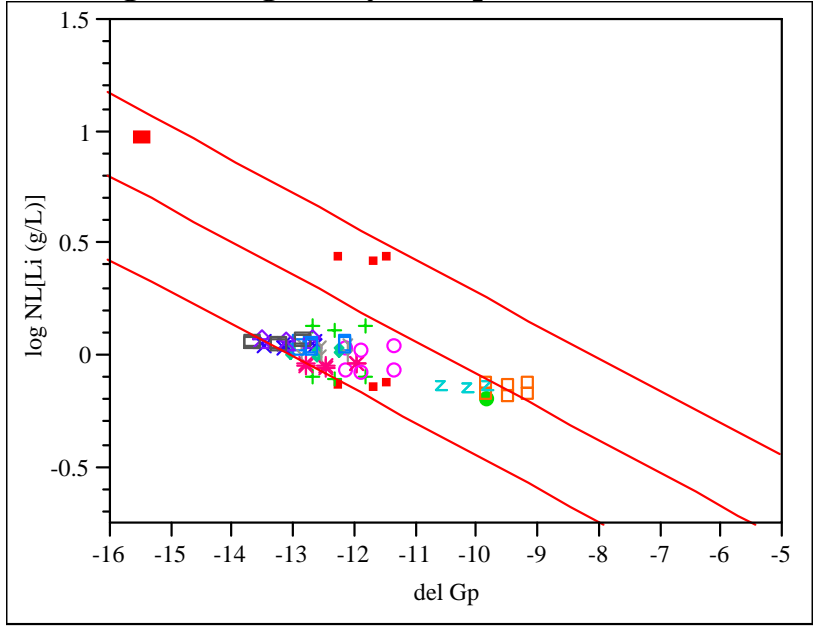

Fit of $\log$ NL[Na (g/L)] By del Gp

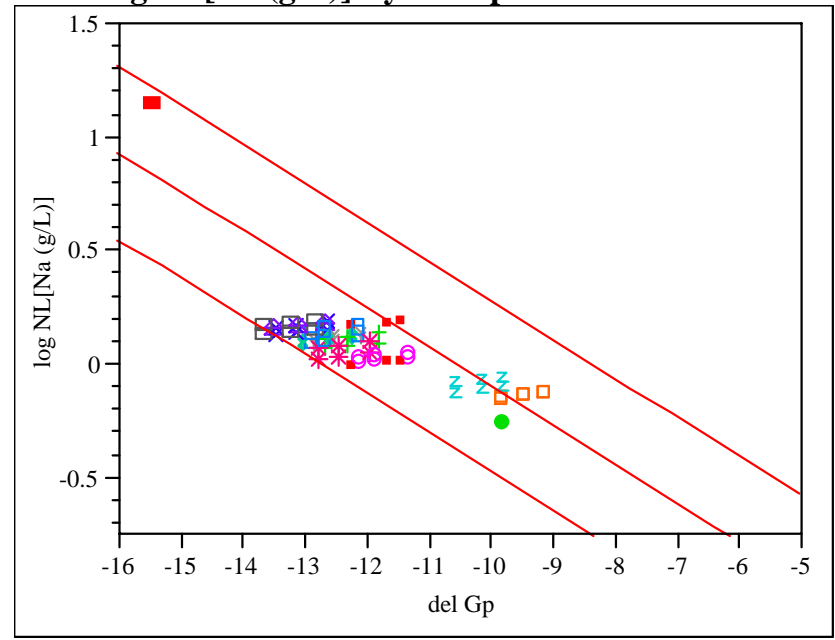

Fit of $\log \mathrm{NL}[\mathrm{Si}(\mathrm{g} / \mathrm{L})]$ By del Gp

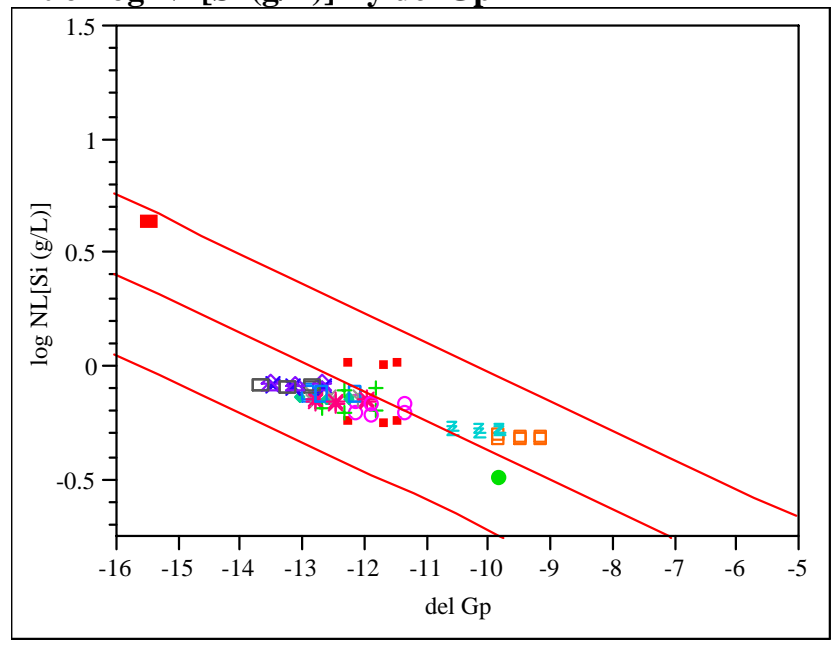




\section{Exhibit D.9: del $G p\left(\Delta G_{p}\right)$ Predictions versus Common Logarithm Normalized Leachate} $(\log \mathrm{NL}[]$.$) for B, Li, Na, and Si by Study Glass Over All Compositional Views and$

\section{Heat Treattment}

Study Glass \# 1 with EA and ARM

Fit of $\log$ NL[B (g/L)] By del Gp

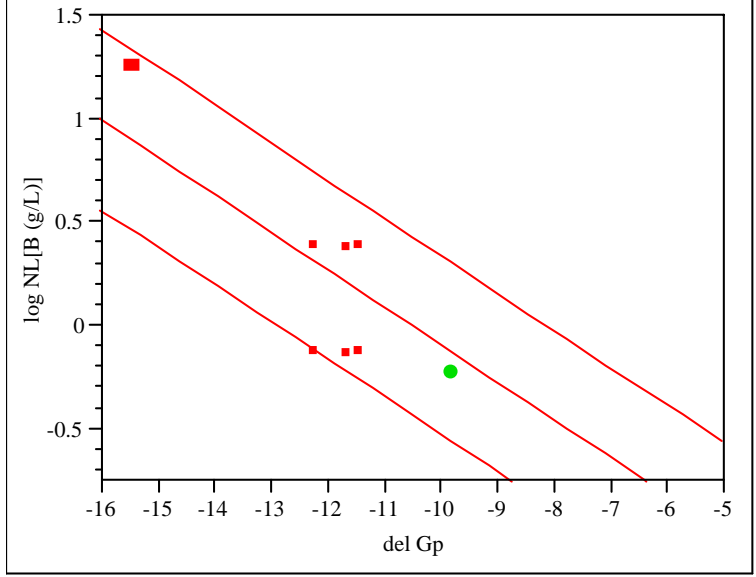

Fit of log NL[Li (g/L)] By del Gp

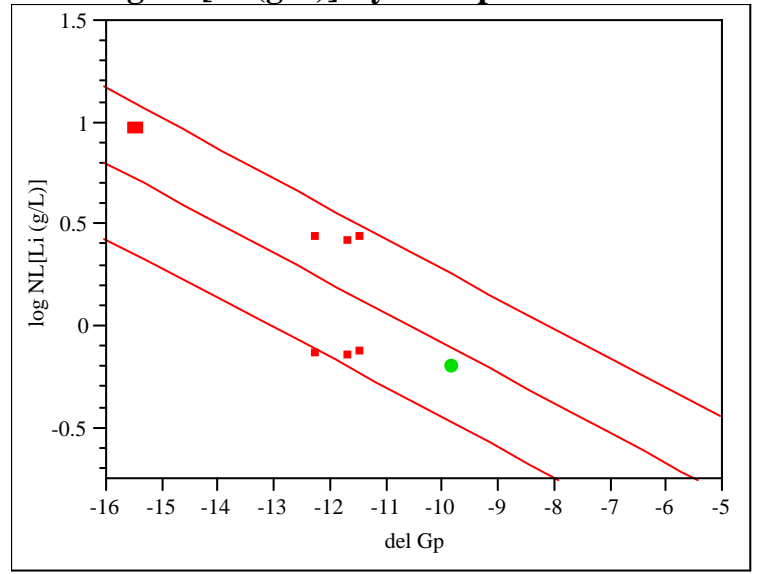

Fit of $\log \mathrm{NL}[\mathrm{Na}(\mathrm{g} / \mathrm{L})]$ By del Gp

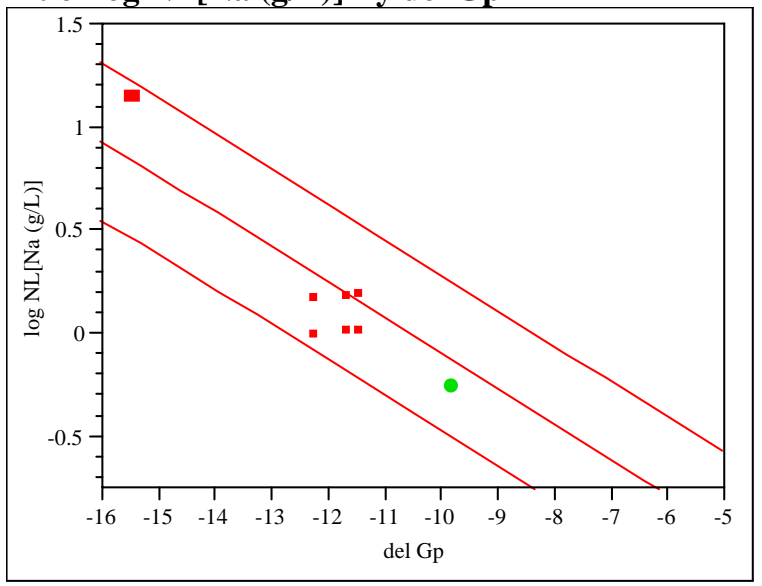

Fit of log NL[Si (g/L)] By del Gp

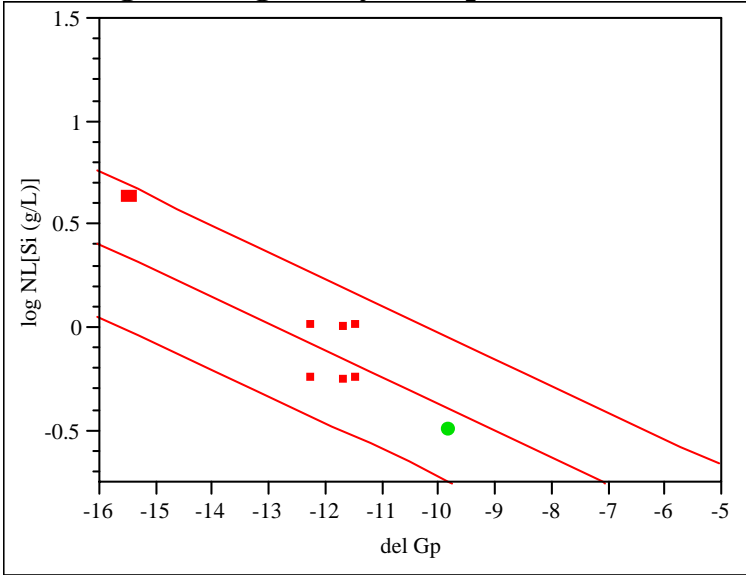


Exhibit D.9: del Gp $\left(\Delta G_{p}\right)$ Predictions versus Common Logarithm Normalized Leachate $(\log \mathrm{NL}[]$.$) for B, Li, Na, and Si by Study Glass Over All Compositional Views and Heat$

Study Glass \# 2 with EA and ARM Treatment

Fit of log NL[B (g/L)] By del Gp

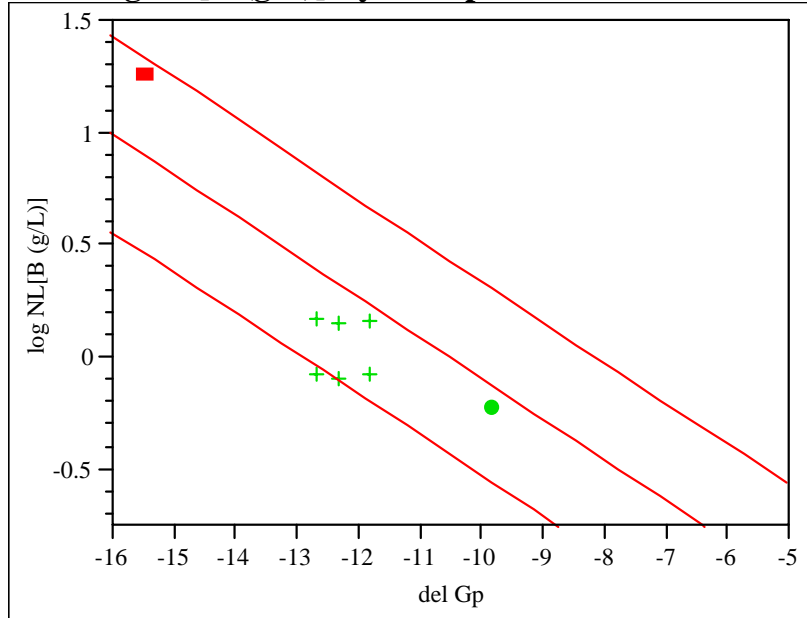

Fit of $\log \mathrm{NL}[\mathrm{Na}(\mathrm{g} / \mathrm{L})]$ By del Gp

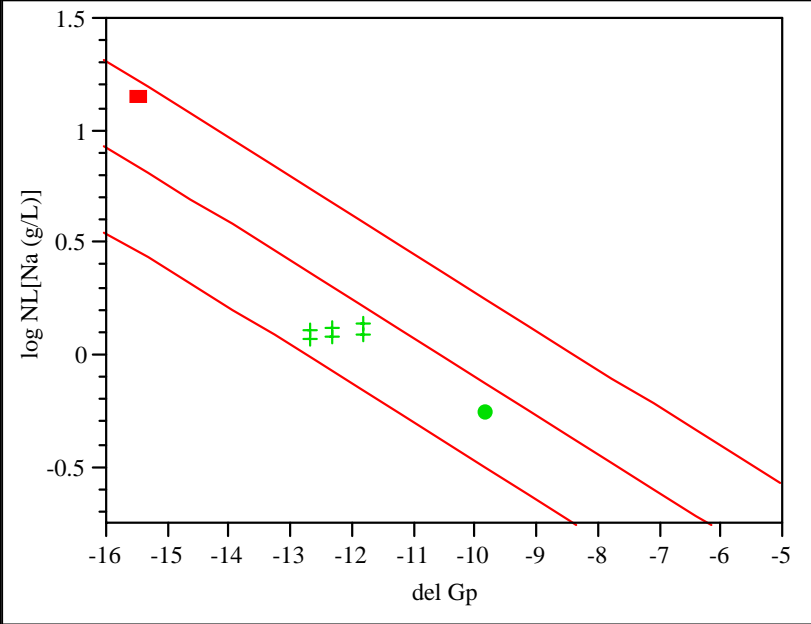

Fit of log NL[Li (g/L)] By del Gp

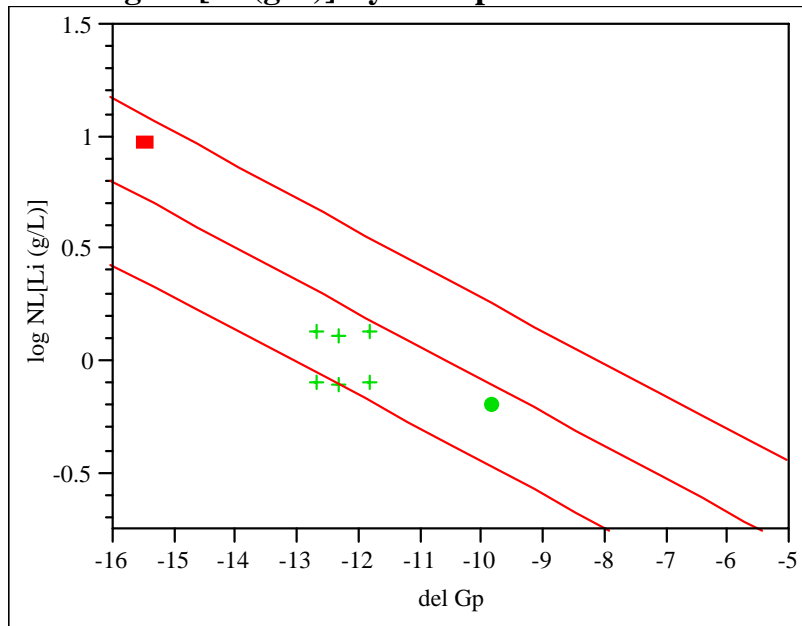

Fit of log NL[Si (g/L)] By del Gp

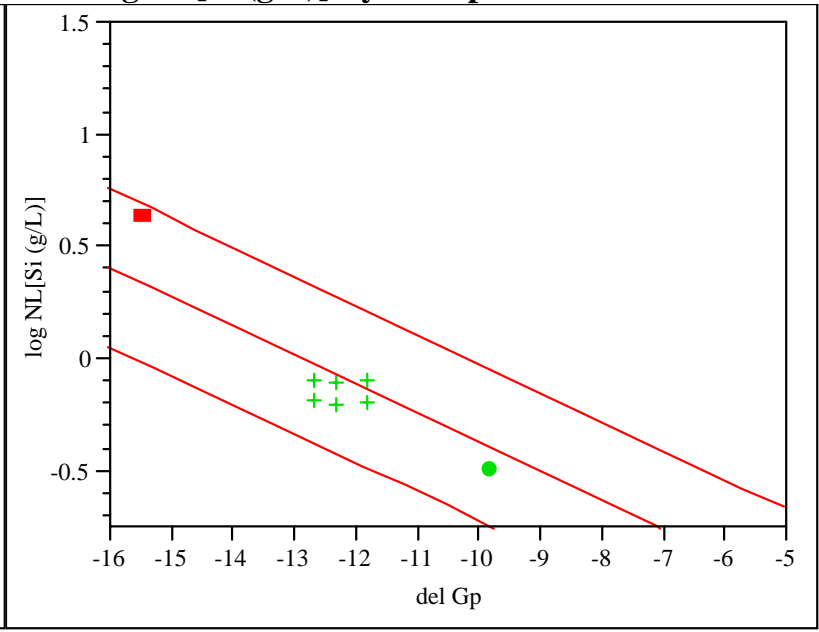


Exhibit D.9: del Gp $\left(\Delta G_{p}\right)$ Predictions versus Common Logarithm Normalized Leachate (log NL[.]) for B, Li, Na, and Si by Study Glass Over All Compositional Views and Heat Treatments

\section{Study Glass \# 3 with EA and ARM}

Fit of $\log$ NL[B (g/L)] By del Gp

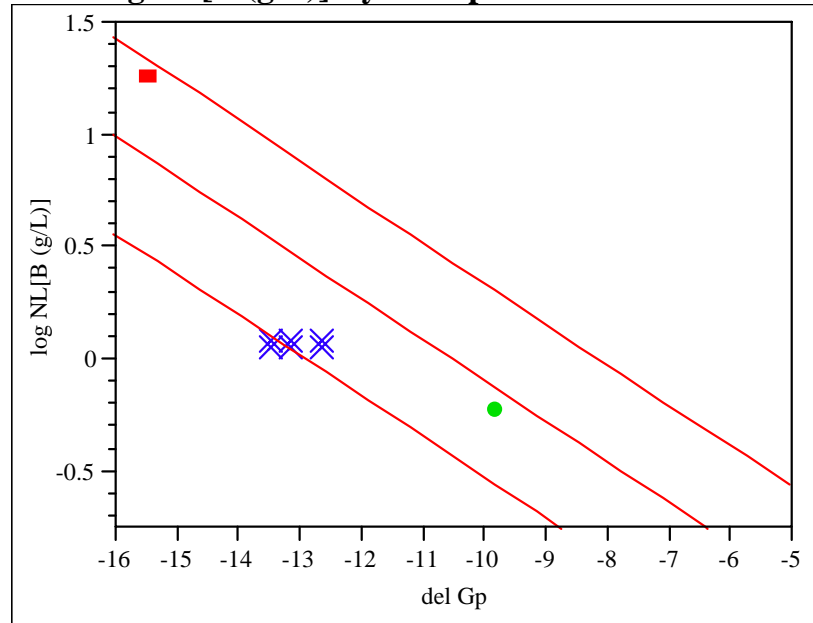

Fit of log NL[Na (g/L)] By del Gp

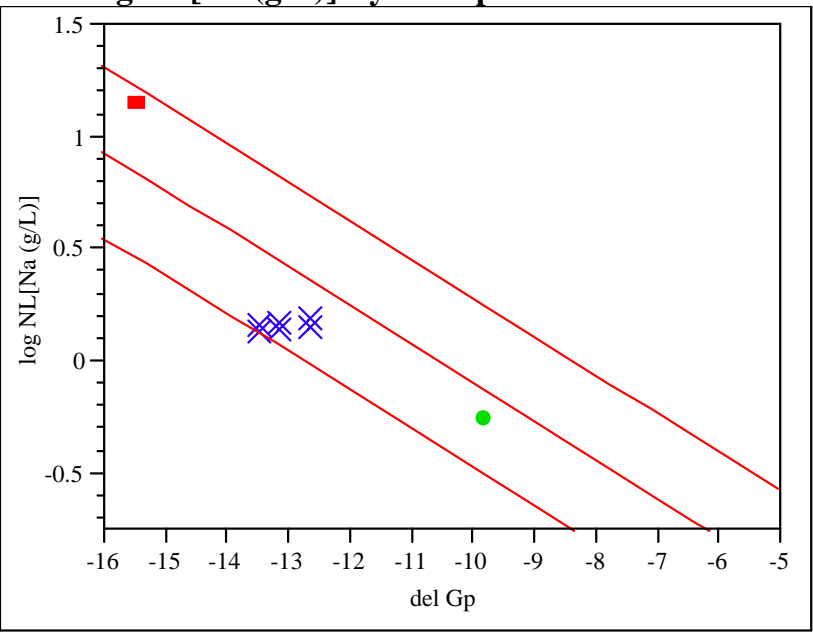

Fit of $\log \mathrm{NL}[\mathrm{Li}(\mathrm{g} / \mathrm{L})]$ By del Gp

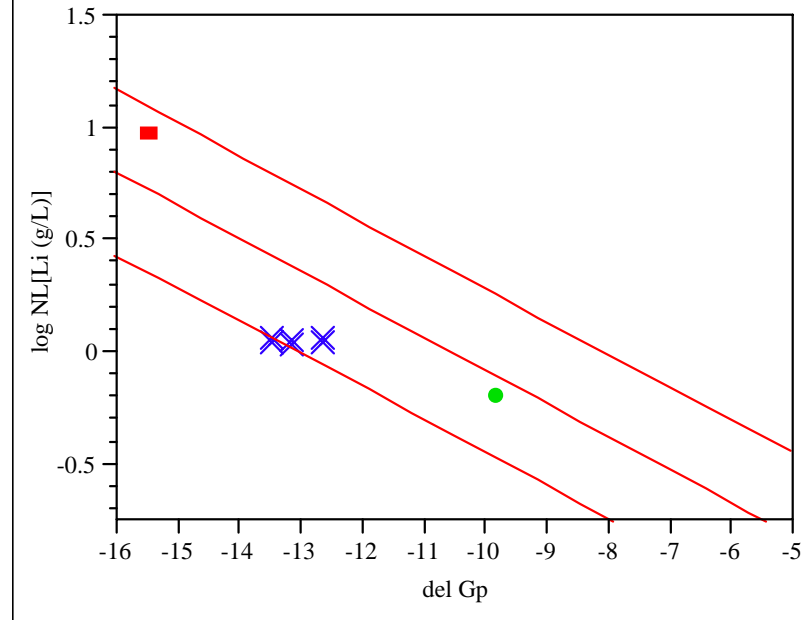

Fit of $\log$ NL[Si (g/L)] By del Gp

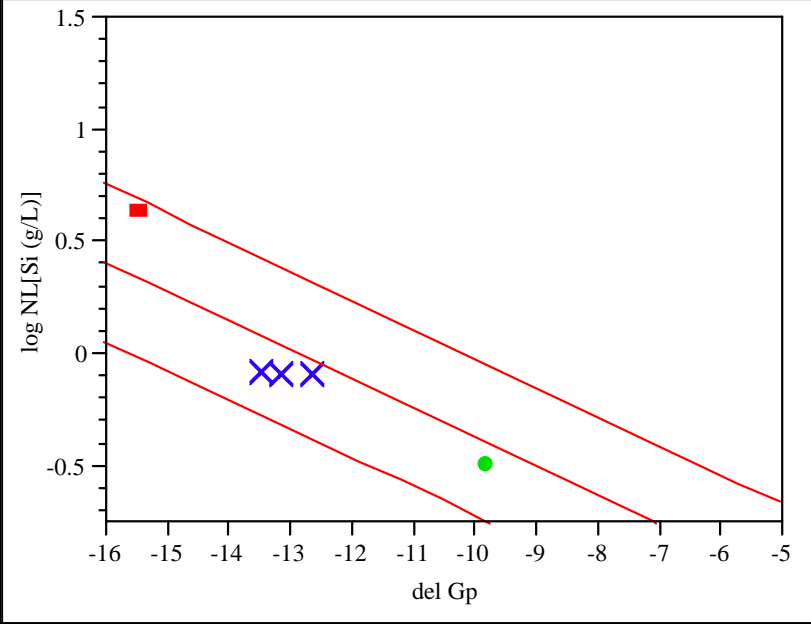


Exhibit D.9: del Gp $\left(\Delta G_{p}\right)$ Predictions versus Common Logarithm Normalized Leachate $(\log \mathrm{NL}[]$.$) for B, Li, Na, and Si by Study Glass Over All Compositional Views and Heat$ Treatments

\section{Study Glass \# 4 with EA and ARM}

Fit of $\log$ NL[B (g/L)] By del Gp

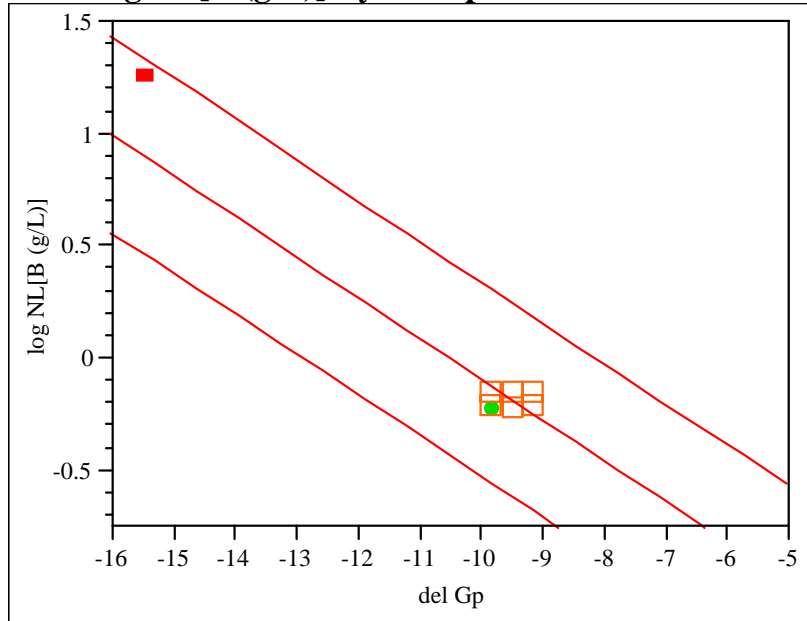

Fit of $\log$ NL[Na (g/L)] By del Gp

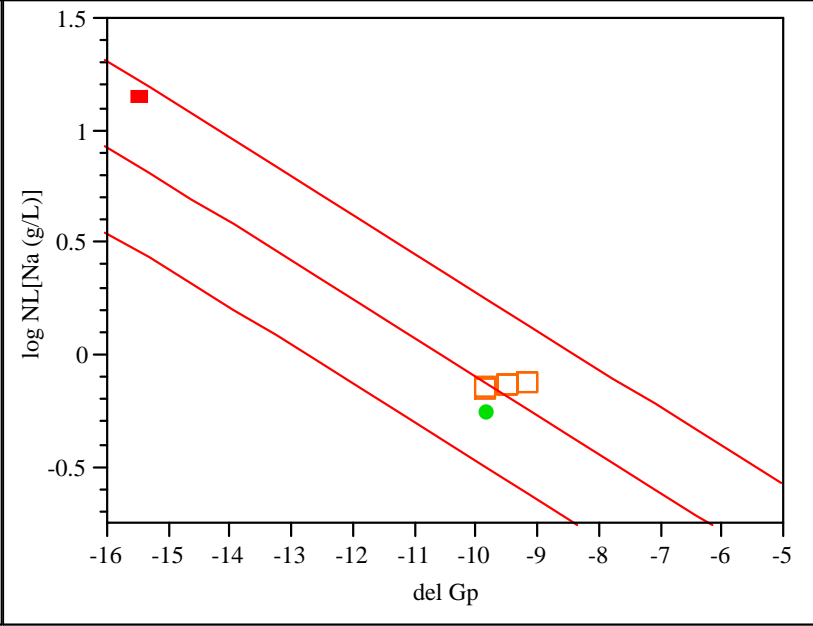

Fit of $\log \mathrm{NL}[\mathrm{Li}(\mathrm{g} / \mathrm{L})]$ By del Gp

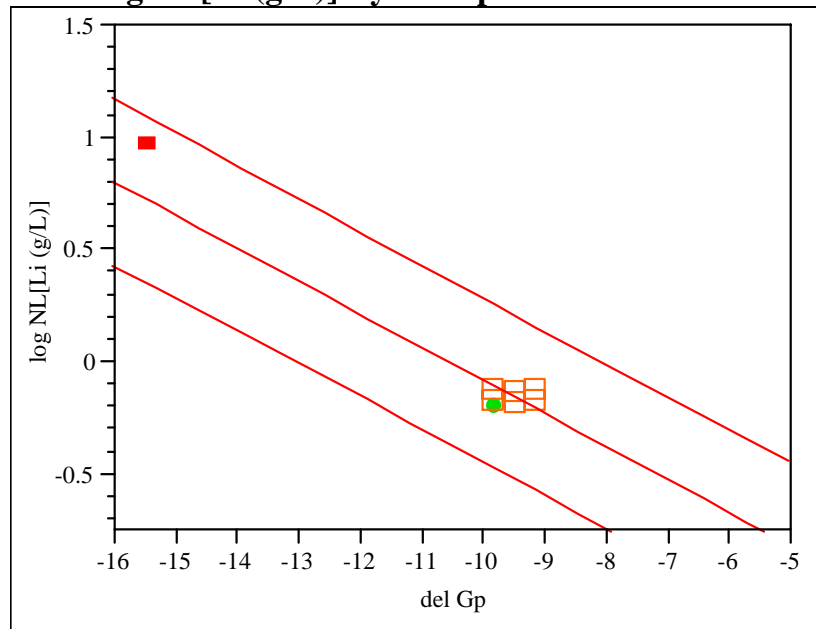

Fit of $\log$ NL[Si (g/L)] By del Gp

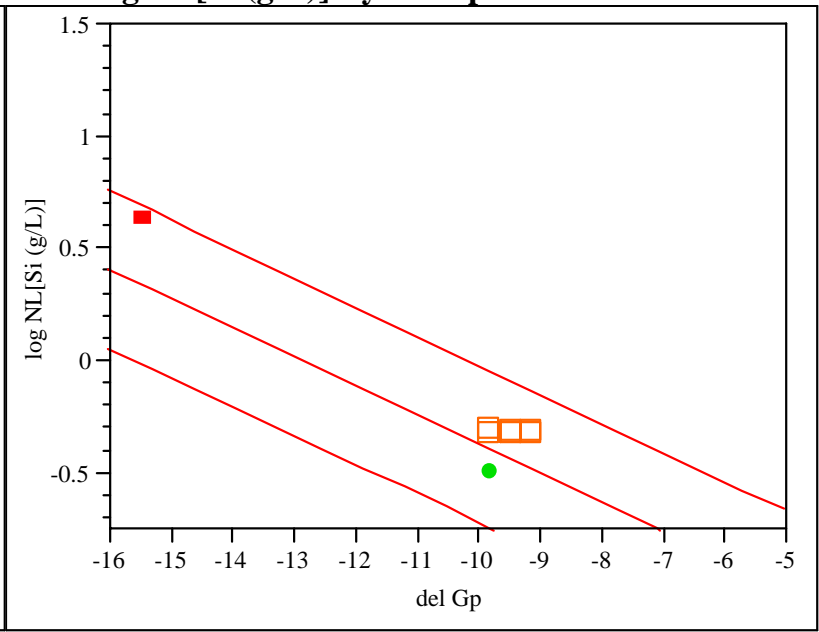


Exhibit D.9: del $G p\left(\Delta G_{p}\right)$ Predictions versus Common Logarithm Normalized Leachate $(\log \mathrm{NL}[]$.$) for B, Li, Na, and Si by Study Glass Over All Compositional Views and Heat$ Treatments

\section{Study Glass \# 5 with EA and ARM}

Fit of $\log$ NL[B (g/L)] By del Gp

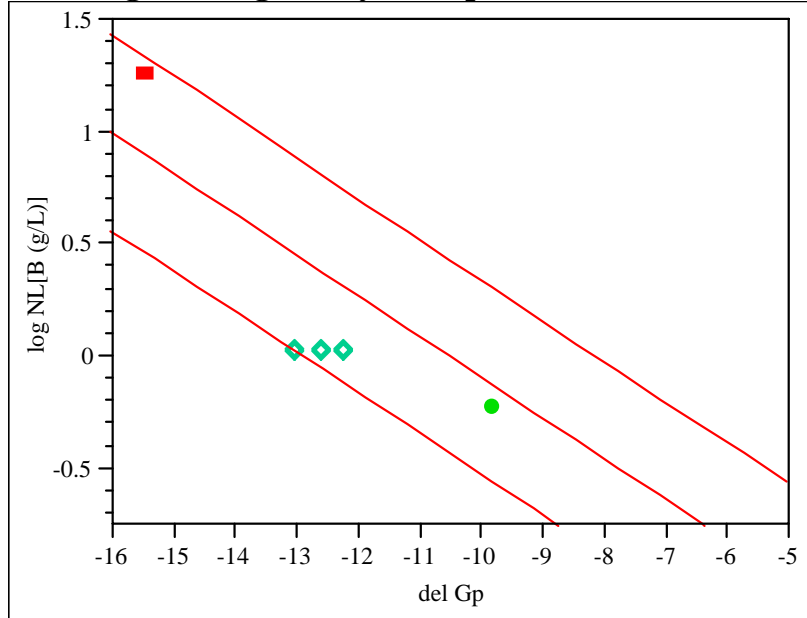

Fit of log NL[Na (g/L)] By del Gp

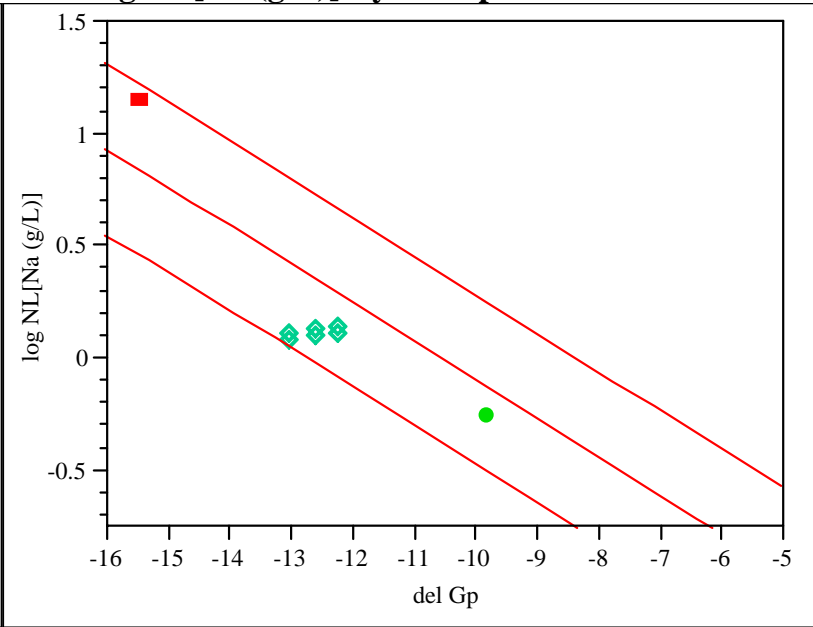

Fit of $\log \mathrm{NL}[\mathrm{Li}(\mathrm{g} / \mathrm{L})]$ By del Gp

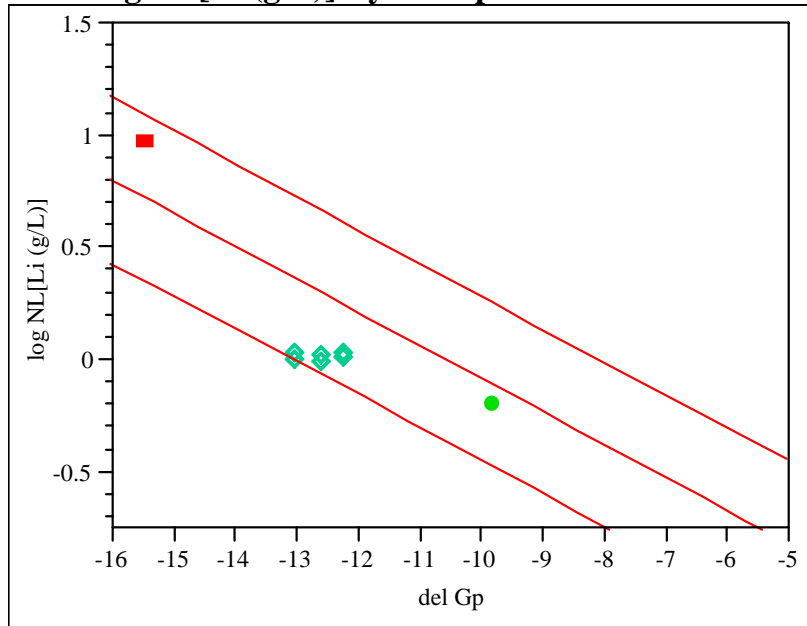

Fit of $\log \mathrm{NL}[\mathrm{Si}(\mathrm{g} / \mathrm{L})]$ By del Gp

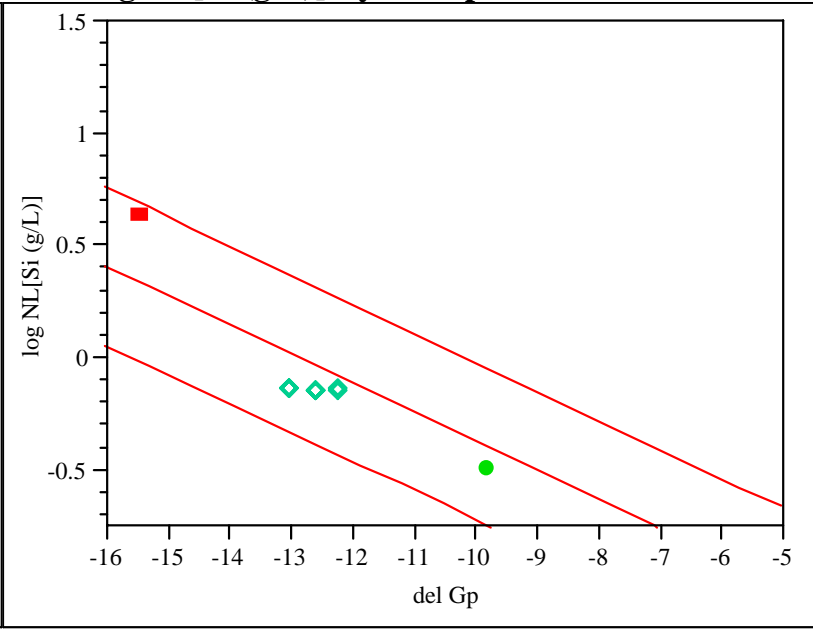


Exhibit D.9: del Gp $\left(\Delta G_{p}\right)$ Predictions versus Common Logarithm Normalized Leachate $(\log \mathrm{NL}[]$.$) for B, Li, Na, and Si by Study Glass Over All Compositional Views and Heat$ Treatments

\section{Study Glass \# 6 with EA and ARM}

Fit of log NL[B (g/L)] By del Gp

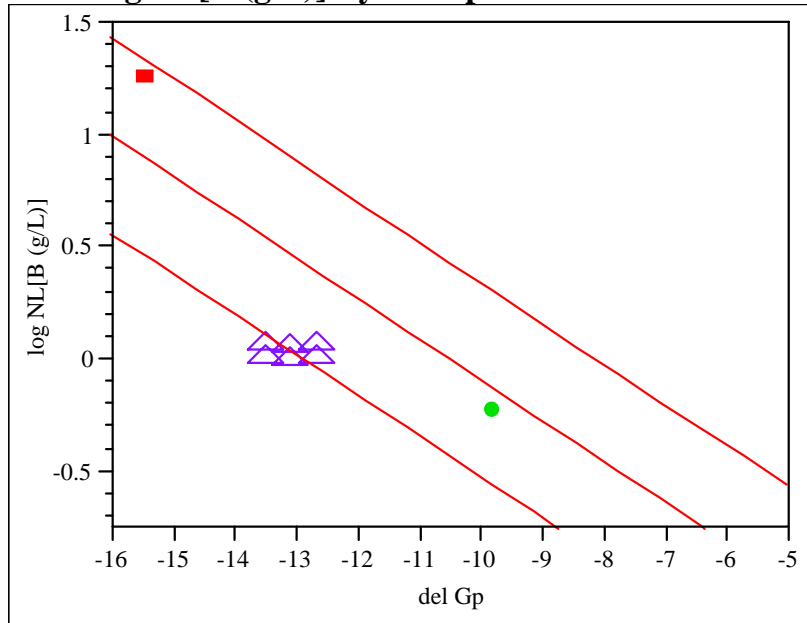

Fit of log NL[Na (g/L)] By del Gp

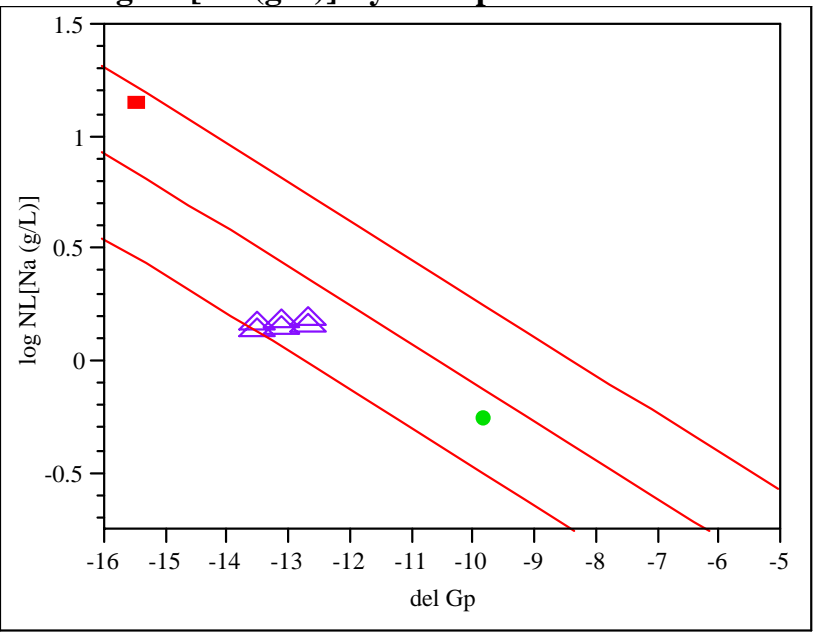

Fit of $\log \mathrm{NL}[\mathrm{Li}(\mathrm{g} / \mathrm{L})]$ By del Gp

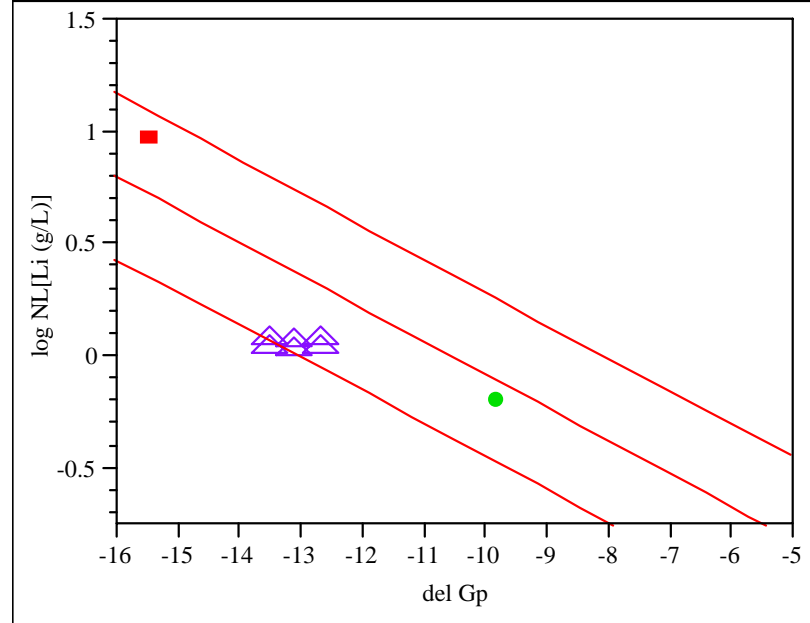

Fit of $\log$ NL[Si (g/L)] By del Gp

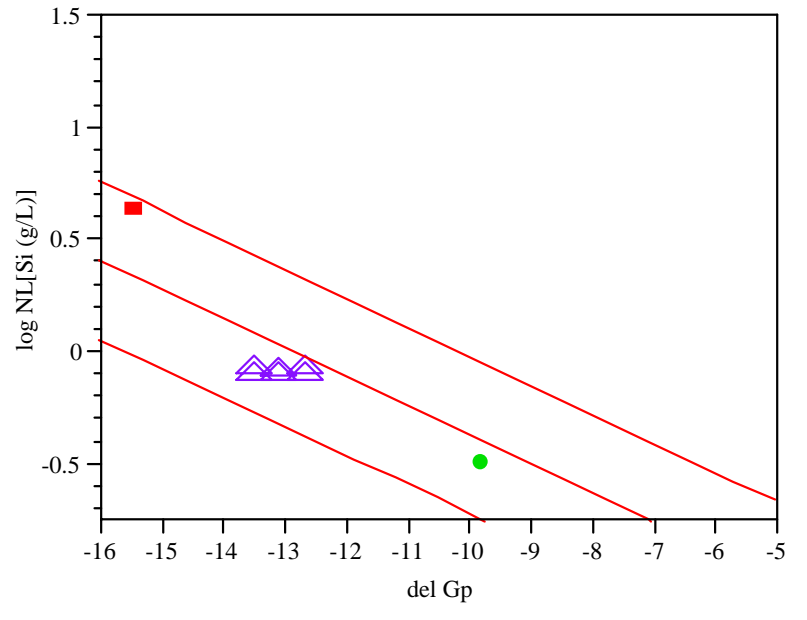


Exhibit D.9: del Gp $\left(\Delta G_{p}\right)$ Predictions versus Common Logarithm Normalized Leachate $(\log \mathrm{NL}[]$.$) for B, Li, Na, and Si by Study Glass Over All Compositional Views and Heat$ Treatments

\section{Study Glass \# 7 with EA and ARM}

Fit of log NL[B (g/L)] By del Gp

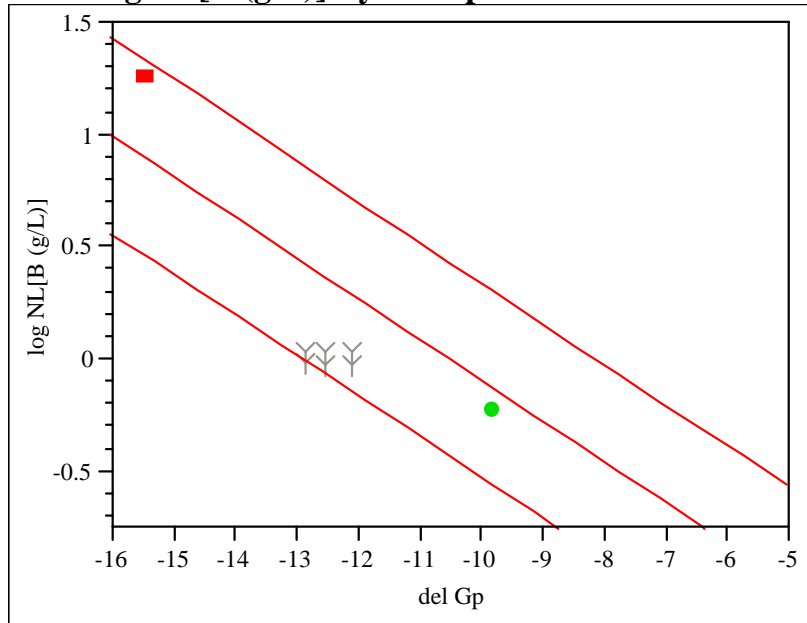

Fit of log NL[Na (g/L)] By del Gp

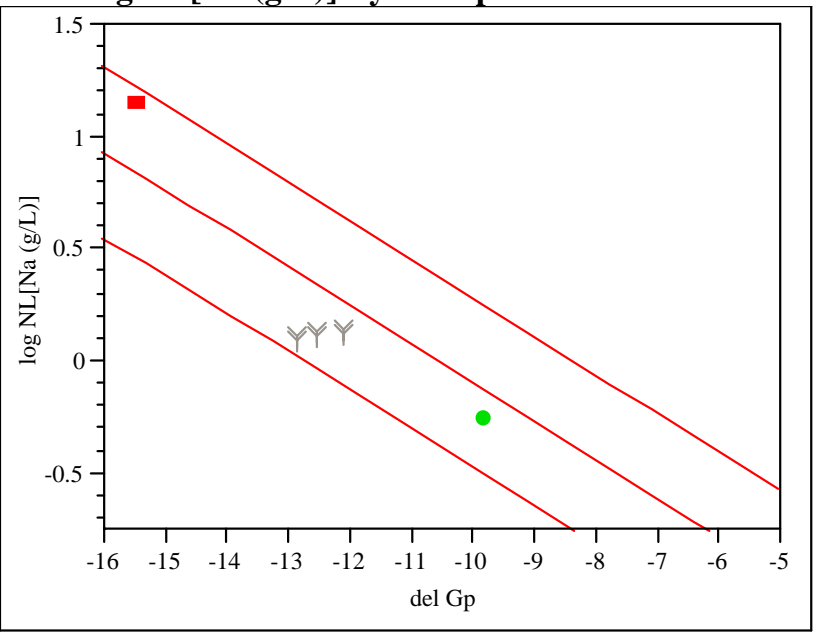

Fit of $\log \mathrm{NL}[\mathrm{Li}(\mathrm{g} / \mathrm{L})]$ By del Gp

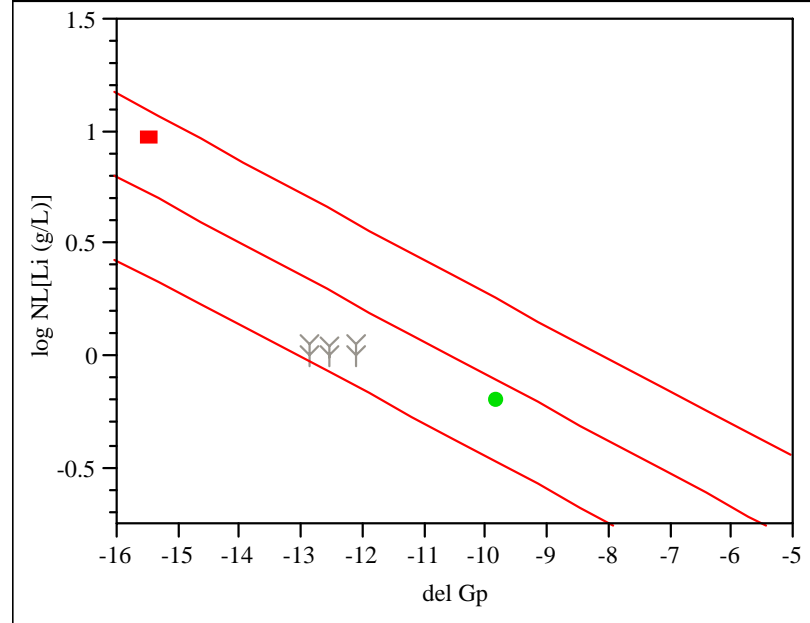

Fit of $\log$ NL[Si (g/L)] By del Gp

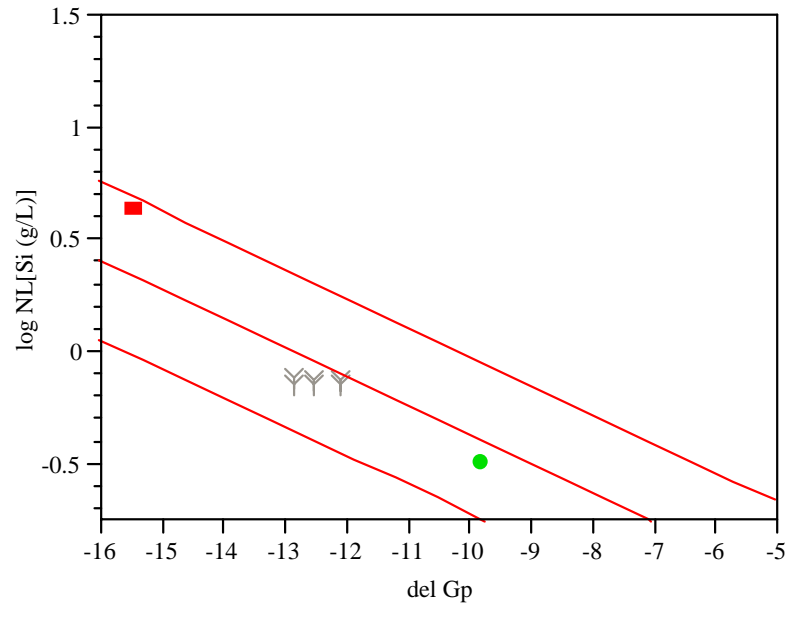


Exhibit D.9: del Gp $\left(\Delta G_{p}\right)$ Predictions versus Common Logarithm Normalized Leachate $(\log \mathrm{NL}[]$.$) for B, Li, Na, and Si by Study Glass Over All Compositional Views and Heat$ Treatments

\section{Study Glass \# 8 with EA and ARM}

Fit of log NL[B (g/L)] By del Gp

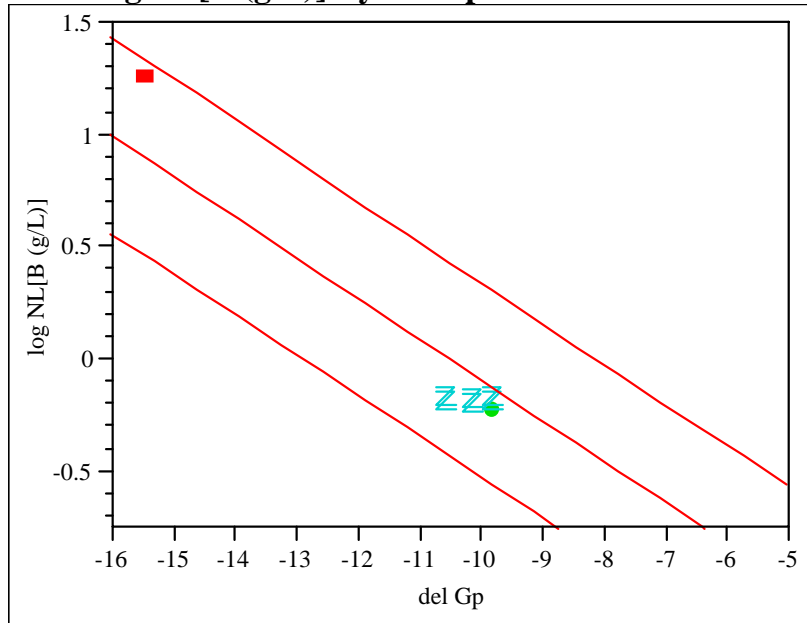

Fit of log NL[Na (g/L)] By del Gp

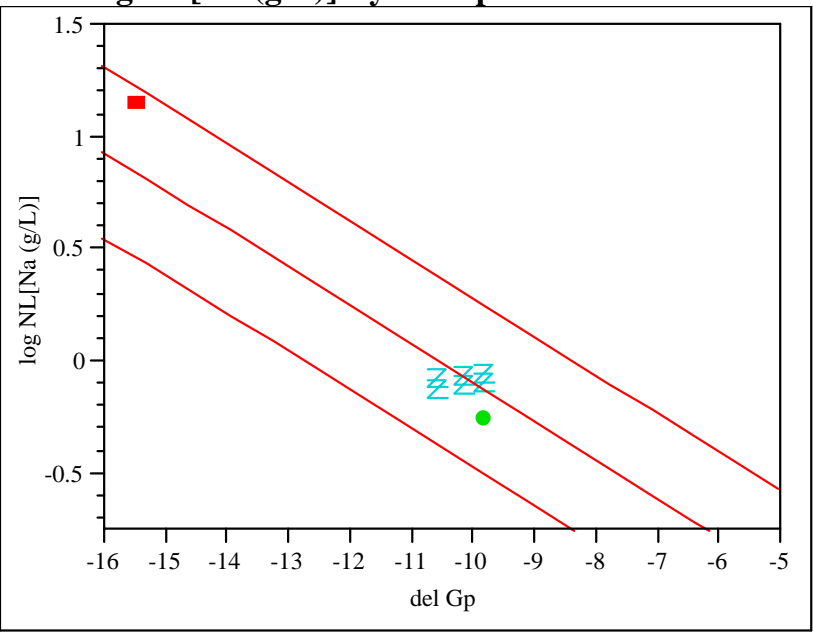

Fit of $\log \mathrm{NL}[\mathrm{Li}(\mathrm{g} / \mathrm{L})]$ By del Gp

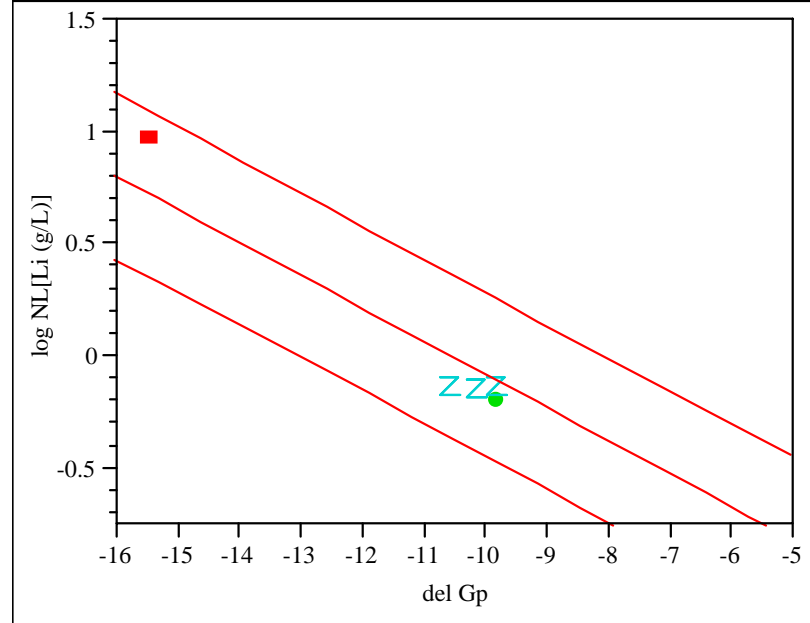

Fit of $\log$ NL[Si (g/L)] By del Gp

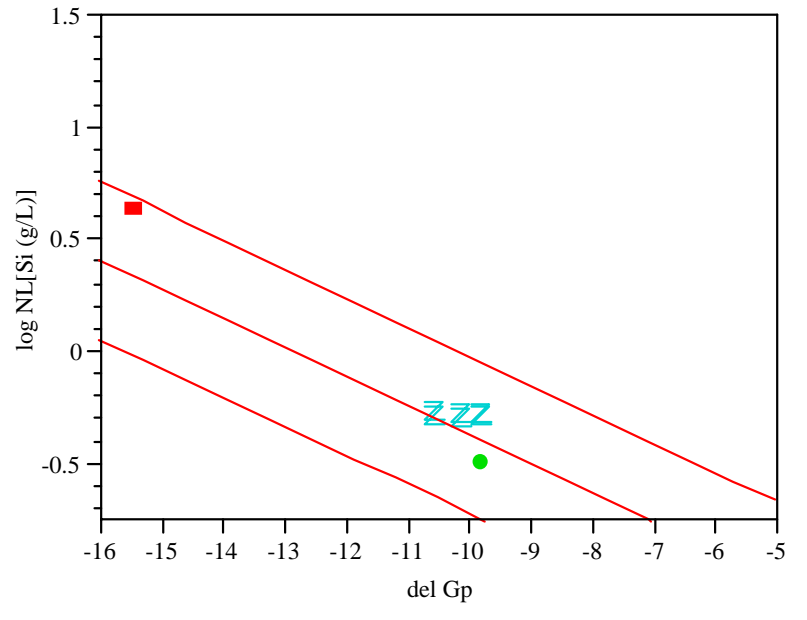


Exhibit D.9: del Gp $\left(\Delta G_{p}\right)$ Predictions versus Common Logarithm Normalized Leachate $(\log \mathrm{NL}[]$.$) for B, Li, Na, and Si by Study Glass Over All Compositional Views and Heat$ Treatments

\section{Study Glass \# 9 with EA and ARM}

Fit of log NL[B (g/L)] By del Gp

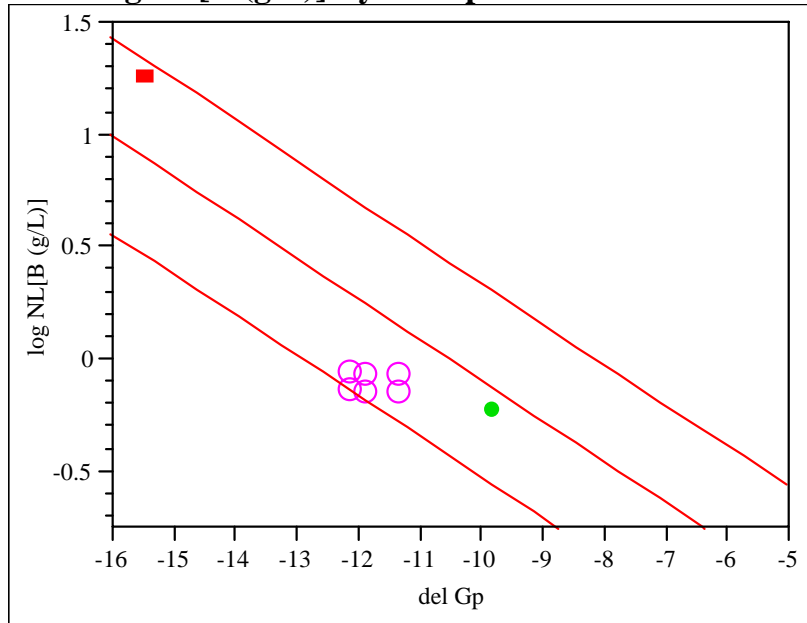

Fit of log NL[Na (g/L)] By del Gp

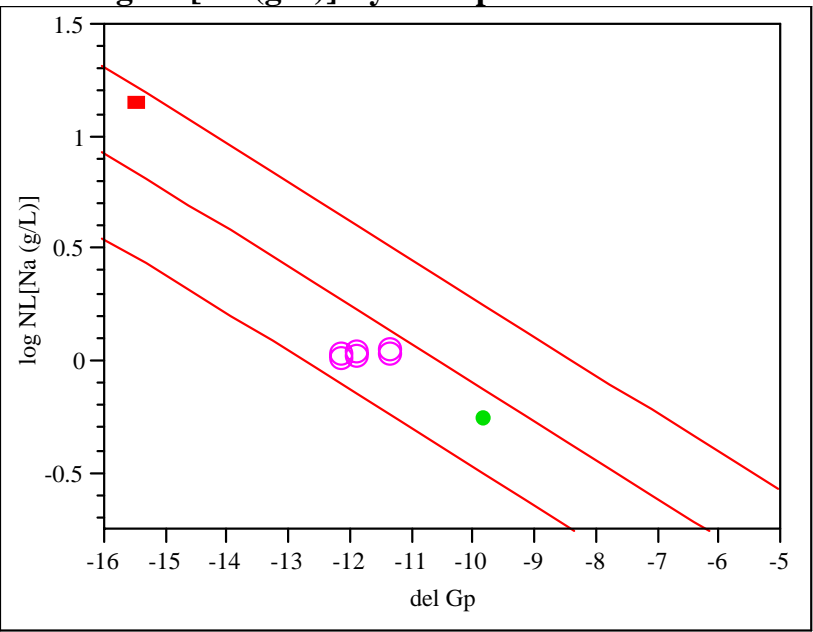

Fit of $\log \mathrm{NL}[\mathrm{Li}(\mathrm{g} / \mathrm{L})]$ By del Gp

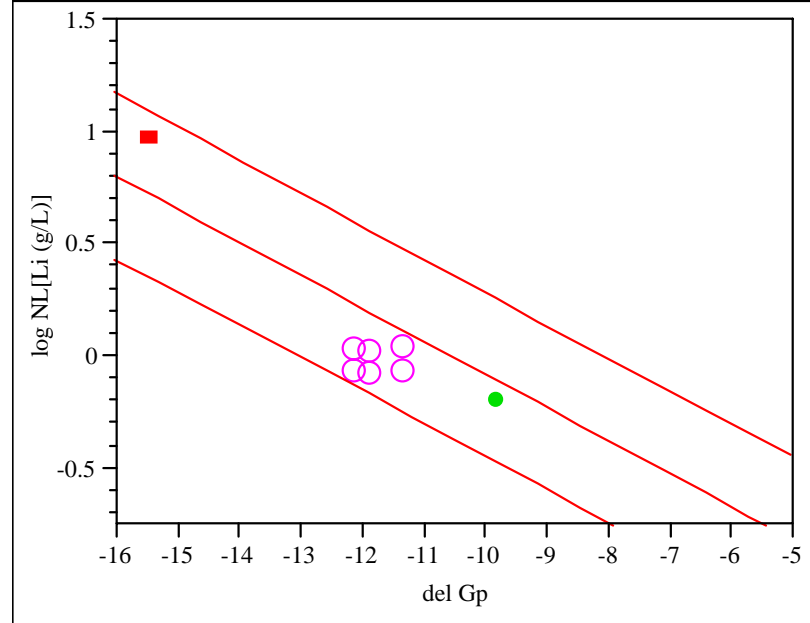

Fit of $\log$ NL[Si (g/L)] By del Gp

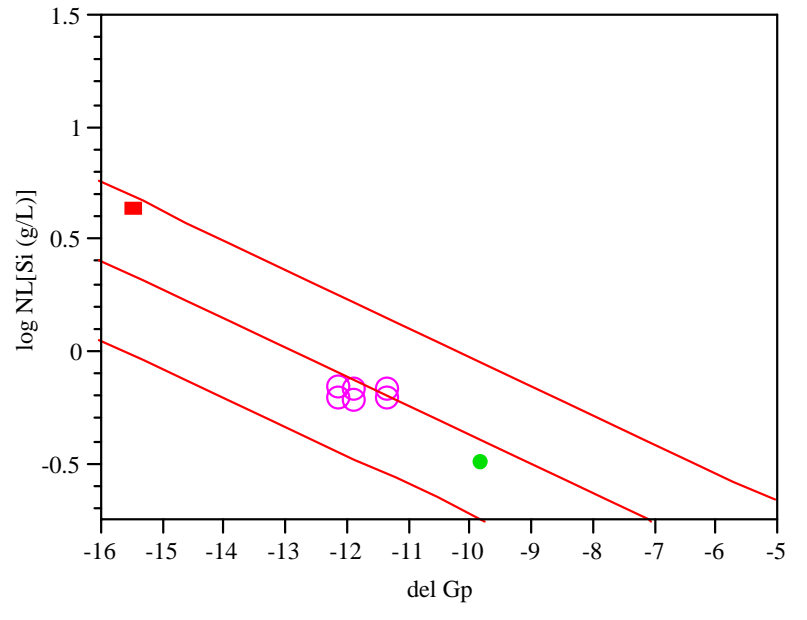


Exhibit D.9: del Gp $\left(\Delta G_{p}\right)$ Predictions versus Common Logarithm Normalized Leachate $(\log \mathrm{NL}[]$.$) for B, Li, Na, and Si by Study Glass Over All Compositional Views and Heat$ Treatments

\section{Study Glass \# 10 with EA and ARM}

Fit of log NL[B (g/L)] By del Gp

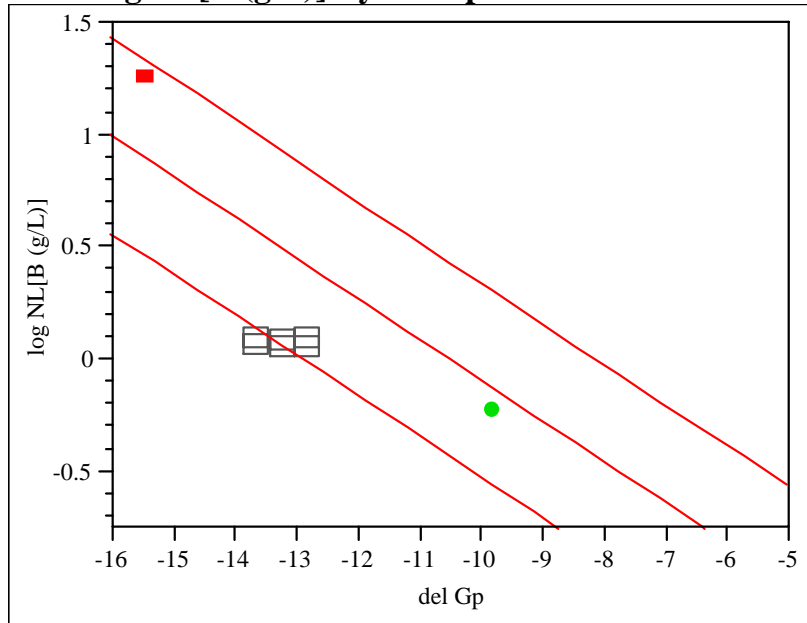

Fit of log NL[Na (g/L)] By del Gp

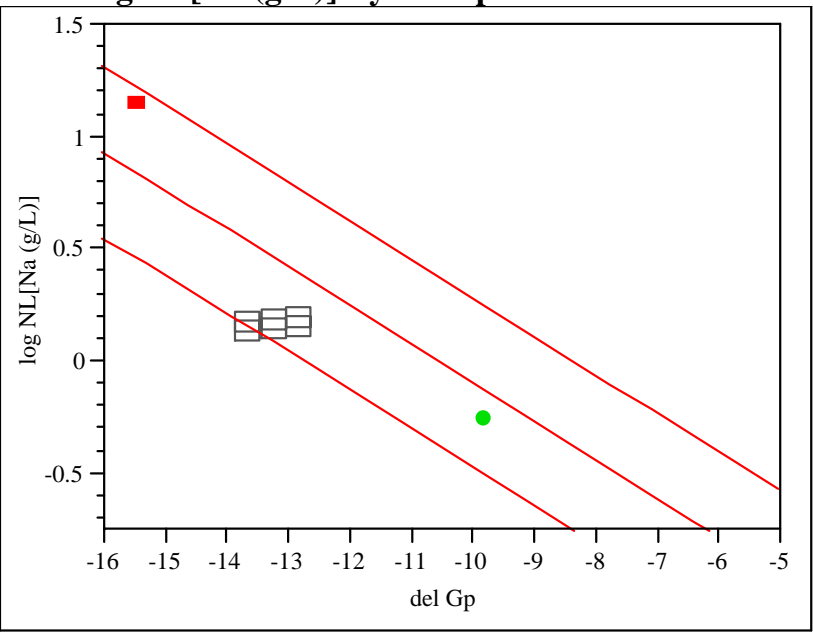

Fit of $\log \mathrm{NL}[\mathrm{Li}(\mathrm{g} / \mathrm{L})]$ By del Gp

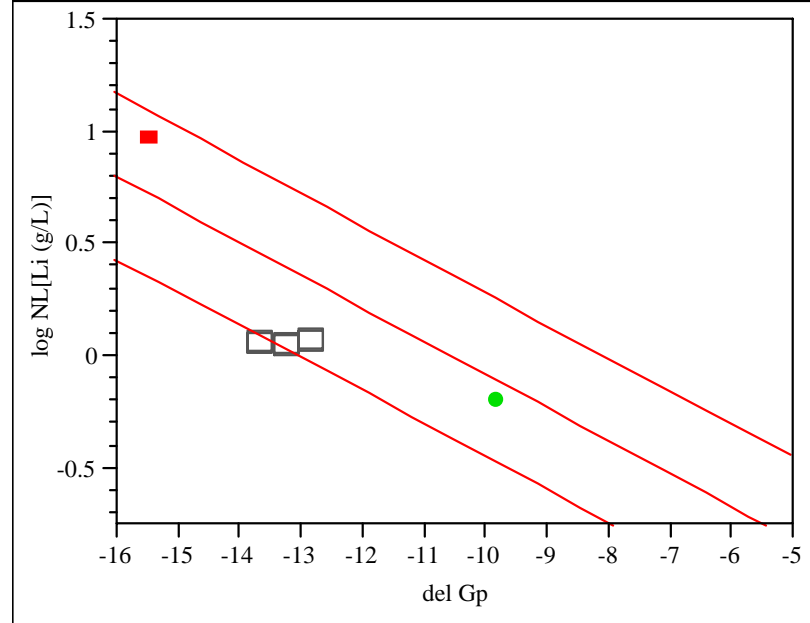

Fit of $\log$ NL[Si (g/L)] By del Gp

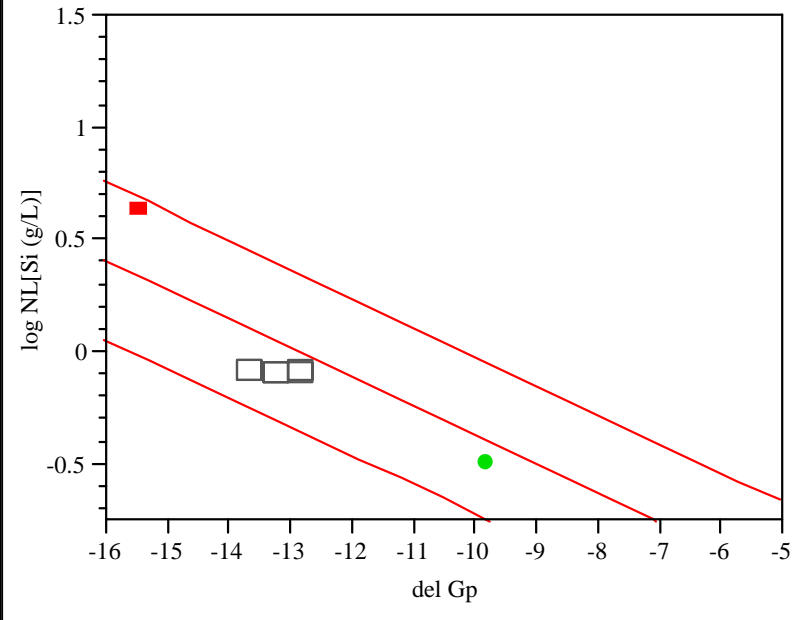


Exhibit D.9: del Gp $\left(\Delta G_{p}\right)$ Predictions versus Common Logarithm Normalized Leachate $(\log \mathrm{NL}[]$.$) for B, Li, Na, and Si by Study Glass Over All Compositional Views and Heat$ Treatments

\section{Study Glass \# 11 with EA and ARM}

Fit of log NL[B (g/L)] By del Gp

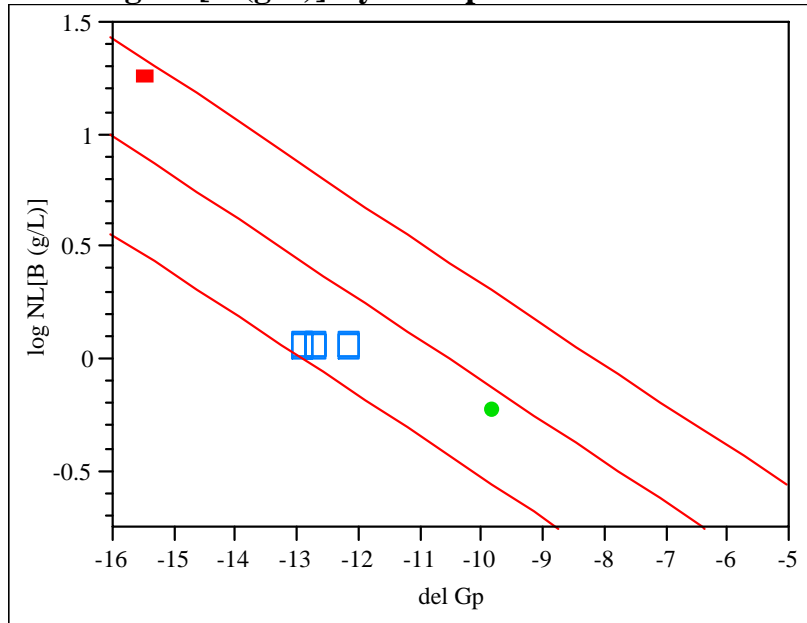

Fit of log NL[Na (g/L)] By del Gp

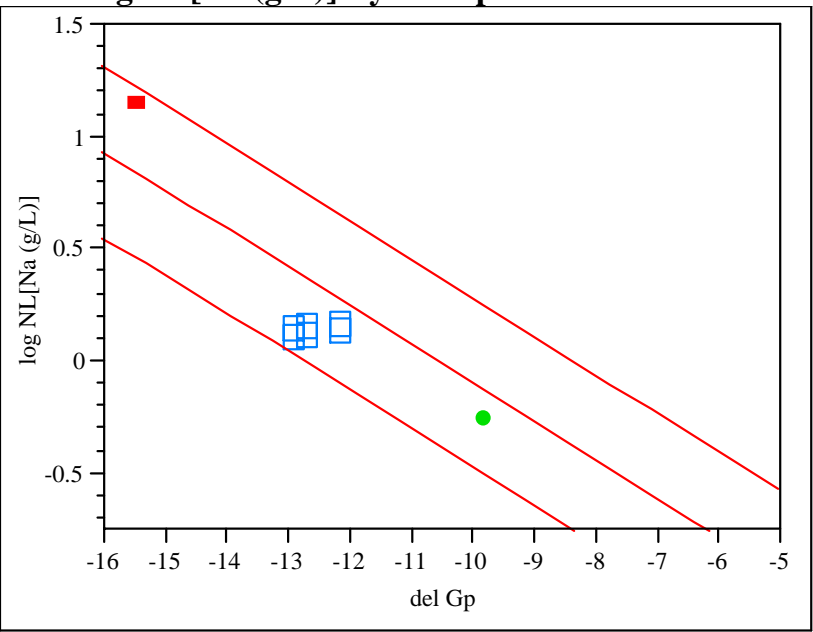

Fit of $\log \mathrm{NL}[\mathrm{Li}(\mathrm{g} / \mathrm{L})]$ By del Gp

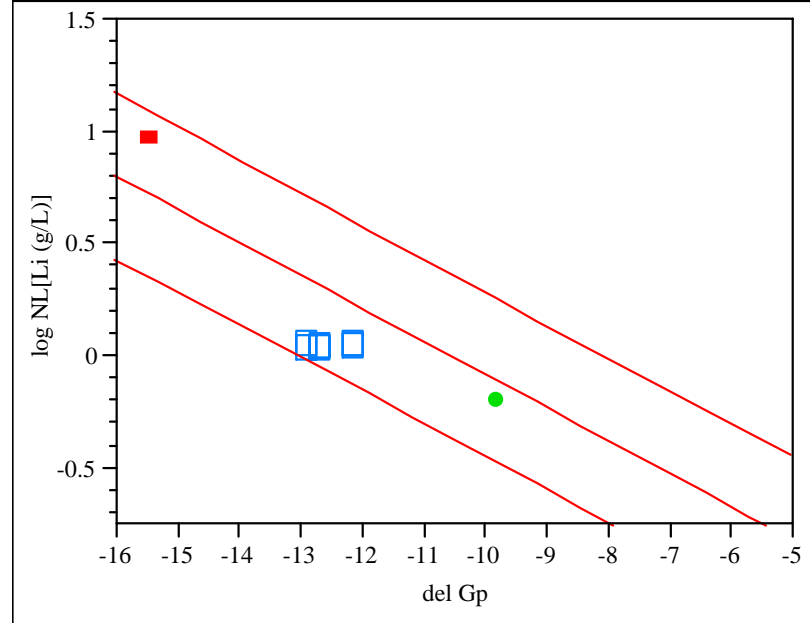

Fit of $\log$ NL[Si (g/L)] By del Gp

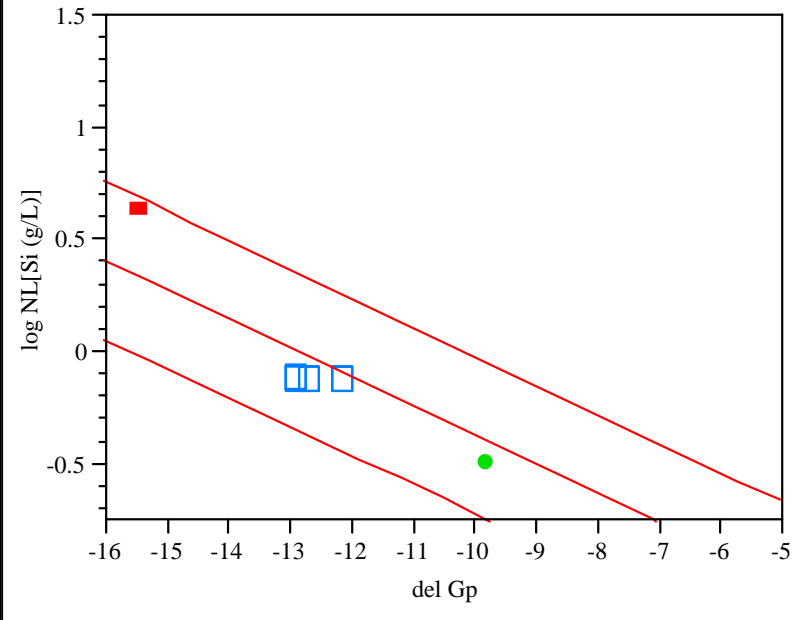


Exhibit D.9: del Gp $\left(\Delta G_{p}\right)$ Predictions versus Common Logarithm Normalized Leachate $(\log \mathrm{NL}[]$.$) for B, Li, Na, and Si by Study Glass Over All Compositional Views and Heat$ Treatments

\section{Study Glass \# 12 with EA and ARM}

Fit of log NL[B (g/L)] By del Gp

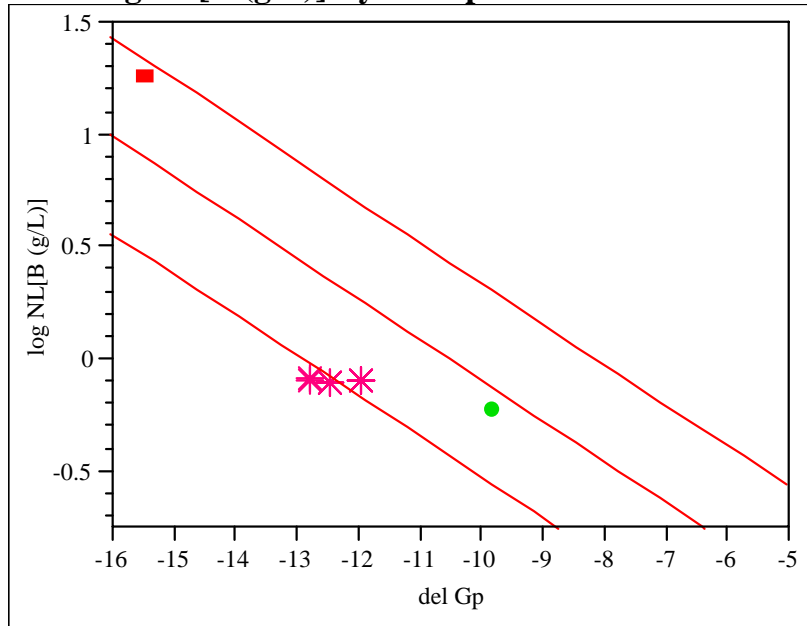

Fit of $\log$ NL[Li (g/L)] By del Gp

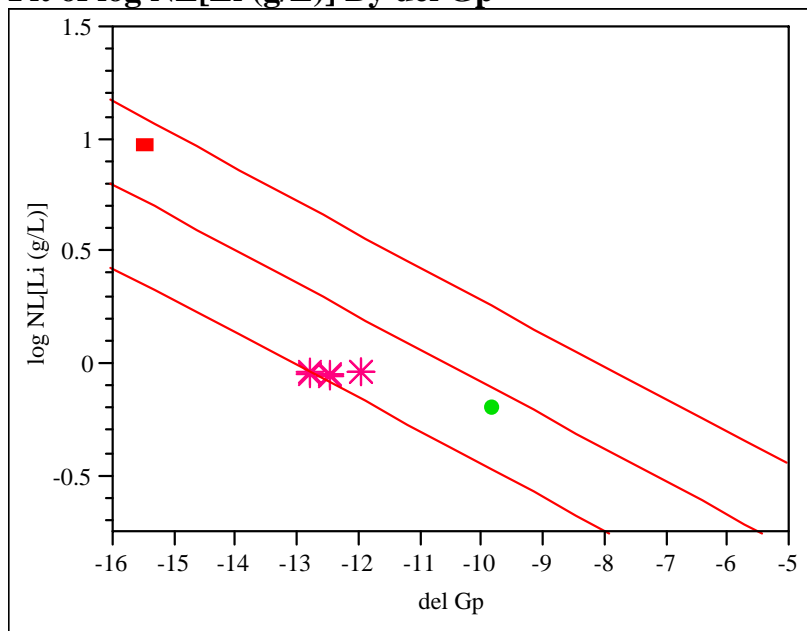

Fit of log NL[Na (g/L)] By del Gp

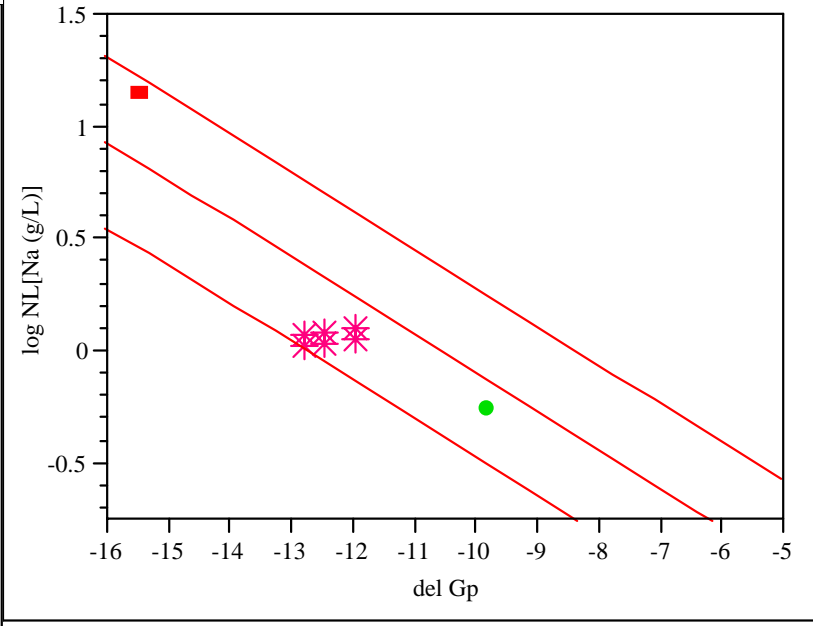

Fit of $\log$ NL[Si (g/L)] By del Gp

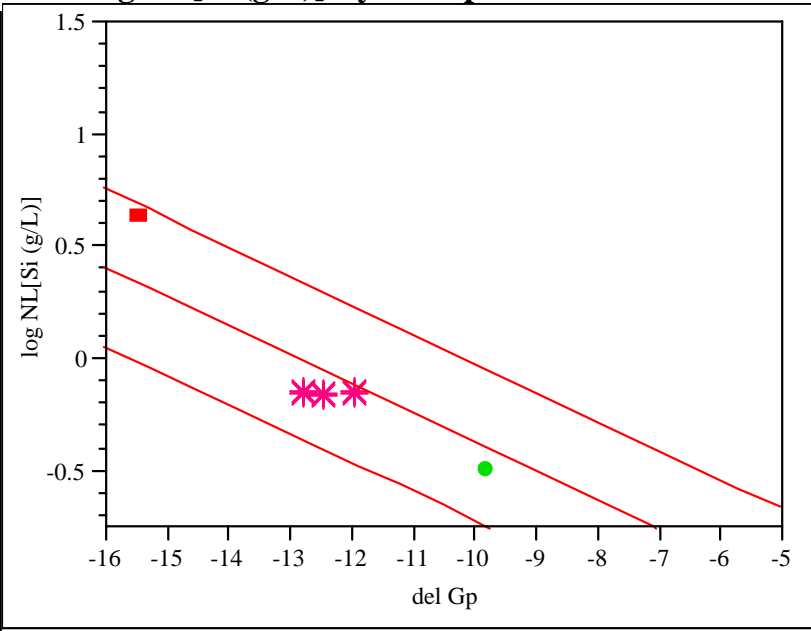

